\title{
Improving Land Governance in West Bengal
}

\section{STATE REPORT \\ Land Governance Assessment \\ Framework}

\section{LGAF Team}

August 2014

Coordination: Landesa/Rural Development Institute - West Bengal

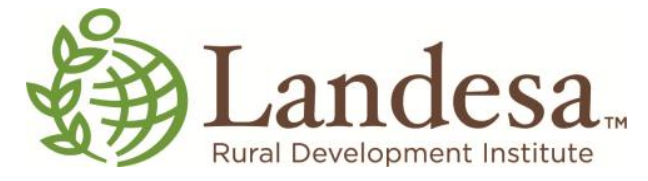

1)Page Land Governance Assessment Framework - West Bengal 


\section{TABLE OF CONTENTS}

\begin{tabular}{|c|c|c|}
\hline Sl. & Content & Page \\
\hline & Acronyms & 3 \\
\hline I. & EXECUTIVE SUMMARY & 5 \\
\hline II. & ACKNOWLEDGEMENTS & 18 \\
\hline III. & INTRODUCTION & 19 \\
\hline IV. & METHODOLOGY & 21 \\
\hline V. & GENERAL STATE CONTEXT & 24 \\
\hline VI. & ASSESSMENT & 36 \\
\hline \multirow[t]{8}{*}{ VII. } & ANALYSIS AND POLICY RECOMMENDATION & 146 \\
\hline & a. Substantive Findings & 146 \\
\hline & b. Strength and Weakness & 147 \\
\hline & c. Policy Matrix and Suggested Reform Actions & 152 \\
\hline & d. Data Gap & 165 \\
\hline & e. Evolution of Land Governance in West Bengal & 166 \\
\hline & f. Suggestion for Monitoring & 177 \\
\hline & g. Best Practices & 177 \\
\hline VIII. & CONCLUSION & 179 \\
\hline IX. & OVERALL SCORE CARD & 181 \\
\hline $\mathrm{X}$. & BIBLIOGRAPHY & 187 \\
\hline \multirow[t]{5}{*}{ XI. } & ANNEXURE & 188 \\
\hline & Annexure 1: Expert Investigator Report (Background Notes) & 188 \\
\hline & Annexure 2: Panel Reports (Aide Memoire) & 285 \\
\hline & Annexure 3: Expert Investigators and Panel Composition & 361 \\
\hline & Annexure 4: Government Orders & 365 \\
\hline
\end{tabular}




\section{Acronym}

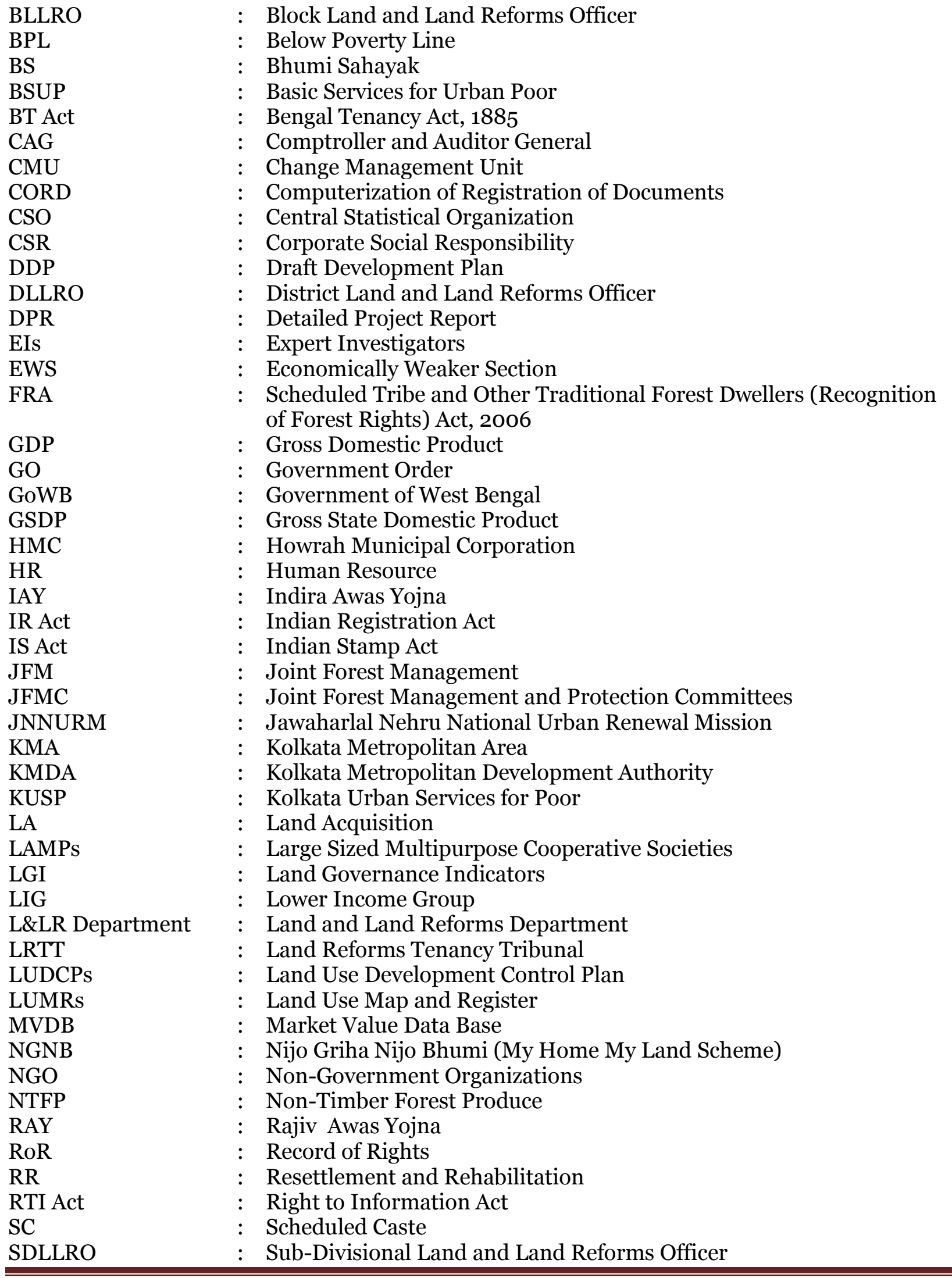

3|Page Land Governance Assessment Framework - West Bengal 
SIPRD $\quad$ : State Institute of Panchayat and Rural Development

TAG

ULB

: Scheduled Tribe

USHA

WBEA Act

WBIDC

WBIIDC

WBLR Act.

WBMMDC

WBSIDC

WBTDCC

: Technical Advisory Group

: Urban Local Bodies

: Urban Statistics And Human Resource Assessment Survey

: West Bengal Estate Acquisition Act, 1953

: West Bengal Industrial Development Corporation

: West Bengal Industrial Infrastructure Development Corporation

: West Bengal Land Reforms Act, 1955

: West Bengal Mines and Minerals Development Corporation

: West Bengal Small Industries Development Corporation

: West Bengal Tribal Development Cooperative Corporation

4|Page Land Governance Assessment Framework - West Bengal 


\section{Acknowledgements}

The State Governments of West Bengal together with Andra Pradesh, Bihar, Karnataka, Jharkhand and Odisha through the Department of Land Resources, Ministry of Rural Development, Government of India, requested in 2012 the World Bank to support the undertaking of an independent land governance assessment in each state using the LGAF approach. In each of the participating states, a well reputed local institution was selected to undertake the State-level Coordination of the LGAF, which was Landesa for West Bengal. Landesa identified the State Coordinator and a team of local State experts to undertake the assessment in consultation with a nodal officer assigned by the State Government. The six State institutions and LGAF teams are supported by the Technical Advisory Group (TAG), comprising of highly accredited and capable team members of nationally recognized experts each covering one of the LGAF thematic areas. The LGAF process and TAG are coordinated by the TAG secretariat, hosted by the Council for Social Development in Delhi. CSD coordinated regularly with DoLR and The World bank, which has provided financial support and methodological guidance.

We are grateful to the Government of West Bengal, particularly the L\&LR Department for continuously encouraging Landesa to conduct the exercise. We also express our deep acknowledgement and appreciation to all the expert investigators, the key technical input providers who in spite of several other preoccupations agreed to take the responsibilities, bear with us even at odd hours to work incessantly with deep involvement and commitment. These expert investigators (list is attached in annexure) are highly respected and widely acknowledged for their background, experience and expertise in specific areas of land governance assigned to them and we have been humbled by their rich contribution in the untiring effort to finalise the background reports, initial ranking of the dimensions in the context of the state with analysis which is understood to be the core area of LGAF.

A lot of effort was spent to identify, coordinate and convince the panel members all with distinguished background from a range of professional fields, but in the end, this has proved to be a highly rewarding exercise when one looks at the rich contribution and value addition these people have made to raise the standard and quality of discussions leading to consensus ranking of the dimensions. LGAF has provided us with a great opportunity to interact with the renowned TAG members who had come forward with their illustrious expertise to provide valuable guidance on LGAF exercise and deliverables.

We also take this opportunity to sincerely thank all the colleagues in Landesa, in Kolkata, Delhi and Seattle who have provided admirable support, encouragement and much needed appreciation to accomplish this challenging assignment and above all endured with the testing priorities. Last but not the least; our special compliment extends to the Global Coordinator, LGAF and National Coordinator, Technical Advisory Group who have been source of continuous encouragement, understanding and advice which greatly facilitated the work.

It has been an eye-opener and a fulfilling experience for me to act as the state coordinator and I also wish to thank all other complementary role players who worked tirelessly to complete the writing of reports, collection and collation of inputs from the experts and panellists to give the report a final shape.

Pinaki Halder State Coordinator, LGAF \& State Director, Landesa, West Bengal

5|Page Land Governance Assessment Framework - West Bengal 


\section{EXECUTIVE SUMMARY}

\section{Background}

West Bengal, the fourth largest Indian state in terms of population, is situated at the eastern part of the country. The state is known across the globe for its successful Land Reforms measures and a tradition of attempts to establish a better Land Governance mechanism. Here, Land governance refers to institutional and legal systems, procedures on ownership, use and transaction of land. The purpose of land governance is to ensure that the institutions, legal framework, process \& procedures follow the principles of equity, efficiency, transparency and accountability as well as positively contribute to economic and social development, and environmental sustainability.

This draft report on West Bengal chapter of Land Governance Assessment Framework (LGAF), a global initiative developed by the World Bank in partnership with FAO, UN Habitat, IFAD, IFPRI, the African Union, and numerous bilateral partners has endeavoured to capture the contextual land governance in the state measured by several indicators on a number of thematic areas. LGAF is a diagnostic tool to assess the status of land governance at country level in a participatory process that draws systematically on local expertise and existing evidence rather than on outsiders. For West Bengal, Landesa was assigned the responsibility of coordinating the entire exercise in the state and the State Director was entrusted with the responsibility of State Coordinator (hereafter referred to as the State Coordinator of LGAF).

\section{Land Issues in West Bengal}

The land situation in West Bengal is marked by three major characteristics: a) Very high population density and an adverse land-man ratio, compared to much of the rest of India, b) Large scale, successful and enduring land reforms by way of land redistribution to the landless and registering the sharecroppers as tillers on government records, c) Quite a high percentage of total population are marginal and small farmers and landless labourers, as well as urban landless ${ }^{1}$.

The land reform in West Bengal has two important components: tenancy reform and redistribution of land. The WBEA Act, 1953 abolished zamindary and all rent receiving interests. Those who held land became tenants directly under the state irrespective of their previous status. The erstwhile proprietor of land and the cultivator at the lowest level were thus brought on the same platform. The Act also imposed a ceiling on individual holding of land in khas. Thereafter, from the early seventies a new ceiling was imposed on holding of land on the basis of the size of a family under the provisions of WBLR Act, 1955. The ceiling surplus lands under the above two Acts were distributed in accordance with the principles laid down in section 49 of the WBLR Act.

The BT Act, 1885 virtually ignored the bargadars. After Independence attempt was made under the West Bengal Bargadars Act, 1950 to make the rights of the bargadars more secure.

The WBLR Act contains detailed provisions to protect the interests of bargadars. However, if the bargadars are not recorded they face the unenviable task of proving in a dispute with the owners

${ }^{1}$ Agriculture survey, Government of India, 2011

6|Page Land Governance Assessment Framework - West Bengal 
of the lands that they cultivate the land as bargadars. During the revision of records under the LR Act till 1978 a little over 6 lakh bargadars were recorded. This was found to be much less than the estimated number of bargadars actually existing. A special drive was taken to record the still unrecorded bargadars. This special drive came to be known as "Operation Barga". Several meetings were held informally to make the bargadars get rid of the fear of incurring the wrath of the owners of the land and instil courage into them so that they could give out that they were cultivating the lands as bargadars. Finally 14 lakh bargadars of which over 30\% were Scheduled Castes (SCs) and 12\% were Scheduled Tribes (STs) were recorded. For the redistributive justice, ceiling surplus land was distributed among the landless of which the share of SC pattadars is more than 37\% and that of STs is more than 19\% (source - West Bengal Human Development Report 2004).

\section{The Rationale: Land Governance \& LGAF}

Land governance refers to institutional and legal systems and procedures on ownership, use and transaction of land. Before getting into the detailed discussion, we need to have a clear understanding on the roles and responsibilities of the public institutions in the land sector. The discussion on this could be streamlined under three pointers:

First, states (land is a state subject in India) need a legal and institutional framework that clearly defines the rules for allocation of property rights and, by allowing cost-effective enforcement, encourages and facilitates land-related investment.

Second, reliable and complete information on land and property rights needs to be made easily available to interested parties. Access to land information would then allow for low-cost verification of land-ownership status, which in turn would form the basis for low-cost land transfers to more productive use or users and may facilitate the use of property as collateral in financial markets.

Weak governance of the land sector and a failure to perform these functions effectively will negatively affect development by reducing investment levels, property transfers, financial sector activity, and the scope for meaningful decentralization. Since the poor lack other assets, access to land is more important to them. Bad land governance will have undesirable distributional consequences and disproportionately hurt the poor.

The points and concerns mentioned above led to the identification of five key areas of good land governance:

1. A legal, institutional, and policy framework that recognises existing rights, enforce them at low cost, and allows the users to exercise them in line with their aspirations and in a way that benefits society as a whole.

2. Arrangements for land use planning and taxation that avoid negative externalities and support effective decentralisation.

3. Clear identification of state land and its management in a way that cost-effectively provide public good; use of acquisition process only as a last resort and only for direct public purposes with quick payment for fair compensation and effective mechanisms for appeal.

4. Public provision of land information in a way that is broadly accessible, comprehensive, reliable, current and cost-effective in the long run.

5. Accessible mechanisms to authoritatively resolve disputes and manage conflict, with clearly defined mandates and low cost operation.

For the five key areas, a series of land governance indicators, each divided into several dimensions, have been selected on the basis of international experience adapted to suit the

7lPage Land Governance Assessment Framework - West Bengal 
Indian context. For each dimension, pre-coded statements are given for scoring (from best practice (A) to weak practice D), again based on international experience.

The LGAF process helps to establish a consensus and priority actions on (i) gaps in existing evidence; (ii) areas for regulatory or institutional change, piloting of new approaches, and interventions to improve land governance on a broader scale (e.g. by strengthening land rights and improving their enforcement); and (iii) criteria to assess the effectiveness of these measures. LGAF also helps to put in place a structure and process to systematically track progress in improving land governance over time. The framework has been completed or is being applied in over 30 countries with growing demand.

\section{Methodology/process}

The process of LGAF studies is a well thought and tested methodology and has been guided by a framework of land governance indicators that cover five thematic areas and relate to a basic principle of governance.

There are 27 "land governance indicators" (LGI). Each indicator is further broken down into a number of "dimensions" with pre-coded statements that draw on global experience (on a scale from A to D). There are in total 116 dimensions in the LGAF.

Nine expert panels organized by subject ranked the dimensions by selecting an appropriate option from the list of pre-coded answers. The panel deliberations were based on preparatory data gathered and analysis by the expert investigator.

The Land Governance Assessment Framework (LGAF) in West Bengal has been implemented by using a highly participatory process for about six months that drew systematically on local expertise and existing evidence. To provide the common basis of information that is indispensable as a basis of consensus on rankings or priority actions three sets written outputs were developed. First, to characterize the setting, a tenure typology describes key types of tenure in the country, quantifies the extent and population under each type, and identifies key gaps and overlaps for each of them. Similarly, a map of institutions in the sector identifies the functions performed by these at different levels as well as gaps and overlaps. Second, relevant material from existing studies and 'grey' literature is synthesized in background reports corresponding to the key LGAF areas to provide the substantive understanding needed. Third, panel briefings are put together by the coordinator to instruct panel members by explaining the indicators and pointing towards relevant material.

Intensive work sessions of between half a day and a day per topic were organized by the State Coordinator for panels consisting of a group of subject matter experts and users of land systems, from different backgrounds/works of life. The panel members discussed each of the dimensions in detail to arrive at a consensus regarding the ranking and agreed policy priorities. Discussions are summarized in aide memoires and the record of these discussions is reviewed and agreed upon by panellists.

This synthesized report would be shared with a wide range of people and would be discussed at a state level validation and policy workshop before consolidation of the key points from the state report into the national report as a part of the national level consolidation of LGAF.

The key points that emerged out of the study are summarised in brief.

\section{Key points from Panel 1 : Land Tenure Recognition}

A system of tenure explains how people, communities and others gain access to land, forests, and fisheries, and how those are regulated by societies. These tenure systems determine who can

8|Page Land Governance Assessment Framework - West Bengal 
use what resources, for how long and on and under what conditions. Such systems may be based either on written policies and laws or unwritten customs and practices.

West Bengal is known for its rich heritage of attempts to develop effective systems of land tenure. The indigenous system of land-law that existed till the end of $12^{\text {th }}$ century was more socio-political than legal. Two persons were basically interested in land and its produce -- the king and the tiller. Intermediate interests or sub-letting were unknown. This system came into a severe conflict in the beginning of the $13^{\text {th }}$ Century with the Islamic jurisprudence brought in by the Muslim conquerors who started with the proposition that upon conquest all individual ownership came to an end, and all land stood vested in the conqueror. During the tenure of the great Mughal Emperor Akbar, his finance Minister Todarmal introduced a system of assessing a fixed sum as rent on actual measurement of land and collecting rent directly from the tillers of the soil ignoring the intermediaries like jagirdars. This system recognised peasant proprietorship.

After getting the Dewani (revenue administration) of Bengal, Behar and Orissa, East India Company adopted the structure of land revenue administration introduced by the previous Muslim ruler Murshid Kuli khan but went on putting pressure for collection of more revenue. This excessive pressure on cultivators is said to be one of the main causes of the great famine of 1176 BS (corresponding to 1770 Christian era) which resulted in the death of nearly one- third of the total population of Bengal.

Cornwallis (the then Governor General) under Regulation I of 1793 permanently settled estates with the zamindars with proprietory rights on land. The permanent settlement was proved to be an unmitigated disaster for Bengal. The Zamindars felt free to do whatever they liked and started creating tenants under them for collection of rent. This is how subinfeudation took place and middlemen of different layers between the landlords and the cultivators came into existence, making the condition of the actual cultivator even worse.

The Bengal Tenancy (BT) Act came into existence in 1885. The most significant contribution of this Act is that it provided for a detailed survey and settlement operation in respect of each and every piece of land of every village. Accordingly cadastral map of each and every village was prepared with each and every piece of land with classification according to use as well as ownership plotted therein.

After independence, the EA Act was passed in pursuance to the constitutional provisions regarding acquisition of estates. This Act abolished the Zamindary system and imposed ceiling on individual holding of land. As a follow-up of the EA Act by a comprehensive measure of land reforms so as to remodel the system of land tenure, the West Bengal Land Reforms Act 1955 (WBLR Act) was passed.

The Government of West Bengal acts both as regulator and manager in respect of all lands within the state. It acts as manager in respect of lands at its disposal, and as a regulator in respect of lands held by raiyats who are the owners of their lands enjoying heritable and transferable rights. The Land \& Land Reforms Department as the administrative department of the West Bengal Land Reforms Act deals with all matters relating to land except the lands held by other departments.

The tenural arrangements before 1955 had a multi-layered rent receiving intermediaries above the actual cultivator. With the abolition of Zamindary under the EA act, the only landlord is the state and whoever holds land is a tenant called a raiyat under the state. The tenure typology table provides a descriptive view of all categories of tenures, mode of creation and recognition of tenure and number of such tenureship and area covered.

9|Page Land Governance Assessment Framework - West Bengal 
The rights of a raiyat in respect of land comprising his tenure are transferable and heritable and the right to use the land is subject to certain restrictions. The sharecropper/ bargadar has the occupancy right to cultivate the land as bargadar which cannot be terminated except in accordance with law on the order of prescribed authority and his right is also heritable but nontransferable. The law does not permit creation of tenancy on private land but there are concealed / oral leasing prevalent in parts of the state.

The occupiers of private land with or without the land owner's leave or squatters on Government land do not have any tenurial security. The government has undertaken time bound programmes for allocation/ regularisation of homestead micro plots to the landless poor, thus creating another form of tenancy (My Home My Land - Nijo Griha Nijo Bhumi programme has helped more than 120,000 landless to receive secure tenure over last three years).

The situation in regard to recording of women's land right in the state is problematic, although more than 70\% agricultural workforce in the state is women. In West Bengal land means land of every description and a raiyat is a person or institution who holds land for any purpose whatsoever. Tenure security is defined as 1) protection against eviction; ii) scope of selling and transferring rights through inheritance, and iii) the possibility of having access to credit under certain conditions. In West Bengal after the reforms, a very skewed and complex land tenure system has been replaced by a simple one where the state is the landlord and whoever holds land is a raiyat under the state. Couple of issues on secure tenure rights to be adhered are:

1. Identification and codification of customary rights

2. Better recording of women's land rights

During post-tenancy reform situation, the government considered and made legislative provisions for providing institutional finance to the sharecroppers to enable them to become landowners of the parcel of land they are cultivating. But this provision has not been implemented. The government may consider implementing the provisions to erase the tension between the land owner and the bargadar, which is inherent in the system of share-cropping. The government might consider undertaking a survey for assessing the extent and pattern of concealed/ oral leasing which is being practiced in rural Bengal significantly in violation of section 4 of the WBLR Act.

The recommendation also mentions about the need of appropriate legal provisions for compulsory mutation during the transfer of property. The tribal land alienation continues to be a main cause of concern. The Govt. may consider developing a complete database on tribal land ownership and subsequent causes of alienation.

\section{Key points from Panel 2 : $\quad$ Rights to Forest and Commons Lands \& Rural Land Use Regulations}

In West Bengal all the lands stands recorded in the latest record of rights either in the name of a raiyat or government. Register VIII maintained at the field office of the Land reforms Department contains the details of government land which is in use by the public and not to be settled. The private lands at times are also used as commons during non- cultivation season. Under the EA Act, 1953, all the recorded forests of the state other than those under lease agreements with the tea gardens had vested in the state and their management was given to Forest Department, West Bengal. Subsequently the Tea garden forests were taken over as "Resumed Forests" and transferred to Forest department. At present, all the recorded forests of the State are classified as Reserved Forests, Protected Forests and Unclassed State Forests, under the Indian Forest Act, 1927. The recorded forestland of the State (11879 sq.km.) is 1.54\% of the recorded forest land of India (770078 sq.km.).

The forest lands are identifiable on revisional survey maps but demarcation on ground does not exist in all cases.

10|Page Land Governance Assessment Framework - West Bengal 
West Bengal changed its forest policy in line with National Forest Policy of 1988, by switching over to Joint Forest Management (JFM), as pioneer in the country, and giving more priority to people's need and biodiversity conservation than commercial exploitation and revenue earning. There is a need to institutionalize and legalize this JFM to ensure that people's participation is independent of Forest department initiative. People- forest interaction for collection of NTFP has been addressed through JFM. Now the monopoly rights for collection of NTFP have been given to LAMPS through WBTDCC. The LAMPS in several forest areas, as collector's cooperatives have applied for the community forests rights under the provisions of FRA 2006, which is pending at the level of higher authorities. Till December 2013, a total of about 31000 individual pattas and 312 community pattas have been issued by the authorities though the number of cases rejected is quite high. Some critical issues which have been discussed in the background note for this panel are: a) conversion of forest villages into revenue villages, b) to make the JFMCs coterminous with Gram Sansads and streamline those under the provisions of FRA 2006.

The key policy recommendations have tried to address the issues mentioned above by suggesting suitable measures; one important area is to endeavour to achieve functional synergy between JFMCs and provisions of FRA 2006.

Regarding rural land use, the WBLR Act has imposed several restrictions on change of land use, particularly from agricultural to non- agricultural purposes. The process for filing application is quite complicated and the disposal process is time-consuming with the main consideration whether the proposed change is likely to affect adversely the interest of any person or will have deleterious effects on environment. However, land use change has to happen to keep pace with rapid urbanization and infrastructure development across the state. The government needs to review the restrictions on effecting land use changes and take a more practical view on this based on present day realities.

\section{Key points from Panel 3 : Urban Land Use, Planning and Development}

West Bengal has witnessed slightly higher decadal urban population growth (31.89\%) than the national average which is $31.16 \%$. The problems faced by the urban land governance are manifold, like scarcity of developed urban land, accumulation of housing backlogs, inadequate infrastructure and services and environmental degradation. The overall situation gets further worsened with the rapid increase in number of urban poor.

Land use planning is understood as a systematic and iterative procedure carried out in order to create an enabling environment for sustainable development of land resources which meets people's needs and demands. It assesses the physical, socio-economic, institutional and legal potentials and constraints with respect to optimal and sustainable use of natural resources and land and empowers people to make decision about how to allocate those resources.

The $74^{\text {th }}$ Constitutional Amendment Act, 1992 and the flagship scheme of the central government, Jawaharlal Nehru National Urban Renewal Mission (JNNURM) brought about much desired changes in the paradigm of thinking, functioning and implementing urban planning and development management process. As a result the planning processes are also undergoing changes, where policy decisions ought to be taken through greater participation of private sector, non-government organizations, and the civil society in which the marginalized and vulnerable poor are included.

The state has a series of acts and regulations which have made adequate and mandatory provisions on urban land use planning but somewhat non-priority approach on this important aspect of urban governance has given rise to informal tenureship across all the cities and towns

11|Page Land Governance Assessment Framework - West Bengal 
in the state. To cope with the urban growth several steps have been taken by the government by creating 10 Development Authorities and Planning Areas in the state. Developing Draft Development Plans (DDP) at the ULB level was introduced through KUSP urban reforms program. The land use plan and development is covered under component I of the DDP along with slum infrastructure, environment development etc. A study conducted by ATI in 2009 indicated that in the public consultation process the issues like encroachment, lack of open green space etc. were given priority and land issues were identified in all the cases as well. One important recommended action to address the challenges faced in urban land use planning is: setting up of modern educational infrastructure to create a cadre of technically qualified urban planners. Another important issue which needs immediate attention is the disaster management and prohibition of settlement in disaster prone urban areas. A proper DDP planning process with application of GIS for developing modern and updated plans is a priority area for consideration. A policy to adopt low cost housing for the urban poor in addition to the centrally sponsored schemes also might be given priority in policy framing.

\section{Key points from Panel 4 : Public Land Management}

Public land in broad sense means lands held by different departments of both the Central and State Governments, such as the Railways, the Defence, the Irrigation Department, Public Works Department, the Forests Department, local bodies etc. The land held by WBIIDC, WBIDC, WBSIDC are also public land. Chapter VII of the WBLR act deals with the management of land at the disposal of the state government and mandates the collector of a district.

The state of West Bengal is the absolute owner of all lands lying within its geographical boundaries. In respect of lands at the disposal of the state government, the role is that of a manager. In terms of distribution of agricultural land to land poor, West Bengal is one of the pioneer states in the country. Of the 12.14 lakh acres of land at the disposal comprising both agricultural land and homestead land the government has distributed till October, 2013 a total of 11.41 acres of land benefiting 31.41 lakh landless and land-poor persons. In selecting the beneficiaries preference has been given to the persons belonging to SCs and STs. The settles have been given heritable rights on lands, but their rights are not transferable so that they can hold on the lands given to them. In the process formalization of land possession by the poor and particularly homestead land has been achieved.

Settlement of land for non- agricultural purpose is also done by the collector of the district with prior approval of the L\&LR Department. Such settlement may take place with a person, a group of persons, an organization or a statutory body on such terms and conditions as may be specified by the department. A total of 6.43 lakh acres of non- agricultural land has vested in the state and a major part of which has been utilized for the purpose of distribution to the land poor as homestead, transfer to other departments, settlement on long-term lease etc. and some land has been kept for development purpose. Settlement of ferries, fisheries, part- vested tank is done by the DL\&LRO.

Acquisition of land under any land acquisition Act is done by the L\&LR Department. Land acquisition whether for public purpose or for private company takes place through the L\&LR Department.

In a state like West Bengal the government does not own large tracts of non-agricultural land in compact blocks. Even if a few blocks are available they are situated at places which are not endowed with infrastructure facilities. Infrastructure facilities are available in the areas where land does not belong to government. But land is needed for growth in industry which is necessary to reduce dependence on agriculture for sustaining a growing population and improving the standard of living. There would be limitation on procuring land directly from farmers. State would be required to exercise its power of 'eminent domain' to acquire land.

12|Page Land Governance Assessment Framework - West Bengal 
Strategies would have to be developed so that minimum use of force is resorted to, and pain caused to the affected families is minimized by providing them adequate compensation, which includes the benefit of the use of acquired land in future, resettlement etc.

In December 2012, the Government of West Bengal came up with a comprehensive 'land allotment policy' applicable for land owned or held by any department or agency funded by the government. The L\&LR Department is the nodal department for inter-departmental transfer of land or long-term lease of land at the disposal of the government. Market value of land to be settled on long-term lease would be based on the sale deeds of the area or the market price as determined by the Inspector General of Registration, whichever is higher.

The policy states that land meant for commercial use shall invariably be auctioned to the highest bidder. The new Land Acquisition law (Right to fair Compensation and Transparency in Land acquisition, Rehabilitation and Resettlement Act, 2014) has replaced the colonial Land Acquisition Act, 1894. The new Act is inclusive, exhaustive and has taken into account many aspects which were earlier not covered in 1894 Act.

\section{Key points from Panel 5 : $\quad$ Transfer of Large Tracts of Land to Private Investors}

Since the government of West Bengal did never have large tracts of land the question of transfer of such land to the private investors has never arisen. However, small parcels of land have been settled with the private investors for non-agricultural purposes strictly in accordance with section 49(5) of the WBLR Act read with Rule 20A (6) and the principles of settlement for nonagricultural purposes contained in the WBLR Manual, 1991. According to the decision of the state government of 2012, lands to be used for non-agricultural purposes have to be settled on long-term basis for 99 years with option for successive renewals. Land meant to be used for commercial purposes shall be invariably auctioned and settled with the highest bidder. Such auction should be given wide publicity including through internet.

Thus attempt is being made to meet the need of industries from whatever land is available with the government. Previously attempt was made to acquire large tracts of land under the LA Act, but such attempt met with stiff opposition from all quarters. The policy of the present government is not to acquire land forcibly for any purpose whatever. Hence the need of land for private industries is sought to be met by land from Land Bank of the government and acquisition with the consent of landowners.

For developmental purpose, be it in the name of public purpose or for setting up of private industry, land transfer or acquisition involves displacement and as it happens everywhere economically and socially disadvantaged groups suffer more in the process. However, developmental needs cannot be entirely compromised for it is also the condition for the transformation of a nation from a low income to a high income group. But care has to be taken that rehabilitation and resettlement schemes are well suited to the needs of the displaced population.

\section{Key points from Panel 6 : Public Provision of Land Information: Registry and Cadastre}

In West Bengal, Land Information System has three distinct divisions, i.e. (a) cadastral map (b) Record of rights (c) registration of conveyance instruments for transfer of land and mortgages. While cadastral map and record of rights are prepared by the Land and Land Reforms Department, registration of deed of conveyance for transfer of land and mortgages is administered by the Finance Department.

The Bengal Tenancy Act 1885 for the first time provided the legal basis for preparation of revenue village maps following the method of cadastral survey. On the basis of such maps the records of rights were prepared. The RoRs contained particulars relating to each tenant or

$\mathbf{1 3}$ | Page Land Governance Assessment Framework - West Bengal 
occupant of the land or sharecropper, the name of each tenants or occupant's landlord, classification and quantity of land of each tenant etc. The RoRs were revised in the fifties under the WBEA Act, 1953. Revision of RoRs was again taken up in 1975 under the WBLR Act, 1955, and is not complete yet in respect of all the mouzas of the state.

The formalization of land possession in rural areas under the provisions of WBLR act was taken up to settle vested land with landless and land poor, and sharecroppers up to one acre if the person together with member of family owns less than one acre. Homestead land is also settled under the appropriate provision up to 0.08 acre. Priority has been given to the persons belonging to SC, ST etc. and such rights are heritable but not transferable. Till October 2012, a total of 11.41 lakh acres of land has been distributed benefitting 31.41 lakh persons. Formalization of land possession was also done under the provisions of Homestead Act 1975 up to the extent of 0.08 acres. Till date the families benefitted under this provision is about 3.26 lakhs. The government has taken up homestead allocation to absolute landless poor by implementation of schemes (NGNB) under which land may be purchased at market price or distribution of vested land fit for homestead.

The tenants within the city of Kolkata (first 100 wards) and Howrah municipal area known as thika tenants and tenants existing in the urban areas beyond the city of Kokata known as nonagricultural tenants did not enjoy well-protected rights before 1949. Thika Tenancy Act and Non-Agricultural Tenancy Act, 1949 between them covering all the urban areas of West Bengal provided for more secure rights to the tenants of urban areas. Their rights were made more secure by the later Acts.

In the year 1990 West Bengal started digitizing the record of rights. Presently the RoRs are completely digitized except those of 1473 odd revenue villages of three districts. Those records are expected to be completed within a short period of time. The digitized maps and records of rights are being updated and managed by software named "Bhuchitra". The map data and textual data of records of rights are available in website http://www.banglarbhumi.gov.in, which can be accessed by the interested citizens

West Bengal is first State to integrate digitized cadastral maps with related RoR. The State has recently amended sec. 50(2) of West Bengal Land Reforms Act, 1955 to facilitate e-delivery of land records by affixing digital signature. West Bengal has rolled out 'over the counter' Information services to provide copy of RoR, Plot Information and Plot Map from counter within 5-15 minutes through process re-engineering. This has enhanced speed of service delivery to great extent.

Analysis of the existing mechanism for recognition of rights over land, clearly indicate that there are robust laws and procedure for formalization of land possession by poor. But, implementation of process for formal recognition of possession needs to be more transparent. Appropriate steps need to be taken for ensuring that RoRs are recorded as soon as the patta is granted to the land-poor families.

As a step to reduce large scale evasion of stamp duty particularly by the poor people in rural area primarily due to high rate of stamp duty, the panel recommended for the reduction in the stamp duty to ensure that each property transfer is registered.

State Government has enacted West Bengal Rights to Public Service Act 2013 to establish service standard and ensure providing service as per established service standard. Under this Act, officials failing to give service as per standard will be punished. It has been recommended by the panel that the service standard for all services needs to be established and notified and service should be ensured. For this purpose, skilled manpower strength should be increased and investments in modern infrastructure need to be made. A proper mechanism should be put in place to monitor service delivery standard. However, the shortcoming that needs mention is that

14 I Page Land Governance Assessment Framework - West Bengal 
RoR has not been maintained update by incorporating all the changes as a result of transfer, inheritance etc., that have taken place since the revision of RoRs. Attempt was made to simplify the process of mutation in 2009. However, the process is still not simple. Moreover, the tone and tenor of the existing procedure suggests that the entire responsibility rests with the transferees or successors. The government overlooks the obligation cast upon it by section 50 of WBLR Act to keep the record up-to-date, steps should be taken immediately to make a special drive to record the changes that have taken place.

\section{Key points from Panel 7 : $\quad$ Land Valuation and Taxation}

The levy and collection of stamp duty and registration fees during the land/ property transfer are regulated under the Indian Stamp (IS) Act, 1899 and the Indian Registration (IR) Act, 1908 and the Rules framed there under as applicable in West Bengal.

West Bengal Municipal Act 1993 provides guidelines about the power to levy Property Tax on lands and buildings within the areas of urban local bodies (ULBs). Property tax is one of the main sources of internal revenue of the ULBs. Provisions have been made to determine such property tax on the basis of a formula. But such tax (annual) shall not exceed 30\% of the annual value of the land or building concerned.

At present in West Bengal the market value of any property (land, building) is determined through the system of the Computerisation of Registration of Documents (CORD) software started in the year 2000. The West Bengal Stamp (Prevention of Under-Valuation of Instruments) Rules 2001 was introduced with effect from 1.3.2001. In the changed scenario of computerisation, the process of determination of market value has been changed accordingly and a digitised market value database covering all the plots under the jurisdiction of the registering officer has been installed and interlinked with CORD software. The digitised market values are periodically revised according to the field situation. In November 2011 online assessment of market value and e-payment of stamp duty and registration fees have been introduced. The discretion used in determination of property tax base and rate as in the present system should be reduced. Market Value Data Base (MVDB) for all registration offices has been prepared and is used for assessment of market value by CORD. Predefined appreciation and depreciation factors were incorporated in CORD for use with MVDB during such assessment to avoid subjectivity in assessment of market value. The system is now working in all 241 registration offices of the state in a PPP model with three technical support providing private partners

Property tax is one of the main sources of internal revenue of the ULBs. Since enactment of the Calcutta Municipal Act, 1923, two systems of assessment of lands and buildings are followed in the Urban Local Bodies, namely Annual Rental Value (ARV) System and Capital Value Method. With growing rate of urbanization and change in the socio-economic scenario the flaws in these two systems are being surfaced that makes the system of assessment of lands and buildings more complex.

The panel discussions indicated that there is a need for coordination among the different layers of the government in use of Market Value Data Base (MVDB) in CORD not only for the purpose of collection of stamp-duty revenue/registration fee as currently done, but also for calculation of base of property/land tax and land revenue.

The panel also recommends reduction of stamp duty in respect of transfer of lands between the poor people who in recent times are avoiding registration because of pre-determined high rate of stamp duty not based on actual prices at which transactions take place between the poor.

Key points from Panel 8 : Dispute Resolution

$\mathbf{1 5 |}$ Page Land Governance Assessment Framework - West Bengal 
Since resolution of dispute by the civil courts being procedure-bound is time-consuming and costly the WBLR Act has barred jurisdiction of civil courts in virtually all matters dealt with in the Act. The mechanism of dispute resolution is this - the disputes either between the raiyats, or between the government and the raiyats are decided by the revenue officers as primary authorities. Appeals lie before the DLLRO or the other senior officers designated and appointed for the purpose of hearing appeals. Against the decisions of the appellate authority aggrieved party may approach the LRTT. The decision of the Tribunal can be challenged before the Division Bench of the High court earmarked for this purpose. West Bengal LRTT was created in 1997 under the West Bengal Land Reforms \& Tenancy Tribunal Act 1997, which started functioning in 1999 for expediting disposal of disputes under six specified Acts, including the WBEA Act 1953 and WBLR Act, 1955. This was done in pursuance to the amendment of the Constitution of India and insertion of Article 323B. The Tribunal has so far disposed of in addition the original applications filed before it 30000 cases transferred to it from the High Court.

In order to augment the speed of disposal of record correction cases, mainly mutation cases by the revenue authorities, it is recommended that, a system should be introduced for interlinking the two departments so that simultaneous updation of Land Records can be done when any transfer is executed (through the Registration Department). This is possible in West Bengal as Land Records maintained by the Revenue Department (i.e. the Land Reforms Dept.) have all been computerized, and the functioning of the Land Registration Department has also been fully computerized. The bridging between the two systems will keep the records updated and thereby reduce the scope of disputes in this sphere to the minimum. The cost of litigation borne by the litigant varies from court to court. In cases before the Revenue Authorities, the cost of both the litigant and the Government is minimal, as the litigant can plead his case in person or through his representative, who may be a lawyer.

However, in Civil Courts, a litigant has to bear a considerable amount of cost towards the fees of lawyers for pleading his case. Poor litigants may take the help of Legal Aid Services, but the prevailing system in the State does come to much of help for them

\section{Key Points from Panel 9: $\quad$ Review of Institutional Arrangements and Policies}

Board of Revenue, the apex administrative body, which was active in colonial state formation during the company period, played a crucial role in revenue management prior to the departmentalization of state affairs. In the year 1996-97 Board of Revenue was abolished and merged with Land \& Land Reforms Department.

The L\&LR Department deals with land issues and as custodian of all government lands acts as a coordinator when any situation arises for allotment of any government land to any department or any public body for public purpose. At the district level this coordination is done by the DLLRO who is also an Additional District Magistrate and Additional Collector.

The land policy of West Bengal may be inferred from the existing legislations. All activities relating to land and land reforms and acquisition of land are carried out in this state under the unifying command of the Land \& Land Reforms Department and this department makes laws and formulates policies for land administration. All activities are to be carried out in accordance with relevant Acts, Rules made there under and Land \& Land Reforms Manual and Land acquisition Manual. The Directorate of Land Records and Surveys is the main agency through which all the provisions of the WBLR Act are implemented. So, there is hardly any scope of overlapping in land and land reforms administration in the state and land acquisition under any LA Act is done by the Collector of the district as an agent of the state government in the land reforms department.

16|Page Land Governance Assessment Framework - West Bengal 
The different government departments or public bodies like municipalities, panchayats etc. maintain inventories of land owned and managed by them but the records are not updated on a regular basis. The land properties belonging to the public bodies are not recorded in the r-o-r maintained in the office of the BLLRO. In order to ensure the maintenance of the information related to land rights, the panel recommended that a drive needs to be initiated by the government for ensuring all the land properties being physically verified, records and registers updated jointly in collaboration with the L\&LR department and field offices.

In dealing with land matters, no formal mechanism to ensure coordination has been set up. Processes of dealing with land by different agencies are not regulated by the same set of rules, manuals and administrative orders. Hence there remains scope for differences of processes and procedures followed for dealing with land by different public institutions.

Most of the land related major Acts in West Bengal were enacted much before ecology and environment issues came in the development discourse in a strident way. In November 2005 West Bengal government promulgated the landmark environmental notification, the East Kolkata Wetlands (Conservation and Management) Ordinance (enactment in 2006) to safeguard the 12,500 hectares (comprising 46\% water body and 39\% agricultural land) fragile wetland located in the eastern fringes of the city of Kolkata. Moreover, the agenda of disaster risk reduction has to be incorporated in collaboration and consultation with the Disaster Management Department while preparing the land use maps under the direct supervision of the L\&LR Department.

Considering all the issues related to an effective and efficient land governance system in West Bengal, the panel recommended that the L\&LR department should have a better human resource infrastructure by way of filling up of the large vacancies in field offices along with a policy for staff capacity development equipping the HR for improved and citizen-friendly service delivery. 


\begin{tabular}{|c|c|c|c|}
\hline \multicolumn{4}{|l|}{ WEST BENGAL POLICY MATRIX } \\
\hline Issues & recommendations & responsible & Monitoring indicator \\
\hline $\begin{array}{l}\text { 1. Rural land records are not updated regularly and often lack } \\
\text { spatial reference; insufficient coordination between } \\
\text { departments }\end{array}$ & $\begin{array}{l}\text { 1.1 Identify \& implement on a priority basis, cost-effective ways of } \\
\text { verification \& updating textual records based on ground reality } \\
\text { 1.2 } \begin{array}{l}\text { Develop and implement mechanism for continued updating of } \\
\text { textual and spatial records, also to overcome need for special } \\
\text { drives/ mission modes. Develop a comprehensive program to }\end{array} \\
\text { accomplish this in a specified and realistic time frame } \\
1.3 \text { Assess the resource requirements for record maintenance, } \\
\text { verification and resurvey, and requirements for sustainability } \\
\text { (such as changes in fee structure) }\end{array}$ & L\&LR & $\begin{array}{l}\% \text { of records verified and } \\
\text { updated } \\
\% \text { of records identified } \\
\text { on maps } \\
\% \text { of area mapped with } \\
\text { land holder identified } \\
\% \text { of area mapped with } \\
\text { land holder identified } \\
\text { having documentation of } \\
\text { tenure (gender } \\
\text { disaggregated) }\end{array}$ \\
\hline $\begin{array}{l}\text { 2. Urban land records are incomplete and not spatially referenced; } \\
\text { High level of buildings is constructed in violation with urban } \\
\text { regulations } \\
\text { High number of plots have no records.. Constructions of many buildings } \\
\text { are violating the prescribed norms; The state does not have a policy to } \\
\text { deal with informal tenureship in urban areas }\end{array}$ & $\begin{array}{l}\text { 1.1 Establish a base map for all cities, using existing information as } \\
\text { much as possible; establish a common spatial data infrastructure } \\
\text { focusing on maintenance and updating of records. } \\
\text { 1.2 } \begin{array}{l}\text { Define workflows and responsibilities for urban land } \\
\text { management, records maintenance, building permits and } \\
\text { monitoring/enforcement, re-engineer where possible }\end{array} \\
\text { 1.3 } \begin{array}{l}\text { Clearly assign institutional responsibilities, assess resource } \\
\text { requirements and identify gaps, in order to arrive at systems that } \\
\text { are effective and sustainable. }\end{array} \\
\text { 1.4 Review laws and systems in place for formalization of urban } \\
\text { housing. }\end{array}$ & $\begin{array}{l}\text { Revenue } \\
\text { Authorities } \\
\text { ULB }\end{array}$ & $\begin{array}{l}\% \text { of area mapped with } \\
\text { land holder identified } \\
\text { having documentation of } \\
\text { tenure (gender } \\
\text { disaggregated) }\end{array}$ \\
\hline $\begin{array}{l}3 \text { Records are not updated automatically and not all transactions } \\
\text { registered } \\
\text { Cost of recording of property transfer is very high and evasion of stamp } \\
\text { duty is particularly common amongst the rural poor. Record of rights also } \\
\text { does not reflect the real ground situation due to time lag between } \\
\text { registration and mutation. Not all encumbrances are recorded }\end{array}$ & $\begin{array}{l}\text { 3.1 Strengthen system for interlinking/bridging registration and } \\
\text { mutation so that simultaneous updating of Land Records can be } \\
\text { done when any transfer is executed (through the Registration } \\
\text { Department). This is possible in West Bengal as Land Records } \\
\text { maintained by the Revenue Department (i.e. the Land Reforms } \\
\text { Dept.) have all been computerized, and the functioning of the } \\
\text { Land Registration Department has also been fully }\end{array}$ & L\&LR & $\begin{array}{l}\text { Ratio of textual to spatial } \\
\text { records } \\
\text { Ration Registered vs. } \\
\text { mutated transactions }\end{array}$ \\
\hline
\end{tabular}

$\mathbf{1 8 | P a g e}$ Land Governance Assessment Framework - West Bengal 


\section{4. legal and administrative opportunities to enhance women's access} to land are not used sufficiently

Less than $15 \%$ of land recorded to physical persons is recorded in the name of women either individually or jointly. This is despite the range of policies in place to enhance women's access to land. WB Government policy is to issue patta (deed of title) in the name of women or joint patta (both in the name of wife and husband) for distribution homestead plot, although joint patta records are not maintained individually. More than $90 \%$ of pattas were issued in the name of women between 2011-2014.

\section{Effectiveness of public land redistribution for eligible poor and} the actual possession for granted public land needs strengthening

West Bengal policy is to use public land for allocation of homestead plots to absolute landless and homeless through legislation and government schemes giving preference to women, ST and SC. Government scheme Nijo-Griho-Nijo-Bhumi Prakalpa in Oct 2011 (My Home My Land scheme) to settle 5.5 lac landless poor and provide up to 0.05 acre.

$3,26,653$ persons have been given land with raiyati status creating equivalent number of tenures; Distribution of ceiling surplus land to ST/SC 31,36,297 persons (aug 2013). Data indicate that patta has been granted to 3141232 persons but 2457347 (78\%) patta recipients are recorded in the RoRs and more importance is to be given to security of tenure by including it as one of the objectives of JNNURM. computerized. The bridging between the two systems will keep the records updated and thereby reduce the scope of disputes to the minimum.

3.2 Reduce stamp to encourage that all property transfers are registered.

4.1 Review effectiveness existing policies and explore opportunities for amendments to enhance women's access to land ( e.g. awareness raising legal rights women; reconsider opening cases land grants without joint titles; mandatory recording women names in ROR -partitionable joint rights or sole rights-; priority allocation of land to ST women requiring amendment of WBLR Act, 1955; exemption/ reductions payable land revenue; stamp duty, land and property tax;

4.2 Introducing 'gender' parameter in recording of information in Record of Rights to help tracking of progress with respect to women land rights.

4.3 Promote representation women working on NTFP in the Large Sized Multipurpose Cooperative Societies (LAMPS) through West Bengal Tribal Development Cooperative Corporation (WBTDCC)

5.1 Identify available land for redistribution as well as the number of land- or homeless who could benefit from land distribution.

5.2 Ensure that all patta-holders who have been allotted land have updated land record (RoR) issued in their names including women's names

5.3 Monitor use and land transfer of land distributed to poor beneficiaries' u/s 49(1) of WBLR Act

5.4 Develop effective steps to ensure continued possession and effective use of land that has been redistributed to eligible marginal groups

5.5 Identify landless poor people occupying a homestead through time bound survey and issue patta;

5.6 Consider extension of benefits to the eligible persons occupying homestead land after 26th June 1975, by amending the West Bengal Acquisition of Homestead Land for Agricultural Labourers, Artisans and Fishermen Act 1975.

5.7 Review strategy for tenure upgrading in informal settlements; increase effectiveness and efficiency

\begin{tabular}{|l|l|}
\hline L\&LR & $\begin{array}{l}\text { Share of ROR held by } \\
\text { women } \\
\text { Share of pattas issued to } \\
\text { women } \\
\text { (share of women holding } \\
\text { land?) }\end{array}$ \\
\hline $\begin{array}{l}\text { L\&LR } \\
\text { Local govt. }\end{array}$ & $\begin{array}{l}\text { \% of area mapped with } \\
\text { land holder identified } \\
\text { having documentation of } \\
\text { tenure (gender } \\
\text { disaggregated) } \\
\% \text { land less ness/ } \\
\text { homestead less }\end{array}$ \\
\\
\end{tabular}

19|Page Land Governance Assessment Framework - West Bengal 
6 Lack of clarity in assignment of institutional responsibility for forestland and tribal land prevents assigning ownership,

There are 126 non - revenue forest mouzas in the state, 126 chitmahal mouzas (enclaves in Bangladesh) and 22 diluvated mouzas in South 24 Parganas district which are not surveyed and recorded creating gap in recognizing the rights of people. Common land within forest areas is not clearly identified. Tribal land alienation continues with high level of non ST communities in forest villages.

Recent improvements in implementation of Scheduled Tribe and Other Traditional Forest Dwellers (Recognition of Rights) Act, 2006; Non-

Forest Tree Act in 2006; National Forest Policy, 1988; around 4000 Joint Forest Management Committees (JFMC) formed and functioning protecting nearly 500,000 hectares of degraded forest area, but JFCM not legally recognised; Under FRA are 30,879 individual and 312

Community tenures create. Forest Department administration well organised but information gap with revenue department.

\section{Urban development and expansion is unplanned and reactive,}

with infrastructure put in place afterwards

An urban land use policy does not exist although a legal framework is in place for urban development and decentralized planning (West Bengal Town and Country (Planning and Development) Act, 1979 and West Bengal Municipal Act, 1993 (as amended in 2007) W.B. District Planning Committee Act 1994, and W.B. Metropolitan Planning Committee Act 1994 along with the W.B. District Planning Committee Rules 1994). All 127 Municipal bodies/ cooperations have draft development plan with support Kolkata Urban Services for the Poor (KUSP). Policy for low cost housing and services exists but implementation not clear; Planned 1 , 58,000 dwelling units under BSUP 58\% completed; for IHSDP, planned 52,000 dwelling units $83 \%$ completed

\section{Public lands not protected nor managed effectively; Transfer of} public land to private investors does not always serve growth and contribute to inequity and conflict

Most public land is not clearly identified on the ground nor on maps; The amount of land at the disposal of the L\&LR Department differs from amount of land in ROR with discrepancies particularly around public land settled with poor people (Section 49(1) of WBLR Act 1955) and land settled through lease with private individuals and institutions; Huge quantum of government land in urban areas is encroached.

Policies and procedures are in place for allotment public land to private
6.1 Full implementation FRA rules and process to protect rights tribal peoples and improve synergy between FRA and JFMC 6.2 prepare cadastral maps and records of rights for forest villages / 126 non-revenue forest mouzas and common lands in forests;

6.3 Define responsibilities and workflows involved in forest land management and assignment of ownership/CPR rights and reengineer where possible; synchronize records maintenance between Forest Department and L \& LR Department;
7.1 Regular updating of urban land use and creation of data base to record the changes in use

7.2 Review the justification for restrictions on urban land use, ownership and transferability, eliminate those that do not serve any useful purpose and improve enforcement.

7.3 Develop and maintain databases that allow for routine and effective implementation of land use restrictions. Simplification of rules governing the permission of a change in use and narrow the discretion of government officials in authenticating such changes.

7.4 Review and assess the resource requirements for town planning; urban development and design strategy to address capacity constraints;

7.5 Review implementation low-cost housing policy and accelerate the implementation of Rajib Awas Yojna (RAY).

8.1 Identification and recording remaining public lands, and establish unified system for land possessed by different State / Central Government Departments and Public Sector Corporations

8.2 Making public land database easily accessible and interpretable and enabling syncing of public land information across spatial and textual records along with ground situation

8.3 Inventory of land that has been privatized following encroachment and Restoration of Govt lands fraudulently settled with private persons

8.4 Develop State Land Use and zoning policy for rural and urban

\section{Forestry \\ $\%$ of land mapped}

department

GP

dentified as CPR/public

land + management

responsibilities clearly

identified (CPR or not)

ULB

$\%$ of urban land with

claimant identified/

documented evidence

20|Page Land Governance Assessment Framework - West Bengal 
parties (Land Allotment Policy document through issuance of Administrative Order (No. 6686 - LP/1A-18/ 2012 dated 26 December 2012; publicly available guidelines on procedure of transfer of land to private investors, Rehabilitation and Resettlement Scheme (R\&R Scheme), 2011). Total area of land transferred to other departments is 132,675.33 acres till Dec 2013. However, lack of transparency in allocating public land to private parties; information is not made publicly available; lack of clarity on paying compensation. Multiple agencies involved in public land management like WBIDC, WBIIDC, WBSIDC in addition to FD and L\&LR dept. There is no avenue for coordination and dispute prevention between central and state governments over large scale acquisition of land where the surface right transfer is dealt with by the state while sub-soil rights (e.g. coal mine) are considered by central government

\section{Improve tax collection and adjust land valuation procedures to reflect real values}

WB set up in 1979 a Municipal Finance Commission in 1979 and a Central Valuation Board to overcome the deficiency of under valuation of properties in the municipal areas; All 239 registration offices are computerized and there is a clear and transparent process in determination of market value for property through CORD (Computerisation of Registration of Documents) software. However, there is difference between data in land valuation register maintained by the registering authorities and value at which land transaction takes place; updating of the register is sporadic;

In WB collection of property tax is regular (around 80\%) and tax collected exceeds costs. In particular government departments are not paying taxes that are due.

\section{Enhance effectiveness of dispute resolution mechanisms and}

\section{develop monitoring capacity}

There are huge numbers of piled up long pending cases in the State, but WB has sufficient legislation for land dispute resolution (West Bengal Estates Acquisition Act, 1953; West Bengal Land Reforms Act, 1955, land, identifying viable land for distribution to poor, zoning of industrial areas, protect remaining public land and assign responsibilities for implementation and monitoring

8.5 Review and streamline responsibilities and procedures and assess resource requirements for every department having public land and legal responsibility for safeguarding public property, prevent and remove encroachment, improve coordination; consider identifying a nodal agency from both state and central government for acquisitions involving both levels.

8.6 Establish independent benefit assessment system needs to be put in place so that maximum benefit can be accrued to the public.

8.7 Regular publication of transfers and lease/rent payment, which also allows follow-up; Ensure that all allocations of public land to private parties are uploaded in the departmental website to maintain transparency (WBIDC is following this practice).

8.8 Consider third party monitoring to ensure compliance of contractual obligations by investor and grievance mechanisms

8.9 Implement and enforce a rehabilitation and resettlement policy Upgrading compliance parameters to global best practices

9.1 Identify and publicize revenue potential vs. actual collection for all major cities; Review cost to government of exemption of taxes to various institutions and religious trusts

9.2 Improve recording of holdings and updating of records to increase the revenue (see also 2)

9.3 Review and streamline procedures for tax collection assess resource requirements to improve the administrative capacity; and improve procedures to collect tax from defaulters, Take up issue that substantial part of outstanding property tax are to be paid by state and central departments and work out an acceptable solution for all the parties involved

9.4 Review coordination among the different layers of the government updating/ using Market Value Data Base (MVDB) in CORD for collection of stamp-duty revenue/registration fee and also for calculation of base of property/land tax and land revenue, also to reduce discretion in determination of tax base, which is essential for a transparent and efficient tax regime

10.1 Develop scheme for categorization/recording of disputes for al courts/instances so as to allow identification of legislative/regulatory bottlenecks, type of land dispute cases that are increasing and causes for slow disposal.

10.2 Review and streamline procedures and identify steps towards

\section{ULB CVB}

\section{$\%$ Property tax}

collection/ potential by municipalities

Courts LRTT

\section{For various courts/}

instances \& categories of disputes

Level of pending land related

21|Page Land Governance Assessment Framework - West Bengal 


\begin{tabular}{|c|c|c|}
\hline $\begin{array}{l}\text { West Bengal Thika Tenancy Act, 2001, West Bengal Land Reforms \& } \\
\text { Tenancy Tribunal Act, 1997) The Land Reform Tenancy Tribunal } \\
\text { (LRTT) is in operation for quick disposal of conflicts. } \\
\text { Dispute resolution through Civil Court is very time consuming and } \\
\text { repeated adjournment in Civil Courts due to various reasons causes } \\
\text { unnecessary delay in disposal of cases; Cost of proceeding at Civil Court } \\
\text { is relatively high which makes it less affordable by poor }\end{array}$ & $\begin{array}{l}\text { speedy disposal of cases by ROs, appellate authority and the } \\
\text { LRTT by preventing unnecessary adjournment, timely } \\
\text { submission of proper records and papers by BLLRO, limit the } \\
\text { number of dates for disposal allowed and reduce time span. } \\
\text { 10.3 Review and assess resource requirements to increase } \\
\text { effectiveness and efficiency of dispute resolution system }\end{array}$ & $\begin{array}{ll} & \text { disputes } \\
-\quad & \text { No. of cases treated; } \\
-\quad & \text { Length }\end{array}$ \\
\hline $\begin{array}{l}\text { 11. Revision of Legislative and institutional framework to eliminate } \\
\text { outdated and ineffective sections, and update specific sections; and } \\
\text { improve institutional coordination, efficiency and effectiveness } \\
\text { WB has comprehensive legislations embodying the policies on land. } \\
\text { However, land related legislations in the State have largely ignored } \\
\text { ecological and environmental issues. There is no mechanism of tracking } \\
\text { the progress of implementation of different policies by the public. Though } \\
\text { there is a well-defined reporting system on a regular basis within the } \\
\text { department but the information is not available to the public. } \\
\text { As per legislation, institutional mandates relating to administration of } \\
\text { land is very clear in the State; The role and function of different layers of } \\
\text { L\&LR Department is clearly defined; there is no scope of overlapping. } \\
\text { However, different public institutions deal with land-related matters quite } \\
\text { differently and there is lack of coordination in practice. }\end{array}$ & $\begin{array}{l}\text { 11.1 Review justification for legal restrictions on land use, } \\
\text { ownership and transferability, eliminate those that do not serve } \\
\text { any useful purpose and improve enforcement and access to } \\
\text { legal services .(e.g. sale of land cultivated with barga; tribal } \\
\text { land alienation, community rights in forest villages) } \\
\text { 11.2 review, rationalize and streamline the administrative structure } \\
\text { for land administration; reduce discretions at all levels and } \\
\text { inventory of resource requirements and resource availability at } \\
\text { all levels }\end{array}$ & \\
\hline
\end{tabular}

\footnotetext{
22 Page Land Governance Assessment Framework - West Bengal
} 


\section{Introduction}

Land governance refers to institutional and legal systems and procedures on ownership, use and transaction of land. The purpose of land governance is to ensure that the institutions, legal frameworks, process \& procedures follow the principles of equity, efficiency, transparency and accountability as well as positively contribute to economic and social development, and environmental sustainability. Land governance assessment framework is a tool that captures the existing legal and institutional scenario of land governance on basis of the above principles, and points out where further action is necessary. Land governance assessment framework for West Bengal is no exception.

A system of tenure explains how people, communities and others gain access to land, forests, and fisheries, and how those are regulated by societies. These tenure systems determine who can use what resources, for how long and under what conditions. Such systems may be either based on written policies and laws or on unwritten customs and practices. As environmental degradation and climate change reduce availability of land, forests and fisheries, tenure systems are put under pressure by world's growing population and food security situation.

The land situation in West Bengal is marked by three major characteristics, a) Very high population density, and skewed land mass ratio, compared to much of the rest of India; b) Large scale successful and enduring land reform by way of land redistribution to the landless and registering the sharecroppers as tillers on government records; and c) Very large population of marginal and small farmers and landless labourers, as well as urban landless. Thanks to successful land reforms, strong local governance institutions, and adaption of green revolution technologies, West Bengal has seen high growth in agricultural production for nearly two decades though now on decline giving rise to a new set of challenges on land governance.

Land governance in West Bengal has four most remarkable features: a) government's enduring commitment to pro-poor land reform, b) excellent progress on updation and digitization of land records, and c) presence of strong and capable land administration down to grass roots level, d) Well articulated laws and procedures of land governance except in a few emerging areas like environment .

Land Governance Assessment Framework (LGAF) is a diagnostic tool to assess the status of land governance at country level in a participatory process that draws systematically on local expertise and existing evidence rather than on outsiders. It is a global initiative developed by the World Bank in partnership with FAO, UN Habitat, IFAD, IFPRI, the African Union, and numerous bilateral partners. The exercise has been carried out or being carried out in around 35 countries along with six states in India. In few countries like Brazil and India it is being carried out at sub-national level. For West Bengal, Landesa was assigned the responsibility of coordinating the entire exercise in the state under the overall supervision of the State Director (hereinafter referred to as the State Coordinator of LGAF).

The process of LGAF studies is based on a well thought and tested methodology. A team of expert investigators and panel members from a wide range of sectors/stakeholders was selected for each of the nine panels by the State Coordinator of West Bengal. The team consisted of people who have vast and varied experiences of working on a specific set of land governance indicators in the State. The expert investigators conducted secondary research for their respective indicators and compiled relevant background studies (organized by indicators) and made them available to the panellists who ranked the indicators.

Details of the findings from the secondary research by the Expert Investigators are presented in the background reports of each panel (as annexure). Initial ranking of the dimensions of each panel by the expert investigator followed by analysis and verification by panels of experts have been detailed in the assessment part of this report. Based on the findings from this exercise, a

23|Page Land Governance Assessment Framework - West Bengal 
synthesis report has been prepared which draws a conclusion from the study, spells out the strength and weakness of the state and prescribes policy recommendations for the state for better land governance in the future.

\section{Methodology}

The entire LGAF process has been guided by a framework of land governance indicators that cover five thematic areas and relate to a basic principle of governance. There are 27 "land governance indicators" (LGI).Each indicator is further broken down into a number of "dimensions" with pre-coded statements that draw on global experience (on a scale from A to D). There are in total 116 dimensions in the LGAF.

Nine expert panels organized by subject ranked the dimensions by selecting an appropriate answer among the list of pre-coded answers. The panel deliberations were based on preparatory data gathered and analysis by the expert investigator. In the final row, each panel provided policy recommendations following the.

There are nine panels as listed below. All expert investigators were invited for panel nine. This panel finalized the tenure typology and institutional map, and supported preparation of the first draft of the policy matrix.

Panel 1 Land Tenure Recognition

Panel 2 Rights to Forest and Common Lands \& Rural Land Use Regulations

Panel 3 Urban Land Use, Planning, and Development

Panel 4 Public Land Management

Panel $5 \quad$ Transfer of Large Tracts of Land to Private Investors

Panel 6 Public Provision of Land Information: Registry and Cadastre

Panel $7 \quad$ Land Valuation and Taxation

Panel 8 Dispute Resolution

Panel 9 Review of Institutional Arrangements and Policies

The steps followed for LGAF implementation in West Bengal can be summarized as follows:

(i) Selection and contracting of the state coordinator. For West Bengal, the State Director of Landesa was engaged through the organization as state coordinator (October 2013)

(ii) Inception Phase conducted by state coordinator- October 2013

- Framework review (indicators/ dimensions) and review of definitions used

- Resource planning;

- Identification expert investigators and panel composition

- Preparation of land tenure typology and institutional map of land agencies.

The Expert Investigators with in-depth subject knowledge, substantial experience were identified from various fields. Panellists were identified from a diverse field of expertise with sound subject knowledge. These individuals included senior technical officials, NGO representatives, civil society and academics. Each panel has 4 to a maximum of 8 members

(iii)Panel Background Reports (expert investigators and state coordinator) - October 2013 - February 2014

- Collection of detailed qualitative and quantitative background information; expert analysis

- Preparation of briefing note for each of the nine panel

24|Page Land Governance Assessment Framework - West Bengal 
(iv)Panels discussions - February 2014 - April 2014

- Panels sessions with specialists from different backgrounds who rank dimensions;

- Aide memoires are prepared after each panel

(v) Draft Report (State Coordinator) - April 2014

- LGAF report

- Score card

- Policy matrix

- Review of report

vi)Technical Validation Workshop and Policy Dialogue (state coordinator) - June 2014

- Validation of findings, rankings, policy matrix

- Discussion of action points

- Develop plan for follow-up action

The State Coordinator took every possible step for having government buy-in in the process. He maintained close collaboration with the designated State Nodal Officer (Director of Land Records \& Surveys) all through the process for support and guidance.

\section{Organizing the Panel Sessions}

(i) Once the panellists were identified and informed about their selection, depending on their availability the dates were finalized for discussions. In case of three panels there were more than one discussion sessions.

(ii) All panellists were given the panel LGAF briefing note, background note on the context and dimension analysis at least five days prior to meeting.

(iii) The panel sessions were moderated by State Coordinator. Landesa office staff assistances was used to organize the panels and for taking notes.

(iv) The discussions started with an introduction of the LGAF objective and way of working. The second part of the session provided panellists with a comprehensive overview of the indicators and dimensions.

(v) The analysis and assessment started with an introduction to the indicator and the results of the background analysis. Subsequently each of the dimensions was analysed one by one. Participants presented ranking followed by deliberations consensus on final ranking, and formulating policy recommendation.

\section{The Draft Report and Policy Matrix}

A synthesized draft report has been prepared by the State Coordinator to summarize the LGAF indicator and dimension findings and policy recommendations. Policy recommendations from the panel deliberations are formulated into a clear policy matrix. The policy recommendations from the panel deliberations and other investigations are to be formulated into a clear policy matrix that sets out policy recommendations in a form that can be readily communicated to policy makers and other key stakeholders.

A state-level technical validation workshop will be organized to present and discuss the results of the LGAF process with a technical group to: i) assure consistency of the results; ii) promote integration of results through interaction between the different LGAF content areas; iii) discuss and prioritize areas for policy reform; iv) propose next steps to provide sustainability to the LGAF process. This is planned in the month of June 2014.

25|Page Land Governance Assessment Framework - West Bengal 
Participants to the workshop will include a select number of panellists, complemented by public officials and land experts brought from civil society organizations (academia, NGOs, private sector organizations, practitioners in the land sector). To maintain the technical nature of the workshop, invited participants should be selected for their knowledge and expertise in the land sector.

\section{Quality Assurance}

The State Coordinator has been supported and whenever needed guided by a Technical Advisory Group (TAG) at national level consisting of panel wise experts. The TAG maintained close relationship with the SC and all the background notes and dimension analyses for each panel developed by the EIs were reviewed by the TAG experts. The TAG Coordinator also ensured that the LGAF was implemented in a standardized way to guarantee consistency and comparability. 


\section{General State Context}

West Bengal state is located at the Latitude $23^{\circ} \mathrm{oo} \mathrm{o}^{\prime} \mathrm{N}$ and Longitude $87^{\circ} \mathrm{oo}$ E. The state is situated on the eastern part of India, stretching from the Himalayas in the north to the Bay of Bengal in the south. The state has a total area of 88,752 square kilo meters $(34,267 \mathrm{sq}$. mi). It is bounded by Sikkim and Bhutan on the north, by Nepal on the North West, by Bangladesh and Assam on the east, by Bihar, Jharkhand and Orissa on the west and south-west and by Bay of Bengal on the south. The northern part of the state is a hilly region. The narrow Terai region separates this region from the plains, which in turn transitions into the Ganges delta towards the south. The Rarh region intervenes between the Ganges delta in the east and the western plateau and high lands. A small coastal region is on the extreme south, while the Sundarbans mangrove forests form geographical area at the Ganges delta. It is the $4^{\text {th }}$ largest state in terms of population having a total population of $91,347,736$ and population density of $1,029 / \mathrm{sq} . \mathrm{km}$. The state is $13^{\text {th }}$ in terms of area and is divided into 19 districts. The capital city is Kolkata. The table below gives key demographic indicators and their comparison.

Regional differences are visible in the climate. In the western plateau region, rainfall is low and variations in temperature are more common; maritime influence in the coastal region makes the climate here moderate and pleasant. The summer temperatures in the state ranges between $26{ }^{\circ} \mathrm{C}\left(79^{\circ} \mathrm{F}\right)$ and $40{ }^{\circ} \mathrm{C}\left(104^{\circ} \mathrm{F}\right)$ while the winter temperatures range from $13{ }^{\circ} \mathrm{C}\left(55^{\circ} \mathrm{F}\right)$ to $19^{\circ} \mathrm{C}$ $\left(66^{\circ} \mathrm{F}\right)$. The rainy season stretches from July to the end of September. During this period, the South-West Monsoons pick up moisture from the Bay of Bengal and blow over the state. Most of the annual average rainfall of $175 \mathrm{~cm}$ about $125 \mathrm{~cm}$ occurs during this period. Heavy rainfall of above $250 \mathrm{~cm}$ is observed in the Darjeeling, Jalpaiguri and Cooch Behar district.

\begin{tabular}{|c|l|c|c|c|}
\hline Sr. No & Indicators & Unit & West Bengal & India \\
\hline O1 & Geographical Area & Lakh Sq. Km & 0.88 & 32.87 \\
\hline O2 & Population & Crore & 9.13 & 121.02 \\
\hline O3 & Decadal Growth Rate & Percentage & 13.93 & 17.64 \\
\hline O4 & Density of Population & Population/Sq. KM & 1029 & 382 \\
\hline O5 & Urban to total Population & Percentage & 31.89 & 31.16 \\
\hline O6 & Sex Ratio & Females/1000 Males & 947 & 940 \\
\hline O7 & Literacy Rate & Percentage & 77.08 & 74.04 \\
\hline Source: Census India, 2011 & \multicolumn{3}{l}{} \\
\hline
\end{tabular}

The state has been experiencing a steady economic growth. When India has grown by 6.48 percent, West Bengal has grown by 6.55 percent as per Central Statistical Organization (CSO) report published on $18^{\text {th }}$ August, 2012. Gross State Domestic Product (GSDP growth in West Bengal was higher than the National Average for 2011-12. Growth rate in National Average of GDP at Current Prices in 2011-12 was 15.02\%, while Growth Rate in GDP in West Bengal for the same period was 15.87\%. Growth rate in National Average of GD Pat Constant Prices in 2011-12 was 6.48\%, while Growth Rate in GDP in West Bengal for the same period was 6.55\%. Similarly, the growth rate in Per Capita Net Domestic Product at Current Prices for 2011-12 for West Bengal was $14.86 \%$ as against the National Average of $13.64 \%$ during the same period.

27|Page Land Governance Assessment Framework - West Bengal 


\begin{tabular}{|l|c|c|c|c|}
\hline \multicolumn{1}{|c|}{ Particular } & Unit & $2009-10$ & $2010-11$ & $2011-12$ \\
\hline Gross State Domestic Product (GSDP) & $\begin{array}{c}\text { Rs. } \\
\text { Crore }\end{array}$ & & & \\
\hline Constant (2004-05) Prices & & 296843 & 317785 & 340234 \\
\hline Current Prices & & 405547 & 473890 & 549876 \\
\hline Economic Growth Rate as per GSDP & Percent & & & \\
\hline Constant Prices & & 8.0 & 7.2 & 6.5 \\
\hline Current Prices & & 16.6 & 17.1 & 15.8 \\
\hline Per Capita Income & Rs. & & & \\
\hline Constant Price (2004-05) & & 30372 & 32228 & 34229 \\
\hline Current Price & & 41837 & 48536 & 55864 \\
\hline Source: Economic Review & & &
\end{tabular}

\section{Land Issue in West Bengal}

The land situation in West Bengal is marked by three major characteristics, a) Very high population density, and adverse land man ratio, compared to much of the rest of India, b) Large scale successful and enduring land reform by way of land redistribution to the landless and registering the sharecroppers as tillers on government records, and c) Very large population of marginal and small farmers and landless labourers, as well as urban landless (Source Agricultural Survey of India 2011).

As per the latest (2011) Agricultural Census findings, the state has 82.16\% marginal farmers (up to one ha), $13.76 \%$ of small farmer (between 1-2 ha), total number of operational holding is $71,23,000$ and total arable land is $55,10,000$ ha out of total area of $88,87,540$ ha.

Thanks to successful land reforms, strong local governance institutions, and adaption of green revolution technologies, West Bengal has seen high growth in agricultural production for nearly two decades which is now on the wane giving rise to a new set of challenges on land governance. The table shown below will depict the augmentation in growth of food production in the state.

\begin{tabular}{|c|c|c|}
\hline \multicolumn{3}{|c|}{ Food Grain Yield in West Bengal } \\
\hline Sl. No. & Year & Quantity (Kg per hectare) \\
\hline 1 & 1961 & 1072 \\
\hline 2 & 1965 & 1117 \\
\hline 3 & 1971 & 1224 \\
\hline 4 & 1975 & 1182 \\
\hline 5 & 1981 & 1358 \\
\hline 6 & 1985 & 1538 \\
\hline 7 & 1991 & 1735 \\
\hline 8 & 1995 & 2077 \\
\hline 9 & 2001 & 2231 \\
\hline 10 & 2005 & 2511 \\
\hline Source: Ministry of Agriculture, Govt. of India \\
\hline
\end{tabular}

Land governance in West Bengal has four most remarkable features: a) government's enduring commitment to pro-poor land reform, b) excellent progress on updation and digitization of land records, and c) presence of strong and capable land administration down to grass roots level, d) well-articulated laws and procedures of land governance except a few emerging areas like environmental issues. However, there are some areas where further improvements are possible and doable, as this assessment would show.

A few overarching land governance issues are:

28|Page Land Governance Assessment Framework - West Bengal 
- Despite appropriate laws, the culture and practice of ignoring women's land rights issue has not received policy focus as it deserves and hence remains unchanged. This could be possibly attributed to traditional and customary practices prevalent in rural society. The belief is that steps to ensure land rights for women has the potential of not only unlocking a number of social and economic barriers of development but achieving wider social equity also.

- From the efficiency perspective, dynamic land use plans and proactive initiatives from various departments, local self-governments for better public land management will help bring improved land governance.

- From the transparency perspective, there is scope to improve public participation and other transparency measures in various land governance indicators.

\section{Land Governance:}

Land governance refers to institutional and legal systems and procedures on ownership, use and transaction of land. The purpose of land governance is to ensure that the institutions, legal frameworks, and process \& procedures follow the principles of equity, efficiency, transparency and accountability as well as positively contribute to economic and social development, and environmental sustainability.

Land Governance Assessment Framework (LGAF) is an important tool in the time for ensuring proper management of land. It captures the existing legal and institutional scenario of land governance on the basis of above principles, and points out where further action is necessary. Land governance assessment framework for West Bengal is no exception.

The LGAF is organized in the prescribed format given by the World Bank to ensure comparability among states and countries. The inception report being the first document in this assessment is presented below. It may be mentioned that this is a draft report which will be refined subsequently through further research and panel discussions.

\section{LAND TENURE TYPOLOGY AND INSTITUTIONAL MAPPING, WEST BENGAL}

\section{Historical background of Bengal's land tenure system}

The British East India Company received from Shah Alam, the Mughal Emperor, and the firman of the Dewani of Bengal, Bihar and Orissa in 1776. In other words, the right to collect land revenue and to conduct civil administration was conferred on the Company. After a long period of trial and error in the matter of settlement of revenue with the zamindars land was settled for a term of five years. As it did not work, it was replaced by the year to year settlement by auction. It failed. Then the land was settled for 10 years known as decennial settlement.

Finally, Lord Cornwallis, after a lot of strident debate in India and the British Parliament, introduced the feudal pattern of land tenure system in the above three provinces by converting the decennial settlement into permanent settlement by Permanent Settlement Regulation I of 1793 .

The feudal system of land tenure system introduced by Lord Cornwallis was nothing but a continuation of the system introduced by Murshid Quli Khan. However, Cornwallis made a mistake of giving proprietory right to the zamindars who were hitherto mere collectors of revenue by depriving the cultivators who were hitherto virtually enjoying the peasantproprietorship.

The baneful consequences of Permanent Settlement on the rural society of the province are well known. There was indiscriminate enhancement of rent, eviction etc. coupled with inhuman

29|Page Land Governance Assessment Framework - West Bengal 
torture upon the raiyats and the peasantry. As a means of mitigating the sufferings, the raiyats were conferred with occupancy right through the Rent Act of 1859. Matters having not improved much, the Bengal Tenancy Act, 1885 were passed, giving marginal relief to the raiyats. To address the issue once for all, the government constituted a Land Revenue Commission presided over by Sir Fancis Floud. The Commission, in 1940, made the revolutionary recommendation that all rent-receiving interests in the land tenure system should be abolished and the tiller of the soil brought directly under the state. Due to outbreak of war no further action on the Commission's report could be taken except constituting a committee called Bengal Administrative Reforms Committee. The committee accepted the views of the Floud Commission. But further action on the recommendations had to await India's Independence in 1947.

\section{The Legal Framework}

In the debate on the rights to property in the Constituent Assembly it was decided to abolish zamindary and impose a ceiling on agricultural land. The Constitution of India having adopted the doctrine of eminent domain made provisions for acquisition of estates and all pre-existing rights therein.

In the post-Independence era the first Act to be enacted in the domain of land tenure was the Bargadar's Act, 1950. This Act for the first time provided for specifying the share of produce between a share-cropper and his landlord, and restricted eviction of bargadars. The West Bengal Land Reforms Act 1955 incorporated many of its provisions, and thus the Bargadar's Act 1950 was repealed.

Then came two reform Acts, namely the West Bengal Estates Acquisition Act, 1953 and the West Bengal Land Reforms Act, 1955 were enacted. These two Acts taken together provided the legal frame work for carrying out agrarian reforms, reforms in tenure and tenancy structure, revenue administration, land management, preparation of land register [record-of-rights] etc.

\section{Main stream raiyati-tenure:}

West Bengal as a constituent state of the Union of India was curved in 1947 out of the then province of Bengal. The state, therefore, inherited all Acts relating to regulation of land tenures, revenue administration etc. from the mother province.

In 1885 the British Government passed the landmark Bengal Tenancy Act which divided all those who held lands into two classes - landlords and tenants. The proprietors including government were the landlords and those who held land under them were tenants. The tenants were divided into different classes, the tenure pattern thus stood as under:

\section{Land Tenure Pattern}

(Pre-reform)

State Government / Collector [on behalf of the state]

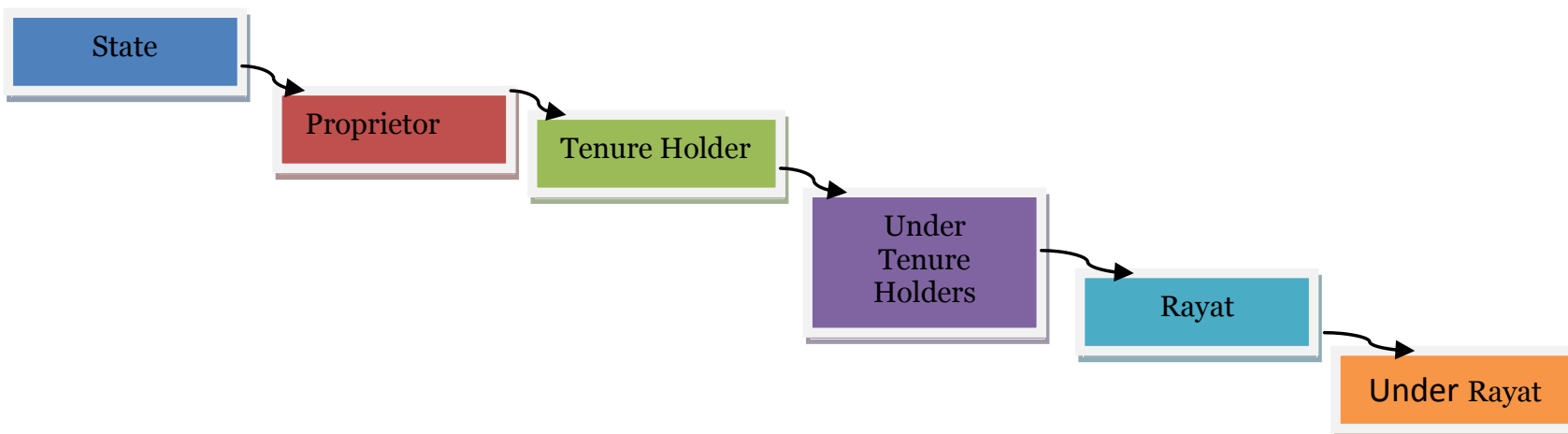

30|Page Land Governance Assessment Framework - West Bengal 
The government used to settle huge tracts of land with the proprietors in lieu of revenue. They, in their turn, would let out the lands at their disposal to a number of tenure holders in lieu of rent. If necessary, they could retain a part of the land for their own use. This process was carried downward till the person at the bottom of the ladder (under-raiyat) was reached. The land holders between him and the state were intermediaries in the chain.

Under the EA Act, zamindary and all other rent receiving interests were abolished with effect from 15.04.1955, and a ceiling was also imposed. Those who retained land within the ceiling limit became tenants directly under the state. Thus the erstwhile proprietor and under-raiyat at the lowest rung were brought on the same platform - tenants under the state, now called raiyats. The changed scenario is shown in the diagram below:

\section{Land Tenure Pattern}

\section{Pre-reform structure}

Government (state)

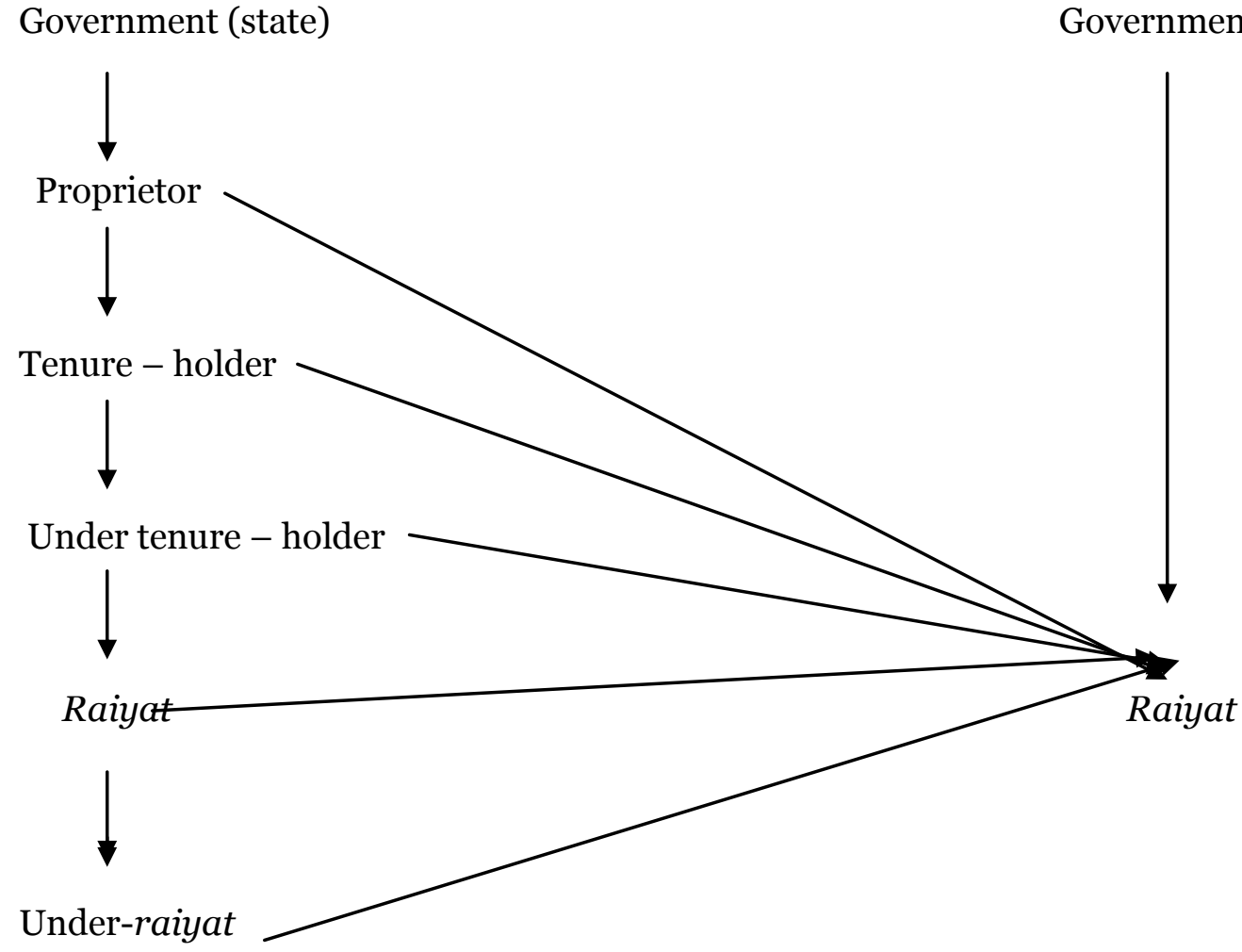

Post-reform structure

Government (state)

As a result of this structural change, the status of proprietors, tenure holders etc. were relegated and the status of under-raiyats rose to that of a raiyat. Now under the LR Act whoever holds land for any purpose whatsoever is a raiyat whose right is heritable and transferrable.

In West Bengal, there is extensive incidence of another category of rural tenures held by cultivators who are known as share-croppers or crop sharers. In local parlance they are known by various names but the most commonly used term is Bargadar. A share cropper is a person who cultivates the land of another person on condition of delivering a share of the produce to the latter. The share cropper has the right of cultivation. He is often referred to as a pseudo

31|Page Land Governance Assessment Framework - West Bengal 
tenant or an informal tenant. For the purpose of this report we will treat him as a holder of tenure which, for all intents and purposes, he is.

\section{Categorization of new classes of post reform raiyti-tenures:}

In addition to the raiyati-tenures some other forms of tenures have been created in course of time. Such tenures are categorized as under: -

\begin{tabular}{|l|l|l|}
\hline 1. & Category 1 & $\begin{array}{l}\text { through distribution of Government lands to the landless and the near } \\
\text { landless under the West Bengal land Reforms Act, 1955.[Sec.49(1)] }\end{array}$ \\
\hline 2. & Category 2 & $\begin{array}{l}\text { Occupiers of private land satisfying certain conditions, under the W.B. } \\
\text { Acquisition of Homestead Land for Agricultural Labourers, Artisans and } \\
\text { fisherman Act, 1975 [Sec.7(i)] }\end{array}$ \\
\hline 3. & Category 3 & $\begin{array}{l}\text { Sharecroppers occupying vested land under certain circumstances (WBLR } \\
\text { Act) [Sec.14s] have become raiyats }\end{array}$ \\
\hline 4. & Category 4 & $\begin{array}{l}\text { Non-agricultural tenants and under tenants through amendment of the } \\
\text { W.B.L.R. Act.[Sec.3A(1)] have become raiyats }\end{array}$ \\
\hline 5. & Category 5 & $\begin{array}{l}\text { Through delivery of documents of title in respect of forest land to the } \\
\text { eligible forest dwellers under the Forest Protection Act, 1980. }\end{array}$ \\
\hline 6. & $\begin{array}{l}\text { Category 6 (regularizing } \\
\text { the squatters) }\end{array}$ & $\begin{array}{l}\text { Squatters on government land in urban and semi-urban areas by the } \\
\text { Refugee, Relief and Rehabilitation Department of the state Government. }\end{array}$ \\
\hline
\end{tabular}

The squatters under the first two categories have been declared as raiyats without the right to transfer their land. The rights of those coming under categories 5 and 6 have been stated in the respective documents of settlement.

\section{Building up of Land Tenure Typology:}

Consequent upon the abolition of rent-receiving interests on land West Bengal's land tenure system has become very simple. All tenants called raiyats hold land directly under the state. This is irrespective of whether the land is agricultural or non-agriculture in character or otherwise and whether the holder of the land is an individual or an institution etc.

The law does not permit any raiyat to induct any tenant under him. In other words, subinfeudation is strictly prohibited. These facts have to be taken account while building up the Land Tenure Typology of the state. 
33|Page Land Governance Assessment Framework- West Bengal 


\section{TYPOLOGY OF TENURE SITUATIONS}

\begin{tabular}{|c|c|c|c|}
\hline Tenure Type & Area Population & $\begin{array}{c}\text { Legal recognition and } \\
\text { Characteristics }\end{array}$ & Overlaps and potential issues \\
\hline $\begin{array}{l}\text { Raiyati-tenure } \\
\text { [main stream] } \\
\text { (Rural) }\end{array}$ & NA & $\begin{array}{l}\text { Legal recognition: All tenures are legally recognized. } \\
\text { Transferability: Transferable without any restriction. There } \\
\text { are certain conditions in regard to use: agricultural land to be } \\
\text { used for the purpose of agriculture only, cannot be kept fallow } \\
\text { for more than three consecutive years. Cannot be let out, } \\
\text { breach will make the land or part thereof, excluding } \\
\text { homestead, liable for vesting in the state. Raiyats belonging to } \\
\text { ST cannot transfer to non-tribal without permission. } \\
\text { Recording : } \\
\text { All tenures with important attributes are recorded in the } \\
\text { record-of-rights which have a presumptive value of } \\
\text { correctness in the eye of law. }\end{array}$ & $\begin{array}{l}\text { On transfer of tenures through sale } \\
\text { succession etc. the successors-in-interest do } \\
\text { not always take interest in getting their names } \\
\text { mutated in the record-of-rights. This } \\
\text { document is relied upon by the administration } \\
\text { for identifying beneficiaries for various social } \\
\text { welfare schemes and in connection with } \\
\text { acquisition of land and payment of } \\
\text { compensation. Government should take } \\
\text { proactive measures to keep the records } \\
\text { updated. }\end{array}$ \\
\hline $\begin{array}{l}\text { Raiyati tenure } \\
\text { (Category 1) } \\
\text { [Rural] }\end{array}$ & $\begin{array}{l}\text { Area - } \\
425,982 \mathrm{Ha} \\
31.36 \text { lakh }\end{array}$ & $\begin{array}{l}\text { Landless and land-poor receiving vested land as a measure of } \\
\text { agrarian reforms accorded the status of raiyat [U/s 49(1) of } \\
\text { WBLR Act] } \\
\text { * Legal recognition : Institution created by law, hence } \\
\text { recognized } \\
\text { Recording: same as in the case of mainstream raiyats. } \\
\text { * Transferability: Transfer not } \\
\text { permissible except by } \\
\text { a simple mortgage of } \\
\text { the land with some selected categories of banks for taking } \\
\text { loan for development of the land, agriculture etc. }\end{array}$ & $\begin{array}{l}\text { The beneficiaries are known as pattadars. } \\
\text { Although all of them have received patta } \\
\text { (document of title), the names of more than } \\
\text { seven lakh pattadars have not yet been } \\
\text { recorded in the RoRs which is primarily a } \\
\text { document of possession. Both the document } \\
\text { of title and possession are necessary for } \\
\text { availing of benefits under various kinds of } \\
\text { development schemes. }\end{array}$ \\
\hline $\begin{array}{l}\text { Raiyati tenure } \\
\text { (Category 2) } \\
\text { [Rural] }\end{array}$ & NA & $\begin{array}{l}\text { * Legal recognition: a creature of West Bengal Land Reforms } \\
\text { Act, } 1955 \text { (Sec 14S) } \\
\text { * All other characteristics are the same as for a mainstream } \\
\text { raiyat. }\end{array}$ & $\begin{array}{l}\text { If land owned by a raiyat in excess of ceiling } \\
\text { area, cultivated by a bargadar vests in the } \\
\text { state and the bargadar becomes a raiyat } \\
\text { (total land ownership up to } 0.4047 \mathrm{Ha}\end{array}$ \\
\hline
\end{tabular}

34|Page Land Governance Assessment Framework - West Bengal 


\begin{tabular}{|c|c|c|c|}
\hline Tenure Type & Area Population & $\begin{array}{c}\text { Legal recognition and } \\
\text { Characteristics }\end{array}$ & Overlaps and potential issues \\
\hline $\begin{array}{l}\text { Raiyati tenure } \\
\text { (Category 3) } \\
\text { [Rural \& semi- } \\
\text { urban] }\end{array}$ & $\begin{array}{l}7883.80 \mathrm{Ha} \\
3.27 \text { lakh }\end{array}$ & $\begin{array}{l}\text { Under the provisions of The West Bengal Acquisition of } \\
\text { Homestead Land for Agricultural Labourers, Artisans and } \\
\text { Fishermen Act, } 1975 \\
\text { * Legal recognition: a creature of law hence recognized. } \\
\text { * Recording: same as in the case of a raiyati-tenure [main } \\
\text { stream]. } \\
\text { * Transferability: limited right; may transfer by a simple } \\
\text { mortgage for development of land. }\end{array}$ & $\begin{array}{l}\text { Private land where any occupier has been in } \\
\text { possession of any land (agricultural or non- } \\
\text { agricultural where there is a homestead) on } \\
26^{\text {th }} \text { of June 1975, such land up to o.0334 ha, } \\
\text { shall stand acquired by the State Government } \\
\text { and shall thereupon stand transferred to and } \\
\text { vest absolutely in favour of such occupier who } \\
\text { will hold it as a raiyat }\end{array}$ \\
\hline $\begin{array}{l}\text { Raiyati tenure } \\
\text { (Category 4) } \\
\text { [Urban, semi- } \\
\text { urban \& rural] }\end{array}$ & NA & $\begin{array}{l}\text { Legal recognition: this category of raiyats was created by an } \\
\text { amendment to the W.B.L.R. Act, } 1955 \text { (Section 3A) }\end{array}$ & $\begin{array}{l}\text { The non-agricultural tenants, under tenants } \\
\text { were not brought within the purview of WBEA } \\
\text { Act, 1953. Subsequently by an amendment of } \\
\text { WBLR Act in 1981, such tenants were treated } \\
\text { as raiyats }\end{array}$ \\
\hline $\begin{array}{l}\text { Tenure on forest } \\
\text { land } \\
\text { (Category 5) } \\
\text { Rural/ Forest }\end{array}$ & $\begin{array}{l}\text { Individual }-30,879 \\
\text { and community - } \\
312 \\
\text { Area }-4958 \mathrm{Ha}\end{array}$ & $\begin{array}{l}\text { Characteristics: right of transfer restricted } \\
\text { Legal recognition: All tenures are legally recognized. } \\
\text { Transferability: Transferable without any restriction. There } \\
\text { are certain conditions in regard to use: Land to be used for } \\
\text { the purpose of agriculture only, cannot be kept fallow for } \\
\text { more than three consecutive years. Cannot be let out except } \\
\text { for special grounds: breach will make the land or part thereof, } \\
\text { excluding homestead, liable for vesting in the state. } \\
\text { Recording: } \\
\text { All tenures with important attributes are recorded in the Land } \\
\text { Register i.e. record-of-rights which have a presumptive value } \\
\text { in the eye of law. }\end{array}$ & $\begin{array}{l}\text { The Scheduled Tribes and Other Traditional } \\
\text { Forest Dwellers (Recognition of Forest Rights) } \\
\text { Act, } 2006 \text { gives rights to the marginal and } \\
\text { tribal communities on the forestland on which } \\
\text { they were traditionally dependent. It provides } \\
\text { for the restitution of deprived forest rights, } \\
\text { including both individual rights to cultivated } \\
\text { land in forestland and community rights over } \\
\text { common property resources. }\end{array}$ \\
\hline $\begin{array}{l}\text { Tenure of squatters } \\
\text { on government land } \\
\text { [Category 6] } \\
\text { Urban, semi-urban } \\
\text { \& rural }\end{array}$ & NA & $\begin{array}{l}\text { Raiyati tenure accorded by the then Refugee, Relief and } \\
\text { Rehabilitation Dept. } \\
\text { Legal recognition: } \\
\text { *recognized by law. } \\
\text { recording: } \\
\text { *recorded in land records. }\end{array}$ & \\
\hline
\end{tabular}

35 | Page Land Governance Assessment Framework - West Bengal 


\begin{tabular}{|c|c|c|c|}
\hline Tenure Type & Area Population & $\begin{array}{c}\text { Legal recognition and } \\
\text { Characteristics }\end{array}$ & Overlaps and potential issues \\
\hline $\begin{array}{l}\text { Share cropping } \\
\text { Tenure } \\
\text { [Rural] }\end{array}$ & $\begin{array}{l}\text { 4.53 lakh Ha } \\
15.21 \text { lakh }\end{array}$ & $\begin{array}{l}\text { Legal recognition: } \\
\text { Recognized by law (West Bengal Land Reforms Act, 1955), } \\
\text { recorded } \\
\text { in the land register i.e. record-of-rights: } \\
\text { Right of share cropping is heritable, but not transferable. } \\
\text { Share croppers enjoy right to cultivate the land and receive } \\
\text { share of the produce quantum of which laid down in WBLR } \\
\text { Act, 1955. Sharecropper enjoys security of tenure till it is } \\
\text { terminated in accordance with law }\end{array}$ & $\begin{array}{l}\text { Sharecroppers enjoy the right to cultivate land } \\
\text { which is a kind of occupancy right }\end{array}$ \\
\hline $\begin{array}{l}\text { A tenure called } \\
\text { ThikaTenency under } \\
\text { Kolkata Thika } \\
\text { Tenancy } \\
\text { (Acquisition and } \\
\text { Regulation) Act, } \\
\text { 2001 }\end{array}$ & NA & $\begin{array}{l}\text { Legal recognition: } \\
\text { *legally recognized } \\
\text { Characteristics: } \\
\text { *heritable } \\
\text { Sec.6(3) } \\
\text { *transferable interest among heirs and co-sharers } \\
\text { "letting out of structure is permitted } \\
\text { "govt. may resume land in public interest } \\
\text { Sec. } 7(3)\end{array}$ & $\begin{array}{l}\text { Vesting of interests of landlords with effect } \\
\text { from 18.01.1982 (Sec 4). They hold land } \\
\text { directly under the state. } \\
\text { Area of operation - first } 100 \text { wards of Kolkata } \\
\text { Municipal Corporation and } 40 \text { wards of } \\
\text { Howrah Municipal Corporation }\end{array}$ \\
\hline Raiyati tenure & NA & $\begin{array}{l}\text { Tenants and under-tenants under the Non Agriculture } \\
\text { Tenancy act, } 1949 \text { given raiyati status by amendment of } \\
\text { WBLR Act, } 1955 \text { [Sec } 3 \mathrm{~A}(1)] \\
\text { Transferable and heritable }\end{array}$ & $\begin{array}{l}\text { These deemed raiyats enjoy all rights of a } \\
\text { mainstream raiyat }\end{array}$ \\
\hline
\end{tabular}

36|Page Land Governance Assessment Framework - West Bengal 


\section{Settlement / Lease / License regime}

\begin{tabular}{|c|c|c|c|}
\hline Tenure Type & Area Population & $\begin{array}{l}\text { Legal recognition and } \\
\text { Characteristics }\end{array}$ & Overlaps and potential issues \\
\hline $\begin{array}{l}\text { Settlement of govt. land } \\
\text { for non-agricultural } \\
\text { purposes under the } \\
\text { provisions of WBLR Act } \\
\text { \& Rules and W.B. Land \& } \\
\text { Land Reforms Manual, } \\
1991 \text { [Section 49(5), Rule } \\
\text { 20A(6) and Rule 215 } \\
\text { onwards of the manual]. }\end{array}$ & NA & $\begin{array}{l}\text { * legally recognized } \\
* \text { lease deed registration compulsory } \\
\text { * lease period ordinarily } 30 \text { or } 99 \text { years, } \\
\text { with options for successive renewals } \\
\text { * heritable } \\
\text { * Transfer only with the permission of } \\
\text { Collector. }\end{array}$ & $\begin{array}{l}\text { Land for non-agricultural purposes shall } \\
\text { ordinarily be settled on long-term leases } \\
\text { by the Collector with prior approval of } \\
\text { the L\&LR dept. }\end{array}$ \\
\hline $\begin{array}{l}\text { Lease of Tea Garden } \\
\text { lands } \\
\text { (Schedule F } \\
\text { [Rule 4] of West Bengal } \\
\text { Estate Acquisition Rules } \\
\text { 1954) }\end{array}$ & $\begin{array}{l}\text { Total number of tea gardens } \\
329 \\
\text { Involving area of } 168478 \text { ha }\end{array}$ & $\begin{array}{l}\text { * lease period thirty years } \\
{ }^{*} \text { renewable } \\
{ }^{*} \text { lease hold interest heritable } \\
\text { * transfer with the permission of } \\
\text { Collector }\end{array}$ & $\begin{array}{l}\text { After determination of the quantum of } \\
\text { required land for a tea-garden u/s } 6(3) \\
\text { of the EA Act, the government granted } \\
\text { lease on terms and conditions contained } \\
\text { in schedule F appended to rule } 4(\mathrm{~A}) \text { of } \\
\text { the EA Rules, } 1954\end{array}$ \\
\hline $\begin{array}{l}\text { Lease of land by } \\
\text { irrigation \& PWD } \\
\text { Department of the state }\end{array}$ & NA & $\begin{array}{l}\text { Legal recognition: } \\
\text { - } \quad \text { at best as an occupier } \\
\text { - not transferable } \\
\text { - } \text { not heritable }\end{array}$ & \\
\hline lease of coal field lands & $\mathbf{N A}$ & $\begin{array}{l}\text { Legal recognition : } \\
\text { - } \quad \text { recognized } \\
\text { - } \quad \text { recorded in record-of-rights } \\
\text { - } \quad \text { heritable with permission of } \\
\text { government } \\
\text { - } \quad \text { transferable with government } \\
\text { permission }\end{array}$ & $\begin{array}{l}\text { Restricted rights of two types } \\
\text { a) for land use } \\
\text { b) for mining }\end{array}$ \\
\hline
\end{tabular}

37|Page Land Governance Assessment Framework - West Bengal 


\section{Customary tenure-like occupancy situations}

\begin{tabular}{|l|c|l|l|}
\hline Tenure Type & Area population & \multicolumn{1}{|c|}{ Legal recognition \& Characteristic } & Overlap and potential issues \\
\hline $\begin{array}{l}\text { Unauthorised occupancy of } \\
\text { government land }\end{array}$ & NA & $\begin{array}{l}\text { Legal recognition: } \\
\text { *not recognized } \\
\text { *not recorded } \\
\text { *Evictable under the Public Land (Eviction } \\
\text { of Unauthorised Occupants) Act, 1976 }\end{array}$ & \\
\hline $\begin{array}{l}\text { Occupation of private land with } \\
\text { leave or license }\end{array}$ & NA & $\begin{array}{l}\text { *egal recognition: } \\
\text { *informally recognized } \\
\text { Recording: } \\
\text { *recorded in the record-of-rights as an } \\
\text { occupier with leave }\end{array}$ & $\begin{array}{l}\text { Informally recognized and recorded in RoR } \\
\text { of the owner as permissive possession }\end{array}$ \\
\hline
\end{tabular}

$\overline{\mathbf{3 8} \text { |Page Land Governance Assessment Framework - West Bengal }}$ 


\section{INSTITUTIONAL MAPPING}

The state is the absolute owner of all lands within the geographical boundaries of West Bengal. The Department of Land and Land Reforms acts as the custodian of these lands on behalf of the state. There are, however, lands at the disposal of other departments of the government. These lands are used, maintained and managed by the respective departments. In the event the lands at the disposal of any department are found to be in excess of its requirement, the department has to return these lands to the Land and Land Reforms department on requisition.

There are several government departments and agencies who are involved in land governance In West Bengal. The involvement of these agencies is of varying degrees. The Institutional map below will reveal the scenario: 


\section{INSTITUTIONAL MAP: Land Agencies of West Bengal}

\begin{tabular}{|c|c|c|c|}
\hline Institution & Type of land resources & Responsibility/Mandate & $\begin{array}{l}\text { Overlap with other } \\
\text { institutions }\end{array}$ \\
\hline $\begin{array}{l}\text { Department of Land and Land } \\
\text { Reforms }\end{array}$ & All lands & $\begin{array}{l}\text { - The department plays a pivotal role in the land and } \\
\text { revenue administration of the state. Its main functions } \\
\text { and duties are : } \\
\text { i. formulation of policy; } \\
\text { ii. making of laws and } \\
\text { iii. Implementation of the above. } \\
\text { Its domain of activities include land reforms, preparation } \\
\text { of Cadastral and topographical maps, determination and } \\
\text { collection of land revenue, land acquisition etc. } \\
\text { Some of the Acts administered by the department like the } \\
\text { West Bengal Estates Acquisition Act, } 1953 \text { and the West } \\
\text { Bengal Land Reforms Act, 1955 are crucial for } \\
\text { management and regulation of land in rural areas. Acts } \\
\text { relating to urban areas administered by the department } \\
\text { are also very important in the sphere of urban } \\
\text { governance. } \\
\text { The department performs its functions through the } \\
\text { Collectors of districts in some matters while } \\
\text { implementation of two major Acts is done through the } \\
\text { DLRS which has its unit down to the gram panchayat } \\
\text { level. }\end{array}$ & 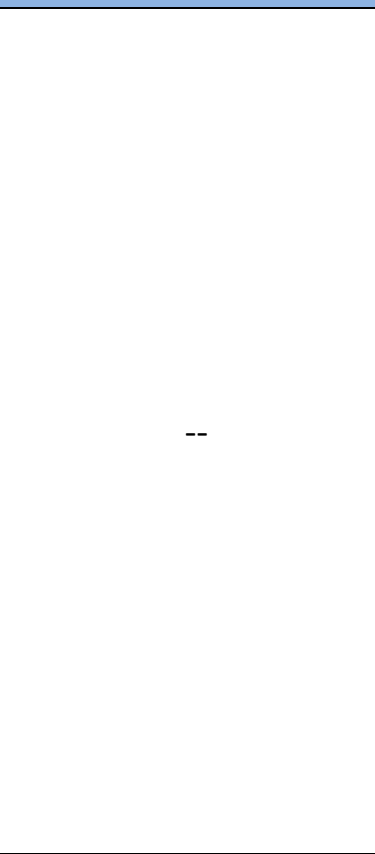 \\
\hline $\begin{array}{l}\text { Panchayat and Rural Development } \\
\text { Department }\end{array}$ & $\begin{array}{l}\text { Small water areas and } \\
\text { lands pertaining to certain } \\
\text { interests. }\end{array}$ & $\begin{array}{l}\text { - Management of water areas up to } 5 \text { acres and } \\
\text { management of interests like huts and bazaars and } \\
\text { assessment and collection of property tax by the gram } \\
\text { Panchayat. }\end{array}$ & -- \\
\hline Fishery Department & $\begin{array}{l}\text { Water bodies and areas } \\
\text { like tanks etc. }\end{array}$ & $\begin{array}{l}\text { - Pisciculture } \\
\text { - Leasing out the water areas to fishermen's Co-operatives. } \\
\text { - } \quad \text { Development of the water areas }\end{array}$ & -- \\
\hline Urban Local Bodies & $\begin{array}{l}\text { Crematorium, burial } \\
\text { ground, dumping ground }\end{array}$ & The ULBs maintain the lands as classified in column 2 & $\begin{array}{l}\text { L\&LR Department, } \\
\text { Local Self Governments }\end{array}$ \\
\hline
\end{tabular}

40|Page Land Governance Assessment Framework - West Bengal 


\begin{tabular}{|c|c|c|c|}
\hline Institution & Type of land resources & Responsibility/Mandate & $\begin{array}{l}\text { Overlap with other } \\
\text { institutions }\end{array}$ \\
\hline Forest Department & $\begin{array}{l}\text { Forest lands in reserved, } \\
\text { protected and unclassed } \\
\text { state forests }\end{array}$ & $\begin{array}{l}\text { Afforestation and tree planting, increasing forest cover in the } \\
\text { state, enhancement of productivity of the forest lands, } \\
\text { securing people's participation in forest management, } \\
\text { biodiversity conservation and issue of land patta to eligible } \\
\text { forest dwellers. }\end{array}$ & $\begin{array}{l}\text { Backward Classes } \\
\text { Welfare department. }\end{array}$ \\
\hline $\begin{array}{lll}\text { Backward } & \text { Classes } & \text { Welfare } \\
\text { Department } & & \end{array}$ & & $\begin{array}{l}\text { Implementation of Scheduled Tribes and Other Traditional } \\
\text { Forest Dwellers (Recognition of Forest Rights) Act, } 2006 \text { in } \\
\text { respect of rights of the Scheduled Tribes forest dwellers on } \\
\text { forest land. }\end{array}$ & $\begin{array}{l}\text { Department of Forest, } \\
\text { Land and Land Reforms } \\
\text { and Panchayat \& Rural } \\
\text { Development } \\
\text { Department }\end{array}$ \\
\hline Irrigation Department & $\begin{array}{l}\text { Government lands at the } \\
\text { disposal of the Irrigation } \\
\text { Department }\end{array}$ & $\begin{array}{l}\text { Putting up embankments to protect lands being engulfed by } \\
\text { rivers, leasing out water areas for short period to augment } \\
\text { state revenue. }\end{array}$ & $\begin{array}{l}\text { Land \& Land Reforms } \\
\text { department }\end{array}$ \\
\hline Public Works Department & $\begin{array}{l}\text { Government lands at the } \\
\text { disposal of PWD }\end{array}$ & Leasing out roadside lands for short periods & -- \\
\hline $\begin{array}{l}\text { Refugee, Relief \& Rehabilitation } \\
\text { Department }\end{array}$ & $\begin{array}{l}\text { Lands at the disposal of } \\
\text { the department }\end{array}$ & Issue of documents of title to eligible persons & -- \\
\hline $\begin{array}{l}\text { Commerce and Industries } \\
\text { Department }\end{array}$ & $\begin{array}{lll}\begin{array}{l}\text { Lands } \\
\text { mines }\end{array} & \text { pertaining } & \text { coal } \\
\end{array}$ & Issue of licenses for mining activities & -- \\
\hline $\begin{array}{l}\text { Kolkata Metropolitan Development } \\
\text { Authority (KMDA) }\end{array}$ & (1) & Providing industrial infrastructure for planned development & -- \\
\hline West Bengal Housing Board & $\begin{array}{l}\text { Infrastructure creation } \\
\text { and housing }\end{array}$ & Planning, development of urban infrastructure in KMDA area & -- \\
\hline Department of Urban Development & $\begin{array}{l}\text { - } \quad \text { Land for housing } \\
\text { - } \\
\text { Planned townships } \\
\text { and housing estates }\end{array}$ & $\begin{array}{l}\text { - To provide housing for people of different income groups } \\
\text { at comparatively low cost; } \\
\text { - Promotion of urban development by setting up several } \\
\text { development authorities spread over the entire state like } \\
\text { Siliguri-Jalpaiguri Development Authority, Asansol- } \\
\text { Durgapur Development authority etc. }\end{array}$ & -- \\
\hline
\end{tabular}

41 Page Land Governance Assessment Framework - West Bengal 


\section{Assessment}

\section{Panel 1 Land Tenure Recognition}

A system of tenure explains how people, communities and others gain access to land, forests, and fisheries, and those are regulated by societies. These tenure systems determine who can use what resources, for how long and on and under what conditions. Such systems may be based either on written policies and laws or unwritten customs and practices.

Panel 1 deals with the land tenure recognition of various types of tenures enjoyed by the raiyats, bargadars, patta holders, lease holders, tenants etc. It also focuses on the issues of rights of women, forest dwellers, tribes and so on. The Expert Investigator assigned for this panel has critically examined how far the rights are recognized by legislations and enforced in practice. He has also incorporated the inputs, suggestions and recommendations which came out from the panel discussions.

\section{Dimension Analysis}

\section{Indicators}

1. Recognition of a continuum of rights: the law recognizes a range of rights held by individuals (incl. secondary rights of tenants. sharecroppers, women etc.)

2. Respect for and enforcement of rights

\begin{tabular}{|c|c|c|c|}
\hline Panel & LGI & Dim. & $\begin{array}{l}\text { Land Governance Indicator } 1 \\
\text { Recognition of a continuum of rights: the law recognizes a range of } \\
\text { rights held by individuals (incl. secondary rights of tenants, } \\
\text { sharecroppers, women etc.) }\end{array}$ \\
\hline \multirow[t]{5}{*}{1} & 1 & 1 & a) Individuals' rural land tenure rights are legally recognized \\
\hline & & & $\begin{array}{l}\text { A: Existing legal framework recognizes and protects rights held by more than } \\
90 \% \text { of the rural population }\end{array}$ \\
\hline & & & $\begin{array}{l}\text { B: Existing legal framework recognizes and protects rights held by } 70 \%-90 \% \text { of } \\
\text { the rural population }\end{array}$ \\
\hline & & & $\begin{array}{l}\text { C: Existing legal framework recognizes and protects rights held by } 50 \%-70 \% \text { of } \\
\text { the rural population }\end{array}$ \\
\hline & & & $\begin{array}{l}\text { D: Existing legal framework recognizes and protects rights held by less than } 50 \% \\
\text { of the rural population }\end{array}$ \\
\hline
\end{tabular}

Analysis:

Recognition of rural land tenure rights in West Bengal which was a part of the old Bengal Presidency has been a continuous process spread over a long length of time. The pre-1885 [B.T. Act] regulations and Acts did mention the holders of different categories of rural land tenures but did not recognize these customary tenures. The Rent Act of 1859 went so far as to grant these customary holders of tenure mostly raiyats the right of occupancy. 
The BT Act, 1885 for the first time recognized the different categories of customary tenures and provided definition for each. This Act conferred several rights upon the raiyats. Finally, the WBLR Act has comprehensively laid down the rights and duties of a raiyat (background note).

All typologies for rural including urban, semi urban etc. tenures have been identified and shown in the table with description in the back ground note. Some of the holders of tenures identified and appearing in the table bear the nomenclature "raiyat" while others are not technically riayats but hold tenures. But these are distinguishable by their attributes like the class of land comprising the tenure, heritability, transferability etc.

There is practically no obstacle to recognizing the rights on rural tenure. New rural tenures are in a constant process of creation and recognition through operation of various laws. Recognition of the illegal occupiers of unassessed lands by granting them tenurial rights through issue of patta or otherwise is an issue which has many dimensions as discussed in the background note. There is no category in the state with informal rights but with legal rights.

The Bengal Tenancy Act was significantly silent as to the status of a bargadar. While the right of barga cultivation was recognized, by a retrogate step in 1928, providing a definition and at the same time declaring that a bargadar is not a tenant.

In W.B. Bargadars Act, 1950 and the WBLR Act, 1955 many rights have been granted and safeguards provided to the bargadars. Moreover, the right of cultivation by a bargadar having been made heritable such rights stands fully secure. Since conferment of tenancy rights on bargadar does not fit with the scheme of the WBLR Act which categorically prohibits creation of any form of tenancy by a raiyat and recognizes only one landlord - the state, the lawmakers wisely provided for an alternative way to make the bargadar not a tenant but the owner of the land. Section $21 \mathrm{C}$ was inserted in the Act in 1981 for constitution of Land Corporation. A bargadar may take loan from the corporation to buy the land he cultivates from the owner of the land.

Policy recommendations: The state government may consider implementation of the provisions of section $21 \mathrm{C}$ by constituting Land Corporations

\section{Data Source:}

1. Bengal Tenancy Act, 1885 .

2. West Bengal Land Reforms Act, 1955

\section{Data Reliability: High}

\begin{tabular}{|c|c|c|c|}
\hline Panel & LGI & Dim. & $\begin{array}{l}\text { Land Governance Indicator } 1 \\
\text { Recognition of a continum of rights: the law recognizes a range } \\
\text { of rights held by individuals (incl. secondary rights of tenants, } \\
\text { sharecroppers, women etc.) }\end{array}$ \\
\hline \multirow[t]{5}{*}{1} & 1 & \multirow[t]{5}{*}{1} & b) Individuals' rural land tenure rights are protected in practice \\
\hline & & & $\begin{array}{l}\text { A: Existing legal framework recognizes and protects rights held by more than } \\
90 \% \text { of the rural population }\end{array}$ \\
\hline & & & $\begin{array}{l}\text { B: Existing legal framework recognizes and protects rights held by } 70 \%-90 \% \\
\text { of the rural population }\end{array}$ \\
\hline & & & $\begin{array}{l}\text { C: Existing legal framework recognizes and protects rights held by } 50 \%-70 \% \\
\text { of the rural population }\end{array}$ \\
\hline & & & $\begin{array}{l}\text { D: Existing legal framework recognizes and protects rights held by less than } \\
50 \% \text { of the rural population }\end{array}$ \\
\hline
\end{tabular}

Analysis:

43 I Page Land Governance Assessment Framework - West Bengal 
The rights granted by the relevant Acts are protected in practice. The laws of the land provide remedial measures against interference with lawful exercise of the rights. Also, if necessary, the local administration including the police administration and the local panchayats afford necessary protection.

As regards share cropping a study [2003] made by SIPRD, Kalyani shows that $19.09 \%$ of the bargadars who provide inputs for cultivation do not deliver any share of the produce to the land owner. In other words, the land owners are deprived of their lawful share of the produce. There is, however, legal forum where the landlord's right to receive his share may be enforced [sec 18, WBLR Act] Many land owners, mostly absentee owners, do not take the trouble of moving the forum and have reconciled themselves to the situation.

Data Source: West Bengal Land Reforms Act, 1955

Data Reliability: High

\begin{tabular}{|c|c|c|c|}
\hline Panel & LGI & Dim. & $\begin{array}{l}\text { Land Governance Indicator } 1 \\
\text { Recognition of a continuum of rights: the law recognizes a range } \\
\text { of rights held by individuals (incl. secondary rights of tenants, } \\
\text { sharecroppers, women etc.) }\end{array}$ \\
\hline \multirow[t]{5}{*}{1} & 1 & 2 & Customary tenure rights are legally recognized and protected in practice. \\
\hline & & & A: There is legal recognition and effective protection of all customary rights \\
\hline & & & $\begin{array}{l}\text { B: There is legal recognition of all customary rights but these are only partly } \\
\text { protected in practice }\end{array}$ \\
\hline & & & C: There is partly recognition and effective protection of customary rights \\
\hline & & & D: Customary rights are not legally recognized and not protected in practice \\
\hline
\end{tabular}

Analysis:

Two customary non-forest rights are rather pronounced are:

(a) Any right of way or other easement attached to the land comprising the tenure.

(b) Fishing right which is also an easement right.

The above two rights are recognized by law.

The customary easement right as at (a) above is recorded in the R-O-R in terms of rule 23(g), WBLR Rules, 1965. The fishing right as at (b) is recorded as a legacy of B.T. Act settlement. Other customary rights of the nature of easement over cremation ground, grave yard etc. are also recorded in the R-O-R under the above rule. The above rights are protected in practice.

A customary practice rather widespread in rural Bengal is occupation of private land with or without the owner's permission. Both these situations used to be recorded in the R-O-R. But with the progress of L.R. Settlement such recording has been discontinued by virtue of a government order.

Another important customary right is the forest right of Forest dwelling Schedule Tribes and other traditional forest dwellers. By virtue of sec 3(1) of the Recognition of Forest (Rights) Act, 2006 right of ownership, access to collect, use and dispose of minor non-timber forest produce which has been customarily collected has been declared as the forest rights of the forest dwelling STs and other traditional forest dwellers. This is in addition to some other rights recognized as forest rights. An important step in enforcing customary tenure rights is mapping/ survey of the boundaries of land held under customary tenure and the recording of right holder.

44 I P g e Land Governance Assessment Framework - West Bengal 
In regard to (a) and (b) above no problem arising out of exercise of these rights has been identified. As regards forest rights some minor functional problems came in the way in course of issue of land pattas to the eligible forest dwellers. These were mostly resolved at the local level.

There are some customary rights which are not legally recognized like, the use of paddy fields as grazing ground during lean season, use of vacant land for drying of fish. Protection of these customary practices not legally recognized, may be under question.

However, legal recognition of customary systems has not resulted in contradiction with rights protected by the Constitution (ranking changed from $\mathrm{A}$ to $\mathrm{C}$ in consultation with $\mathrm{EI}$ and panellist

\section{Data Source:}

- West Bengal Land Reform Rules, 1965

- RoR prepared in the Bengal Tenancy Act settlement

- CSOs working in the field on relevant issues

Data Reliability: High

\begin{tabular}{|c|c|c|c|}
\hline Panel & LGI & Dim. & $\begin{array}{l}\text { Land Governance Indicator } 1 \\
\text { Recognition of a continuum of rights: the law recognizes a range } \\
\text { of rights held by individuals (incl. secondary rights of tenants, } \\
\text { sharecroppers, women etc.) }\end{array}$ \\
\hline \multirow[t]{5}{*}{1} & 1 & 3 & $\begin{array}{l}\text { Indigenous rights to land and forest are legally recognized and } \\
\text { protected in practice. }\end{array}$ \\
\hline & & & A: Recognition and effective protection of all indigenous rights \\
\hline & & & B: Recognition of indigenous rights but only partly protected \\
\hline & & & C: Partly Recognition of indigenous rights, which are protected \\
\hline & & & D: Indigenous rights are not recognized and not protected \\
\hline
\end{tabular}

Analysis:

As commonly understood "indigenous rights" might be a sub-category of "customary rights" generally undocumented rights held by "original" or very long-term occupants of that land, often associated with less density of population and shifting cultivation, and/ or the prominence of forestland. Indigenous rights to land for non-forest areas are recognized and protected in practice. Such rights are also recorded in the R-O-R during settlement operations. Chapter IIA of the WBLR Act deals with the provisions imposing restrictions on alienation of land by STs.

The Scheduled Tribes and other Traditional Forest Dwellers (Recognition of Forest Rights) Act, 2006 has brought about great change in the management of state owned forest. This Act provides for recognition of many of the traditional rights enjoyed by the dwellers in regard to non-timber forest produce like collection of dry leaves, dry branches, fruits etc.

Explicit and clear provisions have been made to recognize the rights over land, forests, and other natural resources.

An important provision in the Act is to deliver land pattas to the forest dwellers for occupation covering a period of 75 years or more. Till December 2013, 3100o individual and 312 community pattas have been issued. But the important step in ensuring customary tenure rights of survey/boundary demarcation of land under such tenure is not done.

The Rules framed under the FRA provide for recording the patta rights in the R-O-R. But all forest villages being non-revenue villages those have been excluded from the survey and settlement operations [B.T. Act, E.A. Act, L.R. Act]. Resultantly, there is neither any cadastral map nor any R-O-R for these villages. But recording is absolutely necessary to infuse in the

45 I P a g L L d Governance Assessment Framework - West Bengal 
minds of the beneficiaries a sense of security of tenure. This issue needs immediate attention of the departments of Forests and Land and Land Reforms.

In a meeting convened later the CSOs working in the field felt that recognition of all rights for the indigenous people depending on forest for living and livelihood is not comprehensive, but agreed that whatever rights are recognised, these are protected. So, they opined for changing the ranking from "B" to "C". One CSO representative mentioned that the indigenous people have to sell the forest produce to the department or government agency only. Here also the rights are not fully recognised. There are large numbers of ST population who are yet to procure the ST caste certificate and are unable to avail the benefits under FRA 2006 (ranking changed from B to $\mathrm{C}$ ).

\section{Data Source:}

- Backward Classes Welfare Department, Govt. of West Bengal

- Recognition of Forest Rights Act, 2006

- Directorate of Land Records and Surveys

\section{Data Reliability:}

\section{Policy Recommendation:}

Cadastral maps plotting the pieces of land given to the forest-dwellers under the FRA 2006 and the record of rights prepared on the basis of such maps will arm the beneficiaries with the essential documents by virtue of which the beneficiaries will be able to exercise their rights recognized under the Act. The state government should, therefore, seriously consider undertaking survey and settlement of the related forest villages concerned.

\begin{tabular}{|c|c|c|c|}
\hline Panel & LGI & Dim. & $\begin{array}{l}\text { Land Governance Indicator } 1 \\
\text { Recognition of a continuum of rights: the law recognizes a range } \\
\text { of rights held by individuals (incl. secondary rights of tenants, } \\
\text { sharecroppers, women etc.) }\end{array}$ \\
\hline \multirow[t]{5}{*}{1} & 1 & 4 & Urban land tenure rights are legally recognized and protected in practice. \\
\hline & & & $\begin{array}{l}\text { A: Existing legal framework recognizes rights held by more than } 90 \% \text { of the } \\
\text { urban population }\end{array}$ \\
\hline & & & $\begin{array}{l}\text { B: Existing legal framework recognizes rights held by } 70 \%-90 \% \text { of the urban } \\
\text { population }\end{array}$ \\
\hline & & & $\begin{array}{l}\text { C: Existing legal framework recognizes rights held by } 50 \%-70 \% \text { of the urban } \\
\text { population }\end{array}$ \\
\hline & & & $\begin{array}{l}\text { D: Existing legal framework recognizes rights held by less than } 50 \% \text { of the } \\
\text { urban population }\end{array}$ \\
\hline
\end{tabular}

\section{Analysis:}

Whoever holds any description of land in the urban areas covered by the WBLR Act is a raiyat. Non-agricultural tenants and under-tenants governed by the W.B. Non-Agricultural Tenancy Act, 1949 became raiyats with effect from 09.09.1980 in terms of section 3A of the WBLR Act. Details of different categories of urban raiyats recognized by different Acts are available in the tenure typology. In a word, the rural and urban households owning lands as raiyats stand on the same footing as far as the rights are concerned, because of the definition of land meaning land of every description under the WBLR Act.

Thika tenants existing within the city of Kolkata (comprising first 100 wards of KMC) and the Howrah Municipal area (comprising the first 40 wards of HMC) took lands on monthly or yearly

46|Page Land Governance Assessment Framework - West Bengal 
rent and made constructions without concrete roof thereon. They were virtually tenants at will and could be evicted any time. The Calcutta Thika Tenancy Act, 1949 sought to curb this eviction. The Act of 1981 bearing the same name abolished landlordism by acquiring the interests of landlords and brought the thika tenants directly under the state and made their interests secure. The W.B. Thika Tenancy (Acquisition and Regulation) Act, 2001 has made their rights more secure. The flat owners coming under the W.B. Apartment Ownership Act, 1972 and Cooperative Housing Societies Act, 2006 hold proportionate share of lands. Properties [flats etc.] under these Acts are heritable and transferable.

Apart from the ordinary laws of the land, there are in-built dispensations in the relevant Acts for protection of the rights granted by them. Those rights are protected in practice.

Data Source: $\quad$ 1. West Bengal Land Reform Act, 1955

2. West Bengal Thika Tenancy Act, 2001

Data Reliability: High

\begin{tabular}{|c|c|c|l|}
\hline Panel & LGI & Dim. & $\begin{array}{l}\text { Land Governance Indicator 2 } \\
\text { Respect for and enforcement of rights }\end{array}$ \\
\hline 1 & 2 & 1 & Accessible opportunities for tenure individualization exist. \\
\hline \multirow{5}{*}{} & & $\begin{array}{l}\text { A: The law provides opportunities for those holding land under customary, } \\
\text { group, or collective tenure to fully or partially individualize land rights if they } \\
\text { so desire. Procedures for doing so are affordable, clearly specified, safeguarded, } \\
\text { and are observed in practice. }\end{array}$ \\
\cline { 2 - 4 } & $\begin{array}{l}\text { B: The law provides opportunities for those holding land under customary, } \\
\text { group, or collective tenures to fully or partially individualize land rights if they } \\
\text { so desire. Procedures to do so are affordable and include basic safeguards } \\
\text { against abuse. }\end{array}$ \\
\hline & $\begin{array}{l}\text { C: The law provides opportunities for those holding land under customary, } \\
\text { group, or collective tenures to fully or partially individualize land rights if they } \\
\text { so desire. Procedures are not affordable or clear, leading to discretion in their } \\
\text { application. }\end{array}$ \\
\cline { 2 - 4 } & $\begin{array}{l}\text { D: Although there is demand, the law provides no opportunities for those } \\
\text { holding land under customary, group, or collective tenures to fully or partially } \\
\text { individualize land rights. }\end{array}$ \\
\hline
\end{tabular}

\section{Analysis:}

As regards customary tenures these were recorded either singly or jointly during the BT Act settlement. In course of first revision of the records under the WBEA Act the same procedure was followed. During the current revision under the WBLR Act all joint tenures have been split according to share of each co-sharer and a single R-O-R [khatian] assigned to each tenure holder for each village. Therefore, as regards customary tenures, those are already individualized.

As regards individualization for collective and group tenures for forest land, the law does not permit any such individualization at the will of any tenure holder. He may come out of the group, but in that case he will have to forgo his tenurial rights. The number of collective or group tenures is not available. However, two categories of such tenures which are common are group tenures on forest land and housing cooperatives. Rights in respect of such tenures are recognized by the relevant laws.

The W. B. Apartment Ownership Act, 1972 provides for ownership of individual apartment which are both transferable and heritable.

47IPage Land Governance Assessment Framework - West Bengal 
Individualization wherever permissible, has to go through the process of registration and mutation.

\section{Data Source:}

1. Bengal Tenancy Act, 1885 RoR

2. West Bengal Estate Acquisition Act, 1953 RoR

3. West Bengal Land Reforms Act, 1955 RoR

4. West Bengal Apartment Ownership Act, 1972

5. West Bengal Co-operative Housing Societies Act, 2006

Data Reliability: High

\begin{tabular}{|c|c|c|l|}
\hline Panel & LGI & Dim. & $\begin{array}{l}\text { Land Governance Indicator 2 } \\
\text { Respect for and enforcement of rights }\end{array}$ \\
\hline 1 & 2 & 2 & Individual land in rural areas is recorded and mapped. \\
\hline \multirow{2}{*}{} & & $\begin{array}{l}\text { A: More than 90\% of individual land in rural areas is formally recorded and } \\
\text { mapped. }\end{array}$ \\
\cline { 3 - 4 } & $\begin{array}{l}\text { B: Between 70\% and 90\% of individual land in rural areas is formally } \\
\text { recorded and mapped. }\end{array}$ \\
\cline { 3 - 4 } & $\begin{array}{l}\text { C: Between 50\% and 70\% of individual land in rural areas is formally } \\
\text { recorded and mapped. }\end{array}$ \\
\cline { 3 - 4 } & $\begin{array}{l}\text { D: Less than 50\% of individual land in rural areas is formally recorded and } \\
\text { mapped. }\end{array}$ \\
\hline
\end{tabular}

\section{Analysis:}

The first step in enforcing individual rights is the recording of boundaries. Cadastral survey and preparation of land register i.e. R-O-R were first carried out in the whole state [then a part of Bengal Presidency] under the B.T. Act (Chap X). During that operation all plots of land comprised in tenure, whether individual or joint, were surveyed, numbered and a map of the mouza [village] prepared. Thereafter R-O-Rs in respect of all such tenures were prepared showing therein all incidences of the tenure like status, rent payable etc. These maps and records were revised under the Estate Acquisition Act, 1953 (Chap V). During the current revision under the WBLR Act (chap VII A) all tenures are individual tenures. Joint tenures that are not legally partitioned were split up according to the respective share of the co-sharers and each such co-sharer was assigned one R-O-R [khatian] for each village following the principle of "one man, one khatian]".

Records and maps are falling out of date mainly because changes due to death of the owner, transfer of land etc. are not being regularly incorporated in the records. The number of mutation cases awaiting disposal in the whole state is 479810 [Aug 2013] and is increasing every day. Records of rights are therefore, not up to date. Another gap lies in registration of individual tenure of land.

Definition of land may be inclusive, but in the RoRs plots stand classified according to use. Nobody has taken account of how much is comprised in homestead and how much is put to farming only. Moreover, the use of land plots keeps on changing.

Data Source: Monthly progress report [December, 2013] of the Directorate of Land Records and Surveys.

Data Reliability: As information is from Cadastral maps and Record of rights it is highly reliable.

48| Page Land Governance Assessment Framework - West Bengal 


\begin{tabular}{|c|c|c|l|}
\hline Panel & LGI & Dim. & $\begin{array}{l}\text { Land Governance Indicator 2 } \\
\text { Respect for and enforcement of rights }\end{array}$ \\
\hline 1 & 2 & 3 & Individual land in urban areas is recorded and mapped. \\
\hline \multirow{2}{*}{} & $\begin{array}{l}\text { A: More than 90\% of individual land in urban areas is formally recorded and } \\
\text { mapped. }\end{array}$ \\
\cline { 3 - 4 } & $\begin{array}{l}\text { B: Between 70\% and 90\% of individual land in urban areas is formally recorded } \\
\text { and mapped. } \\
\text { C: Between 50\% and 70\% of individual land in urban areas are formally } \\
\text { recorded and mapped. }\end{array}$ \\
\hline $\begin{array}{l}\text { D: Less than 50\% of individual land in urban areas is formally recorded and } \\
\text { mapped. }\end{array}$ \\
\hline
\end{tabular}

\section{Analysis:}

All urban areas of the state except the areas comprised in the first 100 wards of KMC came under the purview of all the tenancy laws starting from the B.T. Act to WBLR Act. The lands falling within the urban areas were, at the first instance, mapped and the related revenue records $[\mathrm{RoR}]$ prepared under the B.T. Act. Those have been successively revised under the WBEA Act and the W.B.L.R. Act.

The first hundred wards (1-100) of Kolkata Municipal Corporation comprise the entire area of old Calcutta. R.W. Smart had prepared (1903 - 1914) cadastral maps of these areas on a very large scale. Holding register was prepared by the Calcutta Municipality [as it was then called] on the basis of those maps for tax administration.

It will be seen from the above that the highly built up areas comprising old Calcutta does not have a set of cadastral maps in the true sense of the term, much less any revenue records. The Kolkata Land-Revenue Act, 2003 provides for preparation of maps and records of these hundred wards under the provisions of the WBLR Act which has not so far been extended to old Calcutta. However, KMC for the purpose of assessment holds inspection regularly and updates its register.

Individual properties in all urban areas except Calcutta have been mapped and recorded. But those are badly out-of-date. There is also wide gap in registration of individual urban land tenures.

Group housing schemes in the areas beyond the first 100 wards of KMC which existed from before revision have been mapped and records prepared. In most cases, the mapping of the group housing schemes was confined to the periphery of the housing complex. Due to lack of reliable data the percentage shown in ranking was agreed purely as an assessment (ranking changed from $\mathrm{B}$ to $\mathrm{C}$ in consultation with $\mathrm{EI}$ and panellist)

Data Source: Relevant Acts and Rules

Data Reliability: High

Policy recommendation: The state government may consider mapping and preparation of $\mathrm{r}-$ o-r in respect of different categories of housing complexes, either government or private, and assign this task appropriate priority.

\begin{tabular}{|c|c|c|l|}
\hline Panel & LGI & Dim. & $\begin{array}{l}\text { Land Governance Indicator 2 } \\
\text { Respect for and enforcement of rights }\end{array}$ \\
\hline 1 & 2 & 4 & The number of illegal land sales is low. \\
\hline \multicolumn{3}{|l}{} & $\begin{array}{l}\text { A: Few, if any, illegal transactions occur in practice and mechanisms to } \\
\text { unambiguously identify illegal sales exist and are applied routinely. }\end{array}$ \\
\hline
\end{tabular}

49 | Page Land Governance Assessment Framework - West Bengal 
B: The number of illegal land transactions is low and some are unambiguously identified on a routine basis.

C: The number of illegal land transactions is high and some are unambiguously identified on a routine basis.

D: The number of illegal land transactions is high and none are unambiguously identified on a routine basis.

\section{Analysis:}

Illegal sales not violating any tenancy law or conditions at which government has granted lease do not come within the purview of land governance. There are four areas in which illegal sales take place.

a) Rural area: sale of patta land is barred by law [sec 49(1A), WBLR]. But sale of patta lands is taking place everywhere in the state. A study made by the State Institute of Panchayats and Rural Development Kalyani revealed that over the decades about $2.73 \%$ of the patta holders had sold their lands.

b) Urban area: In Salt Lake City, a satellite township of Kolkata, long-term lease of land was given to a large number of families for residential purposes. Certain restrictions were imposed on the transferability of the lease hold lands. Despite these restrictions a significant number of illegal transfers have taken place in a roundabout way through crafty designs. To deal with this problem the Urban Development Dept. has since changed the rules. Transfer is permissible (in Salt Lake City) now with the approval of the department on payment of Rs.5.0o lakhs for each cottha of land.

Other two areas where such illegal transfer of land is taking place:

c) Transfer of land by a raiyat in contravention of sec 5(1) of the W.B.L.R. Act which requires him to transfer his land by an instrument which must be registered. But in practice transfers are being made through unregistered deeds which are being acted upon. This practice is widespread in rural West Bengal.

d) Transfers made by tribal raiyats in contravention of provisions in sec $14 \mathrm{C}$ of the WBLR Act which states that transfer of land to a non-tribal can be made only for some specified purposes from the appropriate authority

Also a very high percentage of land transfers in rural areas are not registered thus rendering the sales as illegal (ranking changed from B to $\mathrm{C}$ in consultation with the EI).

\section{Policy Recommendations:}

Laws provide for penal actions against illegal transactions. Such actions are taken when such transactions come to the notice of the authority. However, more proactive measures are called for to prevent illegal transactions. Government may consider appropriate steps to curb this.

Government might consider the feasibility of putting in place some sort of dispensation at local level with representation from the departments of Backward Classes Welfare, L and LR, and panchayats and Rural Development tasked with monitoring of identification of illegal transfers and remedial measures taken by the appropriate authorities.

\begin{tabular}{|c|c|c|l|}
\hline Panel & LGI & Dim. & $\begin{array}{l}\text { Land Governance Indicator 2 } \\
\text { Respect for and enforcement of rights }\end{array}$ \\
\hline 1 & 2 & 5 & The number of illegal lease transactions is low. \\
\hline \multicolumn{3}{|r}{} & $\begin{array}{l}\text { A: Existing legal restrictions on land leases if any, are clearly identified, widely } \\
\text { accepted and fully complied with. }\end{array}$ \\
\hline
\end{tabular}

50|Page Land Governance Assessment Framework - West Bengal 
B: Existing legal restrictions on land leases, if any, are clearly identified, justified and accepted by all parts of society, but not fully understood by land users, so that compliance is partial.

C: Existing legal restrictions on land leases are clearly identified but not fully justified or accepted by land users, so that compliance is partial.

D: Existing legal restrictions on land leases are routinely neglected.

\section{Analysis:}

Restriction on land leases have been imposed by Sec 4(4) of the WBLR Act which states that if a raiyat lets out his land such land excluding the homestead is liable to vest in the state.

By a recent amendment of the Act a raiyat has been permitted to let out the whole or part of his land for the purposes of establishment of an industrial park, industrial hub or industrial estate etc. [proviso to clause (d) of sec 4(4), WBLR Act].

This relaxation has been made to make way for private investment in the construction of hubs, parks, estates etc. Those who will acquire land and construct such parks, hubs etc., will not themselves utilize all the spaces. They will have to attract others to come to such parks, hubs etc. That is why this relaxation to enable them to lease out to the small holders.

However, the justification for such prohibition is to pre-empt the emergence of a feudal pattern of land tenure system which was abolished during tenancy reforms in the state. It cannot be claimed that these legal provisions regarding restrictions have been widely accepted particularly in the rural areas. Despite the restrictions incidences of concealed tenancies are being noticed. The consideration is mostly a fixed amount of money for a fixed crop or a fixed period of cultivation.

\section{Data Source:}

- West Bengal Land Reform Act, 1955

\section{Data Reliability: High}

Policy Recommendation: The state government may consider undertaking an in-depth study of the problem to find out its actual nature, geographical, spread etc. so that if necessary, an appropriate change in law may be considered.

\begin{tabular}{|c|c|c|c|}
\hline Panel & LGI & Dim. & $\begin{array}{l}\text { Land Governance Indicator } 2 \\
\text { Respect for and enforcement of rights }\end{array}$ \\
\hline \multirow[t]{5}{*}{1} & 2 & 6 & Women's property rights are recorded. \\
\hline & & & $\begin{array}{l}\text { A: More than } 45 \% \text { of land recorded to physical persons is recorded in } \\
\text { the name of women either individually or jointly. }\end{array}$ \\
\hline & & & $\begin{array}{l}\text { B: Between } 35 \% \text { and } 45 \% \text { of land recorded to physical persons is } \\
\text { recorded in the name of women either individually or jointly. }\end{array}$ \\
\hline & & & $\begin{array}{l}\text { C: Between } 15 \% \text { and } 35 \% \text { of land recorded to physical persons is } \\
\text { recorded in the name of women either individually or jointly. }\end{array}$ \\
\hline & & & $\begin{array}{l}\text { D: Less than } 15 \% \text { of land recorded to physical persons is recorded in the } \\
\text { name of women either individually or jointly. }\end{array}$ \\
\hline
\end{tabular}

51|Page Land Governance Assessment Framework - West Bengal 


\section{Analysis:}

The right of succession is governed by the persons. Muslim personal law gives right to women though not equal according faraj done by a recognized authority recognized in Muslim law. Moreover, Muslim women also get land on their marriage. Hence, names of muslim women stand well recorded right from the time RoRs were prepared under the BT Act taken up from the last decade of the $20^{\text {th }}$ Century.

Hindu personal law in this part of the country did not give property rights to Hindu women before the Hindu Women's Rights to Property Act, 1937. Before the provisions of the Act could be enforced preparation of the RoRs under the BT Act was almost over. Moreover, this Act had some inherent defects and hence was not enforced in right earnest. Hence, the names of women successors were not recorded in the RoRs. The landmark event with regard to Hindu women's right to property is the Hindu Succession Act, 1956. This Act gave equal rights to women successor. However, before the implications of this Act could be fully understood the revision of RoRs under the WBEA Act 1953 was over. Moreover, to carry out the purposes of the Act it was necessary to obtain the position of ownership of land as on $15^{\text {th }}$ April 1955 or $16^{\text {th }}$ April $1956-$ the dates of vesting under the Act. Naturally no attempt was made to record the names of women who became the owners of property by dint of the Hindu Succession Act, 1956.

Revision of RoR was taken up under the WBLR Act, 1955 from 1975 onwards. Unfortunately the names of women successors were not recorded due to unchanged mind-set of men and women in a male-dominated society. Recording the names of women in the RoR could not be availed of due to numerous reasons. Some of those are enumerated below:

1. Reluctance of the male co-sharers to declare the names of female co-sharers to the revenue officials during record writing.

2. Unwillingness of the women to come forward to record their names.

3. A sense of false pride in the mind-set of women in surrendering their right on paternal property.

4. Apprehension of embitterment of relationship with near and dear ones, and

5. Lack of empowerment

\section{Data Source:}

- SIPRD study report [2003]

- WBLR Act, 1955

\section{Data Reliability: High}

\section{Policy Recommendation:}

(1) By way of empowering women through endowment of land assets priority should have been given in the matter of distribution of land as in the case of members of the STs and SCs. For this purpose sec 49(1) of the WBLR Act, 1955 may be amendment.

(2) Women owners of land may be exempted from paying land revenue irrespective of the amount of land possessed. This proposal if accepted will require amendment of the WBLR Act.

\begin{tabular}{|c|c|c|l|}
\hline Panel & LGI & Dim. & $\begin{array}{l}\text { Land Governance Indicator 2 } \\
\text { Respect for and enforcement of rights }\end{array}$ \\
\hline 1 & 2 & 7 & $\begin{array}{l}\text { Women's property rights to land are equal to those by men both in law } \\
\text { and in practice. }\end{array}$ \\
\hline \multicolumn{3}{|r}{} \\
$\begin{array}{l}\text { A: Women's property rights are equal to those by men both across and } \\
\text { within generations both in law and in practice. }\end{array}$ \\
\hline \hline
\end{tabular}

52|Page Land Governance Assessment Framework - West Bengal 


\begin{tabular}{|l|l|}
\hline & $\begin{array}{l}\text { B: Equality of women's property rights to those by men is established by } \\
\text { law and followed in practice most of the time. }\end{array}$ \\
\cline { 2 - 2 } & $\begin{array}{l}\text { C: Equality of women's property rights to those by men is established by } \\
\text { law, but there are considerable limitations to exercising such rights in } \\
\text { practice. }\end{array}$ \\
\hline $\begin{array}{l}\text { D: Equality of women's property rights to those by men is not } \\
\text { established by law. }\end{array}$ \\
\hline
\end{tabular}

\section{Analysis:}

The legal position regarding equality of women's property rights to those by men is as under: Hindu women: Equal in terms of Sections 8, 9 of the Hindu Succession Act, 1956.

Indian Christian women: Equal in terms of Sec 37 of the Indian Successions Act, 1937. Muslim women: Unequal as per Muslim Sariati laws.

In the case of Muslim women the Sariati law itself prescribes inequality in rights to property between men and women. Despite the legal prescription of equality in respect of the other two communities there has always been a lag between the legal dispensation and practice. In spite of the growing awareness among women about their lawful rights and pro-active role of the women's organizations in promoting women empowerment the lag persists though on a reduced scale.

\section{Data Source:}

- Hindu Succession Act, 1956

- Indian Succession Act, 1937

- Muslim Sariati Laws

\section{Data Reliability: High}

\section{Panel 2: Rights to Forest and Common Lands \& Rural Land Use Regulations}

Panel 2 deals with the rights of rural people over forest and common lands. It also encompasses existing formal regulations on rural land use in the state. The Expert Investigator assigned for this panel has critically examined how far the rights of rural people over forest and common lands are recognized by legislations and enforced in practice. He has also incorporated the inputs, suggestions and recommendations which came out from the panel discussions.

\section{Indicators}

1. Rights to forest and common lands

2. Effectiveness and equity of rural land use regulations

\begin{tabular}{|c|c|c|l|}
\hline Panel & LGI & Dim. & $\begin{array}{l}\text { Land Governance Indicator 3 } \\
\text { Rights to forest and common lands }\end{array}$ \\
\hline 2 & \multirow{2}{*}{1} & 1 & $\begin{array}{l}\text { Forests and common lands are clearly identified in law and responsibility } \\
\text { for use is clearly assigned. }\end{array}$ \\
\hline \multirow{2}{*}{} & $\begin{array}{l}\text { A: Forests and common lands are clearly identified and responsibility for } \\
\text { land use is unambiguous assigned. }\end{array}$ \\
\cline { 3 - 4 } & $\begin{array}{l}\text { B: Forests and common lands are clearly identified, responsibility for } \\
\text { land use is clearly identified but implementation is ambiguous. }\end{array}$ \\
\cline { 3 - 4 } & $\begin{array}{l}\text { C: Forests and common lands are not clearly identified; but } \\
\text { responsibility for land use is clearly assigned. }\end{array}$ \\
\cline { 3 - 4 } & $\begin{array}{l}\text { D: Forests and common lands are not clearly identified and } \\
\text { responsibility for land use is not defined. }\end{array}$ \\
\hline
\end{tabular}

53|Page Land Governance Assessment Framework - West Bengal 


\section{Analysis:}

Responsibility of forest land use is legally not very well defined. Though the management of forest land is with the Forest officials under the Indian Forest Act 1927 and Forest Conservation Act 1980, the right to use on the basis of Joint Forest Management resolution of State Government and FRA 2006 has brought in some grey areas with respect to people's rights and active participation in management of forest land. Moreover, though the Forest lands are clearly identified on R.S. maps, demarcation on ground has not been made in all cases. Especially in case of vested common land adjoining the notified but degraded forest land, absence of demarcation on ground gives rise to disputes between the local population and the forest officials (ranking has been changed from B to C in consultation with EI and CSOs working in the field).

\section{Policy Recommendation:}

1. Records need to be updated.

2. Gap in information available between L\&LR Department and Forest Department needs to be bridged.

3. Mechanism should be developed / practical guideline should be prepared so that L\&LR Department and Forest Department work in tandem.

\begin{tabular}{|c|c|c|l|}
\hline Panel & LGI & Dim. & $\begin{array}{l}\text { Land Governance Indicator 3 } \\
\text { Rights to forest and common lands }\end{array}$ \\
\hline 2 & 1 & 2 & Rural group rights are formally recognized and can be enforced. \\
\hline \multirow{2}{*}{} & & $\begin{array}{l}\text { A: The tenure of most groups in rural areas is formally recognized and clear } \\
\text { regulations regarding groups' internal organization and legal representation } \\
\text { exist and can be enforced. }\end{array}$ \\
\cline { 4 - 4 } & $\begin{array}{l}\text { B: The tenure of most groups in rural areas is not formally recognized but } \\
\text { groups can gain legal representation under other laws (e.g. corporate law). }\end{array}$ \\
\cline { 4 - 5 } & $\begin{array}{l}\text { C: The tenure of most groups in rural areas is formally recognized but ways } \\
\text { for them to gain legal representation are not regulated. }\end{array}$ \\
\cline { 3 - 4 } & D: The tenure of most groups in rural areas is not formally recognized. \\
\hline
\end{tabular}

Analysis:

The usufructory benefits of NTFP (non-timber forest produce) to the JFMC member groups from forest areas are outlined in the Govt. resolutions, but the same are not supported by any legal backing. The benefit sharing with user groups again depends on the administrative machinery of Forest department. Moreover, the user groups under JFMC, in many cases, exclude part of the local villagers and there is no legal mechanism to enforce right of all the users to be part of the user group. Some lands in rural areas may be used by several groups for a specific purpose (fish drying in Sundarban area, grazing etc.) and at different moments throughout the year. These user rights are not recognized by law (ranking changed from C to D in consultation with EI, panellist and CSO working in ground).

Data Source: CSOs who are working on FRA in the field

Data Reliability: good

\section{Policy Recommendation:}

1. Provision should be made in FRA to incorporate the system of JFMC.

2. Scope of 'community rights' to be widened up to include other forest dwellers along with ST. 


\begin{tabular}{|c|c|c|l|}
\hline Panel & LGI & Dim. & $\begin{array}{l}\text { Land Governance Indicator 3 } \\
\text { Rights to forest and common lands }\end{array}$ \\
\hline 2 & \multirow{2}{*}{3} & 3 & $\begin{array}{l}\text { Users' rights to key natural resources on land (incl. fisheries) are legally } \\
\text { recognized and protected in practice. }\end{array}$ \\
\hline \multirow{2}{*}{} & $\begin{array}{l}\text { A: Users' rights to key natural resources are legally recognized and } \\
\text { consistently and effectively protected in practice throughout. }\end{array}$ \\
\cline { 3 - 4 } & $\begin{array}{l}\text { B: Users' rights to key natural resources are legally recognized but only some } \\
\text { are effectively protected in practice or enforcement is difficult and takes a } \\
\text { long time. }\end{array}$ \\
\cline { 3 - 4 } & $\begin{array}{l}\text { C: Users' rights to key natural resources are not legally recognized but enjoy } \\
\text { de facto protection in virtually all cases. }\end{array}$ \\
\cline { 3 - 4 } & $\begin{array}{l}\text { D: Users' rights to key natural resources are not legally recognized and often } \\
\text { not protected in practice. }\end{array}$ \\
\hline
\end{tabular}

Analysis:

Except for the Govt Resolution on JFM, users' rights on NTFP are not legally protected unless patta has been given to the individual or community under FRA 2006. Similarly, in case of Sundarbans, local fishermen used to enjoy customary fishing rights in the Sundarbans Rivers within Reserved Forest boundary. However, no such right has been recognized under FRA 2006.

\section{Data Source:}

\section{Data Reliability:}

Policy Recommendation: Synergy is required for provisioning JFMC under FRA.

\begin{tabular}{|c|c|c|l|}
\hline Panel & LGI & Dim. & $\begin{array}{l}\text { Land Governance Indicator 3 } \\
\text { Rights to forest and common lands }\end{array}$ \\
\hline 2 & 1 & 4 & $\begin{array}{l}\text { Multiple rights over common land and natural resources on these lands can } \\
\text { legally coexist. }\end{array}$ \\
\hline \multirow{4}{*}{} & $\begin{array}{l}\text { A: Co-existence of multiple rights is possible by law, respected in practice, } \\
\text { and any disputes that may arise are swiftly resolved. }\end{array}$ \\
\cline { 3 - 4 } & $\begin{array}{l}\text { B: Co-existence is possible by law and respected in practice but mechanisms } \\
\text { to resolve disputes are often inadequate. }\end{array}$ \\
\cline { 3 - 4 } & C: Co-existence is possible by law but rarely respected in practice. \\
\cline { 3 - 4 } & D: Co-existence is not possible by law. \\
\hline
\end{tabular}

\section{Analysis:}

In pursuance of The West Bengal Estates Acquisition Act, 1953, all the private/ zamindary lands recorded as forest in the land records, had vested in the State Govt. and were subsequently transferred to Forest Dept. and notified as Protected Forests under the IFA, 1927. Under Indian Forest Act, 1927, right of management of Govt. notified Forest land rests with forest officials. Forest Conservation Act, 1980 also puts restriction on use of forest land for non-forestry purpose. However, under FRA 2006, user groups/ community can have legal right on Forest land with regard to shelter/ livelihood and also on collection of NTFP from the Forest land. But, in practice, right of individuals/ community vis-à-vis Govt. is considered as mutually exclusive of each other in case of any dispute, the final decision is taken by Forest Department unilaterally, without effectively resolving the dispute rationally through some independent authority.

Data Source: Forest department 


\begin{tabular}{|c|c|c|c|}
\hline Panel & LGI & Dim. & $\begin{array}{l}\text { Land Governance Indicator } 3 \\
\text { Rights to forest and common lands }\end{array}$ \\
\hline \multirow[t]{5}{*}{2} & \multirow[t]{5}{*}{1} & \multirow[t]{5}{*}{5} & $\begin{array}{l}\text { Multiple rights over the same plot of land and its resources (e.g. trees) can } \\
\text { legally coexist. }\end{array}$ \\
\hline & & & $\begin{array}{l}\text { A: Co-existence of multiple rights is legally possible, respected in practice, and } \\
\text { any disputes that may arise are swiftly resolved. }\end{array}$ \\
\hline & & & $\begin{array}{l}\text { B: Co-existence is legally possible and respected in practice but mechanisms } \\
\text { to resolve disputes are often inadequate. }\end{array}$ \\
\hline & & & C: Co-existence is legally possible but rarely respected in practice. \\
\hline & & & D: Co-existence is not legally possible. \\
\hline
\end{tabular}

\section{Analysis:}

Under Indian Forest Act, 1927, right of management of Forest land rests with forest officials. Under FRA 2006, user groups/ community can have legal right on Forest land with regard to shelter/ livelihood and also on NTFP from the Forest land. However, in practice, right of one is considered as exclusive of other and mutual respect for each other's rights hardly exists. There is also no conscious effort to strike a balance between the two sets of rights. But, in practice, right of individuals/ community vis-à-vis Govt. is considered as mutually exclusive of each other and in case of any dispute, the final decision is taken by Forest Department unilaterally, without effectively resolving the dispute rationally through some independent authority.

\begin{tabular}{|c|c|c|l|}
\hline Panel & LGI & Dim. & $\begin{array}{l}\text { Land Governance Indicator 3 } \\
\text { Rights to forest and common lands }\end{array}$ \\
\hline 2 & \multirow{2}{*}{1} & 6 & $\begin{array}{l}\text { Multiple rights over land and mining/ other sub-soil resources located on the } \\
\text { same plot can legally coexist. }\end{array}$ \\
\hline \multirow{2}{*}{} & $\begin{array}{l}\text { A: Co-existence of land and mining rights is possible by law, respected in } \\
\text { practice, and any disputes that may arise are swiftly resolved. }\end{array}$ \\
\cline { 3 - 4 } & $\begin{array}{l}\text { B: Co-existence of land and mining rights is possible by law and respected in } \\
\text { practice but mechanisms to resolve disputes are often inadequate. }\end{array}$ \\
\cline { 3 - 4 } & C: Co-existence is possible by law but rarely respected in practice. \\
\cline { 3 - 4 } & D: Co-existence is not possible by law; mining rights override land rights. \\
\hline
\end{tabular}

\section{Analysis:}

Mining on forest land is considered as non-forestry activity under the Forest Conservation Act, 1980. For mining rights, the forest land is transferred to mining authorities with prior approval of Ministry of Environment \& Forests and almost all coal mines are open-cast in West Bengal. Hence, the community rights of collection of NTFP on Forest land have to automatically cease for technical reasons, if the forest land is diverted for mining purpose. However, as per FRA 2006, clearance of Gram Sabha is mandatory, with respect to existing rights of ST under the FRA, 2006, before the proposal for transfer of Forest land for mining purpose is approved by Central Govt.

\begin{tabular}{|c|c|c|l|}
\hline Panel & LGI & Dim. & $\begin{array}{l}\text { Land Governance Indicator 3 } \\
\text { Rights to forest and common lands }\end{array}$ \\
\hline 2 & 1 & 7 & Accessible opportunities exist for mapping and recording of group rights. \\
\hline \multirow{2}{*}{} & & $\begin{array}{l}\text { A: The law provides opportunities for those holding land under customary, } \\
\text { group, or collective tenure as a group to record and map these rights if they so } \\
\text { desire. Procedures for doing so are affordable, clearly specified, safeguarded, } \\
\text { and are observed in practice. }\end{array}$ \\
\cline { 3 - 4 } & $\begin{array}{l}\text { B: The law provides opportunities for those holding group land under } \\
\text { customary, group, or collective tenures to record and map these rights if they } \\
\text { so desire. Procedures to do so are affordable and include basic safeguards }\end{array}$ \\
\hline \hline
\end{tabular}

56|Page Land Governance Assessment Framework - West Bengal 


\begin{tabular}{|l|l|}
\hline & against abuse. \\
\cline { 2 - 3 } $\begin{array}{l}\text { C: The law provides opportunities for those holding group land under } \\
\text { customary, group, or collective tenures to record and map land rights if they } \\
\text { so desire. Procedures are not affordable or clear, leading to discretion in their } \\
\text { application. }\end{array}$ \\
\cline { 2 - 2 } $\begin{array}{l}\text { D: Although there is demand, the law provides no opportunities for that } \\
\text { holding group land under customary, group, or collective tenures to record } \\
\text { and map land rights. }\end{array}$ \\
\hline
\end{tabular}

\section{Analysis:}

All the forest land, for which community forest rights / patta have been distributed, had been notionally demarcated on the ground, prior to vesting of rights under FRA 2006. However, correct maps of all such land demarcated on the ground, could not be generated due to shortage of manpower and lack of initiatives to use GPS technologies by some of the DFOs. This may lead to disputes in future between the forest officials and the land right holders, due to lack of clarity of the land under possession. There is an urgent need to rectify the situation through a timebound programme. The field experiences shared by the CSOs working on this issue that the formalities associated with application for patta allocation to customary, group or collective tenures are not understood well by the people eligible and there needs to be awareness generation drives. Also the disposal of applications is done without showing proper reasons leaving scope for discretion of the disposing authorities. The ranking has been changed from " $\mathrm{B}$ " to "C" in consultation with EI and CSOs, panellist.

Data Source: Forest department and CSOs working in the field

Policy Recommendation: Recording and mapping of the rights of the groups who are holding land under customary, group, or collective tenures should be made mandatory.

\begin{tabular}{|c|c|c|l|}
\hline Panel & LGI & Dim. & $\begin{array}{l}\text { Land Governance Indicator 3 } \\
\text { Rights to forest and common lands }\end{array}$ \\
\hline 2 & \multirow{2}{*}{1} & 8 & Boundary demarcation of communal land. \\
\hline \multirow{2}{*}{} & & $\begin{array}{l}\text { A: More than 70\% of the area under communal and/or indigenous land has } \\
\text { boundaries demarcated and surveyed and associated claims recorded. }\end{array}$ \\
\cline { 3 - 4 } & $\begin{array}{l}\text { B: } 40-70 \% \text { of the area under communal and/or indigenous land has } \\
\text { boundaries demarcated and surveyed and associated claims recorded. }\end{array}$ \\
\cline { 3 - 4 } & $\begin{array}{l}\text { C: } 10-40 \% \text { of the area under communal and/or indigenous land has } \\
\text { boundaries demarcated and surveyed and associated claims recorded. }\end{array}$ \\
& $\begin{array}{l}\text { D: Less than 10\% of the area under communal and/or indigenous land has } \\
\text { boundaries demarcated and surveyed and associated claims recorded. }\end{array}$ \\
\hline
\end{tabular}

\section{Analysis:}

At the time of processing of applications, under FRA 2006, some of the land had been demarcated on ground and boundary pillars erected. This was particularly true for the registered forest villages in North Bengal where the applicants live in groups. However, in case of individual applications, especially in South Bengal districts, such demarcation on ground, as to be reflected through correctly drawn map attached to the ownership papers, is lacking. The ranking is $\mathrm{D}$. 


\begin{tabular}{|c|c|c|c|}
\hline Panel & LGI & Dim. & $\begin{array}{l}\text { Land Governance Indicator } 4 \\
\text { Effectiveness and equity of rural land use regulations }\end{array}$ \\
\hline \multirow[t]{5}{*}{2} & 2 & 1 & Restrictions regarding rural land use are justified and enforced. \\
\hline & & & $\begin{array}{l}\text { A: Regulations regarding restrictions on rural land use effectively serve public } \\
\text { purpose and are enforced. }\end{array}$ \\
\hline & & & $\begin{array}{l}\text { B: Regulations regarding restrictions on rural land use effectively serve public } \\
\text { purpose but enforcement is weak. }\end{array}$ \\
\hline & & & $\begin{array}{l}\text { C: Regulations often do not effectively serve public purpose and enforcement } \\
\text { is difficult. }\end{array}$ \\
\hline & & & D: Regulations rarely effectively serve public purpose, but can be enforced. \\
\hline
\end{tabular}

\section{Analysis:}

The W.B. L.R. Act severely restricts use of land. The relevant provisions are:

Sec 4A: Deals with restrictions on the right of raiyats on land use in the three hilly subdivisions of Darjeeling district. The Collector may decide the form of cultivation to be adopted by raiyat or prohibit him from cutting more than one tree from his holding except with the previous permission of the Collector.

Sec 4B: Requires every raiyat to maintain and preserve his land. This section prohibits a raiyat from changing the character of the land or from converting the land for any purpose other than the purpose for which it was settled except with the previous order of Collector allowing such conversion [ $\mathrm{sec} 4 \mathrm{C}$, ibid].

It will appear from the above that in case of the hilly subdivisions of Darjeeling the regulatory role of the Collector is intended to prevent landslides, erosion etc. The provisions are necessary and justified.

The main purpose behind sec $4 \mathrm{~B}$ was to prevent indiscriminate conversion of agri land into nonagricultural land because the use of agricultural land for raising crops was considered to be the most important use in the state.

Another legal provision with respect to felling of trees on private land, raised under Social Forestry program, under W.B (protection and conservation of trees in non-forest areas) Act, 2006 puts severe restriction on the choice of optimum land use by the private land owners. The land-owners normally plant trees under Social Forestry programs, either to harvest it at the time of financial need, or to put the non-arable land under best productive utilization. The primary objective of the Act is to prevent large scale felling of trees leading to reduction in green cover. Though the Non-forest tree Act, 2006 has provision to allow felling, subject to certain conditions, the bureaucratic red-tapism sometimes complicates the process for the applicant and leads to corruption. The Act allows felling of a maximum of three trees per year without prior permission. But there is a need to further simplify the process so that the land owners are not de-motivated to plant trees leading to failure of popular social forestry program.

Different Development Authorities like the Durgapur-Asansol Development Authority, Haldia Development Authority etc. created under the provisions of the Town and Country Planning Act are authorized to restrict change of land use in specified areas falling within the area for which a development plan has been drawn up.

Policy Recommendation: The government has to revisit the subject on the use of land. Building of infrastructure, setting up of industries and planned urbanization are the essential requirements of the day. The reason for imposing restrictions in the early eighties of the last century no longer holds good. It's time the restrictions were relaxed in a judicious way

58|Page Land Governance Assessment Framework - West Bengal 


\begin{tabular}{|c|c|c|l|}
\hline Panel & LGI & Dim. & $\begin{array}{l}\text { Land Governance Indicator 4 } \\
\text { Effectiveness and equity of rural land use regulations }\end{array}$ \\
\hline 2 & 2 & 2 & $\begin{array}{l}\text { Restrictions on rural land transferability effectively serve public policy } \\
\text { objectives. }\end{array}$ \\
\hline \multirow{2}{*}{} & $\begin{array}{l}\text { A: There are a series of regulations that for the most part serve public purpose } \\
\text { and that are enforced. }\end{array}$ \\
\cline { 3 - 4 } & $\begin{array}{l}\text { B: There are a series of regulations that are for the most part serving pubic } \\
\text { purpose but that are not enforced. }\end{array}$ \\
\cline { 3 - 4 } & $\begin{array}{l}\text { C: There are a series of regulations that are generally not serving a public } \\
\text { purpose but are not enforced. }\end{array}$ \\
\cline { 3 - 4 } & $\begin{array}{l}\text { D: There are a series of regulations that are generally not serving public } \\
\text { purpose and are enforced. }\end{array}$ \\
\hline
\end{tabular}

\section{Analysis:}

Restrictions on rural land transferability have been imposed by several Acts, namely WBLR Act [Secs 49(1A), 14C] - Sec 49(1A) applies to the patta holders and sec $14 \mathrm{C}$ to the members of scheduled tribes. Restrictions have also been imposed by the Homestead Act [sec 10(1)].

A patta holder is a beneficiary of distributive land reforms and any unfettered right of transfer patta land will defeat the very purpose of distributive land reform. Similarly, an unrestricted right of transfer of land, if available to a member of the Scheduled Tribe to a non-tribal, will encourage alienation of land. Also, a beneficiary under the Homestead Act is given land to provide him a secure shelter. Transfer of the land by him unless restricted will defeat the very purpose of the Act and go against the public policy of socio-economic development of the poorer section of the society. Enforcement level of these legal provisions is rather low and numerous cases are found where the patta-holders and members of ST community have transferred the land in contravention to provisions of WBLR Act (ranking changed while reviewing with EI and panellists from A to B).

\section{Data Source: no data available, assessment by field experience Policy Recommendation:}

\begin{tabular}{|c|c|c|c|}
\hline Panel & LGI & Dim. & $\begin{array}{l}\text { Land Governance Indicator } 4 \\
\text { Effectiveness and equity of rural land use regulations }\end{array}$ \\
\hline \multirow[t]{5}{*}{2} & 2 & 3 & $\begin{array}{l}\text { Rural land use plans are elaborated/changed via public process and resulting } \\
\text { burdens are shared. }\end{array}$ \\
\hline & & & $\begin{array}{l}\text { A: Public input is required and sought in preparing and amending rural land } \\
\text { use plans (incl. rezoning) and relevant decisions are arrived at in a } \\
\text { transparent and public process. }\end{array}$ \\
\hline & & & $\begin{array}{l}\text { B: Public input is required and sought in preparing and amending rural land } \\
\text { use plans (incl. rezoning) but decisions are arrived at in a non-transparent } \\
\text { process. }\end{array}$ \\
\hline & & & $\begin{array}{l}\text { C: Public input is required and sought in preparing and amending land use } \\
\text { plans but comments are not reflected in the finalization of land use plans. }\end{array}$ \\
\hline & & & $\begin{array}{l}\text { D: Public input is not required and/or sought in preparing and amending land } \\
\text { use plans. }\end{array}$ \\
\hline
\end{tabular}

\section{Analysis:}

Land use refers to human activities that takes place on or make use of land, e.g., residential, commercial, industrial etc. The challenge for land use planning is to achieve concurrently the objectives of protecting and consolidating agriculture, diversifying agricultural production and enhancing rural development and moving towards infrastructure and industrial development. District land sue plans are being developed for all districts of the state. For amending land use

59| Page Land Governance Assessment Framework - West Bengal 
plans local level discussions are facilitated through the involvement of local administration and panchayatiraj institutions, but there is ambiguity in incorporation of local inputs in the finalization or amending land use plans (ranking changed from A to C in consultation with EI and panellists).

\section{Policy Recommendation:}

\begin{tabular}{|c|c|c|c|}
\hline Panel & LGI & Dim. & $\begin{array}{l}\text { Land Governance Indicator } 4 \\
\text { Effectiveness and equity of rural land use regulations }\end{array}$ \\
\hline \multirow[t]{5}{*}{2} & \multirow[t]{5}{*}{2} & \multirow[t]{5}{*}{4} & $\begin{array}{l}\text { Rural lands, the use of which is changed, are swiftly transferred to the } \\
\text { destined use. }\end{array}$ \\
\hline & & & $\begin{array}{l}\text { A: More than } 70 \% \text { of the land that has had a change in land use assignment in } \\
\text { the past } 3 \text { years has changed to the destined use (e.g. forest, pastures, } \\
\text { wetlands, national parks etc.). }\end{array}$ \\
\hline & & & $\begin{array}{l}\text { B: Between } 50 \% \text { and } 70 \% \text { of the land that has had a change in land use } \\
\text { assignment in the past } 3 \text { years has changed to the destined use (e.g. forest, } \\
\text { pastures, wetlands, national parks etc.). }\end{array}$ \\
\hline & & & $\begin{array}{l}\text { C: Between } 30 \% \text { and } 50 \% \text { of the land that has had a change in land use } \\
\text { assignment in the past } 3 \text { years has changed to the destined use (e.g. forest, } \\
\text { pastures, wetlands, national parks etc.). }\end{array}$ \\
\hline & & & $\begin{array}{l}\text { D: Less than } 30 \% \text { of the land that has had a change in land use assignment in } \\
\text { the past } 3 \text { years has changed to the destined use (e.g. forest, pastures, } \\
\text { wetlands, national parks etc.). }\end{array}$ \\
\hline
\end{tabular}

\section{Analysis:}

Rural lands the use of which is changed cannot be always swiftly transferred to the destined use. First, it takes time to decide how best a land may be utilized for public good. Once a decision is arrived through public process actual execution depends on numerous factors like availability of funds, technical assistance etc., whenever necessary.

\section{Data Source:}

Data Reliability: Policy Recommendation:

\begin{tabular}{|c|c|c|l|}
\hline Panel & LGI & Dim. & $\begin{array}{l}\text { Land Governance Indicator 4 } \\
\text { Effectiveness and equity of rural land use regulations }\end{array}$ \\
\hline 2 & 2 & 5 & $\begin{array}{l}\text { Rezoning of rural land use follows a public process that safeguards existing } \\
\text { rights. }\end{array}$ \\
\hline \multirow{2}{*}{} & $\begin{array}{l}\text { A: Processes for rezoning are public and clear with effective mechanisms in } \\
\text { place to safeguard existing rights and compensation in case of loss in areas } \\
\text { where land use is to be restricted. }\end{array}$ \\
\cline { 3 - 4 } & $\begin{array}{l}\text { B: Processes for rezoning are public and clear but mechanisms to safeguard } \\
\text { existing rights are not fully effective. }\end{array}$ \\
\cline { 3 - 4 } & $\begin{array}{l}\text { C: Processes for rezoning are not public but care is taken to safeguard existing } \\
\text { rights in virtually all cases. }\end{array}$ \\
\cline { 3 - 4 } & $\begin{array}{l}\text { D: Rezoning processes are not public process and rights are ignored or not } \\
\text { properly or promptly compensated in the majority of cases. }\end{array}$ \\
\hline
\end{tabular}

\section{Analysis:}

Processes for rezoning of rural land use, as in case of notifications under Indian Forest Act, 1927 or Wildlife protection Act, 1972 are well documented and are accessible by public. But there is mostly one-sided action on the part of Forest department to implement the processes, with little

6o I Page Land Governance Assessment Framework- West Bengal 
effort to ensure that the rights of the affected people are fully taken care of. There is an elaborate mechanism under IFA, 1927, to finally notify a Forest as Protected or Reserved, after settlement of all rights. But for most of the Protected Forests in South Bengal, notifications were used without fulfilling the prior needs, which resulted into conflict between the people and forest officials in the early sixties and seventies (ranking changed from A to B in consultation with EI and other stakeholders).

Data Source: Forest department and CSOs Policy Recommendation:

\begin{tabular}{|c|c|c|l|}
\hline Panel & LGI & Dim. & $\begin{array}{l}\text { Land Governance Indicator 4 } \\
\text { Effectiveness and equity of rural land use regulations }\end{array}$ \\
\hline 2 & 2 & 6 & $\begin{array}{l}\text { For protected rural land use (forest, pastures, wetlands, national parks etc.) } \\
\text { plans correspond to actual use. }\end{array}$ \\
\hline \multirow{5}{*}{} & $\begin{array}{l}\text { A: The share of land set aside for specific use that is used for a non-specified } \\
\text { purpose in contravention of existing regulations is less than } 10 \% .\end{array}$ \\
\cline { 3 - 4 } & $\begin{array}{l}\text { B: The share of land set aside for specific use that is used for a non-specified } \\
\text { purpose in contravention of existing regulations is between } 10 \% \text { and } 30 \% .\end{array}$ \\
\cline { 3 - 4 } & $\begin{array}{l}\text { C: The share of land set aside for specific use that is used for a non-specified } \\
\text { purpose in contravention of existing regulations is between } 30 \% \text { and } 50 \% .\end{array}$ \\
& $\begin{array}{l}\text { D: The share of land set aside for specific use that is used for a non-specified } \\
\text { purpose in contravention of existing regulations is greater than } 50 \% .\end{array}$ \\
\hline
\end{tabular}

\section{Analysis:}

The management of forest land and National Parks are controlled by Forest Department and no alternate land use is permitted except for prior approval of Min of Environment \& Forests, GOI and National Board of Wildlife (for National Parks/ Sanctuaries). The same holds true for those wetland notified as Forest under IFA/ Wild Life Protection Act. However, in case of wetland situated on Govt. vested land or in private sector, there are often illegal diversions of same for construction/ Real Estate purposes especially in the towns. Management of such wetland and pasture are mostly neglected and only when there is a protest from civil society, the land use diversion is stopped temporarily. There are also cases of unholy nexus between Govt. officials, Panchayat officials and the unscrupulous promoters towards such illegal land-use changes. There is no data available for making a fair assessment of the dimension ranking, but an estimation of contravention of existing regulations between $10-30 \%$ is considered appropriate (ranking changed from A to B following consultation with EI and stakeholders/ panellists).

Data Source: Forest department, no data available on violation of regulations

Policy Recommendation: Synergy is required for provisioning JFMC under FRA.

\section{Panel 3: Urban Land Use, Planning, and Development}

\section{$\underline{\text { Indicators }}$}

This panel has been allotted the following indicators

1. (LGI 4) Restrictions on rights: land rights are not conditional on adherence to unrealistic standards.

2. (LGI 7) Transparency of land use restrictions: changes in land use and management regulations are made in a transparent fashion and provide significant benefits for society in general rather than just for specific groups.

61|Page Land Governance Assessment Framework - West Bengal 
3. (LGI8) Efficiency in the urban land use planning process: land use plans are current, implemented, do not drive people into informality, and cope with urban growth.

4. (LGI 9)Speed and predictability of enforcement of restricted land uses: development permits are granted promptly and based on reasonable requirements.

\section{5. (LGI 10)Tenure regularization schemes in urban areas}

\begin{tabular}{|c|c|c|l|}
\hline Panel & LGI & Dim. & $\begin{array}{l}\text { Land Governance Indicator 4 } \\
\text { Restrictions on rights: land rights are not conditional on } \\
\text { adherence to unrealistic standards }\end{array}$ \\
\hline 3 & 1 & 1 & $\begin{array}{l}\text { Restrictions on urban land ownership/transfer effectively serve public } \\
\text { policy objectives. }\end{array}$ \\
\hline \multirow{2}{*}{} & $\begin{array}{l}\text { A: There are a series of regulations that are for the most part serving } \\
\text { public purpose and that are enforced. }\end{array}$ \\
& $\begin{array}{l}\text { B: There is a series of regulations that are for the most part serve public } \\
\text { purpose but enforcement is deficient. }\end{array}$ \\
\cline { 3 - 4 } & $\begin{array}{l}\text { C: There are a series of regulations that are generally not serving public } \\
\text { purpose but are not enforced. }\end{array}$ \\
\hline & $\begin{array}{l}\text { D: There are a series of regulations that are generally not serving public } \\
\text { purpose and are enforced. }\end{array}$ \\
\hline
\end{tabular}

\section{Analysis}

Land tenure is defined as the mode by which land is held or owned, or the set of relationships among people concerning land or its products. These relationships may be obtained by law (de jure) or by custom, use or occupation (de facto). The form of tenure determines how strong or weak the claims, rights and entitlements are in relation to land. Individual land title is only one form of land tenure, and not necessarily the only way of ensuring security of tenure.

Issue:-Rapid increase in population and fast dwindling land supply

\section{Legislations:-}

- West Bengal Land Reforms Act, 1955 wherein under section 4C restrictions have been imposed on the raiyat for change of area, character or use of land in both rural and urban areas.

- Urban Land (Ceiling and Regulation) Act, 1976 which ensures equitable distribution of land in urban agglomeration and restricts haphazard land use in the urban areas.

- West Bengal Town and Country (Planning and Development) Act, 1979

- West Bengal Municipal Act, 1993

- Indian Registration Act of 1908: provides for registration of deeds (for any land transaction), which establishes public record of transactions but not validity of transactions. It does not require to verify the history of land ownerships from the seller, thus weakening protection mechanism for the buyers as this makes the land title 'presumptive' and not 'conclusive'.

The Acts and Regulations above explain the restrictions on urban land ownership and/or transfer but enforcement of those acts/regulations is definitely deficient.

Data Source: West Bengal Municipal Act, 1993, West Bengal Town and Country (Development and Planning act, 1979, Urban Land Ceiling and Registration Act, 1976, West Bengal Land Reforms Act, 1955 . 


\section{Policy Recommendation:}

If the cities are to continue to be efficient platforms for future economic growth and to accommodate the rising demands for land for habitation of the burgeoning urban population in the decades to come in a sustainable manner, radical reformation is required within the present land management system and their administration to accomplish the transition of organised urban development. Now there is a series of legislations/regulations that are for the most part serve public purpose but enforcement is deficient. While reformation in the system and administration is recommended, the Government also should reap the benefits of the existing relevant legal framework through a process of proper enforcement.

\begin{tabular}{|c|c|c|c|}
\hline Panel & LGI & Dim. & $\begin{array}{l}\text { Land Governance Indicator } 4 \\
\text { Restrictions on rights: land rights are not conditional on } \\
\text { adherence to unrealistic standards }\end{array}$ \\
\hline \multirow[t]{5}{*}{3} & \multirow[t]{5}{*}{1} & \multirow[t]{5}{*}{2} & $\begin{array}{l}\text { Restrictions on urban land use (disaster risk) effectively serve public } \\
\text { policy objectives. }\end{array}$ \\
\hline & & & $\begin{array}{l}\text { A: There are a series of regulations that are for the most part serving } \\
\text { public purpose and that are enforced. }\end{array}$ \\
\hline & & & $\begin{array}{l}\text { B: There are a series of regulations that are for the most part serving } \\
\text { public purpose but that are not enforced. }\end{array}$ \\
\hline & & & $\begin{array}{l}\text { C: There are a series of regulations that are generally not serving public } \\
\text { purpose but are not enforced. }\end{array}$ \\
\hline & & & $\begin{array}{l}\text { D: There are a series of regulations that are generally not serving public } \\
\text { purpose and are enforced. }\end{array}$ \\
\hline
\end{tabular}

\section{Analysis}

\section{Observations:-}

- The average urban density of population in West Bengal in all the decades are ten times more than the overall density and it is quite high in relation to space.

- Unplanned growth of fringe areas and peri-urban regions.

- For every decadal increase in population there is no increase in the area of towns suggesting lack of spatial planning of towns.

- Forced urbanization in the form of New Towns during the last three decades, which are merely "Bed Room Towns", have been inducted only to harness urban growth.

- MFMG (Metropolitan Fringe and Megacity Governance) has not updated reforms for many years that have led to unscientific, uneconomic and unsustainable utilization of land.

- Unplanned growth in fringe urban areas leads to urban sprawl and consequent increased disaster risk.

- Unplanned urban growth resulting in hazardous industrial plants existing with informal congested settlements.

\section{Issues:-}

There are a number of hindering factors to combat those above mentioned challenges. These may be categorized as follows:

a) Legal \& Institutional Barriers

○ Conflicting legal dictums in different acts i.e. overlapping of powers \& confusion of power jurisdiction.

63 I P a g e Land Governance Assessment Framework - West Bengal 
- Planning never gets importance as it gives no immediate tangible output

- Shortage of qualified town planners

- Lack of coordinated effort between departments

○ Lack of involvement of public in decision making

- Failure to incorporate the issues of disaster management in DDP due to lack of GIS data

b) Political \& Cultural Barriers

c) Technological Barriers: site availability, engineering details and technical performance, lack of key skills and expertise

d) Financial Barriers.

Data Source: Various Acts and legislations

Data Reliability: High

Policy recommendation:

There is a lack of adequate policy-framing to address the several barriers which affect implementation of land use plans although the legal framework is exhaustive.

\begin{tabular}{|c|c|c|c|}
\hline Panel & LGI & Dim. & $\begin{array}{l}\text { Land Governance Indicator } 7 \\
\text { Transparency of land use restrictions: changes in land use and } \\
\text { management regulations are made in a transparent fashion and } \\
\text { provide significant benefits for society in general rather than just } \\
\text { for specific groups. }\end{array}$ \\
\hline \multirow[t]{5}{*}{3} & \multirow[t]{5}{*}{2} & \multirow[t]{5}{*}{1} & $\begin{array}{l}\text { Process of urban expansion/infrastructure development process is transparent } \\
\text { and respects existing rights. }\end{array}$ \\
\hline & & & $\begin{array}{l}\text { A: Information on planned urban expansion and infrastructure development is } \\
\text { publicly available with sufficient anticipation and a process is in place to deal } \\
\text { with land rights by those affected that corresponds to internationally recognized } \\
\text { standards. }\end{array}$ \\
\hline & & & $\begin{array}{l}\text { B: Information on planned urban expansion and infrastructure development is } \\
\text { publicly available with sufficient anticipation and a systematic process to deal } \\
\text { with land rights by those affected in a way that is not fully in line with } \\
\text { international standards. }\end{array}$ \\
\hline & & & $\begin{array}{l}\text { C: Information on planned urban expansion and infrastructure development is } \\
\text { publicly available with sufficient anticipation but the way in which land rights } \\
\text { by those affected are dealt with is largely ad hoc. }\end{array}$ \\
\hline & & & $\begin{array}{l}\text { D: Information on planned urban expansion and infrastructure development is } \\
\text { not publicly available. }\end{array}$ \\
\hline
\end{tabular}

\section{Analysis}

In the 1980s, there was a need for decentralization of planning and development activities which were to be met by decentralized institutional structure of municipal governance. This empowered local bodies with power and responsibilities to deal with urban problems through legislative provisions. Some of the important measures which were taken in this regard are:

- Setting up of the West Bengal Urban Development Strategy committee in 1979 to monitor and strategize state wide urban development.

- Enactment of Town and Country (Planning and Development) Act in 1979: Obligated preparation of Existing Land Use maps and Registers (ELUMR) and Land Use of Development Control Plans (LUDCP) for areas under Calcutta Metropolitan Development Authority (CMDA)

64 I Page Land Governance Assessment Framework - West Bengal 
- Setting up of Municipal Finance Commission in 1979

- Setting up of Central Valuation Board to curb under-valuation of properties in municipal areas

- Enactment of Municipal Corporation Acts since 1980s that Acts provided for a cabinet form of local government for civic administration, with a Mayor-in-Council set up.

- Amendment of Bengal Municipal Act of 1932 and enactment of new W.B. Municipal Act in 1993 for cabinet system of government with Chairman-in-Council set up

- Creation of Parastatal bodies (Development Authorities) and demarcation of planning areas

In the 1990 , due to $73^{\text {rd }}$ and $74^{\text {th }}$ Amendments of the Constitution of India, W.B. District Planning Committee Act 1994, and W.B. Metropolitan Planning Committee Act 1994 along with the W.B. District Planning Committee Rules 1994 was enacted for decentralized spatial and socio-economic Planning.

The $73^{\text {rd }}$ and $74^{\text {th }}$ Constitutional Amendments ushered in major changes in urban planning process. It created mandate for participation of people in the planning process paving the way for a transparent system of urban expansion/development respecting existing rights.

In line with the $73^{\text {rd }}$ and $74^{\text {th }}$ Constitutional Amendments, as mentioned in the background note, the state government introduced the Kolkata Urban Services for the Poor (KUSP), a multi-sector urban reforms program, by creating Change Management Unit (CMU) with DFID funding in the year 1999. It involved all concerned public institutions dealing with urban development and management in the preparation of Draft Development Plan in a participatory manner. It resulted in successful completion of DDP in 40 ULBs involving all stakeholders which also extended up to 126 Municipalities in the State in 2005. DDP embraces all aspects of development including socio-economic development of weaker section, infrastructural development of slum areas, housing facilities for vulnerable section, land use plan, environmental management, and disaster risk reduction plan and so on. But unfortunately, this model could not be sustained.

Data Source: Various Acts and legislations, DDP manual, study as referred conducted by the Administrative Training Institute, Kolkata

\section{Data Reliability: High}

\section{Policy Recommendation:}

While a policy of decentralized planning exists in the state since early eighties of the last century, it seldom gets implemented. DFID assisted KUSP program has helped sketching an outline of how decentralized planning could be prepared with adequate public input. At a certain point of time all the ULBs in the state prepared Draft Development Plans for respective areas including LUDCPs and LUMRs through a participatory planning process. But unfortunately, this model could not be sustained. It is recommended that the KUSP model should be introduced strictly to provide significant benefits for society in general. While there are mandates in the Acts for preparation of such plans, the process of controlling the land use and its enforcement is not sufficiently explicit in the legal framework.

\begin{tabular}{|l|l|l|l|}
\hline Panel & LGI & Dim. & $\begin{array}{l}\text { Land Governance Indicator } 7 \\
\text { Transparency of land use restrictions: changes in land use and } \\
\text { management regulations are made in a transparent fashion and } \\
\text { provide significant benefits for society in general rather than just } \\
\text { for specific groups. }\end{array}$ \\
\hline
\end{tabular}

65|Page Land Governance Assessment Framework - West Bengal 


\begin{tabular}{|l|l|l|l|}
\hline 3 & 2 & 2 & $\begin{array}{l}\text { Changes in urban land use plans are based on a clear public process and input } \\
\text { by all stakeholders. }\end{array}$ \\
\hline \multirow{5}{*}{} & $\begin{array}{l}\text { A: Public input is sought in preparing and amending land use plans and these } \\
\text { responses are explicitly referenced in the report prepared by the official body } \\
\text { responsible for preparing the new plans. This report is publicly accessible. }\end{array}$ \\
\cline { 2 - 2 } & $\begin{array}{l}\text { B: Public input is sought in preparing and amending land use plans and the } \\
\text { public responses are used by the official body responsible for finalizing the } \\
\text { new plans, but the process for doing this is unclear or the report is not } \\
\text { publicly accessible. }\end{array}$ \\
\cline { 2 - 2 } & $\begin{array}{l}\text { C: Public input is sought in preparing and amending land use plans but the } \\
\text { public comments are largely ignored in the finalization of the land use plans. }\end{array}$ \\
& D: Public input is not sought in preparing and amending land use plans. \\
\hline
\end{tabular}

\section{Analysis:}

In West Bengal land Use plans are prepared by the Urban Local Bodies, under Department of Municipal Affairs and by the Development Authorities under Urban Development Departments.

As per the mandate of the section 297 of the West Bengal Municipal Act 1993 (WBM ACT 1993) ULBs prepare Draft Development Plan (DDP), which prescribes existing land use pattern and future land use control of the ULB area. But the process of controlling the Land use is not very clear. The WBM ACT 1993 also gives scope for revision and modification of the DDP not more than once in every three years. Also the WBM ACT 1993 is silent about the process of preparation of DDP and public participation in preparation of DDP. However the ULBS through KUSP initiatives have prepared their DDPs through participatory planning process, involving citizens from scratches to final shape of DDP. To make such participation mandatory, in planning process and amendment of plan preparation process the State Government needs to amend the WBBM ACT 1993 accordingly.

The Development Authorities (DA) and Planning Authorities (PA) of this State prepares existing Land Use Map and Register (LUMR) under section 28 of the West Bengal Town \& Country (Planning \& Development) Act 1979 (WBT\&CP Act 1979) and also prepares Land Use Development Control Plan (LUDCP) under section 31 of the WBT\&CP Act 1979 to control the future development of the planning area. The WBT\&CP Act 1979 also gives scope for amendment of the LUDCP under section 40 of the Act. Public validation of the LUMR prepared under section 28 is being ensured by the section 29 of the WBT\&CP Act 1979. The LUMR are kept accessible for general public for a period of 30 days through public notice and newspaper publication, inviting objections from public and the objections are being heard by a designated officer of the Authority. Eventually the Authority makes such modification in LUMR as per the report of the designated officer.

Similarly, for LUDCP also the WBT\&CP Act 1979 gives mandate for going for public validation under section 36 of the Act. The draft LUDCP is being kept accessible for general public through public notice and newspaper publication for a period of 60 days for inspection and inviting objections from public. A 3 (three) member committee is being formed by the Authority for hearing the objections. The authority may make such modifications in the LUDCP as suggested by the report of the 3 member committee as it consider proper and submit it to the State Government for approval.

So it is clear from the above that for the LUMRs and LUDCPs being prepared by Development and Planning Authorities constituted under the WBT\&CP Act 1979 have specific mandate for going for public validation and giving regards to the public opinions. But for DDPs being prepared by ULB don't have such legal mandate. Also DDP prepared by the ULBs through KUSP had undergone a thorough participatory planning process, which is not being exercised by the

66 | Page Land Governance Assessment Framework - West Bengal 
Planning / Development Authorities at the time of preparation of LUDCP. So degree of public participation is less in preparation of LUDCPs, thus ownership of plan is obviously less. There is deficiency in the process of incorporating inputs/suggestion received from the people.

Data Source: Various Acts and legislations, DDP manual, study as referred conducted by the Administrative Training Institute, Kolkata

\section{Data Reliability: High}

It is recommended that the KUSP model should be introduced strictly to provide significant benefits for society in general.

\begin{tabular}{|c|c|c|l|}
\hline Panel & LGI & Dim. & $\begin{array}{l}\text { Land Governance Indicator } 7 \\
\text { Transparency of land use restrictions: changes in land use and } \\
\text { management regulations are made in a transparent fashion and } \\
\text { provide significant benefits for society in general rather than just } \\
\text { for specific groups. }\end{array}$ \\
\hline \multirow{2}{*}{3} & 2 & 3 & $\begin{array}{l}\text { Changes in assigned urban land use are swiftly followed by actual land use } \\
\text { change. }\end{array}$ \\
\hline & $\begin{array}{l}\text { A: More than } 70 \% \text { of the land that has had a change in land use assignment in } \\
\text { the past } 3 \text { years has changed to the destined use. }\end{array}$ \\
\cline { 2 - 3 } & $\begin{array}{l}\text { B: Between } 50 \% \text { and } 70 \% \text { of the land that has had a change in land use } \\
\text { assignment in the past } 3 \text { years has changed to the destined use. }\end{array}$ \\
\cline { 2 - 3 } & $\begin{array}{l}\text { C: Between } 30 \% \text { and } 50 \% \text { of the land that has had a change in land use } \\
\text { assignment in the past } 3 \text { years has changed to the destined use. }\end{array}$ \\
\cline { 2 - 4 } & $\begin{array}{l}\text { D: Less than } 30 \% \text { of the land that has had a change in land use assignment in } \\
\text { the past } 3 \text { years has changed to the destined use. }\end{array}$ \\
\hline
\end{tabular}

\section{Analysis:}

It is very difficult to ascertain, as we don't have any system and procedure to arrest the dynamic changes of Land use in urban areas of the West Bengal. We generally do not follow the regular updation of Urban Land Use and creation of database to record the changes in use in Urban Areas. Processes of giving Building Plan approval is not linked with Land Use prescriptions and permission. In some cases Land Use prescription of LUDCP of Planning and Development Authorities do not match with the prescription of the DDPs of ULBs. Though Development Authorities keeps records for development permissions but the same record is not being managed spatially on a regular basis. In the panel discussion a fair assessment of 50-70\% of land use change in past 3 years to the destined use was agreed (ranking B).

Thus it is very difficult to give the status of Land Use Change data both in numerical value and represent the same spatially, unless we introduce a new process of keeping the record of land use changes through GIS method dynamically.

Data Source \& Data reliability: No data is available

\section{Policy Recommendation:}

This is another problem of urban development administration as it is very difficult to ascertain or to arrest the dynamic change of land use in urban areas of West Bengal. Generally the regular updating of urban land use and creation of data base to record the changes in use is not followed. Processes of sanctioning building plans are not linked with land use prescriptions and permissions. The Government in the Urban Development Department should ensure either through amendment of Act and/or regulations a process of keeping the record land use changes through GIS which is not there right now.

67|Page Land Governance Assessment Framework - West Bengal 


\begin{tabular}{|c|c|c|l|}
\hline Panel & LGI & Dim. & $\begin{array}{l}\text { Land Governance Indicator 8 } \\
\text { Efficiency in the urban land use planning process: land use plans } \\
\text { are current, implemented, do not drive people into informality, and } \\
\text { cope with urban growth. }\end{array}$ \\
\hline 3 & 3 & 1 & $\begin{array}{l}\text { Policy to ensure delivery of low-cost housing and services exists and is } \\
\text { progressively implemented. }\end{array}$ \\
\hline & $\begin{array}{l}\text { A: A policy for low cost housing and services and effective instruments to } \\
\text { implement it exists so that there is a clear trajectory to provide adequate shelter } \\
\text { for all. }\end{array}$ \\
\hline & $\begin{array}{l}\text { B: A policy for low cost housing and services exists but implementation is not } \\
\text { always effective. As a result, the number of those with inadequate shelter } \\
\text { declines but still remains high. }\end{array}$ \\
\hline & $\begin{array}{l}\text { C: There is a policy for low cost housing and services but implementation has } \\
\text { major gaps so that the number of those with inadequate shelter actually } \\
\text { increases. }\end{array}$ \\
\hline $\begin{array}{l}\text { D: There is no policy for low-cost housing and services and no provisions that } \\
\text { would require private developers to cater to the lower end of the housing } \\
\text { market. }\end{array}$ \\
\hline
\end{tabular}

\section{Analysis}

There are a number of central government schemes and programmes which provide for integrated slum development as well as housing development for the poor. JNNURM has the provision for housing and infrastructure development in slum settlements through two components - (a) Integrated Housing and Slum development Programme (IHSDP) and (b) Basic Services to Urban Poor (BSUP). In addition to that, the government has recently launched a centrally sponsored scheme called Rajiv Awas Yojana (RAY) with the goal of helping the urban poor living in slums gain appropriate housing and addressing the processes by which slums are created and reproduced.

West Bengal Municipal Act, 1993 mandates Municipal Councils to identify and declare slum areas and carry out improvements in them. But, because of various reasons, this mandate has not worked well. It is also noteworthy to mention that lack of tenure for slum dwellers that lead to difficulties in implementation of several government schemes. However, attempts have been made to evolve a policy for providing secured land tenure to urban poor belonging to EWS but the process of policy developing is still underway. Recently, to implement the RAY programme a positive initiative has been taken to bring out exact status of slums in the urban areas.

There is a notification of the Urban Development Department (Notification No.1448/T\&CP/C2/3A-2/2011 dated $20^{\text {th }}$ July, 2011), which speaks about the mandatory provisions for Economically Weaker Section (EWS) and Lower Income Group (LIG) families of population residing within planning areas covered under the West Bengal Town \& Country (Planning \& Development) Act 1979, housing and sub-division of land and plot. So any developer intending for housing project and land/plot sub-division of stipulated sizes and quantum applying for development permission under section 46 of the West Bengal Town \& Country (Planning \& Development) Act 1979 has to abide by the notification mandate and keep minimum stipulated provision of EWS and LIG housing and land/plot. Thus by such notification it is being experienced that the stock of housing for EWS and LIG is gradually being increasing.

It is important and required to look in to the matter of affordability of EWS and LIG population for low-cost housing and also for affordable rental housing, which are not being explored yet. Here affordability is key word. Mere increasing of stock will not cater to the target population, if these are not affordable to them.

Data source: Urban Development Department

Data reliability: High

68 | Page Land Governance Assessment Framework - West Bengal 


\begin{tabular}{|c|c|l|l|}
\hline Panel & LGI & Dim. & $\begin{array}{l}\text { Land Governance Indicator 8 } \\
\text { Efficiency in the urban land use planning process: land use plans are } \\
\text { current, implemented, do not drive people into informality, and cope } \\
\text { with urban growth. }\end{array}$ \\
\hline 3 & 3 & 2 & $\begin{array}{l}\text { Land use planning effectively guides urban spatial expansion in the largest city. } \\
\text { A: In the largest city, urban spatial expansion is guided effectively by a hierarchy of } \\
\text { regional/detailed land use plans that are updated regularly, with land use intensity } \\
\text { being matched with carrying capacity of infrastructure. }\end{array}$ \\
\hline & $\begin{array}{l}\text { B: In the largest city, while a hierarchy of regional/detailed land use plans is } \\
\text { specified by law, in practice urban spatial expansion is guided by the provision of } \\
\text { infrastructure without full implementation of the land use plans. }\end{array}$ \\
\hline & $\begin{array}{l}\text { C: In the largest city, while a hierarchy of regional/detailed land use plans is } \\
\text { specified by law, in practice urban spatial expansion occurs in an ad hoc manner } \\
\text { with infrastructure provided some time after urbanization. }\end{array}$ \\
\hline & $\begin{array}{l}\text { D: In the largest city, a hierarchy of regional/detailed land use plans may or may not } \\
\text { be specified by law and in practice urban spatial expansion occurs in an ad hoc } \\
\text { manner with little if any infrastructure provided recently }\end{array}$ \\
\hline
\end{tabular}

Analysis:

Kolkata Metropolitan Planning Area (KMA) has two 2 Municipal Corporation (KMC \& HMC) and 39 other Municipalities which are preparing their Land Use Plans individually without keeping the overall regional context in mind. So the land use control of the overall KMA is not very effective as a whole. Here, Kolkata Metropolitan Development Authority (KMDA) can play a pivotal role to prepare a comprehensive Land Use Plan for the entire KMA, considering the carrying capacity of the infrastructure of entire KMA region and taking inputs from all ULBs within its jurisdiction and then the ULBs may prepare their Land Use Plan keeping in conformity with the overall Land Use Plan of the KMA region. Such integrated approach is highly required for effective spatial expansion of the largest city, which is not appropriately there in the current system.

\section{Data Source \& Data reliability:}

\section{Policy Recommendation:}

KMDA is an institution which can act as a leader in bringing about an integrated approach for effective spatial expansion of the largest city which is not appropriately there in the current system. The Government should examine the gaps and if necessary create a legal backup to ensure such integration.

\begin{tabular}{|c|c|c|c|}
\hline Panel & LGI & Dim. & $\begin{array}{l}\text { Land Governance Indicator } 8 \\
\text { Efficiency in the urban land use planning process: land use plans are } \\
\text { current, implemented, do not drive people into informality, and cope } \\
\text { with urban growth. }\end{array}$ \\
\hline \multirow[t]{5}{*}{3} & 3 & \multirow[t]{5}{*}{3} & Land use planning effectively guides urban development in the four next largest cities. \\
\hline & \multirow{4}{*}{3} & & $\begin{array}{l}\text { A: In the four major cities urban development is guided effectively by a hierarchy of } \\
\text { regional/detailed land use plans that are regularly updated, with land use intensity } \\
\text { being matched with carrying capacity of infrastructure. }\end{array}$ \\
\hline & & & $\begin{array}{l}\text { B: In the four major cities, while a hierarchy of regional/detailed land use plans is } \\
\text { specified by law, in practice urban development is guided by the provision of } \\
\text { infrastructure which implements only a part of the land use plans. }\end{array}$ \\
\hline & & & $\begin{array}{l}\text { C: In the four major cities in the country, while a hierarchy of regional/detailed land } \\
\text { use plans is specified by law, in practice urban development occurs in an ad hoc } \\
\text { manner with infrastructure provided some time after urbanization. }\end{array}$ \\
\hline & & & $\begin{array}{l}\text { D: In the four major cities in the country a hierarchy of regional/detailed land use } \\
\text { plans may or may not be specified by law and in practice urban development occurs in } \\
\text { an ad hoc manner with little if any infrastructure provided. }\end{array}$ \\
\hline
\end{tabular}

69|Page Land Governance Assessment Framework - West Bengal 


\section{Analysis:}

Durgapur \& Asansol falls within the Asansol Durgapur Development Authority jurisdiction, Haldia falls under Haldia Development Authority jurisdiction and Siliguri falls within Siliguri Jalpaiguri Development Authority jurisdiction. In these areas there are some degree of coordination between the ULBs and Development Authorities, which somehow helps in planned urban development to some extent. But if the overall regional level land use plan prepared by development authorities is being followed by ULBs, it may boost planned urban development in a more effective way. So there should be two way process of flow of information and inputs for land use plan preparation for sustainable urban development in the region keeping carrying capacity of the infrastructure of the existing cities in mind and to reduce ad-hoc planning to the present trend of urbanization pressure.

\section{Data Source \& Data reliability:}

\section{Policy Recommendation:}

The gaps and lapses and lack of integrated approach as mentioned earlier are also the key factors to be addressed here too.

\begin{tabular}{|c|c|c|c|}
\hline Panel & LGI & Dim. & $\begin{array}{l}\text { Land Governance Indicator } 8 \\
\text { Efficiency in the urban land use planning process: land use plans are } \\
\text { current, implemented, do not drive people into informality, and cope } \\
\text { with urban growth. }\end{array}$ \\
\hline \multirow[t]{5}{*}{3} & \multirow[t]{5}{*}{3} & \multirow[t]{5}{*}{4} & Planning processes are able to cope with urban growth. \\
\hline & & & $\begin{array}{l}\text { A: In the largest city, the urban planning process/authority is able to cope with } \\
\text { the increasing demand for serviced units/land as evidenced by the fact that } \\
\text { almost all new dwellings are formal. }\end{array}$ \\
\hline & & & $\begin{array}{l}\text { B: In the largest city, the urban planning process/authority is able to cope to } \\
\text { some extent with the increasing demand for serviced units/land as evidenced by } \\
\text { the fact that most new dwellings are formal. }\end{array}$ \\
\hline & & & $\begin{array}{l}\text { C: In the largest city, the urban planning process/authority is struggling to cope } \\
\text { with the increasing demand for serviced units/land as evidenced by the fact that } \\
\text { most new dwellings are informal. }\end{array}$ \\
\hline & & & $\begin{array}{l}\text { D: In the largest city, the urban planning process/authority cannot cope with the } \\
\text { increasing demand for serviced units/land as evidenced by the fact that almost all } \\
\text { new dwellings are informal. }\end{array}$ \\
\hline
\end{tabular}

\section{Analysis:}

In West Bengal, land use and development of lands is exercised under West Bengal Town and Country (Planning and Development) Act, 1979 in the urban areas. Under this Act, land use planning is mandatory to effectively control urban development in all the cities, areas under Development Authorities and Planning Areas formed by the State Government. Moreover, under Sec 113 of the West Bengal Municipal Act, 1993(amended in 2007), it has become mandatory for all the municipalities to prepare land use plans while formulating development plans for the areas concerned. Under the WBT\&CP Act, 1979 Land Use Development Control Plans (LUDCP) are prepared for the planning areas. In the state of West Bengal the Municipal Authorities have been empowered to regulate land use and construction of buildings. In section 63 of chapter VI ibid indicates the obligatory functions of the Municipalities. In sub section (3) of said section 63 the matter has been dealt with elaborately. It is also worthy to mention that the municipal authorities in this state are empowered to regulate the building activities through an elaborate chapter XIV of the said act and the West Bengal Municipal (Building) Rules,2007 framed there under and to prepare detailed plan, inter alia, the land use plan under chapter XIX

70|Page Land Governance Assessment Framework - West Bengal 
of the said act. It may also be mentioned that such power has been vested with the municipal authorities of this state much before enactment of the $74^{\text {th }}$ constitutional amendment Act.

Data Source \&Data reliability: Same as Dimension 1

\section{Policy recommendation:}

The problems explained in this dimension relate to the planning processes prevalent in the state. There are attempts to combat the hitherto haphazard system but lot more reforms and governance would be required to achieve the desired standard. The suggested recommendations in the earlier dimensions would also be relevant here.

\begin{tabular}{|c|c|l|l|}
\hline \multirow{2}{*}{ Panel } & \multirow{2}{*}{ LGI } & Dim. & $\begin{array}{l}\text { Land Governance Indicator 9 } \\
\text { Speed and predictability of enforcement of restricted land uses: } \\
\text { development permits are granted prompty and based on } \\
\text { reasonable requirements. }\end{array}$ \\
\hline \multirow{2}{*}{3} & 4 & 1 & $\begin{array}{l}\text { Provisions for residential building permits are appropriate, affordable and } \\
\text { complied with. }\end{array}$ \\
\hline \multirow{2}{*}{} & $\begin{array}{l}\text { A: Requirements to obtain a building permit are technically justified, } \\
\text { affordable, and complied with. }\end{array}$ \\
\cline { 2 - 3 } & $\begin{array}{l}\text { B: Requirements to obtain a building permit are technically justified and } \\
\text { affordable but only partly complied with. }\end{array}$ \\
\hline & $\begin{array}{l}\text { C: Requirements to obtain a building permit are technically justified but not } \\
\text { affordable for (and not complied by) the majority of those affected. }\end{array}$ \\
\cline { 2 - 3 } & $\begin{array}{l}\text { D: Requirements to obtain a building permit are over-engineered technically } \\
\text { and not affordable. }\end{array}$ \\
\hline
\end{tabular}

\section{Analysis}

- West Bengal Municipal Act, 1993 draws out the regulations for obtaining building permit which are appropriate and affordable and are complied with in most cases.

- KUSP has initiated modernization of urban governance with the building permits being given decision within 3 months.

- Citizens Charter has enabled the Municipal Authorities to deliver services in time

\section{Policy Recommendation:}

The legal provisions for residential building permits appear to be appropriate and affordable, since time tested, but more vigilance would be required to ensure a corruption free system.

\begin{tabular}{|c|c|c|c|}
\hline Panel & LGI & Dim. & $\begin{array}{l}\text { Land Governance Indicator } 9 \\
\text { Speed and predictability of enforcement of restricted land uses: } \\
\text { development permits are granted promptly and based on reasonable } \\
\text { requirements. }\end{array}$ \\
\hline \multirow[t]{5}{*}{3} & 4 & 2 & $\begin{array}{l}\text { A building permit for a residential dwelling can be obtained quickly and at a low } \\
\text { cost. }\end{array}$ \\
\hline & & & A: All applications for building permits receive a decision within 3 months. \\
\hline & & & B: All applications for building permits receive a decision within 6 months. \\
\hline & & & C: All applications for building permits receive a decision within 12 months. \\
\hline & & & $\begin{array}{l}\text { D: All applications for building permits receive a decision after a period } \\
\text { exceeding } 12 \text { months. }\end{array}$ \\
\hline
\end{tabular}

Analysis:

71|Page Land Governance Assessment Framework - West Bengal 
- West Bengal Municipal Act, 1993 and Building Rules, 2007 provide regulations for building plan which are appropriate and affordable (Rs. 500/- for first 30 sq. metre and thereafter for every 10 sq. metre Rs. 75/-) and are complied with in most cases.

- KUSP has initiated modernization of urban governance with the building permits being given decision within 3 months.

- All the ULBs introduced Citizens Charter under KUSP initiatives which had clear mandates about the formalities for applying to obtain building permits and the maximum period within which (within 90 days) the decision is to be taken. Recently, West Bengal Rights to Public Service Act, 2013 has come up which is giving result and satisfactory response. The decision on issuance of building permit is given within three months

Data Source \& Data reliability: Same as Dimension 1

\section{Policy Recommendation:}

KUSP guidelines were clear regarding the Citizens Charter. Recently, West Bengal Rights to Public Service Act, 2013 has come up which is expected to produce results and satisfactory response. Here also the Government should be vigilant to ensure corruption free system.

\begin{tabular}{|c|c|c|l|}
\hline Panel & LGI & Dim. & $\begin{array}{l}\text { Land Governance Indicator1o } \\
\text { Tenure regularization schemes in urban areas }\end{array}$ \\
\hline 3 & 5 & 1 & Formalization of urban residential housing is feasible and affordable. \\
\hline \multirow{2}{*}{} & & $\begin{array}{l}\text { A: The requirements for formalizing housing in urban areas are clear, straight- } \\
\text { forward, affordable and implemented consistently in a transparent manner. }\end{array}$ \\
\cline { 3 - 4 } & $\begin{array}{l}\text { B: The requirements for formalizing housing in urban areas are clear, straight- } \\
\text { forward, and affordable but are not implemented consistently in a transparent } \\
\text { manner. }\end{array}$ \\
\cline { 3 - 4 } & $\begin{array}{l}\text { C: The requirements for formalizing housing in urban areas are neither clear, } \\
\text { straight-forward, or affordable but many applicants from informal areas are } \\
\text { managing to satisfy the requirements. }\end{array}$ \\
\cline { 3 - 4 } & $\begin{array}{l}\text { D: The requirements for formalizing housing in urban areas are such that } \\
\text { formalization is deemed very difficult. }\end{array}$ \\
\hline
\end{tabular}

\section{Analysis:}

Issue of formalizing housing in urban areas is often compromised in terms of according priority. There is as such no legal provision, neither any policy for formalizing housing in urban areas. The requirements are not clear, determined arbitrarily and at times are unaffordable. There are inherent mind-set issues like lack of awareness on and keeping away from legal framework. The reasons are listed:

- Lack of awareness generation on legal framework sometimes hinders the process of formalization especially for the poor.

- Transparency is affected by vested interests

- Formalization cost is high and may not be affordable for all

- Restrictions on rights also become a bottleneck in straightforward implementation

\section{Policy recommendation:}

72 | Page Land Governance Assessment Framework - West Bengal 
To the extent permissible awareness generation on the provisions of formalizing housing in urban areas and incentives for ending informality may be considered. A policy framing in this regard is recommended to address this important issue. (Ranking changed from $\mathrm{B}$ to $\mathrm{C}$ following review by the EI and panellists).

\begin{tabular}{|c|c|c|l|}
\hline Panel & LGI & Dim. & $\begin{array}{l}\text { Land Governance Indicator 1O } \\
\text { Tenure regularization schemes in urban areas }\end{array}$ \\
\hline 3 & 5 & 2 & $\begin{array}{l}\text { In cities with informal tenure, a viable strategy exists for tenure security, } \\
\text { infrastructure, and housing. }\end{array}$ \\
\hline \multirow{2}{*}{} & $\begin{array}{l}\text { A: Existing regulations do not provide incentives for new informal occupations } \\
\text { and a strategy exists to regularize land rights and provide services to existing } \\
\text { informal occupants. }\end{array}$ \\
\cline { 3 - 4 } & $\begin{array}{l}\text { B: A strategy exists to regularize land rights and provide services to existing } \\
\text { informal occupants but existing regulations provide incentives for new informal } \\
\text { occupations. }\end{array}$ \\
\cline { 3 - 4 } & $\begin{array}{l}\text { C: Strategies to deal with urban informality exist but focus only on either land or } \\
\text { services but not both. }\end{array}$ \\
\cline { 3 - 4 } & D: There is neither process nor strategy to implement it. \\
\hline
\end{tabular}

\section{Analysis:}

Security of tenure for urban poor continues to be a vexed issue. Experts advocate that tenural security, together with an enabling role of the government with reference to provision of housing finance, would go a long way in mitigating the housing problem in cities and assist urban poor, over time, to gradually improve their housing and living condition. The UN-HABITAT generalizes the most common tenure systems which include freehold, leases, provisional or conditional tenure and group tenure arrangements. Further importance is given to security of tenure by including as one of the objectives of JNNURM. West Bengal government does not have a policy, as yet, for granting tenure to slum dwellers or for housing the urban poor. Such policies can be helpful in focusing attention to the problem, developing a commitment and providing a framework for action. In Kolkata most of the bastis are on land held by individuals or thika tenants. The Basti Improvement Program funded by the World Bank was implemented in these localities involving conversion of service latrines, connection of water taps, surface drainage facility, construction and widening of roads, street lighting etc. resulting in improved living condition in bastis (Ramaswamy V, 2008). Those who occupy rooms in small areas either under individual owners or thika tenants enjoy rights as tenants under the Premises Tenancy act, 1997. Hence the target group here are the unauthorized occupiers who somehow manage to live by constructing jhupris on government lands - both central and state.

It was proposed in the KUSP preparatory studies that the respective ULBs should take the lead role in improving tenure security of the poor. This proposal was discussed in detail and in a participatory approach with ULBs, CMU, districts and state level officials. There was general agreement that ULBs will have to take the lead role because of the following reasons:

- ULBs have local knowledge and are close to people, therefore in a better position to develop responsive solutions

- ULBs are not able to go ahead with BSUP projects in spite of the money being available because the land tenure situation has not been sorted out. Since these are the responsibility of ULBs they have to do something urgently

- In spite of their high rank many slums cannot be adequately provided with services through KUSP funds because they are on land over which they have no rights. If ULBs have to really be pro-poor, they have to find solutions to the tenure problem.

73 I P a ge Land Governance Assessment Framework - West Bengal 
- ULBs cannot be fully successful in their mandate to maintain environmental health and provide citizen services unless slums become eligible for investment

- The people consider insecure tenure as one of the reasons for poverty and vulnerability and ULBs have to address this if they have to undertake poverty alleviation.

- ULBs are losing a lot of revenue because they cannot recover tax or levy charges on illegal occupants.

At the same time there is apprehension that ULBs are not in a position to do much by them because

- They do not have much say in land matters, which is looked after by the State Government. In any case most of the slums with tenure problems are on state government service land, railways and private land owners.

- The ULB information base on land ownership and tenure is poor and there is lack of urgency to develop a public land database

- ULBs are not well aware of possibilities and alternatives

- Land market pressures can create problems

$\circ$ If slum dwellers are given tenure documents they may sell the land and go somewhere else

For last three years, some attempts have been made to evolve a policy for providing secured land tenure to urban poor belonging to EWS, occupying government land but no firm policy is there to eradicate the problem of informality. Recently, to implement the Rajiv AwasYojana (RAY) Program, a positive initiative has been taken to conduct a survey as per the RAY guidelines which are gradually bringing out the exact status of slums in the urban area. The survey (urban statistics and HR assessment survey - USHA) has been completed in the KMA area.

\section{Policy recommendation:}

A policy decision of urban informal tenure is long pending. Along with the policy a viable strategy should be in place to address the issue

\begin{tabular}{|c|c|c|l|}
\hline Panel & LGI & Dim. & $\begin{array}{l}\text { Land Governance Indicator 1o } \\
\text { Tenure regularization schemes in urban areas }\end{array}$ \\
\hline 3 & 5 & 3 & $\begin{array}{l}\text { A condominium regime allows effective management and recording of urban } \\
\text { property. }\end{array}$ \\
\hline \multirow{2}{*}{} & & $\begin{array}{l}\text { A: Common property under condominiums is recognized and the law has } \\
\text { clear provisions for management and publicity of relevant records that are } \\
\text { followed in practice. }\end{array}$ \\
\cline { 3 - 4 } & $\begin{array}{l}\text { B: Common property under condominiums is recognized and the law has } \\
\text { clear provisions for management and publicity of relevant records but these } \\
\text { are not always followed in practice. }\end{array}$ \\
\cline { 3 - 4 } & $\begin{array}{l}\text { C: Common property under condominiums is recognized but the law lacks } \\
\text { clear (or regulations) for management and publicity of relevant records. }\end{array}$ \\
\cline { 2 - 3 } & D: Common property under condominiums is not recognized. \\
\hline
\end{tabular}

\section{Analysis:}

- The law has clear provisions for management and publicity of relevant records under the West Bengal Apartment Ownership Act, 1972. Yet the management still remains very poor. 
- The Registration department acts quickly to get the land and the individual flats registered. Other related departments are still to come forward for quick recording resulting in a barrier to commendable management.

\section{Policy recommendation:}

The law has clear provisions for management and publicity of relevant records under the West Bengal Apartment Ownership Act, 1972 but the management still remains very poor. Enforcement of the relevant Act along with coordination of different departments would result in removing the barrier to commendable management.

\section{Panel 4 Public Land Management}

\section{Indicators}

1. Identification of public land and clear management: public land ownership is clearly defined, effectively serves the public purpose, is inventoried, under clear management responsibilities, and relevant information is publicly accessible.

2. Justification and time-efficiency of acquisition processes: the state acquires land for public interest only and this is done efficiently.

3. Transparency and fairness of acquisition procedures: acquisition procedures are clear and transparent and fair compensation is paid expeditiously.

\begin{tabular}{|c|c|c|c|}
\hline Panel & LGI & Dim. & $\begin{array}{l}\text { Land Governance Indicator } 10 \\
\text { Identification of public land and clear management: public land } \\
\text { ownership is clearly defined, effectively serves the public purpose, } \\
\text { is inventoried, under clear management responsibilities, and } \\
\text { relevant information is publicly accessible. }\end{array}$ \\
\hline \multirow[t]{5}{*}{4} & \multirow[t]{5}{*}{1} & \multirow[t]{5}{*}{1} & $\begin{array}{l}\text { Criteria for public land ownership are clearly defined and assigned to the right } \\
\text { level of government. }\end{array}$ \\
\hline & & & $\begin{array}{l}\text { A: Public land ownership is justified by provision of public goods and effectively } \\
\text { and transparently managed at the appropriate level of government. }\end{array}$ \\
\hline & & & $\begin{array}{l}\text { B: Public land ownership is justified by provision of public goods at the most } \\
\text { appropriate level of government but management may be discretionary. }\end{array}$ \\
\hline & & & $\begin{array}{l}\text { C: Public land ownership is justified by provision of public goods but } \\
\text { management responsibility is often at the wrong level of government. }\end{array}$ \\
\hline & & & $\begin{array}{l}\text { D: Public land ownership is not serving the public interest by the cost effective } \\
\text { provision of public goods. }\end{array}$ \\
\hline
\end{tabular}

\section{Analysis:}

In West Bengal public land comprises, a) lands at the disposal of the L\&LR Department, b) lands at the disposal of other departments such as, Irrigation, PWD etc.

Lands at (a) are distributed in public purpose in accordance with the principles laid down in section 49 of the WBLR Act, 1955 and procedure prescribed under the Rules thereunder. Lands at (b) are used and managed in public purpose in accordance with the rules and regulations of the respective department.

Public lands at the disposal of all the departments of state government are presumed to be used for public good and managed effectively in accordance with law. But in actual practice the management of public lands by different departments and agencies is witnessed by lack of proper identification, unplanned/ improper use and measures for keeping the land encroachment free is not cared for much. The level of Lands held by government companies and corporations, municipalities, panchayat bodies are also public lands and are used for public good in accordance with law of the respective organization.

75 IPage Land Governance Assessment Framework - West Bengal 
Management of land entails such activities as protection of land from encroachment, removal of encroachment, if any, settlement / leasing out of land. There is specific division of functions and responsibilities in regard to management of land among the different levels of hierarchy but may be discretionary at times. While specifying the responsibilities the principle of "subsidiarity" is strictly adhered to. (Ranking changed from A to B following review by the EI and panellists).

\section{Data Source:}

\section{Data Reliability:}

\begin{tabular}{|c|c|c|c|}
\hline Panel & LGI & Dim. & $\begin{array}{l}\text { Land Governance Indicator } 10 \\
\text { Identification of public land and clear management: public land } \\
\text { ownership is clearly defined, effectively serves the public } \\
\text { purpose, is inventoried, under clear management } \\
\text { responsibilities, and relevant information is publicly accessible. }\end{array}$ \\
\hline \multirow[t]{5}{*}{4} & \multirow[t]{5}{*}{1} & \multirow[t]{5}{*}{2} & There is a complete recording of public land. \\
\hline & & & $\begin{array}{l}\text { A: More than } 90 \% \text { of public land is clearly identified on the ground and on } \\
\text { maps. }\end{array}$ \\
\hline & & & $\begin{array}{l}\text { B: Between } 60 \% \text { and } 90 \% \text { of public land is clearly identified on the ground } \\
\text { and on maps. }\end{array}$ \\
\hline & & & $\begin{array}{l}\text { C: Between } 30 \% \text { and } 60 \% \text { of public land is clearly identified on the ground } \\
\text { and on maps. }\end{array}$ \\
\hline & & & $\begin{array}{l}\text { D: Less than } 30 \% \text { of public land is clearly identified on the ground or on } \\
\text { maps. }\end{array}$ \\
\hline
\end{tabular}

\section{Analysis:}

During survey and settlement operation all public lands, like all private lands, are surveyed and mapped in the village map with assignment of plot numbers. The lands are entered in the r-o-r of the government department, municipality or the public institution to which the lands belong. The recording is complete in the sense that all particulars regarding plot number, area, classification are entered in the r-o-r.

The lands may not always be identifiable on the ground for various reasons like change of topography, encroachment etc. In such cases they may be marked on the ground with the help of these maps.

\section{Data Source:}

\section{Data Reliability:}

Policy recommendations: A comprehensive ground survey is required to be taken up jointly by the L\&LR department and other departments, local bodies in the field level to identify and update the records of the public land along with present status. The government may take up this exercise on war-footing as land at the control of the departments and local bodies are highly vulnerable to encroachment. An up-to-date inventory of the lands settled with various departments and local bodies by the L\&LR department would facilitate a proper planning for best options to utilize these resources.

\begin{tabular}{|l|l|l|l|}
\hline Panel & LGI & Dim. & $\begin{array}{l}\text { Land Governance Indicator 1o } \\
\text { Identification of public land and clear management: public land } \\
\text { ownership is clearly defined, effectively serves the public } \\
\text { purpose, is inventoried, under clear management } \\
\text { responsibilities, and relevant information is publicly accessible. }\end{array}$ \\
\hline 4 & 1 & 3 & Information on public land is publicly accessible. \\
\hline & & A: All the information in the public land inventory is accessible to the public. \\
\hline
\end{tabular}

76|Page Land Governance Assessment Framework - West Bengal 
B: All the information in the public land inventory is accessible to the public, but information for some types of public land (land used by the military, security services, etc.) is not available for justifiable reasons.

C: All the information in the public land inventory is only available for a limited set of public property and there is little or no justification why records are not accessible.

D: No information in the public land inventory is accessible to the public.

\section{Analysis:}

All information on public land is available in the RoR of the deptt. / institution owning the land. Complete information of these lands is available from the office of Block Land and Land Reform officer [BLLRO] on application. Thanks to computation of RoR such information or a copy of the RoR is ready available by accessing over the counter (OTC) services.

The concerned departments or institutions owning public lands are required to maintain their separate Land Registers which in most of the cases are not done. Information on such public lands is not available to the public on request and there is no justification offered for such nonavailability.

\section{Data Source:}

\section{Data Reliability:}

\begin{tabular}{|c|c|c|c|}
\hline Panel & LGI & Dim. & $\begin{array}{l}\text { Land Governance Indicator } 10 \\
\text { Identification of public land and clear management: public land } \\
\text { ownership is clearly defined, effectively serves the public } \\
\text { purpose, is inventoried, under clear management } \\
\text { responsibilities, and relevant information is publicly accessible. }\end{array}$ \\
\hline \multirow[t]{5}{*}{4} & \multirow[t]{5}{*}{1} & \multirow[t]{5}{*}{4} & $\begin{array}{l}\text { The management responsibility for different types of public land is } \\
\text { unambiguously assigned. }\end{array}$ \\
\hline & & & $\begin{array}{l}\text { A: The management responsibility for different types of public land is } \\
\text { unambiguously assigned to serve objectives of equity and efficiency and this } \\
\text { is implemented by properly equipped institutions. }\end{array}$ \\
\hline & & & $\begin{array}{l}\text { B: The management responsibility for different types of public land is } \\
\text { unambiguously assigned but this is not always consistent with objectives of } \\
\text { equity and efficiency or institutions are not always properly equipped so that } \\
\text { sometimes these are not achieved. }\end{array}$ \\
\hline & & & $\begin{array}{l}\text { C: There is ambiguity in the assignment of management responsibility or } \\
\text { capability for different types of public land and/or major gaps in the extent to } \\
\text { which equity and efficiency are often not attained in practice. }\end{array}$ \\
\hline & & & $\begin{array}{l}\text { D: Ambiguity in management responsibility/ability for key public land makes } \\
\text { it near impossible to manage these equitably and efficiently. }\end{array}$ \\
\hline
\end{tabular}

\section{Analysis:}

Rule 28A of the West Bengal Land Reforms Rules, 1965 clearly mentions that all lands and all interests therein belonging to the state government shall be managed by the Collector of the district under whose jurisdiction the lands are situated provided that the state government may entrust the management of land belonging to it to a local body or an authority constituted by or under any law on such terms and conditions to be decided by the government.

For the purpose of management, land may be categorized as under:

1) Agricultural land

2) Non-agricultural land

3) Water areas

77|Page Land Governance Assessment Framework - West Bengal 
4) Forests

5) Sairati interests like hats, bazars, Ferries etc.

Lands at (1) and (2) have either been distributed among the landless and land-poor, or leased out, or transferred to other departments. Water areas [item (3)] have been mostly assigned to departments of fishery and irrigation and waterways who are equipped technically or otherwise to manage these lands serving the objectives of equity and efficiency. Small water bodies have been handed over to the panchayats for management. As regards forest lands forests department is the only option for assignment having regard to its technical expertise.

With regard to items at (3), (4) and (5), water areas upto 5 acres, ferries, fisheries has been handed over to the panchayat institutions except the following:

a) Ferries and fisheries within municipal areas

b) Water areas above 5 acres

c) Riverine fisheries

d) Part-vested water areas

e) Ferries declared as public ferries under the Bengal Ferries Act, 1885, and

f) Where the panchayat cannot conveniently manage the same

Ownership of such lands coming within (1) to (5) remains with the government. The local bodies (panchayats and ULBs) are sometimes not equipped for managing the precious resources at their disposal. (Ranking changed from A to B following discussion with EI and panellists)

\section{Data Source:}

\section{Data Reliability:}

\begin{tabular}{|c|c|c|c|}
\hline Panel & LGI & Dim. & $\begin{array}{l}\text { Land Governance Indicator } 10 \\
\text { Identification of public land and clear management: public land } \\
\text { ownership is clearly defined, effectively serves the public purpose, } \\
\text { is inventoried, under clear management responsibilities, and } \\
\text { relevant information is publicly accessible. }\end{array}$ \\
\hline 4 & 1 & 5 & $\begin{array}{l}\text { Responsible public institutions have sufficient resources for their land } \\
\text { management responsibilities. }\end{array}$ \\
\hline & & & $\begin{array}{l}\text { A: There are adequate financial and human resources available to ensure } \\
\text { responsible management of public lands (integrated cadastral maps and filled } \\
\text { positions). }\end{array}$ \\
\hline & & & $\begin{array}{l}\text { B: There are some constraints in the financial and/or human resource capacity } \\
\text { but the system makes most effective use of available resources in managing } \\
\text { public lands adequately. }\end{array}$ \\
\hline & & & $\begin{array}{l}\text { C: There are significant constraints in the financial and/or human resource } \\
\text { capacity but the system makes effective use of limited available resources, with } \\
\text { limited impact on managing public lands. }\end{array}$ \\
\hline & & & $\begin{array}{l}\text { D: There are either significantly inadequate resources or marked inefficient } \\
\text { organizational capacity leading to little or no management of public lands. }\end{array}$ \\
\hline
\end{tabular}

\section{Analysis:}

In respect of lands and interests the management of which has not been handed over, the Collector of the district looks after the management. A Collector has all the financial and human resources to manage the same. However, the municipalities and panchayats are not always adequately equipped to ensure effective management in respect of lands handed over to them.

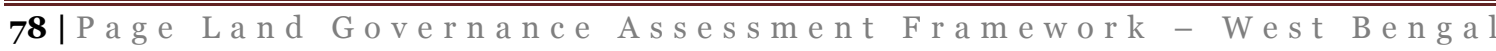




\section{Data Source:}

\section{Data Reliability:}

\begin{tabular}{|c|c|c|c|}
\hline Panel & LGI & Dim. & $\begin{array}{l}\text { Land Governance Indicator } 10 \\
\text { Identification of public land and clear management: public land } \\
\text { ownership is clearly defined, effectively serves the public } \\
\text { purpose, is inventoried, under clear management } \\
\text { responsibilities, and relevant information is publicly accessible. }\end{array}$ \\
\hline \multirow[t]{5}{*}{4} & 1 & 6 & $\begin{array}{l}\text { All essential information on public land allocations to private interests is } \\
\text { publicly accessible. }\end{array}$ \\
\hline & & & $\begin{array}{l}\text { A: Key information for public land allocations (the locality and area of the } \\
\text { land allocation, the parties involved and the financial terms of the allocation) } \\
\text { is recorded and publicly accessible. }\end{array}$ \\
\hline & & & $\begin{array}{l}\text { B: Key information for public land allocations (the locality and area of the } \\
\text { land allocations, the parties involved and the financial terms of the allocation } \\
\text { ) is only partially recorded but is publicly accessible; or the key information is } \\
\text { recorded but only partially accessible. }\end{array}$ \\
\hline & & & $\begin{array}{l}\text { C: Key information for public land allocations (the locality and area of the } \\
\text { land allocations, the parties involved and the financial terms of the } \\
\text { allocation) is recorded or partially recorded but is not publicly accessible. }\end{array}$ \\
\hline & & & D: There is no recorded information on public land allocations. \\
\hline
\end{tabular}

\section{Analysis:}

Settlement of land at the disposal of government is made under section 49 of the WBLR Act and Rule 20A (6) of the WBLR Rules, 1965. Rules 215 - 245 of the W.B. land and Land Reforms Manual, 1991 prescribes the procedure for settlement of non-agricultural land on long and short term basis. Rule 224(i) of the above Manual provides for due publicity of the settlement proposal.

After the settlement is made with the eligible person or institutions etc. details of the settlement are entered in a register which can be accessed by the members of the public on request.

Allocation of govt. land involving large areas is made by the government particularly to private industries ordinarily through negotiations as to the terms and conditions of the allocation. Such allocations are regulated by Rule 20A (6) of the W.B.L.R Rules. All essential information in regard to such allocation is not ordinarily publicly accessible.

\section{Data Source:}

\section{Data Reliability:}

\begin{tabular}{|l|l|l|l|}
\hline Panel & LGI & Dim. & $\begin{array}{l}\text { Land Governance Indicator 11 } \\
\text { Justification and time-efficiency of acquisition processes: the } \\
\text { state acquires land for public interest only and this is done } \\
\text { efficiently }\end{array}$ \\
\hline 4 & 2 & 1 & There is minimal transfer of acquired land to private interests. ${ }^{2}$ \\
\hline & $\begin{array}{l}\text { A: Less than } 10 \% \text { of land acquired in the past } 3 \text { years is used for private } \\
\text { purposes. }\end{array}$
\end{tabular}

\footnotetext{
${ }^{2}$ In some countries in the process of urban expansion privately land held maybe acquired before land use planning is implemented and then sold/returned to previous owners in a different form. This is not to be considered for ranking this dimension. Transfer of acquired land to private interests is excluded.
}

79 | Page Land Governance Assessment Framework - W est Bengal 


\begin{tabular}{|l|l|}
\hline & $\begin{array}{l}\text { B: Between } 10 \% \text { and } 30 \% \text { of land acquired in the past } 3 \text { years is used for } \\
\text { private purposes. }\end{array}$ \\
\hline $\begin{array}{l}\text { C: Between } 30 \% \text { and } 50 \% \text { of land acquired in the past } 3 \text { years is used for } \\
\text { private purposes. }\end{array}$ \\
\\
$\begin{array}{l}\text { D: More than } 50 \% \text { of land acquired in the past } 3 \text { years is used for private } \\
\text { purposes. }\end{array}$ \\
\hline
\end{tabular}

\section{Analysis:}

Lands are acquired under the Acquisition Act to meet both private and public purposes. Over the last three years Govt. of West Bengal has hardly acquired any land for private purpose in tune with the declared policy of not acquiring land from unwilling farmers.

\section{Data Source:}

\section{Data Reliability:}

\begin{tabular}{|c|c|c|c|}
\hline Panel & LGI & Dim. & $\begin{array}{l}\text { Land Governance Indicator } 11 \\
\text { Justification and time-efficiency of acquisition processes: the } \\
\text { state acquires land for public interest only and this is done } \\
\text { efficiently }\end{array}$ \\
\hline \multirow[t]{5}{*}{4} & \multirow[t]{5}{*}{2} & \multirow[t]{5}{*}{2} & Acquired land is transferred to destined use in a timely manner. \\
\hline & & & $\begin{array}{l}\text { A: More than } 70 \% \text { of the land that has been acquired in the past } 3 \text { years has } \\
\text { been transferred to its destined use. }\end{array}$ \\
\hline & & & $\begin{array}{l}\text { B: Between } 50 \% \text { and } 70 \% \text { of the land that has been acquired in the past } 3 \\
\text { years has been transferred to its destined use. }\end{array}$ \\
\hline & & & $\begin{array}{l}\text { C: Between } 30 \% \text { and } 50 \% \text { of the land that has been acquired in the past } 3 \\
\text { years has been transferred to its destined use. }\end{array}$ \\
\hline & & & $\begin{array}{l}\text { D: Less than } 30 \% \text { of the land that has been acquired in the past } 3 \text { years has } \\
\text { been transferred to its destined use. }\end{array}$ \\
\hline
\end{tabular}

\section{Analysis:}

Generally acquired land is transferred to destined use in a timely manner. But sometimes delay occurs for various unforeseen reasons. Land acquisition worthy of mention has not been done in West Bengal over the last three years. But before that during the period 2008-2010, a total of about 7600 acres of land has been acquired by the government (requisitioning body WBIDC) and out of that about $60 \%$ of land has been transferred to its destined use.

\begin{tabular}{|c|c|c|c|}
\hline Name & Product/ services & Location & Area in acres \\
\hline $\begin{array}{c}\text { Bengal Aerotropolis } \\
\text { project }\end{array}$ & Aviation & Durgapur - Asansol & 1818 acres \\
\hline $\begin{array}{c}\text { Raghunathpur steel } \\
\text { and allied industrial } \\
\text { park }\end{array}$ & $\begin{array}{c}\text { Iron and steel, cement } \\
\text { power }\end{array}$ & Raghunathpur, Purulia & 3100 acres (approx.) \\
\hline $\begin{array}{c}\text { Vidyasagar industrial } \\
\text { park }\end{array}$ & $\begin{array}{c}\text { Engineering and } \\
\text { manufacturing }\end{array}$ & Kharagpur, & 1246.05 acres \\
\hline $\begin{array}{c}\text { Rishi Bankim } \\
\text { industrial park }\end{array}$ & Multi-product & Naihati, North 24 Pgs & 163.38 acres \\
\hline $\begin{array}{c}\text { Panagarh industrial } \\
\text { park }\end{array}$ & $\begin{array}{c}\text { Engineering and } \\
\text { manufacturing }\end{array}$ & Panagarh, Burdwan & 1458 acres \\
\hline
\end{tabular}

\section{Data Source: WBIDC}

Data Reliability: High

80|Page Land Governance Assessment Framework - West Bengal 


\begin{tabular}{|l|l|l|l|}
\hline Panel & LGI & Dim. & $\begin{array}{l}\text { Land Governance Indicator 11 } \\
\text { Justification and time-efficiency of acquisition processes: the } \\
\text { state acquires land for public interest only and this is done } \\
\text { efficiently }\end{array}$ \\
\hline 4 & 2 & 3 & $\begin{array}{l}\text { The threat of land acquisition does not lead to pre-emptive action by private } \\
\text { parties. }\end{array}$ \\
\hline \multirow{2}{*}{} & A: None at all. \\
& B: Some. \\
& C: A lot. \\
\hline & D: A lot and regressive. \\
\hline
\end{tabular}

\section{Analysis:}

No case has so far been identified where any private party has taken any pre-emptive action through competent Court or otherwise to avert acquisition of its land.

\begin{tabular}{|c|c|c|c|}
\hline Panel & LGI & Dim. & $\begin{array}{l}\text { Land Governance Indicator } 12 \\
\text { Transparency and fairness of acquisition procedures: } \\
\text { acquisition procedures are clear and transparent and fair } \\
\text { compensation is paid expeditiously. }\end{array}$ \\
\hline \multirow[t]{5}{*}{4} & 3 & 1 & $\begin{array}{l}\text { Compensation is provided for the acquisition of all rights regardless of their } \\
\text { recording status. }\end{array}$ \\
\hline & & & $\begin{array}{l}\text { A: Fair compensation, in kind or in cash, that allows maintenance of } \\
\text { previous social and economic status, is paid to all those with rights in } \\
\text { acquired land (ownership, use, access rights etc.) regardless of the recording } \\
\text { status. }\end{array}$ \\
\hline & & & $\begin{array}{l}\text { B: Compensation, in kind or in cash, is paid, however the level of } \\
\text { compensation where rights are not recorded does not allow for maintenance } \\
\text { of social and economic status. }\end{array}$ \\
\hline & & & $\begin{array}{l}\text { C: Compensation, in kind or in cash, is paid for some unrecorded rights } \\
\text { (such as possession, occupation etc.), however those with other unrecorded } \\
\text { rights (which may include grazing, access, gathering forest products etc.) are } \\
\text { usually not paid. }\end{array}$ \\
\hline & & & $\begin{array}{l}\text { D: No compensation is paid to those with unrecorded rights of use, } \\
\text { occupancy or otherwise. }\end{array}$ \\
\hline
\end{tabular}

\section{Analysis:}

Compensation is paid to the owners of the land recorded or not recorded. In West Bengal provisions have been made to pay some compensation (though not at the same rate applicable for the land owners) to the share-croppers also. Since in the eye of the law there is no distinction between the recorded sharecropper and unrecorded ones. Compensation is paid after verifying on the spot who actually cultivates the land.

A recorded/ or unrecorded bargadar on the land acquired is also eligible for compensation though on a much reduced scale. However, by virtue of an executive order (2006) of the L\&LR department, some compensation is paid even to agricultural labourers who worked on the acquired agricultural lands

\section{Data Source:}

\section{Data Reliability:}

\begin{tabular}{|l|l|l|l|}
\hline Panel & LGI & Dim. & $\begin{array}{l}\text { Land Governance Indicator 12 } \\
\text { Transparency and fairness of acquisition procedures: } \\
\text { acquisition procedures are clear and transparent and fair } \\
\text { compensation is paid expeditiously. }\end{array}$ \\
\hline \hline
\end{tabular}

81|Page Land Governance Assessment Framework - West Bengal 


\begin{tabular}{|l|l|l|}
\hline 4 & 2 & Land use change resulting in selective loss of rights there is compensated for. \\
\hline \multirow{1}{*}{} & $\begin{array}{l}\text { A: Where people lose rights as a result of land use change outside the } \\
\text { acquisition process, compensation in cash or in kind is paid so that these } \\
\text { people have comparable assets and can continue to maintain prior social and } \\
\text { economic status. }\end{array}$ \\
\cline { 2 - 2 } & $\begin{array}{l}\text { B: Where people lose rights as a result of land use change outside the } \\
\text { acquisition process, compensation in cash or in kind are paid so that these } \\
\text { people have comparable assets but cannot continue to maintain prior social } \\
\text { and economic status. }\end{array}$ \\
\hline $\begin{array}{l}\text { C: Where people lose rights as a result of land use change outside the } \\
\text { acquisition process, compensation in cash or in kind are paid such that these } \\
\text { people do not have comparable assets and cannot continue to maintain prior } \\
\text { social and economic status. }\end{array}$ \\
$\begin{array}{l}\text { D: Where people lose rights as a result of land use change outside the } \\
\text { acquisition process, compensation is not paid. }\end{array}$ \\
\hline
\end{tabular}

\section{Analysis:}

Generally speaking transfer of ownership takes place before the land use changes. When agricultural land is used for setting up of an industry the industrialist purchases the land from farmers by paying the market price. Thus the farmers are compensated. Again, if any such land is cultivated by a sharecropper (then some compensation is paid to the sharecropper as notified by the government in 2006 by an administrative order. Some compensation is paid to the agricultural labourers also who had been earning wages from the land. But no compensation is paid where people lose rights as a result of land use change outside the acquisition process.

\section{Data Source:}

\section{Data Reliability:}

\begin{tabular}{|c|c|c|c|}
\hline Panel & LGI & Dim. & $\begin{array}{l}\text { Land Governance Indicator } 12 \\
\text { Transparency and fairness of acquisition procedures: acquisition } \\
\text { procedures are clear and transparent and fair compensation is } \\
\text { paid expeditiously. }\end{array}$ \\
\hline \multirow[t]{5}{*}{4} & \multirow[t]{5}{*}{3} & \multirow[t]{5}{*}{3} & Acquired owners are compensated promptly. \\
\hline & & & $\begin{array}{l}\text { A: More than } 90 \% \text { of acquired land owners receive compensation within one } \\
\text { year. }\end{array}$ \\
\hline & & & $\begin{array}{l}\text { B: Between } 70 \% \text { and } 90 \% \text { of acquired land owners receive compensation } \\
\text { within one year. }\end{array}$ \\
\hline & & & $\begin{array}{l}\text { C: Between } 50 \% \text { and } 70 \% \text { of acquired land owners receive compensation } \\
\text { within one year. }\end{array}$ \\
\hline & & & $\begin{array}{l}\text { D: Less than } 50 \% \text { of acquired land owners receive compensation within one } \\
\text { year. }\end{array}$ \\
\hline
\end{tabular}

\section{Analysis:}

Government of West Bengal by an executive order 1701-LA/3M dated 06.06.2006 by supersession of all provisions of LA Manual, 1991 adopted the procedure of compensation which contains the following clauses:

Clause 22 - the LA Collector shall take all efforts to complete payment of all award money to the awardees as the case may be within a period not exceeding 30 days in case of 100 acres and 45 days in case of above 100 acres

82|Page Land Governance Assessment Framework - West Bengal 
Clause 23 - possession can be taken only after payments are made

Sometimes there is a considerable time lag between acquisition and payment of compensation. It is more often than not that questions arise about the ownership of land acquired. These questions are resolved by field enquiry by the concerned officials. Defective and incomplete documents produced by the persons interested also sometimes cause delay in payment.

We may have a look at a case where compensation payment in reality could be judged. In their paper "Land acquisition and compensation in Singur: what really happened?" by Ghatak, Mitra, Mookherjee and Nath (2012) the main findings are quoted below to provide a real situation about the compensation offered -

a) Government compensation was based on different kinds (classification) of land, and additional solatium of $30 \%$ plus allowance for irrigation, location of plot

b) The researchers found that the above was close to market value as reported by the households, and above market values predicted on basis of past transactions

c) The compensation announced by the government - Rs. 6,01,718/ acre for 'Sali', Rs. $8,80,029 /$ acre for 'sona' and Rs. 18,04,431/ acre for 'homestead' land

d) The study also states that many plots of land that used to be 'Sali' have been converted by owners to 'sona' overtime, but this change had not been noted in government records resulting lower compensation

However, this was the position before the new Act of 2013 came into force.

Data Source: Land acquisition and compensation in Singur - paper by Ghatak, Mitra, Mookherjee and Nath (2012)

\section{Data Reliability:}

\begin{tabular}{|l|l|l|l|}
\hline Panel & LGI & Dim. & $\begin{array}{l}\text { Land Governance Indicator 12 } \\
\text { Transparency and fairness of acquisition procedures: acquisition } \\
\text { procedures are clear and transparent and fair compensation is } \\
\text { paid expeditiously. }\end{array}$ \\
\hline 4 & 3 & 4 & There are independent and accessible avenues for appeal against acquisition. \\
\hline \multirow{2}{*}{} & & $\begin{array}{l}\text { A: Independent avenues to lodge a complaint against acquisition exist and are } \\
\text { easily accessible. }\end{array}$ \\
\cline { 3 - 4 } & & $\begin{array}{l}\text { B: Independent avenues to lodge a complaint against acquisition exist but } \\
\text { there are access restrictions (i.e. only accessible by mid-income and wealthy). }\end{array}$ \\
\cline { 3 - 4 } & & $\begin{array}{l}\text { C: Avenues to lodge a complaint against acquisition exist but are somewhat } \\
\text { independent and these may or may not be accessible to those affected. }\end{array}$ \\
\cline { 3 - 4 } & & D: Avenues to lodge a complaint against acquisition are not independent. \\
\hline
\end{tabular}

\section{Analysis:}

Since no acquisition of land has been made under the new Act of 2013, avenue of appeal as they existed in the LA Act of 1894 are discussed here.

A person interested could object $\mathrm{u} / \mathrm{s}$ 5-A to the acquisition for which preliminary notification was made $\mathrm{u} / \mathrm{s} 4$, to the Collector who is under obligation to give an opportunity of being heard to the objector and then send a report to the state government with his recommendation. The decision of the state government is final. Since neither the Collector nor the state government can be said to be an independent authority because it is on the decision of the state government preliminary notification has been issued $\mathrm{u} / \mathrm{s} 4$, the forum cannot be said to be independent. The only way to go to an independent authority is by way of approaching the High Court in a writ

83|Page Land Governance Assessment Framework - West Bengal 
petition which may not be affordable option for lower income group. (Ranking changed from A to B following discussion with EI and panellists)

\begin{tabular}{|l|l|l|l|}
\hline Panel & LGI & Dim. & $\begin{array}{l}\text { Land Governance Indicator 12 } \\
\text { Transparency and fairness of acquisition procedures: acquisition } \\
\text { procedures are clear and transparent and fair compensation is } \\
\text { paid expeditiously. }\end{array}$ \\
\hline 4 & 3 & 5 & \begin{tabular}{l} 
Timely decisions are made regarding complaints about acquisition. \\
\hline
\end{tabular} \\
& $\begin{array}{l}\text { A: A first instance decision has been reached for more than } 80 \% \text { of the } \\
\text { complaints about acquisition lodged during the last 3 years. }\end{array}$ \\
$\begin{array}{l}\text { B: A first instance decision has been reached for between } 50 \% \text { and } 80 \% \text { of the } \\
\text { complaints about acquisition lodged during the last } 3 \text { years. }\end{array}$ \\
\hline $\begin{array}{l}\text { C: A first instance decision has been reached for between } 30 \% \text { and } 50 \% \text { of the } \\
\text { complaints about acquisition lodged during the last 3 years. }\end{array}$ \\
$\begin{array}{l}\text { D: A first instance decision has been reached for less than } 30 \% \text { of the } \\
\text { complaints about acquisition lodged during the last } 3 \text { years. }\end{array}$ \\
\hline
\end{tabular}

\section{Analysis:}

Objections under section 5-A were expeditiously heard and disposed of by the Collector. 


\section{Indicators}

1. Transfer of public land to private use follows a clear, transparent, and competitive process and payments are collected and audited (with the exception of transfers to improve equity such as land distribution and land for social housing).

2. Private Investment Strategy

3. Policy implementation is effective, consistent and transparent and involves local stakeholders.

4. Contracts involving public land are public with agreements monitored and enforced.

\begin{tabular}{|c|c|c|c|}
\hline Panel & LGI & Dim. & $\begin{array}{l}\text { Land Governance Indicator } 13 \\
\text { Transfer of public land to private use follows a clear, transparent, } \\
\text { and competitive process and payments are collected and audited } \\
\text { (with the exception of transfers to improve equity such as land } \\
\text { distribution and land for social housing). }\end{array}$ \\
\hline \multirow[t]{5}{*}{5} & 1 & 1 & Public land transactions are conducted in an open transparent manner. \\
\hline & & & $\begin{array}{l}\text { A: The share of public land disposed of in the past } 3 \text { years through sale or lease } \\
\text { through public auction or open tender process is greater than } 90 \% \text { (Except for } \\
\text { equity transfers). }\end{array}$ \\
\hline & & & $\begin{array}{l}\text { B: The share of public land disposed of in the past } 3 \text { years through sale or lease } \\
\text { through public auction or open tender process is between } 70 \% \text { and } 90 \% \text {. (Except } \\
\text { for equity transfers). }\end{array}$ \\
\hline & & & $\begin{array}{l}\text { C: The share of public land disposed of in the past } 3 \text { years through sale or lease } \\
\text { through public auction or open tender process is between } 50 \% \text { and } 70 \% \text {. }\end{array}$ \\
\hline & & & $\begin{array}{l}\text { D: The share of public land disposed of in the past } 3 \text { years through sale or lease } \\
\text { through public auction or open tender process is less than 50\%. (Except for } \\
\text { equity transfers). }\end{array}$ \\
\hline
\end{tabular}

\section{Analysis:}

Public land is transferred for non-agricultural purposes in terms of section 49(5) of the WBLR Act and Rule 2oA(6) made thereunder. Detailed procedure has been prescribed in chapter XV of the W.B. Land and Land Reforms Manual, 1991. A recent order, No. 6686-LP/1A-18/2012, dated 26/12/2012 of the department of L\&LR now forms the basis of transfer of public land. The order specifies that lands for non-agricultural purposes shall ordinarily be settled on longterm leases for a period not exceeding 99 years and on expiration of the period the tenant is entitled for successive renewals for the same period. Land meant for commercial use shall invariably be auctioned to the highest bidder for which adequate publicity should be given including through internet.

To maintain an open and transparent manner of such settlements, the Collector/ District Land \& Land Reforms Officer shall identify suitable plots of land and advertise the land inviting applications for long-term settlement. Applications from interested persons for such settlements are also considered [Rule 220 of W.B. L\&LR Manual 1991]. On receiving applications in response to the advertisement for settlement of lands, the Collector/ DLLRO send his recommendation to the department through the Commissioner. For more than one application received for the same land, the selection of the applicant is made on merit considering the background and financial position of the applicant vis-à-vis the purpose for which settlement is sought. Public land at the disposal of government has been settled on long-term leases in the

85|Page Land Governance Assessment Framework - West Bengal 
last three years mostly (estimated 70\%) with interested applicants by observing the public auction/ laid down procedure of the L\&LR Department. Even the provisions of drawal of lots in public can be resorted to if a number of plots are offered in a location at the same time. In case of more than one applicant the reason for selection of a prospective lessee should be explained in the settlement proposal along with a copy of the advertisement. There are provisions for relaxations for economically weaker sections of the population.

As per the provisions of the government order dated 26.12.2012, for project leading to industrial development, the highest price need not be the main criteria nor should auction be the only mode of allotment. The department or the entity (WBIDC etc.) shall prepare and publish a list of its land assets. It may also indicate the kind of industrial development it is seeking (big, medium, knowledge based, non-polluting etc.) along with tentative price which may be determined on the basis of acquisition price, cost of capital, development charges and premium as applicable. This information should be freely available in the public domain for at least one month before. The Government owned corporations like WBIDC, WBIIDC WBSIDC and WBMMDC responsible for development of industries, infrastructures for industries, development of small industries and mines and minerals respectively having land at their disposal follow an open and transparent method when settle land with investors for the respective purposes. The availability of land is advertised in newspapers and in their respective websites with details of land and terms and purpose of settlement inviting expression of interest and allotment of land is made to those who fulfil the criteria specified in the notice in a fair and impartial manner.

With a view to modernizing infrastructure facilities and creating industrial growth centres, Government of West Bengal has identified suitable areas and gone ahead with land acquisition. The principles of participation and appropriate compensation for the land losing community were observed for such acquisition which mostly happened after 2008 (post-Singur). WBIDC is developing sector specific and multi-product industrial parks in the state in the acquired areas. An overview of the large projects:

\begin{tabular}{|c|c|c|c|}
\hline Name & Product/ services & Location & Area in acres \\
\hline $\begin{array}{l}\text { Bengal Aerotropolis } \\
\text { project }\end{array}$ & Aviation & Durgapur - Asansol & 1818 acres \\
\hline $\begin{array}{l}\text { Raghunathpur steel } \\
\text { and allied industrial } \\
\text { park }\end{array}$ & $\begin{array}{l}\text { Iron and steel, } \\
\text { cement power }\end{array}$ & $\begin{array}{l}\text { Raghunathpur, } \\
\text { Purulia }\end{array}$ & 3100 acres (approx.) \\
\hline $\begin{array}{l}\text { Vidyasagar industrial } \\
\text { park }\end{array}$ & $\begin{array}{l}\text { Engineering and } \\
\text { manufacturing }\end{array}$ & Kharagpur, & 1246.05 acres \\
\hline $\begin{array}{l}\text { Rishi Bankim } \\
\text { industrial park }\end{array}$ & Multi-product & $\begin{array}{c}\text { Naihati, North } 24 \\
\text { Pgs }\end{array}$ & 163.38 acres \\
\hline $\begin{array}{l}\text { Panagarh industrial } \\
\text { park }\end{array}$ & $\begin{array}{l}\text { Engineering and } \\
\text { manufacturing }\end{array}$ & Panagarh, Burdwan & 1458 acres \\
\hline
\end{tabular}

In all the above cases the 'Requiring Body' was WBIDC after necessary clearance from the government and observing all the steps and procedure laid down in this respect following submission of a joint venture proposal or expression of interest from the anchor investor. On the basis of the detailed project report (DPR) submitted by the anchor investor and with the approval of the government land acquisition was done by the Collector on behalf of WBIDC. In most of these joint venture cases about 30-50\% of the lands acquired are given on long-term settlement as per agreed terms and conditions to the anchor investor. About50-70\% of the land acquired for these joint ventures was subsequently publicly auctioned for distribution among other willing private investors for setting up of industrial units. Transparency is maintained for such settlements.

86|Page Land Governance Assessment Framework - West Bengal 


\section{Data source:}

- West Bengal L\&LR Act, 1955

- West Bengal Land Reforms Rules 1965

- West Bengal Land and Land Reforms Manual 1991

- West Bengal L \& LR, Land Policy Branch Order No. 6686-LP/1A-18/2012.

- WBIDC

Data reliability: As data are mostly from Laws and Rules, data are considered to be highly reliable.

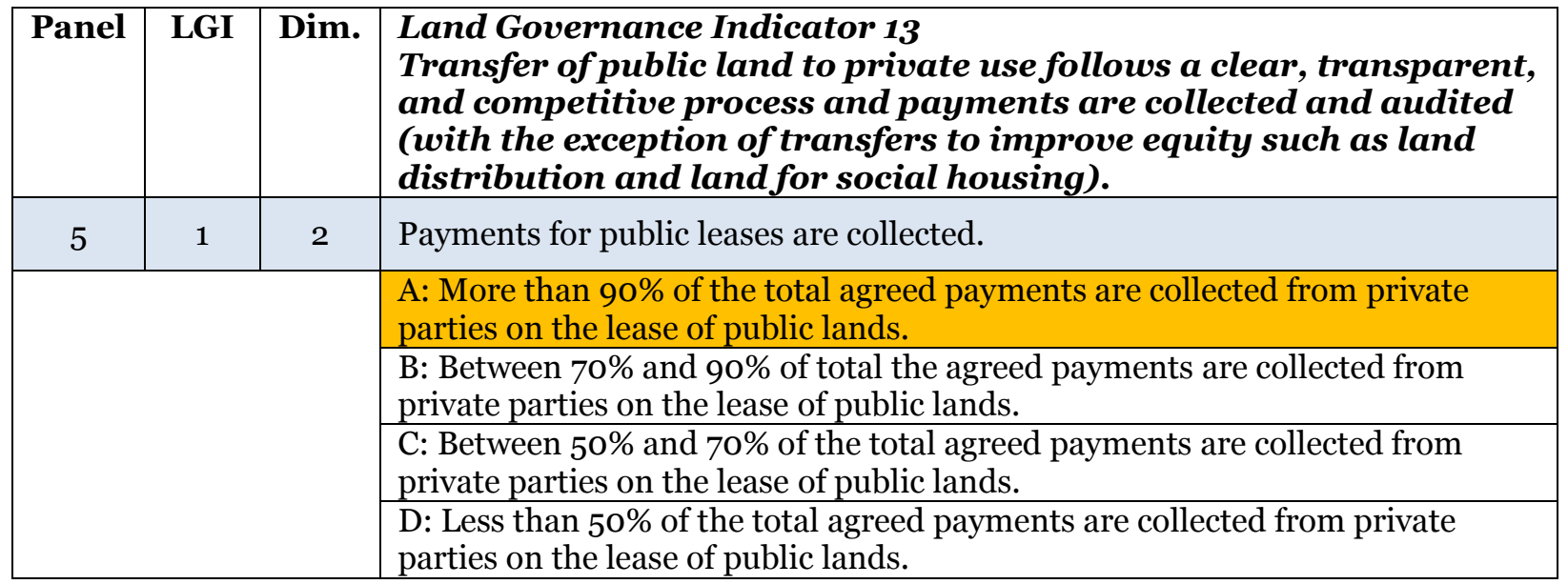

\section{Analysis:}

Payments for long-term leases of 30 years comprise of two components - yearly rent at $4 \%$ of the market value and salami charged at 10 times the rent equalling forty percent of the market price. When the lease is granted for 99 years salami is fixed at $95 \%$ and yearly rent at 0.3 times of market value of land. The department of L\&LR may reduce the rent and salami payable for a land if it is satisfied that the land will be used to serve a public purpose or a charitable purpose. Yearly rent so fixed shall be paid according to the Bengali year and shall fall due on the last day of the Bengali year. The rent may either be paid by a lessee to the Bhumi Sahayak (BS) available at village revenue office or direct to a treasury by cash or postal money order. The BS shall give a signed receipt immediately in the prescribed form against the payment received. In case of a payment made direct to a treasury by cash or by money order, the accountant will send a copy of the challan to the BLLRO office where the BS will account for the payment received [Rule 223, 235, 236 of W.B.L\&LR Manual 1991]. The details of payments collected for three years for public leases are given below.

87|Page Land Governance Assessment Framework - West Bengal 


\begin{tabular}{|l|c|c|c|}
\hline \multicolumn{1}{|c|}{ Period } & 2008-09 & 2009-10 & 2010-11 \\
\hline $\begin{array}{l}\text { Quantum of land } \\
\text { sanctioned on long- } \\
\text { term lease }\end{array}$ & 476.2929 acre & 976.2403 acre & 751.3239 acre \\
\hline $\begin{array}{l}\text { Amount on account } \\
\text { of annual rent (Rs) }\end{array}$ & Rs. 56,39,110 & Rs. 42,68,082 & Rs. 59,11,548 \\
\hline $\begin{array}{l}\text { Amount on account } \\
\text { of salami/transfer } \\
\text { value (Rs) }\end{array}$ & Rs. 132,62,42,261 & Rs. 19,76,48,448 & Rs. 21,35,50,401 \\
\hline $\begin{array}{l}\text { Total amount } \\
\text { involved (Rs) }\end{array}$ & Rs. 133,18,81,371 & Rs. 20,19,16,530 & Rs. 21,94,61,949 \\
\hline
\end{tabular}

Source: Department of L\&LR, Govt. of West Bengal

The lease amount is deposited in the concerned Treasury unless the government decides otherwise.

In addition to above the pricing policy for allotment of land in industrial parks is done in accordance with a separate order. The pricing policy is uniform and arrived at in such a manner that it covers cost of land and cost of development of such land. In these cases also the payment for lease are collected and deposited in government account.

\section{Data source:}

- West Bengal L\&LR Manual, 1991.

- Department of L\&LR

- West Bengal Industrial Development Corporation website link: http://wbidc.com/images/pdf/Pricing_Policy_WBIDC.pdf

Data Reliability: High

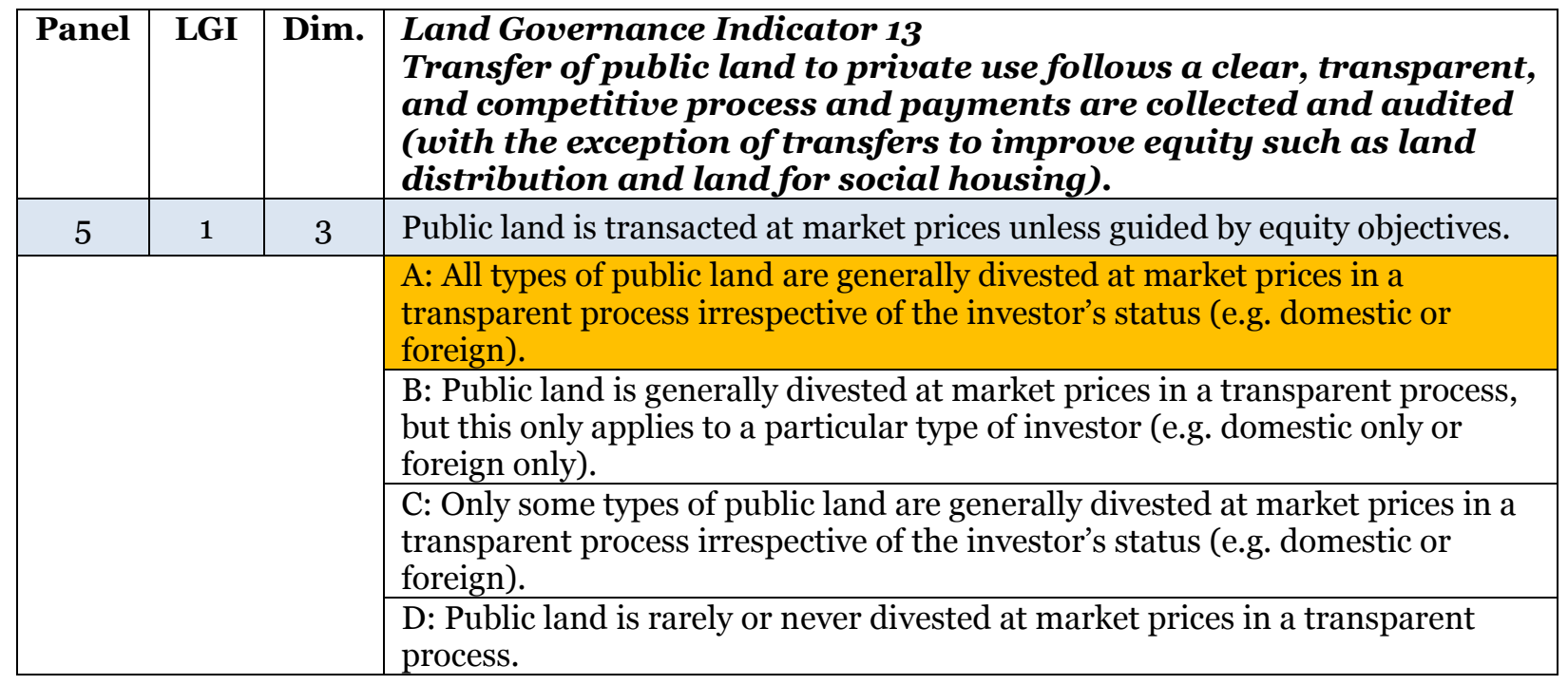

88| Page Land Governance Assessment Framework - West Bengal 


\section{Analysis:}

Transfer of large tracts of land to investors in the form of settlement / lease is done u/s 49(5) of the LR act and rule 20A(6) of the W.B. Land reforms Rules, 1965 on terms and conditions set forth in the formats appended to the Manual of 1991.

Ordinarily, fixation of terms and conditions including premium is preceded by negotiations between the government and the would-be settlee / lessee. In determining the premium and other lease terms factors like location of the land to be settled, the purpose of the settlement, suitability of the land for the lease purpose, prevailing price of land in the locality etc. are taken into account. In the process, the premium exceeds the market price of the land in some cases of transaction.

The order of L\&LR Department (Dec 2012) states that land settled for private use should be based on market prices. The earlier order specifies that for transfer of land from government to private entities should be based on the recent sale prices of land of similar type as obtained from the Registration Office. However, since such transactions often do not reflect true price as prices are under quoted to evade cost of registration. To rectify this, the current order recommends land allotment should be through an open and transparent auction process. To reduce malpractices fixation of reserve price is not allowed before the quotation is received. However, there are provisions for relaxations to accommodate weaker sections of the society (equity issues) or other social objectives.

All the costs involved in acquisition of government land where payment has to be made by awards in favour of the collector shall be borne by the Requiring Body as a part of land acquisition cost and the Land acquisition Collector should include these elements while preparing the estimate of cost for acquisition (G.O. No 1701 LA dated 6 June 2006). So, all the public land transactions irrespective of the status of the investor's status are carried out in a transparent manner. Pricing of land, the process of settlement and collection of payments are duly audited by the Comptroller and Auditor General (CAG).

Data Source: L\&LR Department

\section{Data Reliability:}

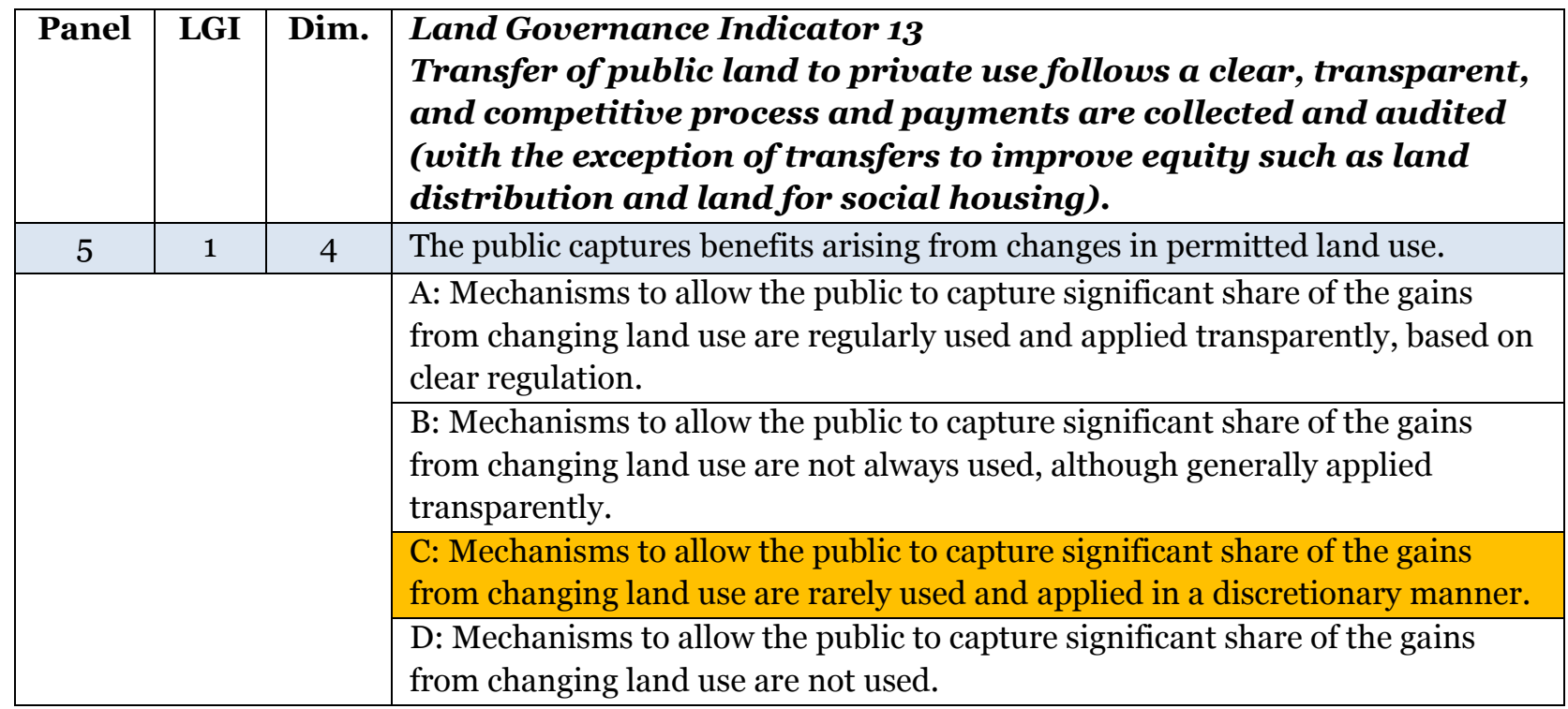

Analysis:

89|Page Land Governance Assessment Framework - West Bengal 
When public land is transferred to other government department or to some organization for provision of public goods, such as construction of power plant, then in general the benefits accrue to all members of the public. However, if the transfer takes place for some use which is more private in nature, such as setting up of industrial units, then benefits accrue to existing residents in the form of ancillary industries or services that come up in the area. However, if land is acquired for the purpose of provision of public goods or for private use then private costs to the existing residents who lose land may exceed the benefits. It may not always be possible to compensate for the future income of them. In general the process is of compensation accruing to land losers is transparent, but hidden fiscal benefits to the entities who are allotted are not transparent.

There is also no mechanism in practice to quantify the benefits as a whole, only tangible benefits are captured in the reports.

Data Source: print and electronic media reporting

\section{Data Reliability:}

Policy recommendations: Considering absence of any mechanism to quantify the short-term and long-term benefits that will accrue to the public, an independent benefit assessment system needs to be put in place.

\begin{tabular}{|c|c|c|l|}
\hline Panel & LGI & Dim. & $\begin{array}{l}\text { Land Governance Indicator 13 } \\
\text { Transfer of public land to private use follows a clear, transparent, } \\
\text { and competitive process and payments are collected and audited } \\
\text { (with the exception of transfers to improve equity such as land } \\
\text { distribution and land for social housing). }\end{array}$ \\
\hline 5 & 1 & 5 & $\begin{array}{l}\text { Policy to improve equity in asset access and use by the poor exists, is } \\
\text { implemented effectively and monitored. }\end{array}$ \\
\hline \multirow{2}{*}{} & & $\begin{array}{l}\text { A: Policy is in place to improve access to and productive use of assets by poor } \\
\text { and marginalized groups, is applied in practice and effective }\end{array}$ \\
\cline { 2 - 4 } & & $\begin{array}{l}\text { B: Policy is in place to improve access to and productive use of assets by poor } \\
\text { and marginalized groups, is applied in practice, but is not effective }\end{array}$ \\
& $\begin{array}{l}\text { C: Policy is in place to improve access to and productive use of assets by poor } \\
\text { and marginalized groups but is not enforced }\end{array}$ \\
\cline { 2 - 3 } & $\begin{array}{l}\text { D: No policy in place to improve access to and productive use of assets by poor } \\
\text { and marginalized groups. }\end{array}$ \\
\hline
\end{tabular}

\section{Analysis:}

In recent times large tracts of land transfers to private entities have incorporated arrangements for benefits of newly built assets to accrue to the poor and marginalized sections of the population. This has particularly been made part of government policy in case of land transfers/ settlement from acquired land. For land holders, landless labourers or bargadars are entitled to benefits if they are displaced because of acquisition in the form of one-time cash receipts as well as a part coming in the form of annuities generated from funds deposited with financial institutions of the choice of the beneficiaries. Financial costs for such benefit are generally borne by the organization which receives the land. However, it has not been very effective in many cases because often the beneficiaries do not have legal rights. Bargadars are often not properly registered; informal arrangements of land sharing among the members of family are the main reasons.

The state government policy (G.O. No. 1706 LA dated 6 June 2006) on mandatory RR package for below poverty line (BPL) families in this regards is:

90|Page Land Governance Assessment Framework - West Bengal 
For any industrial development project, the evicted families by way of land acquisition should be resettled in the nearest vicinity, as far as possible

a) For LA project in an ULB or proposed industrial township area, allotment of two cuttah of plot of land to each evicted family, or free allotment of a constructed flat in the line of government housing projects for poor (in this case the mandatory cash assistance is not provided as prescribed for evicted BPL families)

b) For LA project in rural areas, the evicted BPL families will get two cuttah of plot of land per family or a constructed IAY house (mandatory cash assistance is not provided)

c) The requiring body shall have the rights and privilege to offer any better package above or in lieu of the mandatory cash assistance.

Data Source: The Government Order of the LA Branch of L\&LR Department and West Bengal Industrial Development Corporation Policy Document on Rehabilitation and Resettlement Policy

Data Reliability: High

\begin{tabular}{|c|c|c|l|}
\hline Panel & LGI & Dim. & $\begin{array}{l}\text { Land Governance Indicator 14 } \\
\text { Private investment strategy }\end{array}$ \\
\hline 5 & 2 & 1 & $\begin{array}{l}\text { Land to be made available to investors is identified transparently and publicly, } \\
\text { in agreement with right holders. }\end{array}$ \\
\hline \multirow{5}{*}{} & $\begin{array}{l}\text { A: A policy to clearly identify land that can be made available to investors exists } \\
\text { and has been arrived at based on comprehensive assessment of land potential, } \\
\text { community consultation that is free and informed and reached an agreement, } \\
\text { and is applied in more than 90\% of identified cases. }\end{array}$ \\
\cline { 3 - 4 } & $\begin{array}{l}\text { B: A policy to identify land that can be made available to investors exists, based } \\
\text { on ad hoc assessment of land potential but with community consultation and } \\
\text { agreement, and is applied in more than 90\% of identified cases. }\end{array}$ \\
\hline & $\begin{array}{l}\text { C: A policy to identify land that can be made available to investors exists, based } \\
\text { on ad hoc assessment of land potential and limited consultation with } \\
\text { communities and is applied in more than 90\% of identified cases. }\end{array}$ \\
\cline { 3 - 4 } & $\begin{array}{l}\text { D: There is no policy in place to identify land to be made available to investors } \\
\text { so that any transfers are based on ad-hoc investor demands. }\end{array}$ \\
\hline
\end{tabular}

\section{Analysis:}

The land allotment order issued by the L\&LR Department, dated 26.12.2012 clearly states the policy of land transfer to investors. The L\&LR Manual, 1991 is amended in this respect. However, the Government of West Bengal after the Singur episode involved the local community for acquisition of land for Durgapur Aerotroplois and for industrial parks at Panagarh, Raghunathpur, Kharagpur and Naihati in the matter of selection of sites and fixing compensation package.

Information available for the case of land acquisition during 2008-2010 at Andal, Burdwan district for the joint venture airport project with Bengal Aerotroplois, indicates that initial requirement of 4000 acres land was later brought down to 1818 acres in consultation with the local community and stakeholders. There were 19 meetings held with the local community covering all aspects of land acquisition including area to be acquired, underutilized land identification and mapping, negotiation of land compensation etc. which helped in minimizing potential disputes and differences.

\section{Data Source:}

- West Bengal Land and Land Reforms Manual 1991

91|Page Land Governance Assessment Framework - West Bengal 
- West Bengal L \& LR, Land Policy Branch Order No. 6686-LP/1A-18/2012

- Bengal Aerotroplolis Projects Ltd management

\section{Data reliability: High}

\begin{tabular}{|c|c|c|l|}
\hline Panel & LGI & Dim. & $\begin{array}{l}\text { Land Governance Indicator 14 } \\
\text { Private investment strategy }\end{array}$ \\
\hline 5 & 2 & 2 & $\begin{array}{l}\text { Investments are selected based on economic, socio-cultural and } \\
\text { environmental impacts in an open process }\end{array}$ \\
\hline \multirow{2}{*}{} & $\begin{array}{l}\text { A: Process is in place that properly considers both national and local benefits } \\
\text { and is adhered to. Benefit sharing mechanism are in place }\end{array}$ \\
\cline { 3 - 4 } & & $\begin{array}{l}\text { B: Process is in place that considers only national benefits, but that is adhered } \\
\text { to. No local benefit sharing in place }\end{array}$ \\
\cline { 3 - 4 } & $\begin{array}{l}\text { C: Process is in place but many investments go ahead that are either not } \\
\text { according to the policy or despite unfavourable outcomes. }\end{array}$ \\
\cline { 3 - 4 } & D: No process in place. \\
\hline
\end{tabular}

\section{Analysis:}

Though L\&LR Manual, 1991 has no such provision for the above, West Bengal Industrial Development Corporation has been doing this since last 5-6 years post-Singur incident. This has often been emphasized by WBIDC and Commerce and Industry Department. In fact, while selecting the sites for setting up an Airport City at Andal and Industrial Parks at Panagarh, Naihati, Khargpur and Raghunathpur WBIDC held several rounds of consultations with the local people of the respective area having stake (including right holders) in the acquisition and reaching consensus as regards acquisition of land, compensation to be paid to the land losers, benefit-sharing and the projects to be set up.

\section{Data Source:}

\section{Data Reliability:}

\begin{tabular}{|c|c|c|l|}
\hline Panel & LGI & Dim. & $\begin{array}{l}\text { Land Governance Indicator 14 } \\
\text { Private investment strategy }\end{array}$ \\
\hline 5 & 2 & 3 & $\begin{array}{l}\text { Public institutions transferring land to investors are clearly identified and } \\
\text { regularly audited }\end{array}$ \\
\hline \multirow{2}{*}{} & $\begin{array}{l}\text { A: Institutions to make decisions are clearly identified and have the } \\
\text { necessary capacity (incl. resources for field verification) and strong } \\
\text { incentives in ensuring socially beneficial outcomes in a way that minimizes } \\
\text { transaction costs. }\end{array}$ \\
\cline { 2 - 4 } & $\begin{array}{l}\text { B: Institutions to make decisions are clearly identified and have the } \\
\text { necessary capacity (incl. resources for field verification) and strong } \\
\text { incentives in ensuring socially beneficial outcomes but processes may be } \\
\text { complex and difficult for investors. }\end{array}$ \\
\cline { 2 - 3 } & $\begin{array}{l}\text { C: Institutions to make decisions are clearly identified but lack either } \\
\text { capacity or incentives in ensuring socially beneficial outcomes or their } \\
\text { decisions are not always implemented. }\end{array}$ \\
\cline { 2 - 3 } & D: Institutions are not clearly identified \\
\hline
\end{tabular}

\section{Analysis:}

L\&LR Department is the administrative department for transfer of land. Other than the L\&LR Department, public institutions (acting as requiring body) who transfer land to investors are WBIDC, WBIIDC and WBSIDC and they have the capacity and expertise to handle land transfer to private investors for joint ventures. Annual West Bengal L \& LR, Land Policy Branch Order

92 Page Land Governance Assessment Framework - West Bengal 
No. 6686-LP/1A-18/2012 states that the District Collector has to take sanction from the L\&LR Department prior to any transfer of public land whether already under the management of the department or whether to be acquired. An intergovernmental committee under the Chief Secretary would take final decision on transfer of land. It also states that every department has to frame its own rule consistent with the said decision for issuing letter of intent under the jurisdiction of that department.

In WBIDC there is a Five-man Committee consisting of technical experts from various fields to scrutinize and assess the actual land requirement, water source, viability (technical and social) aspects of any proposal for setting of an industry. This committee also ensures that all the necessary requirements have been taken care of in the detailed project report including social benefits to the land losers, local community etc.

Data Source: West Bengal Land Policy Branch Order No. 6686-LP/1A-18/2012 and WBIDC Data Reliability: High

\begin{tabular}{|c|c|c|l|}
\hline Panel & LGI & Dim. & $\begin{array}{l}\text { Land Governance Indicator 14 } \\
\text { Private investment strategy }\end{array}$ \\
\hline 5 & 2 & 4 & $\begin{array}{l}\text { Public bodies transferring land to investors share information and coordinate } \\
\text { to minimize and resolve overlaps (including sub-soil). }\end{array}$ \\
\hline \multirow{2}{*}{} & $\begin{array}{l}\text { A: A policy is in place for effective inter-ministerial and coordination to ensure } \\
\text { that decisions on land use and land rights are well coordinated across sectors, } \\
\text { and is applied effectively. }\end{array}$ \\
\cline { 3 - 4 } & $\begin{array}{l}\text { B: There is effective coordination to solve competing land use, although no } \\
\text { policy is in place for effective inter-ministerial and coordination to ensure that } \\
\text { decisions on land use and land rights are well coordinated across sectors. }\end{array}$ \\
\hline & $\begin{array}{l}\text { C: No policy is in place but some decisions on land use and land rights are } \\
\text { coordinated across sectors. }\end{array}$ \\
\cline { 2 - 3 } & $\begin{array}{l}\text { D: No policy is in place and decisions on land use and land rights are not } \\
\text { coordinated across sectors. }\end{array}$ \\
\hline
\end{tabular}

\section{Analysis:}

The Land Reforms Manual of 1991 delineates appropriate policies in respect of identification and information sharing of land that will be transferred to private bodies. This is supplemented by the latest government order which clearly states that an interdepartmental committee will be formed to take final decisions regarding land allotment after careful scrutiny at all levels including the L\&LR department (which has the foremost importance in giving the approval for land allotment to start with). The order states that each department will frame its own policy in this respect consistent with the general land allotment policy of the government. But there are issues when the acquisition involves overlapping areas concerning both central and state government.

In cases where the investor proposes to purchase land beyond the ceiling limit for setting up some project, he is required to submit a detail project report (DPR) to the concerned department and to get the project report approved and then L\&LR Department will grant permission to acquire and to hold the ceiling surplus land to the investor $\mathrm{u} / \mathrm{s} 14 \mathrm{Y}$ of the WBLR Act..

\section{Data Source:}

- $\quad$ West Bengal L \& LR, Land Policy Branch Order No. 6686-LP/1A-18/2012.

- WBLR Act, 1955

93|Page Land Governance Assessment Framework - West Bengal 
Policy recommendation: There is no avenue for coordination between central and state governments when large scale acquisition of land is involved leaving scope for disputes being arisen which may take a long time for reconciliation. The surface right transfer is dealt with by the state while sub-soil rights (say coal mine) are considered by central government. Some formal mechanism like identifying a nodal agency from both state and central government for compliance and reconciliation might be considered.

\begin{tabular}{|c|c|c|l|}
\hline Panel & LGI & Dim. & $\begin{array}{l}\text { Land Governance Indicator 14 } \\
\text { Private investment strategy }\end{array}$ \\
\hline 5 & 2 & 5 & $\begin{array}{l}\text { Compliance with contractual obligations is regularly monitored and remedial } \\
\text { action taken if needed. }\end{array}$ \\
\hline & \\
& $\begin{array}{l}\text { A: There is regular monitoring of compliance and results are publicly available } \\
\text { and any gaps identified trigger effective remedial action. }\end{array}$ \\
\cline { 3 - 3 } & $\begin{array}{l}\text { B: There is regular monitoring of compliance, results are publicly available but } \\
\text { remedial action is taken only in some cases. }\end{array}$ \\
\hline & $\begin{array}{l}\text { C: Monitoring of compliance is limited or only part of the results accessible to } \\
\text { the public }\end{array}$ \\
\hline & D: No monitoring or no publicity of results. \\
\hline
\end{tabular}

\section{Analysis:}

There are provisions in the latest land policy order or older act for non-compliance of the provisions of the lease for land allotment. As a matter of fact the recent order clearly states that all land will be allotted as lease hold right only, the lessee cannot mortgage the leasehold right. There are also provisions if the contractual obligations are not satisfied. However, in case of failure of such non-compliance it is a long drawn judicial process as is the characteristic feature of Indian civil law. However, there is no provision for publicly available information on this issue.

Data Source: West Bengal L \& LR, Land Policy Branch Order No. 6686-LP/1A-18/2012.

Data Reliability: High

\begin{tabular}{|c|c|c|c|}
\hline Panel & LGI & Dim. & $\begin{array}{l}\text { Land Governance Indicator } 14 \\
\text { Private investment strategy }\end{array}$ \\
\hline \multirow[t]{5}{*}{5} & \multirow[t]{5}{*}{2} & \multirow[t]{5}{*}{6} & $\begin{array}{l}\text { Safeguards effectively reduce the risk of negative effects from large scale land- } \\
\text { related investments. }\end{array}$ \\
\hline & & & $\begin{array}{l}\text { A: Substantive application and disclosure of safeguards (EIA, SIA etc.) are in } \\
\text { line with global best practice, and mostly applied. }\end{array}$ \\
\hline & & & $\begin{array}{l}\text { B: Substantive application of safeguards (EIA, SIA, etc.) is in line with global } \\
\text { best practice but only part of the information is disclosed. }\end{array}$ \\
\hline & & & C: Safeguards (EIA, SIA, etc.) are partly in line with global best practice \\
\hline & & & D: Safeguards do not exist or are applied only in an ad-hoc manner. \\
\hline
\end{tabular}

\section{Analysis:}

Safeguards related to environmental protection and compliance in respect of pollution control are in place and in line with global practices.

The Environment Protection Act 1986 was legislated in India, which lays down the broad framework of governance in this area. The Govt. of West Bengal's policy is to strike a balance between the needs of development and the preservation and conservation of environment and natural resources. The Govt. of West Bengal's Policy Statement made as far back as June 1995 seeks special emphasis and thrust on:

94 I Page Land Governance Assessment Framework - West Bengal 
- Control over pollution problems created by organized industries

- Control over water, air and noise pollution within permissible limits

- Protection of rivers, water bodies etc. from encroachment

- Preservation, protection and restoration of the coastal zone

- Improvement of the physical environment of cities and towns

- Promotion of bio diversity and preservation of forests and wild life

- Environmental impact assessments prior to location of industries, infrastructure and urban development

- Public private partnership and working relationships with societal organisations to generate awareness and active participation in environment protection

The West Bengal Pollution Control Board is the Statutory Authority, which is entrusted with the responsibility of implementing environmental laws and regulations within the state. The West Bengal Bio-Diversity Board advises the government on conservation of bio-diversity, sustainable use of its components and equitable sharing of resources of biological resources.

Industries have been classified into certain categories keeping in mind the requirements of environmental pollution. Ordinary and Special Red categories (highly polluting) cannot be set up within Kolkata Metropolitan Area, and Orange categories (moderately polluting) not within Kolkata or Howrah Municipal Areas but permissible within Industrial Estates within those areas. Green category industries can be set up in any area subject to pollution and site clearances. Apart from these there is an exempted category that can be set up in any area and only requires local site clearance by the local body. The intending applicant has to obtain the clearance from the West Bengal Pollution Control Board before the Registration certificate (RC) is issued by the Director of Industries.

Data source: The Website of WBIDC

Data reliability: cent percent

\begin{tabular}{|c|c|c|l|}
\hline Panel & LGI & Dim. & $\begin{array}{l}\text { Land Governance Indicator 14 } \\
\text { Private investment strategy }\end{array}$ \\
\hline 5 & 2 & 7 & $\begin{array}{l}\text { The scope for resettlement is clearly circumscribed and procedures exist to } \\
\text { deal with it in line with best practice. }\end{array}$ \\
\hline \multirow{2}{*}{} & $\begin{array}{l}\text { A: Substantive application of resettlement and rehabilitation policy that is in } \\
\text { line with global best practice. }\end{array}$ \\
\cline { 3 - 4 } & $\begin{array}{l}\text { B: Applied resettlement policy is partly in line with global best practice, and in } \\
\text { most cases applied }\end{array}$ \\
\cline { 3 - 4 } & $\begin{array}{l}\text { C: Resettlement policy exists, but is only in part of the cases applied. } \\
\text { D: Resettlement policy does not exist; if resettlement takes place than it in } \\
\text { an ad-hoc manner. }\end{array}$ \\
\hline
\end{tabular}

\section{Analysis:}

The Resettlement and Rehabilitation Policy document of WBIDC states several resettlement policies in case of large scale land transfer. This includes compensation for income from land based on past 3 years' earnings - some upfront and part in the form of annuities from deposits in financial institutions, residential construction in case of homestead land. Bargadars and landless labourers are also given appropriate resettlement benefits. The government (G.O. No 1701 LA dated 6 June 2006) policy is that even patta allottees will get full compensation like a free-hold raiyat. These measures when applied effectively have reduced the negative effects of large scale land transfer.

Data Source: West Bengal Industrial Development Corporation Policy Document on Rehabilitation and Resettlement Policy available in WBIDC website and GO referred to

Data Reliability: High

95|Page Land Governance Assessment Framework - West Bengal 


\begin{tabular}{|c|c|c|l|}
\hline Panel & LGI & Dim. & $\begin{array}{l}\text { Land Governance Indicator 15 } \\
\text { Policy implementation is effective, consistent and transparent } \\
\text { and involves local stakeholders. }\end{array}$ \\
\hline 5 & 3 & 1 & $\begin{array}{l}\text { Investors provide sufficient information to allow rigorous evaluation of } \\
\text { proposed investments. }\end{array}$ \\
\hline \multirow{3}{*}{} & $\begin{array}{l}\text { A: Investors' business plans (application materials) require sufficient } \\
\text { evidence of technical viability, community consultation, and availability of } \\
\text { resources to effectively identify project risk and viability and effectively } \\
\text { monitor progress. }\end{array}$ \\
\hline & $\begin{array}{l}\text { B: Investors' business plans (application materials) require some evidence of } \\
\text { technical viability, community consultation, and availability of resources but } \\
\text { this is only sufficient to identify project risk ex ante. }\end{array}$ \\
\hline $\begin{array}{l}\text { C: Investors' business plans (application materials) require some evidence of } \\
\text { technical viability, community consultation, and availability of resources but } \\
\text { this is insufficient to effectively identify project risk ex ante. }\end{array}$ \\
\cline { 2 - 2 } $\begin{array}{l}\text { D: Investors' business plans (application materials) is insufficient to assess } \\
\text { technical viability, community consultation, and availability of resources. }\end{array}$ \\
\hline
\end{tabular}

\section{Analysis:}

WBIDC website provides the procedure for applying for land from the government. The most important criterion of the procedure is the submission of the detailed investment proposal including DPR which could be called business plan. In practice the technical viability of the business plan is judged by a Five-man Committee constituted by WBIDC comprising technical experts from various fields. For the joint venture project at Andal with Bengal Aerotropolis, the anchor investor had to comply with all the formalities in respect of justifying technical viability and community consultation. The investor had to undertake a full research work to understand the community behaviour and develop formula of compensation for right losers as well as the community in general including the corporate social responsibility (CSR) policy. This has happened in majority of cases for the industrial park joint ventures established with anchor investors in other areas also, but there are instances where this was not done.

Data Source: WBIDC website (http://wbidc.com/images/pdf/Criteria Assessment.pdf)

\section{Data Reliability: High}

\begin{tabular}{|c|c|c|l|}
\hline Panel & LGI & Dim. & $\begin{array}{l}\text { Land Governance Indicator 15 } \\
\text { Policy implementation is effective, consistent and transparent } \\
\text { and involves local stakeholders. }\end{array}$ \\
\hline 5 & 3 & 2 & $\begin{array}{l}\text { Approval of investment plans follows a clear process with reasonable } \\
\text { timelines. }\end{array}$ \\
\hline & $\begin{array}{l}\text { A: All investment application related documents are reviewed according to a } \\
\text { uniform process and receive a response within 3 months of date of submission }\end{array}$ \\
\cline { 3 - 4 } & $\begin{array}{l}\text { B: All investment application related documents are reviewed according to a } \\
\text { uniform process and receive a response within } 6 \text { months of date of } \\
\text { submission }\end{array}$ \\
\cline { 2 - 3 } & $\begin{array}{l}\text { C: The review process for investment application related documents is not } \\
\text { uniform and stable over time; in most cases, investors receive a response } \\
\text { within 9 months of date submission }\end{array}$ \\
& $\begin{array}{l}\text { D: The review process for investment application related documents is not } \\
\text { uniform and stable over time, and in most cases a response is received after } \\
\text { more than 9 months from date of submission. }\end{array}$ \\
\hline
\end{tabular}

96|Page Land Governance Assessment Framework- West Bengal 


\section{Analysis:}

The project appraisal document of WBIDC states that it takes one month to process. However, in practice the time taken to review all the documents by maintaining a uniform process and receive a response is within six months from date of submission.

Data Source: WBIDC

Data Reliability: High

\begin{tabular}{|c|c|c|c|}
\hline Panel & LGI & Dim. & $\begin{array}{l}\text { Land Governance Indicator } 15 \\
\text { Policy implementation is effective, consistent and transparent } \\
\text { and involves local stakeholders. }\end{array}$ \\
\hline \multirow[t]{5}{*}{5} & \multirow[t]{5}{*}{3} & \multirow[t]{5}{*}{3} & $\begin{array}{l}\text { Right holders and investors negotiate freely and directly with full access to } \\
\text { relevant information. }\end{array}$ \\
\hline & & & $\begin{array}{l}\text { A: Those holding rights to land with potential for investment have incentives } \\
\text { and opportunities to obtain truthful information on the extent of their rights } \\
\text { (and the most effective ways to utilize them), and the true potential of their } \\
\text { resources. }\end{array}$ \\
\hline & & & $\begin{array}{l}\text { B: Those holding rights to land with potential for investment have clearly } \\
\text { defined rights and incentives to properly negotiate but opportunities to obtain } \\
\text { relevant information and assistance at reasonable cost are limited. }\end{array}$ \\
\hline & & & $\begin{array}{l}\text { C: Those holding rights to land with potential for investment have incentives } \\
\text { to properly negotiate but their rights are unclear or opportunities to obtain } \\
\text { relevant information or assistance do not exist. }\end{array}$ \\
\hline & & & D: Current users have limited or no rights. \\
\hline
\end{tabular}

Analysis:

There is scope for the investor and the right holders to negotiate on site selection of a project, price of land, rehabilitation of land losers etc. when land is directly purchased or the land is acquired by the operation of Act and both parties have access to relevant information Although the LA Act, 1894 did not have any provision for negotiation on site selection but the West Bengal Government by an Executive order made two committees named 'site selection committee' and 'screening committee' comprising the people's representatives of the area, investor and concerned Govt. official including the Collector. The Land Acquisition Act of 1894, had provision for consent Award whereby compensation could be fixed on agreement of the land losers.

During the site selection visit there is always a scope for some information being provided to the right holders. The practice over the last few years is that the right holders are asked to submit petitions which are disposed of by sharing the information asked for in the petition.

Data Source: Management of Bengal Aerotrolpolis Project Ltd, L. A. Act, 1894 and orders of L\&LR Department

\section{Data Reliability:}

\begin{tabular}{|c|c|c|l|}
\hline Panel & LGI & Dim. & $\begin{array}{l}\text { Land Governance Indicator 15 } \\
\text { Policy implementation is effective, consistent and transparent } \\
\text { and involves local stakeholders. }\end{array}$ \\
\hline 5 & 3 & 4 & \begin{tabular}{l} 
Contractual provisions regarding benefit sharing are publicly disclosed. \\
\hline
\end{tabular} \\
& & $\begin{array}{l}\text { A: Benefit sharing modalities are routinely included in relevant contractual } \\
\text { arrangements, and disclosed publicly. Existing right holders are recognized. }\end{array}$ \\
\cline { 3 - 4 } & $\begin{array}{l}\text { B: Modalities for benefit sharing are routinely included in relevant } \\
\text { contractual arrangements, but there is limited public disclosure. }\end{array}$ \\
\hline & $\begin{array}{l}\text { C: Modalities for benefit sharing included in a significant share of relevant } \\
\text { contractual arrangements and affected parties are aware of these and of ways }\end{array}$ \\
\hline \hline
\end{tabular}

97| Page Land Governance Assessment Framework - West Bengal 
to enforce them even though there is limited public disclosure.

D: The majority of contractual arrangements do not include information on benefit sharing

\section{Analysis:}

The rules in this respect do not bar the government to share the information. However, in order to attract investment government often gives fiscal incentives to the investors which the government may not like to make public for various reasons. So these are often not disclosed. The present system of RTI Act is a mechanism for the public to access the information required.

Policy recommendation: The government may consider making the lease deed a public document

\begin{tabular}{|c|c|c|c|}
\hline Panel & LGI & Dim. & $\begin{array}{l}\text { Land Governance Indicator } 16 \\
\text { Contracts involving public land are public with agreements } \\
\text { monitored and enforced. }\end{array}$ \\
\hline \multirow[t]{5}{*}{5} & 4 & \multirow[t]{5}{*}{1} & $\begin{array}{l}\text { Information on spatial extent and duration of approved concessions is publicly } \\
\text { available. }\end{array}$ \\
\hline & \multirow{4}{*}{4} & & $\begin{array}{l}\text { A: Comprehensive and consolidated information on spatial extent, duration, } \\
\text { and parties involved in concessions/leases is available publicly. }\end{array}$ \\
\hline & & & $\begin{array}{l}\text { B: Spatial and temporal information is available to relevant government } \\
\text { institutions and made available routinely to interested private parties upon } \\
\text { request. }\end{array}$ \\
\hline & & & $\begin{array}{l}\text { C: Spatial information and temporal information is available to relevant } \\
\text { government institutions but not accessible on a routine basis by private parties. }\end{array}$ \\
\hline & & & $\begin{array}{l}\text { D: Comprehensive and consolidated information on spatial extent and duration } \\
\text { of concessions/leases is not readily available to government or different } \\
\text { departments rely on different sources of information. }\end{array}$ \\
\hline
\end{tabular}

\section{Analysis:}

The West Bengal Industrial Development Corporation provides various incentives (not concessions) to the intending industry setting applicants. The incentives as defined in the scheme called “The West Bengal State Support for Industries Scheme, 2013" notified by the Commerce and Industries Department on $1^{\text {st }}$ October 2013, as 'financial support to be given to the industrial units in the form of different types of subsidies which are to be decided solely by the C\&I department and cannot be considered as a matter of right.' All the information related to such incentives to be given to the industries is available in the website of WBIDC and publicly available.

Data Source: WBIDC website

Data Reliability: High

\begin{tabular}{|c|c|c|l|}
\hline Panel & LGI & Dim. & $\begin{array}{l}\text { Land Governance Indicator 16 } \\
\text { Contracts involving public land are public with agreements } \\
\text { monitored and enforced. }\end{array}$ \\
\hline \multirow{2}{*}{5} & 4 & 2 & $\begin{array}{l}\text { Compliance with safeguards on concessions is monitored and enforced } \\
\text { effectively and consistently. }\end{array}$ \\
\hline \multirow{2}{*}{} & $\begin{array}{l}\text { A: Third-party monitoring of investors' (and the state's) compliance with } \\
\text { safeguards is routine and mechanisms to quickly and effectively reach } \\
\text { adherence in case of problems exist. }\end{array}$ \\
\cline { 2 - 4 } & $\begin{array}{l}\text { B: Third-party monitoring of investors' (and the state's) compliance with } \\
\text { safeguards is practiced in some cases but mechanisms to quickly and } \\
\text { effectively reach adherence in case of problems exist. }\end{array}$ \\
\hline
\end{tabular}

98|Page Land Governance Assessment Framework - West Bengal 
C: There is little third-party monitoring of investors' compliance with safeguards and mechanisms to quickly and effectively ensure adherence are difficult to access for affected communities.

D: There is little third-party monitoring of investors' compliance with safeguards and mechanisms to quickly and effectively ensure adherence are virtually non-existent.

\section{Analysis:}

There is a prevailing system which is rigorously followed about third party monitoring of investors' compliance with safeguards and also for the state's by way of annual Comptroller and Auditor General (CAG) audit. But scope is left to improve compliance on audit observations. In addition there is also periodical internal audit system in vogue for WBIDC.

Data Source: WBIDC

Data reliability: Moderate

\begin{tabular}{|c|c|c|l|}
\hline Panel & LGI & Dim. & $\begin{array}{l}\text { Land Governance Indicator 16 } \\
\text { Contracts involving public land are public with agreements } \\
\text { monitored and enforced. }\end{array}$ \\
\hline 5 & 4 & 3 & $\begin{array}{l}\text { Avenues to deal with non-compliance exist and obtain timely and fair } \\
\text { decisions. }\end{array}$ \\
\hline \multirow{2}{*}{} & $\begin{array}{l}\text { A: Third-party monitoring of investors' (and the state's) compliance with } \\
\text { contractual provisions is routine and mechanisms to quickly and effectively } \\
\text { reach arbitration in case of problems exist. }\end{array}$ \\
\cline { 2 - 3 } & $\begin{array}{l}\text { B: Third-party monitoring of investors' (and the state's) compliance with } \\
\text { contractual provisions is practiced in some cases but mechanisms to quickly } \\
\text { and effectively reach arbitration in case of problems exist. }\end{array}$ \\
\hline & $\begin{array}{l}\text { C: There is little third-party monitoring of investors' compliance with } \\
\text { contractual provisions and mechanisms to quickly and effectively reach } \\
\text { arbitration are difficult to access for affected communities but work for } \\
\text { investors. }\end{array}$ \\
\cline { 2 - 3 } & $\begin{array}{l}\text { D: There is little third-party monitoring of investors' compliance with } \\
\text { contractual provisions and mechanisms to quickly and effectively reach } \\
\text { arbitration are virtually non-existent. }\end{array}$ \\
\hline
\end{tabular}

\section{Analysis:}

Again there is system of third party monitoring of investor's compliance with contractual provisions by way of CAG audit.

Data Source: WBIDC

Data Reliability: High

\section{Panel 6: Public Provision of Land Information: Registry and Cadastre}

\section{Indicators}

1. Mechanisms for recognition of rights

2. Completeness of the land registry

3. Reliability: registry information is updated and sufficient to make meaningful inferences on ownership.

4. Cost-effectiveness \& sustainability: land administration services are provided in costeffective ways that are sustainable in the long term. 
5. Fees determined transparently to cover cost of service provision

\begin{tabular}{|c|c|c|l|}
\hline Panel & LGI & Dim. & $\begin{array}{l}\text { Land Governance Indicator 17 } \\
\text { Mechanisms for recognition of rights }\end{array}$ \\
\hline 6 & \multirow{2}{*}{1} & 1 & $\begin{array}{l}\text { Land possession by the poor can be formalized in line with local norms in an } \\
\text { efficient and transparent process. }\end{array}$ \\
\hline \multirow{2}{*}{} & $\begin{array}{l}\text { A: There is a clear, practical process for the formal recognition of possession and } \\
\text { this process is implemented effectively, consistently and transparently. }\end{array}$ \\
\cline { 4 - 4 } & $\begin{array}{l}\text { B: There is a clear, practical process for the formal recognition of possession but } \\
\text { this process is not implemented effectively, consistently or transparently. }\end{array}$ \\
\cline { 3 - 4 } & $\begin{array}{l}\text { C: The process for the formal recognition of possession is not clear and is not } \\
\text { implemented effectively, consistently or transparently. }\end{array}$ \\
\cline { 3 - 5 } & D: There is no process for formal recognition of possession. \\
\hline
\end{tabular}

\section{Analysis:}

In the state possession of land by individual or institution is normally recognized on the basis of documents like registered deed of transfer, lease by government, rent receipts etc. But there are specific provisions in the Acts, rules, government guide lines, government schemes for formalization of land possession by poor without the documents normally insisted under various provisions of Acts and rules.

\section{Formalization of land possession by poor in Rural Areas}

\section{(a) West Bengal Land Reforms Act 1955}

Poor people possessing government land is formalized under section 49(1) of West Bengal Land Reforms Act, 1955 read with sub rules (1) to (4) of rule 20A of the West Bengal LR Rules. The maximum area of agricultural land that can be formalized with a poor person is one acre provided the poor person together with the members of the family possesses less than 0.4047 hectare of land. In case of sharecropper half of the of the area of land cultivated by him is considered to be the land owned by him and balance land after deducting the land so considered to be owned by him from 0.4047 hectare is formalized. Cases of poor person having no homestead land of his own and possessing homestead land at the disposal of the government are also formalized under provisions mentioned above. The maximum area of home stead land that can be formalized is 0.0335 hectare .However no land can be formalized under section 49(1) with any person or with member of family of any such person who is engaged or employed in any business trade, undertaking, manufacture, calling, service or industrial occupation. Before formalization pre- distribution survey and enquiry is conducted by Revenue officer jointly with a member of Bock level Panchayat Samity as (local self-government) nominated by Sabhapati (Chairman) of Block level Panchayat Samity. In course of this survey following information are collected: (a) date from which the poor person or family of the poor person is in possession (b) the area of the land owned by person together with the land owned by the members of his family (c) if the person or any member of his family cultivates any land as sharecropper if so area of such land (d) if the person belongs to scheduled caste or scheduled tribe. On completion of pre distribution survey a priority list of person possessing government land is drawn up in consultation with the Block Panchayat Samity. The order of priority is as follows:(a) landless person in uninterrupted possession for a minimum period of three years, (b) landless agricultural workers belonging to ST, (c) agricultural workers belonging to SCs, (d) landless agricultural workers other than above, (e) land less sharecroppers belonging to ST, (f) landless share croppers belonging to SC (g) landless share croppers other than above, and (h) landless persons who used to cultivate land as sharecropper or agricultural workers under the previous owner whose land was vested under ceiling provisions of WBEA Act 1953 and WBLR Act 1955. Apart from poor person who is in possession of government land, poor person not in possession of government land are also allotted government land as per provision of section 49(1) of WBLR

100|Page Land Governance Assessment Framework - West Bengal 
Act 1955 . The same principle of priority is followed in these cases. Block Land and Land Reforms Officer (BL\&LRO) sends the priority list along with report of pre-distribution survey to Block Panchayat Samity for consideration and recommendation. Panchayat samity makes necessary recommendation specifying the persons to whom land should be distributed and also the quantum of land to be distributed to each. Thereafter BLLRO prepares settlement proposal on the basis of such recommendation and sends the case records along with the recommendation to the Sub-divisional Land and Land Reforms Officer (SDL\&LRO). SDL\&LRO forwards the proposal to Sub Divisional Officer (SDO) for approval. On being satisfied that that formalization proposal is in order and that the eligibility conditions specified in section 49(1) of WBLR Act 1955 and the priority principle fixed by the government has been properly followed SDO approves the formalization proposal and sends his approval to BLLRO through SDLLRO. BLLRO prepares the patta (deed of settlement) in form 8A as prescribed in sub rule (4) of rule 20A of West Bengal Land Reforms Rules1965. The patta so prepared is handed over to the poor people by BLLRO. A separate record of right is opened in the name of each patta holder and land is transferred from the accounts of government land i.e., collectors' record of rights. However the poor person with whom the government land so settled with is not entitled to transfer the land except by way of simple mortgage for the purpose of obtaining loan for development of land or for the improvement of agricultural production or for construction of dwelling house. Procedure of settlement of vested land with land poor or landless persons and sharecroppers has been laid down in clauses 187 to 208 under Chapter XIII of West Bengal Land and Land Reform Manual 1991. As on October 2013, 11,41,345 acres of land has been distributed to $31,41,232$ persons. But the number of persons recoded in RoR is 24,57,347 [Source: Report published by Directorate of Land Records and Surveys, Govt. of West Bengal].

\section{(b) West Bengal Acquisition of Homestead Land for Agricultural Labourer Artisan and Fisherman Act 1975.}

State Government with the objective of recognizing the rights of landless agricultural labourers, artisans and fisherman, occupying homestead land of other land owners enacted West Bengal Acquisition of Homestead Land for Agricultural Labourers', Artisans and Fisherman Act 1975. Under this Act landless person mentioned above were given ownership rights over homestead to the extent of 0.08 acres, by acquiring land of the land owners. The Land owners were given compensation for such acquisition. As on October 2013, this Act provided ownership right to 3,26,725 families [Source: Report published by Directorate of Land Records and Surveys, Govt. of West Bengal].

\section{(c) Chas O BasabaserJanyaBhumidanprakalpa(Homestead and kitchen garden scheme) and NijoGrihoNijoBhumiPrakalpa(My Home My Land scheme)}

In spite of provisions made in the West Bengal Land Reforms Act 1955 and West Bengal Acquisition of Homestead Land for Agricultural Labourers, Artisans and Fisherman Act 1975, large number of landless people remained outside benefit provided by the Act. To cover these landless people the State introduced Chas- O- Basa baser Janya Bhumidan Prakalpa (Homestead and kitchen garden scheme) in the year 2005-06. Under this scheme land up to 0.16 acres were allotted to the landless people for homestead and kitchen garden purpose. This micro- plot distribution is unique in the sense that Govt. purchased the land form landowners at market rate and distributed to the landless people. But, this scheme was not seriously implemented by the State Govt. Under the scheme State granted tenancy right to 5034 persons over 579.79 acres of land [Source: Report published by Directorate of Land Records and Surveys, Govt. of West Bengal]. When the present Government came into power, introduced a new scheme Nijo Griho Nijo Bhumi prakalpa in Oct 2011 (My Home My Land scheme) with purpose to settle 5.5 Lakh landless poor people of the State with land up to 0.05 acre. The land to be settled will be provided from the land at the disposal of state government and land to be purchased by the state government from land owners at market rate. The settles are to be settled in cluster and will be provided with all essential amenities like drinking water, sanitation,

101|Page Land Governance Assessment Framework - West Bengal 
electricity, road and livelihood support by convergence of Govt. schemes. The entire 5.5 lakhs landless people will be covered under the scheme by 2015-16. As on March 2014, 167770 persons have been allotted land [Source: Report of Directorate of Land Records and Surveys, Govt. of West Bengal].

\section{Formalization of homestead sites in urban areas}

\section{(a) West Bengal Thika Tenancy (Acquisition and Regulation) Act, 2001:}

Thika tenants are urban tenants occupying land of a landlord by erecting a structure for residential, business or manufacturing purpose in urban areas paying rent to landlord. Occupation of land may be on the basis of written lease or without the same. Most of the thika tenants are poor people and slum dwellers. Specific provision has been made in this Act for acquisition of interest in the landlords against compensation and for formalising the tenants by bringing them directly under the state. A large number of poor thika tenants without written lease or other valid documents have been given tenancy right under the provision of this Act.

(b) Government of West Bengal issued a circular in 2010[circular no:1469-GE(M)/L-20/10 Dated 17.03 .2010 ] for urban poor who are residing in vested land in urban areas for at least 20 years. Land up to 2 cottah is settled for 99 years with the urban poor on token salami (premium) of Rs 1/ provided beneficiary house hold has monthly income not more than Rs 6000 and the land has not been earmarked for any project. The beneficiary household only has to pay land revenue to be fixed under West Bengal Land Reforms Act 1955 or Kolkata Land Revenue Act 2003.Most of these beneficiaries are slum dwellers.

\section{Data Source:}

1. West Bengal Land Reforms Act 1955

2. West Bengal Land Reforms Rules 1965

3. West Bengal Land and Land Reforms Manual, 1991

4. West Bengal Acquisition of Homestead land for Agricultural Labourers, Artisans and Fisherman Act 1975

5. Chas O Basabaser Janya Bhumidan Prakalpa(Homestead and Kitchen Garden scheme)

6. Nijo Griha NijoBhumi Prakalpa (My Home My Land scheme)

7. Calcutta Thika Tenancy Act, 1949

8. Calcutta Thika Tenancy (Acquisition and Regulation) Act, 1981

9. West Bengal Thika Tenancy (Acquisition and Regulation) Act, 2001

Data Reliability: All data are from Acts mentioned above. Therefore all data are 100 percent reliable.

\section{Policy Recommendations:}

1. Analysis of the existing mechanism for recognition of rights over land, clearly indicate robust law and procedure exist for formalization of land possession by poor. But, implementation of process for formal recognition of possession needs to be more transparent. Recognition of possession is done through joint survey by team consisting of Govt. officials and representative of local self Govt. at the village level. Often political consideration affects settlement of land with eligible beneficiaries. Corruption also affects the process of formalization of land possession by poor. Available data indicates that patta has been granted to 3141232 but 2457347 patta recipients have been recorded 
in the RoRs. The gap should be bridged and it should be ensured that RoRs is recorded as soon as the Patta is granted.

2. There is large number of poor people possessing government land. Efforts should be made to identify poor people through time bound survey and patta be issued.

3. There are 5.5 lakhs landless people in the State as per the National Sample Survey Report ( $59^{\text {th }}$ Round). Though steps have been taken to cover these people under NGNB Scheme by $2015-16$, but only 86883 persons have been granted patta. The progress is slow and it needs to be speeded up to achieve the target set by the State.

\begin{tabular}{|c|c|c|l|}
\hline Panel & LGI & Dim. & $\begin{array}{l}\text { Land Governance Indicator 17 } \\
\text { Mechanisms for recognition of rights }\end{array}$ \\
\hline 6 & 1 & 2 & Non-documentary evidence is effectively used to help establish rights. \\
\hline \multirow{2}{*}{} & & $\begin{array}{l}\text { A: Non-documentary forms of evidence allow full recognition of claims to } \\
\text { property when other forms of evidence are not available. }\end{array}$ \\
\cline { 3 - 4 } & $\begin{array}{l}\text { B: Non-documentary forms of evidence are used to obtain recognition of a } \\
\text { claim to property along with other documents (e.g. tax receipts or informal } \\
\text { purchase notes) when other forms of evidence are not available. They have } \\
\text { about the same strength as provided documents. }\end{array}$ \\
\hline \multirow{2}{*}{$\begin{array}{l}\text { C: Non-documentary forms of evidence are used to obtain recognition of a } \\
\text { claim to property along with other documents (e.g. tax receipts or informal } \\
\text { purchase notes) when other forms of evidence are not available. They have } \\
\text { less strength than the provided documents. }\end{array}$} \\
\cline { 2 - 3 } \\
$\begin{array}{l}\text { D: Non-documentary forms of evidence are almost never used to obtain } \\
\text { recognition of claims to property. }\end{array}$ \\
\hline
\end{tabular}

\section{Analysis:}

Right from the Rent Act, patta of land was insisted upon irrespective of occupancy and nonoccupancy Raiyats. In order to establish right over the land, documents like patta and rent receipt were the statutory requirement. The Bengal Tenancy Act 1885 also laid down the same principle of recognition of rights over the land only in case of occupancy Raiyats i.e. settled right. Onus of proving that Raiyat is not a settled Raiyat was on the land owners who issued patta in favour of the Raiyat.

In the West Bengal Land Reforms Act 1955, provision has been made for allotment of land to landless and land poor people holding land less than 0.4047 hectare. In Section 49 (1) of the Act, provision was made to issue patta up to 0.4047 hectare to the landless and land poor persons occupying government land. In this case no documentary evidence is necessary to prove their rights, only confirmation of possession over the land by revenue officials and representatives of the Local Self-Government is enough to recognize their rights over the land. Homestead rights of landless agricultural labourers, artisans and fishermen occupying their land to the extent of 0.08 acres of other land owners were also recognized without documentary evidence, in the West Bengal Acquisition of Homestead Land for Agricultural Labourers, Artisans and Fishermen Act 1975. In these cases only possession over the land as on $26^{\text {th }}$ June 1975 is enough to record the rights of the beneficiaries. But this benefit was awarded to the beneficiaries who were in possession up to $26^{\text {th }}$ June 1975. This Act did not extend benefit to the person who occupied the land of other land owners after $26^{\text {th }}$ June 1975.

Though sharecropping right is not a tenancy right, but the right to cultivate the land, has been recognized, with the right of the inheritance in the West Bengal Land Reforms Act 1955. Stringent provision has also been made against eviction of sharecroppers. Incidence of sharecroppers' right is recorded in the RoRs on the basis of field enquiry and hearing of the land

$\mathbf{1 0 3}$ | Page Land Governance Assessment Framework - West Bengal 
owners and sharecroppers by the Revenue Officers. In this case also no documentary evidence is required to recognize rights of the sharecroppers.

During preparation of RoRs under the Estate Acquisition Act 1953, general instructions were issued by the government that the rights of persons occupying land of other persons on the basis of consent or forcibly should be recorded in the RoR if they are found to be in possession of the land. But during preparation of RoR under West Bengal Land Reforms Act 1955 same instructions were withdrawn to avoid legal problems and large scale encroachment of land leading to deterioration of law and order.

\section{Source:}

- Rent Act 1859

- Bengal Tenancy Act 1885

- West Bengal Estate Acquisition Act 1953

- West Bengal Land Reforms Act 1955

- West Bengal Acquisition of Homestead Land for Agricultural Labourers, Artisans and Fishermen Act 1975

- General Instruction for Preparation of Record of Rights under West Bengal Estate Acquisition Act 1953 and West Bengal Land Reforms Act 1955 issued by Directorate of Land Records and Surveys.

Data Reliability: As data are from Acts it is 100 Percent Reliable.

\section{Policy Recommendation:}

State Government may consider the extension of benefits to the eligible persons occupying homestead land after $26^{\text {th }}$ June 1975, by amending the West Bengal Acquisition of Homestead Land for Agricultural Labourers', Artisans and Fishermen Act 1975.

\begin{tabular}{|c|c|c|l|}
\hline Panel & LGI & Dim. & $\begin{array}{l}\text { Land Governance Indicator 17 } \\
\text { Mechanisms for recognition of rights }\end{array}$ \\
\hline 6 & 1 & 3 & Long-term unchallenged possession is formally recognized. \\
\hline \multirow{2}{*}{} & & $\begin{array}{l}\text { A: Legislation exists to formally recognize long-term, unchallenged possession } \\
\text { and this applies to both public and private land although different rules may } \\
\text { apply. }\end{array}$ \\
\cline { 2 - 3 } & $\begin{array}{l}\text { B: Legislation exists to formally recognize long-term, unchallenged possession } \\
\text { but applies only to one specific type of land (e.g. either public land or private } \\
\text { land). }\end{array}$ \\
\hline & $\begin{array}{l}\text { C: Legislation exists to formally recognize long-term, unchallenged possession } \\
\text { but due to the way this legislation is implemented, formal recognition is } \\
\text { granted to very few or no applicants for recognition on either public or private } \\
\text { land. }\end{array}$ \\
\hline & $\begin{array}{l}\text { D: Legislation to formally recognize long-term, unchallenged possession does } \\
\text { not exist. }\end{array}$ \\
\hline
\end{tabular}

\section{Analysis:}

The claim to rights and title in relation to private and public land has been recognized in Limitation Act 1908. Under this Act uninterrupted and uncontested possession for a specified period hostile to the rights and interest of the owner is legally recognized in this Act.

Article 65, Schedule I of the Limitation Act 1908 prescribes a limitation of 12 years for a suit for possession of land or immovable property or any interest based on title. The starting point of limitation of 12 years is counted from the point of time when the possession becomes adverse.

104|Page Land Governance Assessment Framework - West Bengal 
But to claim a title on land, a suit is to be filed by the person who possesses the land adversely to the interest of land owner. A civil court is competent to decide the claim. Article 64 governs suits for possession based on possessory right laid down in Section 27 (Extinguishment of right to property) of the Act.

In case of government (Central or State Government) property, the period of limitation for any suit is 30 years and the starting point of limitation is the same as the case of suit by a private person (Article 112, Schedule I of the Limitation Act). Acquisition of easement is provided in Section 27 of the Limitation Act. During preparation of RoR under Bengal Estate Acquisition Act 1953, general instruction was issued to record the possession of the possessors in the RoR, on field verification. But to avoid legal problems and law \& order problems the same was withdrawn during preparation of RoRs under West Bengal Land Reforms Act 1955. Now title accrued out of adverse possession can be recorded in Record of rights only on the basis of decision of the court of law.

\section{Data Source:}

- Indian Limitation Act 1908

- Decision of Supreme Court of India in Karnataka Board of Wakf Govt. of India [10SSC 779] \& Valliamma Champakavs. SivathanuPillai

Data Reliability: As data are from Act and Supreme Court Decision data are 100 percent reliable.

Policy Recommendation: No change in the policy is suggested.

\begin{tabular}{|c|c|c|l|}
\hline Panel & LGI & Dim. & $\begin{array}{l}\text { Land Governance Indicator 17 } \\
\text { Mechanisms for recognition of rights }\end{array}$ \\
\hline \multirow{2}{*}{6} & \multirow{2}{*}{1} & 4 & $\begin{array}{l}\text { First-time recording of rights on demand includes proper safeguards and } \\
\text { access is not restricted by high fees. }\end{array}$ \\
\hline \multirow{2}{*}{} & $\begin{array}{l}\text { A: On-demand recording of rights includes proper safeguards to prevent abuse } \\
\text { and costs do not exceed 0.5\% of the property value. }\end{array}$ \\
\cline { 3 - 4 } & $\begin{array}{l}\text { B: On-demand recording of rights includes proper safeguards to prevent abuse } \\
\text { and costs do not exceed 2\% of the property value. }\end{array}$ \\
\cline { 3 - 4 } & $\begin{array}{l}\text { C: On-demand recording of rights includes proper safeguards to prevent abuse } \\
\text { and costs do not exceed 5\% of the property value. }\end{array}$ \\
& $\begin{array}{l}\text { D: On-demand recording of rights does not include proper safeguards to } \\
\text { prevent abuse or costs exceed 5\% of the property value. }\end{array}$ \\
\hline
\end{tabular}

\section{Analysis:}

Mutation of land is done under the provision of section 50 of West Bengal Land Reforms Act 1955, Rule 21 of West Bengal Land Reforms Rule 1965 and procedure laid down in circular issued by Land and Land Reforms Department.

The procedure laid down in State Government Circular No. 4402 - LR/3M - 135/05 GE (M) dated 28.12.2005, requires a person to submit an application, with application fees of Rs.10/ and process fee mentioned below, registered deed of transfer, rent receipt for recording their rights in RoRs. 
Rate of processing fees per decimal for mutation:

\begin{tabular}{|l|l|l|l|}
\hline $\begin{array}{l}\text { Classification of } \\
\text { land }\end{array}$ & Rural area & $\begin{array}{l}\text { Municipal area other than } \\
\text { KMDA(Kolkata area } \\
\text { Metropolitan Development } \\
\text { Authority) Area }\end{array}$ & $\begin{array}{l}\text { Municipal } \\
\text { within KMDA }\end{array}$ \\
\hline Agricultural land & Rs.1/- & Rs.1/- & Rs.1/- \\
\hline $\begin{array}{l}\text { Non-agricultural } \\
\text { non-commercial } \\
\text { land }\end{array}$ & Rs.10/- & Rs.15/- & Rs.20/- \\
\hline $\begin{array}{l}\text { Commercial and } \\
\text { industrial land }\end{array}$ & Rs.20/- & Rs.30/- & Rs.50/- \\
\hline
\end{tabular}

Therefore, on demand recording of rights is made after proper verification of registered deed of transfer, rent receipts, and after hearing the concerned parties involved by Revenue Officers. The cost of recording is nominal and do not exceed $0.5 \%$ of the property value.

Data Source: State Government Circular No. 4402 - LR/3M - 135/05 GE (M) dated 28.12.2005.

Data Reliability: since data are from Act and Govt. Circulars it is 100 percent reliable.

\section{Policy recommendation:}

Processing fees should be increased by at least 50 times to accommodate cost of manpower and infrastructure for recording of rights over land.

\begin{tabular}{|c|c|c|l|}
\hline Panel & LGI & Dim. & $\begin{array}{l}\text { Land Governance Indicator 18 } \\
\text { Completeness of the land registry }\end{array}$ \\
\hline 6 & 2 & 1 & Total cost of recording a property transfer is low. \\
\hline \multirow{2}{*}{} & & $\begin{array}{l}\text { A: The total cost for recording a property transfer is less than } 1 \% \text { of the } \\
\text { property value (time and effort costs, informal and official fees etc.). }\end{array}$ \\
\cline { 3 - 4 } & $\begin{array}{l}\text { B: The total cost for recording a property transfer is between } 1 \% \text { and less than } \\
\text { 2\% of the property value. }\end{array}$ \\
\cline { 3 - 4 } & $\begin{array}{l}\text { C: The total cost for recording a property transfer is between } 2 \% \text { and less than } \\
5 \% \text { of the property value. }\end{array}$ \\
\hline & $\begin{array}{l}\text { D: The total cost for recording a property transfer is equal to or greater than } 5 \% \\
\text { of the property value. }\end{array}$ \\
\hline
\end{tabular}

\section{Analysis:}

Existing rate of stamp duty and registration fee for registration of property transfer is as follows: 


\begin{tabular}{|l|l|l|}
\hline $\begin{array}{l}\text { Sl. } \\
\text { No. }\end{array}$ & Areas & Rate of registration fee \\
\hline 1 & $5 \%$ on market value in Panchayat area & $\begin{array}{l}\text { Up to Rs.250/-is Rs.2/- } \\
\text { Up to Rs.500/- is Rs.7/- } \\
\text { Up to Rs.1000/- is Rs.8/- }\end{array}$ \\
\hline 2 & $\begin{array}{l}\text { 6\% on market value in Municipal } \\
\text { areas, Corporation areas and } \\
\text { Development areas }\end{array}$ & $\begin{array}{l}\text { Up to Rs.5000/- is Rs.9/- } \\
\text { for Rs.1000/- or part } \\
\text { thereof in excess of } \\
\text { Rs.1000/- } \\
\text { Above Rs.5000/- is Rs.11/- } \\
\text { for Rs.1000/- or part } \\
\text { thereof in excess of } \\
\text { RS.5000/- }\end{array}$ \\
\hline
\end{tabular}

For exchange of property same rate applies. For gift rate is $0.5 \%$ of the market value of the property when made to a member of the family but at the same rate mentioned in the table above for gifts to others. For partition rate is $0.5 \%$ of market value of the separated share or shares of property and registration fee is Rs.7/-.

\section{Data Source:}

- Indian Stamp Act 1899.

- $\quad$ The West Bengal Registration Rules 1962

- The West Bengal Stamp Rules 1964

- The West Bengal (Prevention of Under-Valuation of Instruments) Rules 2001

Data Reliability: As data are from Acts and Rules it is 100 percent reliable

Policy Recommendation: Stamp duty should be reduced to ensure that each property transfer is registered. There is large scale evasion of stamp duty particularly by the poor people in rural area primarily due to high rate of stamp duty.

\begin{tabular}{|c|c|c|l|}
\hline Panel & LGI & Dim. & $\begin{array}{l}\text { Land Governance Indicator 18 } \\
\text { Completeness of the land registry }\end{array}$ \\
\hline 6 & 2 & 2 & \begin{tabular}{l} 
Information held in records is linked to maps that reflect current reality. \\
\hline
\end{tabular} \\
& $\begin{array}{l}\text { A: More than 90\% of records for privately held land recorded in the registry } \\
\text { are readily identifiable in maps (spatial records). }\end{array}$ \\
\cline { 3 - 4 } & $\begin{array}{l}\text { B: Between 70\% and 90\% of records for privately held land recorded in the } \\
\text { registry are readily identifiable in maps (spatial records). }\end{array}$ \\
\hline & $\begin{array}{l}\text { C: Between 50\% and 70\% of records for privately held land recorded in the } \\
\text { registry are readily identifiable in maps (spatial records). }\end{array}$ \\
\hline $\begin{array}{l}\text { D: Less than 50\% of records for privately held land recorded in the registry } \\
\text { are readily identifiable in maps (spatial records). }\end{array}$ \\
\hline
\end{tabular}

\section{Analysis:}

In the State, cadastral parcel maps are digitized and records of rights (RoRs) are also digitized and linked digitally. Therefore, land recorded in the RoRs is readily identifiable in the cadastral maps. But the cadastral maps are more than 30 years old. The RoRs also do not reflect the ground reality. 
A study was conducted to find out whether record of rights reflect al the land parcel appearing in the revenue village maps. A revenue village was selected in each of 18 districts of the state randomly and total number of parcel was counted from the current cadastral map of the revenue village and the number of parcels for which record of rights was prepared was also counted. These were then matched. The result is given in the table below.

\begin{tabular}{|l|c|c|c|c|c|}
\hline \multicolumn{1}{|c|}{ District } & Idn & $\begin{array}{c}\text { Mouza Name in } \\
\text { English }\end{array}$ & J.L.NO. & $\begin{array}{c}\text { No. of } \\
\text { plots in } \\
\text { Map }\end{array}$ & $\begin{array}{c}\text { No. of } \\
\text { plots in } \\
\text { ROR }\end{array}$ \\
\hline Bankura & 0107015 & Pratappur & 015 & 873 & 873 \\
\hline Bardhaman & 0219001 & ParulBaria & 001 & 2325 & 2325 \\
\hline Birbhum & 0317002 & Maliana & 002 & 22 & 22 \\
\hline Darjeeling & 0404018 & Alokjhari & 018 & 662 & 651 \\
\hline Howrah & 0505005 & Jala-Biswnathpur & 005 & 3597 & 3597 \\
\hline Hoogly & 0609006 & Sheorafuli & 006 & 6310 & 6310 \\
\hline Jalpaiguri & 0707001 & Jiti Cha Bagan & 001 & 703 & 703 \\
\hline Cochbihar & 0801197 & KharijaNaldhandra & 197 & 3877 & 3877 \\
\hline Malda & 0905010 & Kotuali & 010 & 499 & 498 \\
\hline PaschimMedinipur & 1011006 & Gopalpur & 006 & 654 & 654 \\
\hline PurbaMedinipur & 1116114 & Mangalchak & 114 & 1437 & 1437 \\
\hline Murshidabad & 1204009 & Dastina & 009 & 829 & 829 \\
\hline Nadia & 1304007 & Balindi & 007 & 746 & 746 \\
\hline Purila & 1410009 & Raydi & 009 & 1190 & 1190 \\
\hline North 24 Parganas & 1506008 & Ashudi & 008 & 1014 & 1014 \\
\hline South 24 Parganas & 1601009 & Faridpur & 009 & 744 & 744 \\
\hline DakshinDinajpur & 1701009 & Jagannathbati & 009 & 542 & 542 \\
\hline Uttar Dinajpur & 1805058 & Baliamoni & 058 & 824 & 823 \\
\hline
\end{tabular}

From the above table it appears that 90\% of privately held land recoded in record of rights is readily identifiable in cadastral map. In the State, cadastral parcel maps are digitized and records of rights (RoRs) are also digitized and linked digitally. Now a parcel in the record of rights can be digitally identified on a cadastral map by a click of a mouse of a computer. Land records and cadastral maps are dynamic in nature and changes with changes in ownership of land and use of land. Land records and cadastral maps are updated by incorporating in the Record of Rights changes on account of transfer, inheritance, partition, exchange, new settlement of land, revenue, alteration in the mode of cultivation for example by a sharecropper. Cadastral maps are also modified accordingly as Record of Rights follows the cadastral maps (Section 50 of WBLR Act 1955). An account of mutation cases disposed of during last five years is given below: 


\begin{tabular}{|l|c|c|}
\hline $\begin{array}{l}\text { Number of mutation cases disposed of and pending for } \\
\text { disposal }\end{array}$ & Disposed of & $\begin{array}{c}\text { Pending for } \\
\text { disposal }\end{array}$ \\
\hline Year & 655074 & 821356 \\
\hline $2008-2009$ & 831603 & 952943 \\
\hline $2009-2010$ & 1288697 & 779577 \\
\hline $2010-2011$ & 1282830 & 724817 \\
\hline $2011-2012$ & 1464232 & 818237 \\
\hline $2012-2013$ & 1050433 & 756673 \\
\hline $\begin{array}{l}2013-2014 \text { (up to } \\
\text { december'13) }\end{array}$ & $\begin{array}{l}|l| \\
\text { (Source: Data published by Directorate of Land Records and Surveys West Bengal) }\end{array}$
\end{tabular}

Similarly changes in the land use are updated by incorporating the changes in land use in the Record of Rights and in the maps. Number of conversion of recorded land use cases disposed of in last five years is given below;

\begin{tabular}{|l|c|c|}
\hline \multicolumn{3}{|c|}{$\begin{array}{l}\text { Number of conversion cases disposed of and pending for } \\
\text { disposal }\end{array}$} \\
\hline \multicolumn{1}{|c|}{ Year } & Disposed of & $\begin{array}{c}\text { Pending for } \\
\text { disposal }\end{array}$ \\
\hline $2008-2009$ & 40868 & 36814 \\
\hline $2009-2010$ & 42769 & 43384 \\
\hline $2010-2011$ & 61877 & 41215 \\
\hline $2011-2012$ & 67050 & 38982 \\
\hline $2012-2013$ & 65551 & 43411 \\
\hline $\begin{array}{l}2013-2014 \text { (up to } \\
\text { decmber'13) }\end{array}$ & 41247 & 44056 \\
\hline
\end{tabular}

(Source: Data published Directorate of Land Records and Surveys West Bengal)

However there are large number of cases in which changes in land ownership or changes in land use have not been incorporated in the record of rights and cadastral maps as it is not mandatory for land owners to approach the officers of the land registry department to mutate their names in Record of Rights. In some cases also officials of land records Department fails to detect changes in the field vis-a-vis in RoR and cadastral maps. Last survey settlement operation was taken up 39-40 years back to update Record of Rights and cadastral maps prepared under WBEA Act 1953. Though land Records are updated through mutation and conversion there are large number of cases either pending for disposal or land owners have not approached for correction of Record of Rights. As a result the RoRs do not reflect the ground reality as regards ownership, possession and land use.

Data Source: Cadastral Maps and Records maintained by Directorate of Land Records \& Surveys

Data Reliability: As information is from Cadastral maps and Record of Rights it is 100 percent reliable.

Policy recommendations: Cadastral parcel maps should be updated by using High Resolution Satellite imagery, Electronic Total Station, and Digital Global Positioning System. RoRs should also be updated and registration of land should not be allowed unless name of the transferor features in the Record of rights.

109|Page Land Governance Assessment Framework - West Bengal 


\begin{tabular}{|c|c|c|l|}
\hline Panel & LGI & Dim. & $\begin{array}{l}\text { Land Governance Indicator 18 } \\
\text { Completeness of the land registry }\end{array}$ \\
\hline 6 & 2 & 3 & All relevant private encumbrances are recorded. \\
\hline \multirow{2}{*}{} & \multirow{2}{*}{} & $\begin{array}{l}\text { A: Relevant private encumbrances are recorded consistently and in a reliable } \\
\text { fashion and can be verified at low cost by any interested party. }\end{array}$ \\
\cline { 3 - 4 } & $\begin{array}{l}\text { B: Relevant private encumbrances are recorded consistently and in a reliable } \\
\text { fashion but the cost of accessing them are high. }\end{array}$ \\
\hline & $\begin{array}{l}\text { C: Relevant private encumbrances are recorded but this is not done in a } \\
\text { consistent and reliable manner. }\end{array}$ \\
\cline { 3 - 4 } & D: Relevant private encumbrances are not recorded. \\
\hline
\end{tabular}

\section{Analysis:}

Private encumbrances are: Irrigation rights, user rights for road, pasture rights, Caracas disposal rights, cremation rights, user rights of tank, pond and such other easement rights. Private encumbrance also includes possession of land with consent, adverse possession, forcible possession and rights of the share croppers. As of now private encumbrances created by nongovernmental bodies (banks, private institutions etc.) and court of law are not recorded in the RoRs. However State government may consider recording private encumbrances created by non-governmental bodies and orders issued by court of law in the RoRs. This will be possible after programme for on line management of land records undertaken by the state government is completed by the end of 2014.

Private encumbrances were recorded in the RoR under Bengal Tenancy Act 1885 and the same were updated under WBEA Act 1953 and WBLR Act 1955. But the RoRs do not reflect the ground reality at present. It needs to be updated on real time basis.

Data Source: Record of Rights (RoR) maintained by Directorate of Land Records \& Surveys

Data Reliability: As information is from Record of rights it is 100 percent reliable.

Policy Recommendation: Record of Rights should be updated on real time basis.

\begin{tabular}{|c|c|c|l|}
\hline Panel & LGI & Dim. & $\begin{array}{l}\text { Land Governance Indicator 18 } \\
\text { Completeness of the land registry }\end{array}$ \\
\hline 6 & 2 & 4 & All relevant public restrictions or charges are recorded. \\
\hline \multirow{2}{*}{} & \multirow{2}{*}{} & $\begin{array}{l}\text { A: Relevant public restrictions or charges are recorded consistently and in a } \\
\text { reliable fashion and can be verified at a low cost by any interested party. }\end{array}$ \\
\cline { 3 - 4 } & $\begin{array}{l}\text { B: Relevant public restrictions or charges are recorded consistently and in a } \\
\text { reliable fashion but the cost of accessing them is high. }\end{array}$ \\
\cline { 3 - 4 } & $\begin{array}{l}\text { C: Relevant public restrictions or charges are recorded but this is not done in } \\
\text { a consistent and reliable manner. }\end{array}$ \\
\cline { 3 - 4 } & D: Relevant public restrictions or charges are not recorded. \\
\hline
\end{tabular}

\section{Analysis:}

Public restriction and charges are recorded in the RoRs prepared under BT Act 1885 and revised and updated under WBEA Act 1953 and WBLR Act 1955.

Public restriction recorded in RoRs are: restriction on transfer of land beyond ceiling limit without approval of revenue officer, long term settlement of land, short term settlement, settlement through patta of government land and non-transferability of such land, term for which settled. Violation of statutory provisions of WBLR Act 1955, land allowed to be retained beyond ceiling limit for industrial and such other purposes specified in WBLR Act 1955 which cannot be transferred to private individual, land revenue chargeable on each RoRs are also

110|Page Land Governance Assessment Framework - West Bengal 
recoded. All public restriction is properly recorded in RoRs except revenue chargeable on land in RoRs. Land revenue chargeable has not been recorded in RoRs, because as per WBLR Act 1955 and West Bengal Land Reforms rules 1965 land revenue and exemption from land revenue requires determination of family of the Raiyat(land owner)and determination of which is a time takingandcumbersome process. There is also lack of initiative on the part of the revenue officers of Land and Land reforms Department of the state government. However State Government may consider amendment of WBLR Act 1955 and West Bengal Land Reforms Rules 1965 to change determination of land revenue on family basis to individual Raiyat basis. This will help determination of land revenue and recording in RoR much easier as RoR are maintained based on individual raiyat not based on family of Raiyat.

Data Source: Record of Rights (RoRs) prepared and maintained by Directorate of Land Records \& Surveys

Data Reliability: As source of information is from Record of rights prepared under different Acts it is 100 percent reliable.

Policy recommendations: Relevant public restriction or charges should be recorded in a consistent and reliable manner.

\begin{tabular}{|c|c|c|l|}
\hline Panel & LGI & Dim. & $\begin{array}{l}\text { Land Governance Indicator 18 } \\
\text { Completeness of the land registry }\end{array}$ \\
\hline 6 & 2 & 5 & There is a timely response to requests for accessing registry records. \\
\hline \multirow{2}{*}{} & & $\begin{array}{l}\text { A: Copies or extracts of documents recording rights in property can generally } \\
\text { be obtained within 1 day of request. }\end{array}$ \\
\cline { 3 - 4 } & $\begin{array}{l}\text { B: Copies or extracts of documents recording rights in property can generally } \\
\text { be obtained within 1 week of request. }\end{array}$ \\
\cline { 3 - 4 } & $\begin{array}{l}\text { C: It generally takes more than 1 week after request to produce a copy or } \\
\text { extract of documents recording rights in property. }\end{array}$ \\
\cline { 3 - 4 } & $\begin{array}{l}\text { D: It is not unusual that an extract or copy of a record cannot be produced in } \\
\text { response to a request as the original record cannot be located. }\end{array}$ \\
\hline
\end{tabular}

\section{Analysis:}

All RoRs and cadastral maps are digitized and digitally integrated. Information on land rights records and cadastral maps are available in the website (http://www.banglarbhumi.gov.in) hosted by the State. State Government has introduced Over the Counter (OTC) service. Citizens can now access RoRs and maps within 5-15 minutes on submission of request. Cadastral maps and land records (RoRs) has been prepared, digitized, integrated for whole of state except 1 to 100 wards of Kolkata city. Digitized land records and cadastral maps are also available in the Website of the State Government. Growth in submission of request by citizen and service delivery since introduction of OTC service is given below.

\begin{tabular}{|c|c|c|}
\hline $\begin{array}{c}\text { No of certified copies of record of rights and parcel information } \\
\text { issued (over the counter service) }\end{array}$ \\
\hline Year & $\begin{array}{c}\text { Number of Record of } \\
\text { rights }\end{array}$ & $\begin{array}{c}\text { Number Plot } \\
\text { Information }\end{array}$ \\
\hline $2011-2012$ & 1747332 & 2003364 \\
\hline $2012-2013$ & 2400314 & 3731702 \\
\hline $2013-2014$ (up to december'13) & 1439027 & 2631993 \\
\hline
\end{tabular}

111 Page Land Governance Assessment Framework - West Bengal 
Data Source: Digitized Cadastral maps and records maintained by Directorate of Land Records \& Surveys and report on OTC published by Directorate of Land Records and surveys West Bengal

Data Reliability: As information is from digital records prepared by Directorate of Land records and surveys West Bengal and report on OTC services published by Directorate of Land Records and Surveys West Bengal it is 100 percent reliable.

Policy Recommendation: Land records information should be updated on real time basis.

\begin{tabular}{|c|c|c|c|}
\hline Panel & LGI & Dim. & $\begin{array}{l}\text { Land Governance Indicator } 18 \\
\text { Completeness of the land registry }\end{array}$ \\
\hline 6 & 2 & 6 & The registry is searchable. \\
\hline & & & $\begin{array}{l}\text { A: The records in the registry can be searched by both right holder name and } \\
\text { parcel. }\end{array}$ \\
\hline & & & B: The records in the registry can only be searched by right holder name. \\
\hline & & & C: The records in the registry can only be searched by parcel. \\
\hline & & & $\begin{array}{l}\text { D: The records in the registry cannot be searched by either right holder name } \\
\text { or parcel. }\end{array}$ \\
\hline
\end{tabular}

\section{Analysis:}

Land records and cadastral maps are available on website of Land and Land Reforms Department. Therefore it is easily searchable. Citizens can now search records at OTC centres.

Data Source: Website of the department

Data reliability: Data is 100 percent reliable.

Policy Recommendations: Land records and cadastral maps are to be updated on real time basis.

\begin{tabular}{|c|c|c|l|}
\hline Panel & LGI & Dim. & $\begin{array}{l}\text { Land Governance Indicator 18 } \\
\text { Completeness of the land registry }\end{array}$ \\
\hline 6 & 2 & 7 & Land information records are easily accessed. \\
\hline \multirow{2}{*}{} & & $\begin{array}{l}\text { A: Copies or extracts of documents recording rights in property can be } \\
\text { obtained by anyone who pays the necessary formal fee, if any. }\end{array}$ \\
\cline { 3 - 4 } & $\begin{array}{l}\text { B: Copies or extracts of documents recording rights in property can only be } \\
\text { obtained by intermediaries and those who can demonstrate an interest in the } \\
\text { property upon payment of the necessary formal fee, if any. }\end{array}$ \\
\cline { 2 - 3 } & $\begin{array}{l}\text { C: Copies or extracts of documents recording rights in property can only be } \\
\text { obtained by intermediaries upon payment of the necessary formal fee, if any. }\end{array}$ \\
\cline { 2 - 3 } & $\begin{array}{l}\text { D: Records on land rights are not publicly accessible or can only be obtained by } \\
\text { paying an informal fee. }\end{array}$ \\
\hline
\end{tabular}

\section{Analysis:}

Land records and cadastral maps and land value information are digitized and are available at a nominal fee from land record and registration offices. State Government has initiated steps to make available land information online against online payment. More over land information and record information are available on government website.

\section{Data Source:}

Data reliability: Data is 100 percent reliable. 
Policy Recommendation: No recommendation is made.

\begin{tabular}{|c|c|c|l|}
\hline Panel & LGI & Dim. & $\begin{array}{l}\text { Land Governance Indicator 19 } \\
\text { Reliability: Registry information is updated and sufficient to } \\
\text { make meaningful inferences on ownership }\end{array}$ \\
\hline 6 & 3 & 1 & $\begin{array}{l}\text { Information in public registries is synchronized to ensure integrity of rights } \\
\text { and reduce transaction cost. }\end{array}$ \\
\hline \multirow{2}{*}{} & $\begin{array}{l}\text { A: Links are in place for all types of public land information registries; } \\
\text { mandatory checks are performed to ensure legitimacy of any transactions } \\
\text { that materially affects certain parties' land rights before they can be finalized. }\end{array}$ \\
\cline { 2 - 3 } $\begin{array}{l}\text { B: Links are in place for all types of public land information registries but } \\
\text { checks on the legitimacy of transactions that affects certain parties' land } \\
\text { rights are only performed ex post. }\end{array}$ \\
\cline { 2 - 3 } $\begin{array}{l}\text { C: Links are in place for some types of land information and checks are } \\
\text { insufficient to eliminate a significant number of potentially fraudulent } \\
\text { transactions. }\end{array}$ \\
\cline { 2 - 3 } & D: Few or none of the relevant links exist. \\
\hline
\end{tabular}

\section{Analysis:}

State Government has taken steps to synchronize digital records of land transaction, RoRs and cadastral parcel and legacy records through intranet at State Data Centre. But land transactions presently are allowed without verification of RoRs.

Land acquisition is made by Bhu-Adhigrahan software and is synchronised with Bhu-Chitra software by which RoRs are updated and managed. Therefore land acquisition details are incorporated in RoRs as soon as land acquisition process is finalized. As of now Bank loans, orders of court of law are not recorded in RoRs. However, state government may consider recording private encumbrances created by non-governmental bodies and orders issued by courts in the RoRs. This will be possible after programme for on line management of land records undertaken by the state government is completed by the end of 2014 .

\section{Data Source:}

\section{Data Reliability:}

Policy Recommendations: Record of rights, cadastral maps legacy records of rights should be updated.

\begin{tabular}{|c|c|c|c|}
\hline Panel & LGI & Dim. & $\begin{array}{l}\text { Land Governance Indicator } 19 \\
\text { Reliability: Registry information is updated and sufficient to } \\
\text { make meaningful inferences on ownership }\end{array}$ \\
\hline \multirow[t]{5}{*}{6} & \multirow[t]{5}{*}{3} & \multirow[t]{5}{*}{2} & Registry information is up-to-date and reflects ground reality. \\
\hline & & & $\begin{array}{l}\text { A: More than } 90 \% \text { of the ownership information in the registry/cadaster is } \\
\text { up-to-date and reflects ground reality. }\end{array}$ \\
\hline & & & $\begin{array}{l}\text { B: Between } 70 \% \text { and } 90 \% \text { of the ownership information in registry/cadaster is } \\
\text { up-to-date and reflects ground reality. }\end{array}$ \\
\hline & & & $\begin{array}{l}\text { C: Between } 50 \% \text { and } 70 \% \text { of the ownership information in registry/cadaster is } \\
\text { up-to-date and reflects ground reality. }\end{array}$ \\
\hline & & & $\begin{array}{l}\text { D: Less than } 50 \% \text { of the ownership information in the registry/cadaster is up- } \\
\text { to-date and reflects ground reality. }\end{array}$ \\
\hline
\end{tabular}

\section{Analysis:}

All RoRs and cadastral maps are digitized and digitally integrated. Information on land rights records and cadastral maps are available in the website hosted by the State. State Government has introduced Over the Counter (OTC) service. Citizens can now access RoRs and maps within

$\mathbf{1 1 3}$ | Page Land Governance Assessment Framework - West Bengal 
5-15 minutes on submission of request. However, since all the changes that have taken place subsequent to the revision of records, RoRs cannot be said to be reflecting the ground reality in all the cases.

Data Source: Digitized Cadastral maps and records maintained by Directorate of Land Records \& Surveys.

There is no readily available data to assess the actual percentage of updated ownership information in registry or cadastre. The assessment is primarily made on the basis of field experience. (As per suggestion of DDG, NIC-West Bengal during panel discussion held on 17-042014).

Data Reliability: As information is from digital records prepared by state government it is 100 percent reliable.

Policy Recommendations: Land records information should be updated on real time basis.

\begin{tabular}{|c|c|c|c|}
\hline Panel & LGI & Dim. & $\begin{array}{l}\text { Land Governance Indicator 2o } \\
\text { Cost-effectiveness and sustainability: land administration services } \\
\text { are provided in cost-effective ways that are sustainable in the long } \\
\text { term. }\end{array}$ \\
\hline 6 & 4 & 1 & $\begin{array}{l}\text { The registry is financially sustainable through fee collection to finance its } \\
\text { operations. }\end{array}$ \\
\hline & $\begin{array}{l}\text { A: The total fees collected by the registry exceed the total registry operating } \\
\text { costs. (Total operating costs include all non-capital investment costs (i.e. } \\
\text { salaries and wages, materials, transportation, etc.) associated with registry } \\
\text { operating costs.) }\end{array}$ \\
\hline & $\begin{array}{l}\text { B: The total fees collected by the registry are greater than } 90 \% \text { of the total } \\
\text { registry operating costs. }\end{array}$ \\
\hline & $\begin{array}{l}\text { C: The total fees collected by the registry are between } 50 \% \text { and } 90 \% \text { of the total } \\
\text { registry operating costs. }\end{array}$ \\
\hline $\begin{array}{l}\text { D: The total fees collected by the registry are less than } 50 \% \text { of the total registry } \\
\text { operating costs. }\end{array}$ \\
\hline
\end{tabular}

\section{Analysis:}

Land rights are now recorded in RoRs and copies of RoRs are provided to citizen at very nominal fee of Rs.20/- per page of information. But huge amount is spent on salary of the employees and infrastructure. Comparative figures of operating cost and revenue collected is given below:

\begin{tabular}{|c|c|c|}
\hline \multicolumn{3}{|c|}{ Comparative figures on collection of revenue and expenditure (in Crores) } \\
\hline Year & Collection of Revenue & Expenditure \\
\hline $2009-2010$ & 244.06 & 479.52 \\
\hline $2010-2011$ & 276.54 & 538.01 \\
\hline $2011-2012$ & 380.16 & 526.29 \\
\hline $2012-2013$ & 483.71 & 559.33 \\
\hline $2013-2014$ (up to december'13) & 236.11 & 534.84 \\
\hline
\end{tabular}

$\mathbf{1 1 4}$ I Page Land Governance Assessment Framework - West Bengal 
From the above comparative figures it is clear that total revenue collected is between $50 \%$ and $90 \%$ of the total registry operating costs.

Data Source: Circular issued by the state government and figures on operating cost and revenue collected received from Director of land Records and Surveys, Govt. of West Bengal.

Data reliability: Data is 100 percent reliable as source is circular issued by state government and information on operating cost and revenue collected received from State Government.

Policy Recommendation: Existing rates should be increased. Graded rates are to be levied for different income groups -higher rates for high income groups and lower rates for low income groups.

\begin{tabular}{|c|c|c|l|}
\hline Panel & LGI & Dim. & $\begin{array}{l}\text { Land Governance Indicator 2o } \\
\text { Cost-effectiveness and sustainability: land administration } \\
\text { services are provided in cost-effective ways that are sustainable } \\
\text { in the long term. }\end{array}$ \\
\hline 6 & 4 & 2 & $\begin{array}{l}\text { Investment in land admin. is sufficient to cope with demand for high quality } \\
\text { services. }\end{array}$ \\
\hline & $\begin{array}{l}\text { A: Investment in human and physical is sufficient to achieve or maintain high } \\
\text { service standards and to proactively respond to future needs and new } \\
\text { developments in the sector. }\end{array}$ \\
\hline & $\begin{array}{l}\text { B: Investment in human and physical is sufficient to maintain high service } \\
\text { standards but does not allow for proactively responding to future needs and } \\
\text { new developments in the sector. }\end{array}$ \\
\hline & $\begin{array}{l}\text { C: Human and physical capital investment is sufficient to maintain medium } \\
\text { service standards but does not allow to proactively adapt to new } \\
\text { developments. }\end{array}$ \\
\hline & $\begin{array}{l}\text { D: There is little or no investment in capital in the system to record rights in } \\
\text { land. }\end{array}$ \\
\hline
\end{tabular}

Analysis:

High quality service demands high level of investment and skilled manpower. Presently number of manpower deployed and amount of investment made is insufficient to support high quality service. Maintenance of land records has always been considered as one of the essential functions of the government.

Data Source: DLRS

Data Reliability: High

Policy Recommendation: Graded fee structure for different services and for different income group should be introduced to provide high quality service at cost effective manner.

\begin{tabular}{|c|c|c|l|}
\hline Panel & LGI & Dim. & $\begin{array}{l}\text { Land Governance Indicator 21 } \\
\text { Fees are determined transparently to cover the cost of service } \\
\text { provision }\end{array}$ \\
\hline \multirow{2}{*}{6} & \multirow{2}{*}{5} & 1 & $\begin{array}{l}\text { Fees have a clear rationale, their schedule is public, and all payments are } \\
\text { accounted for. }\end{array}$ \\
\hline \multirow{5}{*}{} & $\begin{array}{l}\text { A: A clear rationale and schedule of fees for different services is publicly } \\
\text { accessible and receipts are issued for all transactions. }\end{array}$ \\
\cline { 3 - 4 } & $\begin{array}{l}\text { B: A clear rationale and schedule of fees for different services is not publicly } \\
\text { accessible, but receipts are issued for all transactions. }\end{array}$ \\
\cline { 3 - 4 } & $\begin{array}{l}\text { C: A clear rationale and schedule of fees for different services is publicly } \\
\text { accessible, but receipts are not issued for all transactions. }\end{array}$ \\
\cline { 3 - 4 } & $\begin{array}{l}\text { D: A clear rationale and schedule of fees for different services is not publicly } \\
\text { accessible and receipts are not issued for all transactions. }\end{array}$ \\
\hline
\end{tabular}

$\mathbf{1 1 5}$ | Page Land Governance Assessment Framework - West Bengal 


\section{Analysis:}

A clear rationale of fixation of fee is not available as it was decided by the State Government to provide the service at a token rate. However, details of fees for different service are available at respective land record offices and registration offices and receipts are issued for all transactions.

Policy Recommendation: Rationale for fixation of fees for different services should be fixed transparently to cover the cost of services.

\begin{tabular}{|c|c|c|l|}
\hline Panel & LGI & Dim. & $\begin{array}{l}\text { Land Governance Indicator 21 } \\
\text { Fees are determined transparently to cover the cost of service } \\
\text { provision }\end{array}$ \\
\hline 6 & 5 & 2 & \begin{tabular}{l} 
Informal payments are discouraged. \\
\hline
\end{tabular} \\
\cline { 3 - 4 } & $\begin{array}{l}\text { A: Effective mechanisms to detect and deal with illegal staff behavior exist in } \\
\text { all registry offices and all cases are promptly dealt with. }\end{array}$ \\
\cline { 3 - 4 } & $\begin{array}{l}\text { B: Mechanisms to detect and deal with illegal staff behavior exist in all } \\
\text { registry offices but cases are not systematically or promptly dealt with. }\end{array}$ \\
\cline { 3 - 4 } & $\begin{array}{l}\text { C: Mechanisms to detect and deal with illegal staff behavior exist in some } \\
\text { registry offices. }\end{array}$ \\
\hline & $\begin{array}{l}\text { D: Mechanisms to detect and deal with illegal staff behavior are largely non- } \\
\text { existent. }\end{array}$ \\
\hline
\end{tabular}

\section{Analysis:}

In all offices dealing with land transfer, registration and offices preparing RoRs and cadastral maps, illegal staff behavior could be easily detected. Service Conduct Rules for staff are in place and for illegal staff behavior and there is provision for punishment through departmental proceedings and criminal proceedings. But supervision by the officials is not done regularly to detect illegal staff behaviors and to punish them promptly and systematically.

During last three years (2011-13) departmental proceedings were drawn up against 75 employees for illegal staff behavior and 10 employees were punished and 3 vigilance enquiries are continuing against 3 employees. These are information received from office of The Director Land Records and Surveys Government of West Bengal.

Data Source: Office of Director Land Records and Surveys West Bengal

\section{Data Reliability: High}

Policy Recommendation: Strong monitoring and supervision mechanism should be put in place to detect informal payments and illegal staff behavior and to punish them promptly.

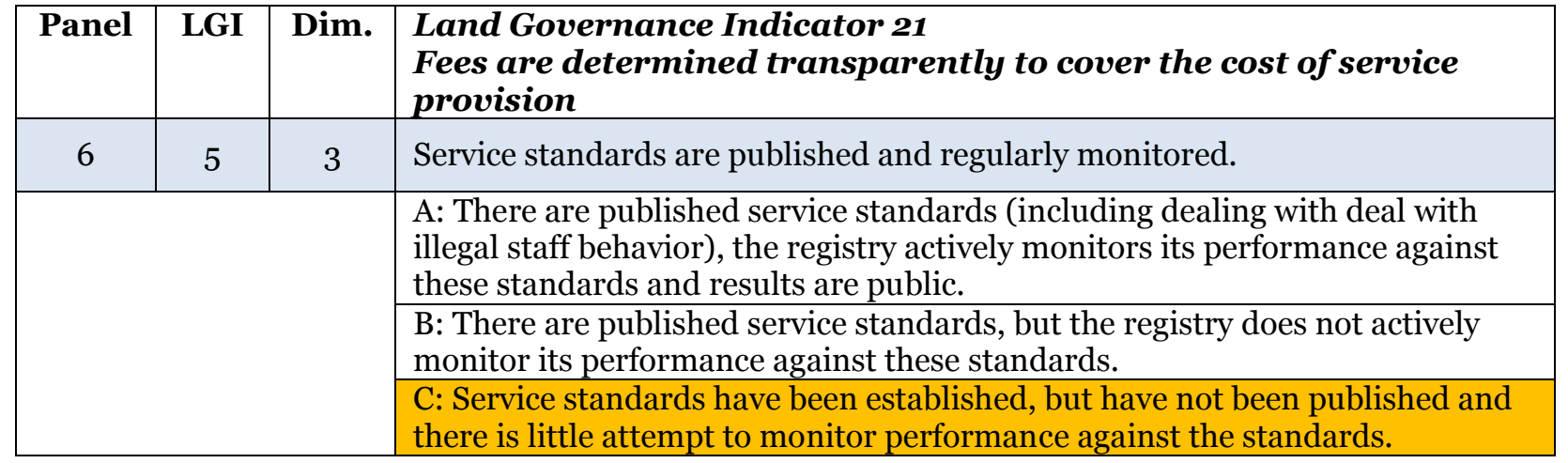

$\mathbf{1 1 6}$ | Page Land Governance Assessment Framework - West Bengal 


\section{Analysis:}

State Government has enacted West Bengal Rights to Public Service Act 2013 to establish service standard and ensure providing service as per established service standard. Under this Act, officials failing to give service as per standard will be punished. But State Government has notified service standard for a few services, not for all services.

\section{Data Source: NA}

\section{Data Reliability: NA}

Policy Recommendation: Service standard for all services should be established and notified and service should be ensured. For this purpose skilled manpower strength should be increased and investment in modern infrastructure be made. A proper mechanism should be put in place to monitor service delivery standard.

\section{Panel 7 Land Valuation and Taxation}

\section{Indicators}

1. Transparency of valuations: valuations for tax and compensation purposes are based on clear principles, applied uniformly, updated regularly, and publicly accessible.

2. Collection efficiency: resources from land and property taxes are collected and the yield from land taxes exceeds the cost of collection.

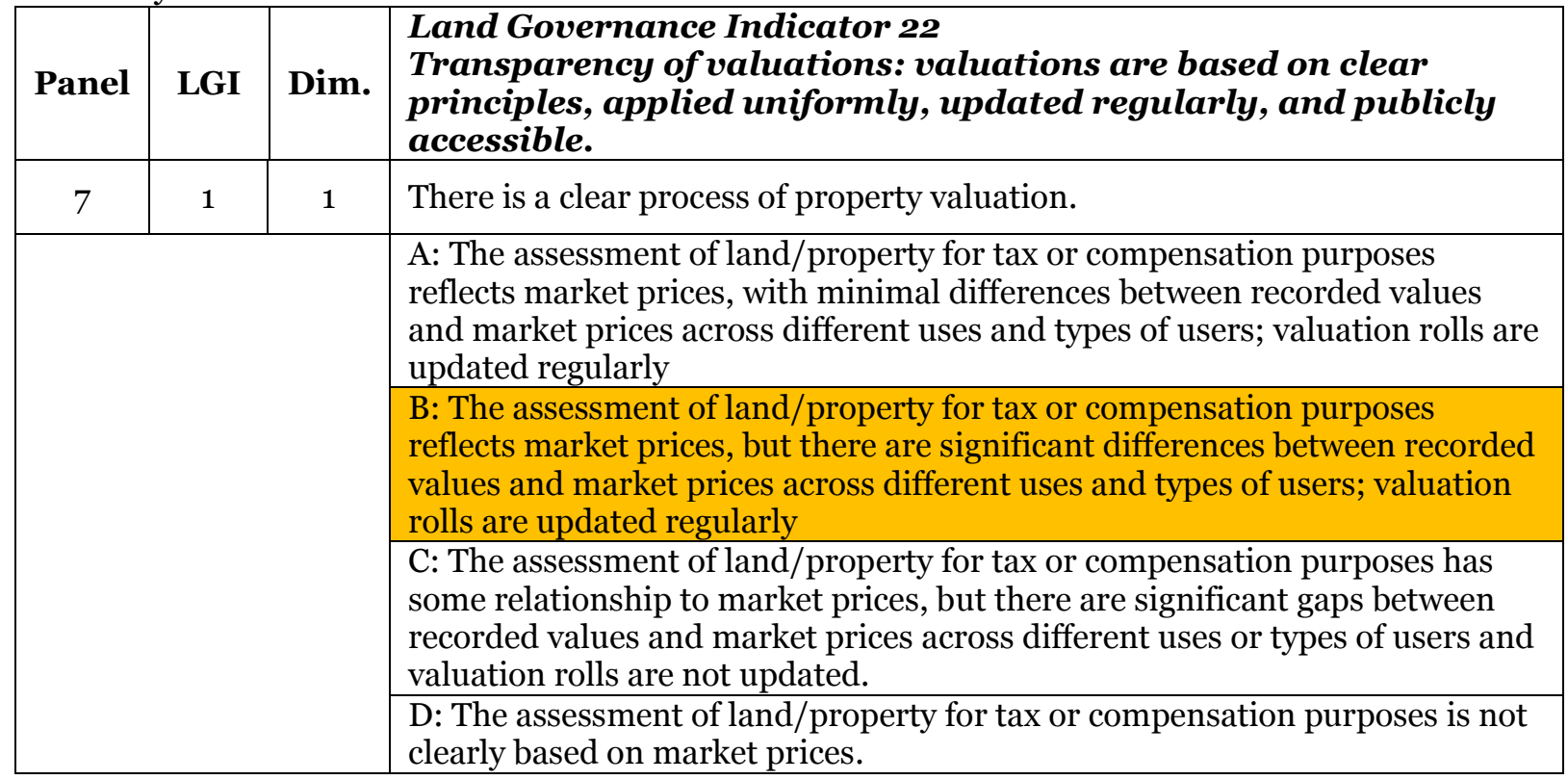

\section{Analysis:}

Computerisation of records in registration offices in West Bengal was taken up in 2001 and at present all 239 registration offices have been fully computerized. West Bengal has thus become an e-state in respect of registration. As a result there has been a clear and transparent process in determination of market value for property through CORD (Computerisation of Registration of Documents) software. The objectives of this e-governance system of registration includes a) replacement of current manual records through a sophisticated imaging system, b) seamless

117| Page Land Governance Assessment Framework - West Bengal 
integration of all related system c) improving quality of services to citizens. At present in West Bengal the market value of any property (land, building) is determined through this system.

The West Bengal Stamp (Prevention of Under-Valuation of Instruments) Rules 2001 was introduced with effect from 1.3.2001. In the changed scenario of computerisation, the process of determination of market value has been changed accordingly and a digitised market value database covering all the plots under the jurisdiction of the registering officer has been installed and interlinked with CORD software. A person desiring to transfer or acquire a property shall have to submit the particulars of the property in the appropriate requisition form. Such particulars are fed in the computer database and the system automatically generates the market value of the property. The digitised market values are periodically revised (at least twice a year) according to the field situation.

The Government of West Bengal, in supersession of all relevant procedures embodied in Land Acquisition Manual, 1991 and previous executive orders, issued a revised procedure and administrative rearrangement order dated 6 June 2006, for various land acquisition related purpose including compensation purpose. The following procedures are to be followed for fixation of appropriate market value of each type-class of land:

1. For each of the specified type-class of the land as separately mentioned for rural and urban land, at least 10 and up to 20 current sale data from the concerned mouza to be collected and placed chronologically in the prescribed format. The sale figures from nearest time up to 12 months back time which can be extended up to 36 months as may be required to get minimum 10 sale data for the relevant class-type of land in the mouza. For the extended period from 12 months to 36 months sale price can be increased by $5 \%$ per annum. In case at least 10 sale data for the relevant mouza is not available from the office of the sub-registrar, sale data from adjacent mouza for same type-class of land needs to be considered.

2. Using the sale data collected for each type-class of land in each mouza in prescribed format, fixation of average market value for the type-class of land is done with a reasoned analysis available. This "value assessment sheet" is prepared, signed and countersigned by the designated officials in the district and used for the purpose of both long-term lease and land acquisition purpose.

3. For such fixation of market value of any type-class of land as stated above, abnormally high or abnormally low value (above or below 200\% of the average value reflected in majority of sales) are carefully discarded.

4. For awarding compensation of each plot of land or for fixing up salami for giving longterm settlement of land, additional valuation is determined on the basis of certain prescribed formulae.

5. In cases of developed urban centres, municipalities and corporations, belting method is applied

6. Fixation of value of land located in rural areas: each mouza is divided into seven typeclass of land

a. Non-irrigated agricultural land

b. Irrigated agricultural land

c. Homestead

d. Danga, patit, fallow and other unused vacant land

e. Land under commercial or industrial use

f. Tanks, ponds and other water bodies

g. Government land including vested land, departmental land and public-utility cum common property land

Each of the above seven type-classes of land in rural areas shall get value addition over and above up to maximum of $10 \%$ on the average market value determined.

$\mathbf{1 1 8}$ | Page Land Governance Assessment Framework - West Bengal 
7. Fixation of value of land located in municipalities and corporations: the classes of land are categorized as under

a. Land under residential use

b. Land under commercial and industrial use

c. Water bodies

d. Public utility land (public roads, parks, cremation ground, burial ground, land under departmental use)

e. Land not covered under above four types-classes

Each of the above type-class of land in municipalities shall get value addition over and above up to maximum of $10 \%$ on the average market value determined.

In spite of all these valuation is not on par with market value in few cases, particularly in rapidly urbanized areas with greater communication and urban infrastructure. But these are rather cases of exception and compared to overall state situation, are negligible. In the state context the transfers are happening at market value mostly and market value is comparable with government valuation (ranking changed from A to B following discussion with EI, panellists).

Data Source: NIC and Registration wing, Finance Department, Govt. of West Bengal

Data Reliability: High

Policy recommendation:

- There is a need for coordination among the different layers of the government in use of Market Value Data Base (MVDB) in CORD not only for the purpose of collection of stamp-duty revenue/registration fee as currently done, but also for calculation of base of property/land tax and land revenue. This will allow for less discretion in determination of tax base, which is essential for a transparent and efficient tax regime.

- The scope of discretion used in determination of property tax base and rate as in the present system should be reduced. The credible mechanisms should be designed towards collection of property taxes from defaulters.

\begin{tabular}{|c|c|c|l|}
\hline Panel & LGI & Dim. & $\begin{array}{l}\text { Land Governance Indicator 22 } \\
\text { Transparency of valuations: valuations are based on clear } \\
\text { principles, applied uniformly, updated regularly, and publicly } \\
\text { accessible. }\end{array}$ \\
\hline 7 & 1 & 2 & \begin{tabular}{l} 
Valuation rolls are publicly accessible. \\
\hline
\end{tabular} \\
& $\begin{array}{l}\text { A: There is a policy that valuation rolls be publicly accessible and this policy } \\
\text { is effective for all properties that are considered for taxation. }\end{array}$ \\
\hline & $\begin{array}{l}\text { B: There is a policy that valuation rolls be publicly accessible and this policy } \\
\text { is effective for most of the properties that are considered for taxation. }\end{array}$ \\
\hline & $\begin{array}{l}\text { C: There is a policy that valuation rolls be publicly accessible and this policy } \\
\text { is effective for a minority of properties that are considered for taxation. }\end{array}$ \\
\cline { 2 - 3 } & D: There is no policy that valuation rolls be publicly accessible. \\
\hline
\end{tabular}

\section{Analysis:}

The Government of West Bengal maintains a policy that the valuation rolls in respect of urban properties are prepared and accessible to public. The draft valuation list for the urban local body prepared by the West Bengal Valuation Board is published for the ULB inviting objections within a specified period. The objections are heard and disposed within six months following which the final valuation list is published for the ULB. The state government under section 9(2) of West Bengal Valuation Act, 1978 issues notification indicating the date from which the list will come into effect.

119| Page Land Governance Assessment Framework - West Bengal 
Similarly for the land valuation purpose after introduction of CORD software all the valuation rolls for each type/ classification of land in a mouza falling under the jurisdiction of a registry office are publicly accessible and could be viewed from the website wbregistration.gov.in

Data Source: www.wbregistration.gov.in

Data Reliability: High

\begin{tabular}{|c|c|c|c|}
\hline Panel & LGI & Dim. & $\begin{array}{l}\text { Land Governance Indicator } 23 \\
\text { Collection efficiency: land and property taxes are collected and } \\
\text { the yield from doing so exceeds collection cost }\end{array}$ \\
\hline \multirow[t]{5}{*}{7} & 2 & 1 & Exemptions from property taxes payment are justified and transparent. \\
\hline & & & $\begin{array}{l}\text { A: There are limited exemptions to the payment of land/property taxes, and } \\
\text { the exemptions that exist are clearly based on equity or efficiency grounds } \\
\text { and applied in a transparent and consistent manner. }\end{array}$ \\
\hline & & & $\begin{array}{l}\text { B: There are limited exemptions to the payment of land/property taxes, and } \\
\text { the exemptions that exist are clearly based on equity or efficiency grounds } \\
\text { but are not applied in a transparent and consistent manner. }\end{array}$ \\
\hline & & & $\begin{array}{l}\text { C: The exemptions to the payment of land/property taxes are not always } \\
\text { clearly based on equity or efficiency grounds and are not always applied in a } \\
\text { transparent and consistent manner. }\end{array}$ \\
\hline & & & $\begin{array}{l}\text { D: It is not clear what rationale is applied in granting an exemption to the } \\
\text { payment of land/property taxes and there is considerable discretion in the } \\
\text { granting of such exemptions. }\end{array}$ \\
\hline
\end{tabular}

\section{Analysis:}

Section 23 of the WBLR Act 1955 (amended in 2005) has streamlined the rates of revenue payable for different categories of land. Section 24 of the said Act has provided with details when such revenue is exempted for payment by a raiyat in case of land held does not exceed 2.428 ha by the family. No exemption is allowed if the land lies within a municipality or any area which is used for mill, factory, workshop or other commercial purposes.

In villages the West Bengal Panchayat Act, 1973 states under section 46(2) about exemptions from imposition of tax by the Gram Panchayat in the area of its jurisdiction. Lands and buildings used exclusively for public purpose, religious, charitable and educational purposes and when the annual valuation of land or buildings is not more than Rs. 250 are exempted.

Section 93 of the WBMA Act 1993 provides guidelines about the power to levy Property Tax on lands and buildings. As per provisions of sections 99 to 105 of this Act Diplomatic Missions, places of public worship, Government or Government aided educational institutions, holdings used for charitable purposes, welfare homes run by the Government and the buildings with a valuation of Rs. 500/- or less are exempted from payment of property tax. In every five years the periodic assessment of holdings is done. Detailed procedure for such assessment is made in the Act.

The Board of councillors may allow part exemptions on a) property of ex-service men b) in case of excessive hardship, and c) holding remaining vacant or unproductive of rent for successive 90 days. It is clear that the exemptions in respect of property tax payment are limited but there is human discretion involved which gives scope of it being applied in an inconsistent manner.

\section{Data Source:}

\section{Data Reliability:}

120|Page Land Governance Assessment Framework - West Bengal 


\begin{tabular}{|c|c|c|c|}
\hline Panel & LGI & Dim. & $\begin{array}{l}\text { Land Governance Indicator } 23 \\
\text { Collection efficiency: land and property taxes are collected and } \\
\text { the yield from doing so exceeds collection cost }\end{array}$ \\
\hline \multirow[t]{5}{*}{7} & 2 & 2 & All property holders liable to pay property tax are listed on the tax roll. \\
\hline & & & $\begin{array}{l}\text { A: More than } 80 \% \text { of property holders liable for land/property tax are listed } \\
\text { on the tax roll. }\end{array}$ \\
\hline & & & $\begin{array}{l}\text { B: Between } 70 \% \text { and } 80 \% \text { of property holder liable for land/property tax are } \\
\text { listed on the tax roll. }\end{array}$ \\
\hline & & & $\begin{array}{l}\text { C: Between } 50 \% \text { and } 70 \% \text { of property holder liable for land/property tax are } \\
\text { listed on the tax roll. }\end{array}$ \\
\hline & & & $\begin{array}{l}\text { D: Less than } 50 \% \text { of property holders liable for land/property tax are listed } \\
\text { on the tax roll. }\end{array}$ \\
\hline
\end{tabular}

\section{Analysis:}

Rule 15 of the WBLR Rules, 1965 speaks about the process of preparation and publication of list of raiyats who are liable to pay revenue in the notice board of the office of the BLLRO after observing the process of inviting claims and objections and disposal thereof. The finally determined revenue shall constitute a demand register. Demand list in the form of Register II (Tenant's Ledger) is prepared mouza wise in each BLLRO office and extracts sent to respective Revenue Inspector for displaying in the Gram Panchayat office (Rule 318 of WBL\&LR Manual, 1991).

For urban areas the general valuation of holdings is made by the Central Valuation Board (Section 110 of West Bengal Municipal Act, 1993). The valuation list prepared becomes the assessment list for the municipality. Such assessment list is published in a public place by the concerned municipality for inspection. Any person dissatisfied has to apply for review before the board of councillors within a period of two months from the date of presentation of bill for property tax payment. There is steady improvement over the years in percentage of property holders listed in tax roll and at present most of the properties within a ULB are listed in the tax roll except the exemption cases, i.e., more than $80 \%$.

From the statistics uploaded in the JnNURM, Government of West Bengal website in respect of JnNURM ULB level reform agenda (No. 3) it is found that most of the ULBs in both the Mission cities of Kolkata and Asansol (consisting of 40 odd ULBs), the property tax coverage is more than 90\% (reporting year 2008-09). For Non-mission Cities, out of 80 ULBs more than 50 have achieved the target during the year 2008-09. For remaining ULBs, it is reported that major part of the properties have been covered.

In case of new notified areas (change from rural to semi-urban) the procedures required for preparation of property tax rolls are taken up simultaneously with the process of notification. In the case of New Town Kolkata Development Authority (RajarhatTownship) the bill has been very recently passed in the Assembly to the effect of making it a municipal body, in a parallel process the tax roll is also under preparation and collection of property tax with arrear will start immediately as informed by the authority.

For rural (Panchayat) areas the tax roll for land and building properties are assessed and collected by the Gram Panchayats (section 46 of W B Panchayat Act, 1973). The demand register is maintained though system of tax roll preparation and notice sending to the property holders need to improve. No figure is available for the rural areas regarding percentage of property holders shown in tax rolls.

Data Source: WBMA Department

121|Page Land Governance Assessment Framework - West Bengal 
Data Reliability:

\begin{tabular}{|c|c|c|c|}
\hline Panel & LGI & Dim. & $\begin{array}{l}\text { Land Governance Indicator } 23 \\
\text { Collection efficiency: land and property taxes are collected and } \\
\text { the yield from doing so exceeds collection cost }\end{array}$ \\
\hline \multirow[t]{5}{*}{7} & 2 & 3 & Assessed property taxes are collected. \\
\hline & & & A: More than $80 \%$ of assessed land/property taxes are collected. \\
\hline & & & B: Between $70 \%$ and $80 \%$ of assessed land/ property taxes are collected. \\
\hline & & & C: Between $50 \%$ and $70 \%$ of assessed land/property taxes are collected. \\
\hline & & & D: Less than 50\% of assessed land/property taxes are collected. \\
\hline
\end{tabular}

\section{Analysis:}

Property tax is the main source of tax revenue for the ULBs. As per the report of the Third State Finance Commission (report published in 2008), during the years from 2003-04 to 2006-07, share of property tax revenue to total tax revenue was $91.22 \%$. The recommendations made by the $13^{\text {th }}$ Finance Commission (2008) mentions that there is tremendous scope for improvement of revenue from property tax without increasing the rates and without any structural alteration of the basis of levy. The West Bengal Valuation Board assists the municipalities in the assessment and valuation of properties for the levy of property tax. The Commission recommended that at least $25 \%$ of estimated number of properties in all urban local bodies should be covered by 31 March 2015. The ULB level mandatory reform agenda under JnNURM asks for $85 \%$ property coverage for taxation and 90\% collection efficiency by the end of 2011-12. In the state government website of JnNURM, figures available till 2008-09 shows an impressive progress in respect of property tax coverage and collection efficiency.

The third State Finance Commission constituted by the Government of West Bengal has observed that there is a laxity on the part of ULBs to collect property tax especially arrear property taxes. The Commission (SFC) recommended (recommendation No. 8.17) a more concerted effort on the part of ULBs to collect outstanding property taxes which was accepted by the government. As per the report published by the third SFC, in the year 2006-07 total demand of property tax was 908.48 crores, but the total collection was only 407.76 crores, i.e., $44.88 \%$ of the total demand. In the same year the percentage of arrear demand collection was $17 \%$ and current demand was 53\%. There was wide variations reported from 124 ULBs (excluding Kolkata and Howrah Municipal Corporations), in 10 ULBs the collection was less than 10\% whereas there were collection of more than $90 \%$ in case of a good number of ULBs. The main arrear in property tax is contributed by state and central government departments and undertakings ( $48 \%$ of total due, $26.84 \%$ of the demand).

The West Bengal Government JnNURM website reports under the ULB level mandatory reform compliance in 2008-09 that out of 45 ULBs covered under the two Mission cities of Kolkata and Asansol, more than 50\% ULBs are showing collection efficiency of $90 \%$ out of the $85 \%$ property coverage. For Non-Mission cities, out of 80 ULBs, 35\% ULBs have achieved the target of same collection efficiency. The main reason for lagging behind this reform agenda is said to be huge arrear property taxes from defaulters like both central and state government establishments. Taking into account the property taxes for both the urban and rural areas the

Data Source: Report of West Bengal Third State Finance Commission

Data Reliability: Very high

Policy recommendation: There is a big issue in respect of realization of outstanding property tax by the ULBs, substantial part of which are due to the state and central departments and

122 | Page Land Governance Assessment Framework - West Bengal 
undertakings. This issue needs to be taken up jointly by the governments for working out an acceptable solution for all the parties involved.

\begin{tabular}{|c|c|c|l|}
\hline Panel & LGI & Dim. & $\begin{array}{l}\text { Land Governance Indicator 23 } \\
\text { Collection efficiency: land and property taxes are collected and } \\
\text { the yield from doing so exceeds collection cost }\end{array}$ \\
\hline 7 & 2 & 4 & \begin{tabular}{l} 
Receipts from property tax exceed the cost of collection. \\
\hline
\end{tabular} \\
$\qquad$ & $\begin{array}{l}\text { A: The amount of property taxes collected exceeds the cost of staff in charge } \\
\text { of collection by a factor of more than } 5 .\end{array}$ \\
\hline & $\begin{array}{l}\text { B: The amount of property taxes collected is between } 3 \text { and } 5 \text { times cost of } \\
\text { staff in charge of collection. }\end{array}$ \\
\cline { 3 - 4 } & $\begin{array}{l}\text { C: The amount of property taxes collected is between } 1 \text { and } 3 \text { times cost of } \\
\text { staff in charge of collection. }\end{array}$ \\
\hline & $\begin{array}{l}\text { D: The amount of property taxes collected is less than the cost of staff in } \\
\text { charge of collection. }\end{array}$ \\
\hline
\end{tabular}

\section{Analysis:}

Drawing a comparison in respect of property tax collection and cost of staff in charge of collection a varying picture emerges. For small municipalities (like Uluberia), the amount of property tax collection is about 3 times the cost of collections which is more than 5 times in medium and large municipalities. In case of municipal corporations the property tax collected is several ten times the cost of staff in charge of collection.

The situation in respect of rural areas (panchayat areas) is altogether different and the amount of property tax collected is many times more than the cost of collection. The government made allocation to the tune of 2.48 crores for payments of allowances to tax collecting sarkars (201213) whereas the total tax revenue collected at the Gram Panchayat level for the entire state was 54.11 crores.

Data Source: Official website of Government of West Bengal, JnNURM, State Finance Commission

Data Reliability: Highly reliable

\section{Panel 8 Dispute Resolution}

\section{Indicators}

1. Assignment of responsibility: responsibility for conflict management at different levels is clearly assigned, in line with actual practice, relevant bodies are competent in applicable legal matters, and decisions can be appealed against.

2. The share of land affected by pending conflicts is low and decreasing. 


\begin{tabular}{|c|c|c|c|}
\hline Panel & LGI & Dim. & $\begin{array}{l}\text { Land Governance Indicator } 24 \\
\text { Assignment of responsibility: responsibility for conflict } \\
\text { management at different levels is clearly assigned, in line with } \\
\text { actual practice, relevant bodies are competent in applicable legal } \\
\text { matters, and decisions can be appealed against. }\end{array}$ \\
\hline \multirow[t]{5}{*}{8} & 1 & 1 & There is clear assignment of responsibility for conflict resolution. \\
\hline & \multirow{4}{*}{1} & \multirow{4}{*}{1} & $\begin{array}{l}\text { A: There are no parallel avenues for conflict resolution or, if parallel avenues } \\
\text { exist, responsibilities are clearly assigned and widely known and explicit rules } \\
\text { for shifting from one to the other are in place to minimize the scope for forum } \\
\text { shopping. }\end{array}$ \\
\hline & & & $\begin{array}{l}\text { B: There are parallel avenues for dispute resolution but cases cannot be pursued } \\
\text { in parallel through different channels and evidence and rulings may be shared } \\
\text { between institutions so as to minimize the scope for forum shopping. }\end{array}$ \\
\hline & & & $\begin{array}{l}\text { C: There are parallel avenues for dispute resolution and cases can be pursued in } \\
\text { parallel through different channels but sharing of evidence and rulings may } \\
\text { occur on an ad-hoc basis. }\end{array}$ \\
\hline & & & $\begin{array}{l}\text { D: There are parallel avenues for dispute resolution and cases can be pursued in } \\
\text { parallel through different channels and there is no sharing of information. }\end{array}$ \\
\hline
\end{tabular}

\section{Analysis:}

WBLR Act 1955 under different provisions has categorically barred the jurisdiction of civil courts both generally and specifically in all matters coming within the purview of the Act. Only on question of pure title involving private individuals, civil courts may be approached. For availing the rights of pre-emption the court may also be approached, but in pre-emption cases the court acts as the authority under the Act. The mechanism of conflict resolution provided under LR Act is this.

At the block level the Revenue Officers (RO) act as the primary authorities to resolve disputes at different stages of the preparation and revision of record of right and also to implement the ceiling provision and to enforce regulatory provisions of the Act. Against the decisions of the ROs appeal can be preferred before the district level officers and such appeals are heard by the DLLRO and Dy. DLLRO. Persons aggrieved with the decisions of the appellate authority may approach the WB Land Reforms Tenancy Tribunal (WBLRTT). Against the decision of the Tribunal appeals can be preferred before a Division Bench of the High Court specially earmarked to hear such appeals.

Only under the provisions meant to prevent alienation of land by raiyats belonging to STs a designated officer of the Backward Classes Welfare Department acts as the RO., against whose decision appeal filed before a Civil Judge having local jurisdiction. Against the decision of the appellate authority revision lies before the District Judge.

This mechanism does not admit of any parallel avenue or overlapping of jurisdiction in conflict management and resolution of disputes. This mechanism provides for adequate remedies against the decisions of the primary authorities.

As such it is obvious that, there is clear assignment of responsibility of conflict resolution in the land laws of West Bengal.

\section{Data Source:}

\section{Data Reliability:}




\begin{tabular}{|c|c|c|c|}
\hline Panel & LGI & Dim. & $\begin{array}{l}\text { Land Governance Indicator } 24 \\
\text { Assignment of responsibility: responsibility for conflict } \\
\text { management at different levels is clearly assigned, in line with } \\
\text { actual practice, relevant bodies are competent in applicable legal } \\
\text { matters, and decisions can be appealed against. }\end{array}$ \\
\hline \multirow[t]{5}{*}{8} & \multirow[t]{5}{*}{1} & \multirow[t]{5}{*}{2} & Conflict resolution mechanisms are accessible to the public. \\
\hline & & & $\begin{array}{l}\text { A: Institutions for providing a first instance of conflict resolution are } \\
\text { accessible at the local level in the majority of communities. }\end{array}$ \\
\hline & & & $\begin{array}{l}\text { B: Institutions for providing a first instance of conflict resolution are } \\
\text { accessible at the local level in less than half of communities but where these } \\
\text { are not available informal institutions perform this function in a way that is } \\
\text { locally recognized. }\end{array}$ \\
\hline & & & $\begin{array}{l}\text { C: Institutions for providing a first instance of conflict resolution are } \\
\text { accessible at the local level in less than half of communities, and where these } \\
\text { are not available informal institutions do not exist or cannot perform this } \\
\text { function in a way that is locally recognized. }\end{array}$ \\
\hline & & & $\begin{array}{l}\text { D: Less than a quarter of communities have institutions formally empowered } \\
\text { to resolve conflicts and a variety of informal institutions may be available in } \\
\text { the rest. }\end{array}$ \\
\hline
\end{tabular}

\section{Analysis:}

The mechanism for conflict resolution at all the stages, whether during preparation of land records or afterwards is in place and accessible to public at local level. The mechanism always operates with the participation of the public, i.e., the raiyats, and other stakeholders. The system of keeping records open during Draft Publication and Final Publication of records for public inspection for a certain period of time makes the records easily accessible to the public who can raise objections for correction of records of right and thereby resolution of conflicts, if any. In all proceedings for conflict resolution under the extant Land Laws, opportunity is always given to all parties being heard before resolving a conflict at any stage, starting from the preparation of preliminary land records, to any disputes raised before the Land Tribunal or the Hon'ble High Court.

\begin{tabular}{|c|c|c|c|}
\hline Panel & LGI & Dim. & $\begin{array}{l}\text { Land Governance Indicator } 24 \\
\text { Assignment of responsibility: responsibility for conflict } \\
\text { management at different levels is clearly assigned, in line with } \\
\text { actual practice, relevant bodies are competent in applicable legal } \\
\text { matters, and decisions can be appealed against. }\end{array}$ \\
\hline \multirow[t]{5}{*}{8} & \multirow[t]{5}{*}{1} & \multirow[t]{5}{*}{3} & $\begin{array}{l}\text { Mutually accepted agreements reached through informal dispute resolution } \\
\text { systems are encouraged. }\end{array}$ \\
\hline & & & $\begin{array}{l}\text { A: There is a local, informal dispute resolution system that resolves a } \\
\text { significant number of conflicts in an effective and equitable manner and which } \\
\text { is recognized in the formal judicial or administrative dispute resolution system. }\end{array}$ \\
\hline & & & $\begin{array}{l}\text { B: There is a local, informal dispute resolution system that resolves a } \\
\text { significant number of conflicts in an effective and equitable manner but which } \\
\text { is not recognized in the formal judicial or administrative dispute resolution } \\
\text { system. }\end{array}$ \\
\hline & & & $\begin{array}{l}\text { C: There is a local, informal dispute resolution system that makes decisions } \\
\text { that are not always equitable but this system is recognized in the formal } \\
\text { judicial or administrative dispute resolution system. }\end{array}$ \\
\hline & & & $\begin{array}{l}\text { D: There is no effective informal or local dispute resolution system in place } \\
\text { that can resolve a significant number of land related disputes effectively. }\end{array}$ \\
\hline
\end{tabular}

125|Page Land Governance Assessment Framework - West Bengal 


\section{Analysis:}

As there is no provision for any mutually accepted agreement through informal dispute resolution system, in the extant Land Laws in West Bengal, any local or informal dispute resolution is not recognized or resorted to in the formal judicial or administrational dispute resolution system in the state. Since registration is expensive all kinds of transfer including temporary transfer for a specific purpose not registered. If any dispute arises over possession of land such dispute is resolved locally and informally. The law does not recognize partition of land except by order of the court or registered instrument. Since the legal process is expensive the cosharers or successors-in-interest of the co-sharer make informal partition and possess land accordingly. Dispute over possession always resolved locally. But law of the land does not recognize such system.

The scope of Lok Adalats, for providing faster relief to the litigants in dispute resolution on land matters under the provisions in sec 19(5) read with section 21 of the Legal Services Authority Act, 1987, is presently confined to only those provisions/sections of the major Land Acts in West Bengal, ie the West Bengal Estate Acquisition Act, 1953 and West Bengal Land Reforms Act, 1955, in respect of disputes in determination of title, partition, pre-emption etc. which can be adjudicated by the civil courts. But in large number of provisions of both the Acts, there has been bar to civil jurisdiction and as such dispute resolution mechanism in respect of those provisions has been left with the Revenue forum as per law.

It has already been mentioned earlier that there being bar to civil jurisdiction in respect of most of the chapters in the extant land laws in the state, the role of civil court is confined to mainly in respect of title determination, pre-emption matters etc. As such the provisions contained in the section 89 or order XIII of the CPC or the Arbitration and Reconciliation Act, 1996 may be applied by the civil courts in the matters under their jurisdiction in the extant land laws. The land law matters have not been in the purview of the Lok Adalat as yet in the State.

The following are the Land Laws, which are now in force in the State:

a. West Bengal Estates Acquisition Act, 1953 (Act I of 1954) -

b. West Bengal Land Reforms Act, 1955 (Act X of 1956) -

c. West Bengal Acquisition of Homestead Land for Agricultural Laborers, Artisans, Fishermen Act, 1975 (West Bengal Act XLVII of 1975)-

d. West Bengal Restoration of Alienated Land Act, 1973 (West Bengal Act XXIII of 1973) -

e. West Bengal Thika Tenancy (Acquisition and Regulation) Act, 2001(West Bengal Act XXXII of 2001) - 
Table showing the relevant Acts, Nature of disputes and Authority of disposal etc

\begin{tabular}{|c|c|c|c|c|c|c|c|}
\hline $\begin{array}{c}\text { Sl } \\
\text { No }\end{array}$ & $\begin{array}{l}\text { Name of } \\
\text { the Act }\end{array}$ & Dispute type & $\begin{array}{l}\text { Authority/ } \\
\text { court at first } \\
\text { instance }\end{array}$ & $\begin{array}{l}\text { First Appellate } \\
\text { Authority }\end{array}$ & $\begin{array}{c}\text { Second } \\
\text { Appellate } \\
\text { Authority }\end{array}$ & $\begin{array}{c}\text { Judicial } \\
\text { review } \\
\text { Authority }\end{array}$ & Remarks \\
\hline 1 & $\begin{array}{c}\text { West } \\
\text { Bengal } \\
\text { Land } \\
\text { Reforms } \\
\text { Act, } 1955\end{array}$ & $\begin{array}{l}\text { Dispute over } \\
\text { ownership, } \\
\text { possession etc. } \\
\text { Recording of } \\
\text { Raiyat u/s } 51\end{array}$ & $\begin{array}{l}\text { Revenue } \\
\text { Officer } \\
\text { empowered } \\
\text { u/s 51A(4) }\end{array}$ & $\begin{array}{l}\text { Before Collector } \\
\text { u/s 51A(5) }\end{array}$ & $\begin{array}{l}\text { No provision } \\
\text { of second } \\
\text { appeal * }\end{array}$ & $\begin{array}{l}\text { West Bengal } \\
\text { Land } \\
\text { Reforms \& } \\
\text { Tenancy } \\
\text { Tribunal }\end{array}$ & $* * *$ \\
\hline 2 & -Do- & $\begin{array}{c}\text { Dispute } \\
\text { between share- } \\
\text { cropper and } \\
\text { owners of land }\end{array}$ & $\begin{array}{c}\text { Prescribed } \\
\text { authority u/s } \\
17,18,19 \mathrm{~B} \& \\
20 \mathrm{~B} \\
\end{array}$ & $\begin{array}{l}\text { Before Collector } \\
\text { / DLLRO u/s } 19\end{array}$ & - Do -* & - Do -** & - Do -*** \\
\hline 3 & -Do- & $\begin{array}{l}\text { Recording of } \\
\text { bargadar }\end{array}$ & $\begin{array}{c}\text { Prescribed } \\
\text { authority u/s } \\
21 \mathrm{D} \text { read with } \\
\text { sec. } 50 / 51\end{array}$ & $\begin{array}{l}\text { Before Collector/ } \\
\text { DLLRO u/s } 54\end{array}$ & - Do -* & - Do -** & - Do -*** \\
\hline 4 & -Do- & $\begin{array}{c}\text { Implementation } \\
\text { of ceiling } \\
\text { provisions }\end{array}$ & $\begin{array}{c}\text { Revenue } \\
\text { Officer u/s } \\
\text { 14T(3), } \\
\text { 14T(5), } \\
14 \mathrm{~T}(6),\end{array}$ & $\begin{array}{l}\text { Before Collector } \\
\text { / DLLRO u/s } 54 \\
\text { read with sec. } \\
14 \mathrm{~T}(7)\end{array}$ & - Do -* & - Do -** & - Do -*** \\
\hline 5 & - Do - & $\begin{array}{c}\text { Dispute over } \\
\text { whether a land } \\
\text { is irrigated or } \\
\text { not }\end{array}$ & $\begin{array}{c}\text { Revenue } \\
\text { Officer u/s } \\
14 \mathrm{~N}\end{array}$ & $\begin{array}{l}\text { Before Collector } \\
\text { u/s } 54 \text { read with } \\
\text { sec. } 14 \mathrm{~T}(\mathrm{O})\end{array}$ & - Do -* & - Do -** & - Do -*** \\
\hline 6. & - Do - & $\begin{array}{c}\text { Ch.IIA } \\
\text { Restriction on } \\
\text { transfer of } \\
\text { Tribal Land }\end{array}$ & $\begin{array}{c}\text { Revenue } \\
\text { Officer u/s } \\
\text { 14C }\end{array}$ & $\begin{array}{c}\text { Appeal before } \\
\text { Civil Judge u/s } \\
14 \mathrm{H}\end{array}$ & $\begin{array}{l}\text { Revision } \\
\text { before } \\
\text { District } \\
\text { Judge }\end{array}$ & - Do - & - Do - \\
\hline 7 & - Do - & $\begin{array}{c}\text { Annulment of } \\
\text { settlement } \mathrm{u} / \mathrm{s} \\
49(1)\end{array}$ & $\begin{array}{c}\text { Revenue } \\
\text { Officer u/s } \\
\text { 49(2) (SDO) }\end{array}$ & $\begin{array}{c}\text { Before Collector/ } \\
\text { DLLRO u/s } \\
49(4)\end{array}$ & $\begin{array}{l}\text { No provision } \\
\text { of second } \\
\text { appeal }\end{array}$ & - Do -** & - Do -*** \\
\hline 8 & - Do - & Mutation & $\begin{array}{c}\text { Prescribed } \\
\text { Authority u/s } \\
50\end{array}$ & $\begin{array}{l}\text { Before Collector/ } \\
\text { DLLRO u/s } 54\end{array}$ & $*$ & ** & $* * *$ \\
\hline 9 & -Do- & $\begin{array}{c}\text { Preemption } \\
\text { u/s } 8\end{array}$ & $\begin{array}{c}\text { Civil Judge } \\
\text { u/s } 9\end{array}$ & $\begin{array}{l}\text { Appeal before } \\
\text { District Judge }\end{array}$ & - Do -* & - Do -** & - Do -*** \\
\hline 10 & -Do- & $\begin{array}{l}\text { Conversion of } \\
\text { land } u / s ~ 4(C)\end{array}$ & $\begin{array}{l}\text { Collector/ } \\
\text { DLLRO u/s } \\
4(\mathrm{C})\end{array}$ & $\begin{array}{c}\text { Before the } \\
\text { Divisional } \\
\text { Commissioner } \\
\text { u/s } 54\end{array}$ & - Do - & - Do - & - Do - \\
\hline
\end{tabular}

*But the order of the appellate authority can be challenged before the Tribunal

**and thereafter before the Division Bench of the High Court

***nobody can approach the High Court as a court of the first instance. Appeal against the order of the Tribunal can be made before a division bench of the High Court specially earmarked for hearing of such appeals 


\begin{tabular}{|c|c|c|c|c|c|c|c|}
\hline $\begin{array}{l}\text { Sl } \\
\text { No }\end{array}$ & $\begin{array}{c}\text { Name of the } \\
\text { Act }\end{array}$ & Dispute type & $\begin{array}{l}\text { Authority/ } \\
\text { court at first } \\
\text { instance }\end{array}$ & $\begin{array}{c}\text { First Appellate } \\
\text { Authority }\end{array}$ & $\begin{array}{l}\text { Second } \\
\text { Appellate } \\
\text { Authority }\end{array}$ & $\begin{array}{c}\text { Judicial } \\
\text { review } \\
\text { Authority }\end{array}$ & Remarks \\
\hline 1 & $\begin{array}{l}\text { West Bengal } \\
\text { Estates } \\
\text { Acquisition } \\
\text { Act, } 1953\end{array}$ & $\begin{array}{l}\text { Revision of } \\
\text { finally } \\
\text { published } \\
\text { Record of } \\
\text { Rights u/s } \\
\text { 44(2a) Suo- } \\
\text { motu }\end{array}$ & $\begin{array}{c}\text { Especially } \\
\text { empowered } \\
\text { Officer u/s } \\
44(2 \mathrm{a})\end{array}$ & $\begin{array}{l}\text { Appeal before } \\
\text { District Judge / } \\
\text { ADJ u/s 44(3) }\end{array}$ & & $\begin{array}{l}\text { West Bengal } \\
\text { Land } \\
\text { Reforms \& } \\
\text { Tenancy } \\
\text { Tribunal }\end{array}$ & \\
\hline 2 & -Do- & $\begin{array}{l}\text { Retention of } \\
\text { land by an } \\
\text { intermediary } \\
\text { u/s 57B }\end{array}$ & $\begin{array}{c}\text { Assistant } \\
\text { Settlement } \\
\text { Officer u/s } \\
57 \mathrm{~B}(3)\end{array}$ & $\begin{array}{c}\text { Before } \\
\text { Settlement } \\
\text { Officer u/s } \\
\text { 57B(4) and the } \\
\text { DLLRO }\end{array}$ & & $\begin{array}{l}\text { West Bengal } \\
\text { Land } \\
\text { Reforms \& } \\
\text { Tenancy } \\
\text { Tribunal }\end{array}$ & \\
\hline 3 & -Do- & $\begin{array}{c}\text { Determination } \\
\text { of } \\
\text { compensation } \\
\text { for } \\
\text { intermediaries } \\
\text { for mines \& } \\
\text { minerals } \\
\end{array}$ & $\begin{array}{l}\text { Compensation } \\
\text { Officer } \mathrm{u} / \mathrm{s} 33\end{array}$ & $\begin{array}{c}\text { The Mines } \\
\text { Tribunal u/s } 35 \\
\text { (District Judge \& } \\
\text { one mining } \\
\text { expert) }\end{array}$ & & $\begin{array}{l}\text { West Bengal } \\
\text { Land } \\
\text { Reforms \& } \\
\text { Tenancy } \\
\text { Tribunal }\end{array}$ & \\
\hline $\begin{array}{l}\text { SI } \\
\text { No }\end{array}$ & $\begin{array}{c}\text { Name of the } \\
\text { Act }\end{array}$ & Dispute type & $\begin{array}{c}\text { Authority/ } \\
\text { court at first } \\
\text { instance }\end{array}$ & $\begin{array}{c}\text { First Appellate } \\
\text { Authority }\end{array}$ & $\begin{array}{l}\text { Second } \\
\text { Appellate } \\
\text { Authority }\end{array}$ & $\begin{array}{c}\text { Judicial } \\
\text { review } \\
\text { Authority }\end{array}$ & Remarks \\
\hline 1 & $\begin{array}{l}\text { West Bengal } \\
\text { Acquisition of } \\
\text { Homestead } \\
\text { Land for } \\
\text { Agricultural } \\
\text { Labourers, } \\
\text { Artisans, } \\
\text { Fishermen } \\
\text { Act, } 1975\end{array}$ & $\begin{array}{l}\text { Homestead } \\
\text { Acquisition }\end{array}$ & Authority u/s 4 & $\begin{array}{c}\text { Before the } \\
\text { Collector } \\
\text { ( District Land \& } \\
\text { Land Reforms } \\
\text { Officer) u/s } 9\end{array}$ & & $\begin{array}{l}\text { West Bengal } \\
\text { Land } \\
\text { Reforms \& } \\
\text { Tenancy } \\
\text { Tribunal }\end{array}$ & \\
\hline 2 & $\begin{array}{l}\text { West Bengal } \\
\text { Restoration of } \\
\text { Alienated } \\
\text { Land Act, } 1973\end{array}$ & $\begin{array}{l}\text { Dispute on } \\
\text { restoration }\end{array}$ & $\begin{array}{c}\text { Special Officer } \\
\text { u/s } 4\end{array}$ & $\begin{array}{l}\text { Before Collector } \\
\mathrm{u} / \mathrm{s} 4 \mathrm{~A}\end{array}$ & & $\begin{array}{l}\text { West Bengal } \\
\text { Land } \\
\text { Reforms \& } \\
\text { Tenancy } \\
\text { Tribunal }\end{array}$ & \\
\hline 3 & $\begin{array}{c}\text { West Bengal } \\
\text { Thika Tenancy } \\
\text { Act, } 2001\end{array}$ & $\begin{array}{c}\text { Dispute on } \\
\text { Thika Tenancy }\end{array}$ & $\begin{array}{c}\text { Thika } \\
\text { Controller u/s } \\
5(3)\end{array}$ & $\begin{array}{c}\text { Appeal before } \\
\text { West Bengal } \\
\text { Land Reforms \& } \\
\text { Tenancy } \\
\text { Tribunal }\end{array}$ & & $\begin{array}{l}\text { Division } \\
\text { Bench of the } \\
\text { High Court. }\end{array}$ & \\
\hline
\end{tabular}

In the above detailed analysis, the dispute resolution provisions of the relevant Land laws in West Bengal have been clearly shown along with specific disputes to be resolved by the Revenue authorities or by the formal judicial dispute resolution system. It has also been discussed with case studies the average time taken for dispute resolution at the Revenue forum and the Judicial forum. For providing faster relief to litigants at the formal judicial forum in cases as per law, the provisions u/s 19(5) read with section 21 of the Legal Services Authority Act, 1987, the matters may brought under the purview of the Lok Adalat, as a forum for mutually accepted agreements reached through informal dispute resolution system at the district level, where large number of land related cases are pending as per report published by The Supreme Court of India on West Bengal.

128|Page Land Governance Assessment Framework - West Bengal 


\section{Data Source:}

\section{Data Reliability:}

\begin{tabular}{|c|c|c|l|}
\hline Panel & LGI & Dim. & $\begin{array}{l}\text { Land Governance Indicator } 24 \\
\text { Assignment of responsibility: responsibility for conflict } \\
\text { management at different levels is clearly assigned, in line with } \\
\text { actual practice, relevant bodies are competent in applicable legal } \\
\text { matters, and decisions can be appealed against. }\end{array}$ \\
\hline 8 & 1 & 4 & $\begin{array}{l}\text { There is an accessible, affordable and timely process for appealing disputed } \\
\text { rulings. }\end{array}$ \\
\hline \multirow{2}{*}{} & $\begin{array}{l}\text { A: A process exists to appeal rulings on land cases at reasonable cost with } \\
\text { disputes resolved in a timely manner. }\end{array}$ \\
\hline & $\begin{array}{l}\text { B: A process exists to appeal rulings on land cases at high cost with disputes } \\
\text { resolved in a timely manner. }\end{array}$ \\
\hline & $\begin{array}{l}\text { C: A process exists to appeal rulings on land cases at high cost and the process } \\
\text { takes a long time/ the costs are low but the process takes a long time. }\end{array}$ \\
\hline & D: A process does not exist to appeal rulings on land cases. \\
\hline
\end{tabular}

\section{Analysis:}

Regarding appeal Cases in Revenue Courts on land related disputes, it takes on an average ten months for disposal with a minimal cost, where as in a Civil Court a Title Suit is seldom resolved before two years in the earliest at a much higher cost. However both the courts are easily accessible to the litigant.

\section{Data Source:}

\section{Data Reliability:}

\begin{tabular}{|c|c|c|l|}
\hline Panel & LGI & Dim. & $\begin{array}{l}\text { Land Governance Indicator 25 } \\
\text { The share of land affected by pending conflicts is low and } \\
\text { decreasing. }\end{array}$ \\
\hline 8 & 2 & 1 & \begin{tabular}{l} 
Land disputes constitute a small proportion of cases in the formal legal system. \\
\hline
\end{tabular} \\
& $\begin{array}{l}\text { A: } \text { Land disputes in the formal court system are less than } 10 \% \text { of the total court } \\
\text { cases. }\end{array}$ \\
\hline $\begin{array}{l}\text { B: Land disputes in the formal court system are between } 10 \% \text { and } 30 \% \text { of the } \\
\text { total court cases. }\end{array}$ \\
\hline $\begin{array}{l}\text { C: } \text { Land disputes in the formal court system are between } 30 \% \text { and } 50 \% \text { of the } \\
\text { total court cases. }\end{array}$ \\
\hline $\begin{array}{l}\text { D: Land disputes in the formal court system are more than } 50 \% \text { of the total } \\
\text { court cases. }\end{array}$ \\
\hline
\end{tabular}

\section{Analysis:}

The number of Land dispute related cases in the formal legal system in the State varies between $10 \%$ and $30 \%$ of total cases. It also varies from district to district. A consolidated report on the total pending cases in the District and subordinate courts in West Bengal at the end of the quarter from 01-07-12 to 30-09-12 reveals the following data: 


\begin{tabular}{|l|r|}
\hline Cases & Number \\
\hline No. of civil cases: & $5,29,593$ \\
\hline No. of criminal cases & $\mathbf{2 1 , 1 5 , 4 1 4}$ \\
\hline Total & $\mathbf{2 6 , 4 5 , 0 0 7}$ \\
\hline
\end{tabular}

It is obvious from the above report that the percentage of civil cases in respect of the total number of cases is approximately $20 \%$ in the formal legal system.

Data Source: Report published by The Supreme Court of India, available on the websitehttp://supremecourtofindia.nic.in/courtnews.htm

Data Reliability: High

\begin{tabular}{|c|c|c|l|}
\hline Panel & LGI & Dim. & $\begin{array}{l}\text { Land Governance Indicator } 25 \\
\text { The share of land affected by pending conflicts is low and } \\
\text { decreasing. }\end{array}$ \\
\hline 8 & 2 & 2 & \begin{tabular}{l} 
Conflicts in the formal system are resolved in a timely manner. \\
\hline
\end{tabular} \\
& $\begin{array}{l}\text { A: A decision in a land-related conflict is reached in the first instance court } \\
\text { within } 6 \text { months for more than 90\% of cases. }\end{array}$ \\
\hline $\begin{array}{l}\text { B: A decision in a land-related conflict is reached in the first instance court } \\
\text { within 1 year for 90\% of cases. }\end{array}$ \\
\hline $\begin{array}{l}\text { C: A decision in a land-related conflict is reached in the first instance court } \\
\text { within 18 months for 90\% of cases. }\end{array}$ \\
\hline $\begin{array}{l}\text { D: A decision in a land-related conflict is reached in the first instance court } \\
\text { within 2 year or more for 90\% of cases. }\end{array}$ \\
\hline
\end{tabular}

\section{Analysis:}

Land disputes at the district land administration level, are normally resolved in a timely manner in most cases, because of inherent dispute resolution system. However, it is not so in the formal legal system, because of lengthy judicial process. In the land administration level, disputes are resolved within a few months after one or two hearing, if the cases are not complicated or large numbers of parties are not involved. But in the judicial forum, cases take much longer time to be heard and resolved, minimum two years on the average.

\section{Data Source:}

\section{Data Reliability:}

\begin{tabular}{|c|c|c|l|}
\hline Panel & LGI & Dim. & $\begin{array}{l}\text { Land Governance Indicator 25 } \\
\text { The share of land affected by pending conflicts is low and } \\
\text { decreasing. }\end{array}$ \\
\hline 8 & 2 & 3 & \begin{tabular}{l} 
There are few long-standing (> 5 years) land conflicts. \\
\hline
\end{tabular} \\
& $\begin{array}{l}\text { A: The share of long-standing land conflicts is less than } 5 \% \text { of the total } \\
\text { pending land dispute court cases. }\end{array}$ \\
\hline $\begin{array}{l}\text { B: The share of long-standing land conflicts is between } 5 \% \text { and } 10 \% \text { of the } \\
\text { total pending land dispute court cases. }\end{array}$ \\
\hline $\begin{array}{l}\text { C: The share of long-standing land conflicts is between } 10 \% \text { and } 20 \% \text { of the } \\
\text { total pending land dispute court cases. }\end{array}$ \\
\hline $\begin{array}{l}\text { D: The share of long-standing land conflicts is greater than } 20 \% \text { of the total } \\
\text { pending land dispute court cases. }\end{array}$ \\
\hline
\end{tabular}

130| Page Land Governance Assessment Framework- West Bengal 


\section{Analysis:}

On study of long pending cases in the Land Reforms Tenancy Tribunal, the grounds for such pendency appear to be, i) repeated adjournments sought by the applicant, ii) non-availability of the lawyer because of his otherwise engagements in other courts iii) non-submission of proper records or papers by interested parties, including the Government, etc.

\section{Data Source:}

\section{Data Reliability:}

\section{Panel 9: Institutional Arrangement and Policies}

\section{Indicators:}

1. Clarity of mandates and practice: institutional mandates concerning the regulation and management of the land sector are clearly defined, duplication of responsibilities is avoided and information is shared as needed.

2. Equity and non-discrimination in the decision-making process: policies are formulated through a decision-making process that draws on inputs from all concerned. The legal framework is non-discriminatory and institutions to enforce property rights are equally accessible to all.

\begin{tabular}{|c|c|c|c|}
\hline Panel & LGI & Dim. & $\begin{array}{l}\text { Land Governance Indicator } 26 \\
\text { Clarity of mandates and practice: institutional mandates } \\
\text { concerning the regulation and management of the land sector } \\
\text { are clearly defined, duplication of responsibilities is avoided } \\
\text { and information is shared as needed. }\end{array}$ \\
\hline 9 & 1 & 1 & $\begin{array}{l}\text { Land policy formulation, implementation and arbitration are separated to } \\
\text { avoid conflict of interest. }\end{array}$ \\
\hline & & & $\begin{array}{l}\text { A: In situations that can entail conflicts of interest or are sensitive to abuse } \\
\text { (e.g. transfers of land rights) there is a clear separation in the roles of policy } \\
\text { formulation, implementation and arbitration. }\end{array}$ \\
\hline & & & $\begin{array}{l}\text { B: In situations that can entail conflicts of interest or are sensitive to abuse } \\
\text { (e.g. transfers of land rights) there is some separation in the roles of policy } \\
\text { formulation, implementation and arbitration. }\end{array}$ \\
\hline & & & $\begin{array}{l}\text { C: In situations that can entail conflicts of interest or are sensitive to abuse } \\
\text { (e.g. transfers of land rights) there is some separation in the roles of policy } \\
\text { formulation, implementation and arbitration. }\end{array}$ \\
\hline & & & $\begin{array}{l}\text { D: In situations that can entail conflicts of interest or are sensitive to abuse } \\
\text { (e.g. transfers of land rights) there is no clear separation in the roles of } \\
\text { policy formulation, implementation and arbitration. }\end{array}$ \\
\hline
\end{tabular}

\section{Analysis:}

\section{Policy formulation}

Unlike some other states of India, in West Bengal there is no separate department in the Secretariat responsible for formulating policies. Policies are formulated at the highest level of government in individual departments. Where the policy involves a major issue approval of the cabinet is sought by the concerned department. Land policy is formulated in the department of Land and Land Reforms at the highest level i.e. the Minister-in-charge and the departmental secretary etc.

Inputs from field officers are sometimes taken into account while formulating policy. If necessary, discussions are also held with officers of the other departments which may be

131|Page Land Governance Assessment Framework - West Bengal 
affected by the proposed policy. The government being a political one, the political viability of the proposed policy is also discussed at the political level. Also, inputs from identifiable stake holders are assessed through discussions at political/ a - political level with the representatives of such stake holders before finalization of any policy. Sometimes the media also acts as a catalyst in formulation / modification of policy.

\section{Implementation}

The major Acts which are relevant for this dimension are, the Land Acquisition Act, the W.B. L.R. Act, the WBEA Act, the Homestead Act, the Kolkata Land Revenue Act and the Forests Acts including the Forests Rights Act, 2006. While the Forest Acts are implemented by the Forest Department, other Acts mentioned above excluding the L.A. Act are implemented by the directorate of land records and surveys. The LA Act is, however, implemented by the department itself through the collector of the district. The implementing agency though placed under the administrative control of the Land LR Department is separated from the area of policy formulation. Similar is the case with the Forest Directorate which is tasked with implementation of the Forest related laws.

\section{Arbitration / Appeal}

The legal forum relating to arbitration / appeal under different Acts is as under :

- Forest Acts:

The conservator of Forests exercises quasi-judicial powers while hearing cases. Therefore, there is no separation of arbitration from implementation, but arbitration is separate from policy formulation.

- WBEA Act :

i. Tribunal u/s 44(3) relating to correction of RoR chaired by either the District Judge or the additional District Judge

ii. Mines Tribunal u/s 361 regarding compensation for vested mining interests chaired by a district Judge or an Additional district Judge.

\section{- WBLR Act :}

i. Collector u/s 54 1(a) and Divisional Commissioner u/s 54 1(b) for any matter where there is no specific provisions for appeal in the Act.

ii. Civil Judge (Munsif)u/s/ 8(1) regarding exercise of right of pre-emption.

iii. Civil Judge $\mathrm{u} / \mathrm{s} 14 \mathrm{H}$ on matters relating to illegal transfer of lands by a tribal raiyat.

- Home stead Act :

Collector $\mathrm{u} / \mathrm{s}$ 9(1) regarding any question relating to vesting

The government has appointed the Sub-Divisional Officer as Collector u/s 9 (1) who is not a part of the implementing agency.

It is evident from the above that the dispensations provided in the WBEA Act, WBLR Act and the Homestead Act for arbitration / appeal are quite independent of and separated from the implementing agencies.

\section{Markings:}

(a) Forest Act:

The conservator of forests exercises quasi-judicial functions: hence the score should be: 
Separation of policy making from implementation: 10

Separation of policy making from arbitration: 10

Separation of implementation from arbitration: 0

Total score: 20 out of 30

(b) Land Acquisition Act :

The collector takes quasi-judicial hearings: hence the score should be :Separation of policy Making from implementation: 10

Separation of policy making from arbitration: 10

Separation of implementation from arbitration: 0

Total score: 20 out of 30

(c) WBEA Act:

Arbitration is made by members of the judicial service: hence the score shall be as under:

All three components i.e. policy making, implementation and arbitration are independent of one another. Hence Total score: 30 out of 30

(d) WBLR Act:

The collector [DLLRO] is part and parcel of the implementation team. Hence the score should be:

Separation of policy making from implementation: 10

Separation of policy making from arbitration: 10

Separation of implementation from arbitration: 0

Total : 20 out of 30

(e) Homestead Act: The collector [in this case the SDO] who hears appeal is not associated with implementation. Hence the score should be as under:

All three components are independent of one another.

Hence total score: 30 out of 30

(f) Kolkata Land - revenue Act:

Appeal u/s 8(1) against assessment of land revenue made by a Revenue Officer u/s 7(1) lies to the collector of Stamp Revenue, Kolkata and collectors of districts coming within the purview of this Act. Further, appeal against an order passed by the collector lies before the West Bengal Land Reforms and Tenancy Tribunal [Sec.8 (2)]. These institutions are independent of the implementing and policy making authorities. Hence the score should be: 30 out of 30 .

The total score for the dimension works out to 20 out of $30+30$ out of $30+20$ out of $30+30$ out of $30+30$ out of $30=130$ out of 150 , i.e., $86 \%$.

So, the ranking would be 'A'.

\section{Data Source:}

- L. A. Act

- W.B.E.A Act

- WBLR Act

- Homestead Act

- Kolkata Land - revenue Act

- Back ground Note for Land Tenure Recognition etc.

$\mathbf{1 3 3}$ | Page Land Governance Assessment Framework - West Bengal 


\begin{tabular}{|c|c|c|c|}
\hline Panel & LGI & Dim. & $\begin{array}{l}\text { Land Governance Indicator } 26 \\
\text { Clarity of mandates and practice: institutional mandates } \\
\text { concerning the regulation and management of the land sector } \\
\text { are clearly defined, duplication of responsibilities is avoided } \\
\text { and information is shared as needed. }\end{array}$ \\
\hline 9 & $\mathbf{1}$ & 2 & $\begin{array}{l}\text { Responsibilities of the ministries and agencies dealing with land do not } \\
\text { overlap (horizontal overlap). }\end{array}$ \\
\hline \multirow{4}{*}{, } & & & $\begin{array}{l}\text { A: The mandated responsibilities exercised by the authorities dealing with } \\
\text { land governance are non-overlapping with those of other land sector } \\
\text { agencies. }\end{array}$ \\
\hline & & & $\begin{array}{l}\text { B: The mandated responsibilities of the various authorities dealing with } \\
\text { land administration issues are defined with a limited amount of overlap } \\
\text { with those of other land sector agencies but there are few problems. }\end{array}$ \\
\hline & & & $\begin{array}{l}\text { C: The mandated responsibilities of the various authorities dealing with } \\
\text { land administration issues are defined but institutional overlap with those } \\
\text { of other land sector agencies and inconsistency is a problem. }\end{array}$ \\
\hline & & & $\begin{array}{l}\text { D: The mandated responsibilities of the various authorities dealing with } \\
\text { land administration are defined poorly, if at all, and institutional overlap } \\
\text { and inconsistency is a serious problem. }\end{array}$ \\
\hline
\end{tabular}

\section{Analysis:}

At the government level the domain of activities i.e. functions, duties and responsibilities etc., of different departments are clearly defined following the RULES OF BUSINESS leaving no or little scope for any overlap which may result in functional conflict. Besides, legislations are made or policies formulated by different departments in consultation with other departments who are stake holders for a particular piece of legislation or policy. This is done not only to make the legislation or policy formulation foolproof but also to pre-empt any overlap in the functional domain.

The L\& LR department makes laws and formulates policies for land administration. Similarly, a few other departments like the Commerce and Industries Department, Department of Urban Development etc. administer laws by which different land related agencies have been created and formulates policies to regulate the functions of these agencies. No overlap worth the name among the different legislations and the policies formulated has been identified. Minor conflicts arising out of 'perceived' overlap or lack of jurisdiction etc are resolved at the appropriate local level.

A case of overlap at the functional [local] level between the Forest Department and the Backward Classes Welfare Department in course of implementing the FRA 2006 may be cited as an example. Way back, during preparation of r-o-r and maps under the EA Act there arose disputes between the forest officials and the L and LR department on the question of recording and vesting of jungles and shrubs measuring less than three acres. These disputes were resolved at the local level in course of time.

As there is no horizontal overlap and the mandated responsibilities exercised by the authorities dealing with land governance is non-overlapping, the ranking is ' $A$ '

Data Source: Rules of Business 2012

Data Reliability: High

\begin{tabular}{|l|l|l|l|}
\hline Panel & LGI & Dim. & Land Governance Indicator 26 \\
\hline
\end{tabular}

$\mathbf{1 3 4}$ | Page Land Governance Assessment Framework - West Bengal 


\begin{tabular}{|c|c|c|c|}
\hline & & & $\begin{array}{l}\text { Clarity of mandates and practice: institutional mandates } \\
\text { concerning the regulation and management of the land sector are } \\
\text { clearly defined, duplication of responsibilities is avoided and } \\
\text { information is shared as needed. }\end{array}$ \\
\hline \multirow[t]{5}{*}{9} & $\mathbf{1}$ & 3 & Administrative (vertical) overlap is avoided. \\
\hline & & & $\begin{array}{l}\text { A: Assignment of land-related responsibilities between the different levels of } \\
\text { administration and government is clear and non-overlapping. }\end{array}$ \\
\hline & & & $\begin{array}{l}\text { B: Division of land-related responsibilities between the different levels of } \\
\text { administration and government is clear with minor overlaps. }\end{array}$ \\
\hline & & & $\begin{array}{l}\text { C: Division of land-related responsibilities between the different levels of } \\
\text { administration and government is characterized by large overlaps. }\end{array}$ \\
\hline & & & $\begin{array}{l}\text { D: Division of land-related responsibilities between the different levels of } \\
\text { administration and government is unclear. }\end{array}$ \\
\hline
\end{tabular}

\section{Analysis:}

The government agencies like the Directorate of Land Records and Surveys (DLRS), the forest directorate etc tasked with implementation of laws and policies are multi-tiered in structure. The tiers spread from the state to the village. For example, the administrative echelon of the land records directorate starts at the state level and ends at the village gram panchayat level with the district, sub-divisional and block levels in between. The functions, duties and responsibilities of the different categories of functionaries manning these layers are so structured that there is no scope for overlap. The functions, duties etc are assigned to each layer keeping in mind the principle of subsidiarity, i.e. the decision making powers and duties should assigned at the appropriate level where those are best exercised and discharged.

The functions and duties of the different categories of functionaries in the same level are clearly defined by order issued by the appropriate authorities, the government or the land records directorate. Resultantly, there is little scope for any inter-layer (vertical) or intra - layer [horizontal] overlap in functioning. Functional overlap of inappreciable measures, if any, does not in any way tell upon the working of the system.

Agencies other than the state government and local institutions dealing with land operate on a structured pattern of distribution of duties among different tiers avoiding overlap as far as possible.

There is another area which may be relevant for the purposes of this analysis, i.e. the area of concurrent jurisdiction. An example may be cited by way explanation. The District Land and Land Reforms Officer is competent to issue permission for conversion of land as Collector $\mathrm{u} / \mathrm{s}$ 4C (i) of WBLR Act. Subsequently this power was conferred upon the Sub-divisional Land and Land Reforms Officers for lands measuring up to 0.30 acres [30 decimals]. Seemingly, this is a case of overlap in so far a subdivision is concerned. But the DLLROs never exercise this power as a matter of administrative expediency unless forced by circumstances to do so. Such overlaps which are sometimes necessitated for implementation of laws should better be appropriately called virtual overlap. So, Assignment of land-related responsibilities between the different levels of administration and government is clear and non-overlapping and the ranking is ' $A$ '

\section{Data Source:}

\section{Data Reliability:}

\begin{tabular}{|l|l|l|l|}
\hline Panel & LGI & Dim. & $\begin{array}{l}\text { Land Governance Indicator } 26 \\
\text { Clarity of mandates and practice: institutional mandates } \\
\text { concerning the regulation and management of the land sector } \\
\text { are clearly defined, duplication of responsibilities is avoided }\end{array}$ \\
\hline
\end{tabular}

135 | Page Land Governance Assessment Framework - West Bengal 


\begin{tabular}{|c|c|c|c|}
\hline & & & and information is shared as needed. \\
\hline \multirow[t]{5}{*}{9} & \multirow[t]{5}{*}{$\mathbf{1}$} & 4 & $\begin{array}{l}\text { Land right and use information is shared by public bodies; key parts are } \\
\text { regularly reported on and publicly accessible. }\end{array}$ \\
\hline & & & $\begin{array}{l}\text { A: Information related to rights in land is available to other institutions } \\
\text { that need this information at reasonable cost and is readily accessible, } \\
\text { largely due to the fact that land information is maintained in a uniform } \\
\text { way. }\end{array}$ \\
\hline & & & $\begin{array}{l}\text { B: Information related to rights in land is available to interested } \\
\text { institutions and although this information is available at reasonable cost, it } \\
\text { is not readily accessible as the information is not maintained in a uniform } \\
\text { way. }\end{array}$ \\
\hline & & & $\begin{array}{l}\text { C: Information related to rights in land is available to interested } \\
\text { institutions but this information is not readily accessible or not available at } \\
\text { a reasonable cost. }\end{array}$ \\
\hline & & & $\begin{array}{l}\text { D: Information related to rights in land is not available to interested } \\
\text { institutions as a matter of policy or practice. }\end{array}$ \\
\hline
\end{tabular}

\section{Analysis:}

In West Bengal preparation of record-of-rights is preceded by a detailed cadastral survey of the mouza (village). All plots in the village are mapped ordinarily in the scale of $16 "=1$ mile and their areas recorded. R-o-R thereafter prepared incorporating therein all tenurial rights in respect of plot / plots so mapped. The original records are kept and maintained in the office of the Block Level Land and Land Reforms Office [BLLRO]. As a matter of fact, this office is of the repository not only of all information and documents relating to land rights and land use but also of documents relating to land, land tenure and land revenue administration.

The different government departments or public bodies like municipalities, panchayats etc. maintain inventories of land owned and managed by them but the records are not updated on a regular basis. The land properties belonging to the public bodies are not recorded in the r-o$r$ maintained in the office of the BLLRO.

Individuals, institutions, unions government departments, public bodies, organizations, academic institutions, researchers etc. have to primarily fall back upon the BLLRO for different kinds of land related information.

Record-of-rights pertaining to all villages of the state have already been computerized. On request a copy of the r-o-r is available from the office of the BLLRO the same day, the cost per sheet being Rs. 10.00 only (over the counter service).

Copies of village maps are available on request from the office of the District Land and Land Reforms Officer [DLLLRO] at a cost of Rs. 100.00 only per sheet. Maps are, however, in a process of digitization. Once this is done, availability of information will be quicker and easier. Maintenance level of the records and maps is rather low. This is primarily due to filing of large numbers of mutation applications resulting in a large gap between filing and disposal. There is no mechanism in place for regular reporting of the key parts of land right and use information.

The L\&LR Department uploads record- of- rights and maps of all villages in the Website of the Department. This has greatly facilitated access to these documents.

Data Source: Directorate of Land Records and Surveys

Data Reliability: High

136|Page Land Governance Assessment Framework - West Bengal 
Policy Recommendation: A drive needs to be initiated by the government for ensuring all the land properties being physically verified, records and registers updated jointly in collaboration with the L\&LR department and field offices.

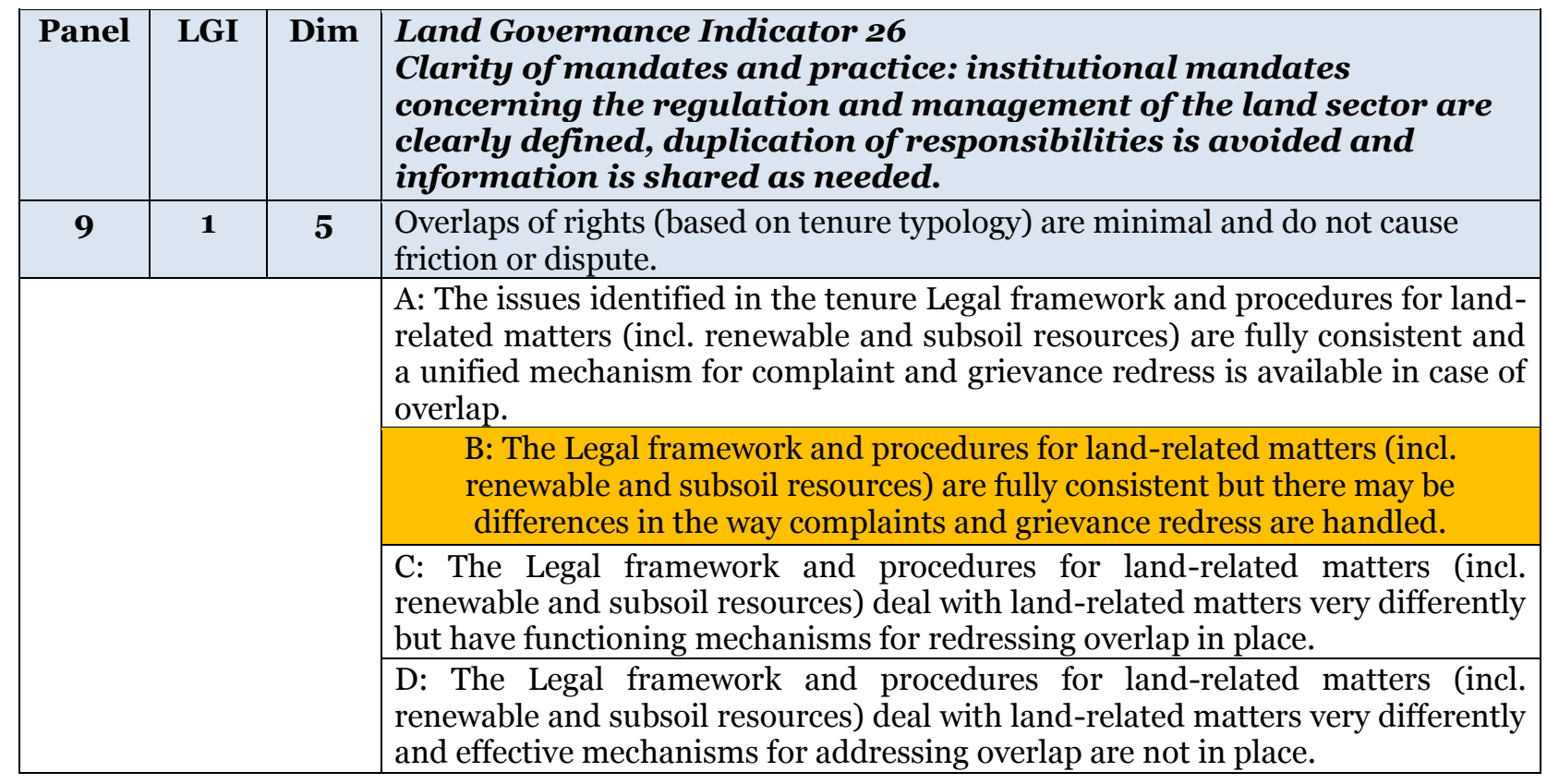

\section{Analysis:}

Overlap of rights is not a very common phenomenon in West Bengal in respect of land administration and management. During preparation of maps of the villages adjoining forest areas under the WBEA Act [mid-fifties to early sixties] minor disputes arose on the question of jurisdiction between the officials of the Land \& LR Department and the Forest Department. These disputes or frictions which were of minor nature were resolved at local level, if necessary with the intervention of the higher authorities.

Another common example of overlap of legally recognized right [of cultivation] and customary right of grazing may be cited here. When the time lag between cultivation of two crops is large the agricultural field is often used by the local community for grazing of cattle. This is a customary right of the nature of an easement. This right is being exercised customarily without any let or hindrance from the owners of the lands.

In case of a mining lease the surface lands are also included in the lease. The lessee ordinarily uses the land for open cast mining, storage of machineries etc. The members of the whole community customarily use these surface lands for pastoral purposes. The exercise of these overlapping rights has not been a cause of friction between the miners and the local community.

The incidence of friction arising out of exercise of multiple rights is so minimal that setting up of any common mechanism for resolution of such friction/conflict has not been considered necessary.

So, the issues of overlap though minimal, a uniform procedure of complaint and grievance redressal is not in place. 


\begin{tabular}{|c|c|c|c|}
\hline Panel & LGI & Dim. & $\begin{array}{l}\text { Land Governance Indicator } 26 \\
\text { Clarity of mandates and practice: institutional mandates } \\
\text { concerning the regulation and management of the land sector are } \\
\text { clearly defined, duplication of responsibilities is avoided and } \\
\text { information is shared as needed. }\end{array}$ \\
\hline \multirow[t]{5}{*}{9} & \multirow[t]{5}{*}{1} & 6 & $\begin{array}{l}\text { Ambiguity in institutional mandates (based on institutional map) does not cause } \\
\text { problems. }\end{array}$ \\
\hline & & & $\begin{array}{l}\text { A: The processes applied by public institutions dealing with land are fully } \\
\text { integrated and consistent. }\end{array}$ \\
\hline & & & $\begin{array}{l}\text { B: With minor exceptions, the processes applied by public institutions dealing } \\
\text { with land are fully integrated and consistent. }\end{array}$ \\
\hline & & & $\begin{array}{l}\text { C: Different public institutions deal with land-related matters very differently } \\
\text { but functioning mechanisms for coordination are in place and regularly used. }\end{array}$ \\
\hline & & & $\begin{array}{l}\text { D: Different public institutions deal with land-related matters very differently } \\
\text { and effective mechanisms for coordination are not in place. }\end{array}$ \\
\hline
\end{tabular}

\section{Analysis:}

In West Bengal no formal mechanism or system has been put in place while dealing with land matters. The L\&LR Department deals with land issues and as custodian of all government lands acts as a coordinator when any situation arises for allotment of any government land to any department or any public body for public purpose. At the district level this coordination is done by the DLLRO who is also an Additional District Magistrate and Additional Collector. This coordination is done by the DLLRO as part and parcel of the collectorate.

The DLLRO is an inseparable part of the Directorate of Land Records and Surveys and the nodal officer at the district level for all functions relating to preparation of maps and r-o-r and related matters. For the purposes of these functions, the DLLRO and all functionaries and officers subordinate to him are quite separated from the district collectorate and act independently subject to the supervision of the Director of Land Records and Surveys.

In addition to the r-o-r which has been fully computerized all other records relating to mutation, land use change etc. are maintained in the office of BLLRO who functions under the DLLRO.

Records relating to land acquisition, registration etc are maintained by different wings of the collectorate i.e. LA records being maintained by the LA wing under an additional collector ordinarily other than the DLLRO as the head and the registration records by the District Register.

In dealing with land matters there is some coordination among the different wings though no formal mechanism to ensure coordination has been set up. Processes of dealing with land by different agencies are not regulated by the same set of rules, manuals and administrative orders. Hence there remains scope for differences of processes and procedures followed for dealing with land by different public institutions.

\section{Data Source:}

- Practice and Procedure Manual

- L.A. Manual

- Records Manual

- Instructions issued by the Land records directorate.

Data Reliability: High

$\mathbf{1 3 8 | P a g e ~ L a n d ~ G o v e r n a n c e ~ A s s e s s m e n t ~ F r a m e w o r k ~ - ~ W e s t ~ B e n g a l ~}$ 


\begin{tabular}{|c|c|c|c|}
\hline Panel & LGI & Dim. & $\begin{array}{l}\text { Land Governance Indicator } 27 \\
\text { Equity and non-discrimination in the decision-making process: } \\
\text { policies are formulated in a broad public process, address equity, } \\
\text { and implementation is meaningfully monitored. }\end{array}$ \\
\hline \multirow[t]{5}{*}{9} & 2 & $\mathbf{1}$ & $\begin{array}{l}\text { Land policies and regulations are developed in a participatory manner } \\
\text { involving all relevant stakeholders. }\end{array}$ \\
\hline & & & $\begin{array}{l}\text { A: A comprehensive land policy exists or can be inferred by the existing } \\
\text { legislation, and those affected by decisions were consulted beforehand and } \\
\text { their feedback on the resulting policy is incorporated. }\end{array}$ \\
\hline & & & $\begin{array}{l}\text { B: A comprehensive land policy exists or can be inferred by the existing } \\
\text { legislation, and sections of the community affected by these decisions are } \\
\text { informed, but feedback is usually not sought or not used in making decisions }\end{array}$ \\
\hline & & & $\begin{array}{l}\text { C: Policy exists or can be inferred by the existing legislation but it is incomplete } \\
\text { (some key aspects are missing or only covers part of the country such as only } \\
\text { urban or only rural areas) and decisions that affect some sections of the } \\
\text { community are made without prior consultation. }\end{array}$ \\
\hline & & & $\begin{array}{l}\text { D: No clear land policy exists or can be inferred by the existing legislation and } \\
\text { land policy decisions are generally taken without consultation of those affected. }\end{array}$ \\
\hline
\end{tabular}

\section{Analysis:}

In West Bengal overall land policy could be inferred from the existing legislations. The state enacted a series of land related laws after Independence. The first law, the W.B. Bargadars Act, 1950 was almost forced upon the government by the famous Tebhaga movement focused inter alia on the issue of division of share in barga cultivation. The principal stakeholders i.e. the bargadars being the agitators there was little scope for consultation with them in the process of formulating policy and subsequent enactment.

The enactment of the second Act i.e. the WBEA Act, 1950 was preceded by deliberations at all India level on the issues of abolition of intermediary interests, imposition of ceiling etc. As a matter of policy the state just fell in line with other states of the country. It is difficult to say at this distant date to what extent, if at all, the state government consulted the stake-holders on important questions like fixing ceiling limit, quantum of compensation etc.

Between the fag end of the seventies and early eighties "concentization" camps were held in rural areas where interaction took place among the different categories of stake-holders i.e. bargadars, land owners etc, representatives of peasants' organizations, panchayat members on the one hand and the administration i.e. Minister-in-charge, senior officers of the L and LR department on the other. Inputs received during such interactions were sometimes taken into account in policy formulation and legislation. A case in point is the insertion of sec $21 \mathrm{~B}$ of the WBLR Act regarding presumption of barga cultivation.

But except in some sporadic cases as mentioned above, feedback is usually not sought or not used in decision making.

Data Source: W.B. Bargadars Act, 1950

Data Reliability: High

139|Page Land Governance Assessment Framework - West Bengal 


\begin{tabular}{|c|c|c|c|}
\hline Panel & LGI & Dim & $\begin{array}{l}\text { Land Governance Indicator } 27 \\
\text { Equity and non-discrimination in the decision-making process: } \\
\text { policies are formulated in a broad public process, address equity, } \\
\text { and implementation is meaningfully monitored. }\end{array}$ \\
\hline \multirow[t]{5}{*}{9} & 2 & 2 & $\begin{array}{l}\text { Land policies address equity and poverty reduction goals; progress towards } \\
\text { these is publicly monitored. }\end{array}$ \\
\hline & & & $\begin{array}{l}\text { A: Land policies incorporate clearly formulated equity and poverty objectives } \\
\text { that are regularly and meaningfully monitored, and their impact on equity and } \\
\text { poverty issues is compared to that of other policy instruments. }\end{array}$ \\
\hline & & & $\begin{array}{l}\text { B: Land policies incorporate clearly formulated equity and poverty objectives } \\
\text { that are regularly and meaningfully monitored but their impact on equity and } \\
\text { poverty issues is not compared to that of other policy instruments. }\end{array}$ \\
\hline & & & $\begin{array}{l}\text { C: Land policies incorporate some equity and poverty objectives but these are } \\
\text { not regularly and meaningfully monitored. }\end{array}$ \\
\hline & & & D: Equity and/or poverty issues are not considered by land policies. \\
\hline
\end{tabular}

\section{Analysis:}

The land laws in West Bengal from which the policy could be inferred contain provisions focusing on equity and poverty objectives. The Bargadars Act, 1950 focused on the bargadars who form a significant segment of the state's cultivating community. The WBEA Act, 1953 demolished the persecutors' institution of intermediaries and brought the persecuted [raiyats] directly under the state. It also provided for imposition of ceiling and vesting of the ceiling surplus land. Provisions for distribution of land assets to the landless in the sister Act i.e. the WBLR Act paved the way for an egalitarian society conducive to an equity-oriented development - the figures available from department of L\&LR indicates (till 31 March, 2011):

Total no. of pattadars benefited out of land distribution- 30.47 lakh
a) Out of this, SC pattadar
- 11.21 lakh
b) ST pattadar
-5.42 lakh
c) Minority community pattadar - 3.66 lakh

Disadvantaged section (SC, ST and Minority) of the rural society benefited is $66 \%$

Through implementation of the provisions of the Homestead Act, 1975 homesteads could be provided to about 3.27 lakh homeless families who mostly comprise of ST, SC and minority community and all are land-poor[Dec, 2013].

The bargadars were armed with a documented right of cultivation and an enhanced sense of security of tenure as a result of recording of their names in the r-o-r during implementation of "Operation Barga" program. This would provide them with impetus to invest more for cultivation both in terms of money and labor. Also, through distributive land reforms land asset could be given to 3.16 million beneficiaries creating as much new tenure [Dec, 2013].

Unfortunately, the land policy and legislation totally lack equity objectives in respect of women. Priority upon women in the matter of land distribution as in the case of members of the scheduled tribes could be a good avenue for empowering women through endowment of land asset. It is only from 1990 joint pattas are being given in the names of both husband and wife by virtue of an administrative order.

Several studies at micro level with very small samples were carried out by scholars and researchers to evaluate the impact of the state's land reform efforts on the beneficiaries i.e. pattadars and bargadars.

140|Page Land Governance Assessment Framework - West Bengal 
Some studies found a change in the levels of living of poor villagers including pattadar. A betterment of the socio-economic status of these people was also observed. Another study had found that as a result of the reforms the rural landed elite has lost their social and political authority over the general rural population. Another researcher found that operation barga resulted in increased production.

A macro level study with large samples [pattadars: 21712, bargadars: 13878] was sponsored by the State Institute of Panchayats and Rural Development, Kalyani. The study did not address issues like child labor, out-migration of labor etc. But results of some of the social indicators revealed that after the reforms there was increased schooling of children, literacy rate of the beneficiaries was found comparable with the general literacy rate, level of immunization of children showed a satisfactory level.

Some of the economic indicators suggested increased purchasing power, higher productivity [comparable with general productivity], enhanced use of fertilizer and access to irrigation etc.

State governments have been traditionally shy of evaluating their own performance through field studies. There is also no formal monitoring system to study the impact of the legal provisions relating to equity and poverty reduction.

\section{Data Source:}

(i) John Harris, what is happening in rural West Bengal, EPW, June 12, 1993

(ii) RatanKhasnobis, Tenurial conditions in West Bengal, EPW, December 31, 1994.

(iii) Directorate of Land Records and Surveys, W.B.

(iv) Anil K. Chakraborti, Apurba Kr. Mukhopadhyay, Debesh Roy, Beneficiaries of Land reforms The West Bengal Scenario, SIPRD Kalyani, 2003.

Data Reliability: High

\begin{tabular}{|c|c|c|c|}
\hline Panel & LGI & Dim & $\begin{array}{l}\text { Land Governance Indicator } 27 \\
\text { Equity and non-discrimination in the decision-making process: } \\
\text { policies are formulated in a broad public process, address equity, and } \\
\text { implementation is meaningfully monitored. }\end{array}$ \\
\hline 9 & 2 & 3 & $\begin{array}{l}\text { Land policies address ecological and environmental goals; progress towards these } \\
\text { is publicly monitored. }\end{array}$ \\
\hline & & & $\begin{array}{l}\text { A: Land policies incorporate clearly formulated ecology and environmental } \\
\text { sustainability objectives that are regularly and meaningfully monitored, and their } \\
\text { impact is compared to that of other policy instruments. }\end{array}$ \\
\hline & & & $\begin{array}{l}\text { B: Land policies incorporate clearly formulated ecology and environmental } \\
\text { sustainability objectives that are regularly and meaningfully monitored but their } \\
\text { impact is not compared to that of other policy instruments. }\end{array}$ \\
\hline & & & $\begin{array}{l}\text { C: Land policies incorporate some ecology and environmental sustainability } \\
\text { objectives but these are not regularly and meaningfully monitored. }\end{array}$ \\
\hline & & & $\begin{array}{l}\text { D: Ecology and environmental sustainability issues are not considered by land } \\
\text { policies. }\end{array}$ \\
\hline
\end{tabular}

\section{Analysis:}

Most of the land related major Acts in West Bengal were enacted much before ecology and environment issues came in the development discourse in a strident way. This will explain why these two issues were not at all addressed by these Acts except the L.R. Act which is the latest in the series. The provisions in the above Act are briefly enumerated below:

141| Page Land Governance Assessment Framework - West Bengal 
A raiyatis required to maintain and preserve his land in such a way that - (i) its area is not diminished; or (ii) its character is not changed; or (iii) it is not used for any purpose other than the purpose for which it was settled, without the permission of the collector. Again by virtue of sec $4 \mathrm{~A}(\mathrm{i})$ of the Act the collector of Darjeeling district may issue directions to the raiyats of the three hilly subdivisions of Darjeeling, Kurseong and Kalimpong as to the form of cultivation to be adopted by them. The collector is also empowered to prevent araiyat from cutting more than one tree from his land without the former's permission. These regulatory measures are intended to prevent soil erosion or landslides so that ecological balance may be maintained.

Sec $4 \mathrm{C}$ (1) requires a raiyat to obtain permission from the collector for any change of classification of his land. If the change sought for is to establish an industry or brick field etc which may result in noxious waste products which may adversely affect environment, the collector may withhold permission of conversion [rule 164(i), W.B. Land and Land Reforms Manual, 2003]

In view of the importance of the above legal provisions those were followed up by the appropriate authorities [the then Board of Revenue] by issue of detailed instructions to the field level officers.

In November 2005 West Bengal government promulgated the landmark environmental notification, the East Kolkata Wetlands (Conservation and Management) Ordinance (enactment in 2006) to safeguard the 12,500 hectares (comprising $46 \%$ water body and $39 \%$ agricultural land) fragile wetland located in the eastern fringes of the city of Kolkata. These wetlands are well known over the world for their multiple uses. The wetlands are man-made and the system of wastewater treatment is the largest in the world. It has saved the city from constructing and maintaining a wastewater treatment plant. The East Kolkata Wetlands Management Authority formed under the provisions of the Act is chaired by the Chief Secretary, has been entrusted with the statutory responsibility for conservation and maintenance of the wetland area by maintaining the existing land use practices.

The provisions related to environment and ecology in these legislations mentioned above needs to be enforced rigorously through a functional monitoring mechanism.

\section{Data Source:}

- W. B. L. R Act

- W.B. Land and Land Reforms Manual, 1991

- East Kolkata Wetland (Conservation and Management) Act, 2006

- General Instructions issued by the Board of Revenue.

Data Reliability: High

142 Page Land Governance Assessment Framework - West Bengal 


\begin{tabular}{|c|c|c|c|}
\hline Panel & LGI & Dim. & $\begin{array}{l}\text { Land Governance Indicator } 27 \\
\text { Equity and non-discrimination in the decision-making process: } \\
\text { policies are formulated in a broad public process, address equity, } \\
\text { and implementation is meaningfully monitored. }\end{array}$ \\
\hline \multirow[t]{5}{*}{9} & 2 & 4 & $\begin{array}{l}\text { The implementation of land policy is costed, matched with benefits and } \\
\text { adequately resourced. }\end{array}$ \\
\hline & \multirow{4}{*}{ 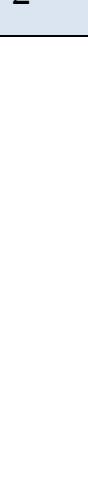 } & & $\begin{array}{l}\text { A: Implementation of land policy is costed, expected benefits identified and } \\
\text { compared to cost, and there are a sufficient budget, resources and institutional } \\
\text { capacity for implementation. }\end{array}$ \\
\hline & & & $\begin{array}{l}\text { B: The implementation of land policy is costed, though not necessarily based } \\
\text { on a comparison of expected benefits and costs. There is an adequate budget, } \\
\text { resources and institutional capacity. }\end{array}$ \\
\hline & & & $\begin{array}{l}\text { C: The implementation of land policy is not fully costed and/or to implement } \\
\text { the policy there are serious inadequacies in at least one area of budget, } \\
\text { resources or institutional capacity. }\end{array}$ \\
\hline & & & $\begin{array}{l}\text { D: The implementation of land policy is not costed and there is inadequate } \\
\text { budget, resources and capacity to implement the land policy. }\end{array}$ \\
\hline
\end{tabular}

\section{Analysis:}

The implementation of land policy is entrusted primarily to the Directorate of Land Records and Surveys. Funds are placed in the annual state budget at the disposal of the directorate under plan and non-plan heads.

No allotment of funds is earmarked separately for each item of implementation programme and is not costed.

No machinery worth the name is in place in any of the implementing agencies to match the implementation of land policy with the benefits accruing.

Financial resources for implementation of land policy come from the Central and State governments. The cost related to HR/ Staff is budgeted from the state resources. But this resource and physical resources are not adequate for proper and timely implementation of land policy. This will be evident from acute shortage of manpower and poor state of physical infrastructure.

\section{Data Source:}

\section{Data Reliability:}

Policy Recommendation: The L\&LR department to have a better human resource infrastructure by way of filling up of the larger vacancies in field offices along with a policy for staff capacity development equipping the HR for improved and citizen-friendly service delivery. 


\begin{tabular}{|c|c|c|c|}
\hline Panel & LGI & Dim & $\begin{array}{l}\text { Land Governance Indicator } 27 \\
\text { Equity and non-discrimination in the decision-making process: } \\
\text { policies are formulated in a broad public process, address equity, } \\
\text { and implementation is meaning fully monitored. }\end{array}$ \\
\hline \multirow[t]{5}{*}{9} & 2 & 5 & $\begin{array}{l}\text { There is regular and public reporting indicating progress in policy } \\
\text { implementation. }\end{array}$ \\
\hline & & & $\begin{array}{l}\text { A: Formal land institutions report on land policy implementation in a regular, } \\
\text { meaningful, and comprehensive way with reports being publicly accessible. }\end{array}$ \\
\hline & & & $\begin{array}{l}\text { B: Formal land institutions report on land policy implementation in a regular } \\
\text { and meaningful way but reports are not made public. }\end{array}$ \\
\hline & & & $\begin{array}{l}\text { C: Formal land institutions report on land policy implementation but in a way } \\
\text { that does not allow meaningful tracking of progress across different areas or in } \\
\text { a sporadic way. }\end{array}$ \\
\hline & & & $\begin{array}{l}\text { D: Formal land institutions report on policy implementation only in exceptional } \\
\text { circumstances or not at all. }\end{array}$ \\
\hline
\end{tabular}

\section{Analysis:}

In West Bengal land policy can be inferred from the provisions in the various land related legislations like the W.B.E.A. Act, the W.B.LR, Act, the Homestead Act, etc. Implementation of the provisions of these laws may be construed as the implementation of the land policy. There is, however, another Act i.e. the Kolkata Land-revenue Act, 2003 regarding survey, preparation of r-o-r and determination and collection of land revenue in respect of the areas coming within the purview of this Act.

The DLRS is primarily responsible for policy implementation i.e. implementation of the provisions of these Acts. The directorate is entrusted with the following key functions:

1. Preparation / revision of cadastral maps

2. Preparation / revision of RoR

3. Implementation of ceiling provisions under the WBEA Act and WBLR Act.

4. Distribution of land to landless and land-poor

5. $\quad$ Recording of such beneficiaries (pattadars)

6. Maintenance of RoR i.e., mutation

7. Determination and collection of revenue under the WBLR Act

8. Recording of beneficiaries under the Homestead Act

9. Collection of revenue under the Kolkata Land Revenue Act.

During the budget speech every year the details of performance of the department along with progress are reported in the Assembly. The monthly and cumulative performance in respect of different programs is documented. Both the assembly speech on departmental activities and progress thereof and the performance reports produced monthly by the DLRS are not publicly accessible.

\section{Data Source:}

- Instructions of the Board of Revenue,

- Directorate of Land Records and Surveys

Data Reliability: High

Policy Recommendation: The budget speech and information related to performance of the department and progress thereof needs to be uploaded in the departmental website banglarbhumi.gov.in

144|Page Land Governance Assessment Framework - West Bengal 


\begin{tabular}{|c|c|c|c|}
\hline Panel & $\begin{array}{l}\text { LG } \\
\text { I }\end{array}$ & Dim & $\begin{array}{l}\text { Land Governance Indicator } 27 \\
\text { Equity and non-discrimination in the decision-making process: } \\
\text { policies are formulated in a broad public process, address equity, and } \\
\text { implementation is meaningfully monitored. }\end{array}$ \\
\hline 9 & 2 & 6 & $\begin{array}{l}\text { Land policies help to improve land use by low-income groups and those who } \\
\text { experienced injustice. }\end{array}$ \\
\hline & & & $\begin{array}{l}\text { A: Policy is in place to improve access to and productive use of assets by poor and } \\
\text { marginalized groups, and is applied in practice and is effective }\end{array}$ \\
\hline & & & $\begin{array}{l}\text { B: Policy is in place to improve access to and productive use of assets by poor and } \\
\text { marginalized groups, is applied in practice, but is not effective }\end{array}$ \\
\hline & & & $\begin{array}{l}\text { C: Policy is in place to improve access to and productive use of assets by poor and } \\
\text { marginalized groups but is not enforced }\end{array}$ \\
\hline & & & $\begin{array}{l}\text { D: No policy in place to improve access to and productive use of assets by poor and } \\
\text { marginalized groups. }\end{array}$ \\
\hline
\end{tabular}

\section{Analysis:}

Land policies of the successive governments in West Bengal have helped the rural poor to make better use of land.

Bringing all the tenants directly under the state in the wake of abolition of zamindary and exemption of the smaller ones from the obligation of paying land revenue have freed the poorer tenants from the fear of losing their lands. They definitely try their best to improve the land use.

The policy towards the bargadars - by preventing eviction, making their rights heritable, providing very cheap mechanism to resolve disputes with the owners of the land at the block level, providing for intervention by the revenue officers to combat the high-handed actions of the owners and recording their names in the RoRs - has made the right of cultivation more secure in respect of more than 14 lakh bargadars.

The policy of imposing ceiling on al kinds of lands and implement such policy in bothe letter and spirit has made it possible to bring more than 29.99 lakh acres of land to the state coffer so that such land can be distributed among the poor landless, marginalised sections of the society. The policy of distribution of land at the disposal of the state government to the landless and landpoor with preference to persons belonging to ST and SC have helped the poorer sections of rural society to become owners of land which they try to make best use of.

The Homestead Act aimed at providing homestead to a poor section of the homeless rural society.

However, these poor people would still better use their land if the provisions of the WBLR Act contained in chapter $\mathrm{V}$ - regarding consolidation of lands and Cooperative Farming Societies could be implemented. Agricultural inputs and other support could not be provided to an adequate extent to the recipients of land for cultivation of the same in a productive and efficient manner. The policy was in place but due to lack of focused approach on post land reform measures the benefit could not be maximized to enhance the impact of pro-poor land reform. The policy and robust implementation related to productive use of land by disbursement of agricultural loans to the marginal farmers and bargadars along with institutional credit access for these targeted groups also has contributed significantly in achieving food sufficiency for the state from a food-deficient situation in the pre-reform era(ranking changed from A to B later)

\section{Data Source:}

\section{Data Reliability:}

145 I Page Land Governance Assessment Framework - West Bengal 


\begin{tabular}{|c|c|c|c|}
\hline Panel & LGI & Dim. & $\begin{array}{l}\text { Land Governance Indicator } 27 \\
\text { Equity and non-discrimination in the decision-making process: } \\
\text { policies are formulated in a broad public process, address equity, } \\
\text { and implementation is meaningfully monitored. }\end{array}$ \\
\hline \multirow[t]{5}{*}{9} & \multirow[t]{5}{*}{2} & \multirow[t]{5}{*}{7} & Land policies proactively and effectively reduce future disaster risk. \\
\hline & & & $\begin{array}{l}\text { A: Policy is in place to prevent settlement in high risks areas which is enforced, } \\
\text { and translates anticipated future risks into land use planning that is enforced. }\end{array}$ \\
\hline & & & $\begin{array}{l}\text { B: Policy is in place to prevent settlement in high risks areas which is enforced, } \\
\text { and translates anticipated future risks into land use planning but which is not } \\
\text { enforced. }\end{array}$ \\
\hline & & & $\begin{array}{l}\text { C: Policy is in place to prevent settlement in high risks areas but which is not } \\
\text { enforced. }\end{array}$ \\
\hline & & & $\begin{array}{l}\text { D: No policy is in place to prevent settlement in high risks areas or anticipated } \\
\text { future risks. }\end{array}$ \\
\hline
\end{tabular}

\section{Analysis:}

There is no policy framed in West Bengal in respect of land use to reduce or prevent disaster risks. The state Land Use Board under the ministry of Planning and Development was constituted in 1975 with one of the principal function as - to evaluate the water and land resources and environment factors like erosion by wind or water, water logging, salinity etc. and decide upon suitable land-use policy for different parts of the state so as to ensure optimum conservation of soil, fertility and moisture, reduction of flood hazard and sustainable utilisation of land resources like forest and grazing land etc. Later in 2009 the State Land Use Board was reconstituted under the chairmanship of the MIC, L\&LR Department and transferred to the department of L\&LR. The agenda of disaster risk reduction didn't find a place in the parameters set for preparation of land use maps. On the basis of initial satellite based Block-wise Maps prepared by the Department of Science \& Technology and sample field verification by the District Offices of Land\& Land Reforms Department, final Block-wise Land Use Maps of twelve districts have been prepared and formally published.

Data Source: L\&LR Department Data Reliability: High

Policy Recommendation: Agenda of disaster risk reduction has to be incorporated in collaboration and consultation with the Disaster Management Department while preparing the land use maps under the direct supervision of the L\&LR Department. 


\section{Analysis and policy Recommendation}

\section{a) Substantive Findings}

The validated consensus ranking of the LGAF 116 dimensions reveals considerable strengths in land governance in West Bengal as 27 (23.28\%) dimensions ranked A and 37 (31.90\%) dimensions ranked B while 33 (28.45\%) and 19 (16.38\%) dimensions were ranked C and D respectively. Land governance in terms of nearly all the thematic areas is relatively strong. The order of weakness based on the percentage of dimensions scoring C and D are: Panel 1, Panel 2 and Panel 3 .

\begin{tabular}{|l|c|c|c|c|c|c|}
\hline \multirow{2}{*}{ Thematic Area } & \multicolumn{2}{|c|}{ Strength } & \multicolumn{2}{c|}{ Weakness } & Total & \% age \\
\cline { 2 - 8 } & No. & $\%$ & No. & $\%$ & & \\
\hline Panel 1: Land Tenure Recognition & 3 & 2.59 & 8 & 6.90 & 11 & 9.48 \\
\hline $\begin{array}{l}\text { Panel 2: Rights to Forest and Common } \\
\text { Lands \& Rural Land Use Regulations }\end{array}$ & 5 & 4.31 & 9 & 7.76 & 14 & 12.07 \\
\hline $\begin{array}{l}\text { Panel 3: Urban Land Use, Planning and } \\
\text { Development }\end{array}$ & 6 & 5.17 & 8 & 6.90 & 14 & 12.07 \\
\hline Panel 4: Public Land Management & 8 & 6.90 & 6 & 5.17 & 14 & 12.07 \\
\hline $\begin{array}{l}\text { Panel 5: Transfer of Large Tracts of Land to } \\
\text { Private Investors }\end{array}$ & 15 & 12.93 & 4 & 3.45 & 19 & 16.38 \\
\hline $\begin{array}{l}\text { Panel 6: Public Provision of Land } \\
\text { Information: Registry and Cadastre }\end{array}$ & 9 & 7.76 & 9 & 7.76 & 18 & 15.52 \\
\hline Panel 7: Land Valuation and Taxation & 6 & 5.17 & 0 & 0.00 & 6 & 5.17 \\
\hline Panel 8: Dispute Resolution & 5 & 4.31 & 2 & 1.72 & 7 & 6.03 \\
\hline $\begin{array}{l}\text { Panel 9: Review of Institutional } \\
\text { Arrangements and Policies }\end{array}$ & 7 & 6.03 & 6 & 5.17 & 13 & 11.21 \\
\hline \multicolumn{1}{|c|}{ Total } & 75 & 64.66 & 41 & 35.34 & 116 & 100 \\
\hline
\end{tabular}

\section{b) Strength and Weakness}

$\mathbf{1 4 7}$ I Page Land Governance Assessment Framework - West Bengal 


\begin{tabular}{|c|c|c|}
\hline Panels & Strengths & Weakness \\
\hline 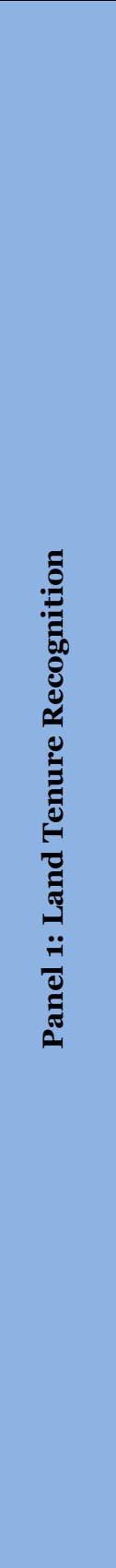 & $\begin{array}{l}\text { - Existing legal framework in the State fully } \\
\text { recognizes the tenurial rights- } \\
\text { The West Bengal Land Reforms Act, } \\
\text { 1955 Best Bengal Acquisition of } \\
\text { West Homestead Land for Agricultural } \\
\text { Labourers, Artisans and Fishermen } \\
\text { Act, 1975 } \\
\text { West Bengal Thika Tenancy Act, } \\
\text { 2001 } \\
\text { - } \\
\text { Distribution of ceiling surplus land among } \\
\text { the landless and land-poor giving preference } \\
\text { to those who belonging to the Scheduled } \\
\text { Tribe and Scheduled Caste. (So far [ Aug } \\
\text { 2013 ] 31,36,297 landless and near landless } \\
\text { persons have been given land by way of } \\
\text { distributive land reforms thereby creating as } \\
\text { many new tenures.) } \\
\text { Allocation of homestead plot to absolute } \\
\text { landless and homeless through legislation } \\
\text { and government schemes giving preference } \\
\text { to women, ST and SC. (3,26,653 persons } \\
\text { have been given land with raiyati status } \\
\text { creating equivalent number of tenures.) } \\
\text { Government has taken initiative to issue } \\
\text { patta (deed of title) in the name of women or } \\
\text { joint patta (both in the name of wife and } \\
\text { husband) during distribution of homestead } \\
\text { plot through scheme (more than 90\% in the } \\
\text { name of women from last three years); } \\
\text { 30,879 individual and 312 Community } \\
\text { tenures were created as a result of } \\
\text { implementation of the Forest Rights Act, } \\
\text { 20o6. frome legal framework recognizes } \\
\text { Existing } \\
\text { individual rights of land; } \\
\text { Women Land Rights is legally recognized; } \\
\text { The state has robust mechanism to secure } \\
\text { tenure of sharecroppers (a study [20o3] } \\
\text { made by the State Institute of Panchayats } \\
\text { and Rural Development found that about } \\
\text { 72\% of share-croppers had a sense of } \\
\text { enhanced security after their names were } \\
\text { recorded in the land records.) } \\
\text { Land purchase and sale is computerized; }\end{array}$ & $\begin{array}{l}\text { - There is gap between legislation and practice; } \\
\text { - Certain group rights and customary rights are not } \\
\text { protected by law; } \\
\text { - There are some illegal transaction of land (especially } \\
\text { for distributed ceiling surplus land to land poor) in } \\
\text { practice; } \\
\text { - Record individualization - in case of issuing joint } \\
\text { patta records are not maintained individually. } \\
\text { - Records are falling out of date because of pending } \\
\text { mutation cases arising out of death, transfer; } \\
\text { - There are } 126 \text { non - revenue forest mouzas in the } \\
\text { state, } 126 \text { chitmahal mouzas (enclaves in Bangladesh) } \\
\text { and } 22 \text { diluvated mouzas in South } 24 \text { Parganas } \\
\text { district which are not surveyed and recorded creating } \\
\text { gap in recognizing the rights of people of those areas. } \\
\text { - Less than } 15 \% \text { of land recorded to physical persons is } \\
\text { recorded in the name of women either individually or } \\
\text { jointly. } \\
\text { Tribal land alienation; }\end{array}$ \\
\hline
\end{tabular}

$\mathbf{1 4 8 | \text { Page Land Governance Assessment Framework - West Bengal }}$ 


\begin{tabular}{|c|c|c|}
\hline Panels & Strengths & Weakness \\
\hline 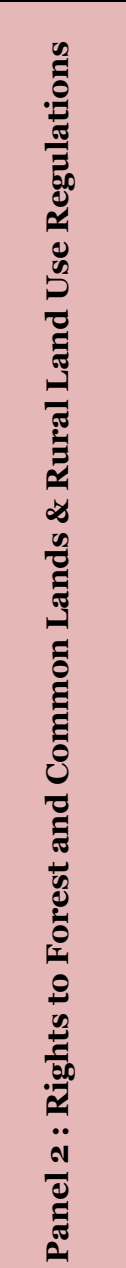 & $\begin{array}{l}\text { - After initial sketchy progress enforcement of } \\
\text { Scheduled Tribe and Other Traditional } \\
\text { Forest Dwellers (Recognition of Rights) Act, } \\
2006 \text { protecting the interest of Scheduled } \\
\text { Tribes and other forest dwellers in the State } \\
\text { is picking up; } \\
\text { Role of the government in implementation of } \\
\text { National Forest Policy of } 1988 \text { giving priority } \\
\text { to Joint Forest Management (JFM), as } \\
\text { pioneer in the country, and giving more } \\
\text { priority to people's need and biodiversity } \\
\text { conservation than commercial exploitation } \\
\text { and revenue earning; } \\
\text { There are around 40oo Joint Forest } \\
\text { Management Committees (JFMC) formed } \\
\text { and functioning under Executive Order } \\
\text { (1988) protecting nearly 5oo,ooo hectares of } \\
\text { degraded forest areas of the State; these } \\
\text { committees are traditionally strong in the } \\
\text { State; } \\
\text { Positive role of the State Government in } \\
\text { protecting trees and maintaining bio- } \\
\text { diversity in rural as well as urban areas by } \\
\text { enactment of Non-Forest Tree Act in 2oo6; } \\
\text { In West Bengal, diversion of Forest land is } \\
\text { one of the minimum in the country; } \\
\text { There is well organized administration in the } \\
\text { Forest Department. } \\
\text { In West Bengal, in case of the NTFP like Sal } \\
\text { Seeds and Kendu Leaves, monopoly rights of } \\
\text { collection from the forest land have been } \\
\text { given to the Large Sized Multipurpose } \\
\text { Cooperative Societies (LAMPS) through } \\
\text { West Bengal Tribal Development } \\
\text { Cooperative Corporation (WBTDCC). }\end{array}$ & $\begin{array}{l}\text { - Recognition and enforcement of rights to STs and } \\
\text { OTFDs as per the FRA, } 2006 \\
\text { - JMFCs are still not recognized by any legislation; } \\
\text { - Functioning of Forest Department does not meet the } \\
\text { basic objective of forest conservation and } \\
\text { implementation of FRA 2006 fully; } \\
\text { 126 non-revenue forest mouzas in the state have not } \\
\text { been cadastrally surveyed keeping grey areas in } \\
\text { recognizing the rights of forest dwellers; common } \\
\text { land within forest areas are not clearly identified. } \\
\text { - Information gap between L\&LR Department and } \\
\text { Forest Department; Records maintained by the Forest } \\
\text { Department are not always in compliance with L \& LR } \\
\text { Department; } \\
\text { There are number of forest villages as well as forest } \\
\text { fringe villages where remarkable number of non - ST } \\
\text { communities are living. There is gap in identifying } \\
\text { and recognizing the actual non-ST forest dwellers; } \\
\text { Users' rights to key natural resources are not legally } \\
\text { recognized and often not protected in practice; } \\
\text { There is no provision for representation of women in } \\
\text { the LAMPS. }\end{array}$ \\
\hline
\end{tabular}

149|Page Land Governance Assessment Framework - West Bengal 


\begin{tabular}{|c|c|c|}
\hline Panels & Strengths & Weakness \\
\hline 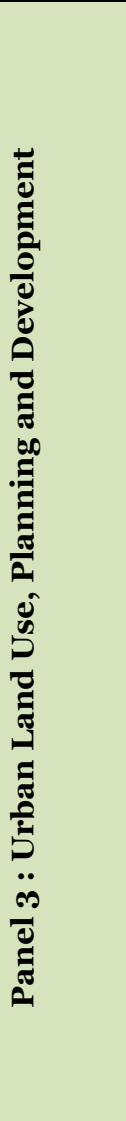 & 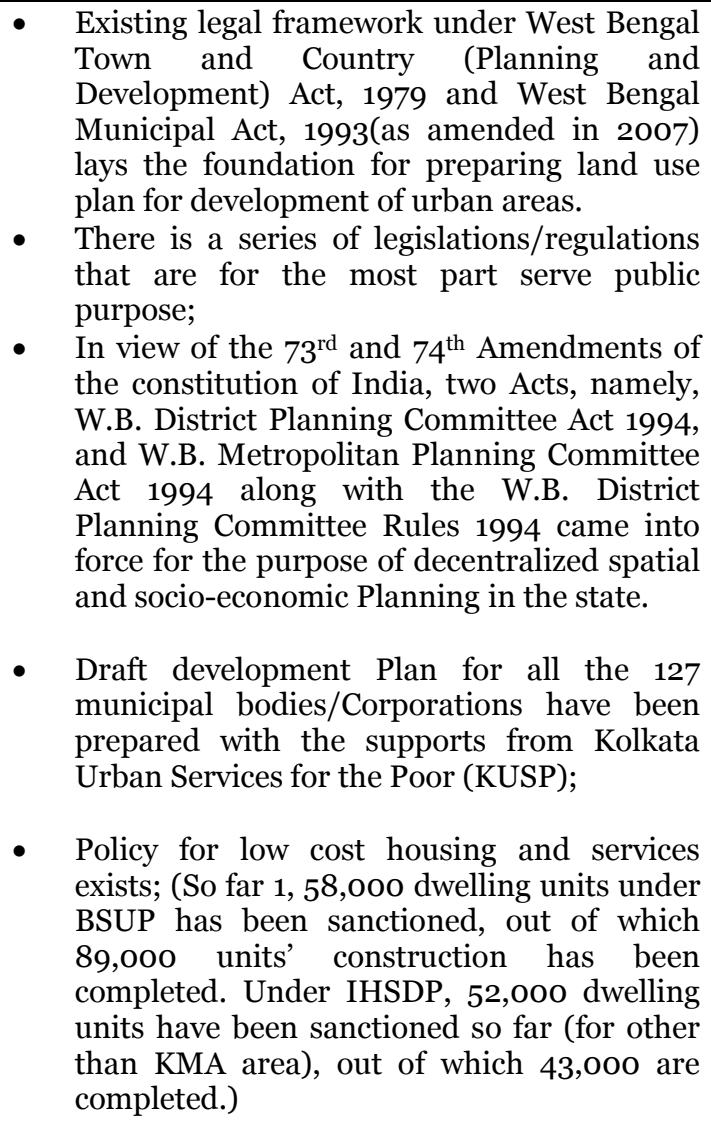 & $\begin{array}{l}\text { - The state does not have any comprehensive land use } \\
\text { policy especially in the context of urban growth; } \\
\text { Enforcement of law is deficient; } \\
\text { - Land related legislations in the State have largely } \\
\text { ignored ecological and environmental issues; } \\
\text { - Regular updating of urban land use and creation of } \\
\text { data base to record the changes in use is not followed; } \\
\text { - Huge quantum of government land in urban areas is } \\
\text { encroached; } \\
\text { - Policy and implementation of low cost housing is not } \\
\text { clear. As a result, the number of those with } \\
\text { inadequate shelter still remains high; } \\
\text { - Construction of buildings violating the prescribed } \\
\text { norms; } \\
\text { The state does not have a policy to deal with informal } \\
\text { tenureship in urnan areas; }\end{array}$ \\
\hline 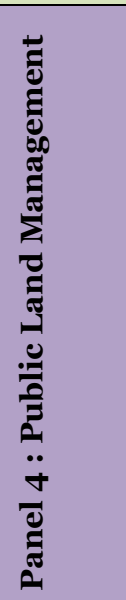 & $\begin{array}{l}\text { - There are professionally managed public } \\
\text { institutions like WBIDC, WBIIDC, WBSIDC } \\
\text { etc. for management of public land and use } \\
\text { for the development of industries. } \\
\text { Till December, 2013, vesting of land under } \\
\text { different Acts: } \\
\quad \text { WBEA Act 26,48,250.86 acres } \\
\circ \quad \text { WBLR Act 3,50,990.16 acres } \\
\circ \quad \text { Total vesting till date 29,99,241.02 } \\
\text { acres }\end{array}$ & $\begin{array}{l}\text { - There are still large tracts of public lands in the State } \\
\text { which are not clearly identified on the ground or on } \\
\text { maps; } \\
\text { The lands may not always be identifiable on the } \\
\text { ground for various reasons like change of topography, } \\
\text { encroachment etc. Information on such public lands } \\
\text { is not available to the public; } \\
\text { - There is lack of transparency in allocating public land } \\
\text { to private parties; information is not made publicly } \\
\text { available; } \\
\text { Inventory of public land management by various } \\
\text { departments and local self-governments are not } \\
\text { properly updated and maintained; }\end{array}$ \\
\hline
\end{tabular}

150|Page Land Governance Assessment Framework - West Bengal 


\begin{tabular}{|c|c|c|}
\hline Panels & Strengths & Weakness \\
\hline 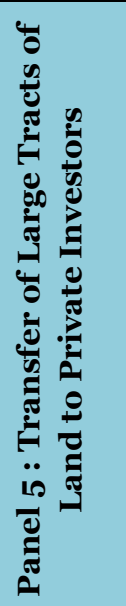 & $\begin{array}{l}\text { - The Government of West Bengal has come } \\
\text { up with a Land Allotment Policy document } \\
\text { through issuance of Administrative Order } \\
\text { (No. 6686 - LP/1A-18/ 2012 dated } 26 \\
\text { December 2012). } \\
\text { The government has a clear procedure of } \\
\text { transfer of land to private investors which is } \\
\text { laid down in the guideline and publicly } \\
\text { available. } \\
\text { WBIDC has introduced Rehabilitation and } \\
\text { Resettlement Scheme (R\&R Scheme) in } 2011 \\
\text { which clearly spells out the standards and } \\
\text { norms. } \\
\text { R\&R Scheme also protects the rights of the } \\
\text { sharecroppers and even labourers. }\end{array}$ & $\begin{array}{l}\text { - Fallow other than current fallows, cultivable waste } \\
\text { land, permanent pasture and other grazing land, and } \\
\text { barren and uncultivable land (which may be be } \\
\text { considered as suitable for industrial growth) } \\
\text { combined together constitute } 1 \% \text { of the total land; } \\
\text { Land demand is ever increasing in the state for raising } \\
\text { agricultural production to meet food demand of } \\
\text { expanding population or for expansion of industrial } \\
\text { activities; } \\
\text { Though there is a standard procedure of transfer of } \\
\text { land to private investors but there is gap in practice; } \\
\text { Still there is lack of transparency on the ground in } \\
\text { paying compensation. }\end{array}$ \\
\hline 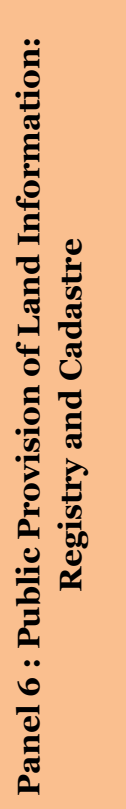 & $\begin{array}{l}\text { - The State has a long history of conducting } \\
\text { survey of land and managing records; } \\
\text { Computerization of records is almost done in } \\
\text { the state; all information regarding land } \\
\text { records, maps etc. are available through } \\
\text { website or through OTC services paying very } \\
\text { minimal charges; } \\
\text { Updating cadastral maps and record of rights } \\
\text { of } 1473 \text { revenue villages (though current } \\
\text { survey-settlement operation under WBLR } \\
\text { Act was initiated in 1975) } \\
\text { The present Government has introduced a } \\
\text { new scheme Nijo-Griho-Nijo-Bhumi } \\
\text { Prakalpa in Oct 2011 (My Home My Land } \\
\text { scheme) with purpose to settle 5.5 Lac } \\
\text { landless poor people of the State with land } \\
\text { up to 0.05 acre. }\end{array}$ & $\begin{array}{l}\text { - Procedure for formalization of land possession of poor } \\
\text { is robust but it is not hundred percent transparent. } \\
\text { Improper selection/ bias exists; } \\
\text { - Cost of recording of property transfer is very high; } \\
\text { - Record of rights also does not reflect the real ground } \\
\text { situation as there is lag between recoded ownership } \\
\text { data in the record of rights and legal transaction of } \\
\text { land taking place; } \\
\text { There is also a lag between value of land in land } \\
\text { valuation register maintained by the registering } \\
\text { authorities and value at which land transaction takes } \\
\text { place because valuation of land is updated } \\
\text { sporadically; } \\
\text { There is a gap between the quantum of land at the } \\
\text { disposal of the L\&LR Department and land recorded } \\
\text { in the record of rights, particularly Government land } \\
\text { settled with the land poor people under Section } 49(1) \\
\text { of WBLR Act 1955 and land settled through lease with } \\
\text { private individual and institutions; } \\
\text { Fee structures for different kind of services are not } \\
\text { rational and transparent. It does not match with high } \\
\text { cost of government service. }\end{array}$ \\
\hline 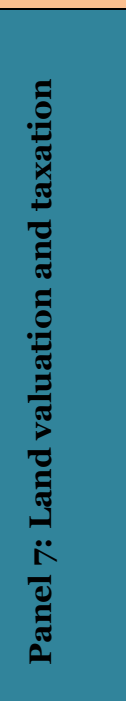 & $\begin{array}{l}\text { - The first Municipal Finance Commission was } \\
\text { set up in } 1979 \text { in the state. } \\
\text { - A Central Valuation Board was set up to } \\
\text { overcome the deficiency of under valuation } \\
\text { of properties in the municipal areas in } 1979 \\
\text { through an Act. The process of property } \\
\text { valuation is clear. } \\
\text { All } 239 \text { registration offices in the State have } \\
\text { been fully computerized. As a result there } \\
\text { has been a clear and transparent process in } \\
\text { determination of market value for property } \\
\text { through CORD (Computerisation of } \\
\text { Registration of Documents) software. } \\
\text { Collection of property tax is regular (around } \\
\text { 8o\%). } \\
\text { The amount of property taxes collected } \\
\text { exceeds the cost of staff in charge of } \\
\text { collection. }\end{array}$ & $\begin{array}{l}\text { More than one fourth of the demand on property } \\
\text { taxes of the ULBs is due from the government } \\
\text { departments and undertakings. }\end{array}$ \\
\hline
\end{tabular}

151|Page Land Governance Assessment Framework - West Bengal 


\begin{tabular}{|c|c|c|}
\hline Panels & Strengths & Weakness \\
\hline 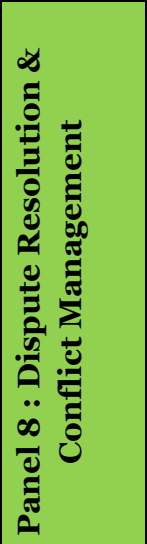 & $\begin{array}{l}\text { - Existing legal framework is competent } \\
\text { enough for dispute resolution through } \\
\text { following Act: } \\
\circ \text { West Bengal Estates Acquisition } \\
\text { Act, 1953 Bengal Land Reforms } \\
\text { West Act,1955 } \\
\text { West Bengal Thika Tenancy Act, } \\
2001 \text { Bengal Land Reforms \& } \\
\text { West Bengal } \\
\text { Tenancy Tribunal Act, 1997 } \\
\text { - In the state Land Reform Tenancy Tribunal } \\
\text { (LRTT) is in operation and quick disposal of } \\
\text { conflicts are possible; }\end{array}$ & $\begin{array}{l}\text { - Non-participation or absence of the parties during the } \\
\text { relevant stages of preparation of land records is one of } \\
\text { the causes of faulty recording in land records. Lack of } \\
\text { awareness on the part of the stake-holders is a major } \\
\text { reason for such absence; } \\
\text { Dispute resolution through Civil Court is very time } \\
\text { consuming compared to the exisiting system. } \\
\text { Repeated adjournment in Civil Courts due to various } \\
\text { reasons causes unnecessary delay in disposal of cases; } \\
\text { Cost of proceeding at Civil Court is relatively high } \\
\text { which makes it less affordable by poor; } \\
\text { There are huge numbers of piled up long pending } \\
\text { cases in the State; }\end{array}$ \\
\hline 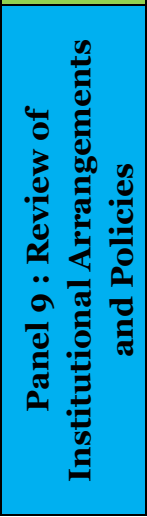 & $\begin{array}{l}\text { - As per legislation, institutional mandates } \\
\text { relating to administration of land is very } \\
\text { clear in the State; } \\
\text { The role and function of different layers of } \\
\text { L\&LR Department is clearly defined; there is } \\
\text { no scope of overlapping. } \\
\text { The state is endowed with comprehensive } \\
\text { legislations embodying the policies on land; }\end{array}$ & $\begin{array}{l}\text { - Different public institutions deal with land-related } \\
\text { matters quite differently and there is lack of } \\
\text { coordination in practice. } \\
\text { The records are not updated on a regular basis. The } \\
\text { land properties belonging to the public bodies are not } \\
\text { recorded in the r-o-r maintained in the office of the } \\
\text { BLLRO; } \\
\text { Though there is a well-defined reporting system on a } \\
\text { regular basis within the department but the } \\
\text { information is not available to the public. There is no } \\
\text { mechanism of tracking the progress of } \\
\text { implementation of different policies by the public; } \\
\text { Land related legislations in the State have largely } \\
\text { ignored ecological and environmental issues; }\end{array}$ \\
\hline
\end{tabular}

\section{c) Policy Matrix with suggested reform action in the short, medium and longer term}

\begin{tabular}{|c|c|c|c|c|c|}
\hline \multirow{2}{*}{$\begin{array}{c}\text { Thematic } \\
\text { Areas }\end{array}$} & \multirow[t]{2}{*}{ Issues } & \multirow[t]{2}{*}{ Findings } & \multicolumn{3}{|c|}{ Reform Actions } \\
\hline & & & $\begin{array}{l}\text { Short } \\
\text { Term }\end{array}$ & Medium & $\begin{array}{l}\text { Long } \\
\text { Term }\end{array}$ \\
\hline 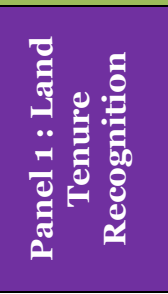 & $\begin{array}{ll}\text { 1. } & \text { Existing legal } \\
\text { framework recognizes } \\
\text { individual rights of land } \\
\text { but there are certain } \\
\text { gaps. Certain group } \\
\text { rights and customary } \\
\text { rights are not protected } \\
\text { by law. }\end{array}$ & $\begin{array}{l}\text { All customary rights need to be } \\
\text { identified by a task force comprising } \\
\text { land tenure experts and codified in } \\
\text { order to ensure protection under law. }\end{array}$ & $\checkmark$ & -- & -- \\
\hline
\end{tabular}




\begin{tabular}{|c|c|c|c|c|c|}
\hline \multirow{2}{*}{$\begin{array}{c}\text { Thematic } \\
\text { Areas }\end{array}$} & \multirow[t]{2}{*}{ Issues } & \multirow[t]{2}{*}{ Findings } & \multicolumn{3}{|c|}{ Reform Actions } \\
\hline & & & $\begin{array}{l}\text { Short } \\
\text { Term }\end{array}$ & Medium & $\begin{array}{l}\text { Long } \\
\text { Term }\end{array}$ \\
\hline & $\begin{array}{l}\text { 2. Implementation of of } \\
\text { provision of section } 21 \mathrm{C} \\
\text { of the LR Act regarding } \\
\text { constitution of Land } \\
\text { Corporation etc. }\end{array}$ & $\begin{array}{l}\text { The rural raiyats were experiencing } \\
\text { great difficulties in selling their lands } \\
\text { with barga cultivation thereon. This } \\
\text { section provides for constitution of a } \\
\text { State Land Corporation or one or more } \\
\text { Regional Land Corporations or both. In } \\
\text { essence, the object of such a } \\
\text { Corporation is to advance funds to a } \\
\text { recorded bargadar or a person eligible } \\
\text { for settlement of land u/s } 49(1) \text { of the } \\
\text { LR Act to enable him to purchase land } \\
\text { from a raiyat who, being in distress, } \\
\text { has failed to sell the land in open } \\
\text { market on account of cultivation of the } \\
\text { land by the bargadar. If for some } \\
\text { reason or other the land cannot be sold } \\
\text { to the cultivating bargadar or any } \\
\text { person eligible to get land u/s } 49(1) \text {, the } \\
\text { Corporation may, on a request from the } \\
\text { owner, purchase the land from him. } \\
\text { The state government may be well } \\
\text { advised to take up this important } \\
\text { provision for implementation. }\end{array}$ & -- & -- & $\checkmark$ \\
\hline
\end{tabular}

$\mathbf{1 5 3 | P a g e ~ L a n d ~ G o v e r n a n c e ~ A s s e s s m e n t ~ F r a m e w o r k ~ - ~ W e s t ~ B e n g a l ~}$ 


\begin{tabular}{|c|c|c|c|c|c|}
\hline \multirow{2}{*}{$\begin{array}{c}\text { Thematic } \\
\text { Areas }\end{array}$} & \multirow{2}{*}{ Issues } & \multirow{2}{*}{ Findings } & \multicolumn{3}{|c|}{ Reform Actions } \\
\hline & & & $\begin{array}{l}\text { Short } \\
\text { Term }\end{array}$ & Medium & $\begin{array}{l}\text { Long } \\
\text { Term }\end{array}$ \\
\hline & $\begin{array}{l}\text { 3. Women Land Rights is } \\
\text { legally recognized but } \\
\text { there is a gap between } \\
\text { legislation and practice; }\end{array}$ & $\begin{array}{l}\text { A research study conducted by Rural } \\
\text { Development Institute (2002) on } \\
\text { women's access and rights to land in } \\
\text { West Bengal. The study found: } \\
\text { a) Very few rural women own either } \\
\text { agricultural land or the houses they live } \\
\text { in } \\
\text { b) Despite government policies } \\
\text { promoting joint titling, little joint } \\
\text { titling of government granted land is } \\
\text { occurring } \\
\text { c) There is general awareness of the } \\
\text { rights of the widows, daughters and } \\
\text { sisters under the codified inheritance } \\
\text { law, but these rights are not always } \\
\text { exercised } \\
\text { d) Separated women almost always lose } \\
\text { access to land they have worked during } \\
\text { marriage } \\
\text { e) Women who hold title to land in } \\
\text { their own names prize the security that } \\
\text { the land endows them with } \\
\text { It is high time the Government should } \\
\text { take up a clear policy on land rights for } \\
\text { women. } \\
\text { By way of empowering women } \\
\text { through endowment of land assets, } \\
\text { priority could be assigned on them } \\
\text { in the matter of distribution of } \\
\text { land as in the case of members of } \\
\text { the Scheduled Tribes. For this } \\
\text { purpose sec } 49(1) \text { of the WBLR } \\
\text { Act, 1955 shall need amendment; } \\
\text { To give some financial relief to } \\
\text { women assesses it could be } \\
\text { considered if some exemption, say } \\
\text { - T5\% of the revenue payable by } \\
\text { them in terms of section } 23 \text { of the } \\
\text { LR Act could be given. The } \\
\text { enhancing awareness on legal } \\
\text { proposed exemption could be over } \\
\text { and above the general exemptions } \\
\text { of revenue for land upto } 2.428 \text { Ha } \\
\text { provided in sec } 24 \text { (ibid). Similarly } \\
\text { exemption may also be considered } \\
\text { in respect of land and property tax } \\
\text { levied by gram panchayat in rural } \\
\text { areas and ULBs in urban areas } \\
\text { Exemption in stamp duty in case of } \\
\text { registration when women acquire } \\
\text { the land } \\
\text { women's it mandatory for including } \\
\text { rights eithe as partitionable joint } \\
\text { rights or sole titles in women's } \\
\text { names; }\end{array}$ & -- & -- & $\checkmark$ \\
\hline & Land Governance & A s s s s ment Framework & W e s t & $\mathrm{B}$ e n g a l & \\
\hline
\end{tabular}




\begin{tabular}{|c|c|c|c|c|c|}
\hline \multirow{2}{*}{$\begin{array}{c}\text { Thematic } \\
\text { Areas }\end{array}$} & \multirow[t]{2}{*}{ Issues } & \multirow{2}{*}{ Findings } & \multicolumn{3}{|c|}{ Reform Actions } \\
\hline & & & $\begin{array}{l}\text { Short } \\
\text { Term }\end{array}$ & Medium & $\begin{array}{l}\text { Long } \\
\text { Term }\end{array}$ \\
\hline & $\begin{array}{llr}\text { 4. } & \text { Sharecropper to } \\
\text { landowner, tenure } \\
\text { security to bargadars. }\end{array}$ & $\begin{array}{l}\text { West Bengal is the only state where } \\
\text { tenancy reform has conferred } \\
\text { substantial benefits to sharecroppers. } \\
\text { The WBLR Act prohibits leasing and } \\
\text { highly regulates sharecropping. The } \\
\text { bargaadars recorded permanent } \\
\text { cultivation right is heritable but is not } \\
\text { transferrable. Bargadars also have the } \\
\text { first pre-emptive right to purchase the } \\
\text { adjacent land being sold. Implementing } \\
\text { the provision made under WBLR Act } \\
\text { for the state to establish a finance } \\
\text { corporation to advance funds to } \\
\text { bargadars to purchase sharecropped } \\
\text { land from the landowner at a mutually } \\
\text { agreed price or market value would } \\
\text { ensure secure tenure, improved } \\
\text { utilization and productivity of the land } \\
\text { as stated by Banerjee, Gertler and } \\
\text { Ghatak, 2oo2. Also government may } \\
\text { expedite the recording of names of } \\
\text { bargadars who are still left in } \\
\text { government record so that they can get } \\
\text { full protection under law; }\end{array}$ & -- & -- & $\checkmark$ \\
\hline & $\begin{array}{l}\text { 5. Record } \\
\text { individualization - in } \\
\text { case of issuing joint } \\
\text { patta records are not } \\
\text { maintained } \\
\text { individually; }\end{array}$ & $\begin{array}{l}\text { The Government may consider the } \\
\text { measures for individualization of } \\
\text { tenure while issuing joint patta, this } \\
\text { will also ensure land rights for women } \\
\text { in their names. An executive order to } \\
\text { this effect is required along with } \\
\text { awareness generation campaign; }\end{array}$ & -- & -- & $\checkmark$ \\
\hline & $\begin{array}{l}\text { 6. There are some illegal } \\
\text { transaction of land } \\
\text { (especially for } \\
\text { distributed ceiling } \\
\text { surplus land to land } \\
\text { poor) in practice but } \\
\text { difficult to identify; }\end{array}$ & $\begin{array}{l}\text { West Bengal LR Act prohibits transfer } \\
\text { of land distributed to poor } \\
\text { beneficiaries' u/s 49(1) of WBLR Act. } \\
\text { But there are quite a good number of } \\
\text { cases where land has been transferred } \\
\text { by patta recipients. Mechanism should } \\
\text { be developed for proper monitoring. }\end{array}$ & -- & -- & $\checkmark$ \\
\hline & $\begin{array}{ll}\text { 7. Legal restrictions on } \\
\text { land leasing routinely } \\
\text { neglected (clandestine } \\
\text { land leasing) }\end{array}$ & $\begin{array}{l}\text { An in-depth research study may be } \\
\text { conducted to assess the extent and } \\
\text { nature of lease transaction focusing on } \\
\text { links between livelihoods of the poor } \\
\text { and clandestine tenancy. The study } \\
\text { should reflect on the practical scenario } \\
\text { and make recommendation to the } \\
\text { government accordingly. It is a proven } \\
\text { fact that land tenancy markets can also } \\
\text { reduce the vulnerability of poor } \\
\text { households by offering a more stable } \\
\text { livelihood source than frequently } \\
\text { volatile and imperfect labor markets. } \\
\text { As opportunity in non-farm economy } \\
\text { increases, tenancy markets may } \\
\text { facilitate a broader choice of livelihood } \\
\text { opportunities such as migration, } \\
\text { specialization and investment. } \\
\text { Households better suited to pursue } \\
\text { non-farm livelihoods would be } \\
\text { benefited if they are able to rent out } \\
\text { their land for others to cultivate; }\end{array}$ & -- & $\checkmark$ & -- \\
\hline
\end{tabular}

$\mathbf{1 5 5 | P a g e ~ L a n d ~ G o v e r n a n c e ~ A s s e s s m e n t ~ F r a m e w o r k ~ - ~ W e s t ~ B e n g a l ~}$ 


\begin{tabular}{|c|c|c|c|c|c|}
\hline \multirow{2}{*}{$\begin{array}{c}\text { Thematic } \\
\text { Areas }\end{array}$} & \multirow[t]{2}{*}{ Issues } & \multirow[t]{2}{*}{ Findings } & \multicolumn{3}{|c|}{ Reform Actions } \\
\hline & & & $\begin{array}{l}\text { Short } \\
\text { Term }\end{array}$ & Medium & $\begin{array}{l}\text { Long } \\
\text { Term }\end{array}$ \\
\hline & $\begin{array}{l}\text { 8. Records are falling out } \\
\text { of date because of } \\
\text { pending mutation cases } \\
\text { arising out of death, } \\
\text { transfer }\end{array}$ & $\begin{array}{l}\text { Compulsory mutation: Maintenance of } \\
\text { r-o-r mainly entails mutation of names } \\
\text { due to transfer, inheritance etc. To } \\
\text { facilitate such maintenance mutation } \\
\text { should be made compulsory. This will } \\
\text { require amendment of section } 50 \text { of the } \\
\text { WBLR Act, } 1955 \text { and of the related } \\
\text { rules; }\end{array}$ & $\checkmark$ & -- & -- \\
\hline & 9. Tribal land alienation & $\begin{array}{l}\text { Despite extensive and long standing } \\
\text { state legislations restricting the } \\
\text { alienation of tribal land, the loss of } \\
\text { tribal land continues. The fact of the } \\
\text { controversy reflects the need for } \\
\text { comprehensive, local research on the } \\
\text { impact of restrictions. Based on the } \\
\text { findings appropriate actions can be } \\
\text { taken at state and local levels to } \\
\text { enhance restrictions, shore up } \\
\text { enforcement programs, provide for } \\
\text { legal services and relaxation of } \\
\text { restrictions (with appropriate } \\
\text { protections) on alienation of tribal } \\
\text { land. Also an exercise across the state } \\
\text { to develop a comprehensive database } \\
\text { on tribal land ownership is } \\
\text { recommended; }\end{array}$ & -- & -- & $\checkmark$ \\
\hline
\end{tabular}

\begin{tabular}{|c|c|c|c|c|c|}
\hline \multirow{2}{*}{$\begin{array}{c}\text { Thematic } \\
\text { Areas }\end{array}$} & \multirow{2}{*}{ Issues } & \multirow{2}{*}{ Findings } & \multicolumn{3}{|c|}{ Reform Actions } \\
\hline & & & $\begin{array}{l}\text { Short } \\
\text { Term }\end{array}$ & Medium & $\begin{array}{l}\text { Long } \\
\text { Term } \\
\end{array}$ \\
\hline 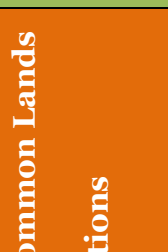 & 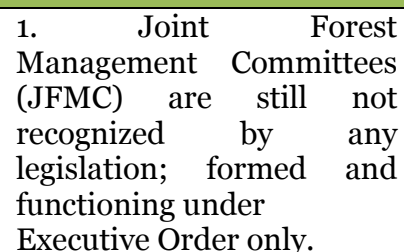 & $\begin{array}{l}\text { 1. There is a need to restructure the } \\
\text { entire mechanism of JFM so as to } \\
\text { make it compatible with the provisions } \\
\text { of FRA 2006. }\end{array}$ & -- & $\checkmark$ & -- \\
\hline 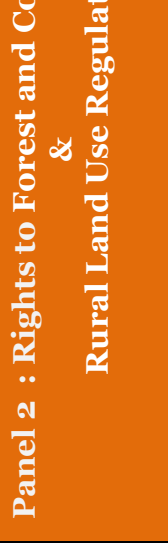 & $\begin{array}{l}\text { 2. Functioning of Forest } \\
\text { Department does not meet } \\
\text { the basic objective of forest } \\
\text { conservation } \\
\text { implementation of FRA } \\
\text { 2006 fully; }\end{array}$ & $\begin{array}{l}\text { 2. Changes in Forest Governance will } \\
\text { definitely strengthen the basic } \\
\text { objective of forest conservation. The } \\
\text { solution will be to: } \\
\square \text { make the forest officials involved in } \\
\text { subsequent management of the land in } \\
\text { question to ensure conservation of } \\
\text { existing flora/ fauna and to develop } \\
\text { the same, } \\
\square \text { take up intensive joint training of } \\
\text { the staff of Forest Department, } \\
\text { Backward Classes Welfare Department } \\
\text { and the civil administration for better } \\
\text { understanding and implementation of } \\
\text { FRA 2006. }\end{array}$ & -- & -- & $\checkmark$ \\
\hline
\end{tabular}




\begin{tabular}{|c|c|c|c|c|c|}
\hline \multirow{2}{*}{$\begin{array}{c}\text { Thematic } \\
\text { Areas }\end{array}$} & \multirow[t]{2}{*}{ Issues } & \multirow[t]{2}{*}{ Findings } & \multicolumn{3}{|c|}{ Reform Actions } \\
\hline & & & $\begin{array}{l}\text { Short } \\
\text { Term }\end{array}$ & Medium & $\begin{array}{l}\text { Long } \\
\text { Term }\end{array}$ \\
\hline & $\begin{array}{l}\text { 3. } 126 \text { non-revenue forest } \\
\text { mouzas in the state have } \\
\text { not been cadastrally } \\
\text { surveyed keeping grey } \\
\text { areas in recognizing the } \\
\text { rights of forest dwellers }\end{array}$ & $\begin{array}{l}\text { 3. These } 126 \text { non-revenue forest } \\
\text { mouzas need to be cadastrally } \\
\text { surveyed for better implementation of } \\
\text { FRA } 2006 \text { in these areas. A set of } \\
\text { cadastral maps and record-of-rights is } \\
\text { a sin qua non for the forest dwellers to } \\
\text { effectively exercise their rights like } \\
\text { ownership of land (delivery of } \\
\text { document of title) and other rights } \\
\text { conferred on them by the Forest Rights } \\
\text { Act. The state government should, } \\
\text { therefore, seriously consider the } \\
\text { question of undertaking survey and } \\
\text { settlement of the related forest } \\
\text { villages. }\end{array}$ & -- & $\checkmark$ & -- \\
\hline & $\begin{array}{l}\text { 4. Information gap } \\
\text { between L\&LR Department } \\
\text { and Forest Department; } \\
\text { Records maintained by the } \\
\text { Forest Department are not } \\
\text { always in compliance with } \\
\text { L \& LR Department }\end{array}$ & $\begin{array}{l}\text { 4. Forest Department is required to } \\
\text { play proactive role in physical } \\
\text { verification of common lands and } \\
\text { updating records (record of common } \\
\text { land, record of forest patta, record of } \\
\text { actual waste lands etc.). Gap in } \\
\text { information between LR Department } \\
\text { and Forest Department in respect of } \\
\text { forest boundary demarcation on real } \\
\text { time basis needs to be bridged. } \\
\text { Executive order should be issued } \\
\text { followed by practical guideline so that } \\
\text { L\&LR Department and Forest } \\
\text { Department work in tandem. }\end{array}$ & -- & -- & $\checkmark$ \\
\hline & $\begin{array}{l}\text { 5. There are number of } \\
\text { forest villages as well as } \\
\text { forest fringe villages where } \\
\text { remarkable number of non } \\
\text { - ST communities are } \\
\text { living. There is gap in } \\
\text { identifying and recognizing } \\
\text { the actual non-ST forest } \\
\text { dwellers; }\end{array}$ & $\begin{array}{l}\text { 5. Scope of 'community rights' to be } \\
\text { widened up to include other forest } \\
\text { dwellers along with ST. } \\
\text { - There is a need for re-looking into } \\
\text { JFMC (Joint Forest Management } \\
\text { \& Protection Committee) orders } \\
\text { and there has to be a synergy } \\
\text { between Forest Rights Act (FRA) } \\
\text { and JFMCs. } \\
\text { Provision should be made in FRA } \\
\text { to incorporate the system of JFMC } \\
\text { giving some waiver or making } \\
\text { some alteration. }\end{array}$ & $\checkmark$ & -- & -- \\
\hline & $\begin{array}{l}\text { 6. Users' rights to key } \\
\text { natural resources are not } \\
\text { legally recognized and } \\
\text { often not protected in } \\
\text { practice; }\end{array}$ & $\begin{array}{l}\text { Recording and mapping of the rights } \\
\text { of the groups who are holding land } \\
\text { under customary, group, or collective } \\
\text { tenures should be made mandatory. }\end{array}$ & -- & -- & $\checkmark$ \\
\hline 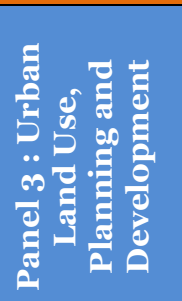 & $\begin{array}{l}\text { 1. The state does not have } \\
\text { any comprehensive land } \\
\text { use policy to encourage } \\
\text { urbanization, building up } \\
\text { of infrastructure }\end{array}$ & $\begin{array}{l}\text { 1. A policy statement on land use } \\
\text { planning with clear and } \\
\text { implementable suggestions and } \\
\text { procedural mechanism needs to be } \\
\text { framed in the perspective of urban } \\
\text { development and consequential } \\
\text { amendment of section } 4 \mathrm{C} \text { of the WBLR } \\
\text { Act }\end{array}$ & -- & $\checkmark$ & -- \\
\hline
\end{tabular}

157|Page Land Governance Assessment Framework - West Bengal 


\begin{tabular}{|c|c|c|c|c|c|}
\hline \multirow{2}{*}{$\begin{array}{c}\text { Thematic } \\
\text { Areas }\end{array}$} & \multirow{2}{*}{ Issues } & \multirow{2}{*}{ Findings } & \multicolumn{3}{|c|}{ Reform Actions } \\
\hline & & & $\begin{array}{l}\text { Short } \\
\text { Term }\end{array}$ & Medium & $\begin{array}{l}\text { Long } \\
\text { Term }\end{array}$ \\
\hline & $\begin{array}{l}\text { Land related legislations in } \\
\text { the State have largely } \\
\text { ignored ecological and } \\
\text { environmental issues. }\end{array}$ & $\begin{array}{l}\text { 2. There is a need to review the present } \\
\text { situation of urban land use to make } \\
\text { changes in policies and legislation. } \\
\text { WBT\&C (P\&D) Act and WBLR act } \\
\text { contain provisions which are } \\
\text { conflicting and contradictory }\end{array}$ & $\checkmark$ & -- & -- \\
\hline & $\begin{array}{l}\text { 3. Regular updating of } \\
\text { urban land use and } \\
\text { creation of data base to } \\
\text { record the changes in use is } \\
\text { not followed }\end{array}$ & $\begin{array}{l}\text { 3. The government may think of } \\
\text { establishing a separate cell for land use } \\
\text { control (ensure effective monitoring). } \\
\text { a. To address the problem of shortage } \\
\text { of qualified Town Planners, the } \\
\text { Government should set up a Town } \\
\text { Planning Educational Institution and } \\
\text { create a cadre of Planners with } \\
\text { adequate powers vested on them } \\
\text { which would ensure the effectiveness } \\
\text { of planning instruments. } \\
\text { b. Kolkata Metropolitan Area (KMA) } \\
\text { has two Municipal Corporations (KMC } \\
\text { and HMC) and 4o other Municipalities } \\
\text { which normally prepare their land use } \\
\text { plans individually not keeping in mind } \\
\text { the overall regional context. KMDA is } \\
\text { an institution which might act as an } \\
\text { umbrella in bringing about an } \\
\text { integrated approach for effective } \\
\text { spatial expansion of the largest city } \\
\text { which is not appropriately there in the } \\
\text { current system. The Government } \\
\text { should examine the gaps and if } \\
\text { necessary create a legal backup to } \\
\text { ensure such integration. }\end{array}$ & -- & -- & $\checkmark$ \\
\hline & $\begin{array}{l}\text { 4. Large quantum of } \\
\text { government land in urban } \\
\text { areas is encroached }\end{array}$ & $\begin{array}{l}\text { 4. There should be an exercise with } \\
\text { purpose to recover city lands from } \\
\text { encroachment }\end{array}$ & -- & $\checkmark$ & -- \\
\hline & $\begin{array}{l}\text { 5. A policy for low cost } \\
\text { housing and services exists } \\
\text { but implementation is not } \\
\text { always effective. As a } \\
\text { result, the number of those } \\
\text { needing adequate shelter } \\
\text { still remains high }\end{array}$ & $\begin{array}{l}\text { 5. A comprehensive policy on low-cost } \\
\text { housing/ housing facilities for the } \\
\text { underprivileged people needs to be } \\
\text { formulated in a participatory } \\
\text { approach; considering the findings of } \\
\text { USHA study government should take } \\
\text { appropriate action to accelerate the } \\
\text { implementation of Rajib Awas Yojna } \\
\text { (RAY). }\end{array}$ & -- & $\checkmark$ & -- \\
\hline & $\begin{array}{l}\text { 6. Construction of } \\
\text { buildings violating the } \\
\text { prescribed norms }\end{array}$ & $\begin{array}{l}\text { 6. The legal provisions for residential } \\
\text { building permits appear to be } \\
\text { appropriate, affordable, but more } \\
\text { vigilance would be required to ensure a } \\
\text { better system of monitoring and } \\
\text { supervision. Good practices from other } \\
\text { cities could be adopted }\end{array}$ & $\checkmark$ & -- & -- \\
\hline
\end{tabular}

158|Page Land Governance Assessment Framework - West Bengal 


\begin{tabular}{|c|c|c|c|c|c|}
\hline \multirow{2}{*}{$\begin{array}{c}\text { Thematic } \\
\text { Areas }\end{array}$} & \multirow[t]{2}{*}{ Issues } & \multirow[t]{2}{*}{ Findings } & \multicolumn{3}{|c|}{ Reform Actions } \\
\hline & & & $\begin{array}{l}\text { Short } \\
\text { Term }\end{array}$ & Medium & $\begin{array}{l}\text { Long } \\
\text { Term }\end{array}$ \\
\hline & $\begin{array}{l}\text { 7. The state does not have a } \\
\text { firm policy as yet for } \\
\text { granting tenure to slum } \\
\text { dwellers; }\end{array}$ & $\begin{array}{l}\text { 7. Security of tenure for urban poor } \\
\text { continues to be a vexed issue. Experts } \\
\text { advocate that tenural security, } \\
\text { together with an enabling role of the } \\
\text { Government with reference to } \\
\text { provision of housing finance, would go } \\
\text { a long way in mitigating the housing } \\
\text { problem in cities and assist urban poor } \\
\text { over time to gradually improve their } \\
\text { housing and living condition. The UN- } \\
\text { HABITAT generalizes the most } \\
\text { common tenure systems which include } \\
\text { freehold, leases, provisional or } \\
\text { conditional tenure and group tenure } \\
\text { arrangements. Further, importance is } \\
\text { to be given to security of tenure by } \\
\text { including it as one of the objectives of } \\
\text { JNNURM. }\end{array}$ & -- & -- & $\checkmark$ \\
\hline & 8. Land use change & $\begin{array}{l}\text { 8. As the state population continues to } \\
\text { grow and additional land is needed for } \\
\text { non-agricultural economic activities, } \\
\text { housing and urban growth, the } \\
\text { pressure to convert agricultural land to } \\
\text { non-agricultural purposes will likely } \\
\text { increase. The need is to establish } \\
\text { government policy statements on the } \\
\text { conversion of agricultural land to non- } \\
\text { agricultural purposes and clear } \\
\text { guidelines for determining whether a } \\
\text { conversion is appropriate (e.g. policy } \\
\text { could automatically permit conversion } \\
\text { within a certain distance from a major } \\
\text { roadway or urban centre to encourage } \\
\text { economic growth). Simplification of } \\
\text { rules governing the permission of a } \\
\text { change in use and narrow the } \\
\text { discretion of government officials in } \\
\text { authenticating such changes }\end{array}$ & -- & $\checkmark$ & -- \\
\hline 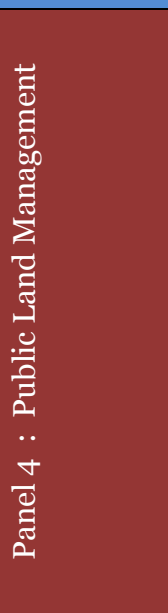 & $\begin{array}{l}\text { 1. There are tracts of public } \\
\text { lands in the State which are } \\
\text { not clearly identified on the } \\
\text { ground or on maps }\end{array}$ & $\begin{array}{l}\text { 1. A comprehensive ground survey is } \\
\text { required to be taken up jointly by the } \\
\text { L\&LR department and other } \\
\text { departments, local bodies in the field } \\
\text { level to identify and update the records } \\
\text { of the precious public lands managed } \\
\text { by these bodies along with present } \\
\text { status. The government may take up } \\
\text { this exercise on war-footing as land at } \\
\text { the control of the departments and } \\
\text { local bodies are highly vulnerable to } \\
\text { encroachment. An up-to-date } \\
\text { inventory of the lands settled with } \\
\text { various departments and local bodies } \\
\text { by the L\&LR department would } \\
\text { facilitate a proper planning for best } \\
\text { options to utilize these resources. }\end{array}$ & -- & $\checkmark$ & -- \\
\hline
\end{tabular}

159|Page Land Governance Assessment Framework - West Bengal 


\begin{tabular}{|c|c|c|c|c|c|}
\hline \multirow{2}{*}{$\begin{array}{c}\text { Thematic } \\
\text { Areas }\end{array}$} & \multirow[t]{2}{*}{ Issues } & \multirow[t]{2}{*}{ Findings } & \multicolumn{3}{|c|}{ Reform Actions } \\
\hline & & & $\begin{array}{l}\text { Short } \\
\text { Term }\end{array}$ & Medium & $\begin{array}{l}\text { Long } \\
\text { Term }\end{array}$ \\
\hline & $\begin{array}{l}\text { 2. The lands may not } \\
\text { always be identifiable on } \\
\text { the ground for various } \\
\text { reasons like change of } \\
\text { topography, encroachment } \\
\text { etc. Information on such } \\
\text { public lands is not available } \\
\text { to the public }\end{array}$ & $\begin{array}{l}\text { 2. The concerned departments or } \\
\text { institutions owning public lands are } \\
\text { required to maintain their separate } \\
\text { Land Registers which in most of the } \\
\text { cases are not done. The above- } \\
\text { mentioned joint operation will be } \\
\text { useful to have complete and updated } \\
\text { records of the resources managed by } \\
\text { the departments and public bodies. } \\
\text { Periodical physical verification and } \\
\text { updating of records should be made } \\
\text { mandatory }\end{array}$ & -- & $\checkmark$ & -- \\
\hline & $\begin{array}{l}\text { 3. There is lack of } \\
\text { transparency in allocating } \\
\text { public land to private } \\
\text { parties; information is not } \\
\text { made publicly available. }\end{array}$ & $\begin{array}{l}\text { 3. Allocation of public land to private } \\
\text { parties should always be uploaded in } \\
\text { the departmental website to maintain } \\
\text { transparency (WBIDC is following this } \\
\text { practice). }\end{array}$ & $\checkmark$ & -- & -- \\
\hline $\begin{array}{l}0 \\
\frac{0}{0} \\
0 \\
0 \\
0\end{array}$ & $\begin{array}{l}\text { 1. Mechanism to assess } \\
\text { benefit sharing when } \\
\text { land is transferred to } \\
\text { private (industry) } \\
\text { purpose; }\end{array}$ & $\begin{array}{l}\text { Considering absence of any } \\
\text { mechanism to quantify the short-term } \\
\text { and long-term benefits that will accrue } \\
\text { to the public, an independent benefit } \\
\text { assessment system needs to be put in } \\
\text { place so that maximum benefit can be } \\
\text { accrued to the public; }\end{array}$ & & & \\
\hline 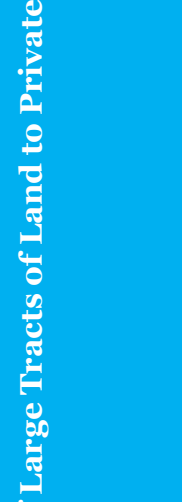 & $\begin{array}{l}\text { 2. There is lack of } \\
\text { effective coordination } \\
\text { to solve competing } \\
\text { land use; }\end{array}$ & $\begin{array}{l}\text { There is no avenue for coordination } \\
\text { between central and state governments } \\
\text { when large scale acquisition of land is } \\
\text { involved leaving scope for disputes } \\
\text { being arisen which may take a long } \\
\text { process for reconciliation. The surface } \\
\text { right transfer is dealt with by the state } \\
\text { while sub-soil rights (say coal mine) } \\
\text { are considered by central government. } \\
\text { Some formal mechanism like } \\
\text { identifying a nodal agency from both } \\
\text { state and central government for } \\
\text { compliance and reconciliation might } \\
\text { be considered. }\end{array}$ & & & \\
\hline 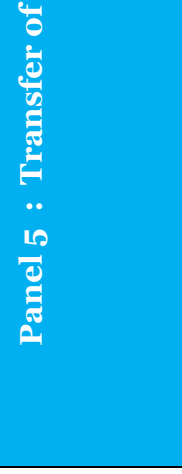 & $\begin{array}{l}\text { There is lack of } \\
\text { transparency in } \\
\text { transferring land by } \\
\text { the public institution } \\
\text { to the private } \\
\text { investors; Policy is in } \\
\text { place but there is gap } \\
\text { in implementation; }\end{array}$ & $\begin{array}{l}\text { An interdepartmental committee } \\
\text { should be formed as per guidelines laid } \\
\text { out in the Land Reforms Manual of } \\
1991 \text { to take final decisions regarding } \\
\text { land allotment after careful scrutiny at } \\
\text { all levels including the L\&LR } \\
\text { department (which has the foremost } \\
\text { importance in giving the approval for } \\
\text { land allotment to start with). Each } \\
\text { department should frame its own } \\
\text { policy accordingly consistent with the } \\
\text { general land allotment policy of the } \\
\text { government. }\end{array}$ & & & \\
\hline
\end{tabular}

160|Page Land Governance Assessment Framework - West Bengal 


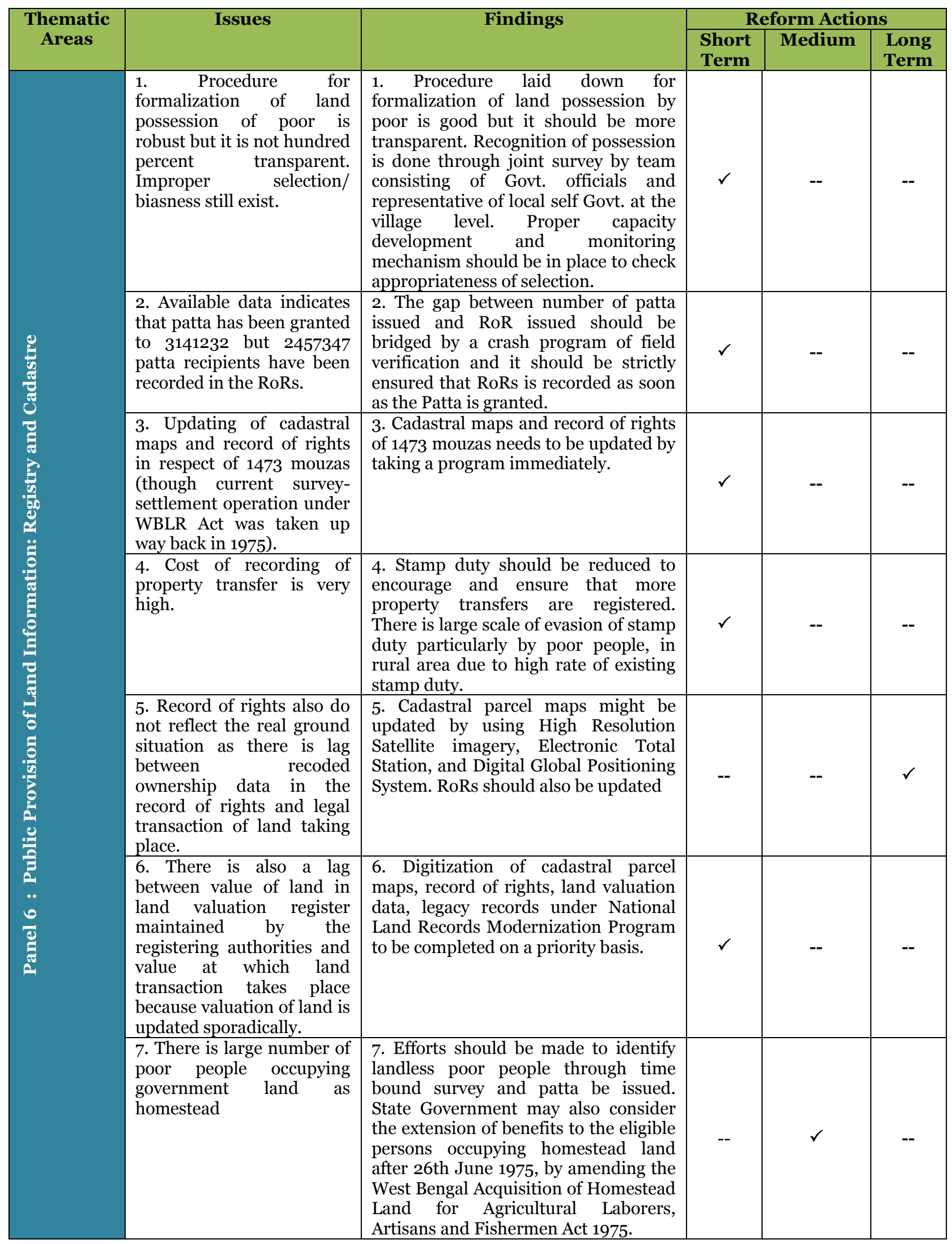

161|Page Land Governance Assessment Framework - West Bengal 


\begin{tabular}{|c|c|c|c|c|c|}
\hline \multirow{2}{*}{$\begin{array}{c}\text { Thematic } \\
\text { Areas }\end{array}$} & \multirow[t]{2}{*}{ Issues } & \multirow[t]{2}{*}{ Findings } & \multicolumn{3}{|c|}{ Reform Actions } \\
\hline & & & $\begin{array}{l}\text { Short } \\
\text { Term }\end{array}$ & Medium & $\begin{array}{l}\text { Long } \\
\text { Term }\end{array}$ \\
\hline & $\begin{array}{l}\text { 8. There is a gap between } \\
\text { the quantum of land at the } \\
\text { disposal of the L\&LR } \\
\text { Department and land } \\
\text { recorded in the record of } \\
\text { rights, particularly } \\
\text { Government land settled } \\
\text { with the land poor people } \\
\text { under Section 49(1) of } \\
\text { WBLR Act } 1955 \text { and land } \\
\text { settled through lease with } \\
\text { private individual and } \\
\text { institutions }\end{array}$ & $\begin{array}{l}\text { 8. Record of rights, cadastral maps } \\
\text { legacy records of rights should be } \\
\text { updated on real time basis. }\end{array}$ & -- & -- & $\checkmark$ \\
\hline & $\begin{array}{l}\text { 9. Fee structures for } \\
\text { different kind of services } \\
\text { are not rational and } \\
\text { transparent. It does not } \\
\text { match with high cost of } \\
\text { government service }\end{array}$ & $\begin{array}{l}\text { 9. Processing fees should be reviewed } \\
\text { and increased by at least } 50 \text { times to } \\
\text { partially accommodate cost of } \\
\text { manpower and infrastructure for } \\
\text { recording of rights over land. } \\
\text { - Relevant public restriction or } \\
\text { charges should be recorded in a } \\
\text { consistent and reliable manner. } \\
\text { - Land records and cadastral maps } \\
\text { are to be updated on real time } \\
\text { basis. } \\
\text { - Existing rates of collection of fees } \\
\text { for providing services should be } \\
\text { increased. Graded rates are to be } \\
\text { levied for different income groups. } \\
\text { Higher rates for high income } \\
\text { groups and lower rates for low } \\
\text { income groups. } \\
\text { Graded fee structure different } \\
\text { services and for different income } \\
\text { group should be introduced to } \\
\text { provide high quality service at cost } \\
\text { effective manner. } \\
\text { Rationale for fixation of fees for } \\
\text { different services should be fixed } \\
\text { transparently to cover the cost of } \\
\text { services. }\end{array}$ & -- & $\checkmark$ & -- \\
\hline & $\begin{array}{l}\text { 10. Illegal staff behavior } \\
\text { and informal payments for } \\
\text { service delivery }\end{array}$ & $\begin{array}{l}\text { 10. Service standard for all services } \\
\text { should be established A proper } \\
\text { supervision and mechanism to be put } \\
\text { in place to monitor illegal staff } \\
\text { behavior and service delivery standard. } \\
\text { The government has enacted West } \\
\text { Bengal Rights to Public Service Act, } \\
\text { 2013 which has helped in improving } \\
\text { service delivery standards }\end{array}$ & $\checkmark$ & -- & -- \\
\hline 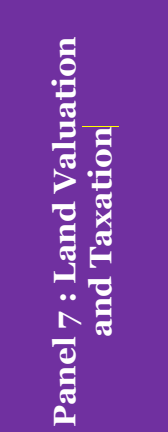 & $\begin{array}{l}\text { Ensure minimal } \\
\text { differences between } \\
\text { the recorded value and } \\
\text { market prices across } \\
\text { different uses and type } \\
\text { of users. There is lack } \\
\text { of coordination among } \\
\text { the different layers of } \\
\text { the government which } \\
\text { results into less } \\
\text { revenue and tax } \\
\text { collection; }\end{array}$ & $\begin{array}{l}\text { There is a need for coordination } \\
\text { among the different layers of the } \\
\text { government in use of Market Value } \\
\text { Data Base (MVDB) in CORD not only } \\
\text { for the purpose of collection of stamp- } \\
\text { duty revenue/registration fee as } \\
\text { currently done, but also for calculation } \\
\text { of base of property/land tax and land } \\
\text { revenue. This will allow for less } \\
\text { discretion in determination of tax } \\
\text { base, which is essential for a } \\
\text { transparent and efficient tax regime. }\end{array}$ & -- & $\checkmark$ & -- \\
\hline
\end{tabular}

$\mathbf{1 6 2 | P a g e ~ L a n d ~ G o v e r n a n c e ~ A s s e s s m e n t ~ F r a m e w o r k ~ - ~ W e s t ~ B e n g a l ~}$ 


\begin{tabular}{|c|c|c|c|c|c|}
\hline \multirow{2}{*}{$\begin{array}{c}\text { Thematic } \\
\text { Areas }\end{array}$} & \multirow{2}{*}{ Issues } & \multirow{2}{*}{ Findings } & \multicolumn{3}{|c|}{ Reform Actions } \\
\hline & & & $\begin{array}{l}\text { Short } \\
\text { Term }\end{array}$ & Medium & $\begin{array}{l}\text { Long } \\
\text { Term }\end{array}$ \\
\hline \multirow{4}{*}{ 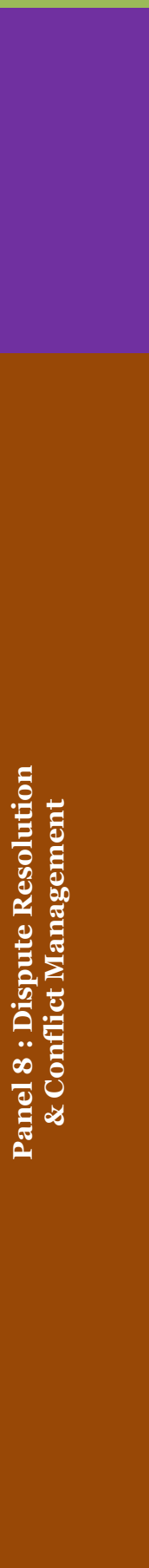 } & $\begin{array}{l}\text { More than one-fourth } \\
\text { of demand of property } \\
\text { tax of the ULBs are } \\
\text { from the government } \\
\text { departments and } \\
\text { undertakings }\end{array}$ & $\begin{array}{l}\text { There is a big issue in respect of } \\
\text { realization of outstanding property tax } \\
\text { by the ULBs, substantial part of which } \\
\text { are due to the state and central } \\
\text { departments and undertakings. This } \\
\text { issue needs to be taken up jointly by } \\
\text { the governments for working out an } \\
\text { acceptable solution for all the parties } \\
\text { involved }\end{array}$ & -- & $\checkmark$ & -- \\
\hline & $\begin{array}{l}\text { 1. } \begin{array}{l}\text { Early disposal of } \\
\text { record correction } \\
\text { cases, mainly }\end{array} \\
\text { Mutation cases, by the } \\
\text { Revenue authorities, is } \\
\text { impeded when } \\
\text { difference exists } \\
\text { between the facts in } \\
\text { the Land Records } \\
\text { maintained by } \\
\text { Revenue authorities } \\
\text { and that in the records } \\
\text { of the Registration } \\
\text { Department. }\end{array}$ & $\begin{array}{l}\text { A system to be in place (on-going) for } \\
\text { interlinking the two departments so } \\
\text { that simultaneous updation of Land } \\
\text { Records can be done when any } \\
\text { transfer is executed (through the } \\
\text { Registration Department). This is } \\
\text { possible in West Bengal as Land } \\
\text { Records maintained by the Revenue } \\
\text { Department ( i.e. the Land Reforms } \\
\text { Deptt) have all been computerized, } \\
\text { and the functioning of the Land } \\
\text { Registration Department has also been } \\
\text { fully computerized. The bridging } \\
\text { between the two systems will keep the } \\
\text { records updated and thereby reduce } \\
\text { the scope of disputes in this sphere to } \\
\text { the minimum. }\end{array}$ & $\checkmark$ & -- & -- \\
\hline & $\begin{array}{l}\text { 2. Non-participation or } \\
\text { absence of the parties } \\
\text { during the relevant } \\
\text { stages of preparation } \\
\text { of land records is one } \\
\text { of the causes of faulty } \\
\text { recording in land } \\
\text { records. }\end{array}$ & $\begin{array}{l}\text { Steps should be taken for awareness } \\
\text { development by wide publicity through } \\
\text { local print and electronic media, which } \\
\text { would ensure greater public } \\
\text { participation during preparation of } \\
\text { land records. This will help in reducing } \\
\text { future litigations. }\end{array}$ & $\checkmark$ & -- & -- \\
\hline & $\begin{array}{l}\text { 3. Dispute resolution } \\
\text { mechanism is in place } \\
\text { under the WBLR Act. }\end{array}$ & $\begin{array}{l}\text { Steps should be taken for speedy } \\
\text { disposal of cases by ROs, appellate } \\
\text { authority and the LRTT as follows - } \\
\text { - There should not be any } \\
\text { unnecessary adjournment, even } \\
\text { on lawyer's ground } \\
\text { The BLLRO should ensure timely } \\
\text { submission of proper records and } \\
\text { papers. } \\
\text { The number of dates for disposal } \\
\text { of a case should be limited, } \\
\text { preferably three dates and those } \\
\text { should also be allowed within a } \\
\text { short span. }\end{array}$ & $\checkmark$ & -- & -- \\
\hline
\end{tabular}

163|Page Land Governance Assessment Framework - West Bengal 


\begin{tabular}{|c|c|c|c|c|c|}
\hline \multirow{2}{*}{$\begin{array}{c}\text { Thematic } \\
\text { Areas }\end{array}$} & \multirow[t]{2}{*}{ Issues } & \multirow[t]{2}{*}{ Findings } & \multicolumn{3}{|c|}{ Reform Actions } \\
\hline & & & $\begin{array}{l}\text { Short } \\
\text { Term }\end{array}$ & Medium & $\begin{array}{l}\text { Long } \\
\text { Term }\end{array}$ \\
\hline 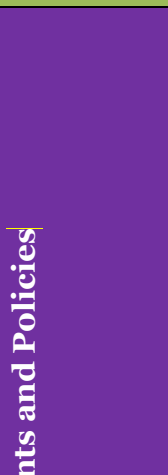 & $\begin{array}{l}\text { Though there is a well- } \\
\text { defined reporting } \\
\text { system on a regular } \\
\text { basis within the } \\
\text { department but the } \\
\text { information is not } \\
\text { available to the public. } \\
\text { There is no } \\
\text { mechanism of tracking } \\
\text { the progress of } \\
\text { implementation of } \\
\text { different policies by } \\
\text { the public. }\end{array}$ & $\begin{array}{l}\text { The budget speech and information } \\
\text { related to performance of the } \\
\text { department and progress thereof } \\
\text { needs to be uploaded in the } \\
\text { departmental website } \\
\text { banglarbhumi.gov.in so that people } \\
\text { can track the progress of } \\
\text { implementation of land reform } \\
\text { measures with equity objectives. }\end{array}$ & $\checkmark$ & -- & -- \\
\hline 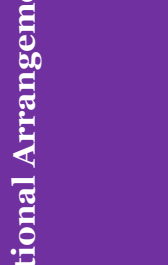 & $\begin{array}{l}\text { 2. Though there are } \\
\text { legislations which } \\
\text { recognizes the rights of } \\
\text { women, State does not } \\
\text { have comprehensive } \\
\text { land policy to address } \\
\text { the issues of gender. }\end{array}$ & $\begin{array}{l}\text { Gender issues should be appropriately } \\
\text { incorporated in the land policy. And } \\
\text { in-built mechanism should be } \\
\text { developed to monitor the } \\
\text { implementation of the policy. }\end{array}$ & -- & $\checkmark$ & -- \\
\hline 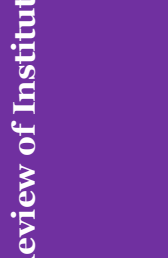 & $\begin{array}{l}\text { 3. Land related } \\
\text { legislations in the } \\
\text { State have largely } \\
\text { ignored ecological and } \\
\text { environmental issues. }\end{array}$ & $\begin{array}{l}\text { Ecological and environmental issues } \\
\text { should be reviewed in the overall } \\
\text { interest of the state and properly } \\
\text { incorporated in the policy (may be by } \\
\text { making amendments in existing } \\
\text { legislations). Policy should spell out } \\
\text { proper mechanism for monitoring. }\end{array}$ & $\checkmark$ & -- & -- \\
\hline 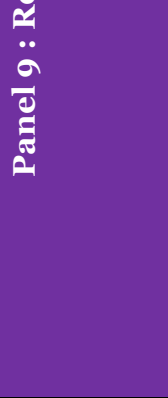 & $\begin{array}{l}\text { 4. Though there are } \\
\text { certain provisions in } \\
\text { the legislation like } \\
\text { wetland management } \\
\text { which addresses the } \\
\text { issues of future } \\
\text { disaster risk but there } \\
\text { is lacuna in } \\
\text { enforcement. }\end{array}$ & $\begin{array}{l}\text { Agenda of disaster risk reduction has } \\
\text { to be incorporated in land policy/ } \\
\text { legislation in collaboration and } \\
\text { consultation with the Disaster } \\
\text { Management Department while } \\
\text { preparing the land use maps for land } \\
\text { zoning under the direct supervision of } \\
\text { the L\&LR Department. A } \\
\text { comprehensive policy should } \\
\text { adequately address the issues of future } \\
\text { disaster risk. }\end{array}$ & $\checkmark$ & -- & -- \\
\hline
\end{tabular}

164|Page Land Governance Assessment Framework - West Bengal 


\section{d) Data Gap}

The following gaps in data availability were identified during the course of LGAF exercise and it would be helpful to collect or create access to the data source in the future for the purpose of monitoring of land governance progress.

\section{Panel 1}

- Actual number of record of rights and land parcels

- Data related to change in economic and social status of land reform beneficiaries

- Assessment of women land ownership in the State

- Data related to illegal land sales and land lease transaction

- Individual land parcels in urban areas in the State

- Data related to commons lands

- Change in land use over a period of time

\section{Panel 2}

\section{Panel 3}

- Urban land use planning and its actual implementation / progress within a period of time

- Building permits applied for and disposed off with time period

- Informal or illegal occupation of urban land

\section{Panel 4}

- Public land managed by Local Self-Government and recording of publicly held land

\section{Panel 5}

- Land acquisition for different purposes over last 5 years

- Data related to compensation payment - quantum of land, period of time taken, disbursement etc.

- Data related to Public land transaction (transfer, lease etc.) and the cost involved

- Data realted to contractual provisions including benefit sharing mechanism

- Information on spatial extent and duration of approved concession

\section{Panel 6}

- Extent of long term, unchallenged possession of government and private land

\section{Panel 7}

- Details of exemption from property tax payment

- Percentage of property tax demand (ULB wise and collection thereof)

\section{Panel 8}

- Number of land dispute pending district wise in the offices of the BLLROs

- Number of cases lodged every year and dispossed off with time taken by the ROs and appellate authorities 


\section{e) Evolution of Land Governance in West Bengal}

To understand the land governance in modern times in the state of West Bengal it is necessary to trace the history of the land tenure system in this part of the country.

During Hindu period extending up to the end of the $12^{\text {th }}$ century land came to be looked upon as a common property like air, water and light. The person, who cleared the jungle to cultivate the land, became the owner of the land. This is the concept of the ownership of land-peasant proprietorship during that period, as we learn from Manu's Sanhita, The Monarch's claim over a share of the produce of the landrestedon the fact that he provided protection to the enjoyment of the Land. Two persons were thus interested in land and its produce -- the king and the tiller of the soil. Intermediate interests or sub-letting was unknown during the Hindu period. Subletting of land began only when the actual occupant of the land either out of necessity or indolence started employing hired men for cultivation. However, the concept of creation of tenancy for cultivation of land was alien to the Hindu sages or shastrakars who were the lawsgivers at that time.

The indigenous system of land-law, more socio-political than legal came into a severe conflict in the beginning of the $13^{\text {th }}$ Century with the Islamic jurisprudence brought in by the Muslim conquers who started with the proposition that upon conquest all individual ownership came to an end, and all land stood vested in the conqueror. Accordingly, the conqueror distributed the lands among soldiers- Jagirdars. The land which could not thus be distributed was given to Muslims, the believers and the Hindus, the Kafers or non-believers. The rent that was collected from the Muslims was much lower than that collected from the Hindus.

Thus the Muslim system completely reversed the principle underlying the land system of the Hindu period. However, the Muslim rulers on practical consideration seldom interfered with the conflicts between the Jagirdars and their sub- lessees, or the cultivating raiyats, the peasant proprietor with the result the old system of cultivation and occupation of land continued as before at the ground level.

The great Mughal Emperor Akbar wanted to bring back the old Hindu system. His finance Minister Todarmal introduced a system of assessing a fixed sum as rent per bigha on actual measurement by abolishing the distinction between the low rate of rent at which the Muslims were paying and high rate of rent at which the Hindus were paying. He also introduced the system of collecting rent directly from the cultivating tenants ignoring the Jagirdars. However, Todarmal's system of assessment of rent on actual measurement occupied by a tenant could not be introduced in full in Bengal Subaha and the land revenue system continued as before till it was systemized by Murshid Kuli Khan who was sent by Arungazeb to Bengal Subha first as the Finance Minister of the Subhadar and later promoted as the Subhadar of Bengal.

It was Murshid Kuli Khan, not Cornwallis, contrary toa common belief, who was the founder of the Zemindary system of Bengal; He largely replaced the Monnsabdars and Jagirdars many of whom were up country Muslims having no vested interests in their estates in Bengal. He appointed a new set of Zemindars, most of whom were Hindus. He also appointed many Bengali Hindus in the high offices ofrevenue administration.

When East India Company obtained the Dewani (revenue administration) of Bengal, Behar and Orissa it inherited the structure of land revenue administration introduced by Murshid Kuli khan. Initially the company did not interfere with the existing system. But land revenue being the principal source of income the company went on putting pressure for collection of more revenue. Collection of revenue in addition to what was being collected before put additional burden on the cultivators and this burden was much more than they could bear. One of the main causes of the great famine of 1176 BS (corresponding to 1770 Christian era) which came to the known as "Chiyattarer Monwantar" is, in the language of W.W. Hunter in the Annals of Rural

166 | Page Land Governance Assessment Framework - West Bengal 
Bengal, "the brutal fleecing of the cultivators of land by the NayebDewanReja Khan" who was entrusted by the company with collection of Revenue in Bengal. Nearly one- third of the total population of Bengal was eliminated as a result of this famine.

The English received a rude shock which awoke them from slumber. The company sacked Reja Khan and took upon itself the land revenue administration. Lands were settled with the Zamindars for five years only. This is known as quinquennial settlement. After expiry of five years this system was discontinued. The company introduced the system of settlement of land on auction for one year only. Many old Zamindars having long experience of managing lands and collecting revenue failed to succeed in the competitive bidding, had to bow out. The new rich who made money in different trades with the company having no knowledge of managing a zamendary took the place of the old Zamindars. Since the tenure was for one year only with no guarantee of renewal the new Zamindars did not bother about the cultivators and the cultivation of land. Their sole object was to make as much money as they could during their very short tenure of zamindary.

When Cornwallis came to India as the Governor General he could realize the mischief caused by the yearly settlement. In 1789, he settled lands with the Zamindars for 10 years. This is known as decennial settlement. This 10-year settlement of land was converted into permanent settlement by the Permanent Settlement Regulation I of 1793.

Permanent settlement gave the Zamindars proprietary rights on land. The Zamindars who were hither to mere collectors of revenue became the proprietors of land, and the sovereign thus parted with the ownership of land with the collectors of revenue. The only obligation of the proprietor-Zamindar was to pay revenue before the sun-set of the last day of Chaitra, the last month of the Bengali year. This is known as the Sun-Set law. The Zamindars paying revenue on time enjoyed unchartered rights over not only the lands but also the lives of those who cultivated the lands. The concept of peasant proprietorship surviving various onslaughts for more than two millennia finally made way for the Zamindary proprietorship.

Although Cornwallis' primary object of ensuring a stable yearly income to balance the Company's budget and creating a powerful but loyal class of landlords on whom the Company could rely for the governance of this country were achieved, the permanent settlement was proved to be an unmitigated disaster for Bengal. The Zamindars felt free to do whatever they liked. Not only did they go on enhancing the rate of rent but invented various means for extracting money from the cultivators in the form of what came to be known as "abwabs". Since, many of the estates permanently settled with the Zamindars were very big in size the Zamindars could not manage their estate. They went on creating tenants under them for collection of rent. This is how middleman between the landlords and the cultivators were created. The net result of permanent settlement was that while the Zamindars and the middleman lived in luxury the cultivators led a miserable life in abject poverty.

The Company's attempt to provide a mechanism for resolution of disputes and conflict management by way of employing patwari for every village and kanungo to supervise the work of the patwaris did not succeed in protecting the tenants against the landlords due to absence of a law, or a reliable document of land and tenancy thereon. It was only after the revolt of 1857 and the taking over of the governance of this country by the British Crown a mechanism for resolution of disputes and conflict management was sought to be provided in the Rent Act of 1859. As a matter of fact during the period between the death of Murshidkuli Khan and gradual weakening of Mughal administration and the coming into force of the Act of 1859 the landlordtenant relationship was in a nebulous condition. However, it is a landmark legislation aimed at protecting the rights of hereditary raiyats and resident raiyats and of occupancy of land and curbing the rights of the Zamindars to increase rent at will. But the mechanism was rendered ineffective by the manipulative tactics adopted by the Zamindars.

167| Page Land Governance Assessment Framework - West Bengal 
The Bengal tenancy Act (BT Act) came into force in 1885. Since the Zamindars' lobby was much more powerful than some of the leaders who took up the cause of cultivating raiyats and organized a movement urging the government to incorporate in the Act some measures which would make their rights more secure. The Act did not contain anything which would mitigate the hardship of the cultivating tenants. Hence, the Act laid more emphasis on systematizing the land tenure system than providing relief to them. This Act aimed at providing a tangible and more precise law on land. It divided those who lived off land into two categories: - landlords and tenants. A landlord was defined as a person including the government under whom a tenant held land. The tenants were classified as:

(a) Tenure-holders including under tenure-holders who acquired land from a proprietor (owner of an estate) or tenure holder a right to hold land for the purpose of collecting rent

(b) Raiyats who acquired a right to hold land for the purpose of cultivating lands by themselves;

(c) Under-raiyats- tenants holding lands under raiyats.

The Act also defined the incidents of tenures and occupancy right. An occupancy raiyat was not to be ejected by his landlord except in execution of a decree of the Civil Court. The Act put restriction on enhancement of rent, which could be made only in accordance with the provisions of the Act.

The most significant contribution of this Act to systemize the land tenure system of Bengal is that it provided for a detailed survey and settlement operation in respect of each and every piece of land of every village. Accordingly cadastral map of each and every village was prepared with each and every piece of land with classification according to use as well as ownership was plotted therein. Each such piece of land came to be known as a plot. Each such plot was given a separate number. On the basis of such map record of rights containing plot or plots of land with the respective rights and interests therein of the landlord and tenant and other incidence attached thereto was prepared. The record of rights is known as Khatian (loosely Parcha) bearing a separate number in relation to a particular mouza or village (the distinction between the two is very subtle) which also was assigned a separate jurisdiction list number in relation to a police station or thana. This is how each and every piece of land of Bengal came to be known as a plot or "dag" and given a distinct identification number. How a plot of land was possessed and the capacity in which such possession was being exercised was also noted.

Armed with the BT Act and the record of rights the tenants sought to assert whatever rights the Act gave them and resist violations of their rights by the landlords. Litigations were in spate. The landlords by virtue of their more resources tilted the decisions in dispute before the executive authorities as well as the Courts in their favour. The objects of the Act were thus frustrated to a great extent. The Act had to be drastically amended is 1928 and 1938 to plug the loopholes through which the landlords escaped.

Fazlul Haque ministry then ruling the Province of Bengal was very vocal in castigating the Zamindary system. The British government came to realize that the diseases from which the Zamindary system introduced by the permanent settlement suffered were incurable. It would be interesting to know that after having introduced permanent settlement of law with the Zamindars with a view to transplanting English aristocracy into the soil of Bengal the English themselves did not do so elsewhere of India except in a few small pockets of Madras Presidency. For other place their preference was for raitwary system in which the government settled lands directly with the cultivating tenants and collected rent from them. In 1938 they set up a Land Revenue Commission under the chairmanship of Sir Francis Floud. The commission in its report submitted in 1940 recommended abolition of Zemindary by bringing the cultivators of the land directly under the state. This report was referred to the Bengal Administrative Inquiry

$\mathbf{1 6 8}$ | Page Land Governance Assessment Framework - West Bengal 
Committee which fully endorsed the recommendation of the Floud Commission. Since the days of the British rule was coming to an end nothing was done on these reports.

The West Bengal Estates Acquisition Act, 1953

India became independent in 1947. In the debates of the Constituent Assembly on the right to property, it was unanimously resolved that the cultivators of land should be conferred with the rights to hold land directly under the state by abolishing the estates and eliminating the intermediaries. The Constitution of India came into force on 26.01.1950. The articles 31, later $31 \mathrm{~A}, 31 \mathrm{~B}$ and $31 \mathrm{C}$ provided for acquisition of estates and all preexisting rights of the intermediaries.

In pursuance to these Constitutional provisions the States passed legislation to abolish Zamindary. In this State, the West Bengal Estates Acquisition Act 1953 (EA Act) was passed. It came into force on $12^{\text {th }}$ February 1954.

The EA Act had two objects:

a) To abolish Zamindary - that is all rent receiving interests;

b) To impose a ceiling on land held by individuals. These objects were sought to be achieved by the scheme of the Act made out in sections 4,5 and 6 contained in chapter II dealing with the acquisition of estates and of the rights of intermediaries therein.

Notification was issued $\mathrm{u} / \mathrm{s} 4$ declaring that with effect from 15.04.1955 (the date of vesting) all estates and the rights of every intermediary in each such estate shall vest in the State. 16.04.1956 is the date of vesting for the raiyats who came to be regarded as deemed intermediaries subsequently. Section 5 lays down what precisely vested in the state on publication of notification $\mathrm{u} / \mathrm{s}$ 4. The combined effect of sections 4 and 5 is that all lands held by an intermediary - be he a proprietor, or tenure-holder or under- tenure- holder or raiyat or underraiyat including all his pre-existing rights, title and interests vested in the state. Only the lands held by a non-agricultural tenant and under-tenant remained beyond the purview of the Act. Section 6 (I) provides that notwithstanding the vesting of all lands in the State, an intermediary is entitled to retain 25 acres of agricultural land and 15 acres of non- agricultural land (20 acres together with homestead land). No ceiling was imposed on other kinds of land. Section 6 (2) says that an intermediary who is entitled to retain possession of land u/s 6(I) shall hold such land directly under the state as a tenant. This is how all those who lived off land came on the same platform as a tenant under the State no matter what was his status previously.

To give effect to the scheme and carry out the purposes of the EA Act as discussed above it was necessary to get the possession of land and all incidences attached thereto obtaining on the relevant date of vesting -15.04.1955 or 16.04.1956, as applicable. Provisions were made under chapter $\mathrm{V}$ of the Act for preparation of records of rights and revision of record of rights prepared previously under the BT Act. Field verifications were made, the changes noted down and the records were draft published inviting objections thereto from the interested persons. After disposal of objections the records were finally framed and published. In the process the disputes between the tenants and the landlords and between tenants lying undecided during the period between preparation of records under the BT Act and revision thereof under the EA Act got resolved. In the final records the interests of all intermediaries were eliminated. The state in each record was the landlord and the person holding the land was shown as tenant.

\section{The West Bengal Land Reforms Act, 1955}

As a follow-up of the EA Act by a comprehensive measure of land reforms so as to remodel the system of land tenure, the West Bengal Land Reforms Act 1955 (LR Act) was passed. It came into force on 30.03.1956. According to the present definition of a raiyat under the Act whoever

169|Page Land Governance Assessment Framework - West Bengal 
holds land for any purpose whatsoever is a raiyat and land as defined in the Act means land of every description.

Chapter II deals with the rights and obligations of the raiyat. His right is heritable and transferable. But he has no right to sub-soil, quarry sand or to dig or use earth or clay for the manufacture of bricks or tiles. He is prohibited from letting out his land. By an amendment of the Act in 2012, some relaxation has been provided. He can now lease out land for certain specific purposes. A raiyat cannot also change the area, character or use of his land except on permission from the appropriate authority. He can transfer land only by a registered instrument, and partition of land among co-sharers shall have to be made either by a registered instrument or a decree or order of a court.

Chapter IIA puts restrictions on the model of the BT Act on alienation of land by a Scheduled Tribe, who can transfer his land in the manner laid down in section 14C. Sale of land to a nontribal can be made only with the previous permission in writing of the appropriate authority. Penalties have been provided for violation of the prohibitory provisions.

Chapter IIB imposes ceiling on land held by a raiyat. Originally LR Act dealing with only agricultural land did not impose any new ceiling. The ceilings prescribed under the EA Act continued. Ceiling under the EA Act was imposed on the land held by an individual raiyat. A family consisting of many raiyats was thus entitled to retain lawfully considerable amount of land in aggregate. Again there was no ceiling on land comprised in tank-fisheries, orchards, and lands held by religious and charitable institutions. Thus, there was scope for making more lands available for distribution among landless people. On the basis of the results of examination of ceiling laws of different states made by the Planning Commission, it was decided in a Chief Ministers' Conference at the beginning of seventies that a new ceiling taking a "family" as aunit as against "an individual" should be imposed. Accordingly, the LR Act was amended in 1971 and chapter IIB was inserted.

A comprehensive definition of "family" has been provided. Land has been classified as in irrigated area and non-irrigated area. A concept of "standard hectare" meaning 1.0 hectare of land in irrigated area is equal to 1.40 hectare of land in non-irrigated area has been introduced. Ceiling area has to be determined according to the size of a family as well as the fact whether the land held by a family is in irrigated area or non-irrigated area. For a one-member family the ceiling area is 2.50 standard hectares, corresponding to 6.18 acres in irrigated area and 8.65 acres in non-irrigated area. For two to five-member families the ceiling area is 5.0 standard hectares. For each member in excess of five, the ceiling area shall be increased by 0.50 hectare subject to a maximum of 7 standard hectares corresponding to 17.35 acres in irrigated area and 24.20 acres in non-irrigated area.

The Act suffered two drastic amendments in 1981 and 1986. Many revolutionary changes were brought in the Act. The notable changes are:

The definition of "land" underwent a sea-change. Previously land under the LR Act meant only agricultural land including homestead. Under the amended definition land means land of every description. All that we see around is land. Lands held by non-agricultural tenants and undertenants under the Non-Agricultural Tenancy Act 1949, remained unaffected by the ceiling provisions under the EA Act and LR Act. Under the amended Act all lands held by such tenants and all their rights therein vested in the state with effect from 09.09.1980. Such tenants are now to be deemed as raiyats under the LR Act and ceiling provisions of the Act will apply on the lands held by them.

Ceiling provisions have been extended to all kinds of land irrespective of their use and the status, nature and character of the raiyats who hold the lands. No land therefore has been kept

170|Page Land Governance Assessment Framework - West Bengal 
beyond the ceiling provisions - tank-fisheries, orchards, lands held by religious and charitable institutions - all have come within the fold of the ceiling provisions.

Chapter III deals with the rights and obligations of Bargadars. A bargadar is a person who cultivates the land of another person on condition of paying a share of the produce. His right of cultivation is heritable but not transferable. The shares of the produce and the manner in which such share shall be tendered have been laid down in the Act in detail. Termination of cultivation of land by a bargadar can be made only in accordance with the procedure laid down in the Act, with the result eviction of a bargadar is well-nigh impossible. Revenue Officers at the field level have been armed with ample powers to decide the disputes between a bargadar and the owner of the land. Jurisdiction of the Civil Court has been ousted. The provision of the Act have been so modeled as to make it almost impossible for the owner of the land to get back his land once he has inducted a bargadar to cultivate his land. A bargadar's right of cultivation is thus fully secure.

A provision exists in the Act to constitute a State or Regional Land Corporation to advance funds to a bargadar to enable to purchase land that he cultivates when the owner of such land intends to sell the land. No step however, has been taken by the government to implement this provision. May be the political groups interested in keeping the bargadars at the existing state for electoral gains do not want this provision of the Act to be implemented.

Chapter IV contains provisions for determination and payment of revenue to the Government of West Bengal, the landlord of all the lands of the state by the tenants - the raiyats. This chapter has a cheqered history. Under the EA Act, the state acquired the rent receiving interests of the intermediaries against compensation. Detailed provisions were made in Act regarding assessment and payment of compensation. It was therefore, necessary to obtain first what was the amount that an intermediary was actually collecting as rent from his tenants as on the date of vesting with effect from which his rent receiving interests vested in the state. Keeping this purpose of the Act in view when the land records were revised under the EA Act the rent that was actually being paid by the tenants to their immediate landlords were noted in the records. The Act however, provided for determination of revenue during revisional settlement operation in respect of only the lands for which no rent was paid (niskar land or rent free land) or rent was paid in kind. The basis of such determination - the average yield per acre of the class of land concerned prevailing in the vicinity - was provided in the Act. The Act also provided for determination of rent for different classes of land held by tea-gardens.

When the LR Act with chapter IV containing provisions for determination of revenue came into force on 30 March 1956, no determination was made till 14.04.1981 and revenue was being collected on the basis of the rent that was recorded in land records revised under the EA Act in the fifties. Obviously the rate was very low rupees $3 / 4$ per acre. If we trace the history of why the rate of rent in Bengal was low compared to that prevailing elsewhere in the country when India became free we got an interesting story which establishes that nothing in this world is an unmixed evil. Since Bengal was a permanently settled area it was the Zamindar's prerogative as a proprietor of land to induct tenant thereon at a rent fixed by him. It was again his prerogative to enhance the rate of rent. The government did not gain thereby because the government could not claim anything more than the revenue at which the estate was settled. The government could not lest curb the tendency of indiscriminate enhancement of rent as they did by the Rent Act 1859 and the BT Act of 1885. But in raiyotary areas, since the government settled the lands directly with the tenants at rent fixed by the government it was open to the government to enhance the rate of rent when the government needed more money and land revenue remained principal source of income of the government. Hence the government freely enhanced the rate of rent. This is how the rate of rent soared in raiyotary area whereas in Bengal the average rate of rent remained low because some Zamindars were more sensible than others and considered

171|Page Land Governance Assessment Framework - West Bengal 
tenant's ability to pay, but the revenue officials and tahasildars of raiyotary areas mechanically collected rent at enhanced rate.

From 15.04.1979 the government exempted the raiyats owning land up to 6 acres from paying revenue. Only the raiyats owning more than 6 acres of land were to pay the revenue, and the number of such raiyats after implementation of two ceiling laws is not great in this state. This can be safely said that only a few persons in this state pay land revenue.

Exemptions to small land owners gave rise to a practical problem. The Rent Act of 1859gave occupancy rights to cultivating tenants and the BT Act of 1885 systematized the rights of such tenants on land. In a dispute between the landlord and the tenant the stock plea of the landlord was that the contestant was not his tenant. Since the tenant was not armed with a patta (a document of creation of tenancy) which the landlord seldom granted in clear violation of of legal provisions the tenant was at a serious disadvantage to prove his tenancy. The civil courts in course of time and in acknowledgement of the hapless condition of the tenants to contest the denial by the landlords of the creation of tenancy tilted in favor of the tenants and accepted rent receipts as a proof of tenancy. This is how rent receipts came to be regarded as a valuable document to the tenants.

As a result of exemption the tenants holding lands up to 6 acres were not to pay revenue and so not to get any receipt. They apprehended that exemption of revenue which was a paltry sum in any case was going to rob them of the valuable document which receipt to them is. The government took notice of this apprehension and provided in the Act that the tenant would pay different kinds of cess as before and get receipts and such receipts would be as good as the revenue receipts.

The West Bengal Land Holding Revenue Act, 1979 with comprehensive provisions for determination and payment of revenue came into force with effect from 14.04.1981. This independent Act dealing with revenue matters omitted chapter IV of the LR Act as a logical corollary. But the Act met a road block in the Calcutta High Court and was never implemented.

In 2000, the LR Act was amended and chapter IV was reintroduced by repealing the Land Holding Revenue Act 1979, and the amended provisions were given retrospective effect from 14.04.1981. In 2003 and 2005 chapter IV of the LR Act was again amended. The latest table of the rates at which land revenue is to be paid with effect from 17.12.2005 was provided by the amendment of LR Act in 2005.

Meanwhile, during the long period between the fifties of the last century when records revised under the EA Act recorded the rent the tenants were actually paying to the landlords and the end of 2005 land use pattern has undergone a sea-change. The traditional classification of land as agricultural land and non-agricultural land no longer holds good. There have been a lot much stratification under both the heads. Land has been put to various forms of commercial and industrial uses, as will be evident from the table containing categories of land and the rates at which revenue is to be paid, provided in the Act. Obviously, the rates vary between Rs. 20/- per acre and Rs. 17,500/- per acre. Main features of the table are the following:

Determination of the rates at which revenue has to be paid is not left with any official of the government. The Act has not only laid down the rates at which revenue has to be paid but also categorized the lands to which such rates apply. What is left is only simple arithmetical calculation. Hence, manipulation at the lower level has thus been minimized, if not fully eliminated.

A clear distinction has been made between the lands within municipal areas and lands in nonmunicipal areas. Although for lands used for the purpose of agriculture in both the areas is the

172 | Page Land Governance Assessment Framework - West Bengal 
same - Rs. 20/- per acre (to be paid by the raiyats holding more than 6 acres of land), for other categories of land in municipal areas the rates are much higher than the rates of similar categories of land in non-municipal areas.

A new concept of "activities allied to agriculture" meaning fisheries, poultries, piggeries, potteries, floriculture, horticulture, sericulture, dairies, livestock breeding and other land based bio-mass production activities - have been introduced and a slightly higher rate of Rs. 30/- per acre has been fixed. For land used as homestead and non-agriculture purposes other than commercial and industrial purposes double the rate of agricultural land has been fixed.

Another new concept on the principle of the ability to pay has been introduced. For the same category of land if it is held by an individual or a cooperative society the rate is much lower than the rate if such land is held by a company. While for land used as homestead or for nonagricultural purposes an individual will pay at Rs. 40/- per acre, a company will have to pay at Rs 150/- per acre, and for land used for brackish water fisheries the individual or a cooperative society will pay at Rs. 200/- per acre but a company will have to pay at Rs. 400/- per acre, and if land is used for multi-storied building by a cooperative society the rate is Rs. 600/- per acre, while for the same land a company will have to pay at Rs. 800/- per acre.

Land in municipal areas has been categorized under five heads - categories A to E, according to the size of the population, plus a special category such as land in Municipal Corporation has been made. While the rate at which revenue is to be paid for land in category E municipal area is the lowest it has graduated upwards and for land within a Municipal Corporation area the rate is the highest.

It is clear from the provisions as to revenue contained in chapter IV that a modern approach has been adopted in determining the rates of revenue for various categories of land. The approach is fairly comprehensive and the principle of equity according to gains a raiyat as defined in the Act including an individual as well as a company makes for putting the land to different uses has been followed.

The revenue for which provisions have been made in chapter IV discussed above is to be paid by the tenants who own lands and pay revenue to the government as landlord because the government acquired the rent receiving interests of the landlords of such tenants. For the lands owned by the government, the approach is absolutely different. When land is settled for a nonagricultural purposes now the rent has to be assessed and at what rate premium or salami is to be charged, when sairati interests such as hats, bazars, fisheries etc., are settled what is the procedure to be followed and what should be the rate of rent for such settlement - have all been extensively dealt with in the West Bengal Land and Land Reforms Manual, 1991, under respective chapters.

Chapter $\mathbf{V}$ provides for consolidation of plots of land and formation of cooperative farming societies. These are post reform measures for improvement of agriculture.

After implementation of the ceiling provisions under the EA Act and LR Act and distribution of surplus lands that came into state coffer land-holding pattern in the state has undergone a revolutionary change, Cultivating raiyats holding 10 acres or above land now constitute less than 10 percent of the total raiyats. They also do not hold their lands in compact blocks. The small and marginal farmers constitute the bulk of the raiyati population. Inheritance, partition, exchange etc., result in division $\mathrm{f}$ the plots of land. The problem of a small state like West Bengal with adverse land man ratio is the existence of huge number of small plots of land. This is not conducive to modern cultivation with even minimum use of mechanical implements. Hence, consolidation of such plots of land, formation of cooperative farming societies and cooperative

$\mathbf{1 7 3}$ I Page Land Governance Assessment Framework - West Bengal 
common service societies are a must and this is what the provisions contained in chapter $\mathrm{V}$ aim at.

Unfortunately, the peasants wings of different political parties of the state who are out in the their slogans to lay down their lives for the good of the peasants and in spite of the state having been ruled for more than 30 years by a left leaning government, have shown scant interest in getting the post reform measures contained in chapter $\mathrm{V}$ implemented. They are unanimous, a rare thing, on one point that the task of making the raiyats concerned convince the good of consolidation of plots vial the route of land acquisition by the state and formation of cooperative societies resulting in the vesting of lands of the members in the societies is much more difficult than the taking away of lands from Ram for giving the same to Shyam or Rahim by operation of laws through paper work. Breaking away from the tradition to embrace a new path is sure to disturb the present equilibrium in rural society. The peasant leaders not bold enough to face such disturbance have preferred maintenance of subsistence farming and the status quo in rural society.

Chapter VI deals with the principles of the distribution of lands at the disposal of the state government. For settlement of lands by the government detailed provisions have been made in Rule 20A of the West Bengal Land Reforms Rules, 1965 as well as the West Bengal Land and Land Reforms Manual of 1991. Bulk of the land at the disposal of the state government is accounted for by the vested lands under the EA Act and the LR Act. The amount of land which always remained with the government as khasmahal land which was not settled with any tenant is insignificant.

The conditions of the settlement of agricultural land and homestead land are that - no premium shall be charged, the settlees must be residents of the locality where the land is situated, they must be landless or hold less than 0.4047 hectare of land (one acre), the settlees who are popularly known as patta-holders who will be given agricultural land must bring the land under personal cultivation, and those having no homestead who will be given such land must construct a dwelling house thereon. In selecting the beneficiaries preference shall be given to persons from Scheduled Tribes or Scheduled Castes who form themselves into a cooperative society. However, no land shall be given to a person, if he or any member of his family is engaged in any business, trade, undertaking, manufacture, calling service or industrial occupation. The target group therefore, is landless or homeless persons who have no other means to live on or no house to reside in. The right given to such settlees is heritable but not transferable except by way of mortgage by deposit of title deed with a Scheduled Bank, or a cooperative society or a government corporation.

Provisions have also been made for settlement of land with a local body or a statutory body or any other person for educational or research institution or industry. The terms and conditions for such settlement have been made in Rule 20A of the LR Rules 1965 and LR Manual 1991.

Chapter VII deals with maintenance of the records of rights. Land records should be kept upto-date by incorporating the changes taking place as a result of transfer or inheritance, partition, exchange, settlement of lands by the government, determination of revenue etc.

Chapter VIIA provides for preparation or revision of records of rights. In spite of the provisions contained in chapter VII land records were not kept up-to-date. Changes taking place since the revision of records in the latter half of fifties under the EA Act were not incorporated. By the middle of seventies the records became hopelessly outdated. A full-scale operation for revising the record of rights had to be taken up from 1975 in respect of all the mouzas of the state in accordance with the provisions contained in chapter VIIA. This revisional operation has almost been completed and records thus prepared have been computerized except in respect of mouzas which have become fully urbanized and congested. The distinctive feature of the new

174 | Page Land Governance Assessment Framework - West Bengal 
records is that in a mouzaone raiyat is having only one khatian (record of right) in his name, in which all his lands situated in the mouza stand recorded on the principle of one-man-one khatian in a mouza. This is the latest record of the state, whether the changes continuously occurring are being regularly incorporated in the records to keep them up-to-date have to be verified on the field. However, from the Order No. $644-\mathrm{LR} / 1 \mathrm{~A}$ dated 06.02.2009 with the heading "Simplified Procedure of Mutation" published in the Kolkata Gazette, Extraordinary dated 06.02.2009 it is clear that - "there are a considerable number of mutation cases lying pending for disposal . . . ... Even this simplified procedure is not as simple as its heading suggests. Application is to be made in prescribed proforma with application fee and process fee with as many as four photocopies of documents and a declaration in the prescribed form with a court fee stamp of Rs. 10/-, two envelopes each with postage stamp of Rs. 5/-. A time limit of 60 days, if no field enquiry is required and 120 days if field enquiry is required, has been prescribed for disposal of the mutation cases. All these requirements of the simplified procedure are quite frightening to the farmers who can very well go on possessing lands without getting their names mutated in the record of rights. The government will suffer by maintaining outdated records and may have to go in for another revisional operation which is nothing but a mass mutation. The simplified procedure shows the government in a very defensive mould. More bold steps are needed to deal with the practical problem. There is absolutely no reason to charge application fee, process fees, court fees, postage stamp. Overwhelming majority of people requiring mutation are not companies or realtors. They are the poor farmers. Government has forgotten that it is the legal obligation cast upon the government under section 50 to keep the records updated. Government cannot shift the obligation to others and pave the way for another operation for mass mutation by incurring a huge expenditure. It would not be out of place to point out here that before abolition of zamindary, mutation of the names of new tenants in the register of Zamindars was an oppressive tool. Not only did the Zamindars charge a hefty sum as mutation fee they also harassed the tenants in various ways. It was a common demand of the tenants in all their peasant movements that the procedure for 'namkharij' (mutation) and the charging of fee should be done away with. The government should have kept in mind this history before issuing an order like this.

Chapter VIII deals with management of lands. All lands to which the LR Act applies, and all lands belonging to the state including the ceiling surplus lands under the EA Act and LR Act be managed in the manner prescribed under the rules made under LR Act and contained in the WBLR Manual, 1991 by the Collector of the district under whose jurisdiction the lands are situated.

Public land in broad sense means lands held by different departments of both the Central and State Governments, such as the Railways, the Defence, the Irrigation Department, Public Works Department, the Forests Department etc. The land held by the West Bengal Industrial Infrastructure Development Corporation and the government undertakings is also public land. However, lands held by these departments were generally acquired under different land acquisition acts on the requisition of the respective department, to be used for specific purposes and handed over to them to use the land for the purpose for which such lands were acquired. Such lands are managed by the departments according to the policies adopted by them.

However, what by "public land" is specifically meant in this state is the land referred to under chapter VIII - land which is at the disposal of the state government. The principles of distribution of such lands have been dealt with under section 49 of the LR act read with Rule 20A of the WBLR Rules 1965 and the WBLR Manual 1991.

The WBLR Act is thus a comprehensive legislation of landlord-tenant relationship covering each and every aspect of land related matters.

175 I Page Land Governance Assessment Framework - West Bengal 
The hierarchical structure for administration of the Act is this. The Land \& Land Reforms Department of the Government of West Bengal is the administrative department of the Act. The Director of Land Records \& Surveys having jurisdiction all over the state is in charge of making village maps and preparing, revising and maintaining the records of rights. At the district level it is the Collector and District Land \& Land Reforms Officer who has been given the powers of a Collector. At the Sub-divisional level there are Sub-divisional Land \& Land Reforms Officers. But the most important functionary is at the block level - Block Land \& Land Reforms Officers. The BLLROs are assisted by some Revenue Officers. At the village level there is a Revenue Inspector for each Gram Panchayat. It is the BLLRO who is the custodian of records of the villages within his block. Most of the actions taken under this Act originate from his office.

However, the remedies against the actions of the Revenue Officers lying at the lowest level of the hierarchical structure are slightly different. When the Act does not provide for any specific appellate authority, appeals should be made before the District Land \& Land Reforms Officer. Against the order of the appellate authority the aggrieved party may move the West Bengal Land Reforms and Tenancy Tribunal created under an Act of 1997 carrying the same name. Against the order of the Tribunal appeal can be preferred before a Division Bench of the High Court exercising writ jurisdiction Under Articles 226 and 227 of the Constitution of India. Nobody can approach the High Court as a Court of the first instance on a matter coming within a specified Act such as West Bengal Land Reforms Act, 1955.

\section{f) Suggestion for Monitoring}

Considering the history of land governance in West Bengal and present situation in the State and taking into account the role of the government to ensure redistributive justice, the Expert Investigators and the Panelists have prepared the documents with their wisdom, experience and expertise in the respective fields. Based on the findings from the exercise, the panels of experts have made specific recommendations.

Now the government may proactively consider implementing the recommendations of the framework after validation of the documents. In this regard the concerned department is Land and Land Reforms, which will lead the team including the departments like Urban Development and Panchayat and Rural Development, Government of West Bengal. Therefore there is a need to set up a High Level Committee at the state comprising 5-9 members that would be decided by the Government of West Bengal. Similarly at the district level and block level there will be the committees in order to facilitate the implementation and monitoring the Land Governance Assessment Framework. Since land is having pivotal role in the growth of economy of the country therefore the LGAF will enable the government to ensuring land use in an appropriate way and efficient manner.

The committees may decide on the frequency to meet at their own level for analyzing all the issues related to land governance and take appropriate measures as described in the LGAF documents once it is validated and being in action.

\section{g) Best Practices}

- Vesting of ceiling surplus land under the provisions of reforms Acts is 13.14 lakh acres in West Bengal (2011) and the corresponding national figure is 69.99 lakh acres comprising all states

176 | Page Land Governance Assessment Framework - West Bengal 
- The state has distributed ceiling surplus land among the landless and land-poor giving preference to those who belong to the Scheduled Tribe and Scheduled Caste. (So far [ Aug 2013 ] 31,36,297 landless and near landless persons have been given land by way of distributive land reforms thereby creating as many new tenures), land involved is 10.44 lakh acres.

- Allocation of homestead plot to absolute landless and homeless through legislation and government schemes giving preference to women, ST and SC. (3,26,653 persons have been given land with raiyati status creating equivalent number of tenures.)

- Government has taken initiative to issue patta (deed of title) in the name of women or joint patta (both in the name of wife and husband) during distribution of homestead plot through scheme (more than 90\% in the name of women either jointly or as single during the last three years in respect of implementation of NGNB);

- The government in recent times has played proactive role in giving land tenure to the forest dwellers. 30,879 individual and 312 Community tenures were created as a result of implementation of the Forest Rights Act, 2006.

- The state has robust mechanism to secure tenure of sharecroppers (a study [2003] made by the State Institute of Panchayats and Rural Development found that about $72 \%$ of sharecroppers had a sense of enhanced security after their names were recorded in the land records.)

- There are around 4000 Joint Forest Management Committees (JFMC) formed and functioning under Executive Order (1988) protecting nearly 500,000 hectares of degraded forest areas of the State; these committees are traditionally strong in the State;

- The state has given monopoly rights of collection of NTFP like Sal Seeds and Kendu Leaves, from the forest to the Large Sized Multipurpose Cooperative Societies (LAMPS) through West Bengal Tribal Development Cooperative Corporation (WBTDCC).

- State government took the initiative of introducing the Kolkata Urban Services for the Poor (KUSP), a multi-sector urban reforms programme by creating Change Management Unit (CMU) with DFID funding. CMU initiated DDP preparation for 40 ULBs under KUSP in July 2005. Subsequently, this programme was rolled out to 127 Municipalities in the state of West Bengal. All the 127 municipal bodies/Corporations have prepared 1st generation Draft Development Plan (DDP) following participatory process.

- The present government has a clear procedure of transfer of land to private investors which is laid down in the guideline and available in public domain.

- Base value of property determined acroos the state, updates happen based on field verification. Valuation rolls are publicly accessible (www.wbregistration.gov.in) and transfer of properties are mostly happening as per market value.

- Computerization of records is almost done in the state; all information regarding land records, maps etc. are available through website or through OTC services paying very minimal charges.

- A Central Valuation Board was set up to overcome the deficiency of under valuation of properties in the municipal areas in 1979 through an Act. The process of property valuation is rational and uniform.

- All 239 registration offices in the State have been fully computerized. As a result there has been a clear and transparent process in determination of market value for property through CORD (Computerisation of Registration of Documents) software.

- In the state Land Reform Tenancy Tribunal (LRTT) is in operation and quick disposal of conflicts are possible;

- As per legislation, institutional mandates relating to administration of land is very clear in the State;

- The role and function of different layers of L\&LR Department is clearly defined; there is no scope of overlapping. 


\section{Conclusion}

The LGAF has provided an exhaustive diagnostic assessment of the most relevant land governance issues in West Bengal. A key characteristic of the LGAF is that it is broad based and multidisciplinary, involving a diversity of themes and it has mobilised expertise to obtain inputs. LGAF tool has provided a synoptic view of land governance in West Bengal that cuts across sectors, institutions and stakeholders. The LGAF methodology has enabled a highly participatory implementation that raised awareness of the importance of using indicators to diagnose and track progress in land governance in the future. The government buy-in was considered to be very important and all efforts were made to maintain very close interface with the State Nodal Officer designated by the government for LGAF. This was critical to ensure that the government agrees with and owns the outcomes from the exercise and understands about its necessity as a tool for improving land governance, a key component of transparent, accountable and good governance as a whole. The standardised methodology of LGAF emphasised on bringing a host of legitimate local experts to head the panels as expert investigators and enabled to arrive at a consensual assessment with the help of panellists from different distinguished fields. The core approach of LGAF exercise in West Bengal was to ensure according ratings of the dimensions through panel of experts who brought together a variety of user perspectives and substantive expertise need to provide a meaningful rating. This tool has helped to identify areas where more in-depth study is needed to facilitate the process of taking important policy decisions and complementary areas of policy that need to be addressed. The tool was also useful to identify certain gaps in policy and the way institutions function or responsibilities between institutions as are assigned in West Bengal.

The findings from this study reiterated that land sector in West Bengal is governed by a comprehensive legal framework that has been progressively updated and requires further updating to improve land governance and come to terms with development realities.

The study has also clearly demonstrated that there is a lack of systematic approach to land use planning and management of public land in spite of having very well-knit legislations in this regard. Comprehensive and integrated approaches to land use planning incorporating both rural and urban lands are needed for the state to govern land system better. This is an area that requires urgent attention considering that there are diverse land uses being practiced in both rural and urban areas and there are also many and diverse interest holders. For urban land there is a good practice of land use planning exercises but plans are not regularly updated and provision of public input should be made. In addition, the plans are not enforced, monitored and controlled due to lack of procedures and capacity (financial and human).

The government needs to review the functional responsibilities of different agencies and specify roles and responsibilities both at State and district level for different categories of land.

The study has also shown that there is inadequate capacity (financial, human) at land registry establishments down the line resulting in gap in information management and service delivery.

The land sector requires systematic monitoring and evaluation of the framework and procedures so that developments in the land sector can be monitored as part of the state development system. This will require setting up of system and enhanced capacity at state and district level to ensure that there is continuous and effective monitoring and reporting in the land sector.

The study reveals that the validated consensus ranking of the LGAF 116 dimensions have considerable strengths in land governance in West Bengal as 38 (32.48\%) and 35 (29.91\%) of the dimension A and B respectively while 25 (22.22\%) and 18 (15.38\%) were ranked C and D

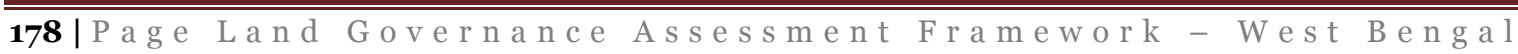


respectively. Land governance in terms of nearly all the thematic areas is relatively strong. The order of weakness based on the percentage of dimensions scoring C and D are: Panel 2, Panel 3, panel 4 \& Panel 6.

The areas requiring further work in land governance in West Bengal include the following:

* There is need to engage the key government departments, Land \& Land Reform Department, Urban Development Department, Development and Planning Department, Finance Department, Environment Department and to discuss the LGAF objectives, outcomes and indicators so that they can be systematically adopted and used in a coordinated manner;

* There is need for an assessment on how to integrate the LGAF into national monitoring and reporting, environmental monitoring or through regular surveys of such as integrated survey;

* The LGAF needs to have set time frame to be undertaken every five years and could be related to major policy reviews in the country.

Among the benefits, LGAF has enabled identification of good practices systematically in several land governance areas in West Bengal. As this tool has already been used in several countries, a good exposure to some of the better practices across countries identified during LGAF implementation are available for discussion with the experts for developing greater understanding in land governance. In India six states have taken up LGAF with the support from World Bank simultaneously under the aegis of the Department of Land resources, Government of India and during the process several interactions with other states in review meetings have helped the state coordinator for widening the look and approach to land governance. LGAF has pointed to a number of areas that change relatively quickly and in which designing quantitative indicators to monitor land governance on a more regular basis will be useful. Lastly it would be useful to share experiences and collaborate across the states in India to effectively address some of the challenges in trying to improve land governance in the country.

\section{Overall Score Card}

\begin{tabular}{|c|c|c|c|c|c|c|c|}
\hline \multirow{2}{*}{$\mathbf{P}$} & \multirow{2}{*}{ LGI } & \multirow{2}{*}{$\operatorname{dim}$} & \multirow{2}{*}{ Panel, Indicator and dimensions } & \multicolumn{4}{|c|}{ Score } \\
\hline & & & & A & B & $\mathrm{C}$ & $\mathrm{D}$ \\
\hline 1 & & & PANEL I: LAND TENURE RECOGNITION & & & & \\
\hline 1 & 1 & $\boldsymbol{o}$ & $\begin{array}{l}\text { Recognition of a continum of rights: the law recognizes a range } \\
\text { of rights held by individuals (incl. Secondary rights of tenants. } \\
\text { Sharecroppers, women etc.) }\end{array}$ & & & & \\
\hline 1 & 1 & $1 \mathrm{a}$ & Individuals' rural land tenure rights are legally recognized & & & & \\
\hline 1 & 1 & $1 \mathrm{~b}$ & Individuals' rural land tenure rights are protected in practice & & & & \\
\hline 1 & 1 & 2 & Customary tenure rights are legally recognized and protected in practice & & & & \\
\hline 1 & 1 & 3 & $\begin{array}{l}\text { Indigenous rights to land and forest are legally recognized and protected in } \\
\text { practice. }\end{array}$ & & & & \\
\hline 1 & 1 & 4 & Urban land tenure rights are legally recognized and protected. & & & & \\
\hline 1 & 2 & $\boldsymbol{O}$ & Respect for and enforcement of rights & & & & \\
\hline 1 & 2 & 1 & Accessible opportunities for tenure individualization exist. & & & & \\
\hline 1 & 2 & 2 & Individual land in rural areas is formally registered and mapped. & & & & \\
\hline 1 & 2 & 3 & Individual land in urban areas is formally registered and mapped. & & & & \\
\hline
\end{tabular}

179|Page Land Governance Assessment Framework - West Bengal 


\begin{tabular}{|c|c|c|c|c|c|c|c|}
\hline \multirow{2}{*}{$\mathbf{P}$} & \multirow{2}{*}{ LGI } & \multirow{2}{*}{$\operatorname{dim}$} & \multirow{2}{*}{ Panel, Indicator and dimensions } & \multicolumn{4}{|c|}{ Score } \\
\hline & & & & A & $\mathrm{B}$ & $\mathrm{C}$ & $\mathrm{D}$ \\
\hline 1 & 2 & 4 & The number of illegal land sales is low. & & & & \\
\hline 1 & 2 & 5 & The number of illegal lease transactions is low. & & & & \\
\hline 1 & 2 & 6 & $\begin{array}{l}\text { Women's rights by law are registered and recognized in practice in both } \\
\text { urban and rural areas. }\end{array}$ & & & & \\
\hline 1 & 2 & 7 & $\begin{array}{l}\text { Women's property rights to land are equal to those by men both in law and } \\
\text { in practice. }\end{array}$ & & & & \\
\hline 2 & & & $\begin{array}{l}\text { PANEL II: RIGHTS TO FOREST AND COMMON LANDS \& RURAL LAND } \\
\text { USE REGULATIONS }\end{array}$ & & & & \\
\hline 2 & 1 & $\boldsymbol{o}$ & Rights to forest and common lands & & & & \\
\hline 2 & 1 & 1 & $\begin{array}{l}\text { Forests and common lands are clearly identified in law and responsibility for } \\
\text { use is clearly assigned }\end{array}$ & & & & \\
\hline 2 & 1 & 2 & Rural group rights are formally recognized and can be enforced. & & & & \\
\hline 2 & 1 & 3 & $\begin{array}{l}\text { Even where ownership or trusteeship is legally with the state, arrangements } \\
\text { to ensure users' rights to key natural resources on land (incl. Fisheries) are } \\
\text { legally recognized and protected in practice. }\end{array}$ & & & & \\
\hline 2 & 1 & 4 & $\begin{array}{l}\text { Multiple rights over the same common land and natural resources on these } \\
\text { lands can legally coexist. }\end{array}$ & & & & \\
\hline 2 & 1 & 5 & $\begin{array}{l}\text { Multiple rights over the same plot of land and natural resources on these } \\
\text { lands can legally coexist (e.g. tree rights). }\end{array}$ & & & & \\
\hline 2 & 1 & 6 & $\begin{array}{l}\text { Multiple rights over land and mining/ other sub-soil resources located in the } \\
\text { same plot can legally coexist. }\end{array}$ & & & & \\
\hline 2 & 1 & 7 & Accessible opportunities exist for registration and mapping of group rights. & & & & \\
\hline 2 & 1 & 8 & Boundary demarcation of communal land & & & & \\
\hline 2 & 2 & $\boldsymbol{O}$ & Effectiveness and equity of rural land use regulations & & & & \\
\hline 2 & 2 & 1 & Restrictions regarding rural land use are enforced. & & & & \\
\hline 2 & 2 & 2 & Restrictions regarding rural land transferability serve public purpose. & & & & \\
\hline 2 & 2 & 3 & $\begin{array}{l}\text { Rural land use plans and changes in these plans (incl rezoning) are based on } \\
\text { clear process for public input and burden sharing }\end{array}$ & & & & \\
\hline 2 & 2 & 4 & $\begin{array}{l}\text { Rural land use changes to the assigned land use in a timely manner and into } \\
\text { the destined use. }\end{array}$ & & & & \\
\hline 2 & 2 & 5 & $\begin{array}{l}\text { There is a clear public process for rezoning of land use classes that } \\
\text { safeguards existing rights. }\end{array}$ & & & & \\
\hline 2 & 2 & 6 & $\begin{array}{l}\text { Use plans for specific rural land classes (forest, pastures, wetlands, national } \\
\text { parks etc.) Are in line with actual use. }\end{array}$ & & & & \\
\hline & & & PANEL III: URBAN LAND USE, PLANNING, AND DEVELOPMENT & & & & \\
\hline 3 & 1 & $\boldsymbol{o}$ & $\begin{array}{l}\text { Restrictions on rights: land rights are not conditional on } \\
\text { adherence to unrealistic standards. }\end{array}$ & & & & \\
\hline 3 & 1 & 1 & $\begin{array}{l}\text { Restrictions regarding urban land ownershipand transferability effectively } \\
\text { serve public purpose and are enforced. }\end{array}$ & & & & \\
\hline 3 & 1 & 2 & $\begin{array}{l}\text { Restrictions regarding urban land use serve public purpose and are enforced } \\
\text { (including risk prone and protected areas). }\end{array}$ & & & & \\
\hline 3 & 2 & 0 & $\begin{array}{l}\text { Transparency of land use restrictions: changes in land use and management } \\
\text { regulations are made in a transparent fashion and provide significant } \\
\text { benefits for society in general rather than just for specific groups. }\end{array}$ & & & & \\
\hline 3 & 2 & 1 & $\begin{array}{l}\text { There is a clear process for expansion of urban land and infrastructure } \\
\text { development that respects existing rights and information on land use } \\
\text { change is public and easily accessible. }\end{array}$ & & & & \\
\hline 3 & 2 & 2 & $\begin{array}{l}\text { In urban areas, land use plans and changes in these plans are based on a } \\
\text { clear public process and on input of all relevant stakeholders. }\end{array}$ & & & & \\
\hline 3 & 2 & 3 & Urban land use changes to the assigned land use in a timely manner. & & & & \\
\hline 3 & 3 & $\boldsymbol{o}$ & $\begin{array}{l}\text { Efficiency in the urban land use planning process: land use plans } \\
\text { and regulations are justified, effectively implemented, do not }\end{array}$ & & & & \\
\hline
\end{tabular}

180|Page Land Governance Assessment Framework- West Bengal 


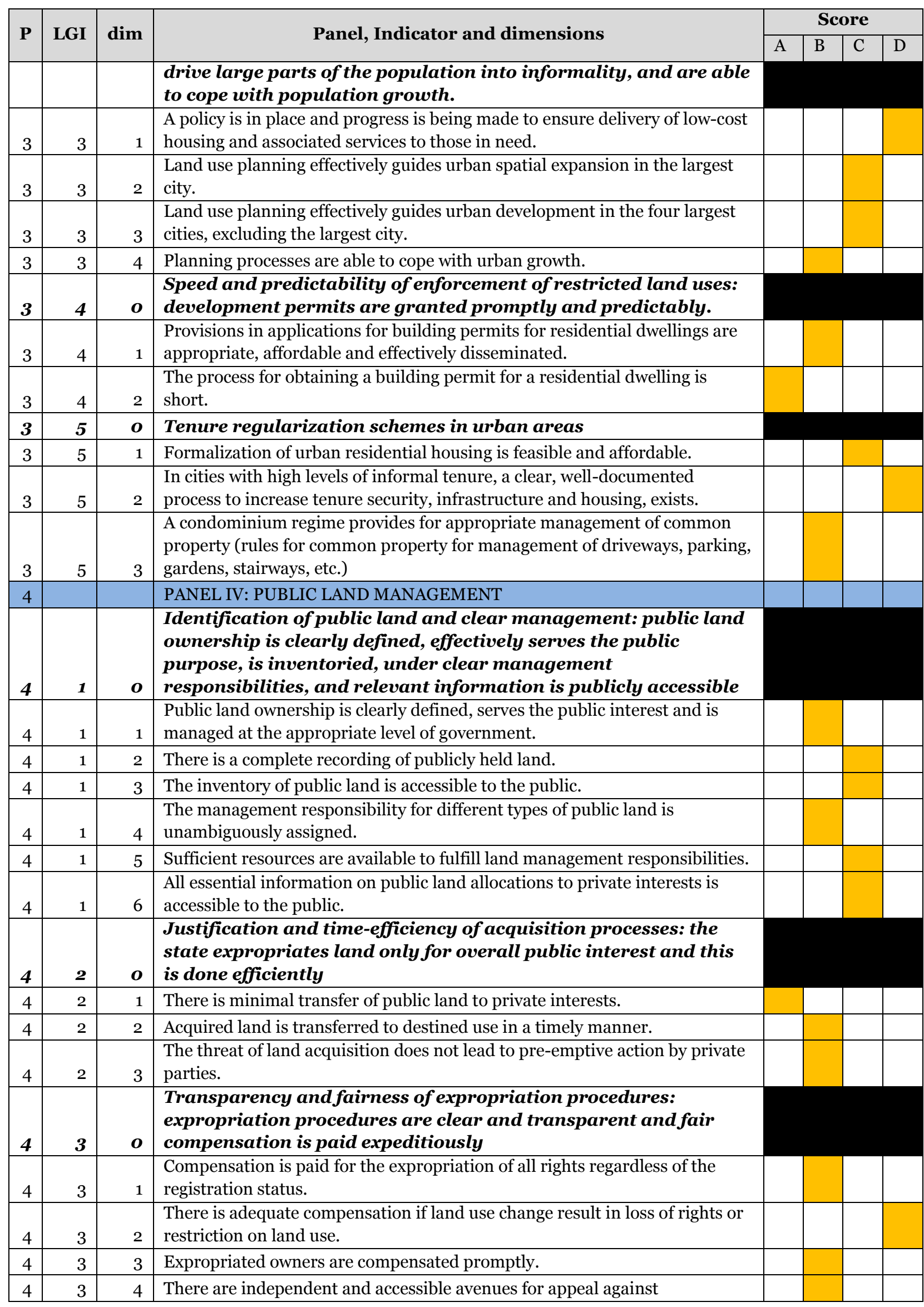

181|Page Land Governance Assessment Framework - West Bengal 


\begin{tabular}{|c|c|c|c|c|c|c|c|}
\hline \multirow{2}{*}{$\mathbf{P}$} & \multirow{2}{*}{ LGI } & \multirow{2}{*}{$\operatorname{dim}$} & \multirow{2}{*}{ Panel, Indicator and dimensions } & \multicolumn{4}{|c|}{ Score } \\
\hline & & & & $\mathrm{A}$ & B & $\mathrm{C}$ & $\mathrm{D}$ \\
\hline & & & expropriation. & & & & \\
\hline 4 & 3 & 5 & Timely decisions are made regarding complaints about expropriation. & & & & \\
\hline 5 & & & $\begin{array}{l}\text { PANEL V: TRANSPARENT PROCESS AND ECONOMIC BENEFIT OF } \\
\text { TRANSFER OF PUBLIC LAND TO PRIVATE USE }\end{array}$ & & & & \\
\hline 5 & 1 & $\boldsymbol{o}$ & $\begin{array}{l}\text { Transfer of public land to private use follows a clear, } \\
\text { transparent, and competitive process and payments are } \\
\text { collected and audited (with the exception of transfers to improve } \\
\text { equity such as land distribution and land for social housing). }\end{array}$ & & & & \\
\hline 5 & 1 & 1 & Public land transactions are conducted in an open transparent manner. & & & & \\
\hline 5 & 1 & 2 & Payments for public leases are collected. & & & & \\
\hline 5 & 1 & 3 & $\begin{array}{l}\text { Public land is transacted at market prices (when not divested for equity } \\
\text { purposes). }\end{array}$ & & & & \\
\hline 5 & 1 & 4 & The public captures benefits arising from changes in permitted land use. & & & & \\
\hline 5 & 1 & 5 & Policy are in place to improve equity in access to and use of assets & & & & \\
\hline 5 & 2 & $\boldsymbol{o}$ & Private investment strategy & & & & \\
\hline 5 & 2 & 1 & $\begin{array}{l}\text { Policy and regulations are in place and applied to unambiguously and } \\
\text { publicly identify land that can be made available to investors, in agreement } \\
\text { with land rights holders. }\end{array}$ & & & & \\
\hline 5 & 2 & 2 & $\begin{array}{l}\text { Policy process is in place to identify and select economically, } \\
\text { environmentally, and social-cultural beneficial investments and implement } \\
\text { these effectively. }\end{array}$ & & & & \\
\hline 5 & 2 & 3 & $\begin{array}{l}\text { Public institutions involved in transfer of large tracts of land to private } \\
\text { investors are clearly identified; without institutional and administrative } \\
\text { overlap. }\end{array}$ & & & & \\
\hline 5 & 2 & 4 & $\begin{array}{l}\text { Public institutions involved in transfer of large tracts of land to private } \\
\text { investors share land information and effective coordination mechanisms are } \\
\text { in place to timely identify and solve competing land use assignment } \\
\text { (inclsub_soil) }\end{array}$ & & & & \\
\hline 5 & 2 & 5 & $\begin{array}{l}\text { Investors' compliance with agreed business plans is regularly and effectively } \\
\text { monitored and remedial action is taken if needed. }\end{array}$ & & & & \\
\hline 5 & 2 & 6 & $\begin{array}{l}\text { Safeguards (socio-economic, culturally and environmental) are established } \\
\text { and applied to prevent that investments involving large tracts of land } \\
\text { infringe on or extinguish existing tenure rights. }\end{array}$ & & & & \\
\hline 5 & 2 & 7 & $\begin{array}{l}\text { Cases were resettlement and rehabilitation are required are clearly } \\
\text { circumscribed and implementation follows uniform, transparent procedures. }\end{array}$ & & & & \\
\hline 5 & 3 & $\boldsymbol{o}$ & $\begin{array}{l}\text { Policy implementation is effective consistent and transparent } \\
\text { and involves local stakeholders }\end{array}$ & & & & \\
\hline 5 & 3 & 1 & $\begin{array}{l}\text { Sufficient information is required from investors for government to assess } \\
\text { the effects of proposed investments. }\end{array}$ & & & & \\
\hline 5 & 3 & 2 & $\begin{array}{l}\text { A clearly identified process is in place for approval of investment plans and } \\
\text { the time required is reasonable and adhered to. }\end{array}$ & & & & \\
\hline 5 & 3 & 3 & $\begin{array}{l}\text { There are free, direct and transparent negotiations between right holders } \\
\text { and investors; rights holders have access to relevant information. }\end{array}$ & & & & \\
\hline 5 & 3 & 4 & $\begin{array}{l}\text { Contractual provisions are publicly available and include benefit sharing } \\
\text { mechanisms with right holders }\end{array}$ & & & & \\
\hline 5 & 4 & $\boldsymbol{o}$ & $\begin{array}{l}\text { Contracts are made public, easily accessible and agreements are } \\
\text { monitored and enforced }\end{array}$ & & & & \\
\hline 5 & 4 & 1 & $\begin{array}{l}\text { Accurate and easily understood information on spatial extent and duration } \\
\text { of approved concessions is publicly available to minimize overlap and } \\
\text { facilitate transfers. }\end{array}$ & & & & \\
\hline 5 & 4 & 2 & $\begin{array}{l}\text { Compliance with safeguards on concessions is monitored and enforced } \\
\text { effectively and consistently. }\end{array}$ & & & & \\
\hline
\end{tabular}

182|Page Land Governance Assessment Framework - West Bengal 


\begin{tabular}{|c|c|c|c|c|c|c|c|}
\hline \multirow{2}{*}{$\mathbf{P}$} & \multirow{2}{*}{ LGI } & \multirow{2}{*}{$\operatorname{dim}$} & \multirow{2}{*}{ Panel, Indicator and dimensions } & \multicolumn{4}{|c|}{ Score } \\
\hline & & & & A & B & $\mathrm{C}$ & $\mathrm{D}$ \\
\hline 5 & 4 & 3 & $\begin{array}{l}\text { Avenues exist for right holders to air complaints if investors do not meet } \\
\text { contractual obligations and decisions are timely and fair. }\end{array}$ & & & & \\
\hline 6 & & & $\begin{array}{l}\text { Panel 6: Public provision of land information: registry and } \\
\text { cadastre }\end{array}$ & & & & \\
\hline 6 & 1 & $\boldsymbol{o}$ & Mechanisms for recognition of rights & & & & \\
\hline 6 & 1 & 1 & $\begin{array}{l}\text { There is an efficient and transparent process to formalize unchallenged land } \\
\text { possession by the poor that is in line with local practice and locally accepted. }\end{array}$ & & & & \\
\hline 6 & 1 & 2 & Non-documentary evidence is effectively used to help establish rights. & & & & \\
\hline 6 & 1 & 3 & Long-term unchallenged possession is formally recognized. & & & & \\
\hline 6 & 1 & 4 & $\begin{array}{l}\text { First-time registration on demand includes proper safeguards and access is } \\
\text { not restricted by high formal fees. }\end{array}$ & & & & \\
\hline 6 & 2 & $\boldsymbol{o}$ & Completeness of the land registry & & & & \\
\hline 6 & 2 & 1 & The total cost of registering a property transfer is low. & & & & \\
\hline 6 & 2 & 2 & The information held in records is incorporated in maps and reflects reality. & & & & \\
\hline 6 & 2 & 3 & All relevant private encumbrances are recorded. & & & & \\
\hline 6 & 2 & 4 & All relevant public restrictions or charges are recorded. & & & & \\
\hline 6 & 2 & 5 & There is a timely response to requests for accessing registry records. & & & & \\
\hline 6 & 2 & 6 & The registry is searchable. & & & & \\
\hline 6 & 2 & 7 & Land information records are easily accessed. & & & & \\
\hline 6 & 3 & $\boldsymbol{o}$ & $\begin{array}{l}\text { Reliability: registry information is updated and sufficient to } \\
\text { make meaningful inferences on ownership }\end{array}$ & & & & \\
\hline 6 & 3 & 1 & $\begin{array}{l}\text { Information regarding land rights maintained in different public registries is } \\
\text { routinely synchronized so as to reduce transaction cost for users and ensure } \\
\text { integrity of information. }\end{array}$ & & & & \\
\hline 6 & 3 & 2 & Registries information is up-to-date and reflect ground reality. & & & & \\
\hline 6 & 4 & $\boldsymbol{o}$ & $\begin{array}{l}\text { Cost-effectiveness and sustainability: land administration } \\
\text { services are provided in a cost-effective manner. }\end{array}$ & & & & \\
\hline 6 & 4 & 1 & The registry is financially sustainable through fee collection. & & & & \\
\hline 6 & 4 & 2 & $\begin{array}{l}\text { Investment is sufficient to cope with demand and provide high quality } \\
\text { services that are clearly defined and adhered to (reliable, accessible and } \\
\text { affordable land information). }\end{array}$ & & & & \\
\hline 6 & 5 & $\boldsymbol{o}$ & $\begin{array}{l}\text { Fees are determined transparently to cover the cost of service } \\
\text { provision }\end{array}$ & & & & \\
\hline 6 & 5 & 1 & $\begin{array}{l}\text { The rational for the determination of fees is clear, the schedule of fees is } \\
\text { publicly accessible and payment is accounted for. }\end{array}$ & & & & \\
\hline 6 & 5 & 2 & Informal payments are discouraged. & & & & \\
\hline 6 & 5 & 3 & Service standards are published and regularly monitored. & & & & \\
\hline 7 & & & PANEL VII: LAND VALUATION AND TAXATION & & & & \\
\hline 7 & 1 & $\boldsymbol{o}$ & $\begin{array}{l}\text { Transparency of valuations: valuations for tax and } \\
\text { compensation purposes are based on clear principles, applied } \\
\text { uniformly, updated regularly, and publicly accessible }\end{array}$ & & & & \\
\hline 7 & 1 & 1 & There is a clear process of property valuation. & & & & \\
\hline 7 & 1 & 2 & Valuation rolls are publicly accessible. & & & & \\
\hline 7 & 2 & 1 & Exemptions from property taxes payment are justified and transparent. & & & & \\
\hline 7 & 2 & 2 & Property holders liable to pay property tax are listed on the tax roll. & & & & \\
\hline 7 & 2 & 3 & Assessed property taxes are collected. & & & & \\
\hline 7 & 2 & 4 & Receipts from property taxes exceed the cost of collection. & & & & \\
\hline 8 & & & PANEL VIII: DISPUTE RESOLUTION & & & & \\
\hline $\boldsymbol{8}$ & 1 & $\boldsymbol{o}$ & $\begin{array}{l}\text { Assignment of responsibility: responsibility for conflict } \\
\text { management at different levels is clearly assigned, in line with }\end{array}$ & & & & \\
\hline
\end{tabular}

$\mathbf{1 8 3}$ |Page Land Governance Assessment Framework - West Bengal 


\begin{tabular}{|c|c|c|c|c|c|c|c|}
\hline \multirow{2}{*}{$\mathbf{P}$} & \multirow{2}{*}{ LGI } & \multirow{2}{*}{$\operatorname{dim}$} & \multirow{2}{*}{ Panel, Indicator and dimensions } & \multicolumn{4}{|c|}{ Score } \\
\hline & & & & A & B & $\mathrm{C}$ & $\mathrm{D}$ \\
\hline & & & $\begin{array}{l}\text { actual practice, relevant bodies are competent in applicable } \\
\text { legal matters, and decisions can be appealed against }\end{array}$ & & & & \\
\hline 8 & 1 & 1 & There is clear assignment of responsibility for conflict resolution. & & & & \\
\hline 8 & 1 & 2 & Conflict resolution mechanisms are accessible to the public. & & & & \\
\hline 8 & 1 & 3 & $\begin{array}{l}\text { Mutually accepted agreements reached through informal dispute resolution } \\
\text { systems are encouraged. }\end{array}$ & & & & \\
\hline 8 & 1 & 4 & $\begin{array}{l}\text { There is an accessible, affordable and timely process for appealing disputed } \\
\text { rulings. }\end{array}$ & & & & \\
\hline $\boldsymbol{8}$ & 2 & $\boldsymbol{o}$ & $\begin{array}{l}\text { The share of land affected by pending conflicts is low and } \\
\text { decreasing }\end{array}$ & & & & \\
\hline 8 & 2 & 1 & $\begin{array}{l}\text { Land disputes constitute a small proportion of cases in the formal legal } \\
\text { system. }\end{array}$ & & & & \\
\hline 8 & 2 & 2 & Conflicts in the formal system are resolved in a timely manner. & & & & \\
\hline 8 & 2 & 3 & There are few long-standing land conflicts (greater than 5 years). & & & & \\
\hline 9 & & & $\begin{array}{l}\text { PANEL IX: REVIEW OF INSTITUTIONAL ARRANGEMENTS AND } \\
\text { POLICIES }\end{array}$ & & & & \\
\hline 9 & $\mathbf{1}$ & $\boldsymbol{o}$ & $\begin{array}{l}\text { Clarity of mandates and practice: institutional mandates } \\
\text { concerning the regulation and management of the land sector } \\
\text { are clearly defined, duplication of responsibilities is avoided and } \\
\text { information is shared as needed. }\end{array}$ & & & & \\
\hline 9 & 1 & 1 & $\begin{array}{l}\text { Processes of policy formulation, implementation, and arbitration affecting } \\
\text { land rights and land use are properly separated. }\end{array}$ & & & & \\
\hline 9 & 1 & 2 & $\begin{array}{l}\text { The responsibilities of the ministries and agencies dealing with land do not } \\
\text { overlap (horizontal overlap). }\end{array}$ & & & & \\
\hline 9 & 1 & 3 & Administrative (vertical) overlap is avoided. & & & & \\
\hline 9 & 1 & 4 & $\begin{array}{l}\text { Information on land ownership and use is shared among responsible } \\
\text { institutions and relevant parts are freely accessible to the public. }\end{array}$ & & & & \\
\hline 9 & 1 & 5 & $\begin{array}{l}\text { Overlaps of rights (based on tenure typology) are minimal and do not cause } \\
\text { friction or dispute }\end{array}$ & & & & \\
\hline 9 & 1 & 6 & $\begin{array}{l}\text { Ambiguity in institutional mandates (based on institutional map) does not } \\
\text { cause problems. }\end{array}$ & & & & \\
\hline 9 & 2 & $\boldsymbol{o}$ & $\begin{array}{l}\text { Equity and non-discrimination in the decision-making process: } \\
\text { policies are formulated through a decision-making process that } \\
\text { draws on inputs from all concerned. The legal framework is non- } \\
\text { discriminatory and institutions to enforce property rights are } \\
\text { equally accessible to all }\end{array}$ & & & & \\
\hline 9 & 2 & 1 & $\begin{array}{l}\text { Land policies and regulations exist and are developed in a participatory } \\
\text { manner involving all relevant stakeholders. }\end{array}$ & & & & \\
\hline 9 & 2 & 2 & $\begin{array}{l}\text { There is meaningful incorporation and monitoring of equity and poverty } \\
\text { reduction goals in land policy. }\end{array}$ & & & & \\
\hline 9 & 2 & 3 & $\begin{array}{l}\text { There is meaningful incorporation and monitoring of environmental and } \\
\text { sustainability goals in land policy. }\end{array}$ & & & & \\
\hline 9 & 2 & 4 & $\begin{array}{l}\text { The implementation of land policy is costed, matched with benefits and } \\
\text { adequately resourced. }\end{array}$ & & & & \\
\hline 9 & 2 & 5 & $\begin{array}{l}\text { There is regular and public reporting indicating progress in policy } \\
\text { implementation. }\end{array}$ & & & & \\
\hline 9 & 2 & 6 & $\begin{array}{l}\text { Land policy is effective in ensuring that suitable land is available for } \\
\text { smallholder farming and housing for low-income groups }\end{array}$ & & & & \\
\hline 9 & 2 & 7 & $\begin{array}{l}\text { Land policy is effective in preventing settlements in high risk areas and } \\
\text { prepare for future disasters risk }\end{array}$ & & & & \\
\hline
\end{tabular}

184|Page Land Governance Assessment Framework- West Bengal 


\section{Bibliography}

1. Directorate of Land Records and Surveys

2. Backward Classes Welfare Department

3. Floud Commission in its report submitted in 1940

4. A research study jointly undertaken by the World Bank and Michigan State University in 2011 and subsequent reports published "Complete the incompleteness of Land reform" (by Klaus Denienger, Songquin Jin and Vandana Yadav) reveals some interesting facts on tenancy reforms in West Bengal

5. National Sample Survey Organization in its $59^{\text {th }}$ and $60^{\text {th }}$ round reports

6. Backward Classes Welfare Department, Govt. of West Bengal

7. Directorate of Land Records and Surveys

8. Monthly progress report [December, 2013] of the Directorate of Land Records and Surveys.

9. DDP manual, study as referred conducted by the Administrative Training Institute, Kolkata

10. Directorate of Agriculture (Evaluation Wing), Govt. of West Bengal, reproduced in Economic Review, 2011-12

11. Land and Lard Reforms Department, Government of West Bengal

12. http://wbidc.com/images/pdf/Pricing Policy WBIDC.pdf

13. Anim-Odame, W. F. (2011): Compulsory Acquisition and Compensation in Ghana: Principles \& Practice, Paper presented at the American Real Estate Society Conference, Seattle, Washington, USA

14. Wallace, J. (2010): Land Acquisition in Developing Economies, International Federation of Surveyors, February, 1-21

15. WBIDC

16. Bengal Aerotroplolis Projects Ltd management

17. http://wbidc.com/images/pdf/Criteria Assessment.pdf

18. http://www.banglarbhumi.gov.in

19. Official website of Government of West Bengal, JnNURM, State Finance Commission

20. Sen, Arindam (2002): Social - Democratic Agrarian Programme in West Bengal

21. Anil K. Chakraborti, Apurba Kr. Mukhopadhyay, Debesh Roy (2003): Beneficiaries of Land reforms - The West Bengal Scenario, SIPRD Kalyani.

22. Jennifer Brown, Sujata Das Chowdhury (2002): Women's Land Rights in West Bengal: A Field Study, RDI/Landesa.

23. Hanstad, Haque, Nielsen, Brown: Meeting the Goals of Land Reforms in India. 


\section{Annexure 1: Expert Investigator Report (Background Notes)}

\section{Panel 1: Land Tenure Recognition}

\section{The Legal Frame work}

In West Bengal land and land tenure administration is regulated by the provisions of the following Acts:

- $\quad$ West Bengal Estates Acquisition Act, 1953

- $\quad$ West Bengal Land Reforms Act, 1955

- West Bengal Acquisition of Homestead Land for Agricultural Labourers, Artisans and Fishermen Act, 1975

- $\quad$ West Bengal Thika Tenancy Act, 2001

Other Acts like the Rent Act, 1859, the B.T. Act, 1885 and the Bargadars Act, 1950 have been repealed but are often referred to in academic discussions and in the literature.

The West Bengal Estates Acquisition Act, 1953

India became independent in 1947. In the debates of the Constituent Assembly on the right to property, it was unanimously resolved that the cultivators of land should be conferred with the rights to hold land directly under the state by abolishing the estates and eliminating the intermediaries. The Constitution of India came into force on 26.01.1950. The articles 31, later $31 \mathrm{~A}, 31 \mathrm{~B}$ and $31 \mathrm{C}$ provided for acquisition of estates and all preexisting rights of the intermediaries.

In pursuance to these Constitutional provisions the States passed legislations to abolish Zamindary. In this State, the West Bengal Estates Acquisition Act 1953 (EA Act) was passed. It came into force on $12^{\text {th }}$ February 1954.

The EA Act had two objects:

c) To abolish Zamindary - that is all rent receiving interests;

d) To impose a ceiling on land held by individuals. These objects were sought to be achieved by the scheme of the Act made out in sections 4, 5 and 6 contained in chapter II dealing with the acquisition of estates and of the rights of intermediaries therein.

Notification was issued u/s 4 declaring that with effect from 15.04.1955 (the date of vesting) all estates and the rights of every intermediary in each such estate shall vest in the State. 16.04.1956 is the date of vesting for the raiyats who came to be regarded as deemed intermediaries subsequently. Section 5 lays down what precisely vested in the state on publication of notification $\mathrm{u} / \mathrm{s}$ 4. The combined effect of sections 4 and 5 is that all lands held by an intermediary - be he a proprietor, or tenure-holder or under- tenure- holder or raiyat or underraiyat with all his pre-existing rights, tittle and interests vested in the state. Only the lands held by a non-agricultural tenant and under-tenant remained beyond the purview of the Act. Section 6 (I) provides that notwithstanding the vesting of all lands in the State, an intermediary is entitled to retain 25 acres of agricultural land and 15 acres of non- agricultural land (20 acres together with homestead land). No ceiling was imposed on other kinds of land. Section 6 (2) says that an intermediary who is entitled to retain possession of land u/s 6(I) shall hold such land directly under the state as a tenant. This is how all those who lived off land came on the

186 | Page Land Governance Assessment Framework - West Bengal 
same platform as a tenant under the State no matter what was his status previously. Till December 2013, a total of 26,48,250.86 acres of land vested in the state under EA Act.

To give effect to the scheme and carry out the purposes of the EA_Act as discussed above it was necessary to get the position of land and all incidences attached thereto obtaining on the relevant date of vesting -15.04.1955 or 16.04.1956, as applicable. Provisions were made under chapter $\mathrm{V}$ of the Act for preparation of records of rights and revision of record of rights prepared previously under the BT Act. Field verifications were made, the changes noted down and the records were draft published inviting objections thereto from the interested persons. After disposal of objections the records were finally framed and published. In the process the disputes between the tenants and the landlords and between tenants lying undecided during the period between preparation of records under the BT Act and revision thereof under the EA Act got resolved. In the final records the interests of all intermediaries were eliminated. The state in each record was the landlord and the person holding the land was shown as tenant.

Women's land right and EA Act - The Hindu Succession Act giving the right of inheritance to the women and converting life interest into absolute interest came into existence in 1956 when the record of rights under the BT Act were being revised under the EA Act. Before the implications of the revolutionary Hindu Succession Act could be fully understood, the revisional operation was almost over. Moreover, the thrust of revisional operation under EA Act was to obtain the position of land and all pre-existing rights therein as on 15.04.1955 or 14.04.1956, the date of vesting under EA Act. Naturally recording the names of women according to the new law did not get the importance it deserved. So, in this way another opportunity for recording women's land right was missed out.

\section{The West Bengal Land Reforms Act, 1955}

As a follow-up of the EA Act by a comprehensive measure of land reforms so as to remodel the system of land tenure, the West Bengal Land Reforms Act 1955 (WBLR Act) was passed. It came into force on 30.03.1956. According to the present definition of a raiyat under the Act whoever holds land for any purpose whatsoever is a raiyat and land as defined in the Act means land of every description.

Women's land right in WBLR Act- a missed opportunity again; the latest revision of the records was taken up in 1975 under the LR Act, when the women's legal right to property stood fully established. Hence, attempt was made to record the names of women owners of land. However, the same problem of ascertaining the truth has been faced. The male heirs who normally attend the place where record-writing is done have been found to be reluctant to give out the names of female heirs particularly when they have been married off to a distant place. Brothers are still not reconciled to the sharing of paternal property with the sisters. In a male dominated society where the mind-set of even the persons entrusted with preparation or revision of records is not women-friendly as far as married women's right to paternal property is concerned it has been difficult to elicit information about the existence of female heirs.

Since revisional operation under the LR Act has almost come to an end, the effect of the amendment Act of 2005 giving more rights to the Hindu women belonging to a family governed by the Mitakshara School was not featured in the records.

\section{Classification of all lands of the state for management purposes:}

The Government of West Bengal acts both as a regulator and manager in respect of all lands within the state. It acts as manager in respect of lands at its disposal, and as a regulator in

$\mathbf{1 8 7}$ I Page Land Governance Assessment Framework - West Bengal 
respect of lands held by raiyats who are the owners of their lands enjoying heritable and transferable rights.

\section{Role of $L$ and $L R$ department:}

The Land \& Land Reforms Department is the administrative department of the WBLR Act and deals with all matters relating to land except the lands held by other departments who use and manage such lands for their own purposes. The main functions of the L\&LR Department are as follows:

(i) Formulation of policies with regard to the management of the land at the disposal of state government and regulation of lands held by the raiyats

(ii) Making legislation to give a legal basis to the policies

(iii) Distribution of land to the landless and land-poor [Section 49(1) of the WBLR Act] till December 2013, a total of 10,50,984.71 acres of land distributed]

(iv) Settlement of land for non-agricultural purposes [ rules 215 onwards, W.B. Land and Land Reforms Manual, 1991](area settled as long-term lease 6299.63 acres till December 2013)

(v) Prevention and removal of encroachment on the land at the disposal of the state government

(vi) Transfer of lands to other departments and to act as a coordinator among those departments (total of agri and non-agri land transferred to other departments is 132,675.33 acres till December 2013).

(vii) Acquisition of land

\section{Lands held by other Government departments:}

Many departments have lands at their disposal. They require the lands for their own use and they themselves manage such lands. The purposes to which the lands are used are as follows:

\begin{tabular}{|l|l|l|}
\hline \multicolumn{1}{|c|}{ DEPARTMENT } & & \multicolumn{1}{c|}{ PURPOSE OF LAND USE } \\
\hline Forest department & $:$ & $\begin{array}{l}\text { Afforestation and tree planting, including forest } \\
\text { cover, issue of pattas to eligible forest dwellers } \\
\text { under Forest Rights Act, 2006. }\end{array}$ \\
\hline Fishery department & $:$ & $\begin{array}{l}\text { Pisciculture, leasing out water bodies to } \\
\text { Fishermen's Co-operatives, development of } \\
\text { water areas for the purpose of pisciculture. }\end{array}$ \\
\hline $\begin{array}{l}\text { Irrigation and Waterways } \\
\text { Department }\end{array}$ & $:$ & $\begin{array}{l}\text { Construction of embankments on river banks, } \\
\text { leasing out water areas for short periods. }\end{array}$ \\
\hline Public Works department & $:$ & $\begin{array}{l}\text { Construction of roads and buildings and issue } \\
\text { short term leases in respect of roadside lands. }\end{array}$ \\
\hline $\begin{array}{l}\text { Commerce and Industries } \\
\text { Department }\end{array}$ & $:$ & $\begin{array}{l}\text { Issue of license for industrial activities, } \\
\text { providing infrastructure for planned } \\
\text { development. }\end{array}$ \\
\hline $\begin{array}{l}\text { Urban Development } \\
\text { Department }\end{array}$ & $:$ & \begin{tabular}{l} 
For planned development of cities and towns \\
\hline
\end{tabular}
\end{tabular}

\section{Land related agencies}

Town \& Country Planning Act has been enacted for planned development of cities and towns. Kolkata Metropolitan Development authority is an authority under such Act. For construction of important roads and buildings containing flats for higher, middle and lower income group people. Land has been given to KMDA either after acquiring it under the Land Acquisition Act, 
or by lease of government land granted by the L\&LR Department. Similarly land was given to other authorities under the Act. Land was also given to West Bengal Housing Board under the Housing Department for construction of flats for MIG and LIG.

Evolution and recognition of tenancies in Bengal / West Bengal

\section{Tenurial structure in the state before the abolition of zamindary with effect from 15.04.1955}

The BT Act, 1885 divided people living off agricultural land into two classes - landlords and tenants - the rent receivers and rent payers. A landlord was defined as a person under whom a tenant holds and includes the government. A proprietor is the owner of an estate and for that he paid revenue to the government. The Act then classified the tenants as tenure-holders including under-tenure-holders, raiyats and under-raiyats:

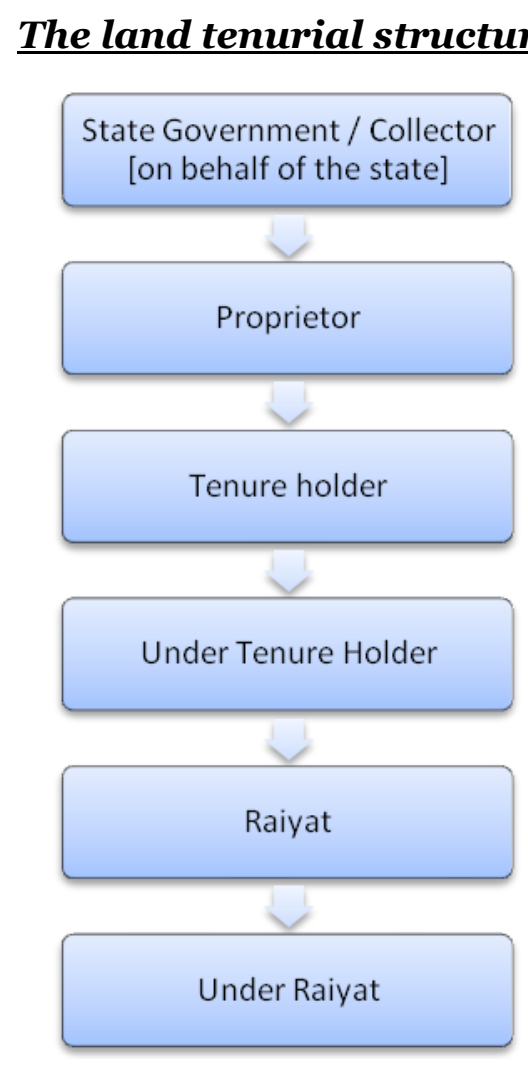

\section{Tenure holders and raiyats}

A tenure holder is primarily a person who holds land under a proprietor or another tenureholder for the purpose of collecting rent or bringing it under cultivation by establishing tenants on it [ sec 5(1) B.T. Act]. A raiyat is primarily a person who holds land for the purpose of cultivating it by himself or by members of his family or by servants or by hired labourers [Sec. 5(2) B.T. Act]. In reality, the raiyats who were primarily cultivators used to induct tenants under them and such tenants came to be known as under-raiyats. The raiyats thus became both payers and receivers of rent. The under-raiyats also had tenants under them. Such tenants were called under-under-raiyats.

\section{The Scenario after abolition of zamindary}

After acquisition of all rent receiving interests and imposition of ceiling under the EA Act, the intermediaries defined in the Act who retained land within the ceiling limit became tenants

189|Page Land Governance Assessment Framework - West Bengal 
directly under the state. Thus all kinds of previous landlords and tenants were brought on the same platform - the tenants under the state, the only landlord is the state and whoever holds land is a tenant under the state. To deal with the scenario brought about by the abolition of zamindary system WBLR Act, 1955 was enacted to regulate the landlord-tenant relationship. The tenants who held lands for the purpose of agriculture were defined as raiyats, and land was defined as agricultural land including homestead. Thus the only status the Act confers on the tenant of agricultural land is that of a raiyat. Thereafter whoever came to own land for agricultural purpose came to be known as raiyat.

The position underwent a sea-change with effect from 07.08.1969 as a result of amendment of the Act. Now land means land of every description and a raiyat means a person or institution holding land for any purpose whatsoever. With effect from 09.09.1980 the non-agricultural tenants and under-tenants also came to be treated as raiyats [section 3A of WBLR Act]. Now whoever holds land in this state other than a lessee under the government holding land for nonagricultural purpose is a raiyat.

A share-cropper becomes a raiyat by operation of law when the land cultivated by him vests in the state as the surplus land of the owner, within a certain ceiling limit [Section 14(S) of WBLR Act]. An occupier under the W B Acquisition of Homestead Land for agricultural Labourers, Artisans and Fishermen Act, 1975, becomes a raiyat when the land occupied by him within a limit vests in his favour [Section 7 of the Act]. The landless and land-poor who have been given agricultural or homestead land under section 49(1) of the WBLR Act have become raiyats whose right is inheritable but not transferable.

\begin{tabular}{|c|c|c|c|c|}
\hline Category & Tenure type & $\begin{array}{l}\text { Mode of creation and } \\
\text { recognition }\end{array}$ & Number & $\begin{array}{c}\text { Area of } \\
\text { occurrence }\end{array}$ \\
\hline 1. & Rayati-Tenure & 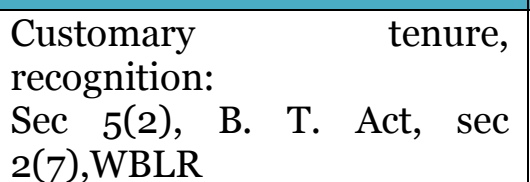 & NA & Rural \\
\hline 2. & -do- & $\begin{array}{l}\text { A share cropper cultivating } \\
\text { vested land straightaway } \\
\text { assigned raiyati status under } \\
\text { certain circumstances [sec } \\
\text { 14S(2), WBLR] }\end{array}$ & NA & Rural \\
\hline 3. & -do- & $\begin{array}{l}\text { Created by operation of sec } \\
7(\mathrm{i}) \text { of the W.B. Acquisition } \\
\text { of Homestead land for } \\
\text { Agricultural Labourers, } \\
\text { Artisans and Fisherman Act, } \\
1975 \text { only known as the } \\
\text { "Homestead Act". Persons of } \\
\text { the above three categories in } \\
\text { occupation of private land as } \\
\text { on } 26^{\text {th }} \text { June } 1975 \text { are under } \\
\text { certain circumstances, } \\
\text { assigned raiyati status in } \\
\text { respect of such land or part } \\
\text { thereof. }\end{array}$ & $\begin{array}{c}{ }^{*} \text { No. } \\
\text { 3.27 lakh } \\
\text { Area. } \\
7883.80 \\
\text { Ha }\end{array}$ & $\begin{array}{l}\text { Rural, Semi- } \\
\text { Urban and } \\
\text { Urban }\end{array}$ \\
\hline 4. & -do- & $\begin{array}{l}\text { Landless and semi landless } \\
\text { persons distributed vested } \\
\text { land as a measure of } \\
\text { agranian reforms accorded }\end{array}$ & $\begin{array}{l}\text { *No. } \\
\text { 31.36 lakh } \\
\text { Area } \\
425982\end{array}$ & Rural \\
\hline
\end{tabular}

$190 \mid$ Page Land Governance Assessment Framework - West Bengal 


\begin{tabular}{|c|c|c|c|c|}
\hline & & $\begin{array}{l}\text { the status of a raiyat }[\mathrm{u} / \mathrm{s} \\
49(1), \mathrm{WBLR}]\end{array}$ & $\mathrm{Ha}$ & \\
\hline 5. & $\begin{array}{l}\text { Raiyati- } \\
\text { Tenure }\end{array}$ & $\begin{array}{l}\text { Tenants and under tenants } \\
\text { under the Non-agricultural } \\
\text { Tenancy Act, 1949 given } \\
\text { raiyati status by amendment } \\
\text { of the WBLR Act [sec 3A (1)]. }\end{array}$ & NA & $\begin{array}{l}\text { Rural, Semi- } \\
\text { urban and } \\
\text { Urban }\end{array}$ \\
\hline 6. & $\begin{array}{l}\text { Other kind of } \\
\text { tenures }\end{array}$ & $\begin{array}{l}\text { Through delivery of } \\
\text { documents of title to forest } \\
\text { dwellers under the Forests } \\
\text { Rights Act, } 2006\end{array}$ & $\begin{array}{c}\text { (+)No. } \\
\text { individual } \\
30,879 \\
\text { community } \\
312 \\
\text { Area total } \\
4958 \mathrm{Ha} \\
\text { (17247.12 } \\
\text { Acre) }\end{array}$ & Rural \\
\hline 7. & -do- & $\begin{array}{l}\text { Squatters on govt. land by } \\
\text { the then Refugee, Relief and } \\
\text { Rehabilitation department } \\
\text { have been given documents } \\
\text { of settlement. }\end{array}$ & NA & $\begin{array}{c}\text { Urban and } \\
\text { Semi-urban }\end{array}$ \\
\hline 8. & $\begin{array}{l}\text { Share cropping } \\
\text { tenure }\end{array}$ & $\begin{array}{l}\text { Customary: } \\
\text { Recognised, [clause(b) of sec } \\
2 \text { of W.B. Bargadars Act, } \\
\text { 1948, sec-2(2), WBLR }\end{array}$ & $\begin{array}{l}\text { *No.15.21 } \\
\text { lakh } \\
\text { Area } \\
\text { 4.53 lakh } \\
\text { Ha } \\
\end{array}$ & Rural \\
\hline
\end{tabular}

Source:* Directorate of Land Records and Surveys

(+) Backward Classes Welfare Department

\section{Distribution of land among landless and land-poor (creation of tenure and equity)}

Distribution of ceiling surplus land among the landless and land-poor of which those belonging to the Scheduled Tribe and Scheduled Caste getting preference is one of the main items of agrarian reforms to ensure redistributive justice. So far [ Aug 2013 ] 31,36,297 landless and near landless persons have been given land by way of distributive land reforms thereby creating as many new tenures. Again, by implementing the Homestead Act, 3,26,653 persons have been given land with raiyati status creating equivalent number of tenures. Likewise, 30,879 individual and 312 Community tenures were created as a result of implementation of the Forest Rights Act, 2006.

The beneficiaries who have got lands are mostly all from the poorer section of the society (Rule 194 of the WBL\&LR Manual 1991 provides principles for making a priority list). It is, therefore, clear that the policy of the government is to provide land and homestead to the downtrodden land-poor for improvement of their lot. In essence, the policy is equity oriented.

\section{Rights on land and duties of a raiyat in respect of the land comprising his tenure}

\section{$\underline{\text { Rights }}$}

A raiyat has the following rights over the land comprising his tenure:

- Heritability i.e. the lawful successors inherit the land of a deceaced raiyat

- A right to use the land subject to certain restrictions

191| Page Land Governance Assessment Framework - West Bengal 
- A right to derive income from the land

- A right to protection from illegal expropriation of the land

- A right to transfer the land either wholly or in part subject to certain restrictions in respect of some categories of tenures.

- A residuary right to the land

- A right to enjoy the landed property in perpetuity unless terminated under a due process of law

- Right of pre-emption (this right is available to a raiyat whose lands have a common boundary with the lands of another raiyat).

\section{$\underline{\text { Duties }}$}

- Maintenance and preservation of land as prescribed under WBLR Act

\section{Rights of a bargadar over the land cultivated by him}

- Occupancy right [right of a bargadar to cultivate lands cannot be terminated except in accordance with law

- Right to succession [the lawful heirs of a deceased bargadar has a right to succession of cultivating right of the bargadar. Succession in this case does not follow the ordinary laws of succession. The lawful heirsm according to the succession law applicable, decides by consensus who among them will inherit the right of cultivation. On their failure to do so, the competent officers determine a successor from among the heirs.

- Right of pre-emption [available to a bargadar when the land under barga cultivation has a common boundary with the land of another person]

- Right to voluntarily surrender the right of cultivation.

\section{Restrictions on the rights of a raiyat:}

Sub-section (2) and sub-section (4) of the WBLR Act takes away sub-soil right from a raiyat. In terms of sub-section (2A) of the WBLR Act a raiyat is not permitted to quarry sand from his plot or dig or use earth or clay of his plot for manufacture of bricks or tiles etc. He may, however, do so only for his own use with the permission of the state government. Sub-section (4) ibid puts some restrictions on use of the land of the tenure. In brief, these are:

(i) The land cannot be used for any purpose other than for which it was taken [ ordinarily agriculture] [sec 4(4)(1)(a)]

(ii) The land cannot be left fallow for more than three consecutive years. $[4(4)(1)(b)]$.

(iii) The holder has to bring the land under personal cultivation [sec 4(4)(1)(c)].

(iv) The holder cannot let out any part of the land $[\sec 4(4)(1)(d)]$.

Restrictions on transfer have been imposed by law on a few categories of lands.

To enumerate:

a) The land of a tenure created u/s 49(1) of the LR Act can be transferred only by way of a simple mortgage to specified institutions for the purpose of taking loan for improvement of land or for construction of a dwelling house [ $\sec 49(1 \mathrm{~A})]$. 
b) An occupier under the WB Acquisition of Homestead land for Agricultural Labourers, Artisans and fisherman Act, 1975 may transfer the land as at (a) above only for the purpose of development of the land [sec 10(2)].

Chapter IIB of the WBLR Act has put restrictions on the transfer of land of tribal raiyat. He cannot transfer land except in the ways mentioned in Sec 14C (1). The focus of this section is to restrict transfer of tribal lands to non-tribals. In terms of sec $14 \mathrm{E}$ a Revenue officer may annul any transfer made in contravention of the provisions contained in sec $14 \mathrm{C}$.

The obligations cast upon the general category raiyats were meant for keeping the area of arable land undiminished and agricultural land was to be held by farmers only. The restriction on letting out by raiyats is in keeping wth the principle of abolition of all kinds of rent-receiving interests. According to the present tenurial structure the State is only landlord and whoever holds land is a tenant under the State. However, in view of the changed situations calling for various use of land it has to be considered whether such restrictive use of land will serve the purpose. However, restriction of transfer of land by those raiyats who have got lands from the government as beneficiaries of land reforms measure is justified in the sense that without such restrictions they cannot hold on their lands. In reality, a lot many have transferred their lands in spite of such restrictions. Curiously those who have purchased such lands illegally are in most cases as poor as the transferors. As for tribals, the restriction on transfer is meant for preventing the non-tribals from purchasing their lands.

\section{Ban on creation of tenancy on private land}

The law does not permit creation of tenancy on private land. But such tenancies or tenancy like situations operate clandestinely. These 'concealed tenancies' (lease) as they are called are, in effect, a mode of cultivation in violation of the modes permissible under the LR Act. Ban on tenancies imposed by law as a measure of tenancy reform in the state is quite relevant. Reintroduction of this institution would amount to emergence of feudalism in land tenural system with its concomitant social ills.

\section{Security of Tenure of a Raiyat}

Tenure security is defined as i) protection against eviction; ii) the possibility of selling, and transferring rights through inheritance; iii) the possibility... (of having) ... mortgage, and having access to credit under certain conditions (UN-HABITAT).

In West Bengal after reforms, a very skewed and complex land tenure system has been replaced by a simple one where the state is the landlord and whoever holds land is a raiyat under the State. The rights of a raiyat are clearly laid down in the WBLR Act as pointed out earlier. His right is heritable and transferable. Since this right is protected by law under the umbrella of the right to property under Article 300A of the Constitution of India his right is well secured. However, the extreme penalty of vesting of land for violation of any of the obligations u/s 4(4) of the WBLR Act is sub-judice before the Supreme Court. If however the land of a raiyat is acquired under any land acquisition Act he has to be compensated adequately and such compensation cannot be less than what has been provided for under the new LARR Act 2013.

\section{Bargadars}

Before reforms the tenure of the share cropper was the most insecure. After reforms security of a share cropping tenure has been greatly enhanced because of the following factors:

193 I Page Land Governance Assessment Framework - West Bengal 
(a) Recording of the names of the share-croppers in the record-of-rights - a public document.

(b) Very stringent legal provisions regarding eviction of share cropper by the owner.

(c) Share-cropper-friendly ambience in the State.

Security of tenure cannot be measured or quantified. However, a study [2003] made by the State Institute of Panchayats and Rural Development found that about $72 \%$ of share-croppers had a sense of enhanced security after their names were recorded in the land records.

\section{Occupiers of private and public land}

Occupiers of private land with/without the land owner's leave or illegal occupiers of government land do not have any tenurial security. Of late the government has been implementing an innovative scheme Nijo Griha Nijo Bhumi for homestead micro-plot (up to 5 decimals by either land purchase at market price from willing sellers or vested land fit for distribution) allocation to the poorest. The scheme takes into account regularization of the poor settlers' illegal occupation on government land by granting patta and record of rights jointly in the name of wife and husband, judging suitability of each case as per the provisions of beneficiary selection.

\section{Land and Land Tenure Governance}

In common parlance land and land tenure governance means - institutionalization of legal provisions related to the subject of land; respect of security, protection, exercise of rights and delivery of justice through an appropriate system developed by the state. Governance also includes effective functioning of a tax and land revenue collection machinery.

\section{Administrative framework}

Following is the land reforms administrative set up in West Bengal

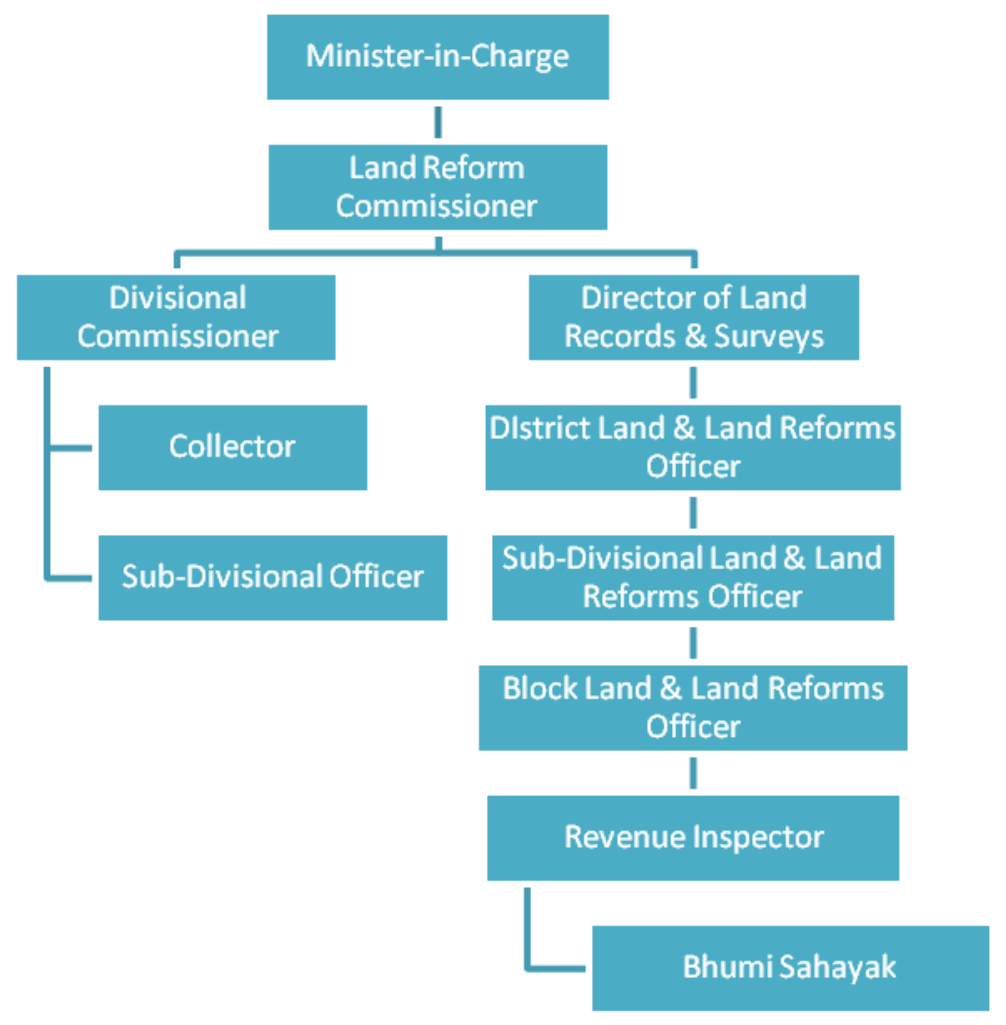

$\mathbf{1 9 4}$ | Page Land Governance Assessment Framework - West Bengal 
Divisional Commissioner can hear appeal under section 54(1)(b) of the WBLR Act, only in respect of the orders passed by the Collector. The DL\&LRO enjoys all the powers of a Collector under the WBLR Act. The DLLRO is an appellate authority in respect of an order made by a Revenue Officer.

\section{Major functions of the field level functionaries relating to land and land reforms:}

- $\quad$ Settlement of land u/s 49(i) L.R. Act and issue of pattas (Deed of settlements)

- $\quad$ Recording of bargardars

- To ensure that the restrictions imposed by law on the use of land is adhered to by the raiyats

- $\quad$ To ensure that protection to the tribal raiyats given by law is made available to them

- $\quad$ To adjudicate disputes / conflicts between land owners and bargadars in relation to share of produce, termination of barga cultivation etc.

- $\quad$ Keeping a vigil on illegal conversion of land

- $\quad$ Assessment of land revenue and collection thereof.

- Maintenance of r-o-r.

[The list is illustrative only]

\section{Mode of formulation of policy}

Policy is formulated at the highest level of the Land \& Land Reforms Department. Inputs from field officers are sometimes taken into account in formulating the policy. Sometimes discussions with officials of other departments which may be affected by the proposed policy also take place. And finally, as the ministry is formed by the elected representatives of the political parties, the political input is supplied by the Minister-in Charge.

\section{Preparation of Cadastral maps and Record - of - Rights}

A set of updated cadastral maps and RoR based thereon is a sin qua non for good land and land tenure governance. In West Bengal all rural lands except the following were surveyed and record of r-o-r thereof prepared under the B.T. Act and successively revised under the WBEA Act and the WBLR Act:

(a) 126 non - revenue forest mouzas in the state

(b) 126 chitmahal mouzas (enclaves in Bangladesh)

(c) 22 diluvated mouzas in South 24 Parganas

As regards urban lands, all such lands were surveyed and r-o-r thereof prepared as in the case of rural lands except the areas comprising the first hundred Wards of present Calcutta Municipal Corporation.

Schedule A appended to the W.B. Land Reforms Rules, 1965 prescribe the steps to be followed for revision or preparation of record-of-rights.

Detailed technical instructions are issued by the Directorate of Land Records and Surveys for Traverse and Cadastral surveys. Maps for mouza (village) are prepared after detailed survey. Each plot is separately demarcated on the map and assigned a distinct number. Based on the plot/plots so mapped and details thereof are incorporated into the record-of-rights prepared for the tenure comprising the plots.

195 I Page Land Governance Assessment Framework - West Bengal 
The finally published record-of-rights contains particulars regarding the raiyats, class of land comprising the tenure, name of bargadar, if any, etc. [rule 23], particulars of the plot/plots comprising the tenure. A copy of the r-o-r so finally published [parcha] is handed over free of cost to the raiyat. A parcha is a very important and useful piece of document particularly for a rural raiyat. A copy is also handed over to the bargadar, if there is any.

\section{Status of record-of-rights in regard to question of title}

The old system of issue of patta [document of creation of tenancy] by the landlord and execution of a Kabuliyat by the tenant was given legal sanction by the Rent Act, 1859. The landlords were largely reluctant to issue a patta, and so the practice had already died down when settlement under BT Act was taken up. But the BT Act provided that the landlords should grant rent receipts and maintain counterfoils thereof. The law courts accordingly accepted the rent receipts as proof of creation of tenancy and also held that since tenancy is a question of fact oral evidence and other forms of evidence were admissiable. During preparation of RoR under the BT Act tenancies were accordingly recorded based on possession backed up by rent-receipts.

During revisional settlement under the EA Act, designing landlords freely used the rent receipts to show creation of tenencies in favour of their near relations to frustrate the ceiling provisions of the Act. The ROs at that time could not reject such rent receipts and unwittingly made records in favour of such fake tenants. Afterwards, it took considerable effort on the part of the authorities to cancel records made on the basis of such fake tenancies.

WBLR Act doesn't permit creation of tenancies and does not recognize and transfer except through registered documents. Hence, in course of current revision under the LR Act only transfer executed through registered deeds has been accepted and recorded. To the law courts RoR is primarily a document of possession and not title. However, since RoR is made to record possession of land backed up by registered documents recognized by law RoR can be accepted as an indicator of title.

\section{Recording of women's land rights in the R-O-R}

Since the Hindu women did not have the right of inheritance very few women land owners were recorded under the BT Act operation. There was no significant improvement in the two successive operations under the EA Act and LR Act although women's right to inheritance stands established. Pattas issued to women singly or jointly with their husbands are, however, being brought into the records. A study by SIPRD finds that the total number of pattas, joint inclusive, issued to women constitutes about $14.89 \%$ [March, 2002] of the total number of pattas issued.

\section{Accuracy of land records and maps}

The accuracy of maps and records prepared under the BT Act is proverbial. Such maps and records have only been revised. Records are continuously updated through maintenance. The present records are fairly accurate. West Bengal being a State of small land-holders the incidence of change as a result of inheritance, transfer etc. is very high and reluctance of the successors to approach the authority for incorporating the changes in the records is so great that by the time revision of records comes to an end, the record gets out of date. A programme of mass-mutation has become imperative to make the records up-to-date.

\section{Computerization of cadastral maps and records}

All large scale maps of villages have been digitized (till date 40,585 out of 42042, source NIC). Also, records of rights of these villages have been computerized. As a result, copies of such records (parcha) may be instantly made available to the members of the public. Similar facility will be available soon in respect of supply of digitized maps.

196 | Page Land Governance Assessment Framework - West Bengal 


\section{A simple land tenure pattern}

Tenancy reforms in the state have resulted in the following:

(i) All raiyats hold land under the state and so the landlord-tenant relationship is simple.

(ii) Abolition of different kinds of rent like rent in kind, service rent etc. - acceptance of cash rent only also have made things simple.

This has given the West Bengal land-tenure system a very simple pattern.

\section{Implementation of the Reform Acts: an overall assessment}

\section{Objectives and scheme}

In keeping with the national policy and in pursuance to the Constitutional provisions West Bengal enacted WBEA Act 1953 for abolition of Zamindary and all forms of rent receiving interests and imposition of ceiling on individual holding of land. Since all those who retained land under the Act became tenants directly under the state, WBLR Act 1955 was passed to provide for a landlord - tenant law and other land reforms measures.

These two Acts form the legal framework for West Bengal land reforms with focus on the following:

- $\quad$ Abolition of Zamindary and all rent-receiving interests [WBEA]

- $\quad$ Imposition of ceiling on land [WBEA]

- $\quad$ Rationalisation of tenancy structure [WBEA]

- $\quad$ Equalisation of rent [WBEA]

- $\quad$ Equalisation of social status of different categories of tenants [WBEA]

- $\quad$ Vesting of ceiling surplus land [WBEA]

- $\quad$ Vesting of land on application of family ceiling [WBLR], and

- $\quad$ Bringing all kinds of land within the definition of 'land' under the WBLR Act

- $\quad$ Abolition of non-agricultural tenancy and treating the non-agricultural tenants and under-tenants as rayats [WBLR Act]

\section{Some observations on implementation of land reforms measures}

The Zamindars constituting the landed aristocracy of Bengal started losing interest in Zamindary from the last quarter of the $19^{\text {th }}$ Century and preferred living in the city of Calcutta pursuing various professions leaving management of Zamindary to the employees called Nayeb and Gomostas. A direct outcome of the $19^{\text {th }}$ Century Bengali Renaissance. Moreover, the compensation provided for in the WBEA Act for the acquisition of rent-receiving interest was reasonably fair. So there was least resistance to the abolition of Zamindary.

Imposition of ceiling on their Khas lands (lands held in personal cultivation), both agricultural and non-agricultural was severely resisted, not physically but legally. In spite of Constitutional provisions for acquisition of estates and any rights therein all legislations relating to agrarian reform Constitutional validity of each and every provision of ceiling was challenged before the High Court. As goes the judicial procedure the matter is to be decided first by a single bench and then appeal to be heard by a division bench of the High Court. Finally the matter is to be decided by the Supreme Court. It takes years for a final decision. During the period the matter is before the court possession of land held in excess of the ceiling limit by the petitioners cannot be taken. This is exactly what happened to the ceiling provisions under both the WBEA Act and WBLR Act. Constitutional validity of the amendment of the WBLR Act made in 1981 and 1986 is yet to

197| Page Land Governance Assessment Framework - West Bengal 
be decided by the Supreme Court. In addition to this, the big land owners who were going to lose land as a result of ceiling did all they could do to evade the ceiling provision. They resorted to various designs to keep more lands than the ceiling permits by circumventing the law. And they displayed rare ingenuity in crafting the designs. Since mid-1960s it has been one of the most important items of work of the Revenue Officers to detect lands held clandestinely and draw up proceeding to vest such lands in accordance with law. But almost all such actions have been challenged in the court giving rise to a spate of litigations involving thousands of acres of vested lands. It took years for disposal of such cases and still a lot many remained pending. It is only after constitution of the West Bengal Land and Land Reforms Tribunal (WBLRTT) by excluding the jurisdiction of the High Court as a court of the first instance, transfer of pending cases from the High Court to the Tribunal and automatic vacation of stay orders passed in such cases, that orders of vesting passed by the Revenue Officers and approved by the Tribunal could be given effect to and possession of vested land taken over. Thus the authorities implementing the ceiling law faced hurdles at every step.

\section{Cultivation of land by Sharecroppers (Bargadars)}

Share-croppers, generally known as bargadars in this State, who cultivate lands belonging to others on condition of paying a share of the produce, have been cultivating considerable extent of land for centuries. Floud Commission in its report submitted in 1940 estimated that 22.5\% of the total arable land was being cultivated by bargadars. The 1941 Census corroborated this figure. But the Bengal Tenancy Act 1885 virtually ignored the bargadars except in a negative way that they are not the tenants. Since they did not enjoy any protection of law the bargadars could be evicted by the owners of land at will. Bargadars were actual tillers of the soil but their right to cultivation was insecure.

After independence and before the WBEA Act and WBLR Act came into existence the Bargadars Act of 1950 was passed to provide for protection to the bargadars against eviction. The WBLR Act of 1955 incorporated the provisions of the Bargadars Act 1950. However, when effort was on to give legal protection to the right of cultivation of bargadars a few thousands of them became a victim of legal fiction and got evicted. The right of cultivation of bargadars was an "incumbrance" as defined in the Estate Acquisition Act. When the ceiling provisions under the Act were applied the owners of lands had the option to select the lands they would like to retain.

They naturally opted for retaining the lands which were not being cultivated by bargadars. The lands cultivated by the bargadars were thus surrendered. Since the lands vested in the State free from all incumbrances the right of cultivation by the bargadars got terminated by operation of law.

This legal imbroglio has been rectified under the WBLR Act. In the definition of "encumbrance" it has been clearly stated that encumbrance does not include the right of cultivation by a bargadar. Hence, when lands cultivated by a bargadar vested under the WBLR Act his right of cultivation did not get terminated automatically in respect of all the lands he cultivates. His right of cultivation stood terminated only in respect of land cultivated in excess of a limit laid down in the Act [Sec $14 \mathrm{~S}(2)]$. On the other hand, he becomes a raiyat automatically in respect of the land which he was cultivating as a bargadar up to that limit [Sec $14 \mathrm{~S}(3)]$.

Again, since most of the bargadars did not get their names recorded in the record of rights for fear of incurring the wrath of the owners, they could not avail of the protection against eviction provided by the WBLR Act. Although the law does not distinguish between a recorded bargadar and an unrecorded bargadar the grim fact is that whenever there is a dispute between an unrecorded bargadar and the owner of the land the stock plea of the owner is that his land is not cultivated by a bargadar. It becomes difficult for an unrecorded bargadar to prove that he cultivates the land. A special drive was taken to record the unrecorded bargadars in 1978-79. This drive came to be known as "operation barga".

198|Page Land Governance Assessment Framework - West Bengal 
Thereafter, in the amendment of the WBLR Act made in 1981 and 1986 many pro-bargadar provisions were inserted in the Act. A bargadar's right of cultivation became heritable, though not transferable. As a result of these amendments the right of cultivation of a bargadar is fully secure.

Transfer of Barga land: The SIPRD study addressed the crucial issue of dispossession of barga lands through eviction transfer, mortgage and various other modes. The following results emerged:

- $14.37 \%$ of the bargadars had lost possession of their barga lands with $85.63 \%$ remaining in possession.

- Eviction [either lawful or unlawful] accounts for $24.14 \%$ and inability to invest for $9.82 \%$ of dispossession. The remaining $66.04 \%$ is accounted for by transfer, mortgage etc.

Transfer of the right of cultivation by a Bargadar is not permissible under law. However, a bargadar mau surrender his right of cultivation or abandon cultivation of a particular plot of land. Consequential actions in such cases have been provided under section $20 \mathrm{~B}$ of the WBLR Act.

\section{Objectives of Reform Acts: How far achieved.}

Imposition of ceiling provisions followed by implementation and abolition of intermediary interests weakened the landed aristocracy and subsequent distribution of vested lands to the poorer section of the society empowered the poor with land assets. With this asset they could improve their economic condition which ultimately made them socially relevant and politically articulate. Several studies on micro level and a macro level by State Institute of Panchyats and Rural development suggest empowerment in the socio-economic status of the beneficiaries and their political importance. These studies further indicate the emergence of some sort of economic egalitarianism in rural society of West Bengal. However, their income level has not gone up nor can they provide for the next generation with such meagre asset.

\section{Distributive land reforms in West Bengal: the state and National scenario.}

Lands held in excess of the ceiling limits under the WBEA Act and WBLR Act have been duly taken away by the government, and such lands have been distributed among the landless and land-poor.

A quantitative evaluation of performance shows that till March, 2013, about 10, 51,731 acres of land were distributed to $31,26,527$ beneficiaries. A comparison with the all India scenario may not be out of place. The Table below shows the performance of a few states who have done comparatively better in the area of distributive land reforms:

\section{Distributive land reforms \\ State wise performance (March, 2013)}

\begin{tabular}{|l|l|l|l|l|l|}
\hline Sl. No. & \multicolumn{1}{|c|}{ Name of state } & $\begin{array}{c}\text { Area distributed } \\
\text { (in acre) }\end{array}$ & $\begin{array}{c}\text { \% of All } \\
\text { India } \\
\text { performance }\end{array}$ & $\begin{array}{c}\text { No. of } \\
\text { beneficiaries }\end{array}$ & $\begin{array}{c}\text { \% of All } \\
\text { India } \\
\text { performance }\end{array}$ \\
\hline 1. & Andhra Pradesh & 562226 & 10.99 & 471548 & 8.42 \\
2. & Assam & 545875 & 10.67 & 445862 & 7.97 \\
3. & Maharashtra & 634158 & 12.39 & 139755 & 2.49 \\
\hline
\end{tabular}

199|Page Land Governance Assessment Framework - West Bengal 


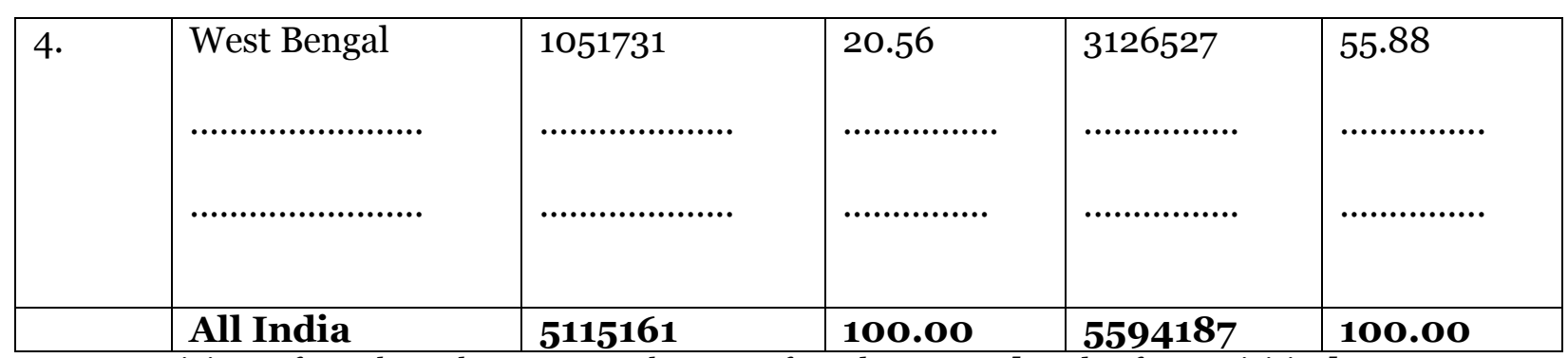

Source: Ministry of Rural Development, Development of Land resources [Land Reforms Division]

The figures speak for themselves. West Bengal being the smallest of the four States ranks by far the highest both in terms of land distributed and number of beneficiaries covered. As regards recording of bargadars till December, 2013 the names of as many as 15, 20,431 bargadars have been brought into the land records.

In the distribution of land the stress has been on the redistribution of the landed asset rather than economic viability and sustainability of a family of five. There is no disputing the fact that in West Bengal the land at the disposal of the government is too inadequate to meet the demand of all the landless and land-poor of the State. Still, keeping in view the sustenance of a family of five the maximum limit up to which land could be settled was determined as 1.o hectare (almost 2.47 acre) before the Left Front came to power in 1977. The Left Front Government brought the limit down to 0.4047 hectare (one acre) so that more people could avail of the benefit. In reality, less than one bigha of land (one third of an acre) and that also, in many cases, not in one block but comprising two/three tiny pieces of land. In this way, the number of the beneficiaries has been increased. But whether or not the benefit of such land even with the back-up support of the government by way of providing fertilizer, seeds, pesticides etc. at subsidized rate can make the beneficiaries economically viable is a matter of debate. The reality is this. Traditional agricultural pattern has been followed. Income of the rural people has not increased. It is said that whatever may be the extent of land given to the poor the very fact that they now own land has empowered them and made them hold their heads high. Empowerment by itself does not do much good to the poor if their income does not increase. That is why more and more people from rural West Bengal migrate to other States to augment their income by taking even menial jobs. Moreover, since the interests of the rural women have not received any particular importance in the schemes of land reforms except as a member of the family their lot has not improved at all. This explains why in the list of trafficking of women this state occupies one of the top positions.

The object of land reforms is integrated development of rural economy and all round development of life. This State has a long way to go to achieve this object despite its spectacular achievements in implementing some of the items of land reforms measures.

A research study jointly undertaken by the World Bank and Michigan State University in 2011 and subsequent reports published "Complete the incompleteness of Land reform" (by Klaus Denienger, Songquin Jin and Vandana Yadav) reveals some interesting facts on tenancy reforms in West Bengal:

1. Beneficiaries of tenancy reform are those households who were endowed with little or no land and were relatively poorer and whose livelihood was more dependent upon agricultural sector

2. In 1978, the average land endowment, inclusive of patta land, for barga and patta $(\mathrm{u} / \mathrm{s} 49$ of LR Act) beneficiaries was respectively 1.92 and 1.31 acres

3. Land reform benefited more households from lower castes, as indicated by the fact that $56 \%$ of barga beneficiaries and $73 \%$ of patta beneficiaries are from the marginalized SCs and STs

200|Page Land Governance Assessment Framework - West Bengal 
The study also revealed that "tenants have less incentive to make long-term land investment on reform land than their own land. Appropriate policy to address this loss of productivity on reform land needs to be devised. These differences in productivity can be mitigated by making changes in tenancy status which prevents sufficient use of labour, inputs and investments in the plots".

\section{A step forward towards agrarian reforms: "Nigo Griha Nijo Bhumi [NGNB]}

As a measure of agrarian reforms the state government addressed the acute problem of homestead and landlessness in the state [above 5.5 lakh families according to the estimates of the National Sample Survey Organisation in its $59^{\text {th }}$ and $60^{\text {th }}$ round reports]. The scheme launched upon for the purpose [NGNB] covers agricultural labourer, rural artisan and fisherman community. The key features of the scheme are:

- $\quad$ Proposed coverage 5.5 lakh absolute landless families by 2016

- $\quad$ Assignment of 5 decimals of homestead land along with land patta (land title)

- $\quad$ Patta in the name of wife or jointly in the name of wife and husband.

- $\quad$ Land for assignment made available from the land at the disposal of the government or by purchase from raiyats.

- $\quad$ Land use : homestead and home garden etc

- $\quad$ Cluster approach and support through convergence of various departmental schemes

Since inception of the scheme [October, 2011] and up to February 2014 more than 150,000 families have been covered by it. The scheme bids fair to attain the target by the stipulated time frame.

Considering rural landlessness as one of the strongest indicators of poverty this innovative scheme launched by the state government has targeted to provide land tenure security to most disadvantaged and excluded poor with $87 \%$ women tenure holder either self or in joint name with spouse.

\section{Issues and policy recommendations}

\section{Regularisation of illegal occupation of public lands}

In all the records of rights - first prepared from the beginning of the 1900 under the BT Act, revised in the fifties under the EA Act and again revised under the LR Act taken up from 1975 a clear process for formal recognition of possession of any kind of land has been followed.

When the owner is in possession of his land there has been no problem. However, when the person possessing the land is not the owner different nomenclatures have been used to record such possession. Persons possessing government land without being legally inducted on such land have been recorded as "unauthorised occupiers". Persons forcibly occupying the lands of another private person have been recorded as "forcible occupiers". Persons possessing lands on permission from the owners of such lands have been recorded as "permissive possessors". Legally speaking, such possessions differ in character and import. But the fact remains that possession of any kind has scrupulously been recognised in this state. However, recording of possession of government land that is unauthorised possession has not been recorded in recent times.

Considerable area of public lands particularly government lands is under illegal occupation in the state. The phenomenon is more pronounced in and around urban and semi-urban areas. There are laws for eviction of the illegal occupiers; but those are seldom used. Legal provisions are available for regularization of such illegal occupation by higher income group which will

201|Page Land Governance Assessment Framework - West Bengal 
fetch a considerable amount of revenue to government by way of long-term settlement. Such regularization may, however, invite fresh illegal occupation. The issue needs attention with a holistic approach. The NGNB scheme stated above has been leveraged to regularize more than 150,000 cases of occupation of public lands, used for homestead purpose by the most disadvantaged landless poor over the last three years.

\section{Compulsory mutation of names in the R-O-R}

Raiyats are not always interested in getting their names mutated in the r-o-r. This is one of the reasons why the records cannot be maintained updated. The Land Reforms Act and related Rules may be amended to provide for compulsory mutation of names by the raiyats through filing of applications for the same to the appropriate revenue authorities. [Maharashtra has legal provisions for compulsory mutation].

\section{Women empowerment: Individualization of Joint Pattas, issue of separate patta for husband and wife, reduction of revenue burden for women assesses.}

By way of women empowerment through endowment of land asset the state government had started grant of Joint pattas in the name of both husband and wife with effect from 1994-95. This is being done on the basis of an administrative order which is inconsistent with the provisions of sec 49(1) of the WBLR Act. It is necessary to amend the law to provide for grant of joint patta with wife's name coming first as has been stated in the implementation guideline of NGNB. In this context the following issues are relevant:

(a) Reopening of the past cases where the patta has been issued in favour of a single person.

(b) Individualisation of tenure i.e. assigning separate r-o-r to husband and wife in case of a joint patta already granted.

(c) Grant of separate pattas for all future cases of settlement u/s 49(1)

In case of (a) the task is herculean. As regards (b) the measure on the face of it may enhance the level of women empowerment, but there are many other factors to be considered.

The measures will require amendment of the WBLR Act.

Reduction of Revenue Burden for women assesses: Section 23 of the WBLR Act provides for payment of revenue by a raiyat for his holding according to the rate mentioned in the related Table. In order to give some financial relief to the women assesses it could be considered if some exemption say $25 \%$ of the rent payable by them in terms of this section could be given. The proposed exemption shall be in addition to the general exemption up to 2.428 acres as provided in Sec 24(1), WBLR Act.

\section{Bridging the gap between legislation and implementation}

\subsection{Implementation of sec $21 \mathrm{C}$, WBLR Act regarding constitution of State Land Corporation etc}

Section $21 \mathrm{C}$ was inserted in the Act in 1981 to address the difficulties faced by a section of the rural raiyats in selling their lands cultivated by bargaders. Implementation of this need driven section has been hanging fire for more than three decades. This should be taken up for implementation because West Bengal's rural society still continues to be plagued by the above problem.

4.2 Implementation of the provisions in the WBLR Act (Chap V) regarding consolidation of Holding, Co-operative Farming Society and Co-operative Common Service Society.

202|Page Land Governance Assessment Framework - West Bengal 
The above provisions are critical for agrarian reforms in the West Bengal context, have been lying dormant in the statute book with none of the state governments since Independence having taken any interest in implementing them. It should be seriously considered if these provisions should be implemented to further the state's land reforms efforts and achieve the long term goal of improved agriculture and higher income.

\section{Conferring tenancy right upon bargadars}

The Bengal Tenancy Act, 1885 was significantly silent as to the status of a bargadar. During settlement operations under the B.T. Act bargadars were recorded as tenants with assignment of khatian (r-o-r) in several districts. In the 1928 amendment of the BT Act bargadars were expressly excluded from the definition of a tenant. In its report [1940] the Floud Commission had inter alia recommended grant of tenancy right upon the bargadars with one third produce as rent. Taking a cue from this recommendation the left parties built their tebhaga movement. However, they did not demand tenancy rights for the bargadars. After abolition of all kinds of rent receiving interests and bringing all the tenants under the state, the only land lord in this state and prohibiting letting out of land by the rayats a new land tenure structure has come into place. Creation of new tenancies in favour of the bargadars means creation of rent receiving interests by the rayats. This does not fit in with the present structure. The legislators in their window instead, wanted to make the bargadars the owners of land by taking loan from Land Corporation to be set up in accordance with the provision of section $21 \mathrm{C}$ of the WBLR Act. Since the peasant organizations did not shown any interest in such measure Sec $21 \mathrm{C}$ has not been implemented. The present government may consider implementing this provision to bring to an end once for all the inherent clash of interest between the bargadars and their owners of land.

\section{Non-revenue Forest mouzas}

126 non-revenue forest mouzas in the state have not been cadastrally surveyed. The eligible forest dwellers are being endowed with numerous rights including issue of land-pattas through implementation of forest Rights Act, 2006. It is necessary to cadastrally survey these mouzas and incorporate these rights in the r-o-r to be prepared. The job is pretty tough as it will entail Traverse connection in the forest areas. The issue may be considered by the government.

\section{$\underline{\text { Data source }}$}

The data relating to the land quantum and number of beneficiaries used in the document have been sourced from Director of Land Records \& Surveys, Government of West Bengal.

\section{Panel 2: Rights to Forest and Commons Lands \& Rural Land Use Regulations}

\subsection{Background}

The total reported area under different categories of land use in West Bengal in 2007-08 was 8.684 million ha (excluding Kolkata district) of which four categories of land use comprising 120,450 ha are as below:

a. Permanent pastures and other grazing land (6110 ha)

b. Land under misc. tree groves not included in net sown area (61310 ha)

c. Culturable waste land ( $32850 \mathrm{ha})$

d. Fallow land other than current fallow (20180 ha)

This area constitutes only $1.38 \%$ of the reported area under different uses in West Bengal (source, Director of Agriculture, Evaluation Wing).

\subsubsection{Commons}

203|Page Land Governance Assessment Framework - West Bengal 
For the purpose of LGAF communal land (or commons) is defined as "land over which a community has right or access to, the community may or may not have legally recognized ownership over the land. In some cases the state may be considered as owner”. In West Bengal all the lands per se latest RoR are either recorded in the name of a raiyat or government. The West Bengal Land and Land Reforms Manual, 1991 specifies about maintaining Register VIII for unoccupied government land which are in use by the public and not to be settled, e.g., roads, drinking water tanks, grazing land, cremation ground, burial ground, disposal ground etc. There are of course raiyati agricultural lands which are traditionally used by the community for cattle grazing purpose purely on temporary basis in the lean season. Except where the record of the land clearly mentions about 'meant for communal use' (as in the case of Register VIII) there is no scope of legal coexistence of multiple rights on seasonal common land. Vested, resumed and abandoned lands are also entered in this Register and are settled according to the prescribed procedure.

All the forest lands are clearly identifiable on revisional survey maps, but demarcation on ground does not exist in all cases. Patches of blank forest land within the notified forest area or adjacent to the notified but degraded forest land are traditionally used by the community residing in forest villages or in the fringe area for grazing or other social/ community purposes like village huts etc. There is no proper record or boundary demarcation for these lands in many of the cases and exercising customary rights over these lands often comes under question from forest authorities.

West Bengal does not have large areas of common land as is found in other less densely populated states of India. In West Bengal access to many natural resources (common property resources) is not clearly defined legally but depends on a process of negotiation, bargaining or conflict between the rich and poor, an on a system of customary rights whereby the poor access land of the rich (Beck, 1998). While some resources are open access (for example stubble left after harvesting or wild foods that grow in drainage ditches or by the sides of ponds), borrow pits, other important CPRs (such as gleaned grains, fallen fruits, the right to collect cow dung or graze cattle on the boundaries between fields) should be defined as products that are mainly found on private land or which are controlled by richer villagers, or to which the poor have customarily negotiated access. While from the perspective of the rich these latter resources may be privately owned, from the perspective of the poor these resources are common in that the poor have attempted to maintain a right of access to them (source - Excluding the Poor from their Rights - the case of natural resources in West Bengal, by Tony Beck). Beck's analysis highlights an important issue, namely the de facto CPRs are in fact better indicator of CPR use, as an enquiry into use of de jure CPRs only might underestimate dependence.

\subsubsection{Forests}

The State of West Bengal has a total geographical area of 88752 sq. km., which is $2.7 \%$ of the total geographical area of the country. Population density of the state was 1029 per sq.km as compared to that of the country at 382 per sq.km (2011 Census). By reason of the Estates Acquisition Act, 1953, all the recorded forests of the state other than those under lease agreements with tea gardens had vested in the State and are now managed by the Forest Department, West Bengal. Subsequently the Tea garden forests had vested with Forest Department as "Resumed Forests". At present, all the recorded forests of the State are classified as Reserved Forests, Protected Forests and Unclassed State Forests, under the Indian Forest Act, 1927. The recorded forestland of the State (11879 sq.km.) is $1.54 \%$ of the recorded forest land of India (770078 sq.km.).

Working Plan Divisions of Forest Department regularly carry out boundary survey between forest and non-forest land, using GPS, and boundaries are permanently demarcated with pillars having Lat/ long positions. Except in the district of Purulia, status of clear forest boundary is

204|Page Land Governance Assessment Framework - West Bengal 
reasonably good and extents of old encroachments, which are now being regularised under FRA, are well documented.

West Bengal has one of the oldest histories of scientific management of its forests which dates back to mid-nineteenth century. Detail working plans were prepared by the British Foresters for management of this natural resource, which depended heavily on economic aspect of value addition, but did not totally overlook the aspect of Bio-diversity Conservation as well. In late nineteenth and early twentieth centuries, the art and science of artificial regeneration with fast growing spp. like Teak (tectona grandis), Sal (Shorea robusta), Champ (Michelia champaca), etc. in Northern Bengal, after clear-felling of natural forest, was perfected. During the early parts of twentieth century, in order to ensure steady labour availability in the remote forest areas, for carrying out commercial forestry operations, people, mostly tribals, were brought in and made to settle in the forest areas with allotment of per capita land for shelter and cultivation. These Forest villages in North Bengal were registered with Forest Department, but these villagers were deprived of the benefits of any rural development activities as they were neither part of civil villages nor under the Panchayati Raj Institutions. This continued till the 1980s, and the economic development of forest villages remained totally dependent on the Forest Department.

However, in the districts of undivided Midnapore, Bankura and Purulia, the post-independence scenario was different. On the basis of Estate Acquisition Act of 1953, all the zamindari forests in these districts were taken over by the State and their management was vested with State Forest Department. These forests were notified as Protected Forests, under Indian Forest Act of 1927, without clearly defining or settling the rights of forest fringe people as per the provisions of the Act. These notified forests were in disjointed patches, varying between a few hectares to a few hundred hectares. The forests were surrounded by villages with large population and high population density. The poverty level in these villages was also high due to near-absence of irrigation facilities and industries, as well as low agricultural productivity as the fields were monsoon-cropped. The fringe population depended heavily on the sal coppice forests for their subsistence, fuel wood and fodder requirement. The heavy biotic pressure started denuding the forests and by the beginning of 1970s, most of the sal coppice forests in these districts had degenerated to bushy/ scrub forests. The efforts of the Forest Department staff to control the process of degradation, by mere use of force or legal measures, led to total failure. The trend continued till mid-seventies.

Meanwhile, in South Bengal, in the districts of Bankura, Midnapore, Purulia and elsewhere, large scale Eucalyptus and Acacia auriculiformis (Akashmoni) plantations were raised by the Forest Department during nineteen sixties and seventies, as part of "degraded forest regeneration”. Sal (Shorea robusta) plantations were also tried in degraded sal forest areas, however, with limited success due to heavy biotic pressure from fire and grazing in the young plantations. Beautiful patches of Eucalyptus and Akashmoni plantations provided ground cover to all those barren / degraded forest areas, which could not be otherwise regenerated with slow growing, miscellaneous spp. Simultaneously, another socio-economic experiment was initiated in Arabari village of Midnapore district by Dr A.K.Banerjee, Forest Silviculturist in 1972-73, trying to regenerate nearly 1200 hectare of degraded/ blank forest area with the help of around 615 families. The idea of sharing of usufructs with the villagers, from the resuscitated forest areas, was conceived in the Project. The success of the experimental project ultimately led to the generalized concept and adoption of Joint Forest Management (JFM) at the State and National level. The first Government Order on sharing of usufructs and constitution of Joint Forest Management Committees was issued in 1988 and over the next few years, the voluntary movement of forest protection through people's participation spread like wild fire. Nearly 4000 Forest Protection Committees (FPC) were formed to protect nearly 500,000 hectares of degraded forest areas of the State. Government Orders were issued separately for forests of North Bengal, South West Bengal and Sundarban regions. Similarly, Eco-development Committees (EDC) were formed around the national Parks/ sanctuaries and the schemes on

205|Page Land Governance Assessment Framework - West Bengal 
development of Sustainable, alternate livelihood were initiated to reduce the pressure of poor fringe population on the forest land for their sustenance. Government Orders were issued separately for the EDCs, outlining the duties, responsibilities and usufructuary benefits for the EDC members.

The movement received a material boost with the introduction of World Bank sponsored Social Forestry Project from the beginning of 1980s and the World Bank funded Joint Forest Management Project from the early 1990s. The distribution of vested waste land to landless rural families, in the three districts of South West Bengal, in later part of the 1970s/ early '80s was also a giant step towards the future success of farm forestry in South West Bengal.

National Forest Policy of 1952 had one of the objectives as conservation of wild flora and fauna of the country. In West Bengal, the concept of preservation of wildlife and its habitat was always part of the forest management, even when the major thrust was on commercial forestry ignoring the need of local population. Senchal Santuary was notified as early in the 1940s, Jaldapara Sanctuary was also notified- and subsequent notifications followed Gorumara \& Chapramari Sanctuaries respectively, all those notifications being issued under the Indian Forest Act of 1927, prior to promulgation of Wildlife Protection Act, 1972. However, with the advent of the later Act, the preservation of floral \& faunal biodiversity received a tremendous boost \& statutory support.

Early eighties also saw the global resurgence of Biodiversity conservation and renewed interest in the preservation of the endangered flora \& fauna of the world. In keeping with the international \& national trend, West Bengal too shifted its priority in forest management towards conservation of natural flora \& fauna in the forests \& the wetlands. National forest policy of 1988 and the Forest Conservation Act, 1980 put severe restriction on the harvesting of the natural forests. The late eighties \& early nineties saw increased activities in wildlife management in West Bengal. Large tracts of forest areas, having ecological importance and significance, had been declared as protected areas in the form of National Parks, Sanctuaries, Biosphere Reserves and Tiger Reserves. Policy decisions were taken to hand over administrative control of these protected areas (PA) to Wildlife Wing for more intensive management from wildlife conservation angle. Till date, nearly $34 \%$ of the total recorded forest areas of the State have been declared as P.A., as compared to $16.5 \%$ for the entire country.

\subsection{Critical issues}

1.2.1 West Bengal changed its Forest Policy, in line with National Forest Policy of 1988, by switching over to Joint Forest Management (JFM), as pioneer in the country, and giving more priority to people's need and biodiversity conservation than commercial exploitation and revenue earning. Government Resolutions were first issued in the State in 1988, taking the profringe people stand by allowing sharing $25 \%$ share of harvested forest produce with the forest fringe population. However, such orders, issued more than two decades back, need to be reviewed and the mechanism of JFM need to be amended in order to ensure more active participation of the forest fringe population and to empower these people in sustainable management of the Community Property Resources (CPR). A large number of Forest Village Development projects were implemented by Forest Department during 1980s to 2012, for development of infrastructure and livelihood options in the recorded Forest villages in North Bengal. However, there is a felt need to synergize the benefits from the JFM mechanism with the proposed benefits of FRA, 2006. There is also a need to institutionalize and legalize the JFM, so that the people's participation does not depend on the initiatives of Forest Department alone.

1.2.2 Clear felling of Natural Forest had been stopped in the State from 1990s, on the basis of Forest Conservation Act, 1980 and in compliance with order of Hon'ble Supreme Court. Only felling of plantations and coppice forest is carried out in the State, as per prior approval of Govt. of India/ Ministry of Environment and Forests (MoEF), in order to sustain the JFM model and sharing usufruct with the forest fringe population. Afforesation of degraded/ blank forest land is

206|Page Land Governance Assessment Framework - West Bengal 
done with indigenous/ local species. In South Bengal, a small percentage of plantation areas include Eucalyptus/ acacia spp. which has a strong local demand for fuel/ small timber and these species are always preferred by the Social Forestry planters as they are grazing and drought hardy.

As per an Act of State Govt. namely Non-Forest Tree Act of 2006, there are some restrictions on felling of trees in urban and rural areas. However, there is also a lot of relaxation in case of felling up to 3 trees in each case, by bonafide owners, and farm forestry spp. like Eucalyptus, Acacia spp. are exempted from certain provisions of the Act. The objective is to encourage people for planting trees, facilitate harvesting of trees on private land and also prevent large scale conversion of non-forest tree land by the timber mafia resulting into loss of green cover.

1.2.3 In West Bengal, diversion of Forest land is one of the minimum in the country. Most of the diversions, under FC Act, 1980 with prior approval of MoEF, are for infrastructure developments, like roads/ Rlys/ Electrification/ Water supply/ irrigation etc. benefitting the local people more than others. No subsidy on any forest produce is given to any industry. There is no case of mining on Forest land by industries without prior approval of MoEF under FC Act and as per order of Hon'ble Supreme Court of India.

1.2.4 People - forest interaction with regard to collection of Minor Forest Produce (now coined as Non-Timber Forest Products nationally) have been addressed in the Government Resolutions on JFM. However, The Government Resolution involves more of voluntary association, where forest officials play a major role, and does not have legal backing for the participating people. NTFP are not nationalized in the State. In West Bengal, in case of the NTFP like Sal Seeds and Kendu Leaves, monopoly rights of collection from the forest land have been given to the Large Sized Multipurpose Cooperative Societies (LAMPS) through West Bengal Tribal Development Cooperative Corporation (WBTDCC). Every year this Corporation deposits the Royalty at fixed rates to the Forest Department on behalf of the LAMP societies participating in the NTFP operations. Till December 2013, a total of 301 Community Forest Rights (CFR) under FRA 2006 have been claimed by the LAMPS. Whether benefits of the monopoly right reaches the tribal, who are the members of LAMPs can be evaluated better by Tribal Development department of the State. But, Forest department gets a very nominal Royalty towards these NTFPS from the WBTDCC.

1.2.4 Regarding the observations on JFM, a few studies have been conducted but none of them are comprehensive. With reference to the State of Forest Report, 2011, published by Forest Survey of India which has concluded that West Bengal is one of the few States in India which has reversed its earlier trend of forest degradation, and has effectively increased its forest cover over the recorded forest land. The W.B State Forest Report 2010, based on satellite imageries, shows that in state forest cover has increased from $13.4 \%$ in pre-1988 to more than $16 \%$ as in 2010 , primarily due to success of JFM. Reference may also be made to the Report titled "Joint Forest Management in West Bengal : A critique" prepared by Mr. P. Guhathakurta et al, and published by World Wide Fund for Nature - India in 2000, about the success of JFM in resuscitation of degraded forests of the State. However, after more than two decades of its initiation, present form of JFM has reached the crossroads and a more innovative mechanism of people's active participation and sustainable management of the CPR. Most of the JFM Committees have become controlled by a handful of villagers, who are either more concerned socially or are selfstyled village leaders. Micro-level planning in most JFMC areas have become confined to the small group of villagers and the field forest staff and the micro plans mostly overlook the real need and aspiration of the poorer section who are neither verbally nor socially vocal. The very objective of JFM, to empower the forest fringe villagers and transfer the management of the CPR to the community, has met a dead end. A time has come to explore the option of Community Forest Management (CFM) of the Forest land, without active control of Forest Department. We may start with a few Pilot Projects on CFM.

207|Page Land Governance Assessment Framework - West Bengal 
Some reasons could be cited for success of JFM in South Bengal:

a) Fast degradation of Protected Forests, mostly ex-zamindari forests which had vested in the State as per Estate Acquisition Act of 1953, by the forest fringe population for collection of fuel/ timber for their livelihood. Some of the rights of the fringe dwellers had not been settled, as required under Indian Forest Act, 1927, and the vested forests had stopped suo motu all the existing rights, resulting into forest-people conflict.

b) Success of fast growing Eucalyptus plantations, on degraded and blank forest patches raised under Social Forestry programmes, as alternate land-use options for the lateritic, non-irrigated, low-productivity private land in South west Bengal.

c) Distribution of large chunks of vested waste land, in these districts, to the landless families resulting into adoption of large-scale group Farm Forestry.

d) Incentives of sharing $25 \%$ of harvested forest produce (poles and not timber) with the JFMCs.

e) Breaking the barrier, between the forest fringe population and the foresters, through micro-planning under Joint Forest management.

The reasons for limited success of JFMCs in North Bengal are as follows:

a. Absence of conditions (i) to (iii) mentioned above

b. Most of the forests in North Bengal are Reserved Forests, as per IFA 1927, and pressure from the forest fringe population was marginal. Unlike in South Bengal, North Bengal forests have long-rotation crops, producing timber. Major theft of forest produce is by timber mafia.

c. Because of above facts, JFM never developed spontaneously in North Bengal, unlike in South Bengal, and Forest officials had to introduce the concept, to some extent mechanically, amongst the fringe people other than Forest villages.

d. Other stakeholders, i.e., Forest villagers were already allocated land, for habitation and cultivation, on lease-hold basis from the time of their settlement and also they were provided with other infrastructural support like village roads, irrigation facilities, houses, primary schools by the Forest Dept. with Central Govt. fund for Tribal development.

\subsection{Scheduled Tribe and Other Traditional Forest Dwellers (Recognition of Rights) Act, 2006}

The significance and fundamental contribution of the Act lies in its community orientation, going beyond the paradigm of individual rights not only in respect of community claims over its resources but also in overall procedure for recognizing forest rights even at the individual level. The Act is qualified with construction of a political community at least at the village level, where sole "responsibility and authority" has been given to the Gram Sabha to settle peoples livelihoods rights, ensure food security, sustainable use of resources as well as to protect forests and biodiversity to maintain an ecological balance for strengthening the conservation regime of the forests. But, unfortunately, the whole process of community building and community control has been diluted into a mere patta giving process (Sourish Jha, EPW, 14 August, 2010).

This Act brought another major change in the management of the State-owned forests. Historically, West Bengal had around 170 forest villages, with a registered population of 45000 (approx). These Forest Villages were established by the Forest Department, in the districts of Jalpaiguri and Darjeeling, in early $20^{\text {th }}$ century on forest land for the purpose of supply of labour for forestry activities. Each household was provided with 2/ 3 acres of forest land for building

208|Page Land Governance Assessment Framework - West Bengal 
their huts and for the purpose of cultivation, as their lease-hold rights. Forest Department also built up rudimentary infrastructural facilities, from time to time, through various schemes and Projects. All such bonafide forest villagers have been recognized under FRA and patta has been given to most of them as per the provisions of the Act.

In case of South Bengal, there was no such officially recognized Forest Villages. The applicants under the FRA were traditionally considered as individual encroachers of forest land and these cases are also mostly regularized in case of Bardhaman, Birbhum districts. In case of Paschim Medinipur, Bankura and Purulia districts, left-wing extremism problem in the past had slowed down the process of recognition of rights under FRA.

Another problem faced in the State is the settlement of Rights for the Other Traditional Forest Dwellers who are hardly able to provide proof/ documents in support of their claim for occupation for 75 years or more. Though some guidelines have been issued by the Ministry of Tribal Welfare, GOI in this regard, yet the problems persist in the field.

As per official records (Department of Backward Classes Welfare Department), around 1,34,000 applications for Individual Rights and another 3,100 applications for CFR rights were received by the Gram Sabhas in different blocks of 10 districts of the state. Till December 2013, total individual pattas issued are 31,000 and 312 cases of CFR rights were officially recognized and pattas were issued (source Department of Backward Classes Welfare, GoWB). Around 78,000 cases were rejected at FRC level. Applications for CFR mostly comprised cases of Playground, Burning ghats, Primary schools and the members of the community enjoying the benefits, had applied for the Rights. Pattas had been given to the community (comprising the listed members) for the specific benefits they had been enjoying earlier.

In most of the cases, the forest land, for which Rights were given, had been demarcated and the maps were enclosed along with patta documents. Backward Classes Welfare department had sanctioned purchase of 70 GPS for use by the field foresters to facilitate speedy demarcation of the land in question.

The question now remains how to provide food security to the patta holders of Forest Land under FRA, after ensuring their shelter security. Most of the patta lands in South Bengal are either agriculturally unproductive or unfit to sustain the livelihood of these beneficiaries under FRA. A mechanism has to be evolved to ensure holistic development of the tribal/ OTFD beneficiaries under the Act.

\section{Forest Rights Act and LAMPS}

1) The 70s saw the emergence of tribal co-operatives, 'Large Sized Multipurpose Cooperative Societies' (LAMPS). They owe their existence to a set of recommendation of a certain Committee (Bawa Committee) which sought to harness the co-operative spirit existent among the tribal in their development. It was also an effort to bolster the Tribal Sub Plan. Tribal Development Cooperative Corporations came into existence as apex society of these primary societies.

One of the main activities of LAMPS $s$ is collection of minor forest produce (MFP Operation) and as far as record goes the LAMPS in the districts of Purulia, Bankura and Paschim Medinipur (erstwhile Medinipur) collected kendu leaves right from the late 70s and early 80s. They also collected sal seeds in certain pockets, yet this aspect, fizzled out owing to a lack of organized market.

As per the Forest Rights Act 2006, community forest rights can be claimed in two forms, first as the right to live or rights of entitlements or uses as is incorporated in Sec 3 (1) of the Act and second as the right to protect, regenerate, conserve or manage any community forest resource which tribal people have been protecting or managing traditionally for sustainable use [Sec

209|Page Land Governance Assessment Framework - West Bengal 
3(1)(i)]. This right to Community Forest Resource is given under Form-C while community forest right patta is issued through Form B. Alongside under Sec 3(2) central government can allow diversion of forest land for infrastructure purpose involving felling of trees. An essential condition for this diversion is the recommendation of Gram Sabha and the quantum of such diversion should be less than one hectare in each case.

Under Community Forest Resource Rights the LAMPS feature actively as kendu leaf collectors are predominantly members of these co-operative societies, and they have traditionally been involved in collection, preservation and management of kendu leaves. Consequently the LAMPS being the collectors' co-operatives staked their claims for Community Forest Resource Rights under this act. In general members of around 25 LAMPS of Paschim Medinipur, Bankura and Purulia traditionally collect the Kendu leaves and they are in the process of staking their claim to the competent authorities. Till December 2013, 301 claims have been preferred by the LAMPS for sanction of this right. West Bengal is somewhat late starter here and only after the September 2013 round of meeting held by Ministry of Tribal Affairs, Government of India with the state governments in this regard the LAMPS stepped in. These claims of the LAMPS are in the process of being enquired into by the FRCs.

WBTDCCL has conducted three rounds of awareness meeting with the LAMPS in this regard.

2) It may also be recommended to the competent authority that the patta issued in regard to individual rights under FRA, should be issued compulsorily in names of wife and husband, with the name of the wife featuring in the patta ahead of that of husband. .

3) As mentioned above the amount of Royalty charged is minimal and charging Royalty by an agreement between Forest Dept. and Backward Classes Welfare Department is a policy matter of State government which could possibly be reviewed and the beneficiaries in that case will be the LAMPS, the collectors' cooperative.

\subsection{Critical issues}

2.2.1 In West Bengal, only pattas have been issued to the individuals under FRA, 2006. No action has yet been initiated, till date, to convert the Forest Villages in North Bengal into revenue villages. However, with amendment of Panchayat Act in the State, in 1990s, all the Forest Villages have been brought under the Panchayats and are eligible for receiving development funds like other revenue villages. The villagers are also part of Gram Sansads.

2.2.2 It is true that progress on issue of CFR in West Bengal leaves much to be desired, mainly due to following reasons, cited by the Forest officials:-

1) All the recorded Government Forest lands are now under Joint Forest Management, with participation of forest fringe dwellers. The villagers include ST/ SC as well as General category population, mostly dominated by SC and General Categories who may not qualify under FRA, 2006. Under JFM Resolutions in West Bengal, Community Rights as envisaged in Sec 3 (1)(c) of FRA, are already accorded to JFM Committees but these Rights are pre-conditional and are not of statutory nature. Since FRA 2006 over-rides all other previous Acts/ Rules/ Govt. Orders, (i) the JFM Resolutions of the State can be modified to make the JFM Committees co-terminus with Gram Sansads so that the Rights given under JFMCs have a legal backing and also covers the provisions under FRA, (ii) In Sec 2, a sub-section "(aa) community includes forest dwelling scheduled tribes, other traditional forest dwellers and any other community residing, along with the previous two categories and are an integral part of the Gram Sabha, in the fringes/ on the forest land" may be incorporated under FRA 2006.

210|Page Land Governance Assessment Framework - West Bengal 
2) If the qualifying community only gets the CFR right, then other category of population, who had also been enjoying rights of common property resources, through the Government Resolution on JFM/ Eco-development, will be deprived of their rights under FRA, 2006.

3) JFM in West Bengal is mostly apolitical in nature, and are conglomeration of fringe people irrespective of caste, creed, economic or social status. Implementation of CPR under FRA, 2006 may bring in social division amongst the villagers and will give rise to non-resolvable social conflict, ultimately threatening the JFM and leading to degradation of the Forest/ wildlife resources.

4) Undoubtedly, JFM till now had been able to restore most of the degraded forests in West Bengal. Any sudden change in the existing management practice should be looked into carefully.

2.2.3 However, the ground reality is that the feudal mentality of possessiveness is still present in the minds of a few foresters at every level, from the field staff to the senior managers. According to these people Right of ownership to forest fringe people are considered as synonymous to mismanagement and loss of forest cover. There is a strong need to bring about this change of attitude of those few foresters who do not believe in empowerment of people through well defined mechanism and training.

2.2.4 The perception of FRA 2006 at the forester's level is that the implementation of FRA is the primary responsibility of Tribal Affairs Department. Forest Department officials at field level, in general are apathetic towards providing maps/ documents/ evidences in support of the claims unless the same are specifically called for. Forest Rights Committees at the field level are not capable enough to handle the bureaucratic processes and unless the field level officials of line Government Departments take proactive action to provide evidences, it will be impossible for the FRCs to examine the applications in its right perspective. This may be one of the reasons for large scale rejection of applications and poor performance of distribution of Forest Rights under FRA 2006.

2.2.5 It may be mentioned that the State Government has initiated process of reviewing all rejected applications, at FRC levels, under FRA 2006 so that justifications are given for rejecting any application, both individual and Community rights.

2.2.6 In order to improve the scenario, there is a need to restructure the entire mechanism of JFM so as to make it compatible with the provisions of FRA 2006. The existing dual mechanism of empowerment only acts as counter-productive whereas their compatibility can be synergistic in effect. Changes in Forest Governance will definitely strengthen the basic objective of Forest conservation.

2.2.7 Regarding interpretation of the definition of Other Traditional Forest Dwellers (OTFD), Forest and other State Government officials are of the general opinion that Sec 2 (o) of FRA, 2006 clearly defines the status of OTFDs. Sec 4 (3) of the Act defines the eligibility of Rights of OTFDs under Sec 3(1)(a). If OTFDs have to be given benefits like FDSTs (defined under Sec 2(c)), then the Act needs to be amended. Forest officials are of opinion that the criteria of 75 years of residence in an area (not necessarily on the plot being claimed), and dependence on the forest land as of December 2005, and occupation does not have to be for 75 years, will only allow Right of ownership to those who had encroached Forest land between the enactment of Act and invitation of applications by the FRC under FRA. The Forest Officers, implementing the Act, do not desire to interpret the Act in violation of provisions of the Act passed by the Parliament. They feel that Ministry of Tribal Affairs should do the needful in this regard and the Act amended suitably to pass on similar benefits to the OTFD also.

211 Page Land Governance Assessment Framework - West Bengal 
2.3.1 Forest Development Agency: FDAs have been constituted in all the States, under the guidelines of Min of Environment \& Forests, GOI, for empowering the villagers in implementation of National Afforestation programme and other forestry development activities. However, in the absence of effective delegation, the FDAs remain mostly controlled by the Government and have degenerated into another quasi-government department. The present status is almost analogous to the failure of FDA mechanism. Moreover, the scheme could never really take off in full swing due to the erratic and late release of fund by GOI, leading to failure of time-bound works of afforestations. In order to make FDAs sustainable and functional, there is a need to (i) empower the villagers in technical and financial management of the afforestations/ rural development works, (ii) capacity building of forest officials and the members of JFMCs and (iii) timely release of fund to allow completion of time-bound afforesation works.

\subsubsection{Legal conflict}

There is as such no legal conflict between Forest Rights Act 2006, Wild Life Protection Act 1972 and Forest Conservation Act 1980 as the FRA 2006 over-rides other two Acts when in contradiction. However, the common belief in the minds of all foresters is that, according rights on forest land to an individual tantamount to loss of control on and lack of management of forest land leading to degradation and violation of FC Act/ WLP Act/ IF Act 1927 by the patta recipients under FRA. In practice, once the owner acquires the Right under FRA, Forest Dept. becomes oblivious of the management practices of the said Forest land. This may result into diversion of the forest land for some other purpose, sometimes taking advantage of simplicity of tribal/ backward population, since Forest Department in practice no longer remain the custodian of the land.

The solution will be to (i) make the forest officials involved in subsequent management of the land in question to ensure conservation of existing flora/ fauna and to develop the same, (ii) carry out intensive joint training of the staff of Forest deptt, Tribal Affairs Deptt and the civil administration for better understanding and implementation of FRA 2006.

However, the following suggestions are again re-iterated:-

1) Sec 2(a) of FRA 2006 defines the "Community Forest Resources" under the said Act. Also, Sec3(1)(c) to (d) of FRA explains the nature of Community Rights under the Act, which is of statutory nature.

Under JFM Resolutions in W.B, Community Rights as envisaged in Sec 3 (1)(c) of FRA, are already accorded to JFM Committees but these Rights are pre-conditional and are not of statutory nature. Since FRA 2006 over-rides all other previous Acts/ Rules/ Govt Orders, (i) the JFM Resolutions of the State can be modified to make the JFMCs coterminus with Gram Sansads so that the Rights given under JFMCs have a legal backing and also covers the provisions under FRA, (ii) In Sec 2, a sub-section "(aa) community includes forest dwelling scheduled tribes, other traditional forest dwellers and any other community residing, along with the previous two categories and are an integral part of the Gram Sabha, in the fringes/ on the forest land" may be incorporated under FRA 2006.

2) There is as such no legal conflict between FRA 2006, WLP Act 1972 and FC Act 1980 as the FRA 2006 over-rides other two Acts when in contradiction. However, the common belief in the minds of all foresters is that, according rights on forest land to an individual tantamount to loss of control on and lack of management of forest land leading to degradation and violation of FC Act/ WLP Act/ IF Act 1927 by the owners under FRA. In practice, once the owner acquires the Right under FRA, Forest or any other Deptt becomes oblivious of the management practices of the said Forest land. This may result into diversion of the forest land for some other purpose, sometimes taking advantage of

212 P a ge Land Governance Assessment Framework - West Bengal 
simplicity of tribal/ backward population, since Forest Department in practice no longer remain the custodian of the land.

The solution will be to (i) make the forest officials involved in subsequent management of the land in question to ensure conservation of existing flora/ fauna and to develop the same, (ii) carry out intensive joint training of the staff of Forest deptt, Tribal Affairs Deptt and the civil administration for better understanding and implementation of FRA 2006.

\subsection{Rural Land Use Regulations}

In West Bengal whoever holds land for any purpose whatsoever is called a raiyat. He is the owner of the land and his right is heritable and transferable. Before 1981 he could change the use of his land according to his choice. By an amendment of the West Bengal Land Reforms Act 1955 (hereafter WBLR) made in 1981 restrictions were imposed on the change of the use of land from its present position. The raiyat has been prohibited from making any change in the use of his land without the permission in writing from the competent authority. Detailed procedure for obtaining such permission as well as giving such permission has been provided in the WBLR Act, Rules framed thereunder and the West Bengal Land and Land Reforms Manual, 1991 embodying the policy of the Government.

The application for conversion must be made in prescribed form along with several documents such as - (1) a copy of the current record of rights which is not readily supplied in respect of lands in the adjacent villages of the city of Kolkata and other villages in and around the towns; (2) a copy of the current rent receipt; (3) a sketch map of the plot/plots of land with side measurement and surroundings including approach road; (4) an affidavit for creation of compensatory water-body if the land proposed to be converted includes any water-body of any size and description; (5) a no-objection certificate from the WB Pollution Control Board; (6) a copy of the detailed project report (DPR) duly vetted by the competent authority under the WB Town and country (Planning and Development) Act 1979; (7) and an undertaking by way of an affidavit as to various other obligations.

The authority dealing with an application for conversation has been asked to hold an enquiry to ascertain: (1) Whether the proposed conversion is likely to cause any inconvenience to the residents of the locality; (2) if the conversion will interfere with the normal agricultural activities in the surrounding area; (3) if the conversion will in any way hamper the public easement; (4) if the conversion will lead to eviction of a bargadar; (5) if the permission for conversion will in any way prejudice the application of the provision of WB Estates Acquisition Act,1953, Urban Land (Ceiling and Regulation) Act, 1976, WB Town and Country (Planning and Development) Act, 1979, East Kolkata Wetland (Conservation and Management) Act, 2006.

It has been mandated that the principal consideration should be whether the proposed change is likely to affect adversely the interest of any person or have deleterious effects on the environment. To clear this mandate an example has been given. If permission is given to convert an agricultural land for setting up an industry then the interests of the bargadar cultivating such land will be adversely affected.

It has been further mandated that the authority before granting permission for conversion must make a prior consultation in writing with the Fisheries Department and Environment Department for clearance.

Conversion of land without permission has been made a cognizable and non-bailable offence punishable with imprisonment up to three years or with fine up to Fifty thousand rupees or with both. Land is meant to be used for agricultural purposes only. Agricultural land should not be used for infrastructure, industry, or urbanization including real estate. This may be pointed out

$\mathbf{2 1 3}$ | Page Land Governance Assessment Framework - West Bengal 
that if provision for some water for irrigation is made, any piece of land in this state can be used for producing this or that crop.

To achieve this end of keeping land in its present use the applicant has been burdened with obtaining so many no-objection certificates from different authorities including the local people, the whole process has been made unnecessarily time-consuming, the authority who is none but the Collector or District Land and Land Reforms Officer if the area of the land proposed to be converted is more than one acre has been saddled with so many don'ts and left with no discretion to decide according to the merit of a case, and the penalty for conversion without permission has been made so harsh.

Before 1981 land under the WBLR Act meant agricultural land only and a raiyat meant a person or institution holding land for the purpose of agriculture. In the amendment of the Act made in 1981 in which the restrictions on the change of the use of land were brought into existence the definition of land was changed from agricultural land to land of every description and that of raiyat was changed from a person or institution holding land for agricultural purpose to holding land for any purpose whatsoever.

The logic behind these contradictory steps is this. The definitions of land and raiyat were made wider not for making more land available for various purposes but for bringing all kinds of land both agricultural and non-agricultural within the purview of ceiling limit. Hence, the restrictions on the change of the use were simultaneously introduced. Wider definitions of land and raiyat are good for taking away excess lands from the owners, but bad if they want to use their lands for purposes according to their choice. One may find similarity in logic with the approach of the confused intellectuals and activists to the doctrine of eminent domain. The power of eminent domain is good when it is exercised to abolish Zamindary and take away land held in excess of the ceiling limit. It is bad when it is exercised to acquire land held within the ceiling limit for infrastructure, industry and urban development.

\section{Panel 3: Urban Land Use, Planning and Development}

\section{Introduction}

For the first time in the history more than half of the world's population lives in urban areas. Between 2000 and 2030, in developing countries including India the urban population is expected to double. West Bengal is neither an exception from this trend and Census data confirms that since 2001 there has been a huge increase in urban centres across the Stateagainst a decline in the number of villages.

The decadal growth of urban population in West Bengal has been found to be a shade higher than the national average. While the national average is 31.16 per cent, the decadal growth rate in the State is 31.89 per cent.

A sharp rise of the number of 'census towns' since 2001 is a clear indication that people from rural backgrounds are increasingly discarding agriculture as a livelihood option and opting for more urban alternatives. A census town is defined as a semi-urban centre with a minimum population of 5,000 people, a population density of 400 persons per sq $\mathrm{km}$ and where over 75 per cent of the male population is engaged in non-agricultural activities. The number of such 'census towns' has gone up from 255 in 2001 to 780 in 2011 and the number of towns has increased from 378 to 909. Meanwhile, the number of villages has come down from 40,782 in 2001 to 40,203 in 2011.

214 I Page Land Governance Assessment Framework - West Bengal 
While the rural population has grown by only 7.73 per cent since 2001, the urban population has leapt up by 29.90 per cent in 10 years with each of the 19 districts showing a higher population growth in urban areas. Malda district has recorded the highest decadal growth rate in urban areas at 129.07 per cent and Howrah district has shown the lowest decadal growth rate in rural areas at (-)16.22 - both indicating cases of rapid urbanisation.

The problems faced by the urban areas seriously impeding the development agenda are manifold - scarcity of developed urban land, continuously accumulated backlog of housing, inadequate urban infrastructure and services to match the ever-growing demand, environmental degradation and alarming increase in the number of urban poor (urbanisation of poverty).

The $74^{\text {th }}$ Constitutional Amendment Act, 1992 and the flagship scheme of the central government, Jawharlal Nehru National Urban Renewal Mission (JNNURM) brought about much desired changes in the paradigm of thinking, functioning and implementing urban planning and development management process. As a result the planning processes are also undergoing changes where policy decisions are ought to be taken through greater participation of private sector, non-government organisations, and the civil society in which the marginalised and vulnerable poor are included. Under the provisions of $74^{\text {th }}$ Amendment, activities such as urban planning including town planning, regulations of land use and slum improvement and upgradation and provisions of basic services have been included in the list of municipal functions.

West Bengal has fully implemented the provisions of $74^{\text {th }}$ Amendment Act by ensuring decentralized approach to planning and development that would make urban local bodies responsible for all planning and development activities within the areas of their jurisdiction.

Land use planning is understood as a systematic and iterative procedure carried out in order to create an enabling environment for sustainable development of land resources to meet people's needs and demands. It assesses the physical, socio-economic, institutional and legal potentials and constraints with respect to optimal and sustainable use of natural resources and land and empowers people to make decision about how to allocate those resources. Another definition of 'land use planning' is the process of evaluating land and alternative patterns of land use and other physical, social and economic conditions for the purposes of selecting and adopting those kinds of land use and course of action best suited to achieve specified objectives. Land use planning may be at national, regional, state, district, watershed, city, village or other local levels.

We shall here discuss about the status of the land use plan of West Bengal in relation to the State's urban development policy. The 74th CAA,1992 provides for District Planning and Metropolitan Area Planning that consolidates plans of both panchayats and municipalities having regard to spatial (land use) planning. The district plan prepared currently, in general, do not cover spatial (land), environmental as well as other urban concerns.

In practice though, urban planning (includes land use plan) leaves much space for improvement. The causes for disconnect between regulations on paper and the reality on ground include accelerated urban growth and a absence of organic coordination between regional planning bodies with local ones to streamline uniformity in priorities and actions.

\section{Legal Framework}

In West Bengal, land use and development of lands is exercised under West Bengal Town and Country (Planning and Development) Act, 1979 in the urban areas. Under this Act, land use planning is mandatory to effectively control urban development in all the cities, areas under Development Authorities and Planning Areas formed by the State Government. Moreover,

215|Page Land Governance Assessment Framework - West Bengal 
under Sec 113 of the West Bengal Municipal Act, 1993(amended in 2007), it has become mandatory for all the municipalities to prepare land use plans while formulating development plans for the areas concerned. Under the WBT\&CP Act, 1979 Land Use Development Control Plans (LUDCP) are prepared for the planning areas. In the state of West Bengal, the municipal authorities have been empowered to regulate land use and construction of buildings. In section 63 of chapter VI ibid indicates the obligatory functions of the Municipalities. In sub section (3) of said section 63 , the matter has been dealt with elaborately. It is also worthy to mention that the municipal authorities in this state are empowered to regulate the building activities through an elaborate chapter XIV of the said act and the West Bengal Municipal (Building) Rules,2007 framed there under and to prepare detailed plan, inter alia, the land use plan under chapter XIX of the said act. It may also be mentioned that such power has been vested with the municipal authorities of this state much before enactment of the $74^{\text {th }}$ constitutional amendment Act.

\section{Criteria for land conversion}

Land use in West Bengal is characterised by its intensiveness, the challenge for land use planning is to achieve concurrently the objectives of protecting and consolidating agriculture, diversifying agricultural production and enhancing rural development and moving firmly towards industrialisation and infrastructure development. The policy must take into account the pressure for urbanisation and the developments of urban environments.

The main sources of new demand for land at present are industry, housing, urban spaces and infrastructure. The provision of land for each of these purposes will require the conversion of land from other uses. The factors to be considered when land is converted to any of these uses from other current use include the following:

1. The current use to which land is being put and the social costs of land conversion. Where land is agricultural, the factors to be considered are the number of crops grown on the land, irrigation facilities current levels of employment and income generation and the productive potential of land.

2. The impact of land conversion on the present users of the land, particularly when they belong to the working poor. Full and just compensation must be provided for any land that is converted to alternative purposes. This is a matter of the people's entitlement.

3. The benefits from the alternative uses to which the land will be put, particularly with regard to employment and income generation.

4. Environmental considerations, particularly with respect to fragile or endangered ecological zones.

5. Identify vacant land first. As stated, the Government has initiated action to create an inventory of land that is not currently in use

\section{Land Use Data Base}

A rational land use policy requires a modern and scientific data base. In particular, the new demands for land in different spheres of development have brought to the fore the need to reform and update the systems of land statistics in West Bengal. The State Government intends to revamp the statistical system with respect to land use and to undertake a three-pronged medium-term and short-term programme in this regard:

1. The Government will establish an information system on the land that is based on annual plot-by-plot verification of land tenure, land use, irrigation and cropping. It has been estimated that such a data base can be built over a period of five or six years, and the Government will organise the administration and the arrangements for a change over to such a system of consolidated land records in the near future.

216|Page Land Governance Assessment Framework - West Bengal 
2. Government has initiated a programme to create, in the short run, a land bank. All districts have been asked to provide information on vacant land in the districts at the disposal of government in the first instance and on significant and unused tracts of land in the private sector in the next instance. The objective of the State Government is that, in future, when land is required for industrialization, housing and infrastructural development the State Government be able to specify land identified through rational criteria as being available for industrialization.

3. The Government of West Bengal will begin an exercise to scientifically evaluate the demand for land in the State for different development activities. Evaluation will be made, in particular, of the demand for land for cultivation and related activity, urbanisation, housing, physical infrastructure, and industry for over a five-year and a ten year period.

\section{Background \& Best Practices}

During early eighties, it was felt by the government of West Bengal that the policy of decentralization of planning and development activities should be implemented through a decentralized institutional structure for the municipal governanceand the local bodies are to be given adequate power and responsibilities to deal with urban problems through legislative provisions. Some of the important measures which were taken in this regard are:-

- The West Bengal Urban Development Strategy committee was set-up in 1979 to critically look into the process of urban development in the state as a whole and to devise strategy for state-wide urban development.

- The Town and Country (Planning and Development) Act 1979 was enacted. Statutory obligations are to produce Existing Land Use maps and Registers (ELUMR) and land Use of Development Control Plans (LUDCP) for the areas under the jurisdiction of Calcutta Metropolitan Development Authority (CMDA).

- The first Municipal Finance Commission was set up in 1979 in the state.

- A Central Valuation Board was set up to overcome the deficiency of under valuation of properties in the municipal areas in 1979 through an Act. Municipal Corporation Acts were enacted since 1980 for Calcutta, Howrah, Assansol, Siliguri and Chandernagore. These New Acts provided for a cabinet form of local government for civic administration, with a Mayor-in-Council set up.

- The Bengal Municipal Act of 1932 was substantially amended and the new W.B. Municipal Act 1993 was enacted for cabinet system of government in the manner of Chairman -in Council set up.

- In the $1990 \mathrm{~s}$, in view of the $73^{\text {rd }}$ and $74^{\text {th }}$ Amendments of the constitution of India, two more Acts, namely, W.B. District Planning Committee Act 1994, and W.B. Metropolitan Planning Committee Act 1994 along with the W.B. District Planning Committee Rules 1994 came into force for the purpose of decentralized spatial and socio-economic Planning in the state.

This apart, to cope with urban growth, several steps have been taken by the Government through a process of urban planning by creating Development Authorities and planning areas. There are as many as 10 such Development Authorities and planning Areas in the state where the planning process is able to cope with the urban growth. The old municipal cities are also into such process after the preparation of Development plans has been made mandatory under law.

Draft Development Plans and stakeholders' participation

217| Page Land Governance Assessment Framework - West Bengal 
The scenario changed when the state government took the initiative of introducing the Kolkata Urban Services for the Poor (KUSP), a multi-sector urban reforms programme by creating Change Management Unit with DFID funding. Targeted towards 40 Urban Local Bodies in Kolkata Metropolitan Area, some of the key objectives of this programme were:

- Improved urban planning and governance

- Enhanced access of basic urban services to the poor and

- Promoting pro poor economic growth

It was decided that the Municipal Affairs Department would be in the lead and other organizations would provide support at various levels of operation viz.;

- Directorate of Local Bodies(DLB)

- State Urban Development Agency(SUDA)

- Kolkata Metropolitan Development Authority (KMDA)

- West Bengal Valuation Board (WBVB)

- Municipal Engineering Directorate (MED) and

- Institute of Local Government and Urban Studies(ILGUS)

Draft development plan (DDP) preparation became mandatory function of the ULBs as per the Act (WB Municipal Act 1993 amended during 1998-2007). CMU initiated DDP preparation for 40 ULBs under KUSP in July 2005. Subsequently, this programme was rolled out to 126 Municipalities in the state of West Bengal. The common guidelines for DDP development mentions about two important groups to be constituted with a view to ensuring stakeholders' participation.

- DDP Policy Group (DPG) - the DPG will provide policy guidance and strategic support for preparation and implementation of the DDP and will also coordinate with higher levels of the government. Elected decision makers and in some cases nominated members are included in the DPG

- DDP Technical Group (DTG) - will be responsible for preparing the project proposals and plans for each of the sub-component of the DDP, with overall guidance from DPG. The members of DTG are urban planners, engineers, community development experts, executive officer etc., depending on the DTG category.

To ensure participation and consultation/ inputs from widest possible range of stakeholders, ward committees, neighborhood groups (NHG), and community development societies (CDS) are involved in the process of DDP preparation.

One of the important features of DDP process is to ensure all possible attempts being taken for assessment of socio-economic needs including housing needs of the poorest and most disadvantaged living in formal and informal settlements. A transparent process is recommended to be maintained for prioritizing the issues in DDP.

Land use plan and development is covered under component I of the DDP along with slum infrastructure, intra and trans-municipal infrastructure and environment development. A study conducted on 'West Bengal experience of DDP preparation' by the Administrative Training Institute (by Uttam Kr. Roy and Madhubanti Ganguly) in 2009 covering 14 municipal towns covered under KUSP reveals that DTG was asked to frame the land use development plan in three subthemes:

1. Making land available

2. Development of municipal owned land

3. Regulatory controls on development of area under jurisdiction of ULBs

218| Page Land Governance Assessment Framework- West Bengal 
Excerpts from the study - The study also mentions that involvement of public and other stakeholders was made for a) problem identification b) prioritization and c) validation of the plans. 50\% of all ULBs did study the existing situation on the basis of Urban Development Plan Formulation and Implementation guidelines (1996) which was developed by the Ministry of Urban Development for assisting the policy makers, administrators and urban planners to align the future needs of the ever growing population with planned urbanization. It appeared that the issues related to immediate need of the people were addressed better. For example existing issues like encroachment, lack of open green space etc. were given priority and land issues were identified almost by all cases. Further, the prioritization of projects identified by public has been done in an open and participatory method by all ULBs. Whereas the expected plan outcome like innovative land assembly system, development control plan, future growth \& land use plan have not emerged. Only 20-4O\% ULBs (2 to 5) have come up with identified public land, land assembly procedure, development controls/strategy etc. No single ULB has come up with a future spatial land use plan. Land acquisition and purchase has been the only mode of land assembly for only three ULBs. No ULB took any area development projects for future residential growth. Fragmented small scale projects like beautification of parks, creation of market complex, ward office or health centre remained as majority. Five ULBs mentioned or undertook projects on LUDCP enforcement of local revisions. Interestingly, it was found that the ULBs who got additional advisory or support from university or institute could address more parameters under the study.

It has been found that, in general, that outcome like 'existing issues', 'priority projects' have been better from the bottom up approach of planning. However more proactive planning objectives could not be fulfilled by adopting bottom up approach. Those are best suited for top down or conventional approach.

By now most of the ULBs have completed first generation DDP. Review of the plans produced in a participatory approach has been done. This has helped the ULBs in enhancing their capacity. This process had also a component called 'Organizational Development' which again has taught the ULBs the concept of 'Citizens Charter'. Introduction of Citizens Charter enabled the ULBs to make commitment to the citizens for service delivery while DDP was prepared based on public input. But despite such best practices and a background of quite a few positive initiatives, implementation is still hindered for lack of constant monitoring, political will and proper coordination among the departments. The following paragraph would speak of the barriers to implementing several Acts especially the land use plan.

\section{Barriers to implementation (urban land use planning)}

While there is adequate legal framework (WBT\&CP Act, 1979, West Bengal Municipal Act, 1993, amended in 2007) for implementing land use plans in the overall planning process in urban areas, it has been observed during last two decades that there are several barriers to such implementations. The barriers or constraints as envisaged are enumerated below.

- Capacity gap - planned development in cities need smart urban and regional land use planning. The $12^{\text {th }}$ Five Year Plan approach paper has identified the capacity gap in this area as a major constraint. Shortage of staff, especially technically qualified personnel is a real barrier to urban (land use) planning. Dedicated urban planning technical cadres should be created, with more Schools of Planning and Urban Management Programmes are the need of hours

- Institutional barriers - at the state level better convergence should be sought as envisaged in the $74^{\text {th }}$ CAA between the state, district level and metropolitan planning (KMDA and alike)

- Financial barriers - to bridge the gap in financing land development and infrastructure projects. In order to improve financial health of the ULBs, GIS based land records to be

219| Page Land Governance Assessment Framework - West Bengal 
prepared to update the property taxation mechanism as per the mandatory reforms agenda of JNNURM.

- Political and cultural barriers, and in particular opposition from those who are adversely affected. There is lack of adequate policy framing to address these issues. These involve lack of political or public acceptance of an instrument, restrictions imposed by pressure groups and cultural attributes such as attitude to enforcement, which influence the effectiveness of instruments.

- Data and information barrier - creation of GIS and MIS based information database for all the ULBs in the state is the most important step to be taken to enable bridging information gap to support developmental practices

Proper GIS database provides crucial planning input for infrastructure planning, land use planning, environment planning, slum development planning, local economic development, livelihood support and planning related to health and education. GIS database provides invaluable inputs not only for planning of infrastructure, like road, sewerage and drinking water, but also helps manage important services to various stakeholders. All these planning components are interlinked with each other. Moreover, the whole municipal planning is related with the regional planning and the planning of neighboring municipalities. It is possible to integrate slum development plan with infrastructure development as well as the local economic development plan. In a democratic setup, this GIS framework simultaneously provides transparency to the elected representatives who run the municipalities and to the stakeholders.

Another very important area is disaster management where the DDP planning process till now failed to utilize GIS although in DDP programme the planning related to disaster management is clearly specified (Reference - 'Application of GIS in urban development plan' by Sujit Chowdhury).There are though a few ULBs which have adopted this technology to develop modern and updated plans with difference and better practical, priority options for implementation.

However, during last six to seven years signs of improvement have been observed in preparations of Urban Policies to address these issues of constraints. Now, under Sec 29 and Sec 36 of the WBT\&CP Act 1979, and under Sec 113 of the West Bengal Municipal Act, 1993(Amended in 2007), land use plans and changes in those plans are based on public inputs through a process of consultation with the civil societies and marginalised sections of urban areas. To implement land use plans in the state with right earnest, other than what have been stated above, three types of integration are needed.

- Horizontal: between sectors within an authority.

- Spatial: between adjacent authorities.

- Vertical: between tiers of Government.

This suggested integration would not only help in implementing land use plans in the state, but also the overall planning process for which the capacity building of the stakeholders has been initiated properly. Providing municipal services and proper implementation of development plans (which are already there) would help the urban local bodies achieving amore citizenfriendly governance along with improved spatial planning for land use and development.

\section{Security of tenure to urban poor}

The UN-HABITAT generalises the most common tenure systems which include freehold leases, provisional or conditional tenure and group tenure arrangements. Further importance is given to security of tenure by including as one of the objectives of JNNURM. In West Bengal no policy has yet been framed to ensure security of tenures to informal section who are residing forcibly on private land or unauthorizedly on government land in cities and towns. Those who are

220|Page Land Governance Assessment Framework - West Bengal 
residing in slums or bustees within the first 100 wards of KMC and beyond are bharatias whose rights are protected under the Perimeses Tenabcy Act, 1997.

It was proposed in the KUSP preparatory studies that the respective ULBs should take the lead role in improving tenure security of the poor.

The survey (urban statistics and HR assessment survey - USHA) facilitated by State Urban Development Agency (SUDA) has been completed in the KMA area, a brief look at the result of the survey indicates that covering 41 ULBs within KMA area (excluding Kolkata Municipal Corporation), total number of slum households surveyed is 551,501 and the population is 23,40,440 (data source SUDA, survey has been conducted taking into account the 'whole slum' where other infrastructures have not been provided as yet).

\section{Housing coverage under JNNURM}

So far 1,58,00o dwelling units under BSUP has been sanctioned, out of which 89,000 units' construction has been completed. Under IHSDP, 52,000 dwelling units have been sanctioned so far (for other than KMA area), out of which 43,000 are completed.

\section{Conclusion}

It is reassuring to note that under RAY, a state level sanctioning and monitoring committee has been set up under the chairmanship of the Hon'ble Chief Minister. This committee is seriously considering providing property rights in the form of lease to the beneficiaries in the slums.

It may be mentioned here that West Bengal under the mandatory reforms agenda committed for leveraging JNNURM resources, has shown remarkable progress and touched upon the benchmarks set by the reforms issues within stipulated seven years since 2005. The coverage of property tax has been 95\% during the financial year 2012-13 for all 128 ULBs of the state including KMC. As per the $12^{\text {th }}$ Schedule of $74^{\text {th }}$ CAA decentralization of all departmental functions excluding fire services have now been transferred to the ULBs by state government. Enactment of Right to Public Service Act, 2013, has enabled the ULBs to deliver more citizenfriendly services in a time-bound manner. This committed legislation and initiative has replaced the early practice of citizen's charter.

\section{Panel 4: Management of Public Land}

Public land in broad sense means lands held by different departments of both the Central and State Governments, such as the Railways, the Defence, the Irrigation Department, Public Works Department, the Forests Department, local bodies etc. The land held by the West Bengal Industrial Infrastructure Development Corporation and the government undertakings is also public land. However, lands held by these departments were generally acquired under different land acquisition Acts on the requisition of the respective department, to be used for specific purposes and handed over to them to use the land for the purpose for which such lands were acquired. Such lands are managed by the departments according to the policies adopted by them.

However, what by "public land" is specifically meant in this state is the land referred to under chapter VIII of the WBLR Act 1955- land which is at the disposal of the state government. The principles of distribution of such lands have been dealt with under section 49 of the LR act read with Rule 20A of the WBLR Rules 1965 and the WBLR Manual 1991.

Chapter VIII of the West Bengal Land Reforms Act, 1955 deals with the Management of Lands. Section 52(2) of the Act and Rule 28A of the W. B. Land Reforms Rules, 1965 states that any

221| Page Land Governance Assessment Framework - West Bengal 
land belonging to the state or land which is at the disposal of the state government or held under the state by virtue of the WBEA Act and WBLR Act, and all interests therein belonging to the state government shall be managed in such manner as may be prescribed by the Collector of the concerned district. As regards government lands management is entrusted to different departments who require land for their activities. Management of land entails such activities as protection of land from encroachment, removal of encroachment, if any, settlement / leasing out of land. There is specific division of functions and responsibilities in regard to management of land among the different levels of hierarchy. While specifying the responsibilities the principle of "subsidiarity" is strictly adhered to. As regards lands belonging to municipalities and the public institutions those are managed in the same way as government lands.

The state of West Bengal is the absolute owner of all lands lying within its geographical boundaries. Having regard to their use and potential these lands have been divided into various categories. All these categories have been clubbed and brought within the ambit of the amended definition of "land" [sec 2(7), WBLR]. From the management point of view these lands may be broadly divided into the following two categories:

(1) Lands in the domain of the state i.e. lands retained by the state in its own possession now described as land at the disposal of the State Government.

(2) Lands settled with individuals or institutions known as tenanted lands.

In respect of lands at its disposal the government's role is that of a manager. As regards tenanted lands, it acts as a regulator.

\section{Management, administration etc. of khas lands: Role of L\&LR Department}

The L and LR department is the custodian of all lands and is the nodal department in respect of matters relating to land. It only acts as a coordinator among the various departments and has no supervisory power. This dispensation facilitates good land governance. Its main functions, inter alia, are:

(i) formulation of policy regarding land management

(ii) settlement of land by way of implementation of land reforms [ sec 49(1), WBLR]

(iii) settlement of lands of non-agricultural character to individuals and institutions [ rules 215 onwards, W.B. Land and Land Reforms Manual, 1991]

(iv) Prevention and removal of encroachment on its own lands

(v) Transfer of lands to other departments and to act as a coordinator among those departments.

(vi) Land Acquisition

[The list is illustrative, not exhaustive]

\section{Other Government departments}

Almost all departments have some lands at their disposal. Those departments are required to manage those lands. Some departments, however, have significant roles to play for management of the lands at their disposal. A few of those departments are listed below with a brief narration of their functions:

\begin{tabular}{|l|l|l|}
\hline Department & & \multicolumn{1}{c|}{ Purpose of Land Use } \\
\hline Forest department & $:$ & $\begin{array}{l}\text { Afforestation and tree planting, including forest } \\
\text { cover, issue of pattas to eligible forest dwellers } \\
\text { under Forest Rights Act, 2006. }\end{array}$ \\
\hline
\end{tabular}

222|Page Land Governance Assessment Framework - West Bengal 


\begin{tabular}{|l|l|l|}
\hline Fishery department & $:$ & $\begin{array}{l}\text { Pisciculture, leasing out water bodies to } \\
\text { Fishermen's Co-operatives, development of } \\
\text { water areas for the purpose of pisiculture. }\end{array}$ \\
\hline $\begin{array}{l}\text { Irrigation and Waterways } \\
\text { department }\end{array}$ & $:$ & $\begin{array}{l}\text { Putting up embankments on river banks, } \\
\text { leasing out water areas for short periods. }\end{array}$ \\
\hline Public Works department & $:$ & $\begin{array}{l}\text { Issuing short term leases in respect of roadside } \\
\text { lands }\end{array}$ \\
\hline $\begin{array}{l}\text { Commerce and Industries } \\
\text { Department }\end{array}$ & $:$ & $\begin{array}{l}\text { Issue of license for industrial activities, } \\
\text { providing infrastructure for planned } \\
\text { development }\end{array}$ \\
\hline
\end{tabular}

The land use pattern of West Bengal is shown below:

\begin{tabular}{|l|l|l|}
\hline \multicolumn{1}{|c|}{ Land Use } & \multicolumn{1}{c|}{$\begin{array}{c}\text { Area (in thousands) } \\
\text { (ha) }\end{array}$} & Percentage \\
\hline Total geographical area & 8875 & NA \\
\hline Reporting area for land utilization & 8684 & 100.00 \\
\hline Forests & 1174 & 13.52 \\
\hline Not available for cultivation & 1814 & 20.89 \\
\hline $\begin{array}{l}\text { Permanent pastures and other grazing } \\
\text { lands }\end{array}$ & 7 & 0.08 \\
\hline Land under misc. tree crops and groves & 55 & 0.63 \\
\hline Culturable wasteland & 32 & 0.37 \\
\hline Fallow lands other than current fallows & 22 & 0.25 \\
\hline Current fallows & 287 & 3.30 \\
\hline Net area sown & 5294 & 60.96 \\
\hline
\end{tabular}

Source: India State of Forest Report, 2011

Till December, 2013, vesting of land under different Acts:
1. WBEA Act :
$26,48,250.86$ acres
2. WBLR Act :
$3,50,990.16$ acres
3. Total vesting till date:
29,99,241.02 acres

Source: Director of Land Records \& Surveys

Settlement of agricultural land at the disposal of government

Agricultural lands at the disposal of the government are settled under the provisions of subsections (1) of Section 49 of the W. B. LR Act, 1955 read with Rule 20A of W. B. LR Rules, 1965. Lands at the disposal of the government include the following:

a) Agricultural khas mahal lands;

b) Agricultural lands vested under the provisions of the WBEA Act;

c) Agricultural lands vested under the provisions of WNLR Act; and

d) Agricultural land owned by the government by any other means, e.g., acquired and relinquished land not taken over by ex-owner

Such agricultural land settlement by way of distribution has to be made to persons living within the vicinity of the lands who want to cultivate the lands personally or who want to construct

223 Page Land Governance Assessment Framework - West Bengal 
dwelling house thereon. Distribution is to be made to a person who together with the members of his family owns no land or owns less than one acre of land. In case of a bargadar, half of the land cultivated by him as a bargadar has to be taken into account in computing the area to be distributed to him. For homestead purpose the quantum of land to be distributed to a person shall not exceed 0.08 acre. For such distribution no premium is charged and the person is not required to pay any revenue for the land, but liable to pay cess assessed. The related statistics* (till December 2013):
a. Total agricultural land available for distribution -
$12,14,770.62$ acres
b. Total agricultural land distributed [U/s 49 (1)] -
$10,50,984.71$ acres
c. Transferred to other departments (including panchayats)
d. Land recorded in the name of bargadar $[\mathrm{u} / \mathrm{s} 14 \mathrm{~S}(3)]-$
- 85,280.41 acres
e. Total non-agricultural land distributed -
2088.03 acres
$55,752.12$ acres

*Source: Director of Land Records \& Surveys (DLRS)

Land at the disposal of government can be settled with a local body or an authority constituted or established by or under any law. Settlement for public purpose or for establishment, maintenance of preservation of any educational or research institution or industry can be made with any person or institution on terms and conditions as may be decided by the government.

\section{Settlement of non-agricultural land at the disposal of government}

Settlement of land for non-agricultural purpose is governed by Section 49 (5) read with Rule 20A (6) of the W.B. LR Rules, 1965. The Collector of the concerned district is authorised, with prior approval of the L\&LR Department, to settle a land of any classification or description which is at the disposal of the state government. Settlement may take place with a person, a group of persons, an organisation or a statutory body on such terms and conditions as may be specified by the department. Some statistics*:
a. Net non-agricultural land vested
$6,43,771.48$ acres
b. Non-agricultural land distributed
$55,752.12$ acres
c. Area found fit for agriculture purpose
$73,250.31$ acres
d. Area found fit for farm forestry
25,368.04 acres
e. Area transferred to other departments
47,394.92 acres
f. Area settled as long-term lease
6299.63 acres
g. Area comprising sairati interest
29,232.90 acres
h. Area comprising village road/ public road
$56,997.53$ acres
i. Area kept for development purpose
4570.14 acres

\section{${ }^{*}$ Source: Director of Land Records \& Surveys (DLRS)}

Lands for non-agricultural purposes are ordinarily settled by the Collector with prior sanction of the L\&LR Department on long-term leases, except when long-term settlement is not possible for any reason, the land may be settled on a short-term lease. Short-term lease is prohibited for land in urban agglomerations, to which the Urban Land (Ceiling and Regulation) Act, 1976 is applicable. The long-term settlement shall ordinarily be for a period of 30 years and on expiration of the period the tenant is entitled for successive renewals of the lease for the same period. In giving long-term lease for the first time the rent shall be fixed at $4 \%$ of the market value of the land proposed for settlement and salami charged at 10 times the rent equalling to $40 \%$ of market price. The L\&LR Department may reduce the rent and salami for a land if it is satisfied that the land will be used for public or charitable purpose. For extended lease period of 99 years, the rent shall be fixed at $0.3 \%$ of the market value and salami at $95 \%$ of the market value. For the period covering financial years 2008-09 to 2010-11, a total of 2193.85 acres of

224|Page Land Governance Assessment Framework- West Bengal 
non-agricultural land has been settled on long-term lease at a total amount of Rs. $185 \cdot 31$ crores including rent and salami.

Settlement of sairati interest -

a. Ferries - only vested and khasmahal ferries which are not declared as public ferries under the Bengal Ferries Act, 1885, are settled on public auction by the DL\&LROs. They are empowered to accord sanction to the settlement of ferries with a revenue not exceeding Rs. 10,000/-. The Divisional Commissioner is empowered to confirm settlement with a revenue not exceeding Rs. 50,000/-. For settlement of ferry with revenue exceeding Rs. 50,000/-, the department of L\&LR is empowered to confirm.

b. Fisheries- are settled for a period not exceeding seven years. $25 \%$ of the average of the net income of the concerned fishery for preceding three years is charged as economic rent of the fishery. The DL\&LRO is empowered to confirm settlement of fishery at rent not exceeding Rs. 2500/-. The Divisional Commissioner is empowered to confirm settlement at rent not exceeding Rs. 20,000/- beyond which the L\&LR Department is empowered to confirm settlement.

c. Part-vested tank - if less than 50\% of a part vested tank is vested then the vested portion is settled with private co-sharer(s) for a period of 30 years for salami and rent as in the case of settlement of non-agricultural land on long-term lease. If more than $50 \%$ of a part-vested tank is vested then the tank shall not be settled with the private co-sharers. The private co-sharers shall form a Fish Production Group with suitable number of fishermen, and if local fishermen are not available, with local unemployed youths selected from out of the families living below poverty line and take settlement for a period not exceeding seven years.

$\underline{\text { Land Acquisition }}$

\section{Conceptual and Legal Issues}

Land acquisition in the country in the present legal system has its basis in the Doctrine of Eminent Domain of the State, which in simple terms means the sovereign power of the state to acquire subject's property without its consent for purposes of public purpose. The principle underlying appropriation by State of Private Property is that the appropriation must be for 'public utility' or 'public purpose' as it is called in India. Land acquisition in India since independence was executed in terms of Land Acquisition Act of 1894 and other Acts made by different state governments to acquire land for specific purposes. It is only with effect from $1^{\text {st }}$ January 2014 that the central Act, the LA Act of 1894 has been replaced by a new Act. So it is the Land Acquisition Act of 1894 (henceforth 1894 Act) is the basis of any discussion on land acquisition. Since land belongs to concurrent list different states have made amendments to 1894 Act to serve state specific purposes.

The Preamble of the Land Acquisition Act of 1894 explains the reason which led to its enactment, "for the acquisition of land needed for public purposes and for companies and for determining the amount of compensation to be made on account of such acquisition". The word 'acquisition' means and includes acquisition of all rights and interests of a tenant in a particular piece of land by paying fair value or compensation. Under Article 298(i) of the Constitution of India, the executive power to acquire land for the purposes of a state rests with the state government concerned, while power to acquire land for the purposes of the Union has been vested in the central government. The Constitution of India contains articles 31 (omitted in 1978), 31A,31B, 31C and 300A (from 1978) and provides for compulsory acquisition of land. However, the second proviso to Article 31A clearly lays down that for acquisition of land being held in excess of the ceiling limit prescribed in any Act compensation need not be paid at the market value, but for acquisition of land held within the ceiling limit compensation shall not be less than the market value.

225|Page Land Governance Assessment Framework - West Bengal 
For setting up of industry or infrastructure facilities land acquisition is inevitable. In a state like West Bengal there are hardly available large holdings of land under direct government control or even if available, are available in places which are not endowed with infrastructure facilities. Infrastructure facilities are available in the areas where land holdings are in private hands, mostly for agricultural activities. During post independent period a number of Acts were passed to supplement 1894 Act with the specific purpose of land acquisition in particular context. These are (a) West Bengal land (Requisition and acquisition) Act, 1948, (b) the West Bengal Land Development and Planning Act 1948, (c) Calcutta Municipal Act 1951, (d) Calcutta Municipal Corporation Act 1980 (for acquisition of land and building), (e)The West Bengal Industrial Infrastructure Development Corporation Act 1974 (for acquisition of land for the purpose of state govt. undertakings), (f) West Bengal Acquisition and Settlement of Homestead Land Act 1969, (g) West Bengal Acquisition of Homestead Land for Agriculture Lobourers, Artisans and Fishermen Act 1975 (for acquisition of land for various public purposes). An amendment to 1894 Act provision was made for giving compensation to the bragadars in addition to land owners.

The 1894 Act has survived the test of time for its superiority in many respects compared to other Acts even though those were passed in the post-independence period. For example the Act (a) listed is more draconian than 1894 Act for it applies to acquisition for any purpose (not public purpose), does not have provision for prior notice or raising any objection or representation; land can be acquired just by passing an office order. It is after several admonitions by the Supreme Court that the Act was not further extended. Act (b) was meant specifically for the rehabilitation of the displaced people of the erstwhile East Pakistan and was used to acquire small quantum of land against meager compensation.

The 1894 Act has well laid out principles, from notification well ahead of actual acquisition, compensation criteria etc. However, compensation is calculated on the basis of market price which is calculated on the basis of the transactions during preceding 12 or even 36 months that took place in the nearby moujas (revenue villages). Here market price means price at which sale deed is registered in the office of local registrar. From a set of prices (remember land is not a product for which there is unique price) obtained from the office of the registrar the very high or very low prices are excluded as they might be outliers, then an average price is calculated on the basis of the rest. The Act also requires notification about acquisition well ahead in time; the Act has provisions for raising objections by potential land losers which has to be heard by competent authority and people can make representations. However, this has remained a source of controversy even if all procedures have been fully followed possibly because land acquisition is considered to be interference in individual's choice.

To make large quantum of land available within shortest possible time and to expedite the disposal of land acquisition cases efficiently, the state government issued order No. 1701-LA3M-07/o6 Kolkata the $6^{\text {th. }}$ June, 2006, and overruled West Bengal Land Acquisition Manual, 1991 and previous executive orders. The order specifies land acquisition is justified on the ground of public purpose even if government contribution for the project is just Re. One. This clause of 'public purpose' has often been subjected to close scrutiny and explanation when land is acquired by government and subsequently transferred to private sector for setting up of industry. Some noteworthy features of the order:

- Consent awards system introduced and thereby reducing one-sided authoritarianism of the state machinery

- Collectors empowered financially and administratively

- Formal introduction of bare minimum Resettlement packages to the BPL families evicted on account of compulsory acquisition

- Patta-allottees to get full compensation like a free hold rayat

- Rescheduling time table for acquisition and payment of compensation

226|Page Land Governance Assessment Framework - West Bengal 
By leveraging the public purpose clause of the 1894 Act, the state government before in recent times acquired land for West Bengal Industrial Development Corporation (WBIDC), a public sector organization, to be subsequently transferred to private industrial house. The "public purpose' clause makes land acquisition easier for the government. Hence from the time of Singur land acquisition the Government of West Bengal under the left Rule first introduced the practice of acquiring land under the aegis of WBIDC and then transferring the same land to private sector. At the same time new practices were also introduced for compensation and Rehabilitation and Resettlement Scheme. But the outcome has not been desirable. Subsequently after the new Government came to power in the state the state government clearly states that the government shall not forcibly acquire land.

In December 2012, the Government of West Bengal declared a comprehensive 'land allotment policy' applicable for land owned or held by any department or agency funded by the government. The L\&LR Department is the nodal department for inter-departmental transfer of land or long-term lease of vested/ khas land. Market value of land to be settled on long-term lease would be based on the sale deeds of the area or the market price as determined by the Inspector General of Registration, whichever is higher.

The policy states that land meant for commercial use shall invariably be auctioned to the highest bidder. To reduce discretion and ensure transparency wide publicity including website publication for such bidding is done and no reserve price prior to bidding is fixed. For projects leading to industrial development, the highest price need not be the criteria nor should auction be the only mode of allotment. The policy states that the department shall prepare and publish a list of its own land assets with possible indication on what kind of industrial development along with the tentative price to be determined on the basis of acquisition price, cost of capital, development charges and premium as applicable.

Auction will not be required for construction of housing for poor, economically weaker sections and low income group people through developers.

Land and Land Reforms Department is mandated under Rules of Business of the State Government to manage the Government land. But once the department has transferred/ settled government land with different departments, the responsibility to manage those land vests with them. Unfortunately most of land held by the departments is not recorded in the record of rights of land. 


\section{Background:}

Land attains its significance as a factor of production unlike capital in the sense that land supply cannot be increased either in the short or long run. The area of the state of West Bengal is 88,752 sq. Km with a population density of 1029 per sq. Km (Census 2011) which is the second highest in the country. Land use statistics in West Bengal at the Block and higher administrative levels are available by the standard nine-fold classification. Total reported area under different categories in 2003-04 was 9.69 million hectares.

The main features of the data given in figure below can be summarised as:

1. Net sown area (or area actually under cultivation) share is shown as $63 \%$, the corresponding figure for India was $46 \%$

2. The share of fallow land, unculturable land and pastures in West Bengal is very low. It is noteworthy that in four categories of land use - fallow other than current fallows, culturable waste land, permanent pasture and other grazing land, and barren and unculturable land combined together constitute $1 \%$ of the total land (corresponding figure for India is $17.6 \%$ )

3. Fallows and unculturable land in the state are concentrated in specific regions of the state. The district level analysis shows that much of the barren and uncultivable land, culturable waste land and fallows other than current fallow are concentrated in six districts (five Western districts, Bankura, Purulia, Birbhum, Paschim Medinipore, Bardhaman and Northern district of Darjeeling).

4. The area under forest is limited and concentrated regionally. Forests are concentrated in Western districts of Paschim Medinipore, Purulia and Bankura, in the estuarine areas of South 24 Parganas and in the Himalayan regions of Darjeeling and Jalpaiguri.

Table 1: Land according to use (,ooo ha)

\begin{tabular}{|c|l|c|c|c|}
\hline Sl. No. & Classification & $2008-09$ & $2009-10$ & $2010-11$ \\
\hline 1 & Net sown area & $\begin{array}{c}5294 \\
(61.0)\end{array}$ & $\begin{array}{c}5256 \\
(60.5)\end{array}$ & $\begin{array}{c}4991 \\
(57.5)\end{array}$ \\
\hline 2 & Current fallows & 287 & 323 & 574 \\
& & $(3.3)$ & $(3.7)$ & $(6.6)$ \\
\hline 3 & Forests & 1174 & 1174 & 1174 \\
& & $(13.5)$ & $(13.5)$ & $(13.5)$ \\
\hline 4 & Not available for & 1793 & 1820 & 1840 \\
& cultivation & $(20.6)$ & $(21.0)$ & $(21.4)$ \\
\hline 5 & Other uncultivated & 136 & 112 & 105 \\
& excluding current fallows & $(1.6)$ & $(1.3)$ & $(1.2)$ \\
\hline 6 & Total & 8684 & 8685 & 8684 \\
\hline
\end{tabular}

Source: Directorate of Agriculture (Evaluation Wing), Govt. of West Bengal, reproduced in Economic Review, 2011-12

Note: Figs. in parenthesis are percentage to total.

Reclamation of land is not very useful method to increase effective availability of land. Converting forest land for agricultural or non-agricultural purposes is also forbidden because of environmental concern. But land demand is ever increasing for raising agricultural production to meet food demand of expanding population in a developing country like India or for expansion of industrial activities. In recent times use of land for industrial purpose or for the expansion of infrastructure facilities like expansion of roads, power generation etc. have become 
contentious issue. Nobody denies that industrialization is necessary for the economic and social upliftment of general population, but it is very difficult to settle the issue of rehabilitation of the people affected by such changes in land utilization. The gravity of the situation can be assessed by recent unrest associated with land allotment/ acquisition for industrial or infrastructure purpose in many states and even change of regime in the political arena. In this context, West Bengal assumes special importance in view of the highest population to land ratio in the country. Population per square Km of land in West Bengal rose from 903 in 2001 to 1029 in 2011 as per Census data. The national average is much lower, viz. 382 as per 2011 Census.

Table 1 provides distribution of land according to type. There is very little change in respect of the categories of not available for cultivation (Category 4), other uncultivated excluding current fallows (Category 5). This shows the severity of availability of land for transfer to private use. The problem is further accentuated in the context of West Bengal as the average land size is very small compared to other states in the country because of fragmentation due to inheritance. Setting up of industry requires large stretch of land. Another problem is that availability of infrastructure facility, such as port, power etc. are concentrated in and around the state capital, Kolkata. So demand for land for industrial purposes is mainly for the land in the vicinity of Kolkata. But land in the areas close to Kolkata such as in Hooghly, Bardhaman is also very fertile. So cost of rehabilitation and resettlement will be also very high. Land under public holding (Khas) is very small and if it is available it is in the places like Purulia or West Medinipore for which there is no demand. Given the constraints, transfer of land to private sector involves large scale acquisition in West Bengal. Hence any discussion on transfer of land to private sector in West Bengal is intricately linked with the issue of acquisition.

Fig. 2: Land use in West Bengal 2010-11 (\% of Reported Area)

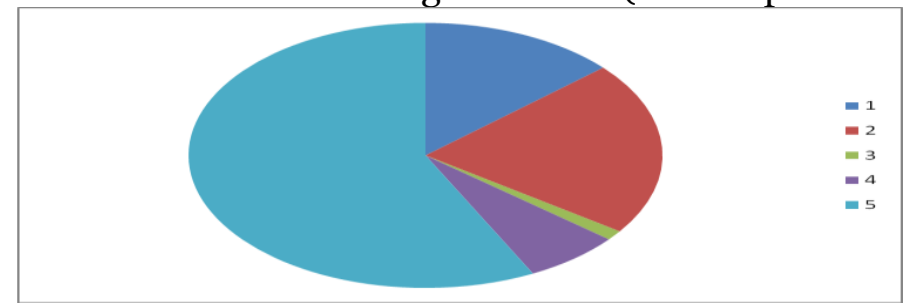

Source: Directorate of Agriculture (Evaluation Wing), Govt. of West Bengal, reproduced in Economic Review, 2011-12

Note: Reported area 87,0oo h

Legends: 1. Forests (13.5\%) 2. Area not available for cultivation (21.2\%) 3. Other uncultivated Land excluding current fallow (1.2\%) 4. Current fallow (6.6\%) 5. Net sown (57.5\%)

With this background to the realities prevailing in West Bengal we discuss the following issues in this document. Section 2 discusses the Land Acquisition Procedure, Section 3 Transfer Procedure to Private Sector and Pricing, Section 4 Rehabilitation and Resettlement Scheme, and finally Section 5 concludes.

\section{Land Management Issues}

The notion of eminent domain clause applies in respect of land in India. All land in this country is owned by the state. In the federal structure of India land is in the concurrent list, i.e. both states and the union government can pass legislation. If there arise any dispute between the state and the union law then the union law prevails. Individual land holding whether for cultivation or for residential purpose is given against rent by the state where the individual land holder is called raiyat. Over and above such 'individual holding' there is land under the direct ownership of the government which is discussed under the Public Land Management module

229|Page Land Governance Assessment Framework- West Bengal 
(Panel 4). However, land is not always transferred to private sector via acquisition. Such transfer is also made out of land under public holding though in the context of West Bengal it is less important for the reasons already discussed. In any case land acquisition whether for public purpose or for transfer to private sector takes place through the Land and Land Reforms Department. We will start with some of the issues of public management discussed below that are relevant for transfer to private sector.

Prior to independence majority of the land for cultivation or other commercial uses were held by the zamindars who were intermediaries between the state and the cultivators (there were often multi layers of intermediaries). State's direct hold was mainly khas land and forest land. After independence all the states enacted laws for the abolition of zamindari system. The relevant act for West Bengal is the West Bengal Estates Acquisition Act, 1953 and subsequently the West Bengal Land Reforms Act, 1955. The basic principle of acquisition is that land over and above ceiling amount is vested to the government. The ceiling amount is 6.18 acres for irrigated and 8.65 acres for un-irrigated land if family member is one and then ceiling amount increase with the size of family with a maximum of 17.30 acres for irrigated and 24.22 for non-irrigated land per family. By and large the maximum holding of 17.30 acres for irrigated and 24.22 acres for un-irrigated land are considered to be ceiling amount. For raiyat other than family the same ceiling amount applies. Ceiling amount for tea garden, factory, dairy development, animal husbandry, religious and charitable trust of public nature may be increased by government.

As a result of vesting of ceiling surplus land by applying reforms Acts, a large amount of land became public land as at the disposal of the state government. Large amount of vested land has been distributed to the rural landless labourers, rural artisans and fishermen who are land-poor. However, there remained a large amount of land that was not distributed. As on June 1979 a total of 0.95 million acres was available for distribution (Table 5.17, Economic Review, 1979-80, Government of West Bengal).

WBEA Act 1953 imposed ceiling on indviual holding of 25 acres of agricultural land 15 acres of non-agricultural land (20 acres together with homestead). The WBLR Act 1955 initially did not impose any new celling. From 15.02.1971 new ceiling was imposed on the size of a family. For one-member family the ceiling area is 2.50 standard hectares. For two to five-member family the ceiling area is 5.00 standard hectares. For a family having more than five members for each member ceiling area will be increased 0.50 standard hectares subject to a maximum of 7.00 standard heactares. Thus, the maximum ceiling area is 7.00 standard heactares. For any other raiyat the ceiling area is 7.00 standard heactares. The concept of 'standard heactare' has been introduced to distinguish between the ceiling limits on irrigated land and non-irrigated land. Standard heactare means one hectare in irrigated area and 1.4 hectare in non-irrigated area.

The total land vested under the EA Act \& LR Act plus some khas lands of the government and lands coming under some minor heads comprise the land at the disposal of the State Government. Most of such land has been distributed as shown in the table below:

Table 2: Amount of vest land and its distribution

\begin{tabular}{|c|c|c|c|c|c|}
\hline & $\begin{array}{l}\text { Vest land - } \\
\text { agriculture }\end{array}$ & $\begin{array}{l}\text { Vest land - } \\
\text { all categories }\end{array}$ & $\begin{array}{l}\text { Agricultural } \\
\text { land } \\
\text { distributed }\end{array}$ & $\begin{array}{l}\text { No of } \\
\text { beneficiaries }\end{array}$ & $\begin{array}{l}\text { Bargadars } \\
\text { recorded }\end{array}$ \\
\hline $\begin{array}{l}\text { Estates } \\
\text { Acquisition } \\
\text { Act, } 1953\end{array}$ & $\begin{array}{l}\text { 1.007 million } \\
\text { acres }\end{array}$ & $\begin{array}{l}2.648 \text { million } \\
\text { acres }\end{array}$ & \multirow[t]{2}{*}{$\begin{array}{c}1.141 \text { million }^{\#} \\
\text { acres }^{\#}\end{array}$} & \multirow[t]{2}{*}{$\begin{array}{l}3.14 \text { million } \\
\text { families }^{\$}\end{array}$} & \multirow[t]{2}{*}{$\begin{array}{l}1.52 \text { million } \\
\text { families }^{*}\end{array}$} \\
\hline Land Reforms & 0.311 million & O.347 million & & & \\
\hline
\end{tabular}

230|Page Land Governance Assessment Framework- West Bengal 


\begin{tabular}{|l|l|l|l|l|l|}
\hline Act, 1955 & acres & acres & & \\
\hline
\end{tabular}

Source: Land and Lard Reforms Department, Government of West Bengal

Note: \#: Land distributed as on 1979 was 0.615 million acres.

$\$$ : No of beneficiaries as on 1979 was 0.98 million.

*: No of bargadars recorded as on 1990 was 1.42 million.

Sub-section 52 (2) of the West Bengal Land Reforms Act, 1955 states that any land belonging to the state or land which is at the disposal of the state government shall, unless the state government otherwise directs, be managed by the Collector of the district under whose jurisdiction the lands are situated. The present system of public land management entirely lies with the Land and Reforms (L\&LR) Department of the Government of West Bengal. Collector or District Magistrate is the competent authority for looking after all matters relating to land management including transfer in a district. The actual management takes place through several tiers of administration of the Land and Land Reform Department down to the Block level. If a department requires land for some specific purpose it places requisition with the L\&LR department. There is well laid down procedure for the transfer of land from L\&LR to the requisitioning authority. It may be noted that such transfer from L\&LR to the requisitioning authority is specific to the stated purpose; the land so requisitioned cannot be used for any other purpose. Land required for establishment of industry, infrastructure such as construction of power station or for any other purpose under private sector management or public sector management has to be routed through the relevant department to the L\&LR department.

The West Bengal land reforms Rules, 1965 describe the procedure for settlement of land for non-agricultural purposes. Rule 20A(6) authorizes the Collector to settle a land of any category at the disposal of the state government with a person, or group of persons or any other organization on terms and conditions set by the L\&LR Department. Normally, lands for nonagricultural purposes are settled on a long-term lease. This part has been dealt with in Panel 4 discussions.

The Government of West Bengal has of late come up with a Land Allotment Policy document through issuance of Administrative Order (No. 6686 - LP/1A-18/ 2012 dated 26 December 2012) which is applicable to land owned or held by any department of the state government or agency funded by the state government. The key features:

- Manner of such allotment would be by way of long-term settlement (LTS) for a period not exceeding 99 years, with the option of renewal of such lease for the same period with same terms and conditions.

- The Land and Land Reforms Department is the nodal department for inter-departmental transfer of land and long term lease of vested/ khas (government) land.

- An inter-departmental committee under the Chief Secretary formed for the purpose would handle all cases of inter-department land transfers.

- The valuation for LTS would be based on the sale deeds of the area or the market price as determined by the I.G. Registration, West Bengal whichever is higher.

- Clear mention about adequate publicity including through internet has been made in the order for land meant for commercial use invariably to be auctioned to the highest bidder.

- Commercial use for this purpose will mean use for office, shops, shopping malls, housing not meant for economically weaker sections, low income group or poor, Cineplex, theme park, hospitals, educational institutions etc.

- To avoid malpractices, no fixing of reserve price by the government will be made. For projects leading to industrial development, the highest price needs to be the main criteria nor should auction be the only mode of allotment.

231|Page Land Governance Assessment Framework - West Bengal 
- Most importantly, all decisions related to land allotment etc. should be proactively disclosed under section 4 of the RTI Act.

- There will be however, relaxations in case of land for housing for the poor, setting up educational institutions and medical facilities to be set up by public charitable trusts with no-profit motives.

- Considering the impact on tariffs and questions of larger public interest, projects in power generation sector, auction route is exempted.

With its policy of no land acquisition from unwilling owners, the state government has put emphasis on developing industrial parks on public land and transfer of the same to private sector. The process has been initiated for updating information on land bank, which presumably would be made available from public land. This information is made publicly available in WBIDC, West Bengal Infrastructure Development Corporation, West Bengal Small Industries Development Corporation websites.

The new central act on land acquisition, viz. Right to Fair Compensation and Transparency in Land Acquisition, Rehabilitation and Resettlement Act 2013 which replaced the 1894 Act has come into force with effect from 02.01.2014. However, the state government has expressed its opposition to the new Act. The present government has also expressed its strong initiative for industrialization drive. In that case land acquisition cannot be entirely avoided for the reasons already discussed at the beginning of this document. Some policy changes will be required. But as of now there is no point in speculating on this issue.

\section{Transfer Procedure to Private Sector and Pricing}

The transfer of land whether for public purpose or to private sector is made through the L\&LR Department. The West Bengal Land Reforms Manual 1991 provides the necessary guidelines. The historical evolution of the transfer procedure has been dealt with in greater detail in clause 2.2. The present government has been following the same procedures as laid down in its administrative order, vide No. 6686 - LP/1A-18/ 2012 dated 26 December 2012 for transfer of land or modules of the industrial parks. The document is available in the WBIDC website (http://wbidc.com/images/pdf/Approved Terms Condition.pdf, dated 30.12.2013). The document by and large contains the terms and conditions consistent with the administrative order of 26.12.2012 for transfer of public land or modules of industrial parks.

The WBIDC website (http://wbidc.com/images/pdf/Pricing Policy WBIDC.pdf) also displays the pricing policy for transfer of land to private sector. This together with the document mentioned earlier constitutes the pricing policy. The salient features are listed below.

- Price of land should be through bidding system. This may be replaced in some special cases.

- For land where bidding process is not used the cost of land is based on amount paid to the District Magistrate by WBIDC on the basis of the award of the government + infrastructure cost + cost of capital @13\% + administrative cost @10\% charged on all items except infrastructure.

- Some extra charges for lucrative position, such as on the main arterial roads etc.

- If the court order asks the compensation price low in the future then the additional cost has to be borne by the leaseholder.

- Operation, maintenance, statutory duties, levies and all other costs will be paid by the leaseholder.

- Other terms and conditions follow general lease holder agreement clauses.

232|Page Land Governance Assessment Framework - West Bengal 


\section{Rehabilitation and Resettlement}

The 1894 Act had appropriate provisions for compensation, notification, objections etc. However, the compensation mechanism has often been criticized on the ground that the government officials have the tendency to calculate average market price after dropping the higher prices from the list on the ground of outliers. The issue is further accentuated by the fact that land market is not like other markets in the sense that it does not have a unique price even after controlling for quality etc. The land losers always find that they are being offered lower price because they internalize the expected future appreciation of land price because of the upcoming industrial project in that very land. Additionally absolute government control makes allotment/ change of use subject to various kinds of arbitrariness, unfair practices and source of corruption.

It has also been observed that eviction of poor from land deprives them of their safe means of livelihood. It affects rich also, but rich can make alternative arrangements. The farmers with inadequate knowledge of investment in bank fixed deposits or other financial assets or in entrepreneurial activities cannot fruitfully utilize the compensation money. So within a very short period they fritter away the entire compensation money. Thus history of land acquisition in this country for poor has been history of destitution for them. With the advent of democratic institutions it has raised dissent. In recent times the demand for job in the establishment due to come up on the acquired land, has always been raised. This is in general not viable for the lack of skill or employment creation for all those displaced. The issue is more pertinent for rehabilitation than for fair compensation and becomes more relevant because the areas where land is acquired comprise fertile land. The importance of the issue stems from the fact that inadequate rehabilitation of the displaced people specially the poor and the marginal sections of the population who are more vulnerable to destitution, have often happened. This goes against the principle of welfare state and more importantly becomes a source of social and political instability.

However, government also brought in some new schemes for rehabilitation and resettlement of the land losers including share croppers. To this effect WBIDC introduced rehabilitation and resettlement scheme (R\&R Scheme) the final version, dated 28.02.2011 of which is still available in the WBIDC website and can be thought of as the standing R\&R Scheme. After conducting socio-economic survey for assessing the impact on livelihood of the affected people, R\&R Scheme was formulated under corporate social responsibility. As already mentioned compensation for land as per 1894 Act has often underestimated the correct market value and does not have provision for future price appreciation because of forthcoming project. The new R\&R Scheme introduced a process of negotiation to arrive at agreed land price between the land losers and anchor investor in the presence of political parties, requiring body (WBIDC) and the district administration. This was supposed to be conciliatory, but in practice has been criticized on the ground of manipulation by the ruling party. In order to give the land losers the benefits of land price appreciation it was proposed that a quantum of land to be given back to land owners form whom 0.33 acres or more land had been acquired. The quantum of land to be given back depends on the size of land lost. Those who have lost less than 0.33 acres shall receive an annuity depending upon the quantum of land lost.

The R\&R scheme proposes sharecroppers to be paid compensation estimated for three years' of income which comprised of 10-12\% of compensation for value of land. Additionally they were paid compensation by the requiring body. Together they constitute around 25\% of land compensation. Landless agricultural labourers are proposed to be paid a compensation amounting to 250 days' of wage as per MGNREGA rate. A team appointed by the District Magistrate is supposed to enquire that nobody was deprived of the compensation package. For acquisition of homestead land compensation was proposed for land and shifting of structure depending on size of land acquired.

233|Page Land Governance Assessment Framework - West Bengal 
Over and above the compensation schemes, the requiring body was supposed to arrange for training for skill development for the family members of the affected families. The investor should arrange for sanitation, healthcare, educational capacity building in the vicinity of the project in consultation of the R\&R Committee. It was suggested that an R\&R Committee would be set up for the implementation of the package proposed. However, the proposed schemes other than compensation to land losers, share croppers or land less agricultural labourers other schemes to be implemented in the future have been evaluated with suspicion.

In west Bengal it has been found that land for project was selected in terms of the choice of the investor and there was no pre-acquisition survey to assess the land holding pattern of the area before initiating land acquisition process. There was no study of the impact that a particular project was likely to make in the lives of the people. Apart from dispossession from land that is acquired many of the villagers are left with land that are situated on the other side of the acquired portion and to reach there for cultivation becomes hazardous for them. The investor puts up boundary wall closing the connecting roads between the villages and even when alternative roads are built the people have to make long detour to reach the field or the place of work entailing a lot of inconveniences. Person with small holding in the areas as aforesaid, in fact find no option but to sell his land compromising his bargaining power in the price of the land. Moreover, people face serious problems in maintaining the cattle population of the area. A vast tract of land which was the traditional grazing ground of the cattle for most of the time of a year when acquired for some industrial concern, throws the cattle and their owners in utter distress. With sudden loss of grazing ground people are forced to sell the cattle and those who were earning their livelihood from goattery or animal husbandry are thrown out of the occupation and are dispossessed of their own mode of living. Most of these people are unskilled labourers and the modern capital intensive and technologically sophisticated industries that come up on their land have no place for them for employment.In fact, such problems have now surfaced in the land acquisition for Aerotropolis Project at Andal and for the projects of Tata Metalik in Kharagpur. The new Land Acquisition Act of the Govt. of India has made elaborate provisions for these matters. It remains to be seen how the law is put into operation.

In view of the controversial issues that have always been raised in case of transfer of land from public holding or through acquisition appropriate $R \& R$ schemes should be designed. The approach should be humanitarian rather than the Doctrine of Eminent Domain of the State. A very good survey of the literature can be found in Wallace (2010). A well laid procedure for renegotiation can also be introduced when displacement of population is large scale. AnimOdame (2011) has documented the case of Ghana where the scope of renegotiation through representation of private valuers reduced the difference of agreed and asked price for land transfer for private interest.

\section{Conclusion}

Transfer of land for private use, especially if it involves large tracts of land is a contentious issue in West Bengal as it is elsewhere in the country or throughout the globe. The most controversial aspect lies in pricing because of the very nature of land market. In the first place land is an asset that generates income forever. So it is difficult to estimate future income flow. Secondly there is no unique price for land even after controlling for quality. So any price set for transfer from government or for acquisition (which is an integral part of transfer in state like West Bengal) always questions the fairness of compensation scheme. It is further complicated by the fact that apart from land losers there are other groups who are indirectly dependent on land based rural economy.

For developmental purpose, be it in the name of public purpose or for setting up of private industrial sector, land transfer or acquisition involves displacement and as it happens everywhere economically and socially disadvantaged groups suffer more in the process.

234 I Page Land Governance Assessment Framework - West Bengal 
However, developmental needs cannot be entirely avoided for it is also the condition for the transformation of a nation from a low income to a high income group. But care has to be taken that rehabilitation and resettlement schemes are well suited to the needs of the displaced population. UN Refugee settlement recommendations could be useful starting point with appropriate amendments to suit local needs.

\section{References}

- Anim-Odame, W. F. (2011): Compulsory Acquisition and Compensation in Ghana: Principles \& Practice, Paper presented at the American Real Estate Society Conference, Seattle, Washington, USA.

- Government of West Bengal (1955): West Bengal Land and Land Reform Act, 1955.

- Government of West Bengal (1965): West Bengal Land Reforms Rules 1965.

- Government of West Bengal (1991): West Bengal Land and Land Reforms Manual 1991.

- Government of West Bengal (2012): West Bengal Land and Land Reform, Land Policy Branch Order No. 6686-LP/1A-18/2012.

- Wallace, J. (2010): Land Acquisition in Developing Economies, International Federation of Surveyors, February, 1-21.

\section{Panel 6: Public Provision of Land Information: Registry and Cadastre}

\section{Registry and Cadastre: A Brief History}

In West Bengal Land Information System has three distinct divisions, i.e. (a) cadastral map (b) Record of rights (c) registration of conveyance instruments for land and mortgages. While cadastral map and record of rights are prepared by the Land and Land Reforms Department, registration of deed of conveyance for transfer of land and mortgages is administered by the Finance Department. West Bengal has a chequered history of preparation of accurate set of cadastral maps and record of rights and registration of land transfer and mortgages through deed of conveyance.

\section{a. Touzi Register:}

After introduction of Permanent Settlement, British settled the land with Zamindars by an instrument of Settlement called Touzi. A register was maintained to record the details of land settled and the revenue payable by the Zamindars and changes of the revenue for increase or decrease of the area settled for reasons of alluvion or diluvion. Other important information were duties, towards raiyats (tillers of the land) and undertaking certain type of development work like flood protection embankments, roads and pathways.

Preparation of Touzi register was the first attempt to prepare land registry, i.e. record the land rights and revenue assessed for land settled with Zamindars, though details of the parcels and accurate measurement of areas settled was not recorded in Toluzi register.

The Zamindars got permanent settlement of huge quantum of land spreading over different districts. They found it impossible to manage the entire land settled with them. Therefore they started creating sub-tenancy and settling land with other people. In this way an intermediary system was created with a layered structure of tenancy. To validate this intermediary system, East India Company passed a Regulation called the Bengal PatniTaluk Regulation in 1819. This Regulation defined the rights of Zamindars, and PatniTalukders, and gave unfettered rights in creating subordinate tenure holders in any manner they liked. Though Permanent Settlement Regulation I of 1793, in terms of Regulation VIII granted proprietary rights to Zamindars, it safeguarded the interest of the tenants, as Zamindars were required under the Regulation to 
deliver Patta (deed of settlement) to the tenants specifying the area of holding, and rent payable under the Regulation, the rights of the Raiyats possessing land and enjoying usufruct through generation by inheritance (Mourasi). They were protected from eviction for temporary default in payment of revenue (Section 54, 55, 59 and 61 of Regulation VIII).

\section{b. Khas Mahal Register:}

The British kept a large tract of land in different mouzas (revenue villages) outside the land settled with the Zamindars for the development of infrastructure, i.e., Military and Civil towns, administrative buildings, civil lines and for other strategic purposes. Some of these land kept at the disposal of the British were also settled for long term basis i.e. 30 years or 99 years with the public at a onetime salami (Premium) and annual rent. Details of the land at the disposal of British and settlement of such land with public, rent at which settled, were recorded in Khas Mahal Registers maintained by the British.

Touzi Register and KhasMahal Register can be called the first set of land registry in the history of land administration in India and undivided Bengal, of which West Bengal was a part.

\section{c. Thak Survey:}

Permanent Settlement Regulation and subsequent regulations like Regulation VII and V made the life of the raiyats i.e. tillers of land miserable due to rack renting and large scale eviction of raiyats and sharecroppers. This situation led to agricultural depression and potential threat to law and order. The Court of Directors of East India Company to control the deteriorating agrarian relation decided in 1824 to make a survey and prepare record of rights for defining and maintaining right of raiyats. However, there was no map cadastral or any kind for the mouza (i.e. revenue village) prepared before 1859. In the year 1859 a survey called Thak Survey was conducted. In this survey boundary of eachrevenue village was correctly drawn by cadastral method but the configuration of the parcels inside the boundary was approximately drawn. Every parcel was allotted a number and approximate area of each parcel was calculated. The Thak survey was the first attempt to prepare cadastral maps in Bengal.

\section{d. Bengal Rent Act 1859}

To regulate the rent payable by the tenants and to prevent eviction of tenants, British Government enacted Rent Act 1859 (Act X of 1859). In terms of Section 2 of the Act every Raiyat was to receive from the whom the land was held under rent, a patta clearly mentioning (1) the quantum of land (2) the number of parcel, the area settled on rent (3) amount of annual rent (4) installments in which payable, (5) manner of delivery and (6) special condition of settlement..Section $3 \& 4$ provided that a Raiyat would get permanent patta if rent of the land had not changed for 20 years from the time of permanent settlement. Section 5provided that occupancy Raiyats who were not holding land at fixed rent would be entitled to patta at fair and equitable rent. Section 5 also declared that every Raiyats who cultivated or held land for a period of 12 years has a right of occupancy in the land. Provision was also made in Section 10 of the Act for granting receipts by the landlords to the tenants specifying the amount, the year and years on account of which rent was paid. However, the tenants were liable to be evicted, by the order of D Collector of the District, if the tenant failed to clear the revenue payable by $31^{\text {st }}$ Chaitra of Bengali year. This curbed the rights of the landlords to evict the tenants at their will and established an independent system of adjudication of dispute over rent by the government machinery.

But the Rent Act 1859 could not protect the Raiyats from rack renting by the landlords. There was large scale eviction of non-occupancy Raiyats i.e. Raiyats cultivating land for less than 12 years, as there was no compulsion under the Act on the part of landlord to issue patta or to grant any form of rent receipts. The non-occupancy Raiyats failed to prove that they were cultivating

236|Page Land Governance Assessment Framework - West Bengal 
land for 12 years due to non-maintenance of records and ignorance on the part of nonoccupancy Raiyats. Even Poor Raiyats could not approach the judicial courts to press their grievance as it was very expensive and the process was time taking. The situation became unbearable for the Raiyats and Bengal witnessed a number of peasant revolts seeking end of it. British Government sensing the danger enacted Bengal Tenancy Act 1885 .

\section{e. Bengal Tenancy Act (BT ACT) 1885}

The Bengal Tenancy Act 1885 for the first time categorized different type of tenants and their liabilities and put restriction on enhancement of rent.Sections27, 29, 30 and 38 of this Act provided that a settled Raiyat shall not be ejected by the landlord, unless the landlord can prove that he is not a settled Raiyat. Ejectment of occupancy Raiyat was also restricted under Section 21 of the Act. The Act provided that an occupancy Raiyat shall not be ejected except in execution of decree passed by a competent civil court.

\section{f. Preparation of Cadastral maps and Records under BT Act 1885}

The Bengal Tenancy Act for the first time provided (chapter X, section 101-120) the legal basis for preparation of revenue village maps, i.e., mouza maps following the method of cadastral survey (CS) and it mandated that only on the basis of such CS maps the record of right be prepared. BT Act 1885 for the first time made provision for integration of cadastre and registry in the history of land administration in India and in West Bengal.

On the basis of provisions made in BT Act 1885 first set of revenue village maps were prepared during the period $1885-1940$, by theodolite traverse survey following the survey principle from whole to part. Ground Control Points of high accuracy (1:1000) were first established by theodolite. Astronomical observation were taken at regular interval for determination of Azimuth of survey lines in respect of true north and the traverse survey was connected with local great trigonometrically survey (GTS) Pillars for determination of accuracy of survey. GTS Pillars are Pillars established by a nationwide survey throughout India during 1802-1876, which acted as reference points to which ground control points established by theodolite survey were linked to ensure accuracy of survey. On the basis of the ground control points parcel details on the ground were plotted on revenue village map sheets by plain table and chain survey (accuracy 1:200). Different scales were chosen for different areas depending on the size and density of parcels and all parcels within the boundary of the revenue village were featured in the map. Plots were numbered from north-west corner and ended in south-east. The area of each map was measured with the help of instrument acrecomb. Land other than agricultural were featured in the map with separate standard alamat (legend): river, road, water body, homestead, drinking water tube wells, wells, temple, mosques, telegraph posts, etc. were featured with fair degree of accuracy with separate legend. Each revenue village was given a number police station wise starting from north-west to south-east. This number is called Jurisdiction List Number (JL No.). To identify a parcel in any revenue village, Jurisdiction List Number (JL No.) and Parcel number is necessary. The scale of the map was $16 "=1$ mile. Record of rights was for the first time prepared on the basis of cadastral maps prepared under BT Act 1885. The record of rights were prepared in a number of stages i.e. (1) Khanapuri (preliminary record writing) (2) Bujharat, (local explanation) (3) Attestation, (4) Draft Publication, (5) Hearing of objections, (6) correction of record of rights on the basis of decision of hearing of objections, (7) final publication of record of rights and (8) Inviting application for correction of mistakes if any in the finally published record of rights. In each stage citizens and Government departments participated to make the record error free. The record of rights featured the names of the land owners, their tenants, share of the land parcel, area of the land against parcel number, incidence of tenancy, easement rights, common property rights, share cropper's right to cultivate the land and description of boundaries of the parcel.

237|Page Land Governance Assessment Framework- West Bengal 
Though the BT Act took care of agricultural tenants, there was no specific provision to protect the rights of non-agricultural tenants. As a result, non-agricultural tenants could be evicted after expiry of the period of lease and landlords could also increase the rent at the time of renewal of lease.

\section{g. West Bengal Non Agricultural Tenancy Act 1949}

To protect the rights of the non-agricultural tenants, independent India enacted its first Act on Tenancy Reforms: West Bengal Non Agricultural Tenancy Act 1949. This Act provided (1) Lesees who got leases after 1882 and are in occupation of the land for more than 12 years or lesees who are in occupation by constructing buildings or in occupation after expiry of the lease, cannot be evicted (2) only the tenants holding land less than 12 years but more than one year, can be evicted after paying compensation and by giving prior notice and (3) rent fixed at the time of creation of tenancy will remain fixed for 15 years. In Chapter VI (section 27-32) of West Bengal Non Agricultural Tenancy Act provision was made for preparation of record of rights and settlement of rent. However no Survey and Settlement operation was taken up for preparation for record of rights for non-agricultural land or for revision of record of rights prepared under BT Act 1885 .

The Bengal Tenancy Act 1885 did not provide adequate protection to the sharecroppers, who constituted one third of agricultural tenants from eviction and rack renting. A strong "Tebhaga" movement by the sharecroppers to secure three fourth of the share of the produce compelled the Government of West Bengal to enact West Bengal Bargadar Act 1950.

\section{h. West Bengal Bargadar(share cropper) Act 1950}

The act laid down principles for the division of produce.

(a) The share cropper or the owner as the case may be will be entitled to an amount of share of the produce equivalent to quantum of seed supplied.

(b) The remainder of the produce will be divided between the share croppers and the owner in proportion to their contribution to the cost of cultivation including supply of plough cattle, agri-implements, fertiliser,cost of protection of crop.

The above mentioned stipulated principles of division of produce were in no way any radical principles. The Act could not bring any benefit to the exploited bargadars (sharecroppers).

\section{i. West Bengal Estate Acquisition Act 1953}

From the early part of $20^{\text {th }}$ century it was felt that Permanent Settlement was an obstacle to the growth of agriculture and rural economy. Ultimately in 1937, a Commission was set up under the chairmanship of Sir Francis Floud to study the agrarian situation prevailing in the country. On the basis of the recommendation of the Floud Commission, Government of Wet Bengal enacted Estate Acquisition Act 1953 with the following objectives:

(a) Eliminate interest of Zamindars and other intermediaries by acquisition on payment of compensation.

(b) Permit the intermediaries, raiyats and under raiyats to retain possession of their khaslands up to certain limit (individual ceiling) and to treat them as tenants holding directly under the state.

(c) Acquire interest of Zamindars and other intermediaries in mines.

(d) Update cadastral maps and records. 
Section 4 of the Act empowered State Govt. to issue notification for vesting all estates and rights therein of all intermediaries in the state free from all encumbrances. The statutory date of such vesting was $15 \cdot 04 \cdot 55$.

Though initially raiyats and under-raiyats were not brought under the ambit of the Act, subsequently they were brought in the same footing of intermediaries under the Act. The date of vesting in this case was 14.04.1956.

This landmark piece of legislation brought every one, holding land i.e. intermediaries and tenants under the management and control of the State Government. Ceiling on individual land holding was introduced and ceiling surplus land was vested by the state.

\section{Preparation of Record of rights and Cadastral maps under Estate Acquisition Act 1953}

Implementation of provision of the Act required preparation of Record of rights for each intermediary showing details of his rights and interests and other incidences. Provision for preparation of Record of rights was made in chapter V of the Act (section 39-46) Section 39 provides that subject to the provision of subsection (4), the State Government may, for carrying out the purposes of the Act ,make an order directing-(a)that record of rights be prepared in respect of any district or part of a district (b) that record of rights prepared and finally published under chapter X of Bengal Tenancy Act,1885 in respect of any district or a part of the district be revised. Cadastral maps and Record of Rights (RoRs) prepared under The Bengal Tenancy Act 1885 were revised and updated by abolishing zamindary rights under the West Bengal Estate Acquisition Act,1953. Maps and RoR revised and updated under the Act are known as Revisional Survey (RS) maps and RoRs. The record of rights so prepared contained following particulars:

- the name of each tenant or occupant of the land or sharecropper

- the class and classes of tenant

- the name of each tenant's or occupant's land lords

- the situation and quantity of land by each tenant, occupant or share cropper

- easement rights or right of way(f)rent and cess payable(g)rights and obligation of each tenant and landlord etc.

\section{j. West Bengal Land Reforms Act 1955}

In the West Bengal Estate Acquisition Act, 1953 there was no provision for (1) distribution of ceiling surplus land vested under the Act to the land-poor or the landless persons (2) protection of the rights of the sharecroppers. Considering the limitation of the West Bengal Estate Acquisition Act 1953, the West Bengal Land Reform Act 1955 was enacted to complement and improve upon the provisions made in the West Bengal Estate Acquisition Act 1953. The main features of the Act are -

1) The rights and obligation of the Raiyats are clearly defined. The raiyats can inherit the land and transfer the land through registered deed of conveyance only but raiyats are not allowed to lease out the land or claim sub soil rights i.e. rights of minerals beneath the land [Chapter II, Section 4 - 14].

2) Restrictions are imposed on transfer of land of Scheduled Tribes to people other than Scheduled Tribes, except with the permission of Revenue Officer and except on certain purposes like (a) improvement of land (b) investment etc. [Chapter IIA, Section 14A 14I].

3) Family ceiling and institutional ceiling on land was introduced. Ceiling surplus land was vested to the State. Maximum ceiling allowed was 7 standard hectares.[chapter IIB section $14 \mathrm{j}-14 \mathrm{z}]$

239|Page Land Governance Assessment Framework - West Bengal 
4) As the West Bengal Bargadar Act 1950 could not protect the rights of sharecroppers, and the principle of share of produce between the land owner and the sharecropper was not rational one, the West Bengal Bargadar Act 1950 was repealed and provisions were made in the West Bengal Land Reform Act 1955 to (a) record the name of the sharecroppers in the RoR (b) stop illegal eviction of sharecroppers (c) make sharecropping rights heritable (d) fix the share of produce between land owner and sharecropper . Total number of sharecroppers recorded in the RoR is 15,20,366 as on October 2013 (Source: Report published by Directorate of Land records and Surveys) [section 15-23, chapter III].

5) Provision has been made to settle vested agricultural land with landless, and land poor, and sharecroppers up to 0.4047 hectares if the person together with member of the family owns land less than 0.4047 hectare.. Provision has also been made to settled land up to 0.0335 hectares with the person, for homestead purpose if he has no homestead land of his own. Preference is given to persons belonging to scheduled castes or scheduled castes during such settlement. [Section 49(1) of Chapter VI].

\section{Preparation and maintenance of record of rights under Land Reforms Act 1955}

In West Bengal Land Reforms Act1955provision has been made in chapter VIIA (section 5051A) for preparation or revision of record of rights. Procedure for revising or preparing record of rights has been laid down in rule 22-25 and schedule A of West Bengal Land Reforms Rules 1965.Stages involved in preparation of record of rights include:

(a) Traverse Survey

(b) cadastral Survey

(c) preliminary record writing (khanapuri)

(d) local explanation (Bujharat)

(e) Attestation

(f) Publication of record of rights in draft

(g) Disposal of objections

(h) Preparation and publication of the final record of rights.

A record of rights prepared under the Act has following particulars:

a) Name of each raiyat or occupant or sharecropper

b) Class, quantity and shareof land held by each raiyat, occupant or sharecropper

c) Revenue and cess payable

d) Private encumbrances like irrigation rights, user rights for road, pasture rights, caracas disposal rights, cremation rights, user rights of tank, pond and such other easement rights, possession with or without consent of the raiyat

e) Public restriction like restriction on transfer of land beyond ceiling limit without approval of revenue officer, long term government lease, short term government lease, terms of settlement, settlement with land poor by patta (deed of settlement) and nontransferability of such land, land allowed to be retained beyond ceiling limit for industrial and such other purpose specified in WBLR Act 1955 which cannot be transferred to private individual, land revenue chargeable, violation of statutory provisions of WBLR Act 1955 etc.

Provision has also been made in chapter VII for maintenance and updating of record of rights on account of (a) mutation as result of transfer or inheritance (b) partition, exchange, consolidation of land (c) new settlement of land (d) variation of revenue (e) alteration in mode of cultivation for example by a sharecropper (f) such other causes as necessitates a change in record of rights. Cadastral (maps and RoRs prepared under West Bengal Estate Acquisition Act 1953 were

240 | Page Land Governance Assessment Framework- West Bengal 
updated under provision of Chapter VIIA and VII. One man one RoR (One-man one-khatian) concept was introduced to record tenancy details, parcel details, parcel number, share, area easement right etc. for each land owner in respect of all land held by him in one record of right. The scales of cadastral maps are now $16 "=1$ mile for rural areas, $32 "=1$ mile for semi urban areas and $64 "=1$ mile, $128 "=1$ mile and $1 "=50$ feet for urban areas. West Bengal has now 42042 revenue villages and 68328 revenue village sheets. The average revenue villages consists of 2-3 sheets each sheet covering 250 to 300 acres. Cadastral maps and records presently accounts for all the parcels, areas and tenancy details of whole of West Bengal in a very accurate manner.

\section{Formalization of land possession by the poor in rural areas}

\section{i. West Bengal Land Reforms Act 1955}

Under Section 49(1) of Chapter VI, provision has been made to settle land with landless, and land poor, and sharecroppers up to 0.4047 hectare if the person together with member of the family owns land less than 0.4047 hectare. Homestead land is also settled with the person, for homestead purpose if he has no homestead land of his own. The maximum quantum of land to be allotted is 0.0335 hectare. Priority has been given to the persons belonging to Scheduled caste and Scheduled tribes communities in allotting vested lands. The land so allotted is heritable but not transferable. A detailed procedure of settlement of vested land with land poor or landless persons and sharecroppers has been laid down in Clause 187 to 208 under Chapter XIII of West Bengal Land and Land Reform Manual 1991. As on October 2013, 11,41,345 acres of land has been distributed to $31,41,232$ persons. But the number of persons recorded inRoR is 24,57,347 [Source: Report published by Directorate of Land Records and Surveys, Govt. of West Bengal.

\section{ii. West Bengal Acquisition of Homestead Land for Agricultural Labourers, Artisans and Fisherman Act 1975}

State Government with the objective of recognizing the rights of landless agricultural labourers, artisans and fisherman, occupying homestead land of others as on June 1975 enacted West Bengal Acquisition of Homestead Land for Agricultural Labourers, Artisans and Fisherman Act 1975. Under this Act landless person mentioned above were given ownership rights over homestead to the extent of 0.08 acres, by acquiring land from the land owners. The Land owners were given compensation for such acquisition. Under this Act ownership right was formalize in respect of 3, 26,725 families [Source: Report published by Directorate of Land Records and Surveys, Govt. of West Bengal.

\section{iii. Chas O BasabaserJanyaBhumidanPrakalpa Homestead and Kitchen Garden Scheme) and Nijo-Griha-Nijo-BhumiPrakalpa (My Home My Land scheme):}

Distribution of land to be used for homestead under the WBLR Act and formalization of occupation as on a particular date under the Act of 1975 could not cover all the homeless persons. To cover such homeless people the State introduced Chas- OBasabaserJanyaBhumidanPrakalpa (Homestead and kitchen garden scheme) in the year 2005o6. Under this scheme land up to 0.16 acres were allotted to the landless people for homestead and kitchen garden purpose. This micro- plot distribution is unique in the sense that Govt. purchased the land form landowners at market rate and distributed to the landless people. But, this scheme was not seriously implemented by the State Govt. Under the scheme, State granted tenancy right to only 5034 families over 579.79 acres of land [Source: Report published by Directorate of Land Records and Surveys, Govt. of West Bengal]. The present Government introduced a new scheme NijoGrihoNijoBhumiprakalpa in Oct 2011 (My Home My Land scheme) to settle land up to 0.05 acre to 5.5 lakh homeless persons. The land to be settled will be provided from the land at the disposal of State Government and land to be purchased by the State Government from land owners at market rate. The settlees are to be given land in cluster

241|Page Land Governance Assessment Framework - West Bengal 
and will be provided with all essential amenities like drinking water, sanitation, electricity, road and livelihood support by convergence of Govt. schemes. The entire 5.5 Lakh homeless people will be covered under the scheme by 2015-16. As on December 2013 86,883 families were allotted land [Source: Report of Directorate of Land Records and Surveys, Govt. of West Bengal.]

\section{Formalization of homestead land held by the poor in urban areas}

State government issued a circular in 2010 [circular no-1469-6E(M)/L-20/10 dated 17.03.2010] for formalization of government land occupied by urban poor for at least 20 years. Provision has been made in this circular to settle land with urban poor on lease for 99 years at a token salami (premium) of Re. 1 provided beneficiary house hold has monthly income not more than Rs 6000 and the land has not been earmarked for any government project. The beneficiary house hold has to pay land revenue to be fixed under west Bengal Land Reforms Act 1955 or Kolkata Land Revenue Act 2003 as the case may be. Most of the beneficiaries are slum dwellers.

West Bengal ThikaTenancy (Acquisition and Regulation) Act 2oo1: In 1949 Calcutta Thika Tenancy Act was enacted to regulate a very special type of tenancy in the twin city of Calcutta and Howrah. Thika Tenant was defined to mean any person who held whether by a written lease or otherwise, land under another person and has erected or acquired by purchase or gift any structure on such land for residential, manufacturing or business purposes and includes the successors in interest except (a) who holds land under another person in perpetuity (b) who holds land under another person under a registered lease for more than 12 years (c) who holds land for another person and uses occupies such land for Khattal. What makes a Thika tenancy special is that the owner of the land and owner of the structure raised on the land are two different people as opposed to normal tenancy. This act of 1949 was repealed and replaced by Calcutta Thika Tenancy (Acquisition and Regulation) Act 1981. In this Act definition of Thika Tenant was broadened to bring in to its fold the persons who were excluded from the definition of 1949 Act. What is most significant is that this Act for the first time provided for (a) acquisition of interests of the superior landlords against compensations and (b) recognizing Thika tenants as tenants directly under the state. This Act of 1981 was again repealed and replaced by West Bengal Thika Tenancy (Acquisition and Regulation) Act 2001 to extend jurisdiction of The Act beyond Calcutta and Howrah. The declared objective of the Act was to abolish intermediary, bring tenants directly under the state, utilise the Thika land vested to the state under the Act for development purpose and to serve common good .It need be mentioned here that most of Thika landhas turned into slums and shelters the urban poor. Thika tenancy Act 1949, 1981, and 2001 recognized the rights of tenants who were basically lessees (by written lease or verbal lease or occupying the land otherwise) and formalized their rights over the land as tenant.

\section{Modernization of Registry and Cadastre: Digitization of land record of rights and cadastral maps, digitization of Land Transfer Registration Offices, integration of record of rights and cadastral maps digitally and interconnectivity of Land Reforms Offices and Land Reforms Offices under National Land Records Modernization Programme (NLRMP): Present Status}

In the year 1990 West Bengal started digitizing the record of rights. Presently the record of rights are completely digitized except record of rights of 1473 odd revenue villages of Purulia, North 24 Parganas and South Dinajpur districts, where updation of cadastral maps and record of rights are in progress and is expected to be completed within two years. The cadastral maps have been digitized and integrated with record of rights digitally. The digitized maps and records of rights are being updated and managed by software named "Bhuchitra". The map data and textual data of records of rights are available in website http://www.banglarbhumi.gov.in, which can be accessed by the interested citizens. Cadastral maps and record of rights are accepted carry statutory presumption of correctness and are admissible in evidence as public documents.

242|Page Land Governance Assessment Framework - West Bengal 
Cadastral maps and record of rights are available for all the parcels of land in the state except first 100 wards of the city of kolkata. But land data is a dynamic data, because changes in the land ownership, area, share of land and use of the land are incorporated in there. In the State, registration of transfer of land and management of record of rights are administered by two separate departments. Since such changes are not regularly incorporated in the records to keep the records up to date government may think of a special drive to make mass mutation.

Measures have been taken to connect the Registration of Land offices with Land Reforms offices dealing with cadastral maps and record of rights, through dedicated intranet connectivity to track the cases of land transfer ,update the records on the basis of such land transfer and to make the record of rights real time records.60,665 map sheets out of 68,328 revenue village map sheets have been digitized and land records of 40,196 revenue villages out total 42042 revenue villages of the State have also been digitized and updated. The digitized map data have been integrated with RoR. West Bengal is first State to integrate digitized cadastral maps with related RoR which has been accepted as model by the Department of Land Resources, Government of India. Presently under MPLS-VPN Project of Finance Department, all the service locations i.e. 346 Block Land and Land Reforms (BL\&LRO offices), 63 Subdivisional Land and Land Reforms (SDL\&LRO )Offices and 18 District Land and Land Reforms (DL\&LROo )offices of Land \& Land Reforms Department are expected to be interconnected by March, 2014. As on November, 2013, 94 BL\&LRO Offices, 45 SDL\&LRO Offices and 15 DL\&LRO offices have been interconnected through MPLS-VPN having 2Mbps connectivity. Land records database of the State will be collocated in State Data Centre (SDC). Procurement of hardware for such collocation will be completed by March, 2013. Presently land database of 11 BL\&LRO offices went live from central server located at Survey Building at Kolkata. All 271 service locations of directorate of Registration are digitized. Out of 271 service locations of Directorate of Registration, 159 service location i.e. Additional District Sub Registrar (ADSR) office, District Sub Registrar(DSR) office, Deputy Inspector General, Registration( DIGR )and Inspector General registration (IGR) office are interconnected up to November, 2013. The service provider is providing $2 \mathrm{Mbps}$ bandwidth in each site dedicatedly. Both database of land records and property registration will be collocated at SDC. When a person will approach for registration of property, the Sub-Registrar may view the land records through his system and allow property registration. On registration, such information will be electronically transferred to concerned BL\&LRO office and BL\&LRO office will generate notice for hearing and thereby will initiates mutation process. This will ensure mutation of land transferred instantly in the record of rights.

In Howrah district a pilot project e-integrating land records with property registration is running successfully and during the current financial year (2013-14) this facility will be rolled out in another four locations involving 11 BL\&LRO offices additionally. In next financial year such e-integration will be rolled out throughout the State. Such integration will help in mutation on registration instantly and curb fraudulent registration greatly.

The State has recently amended sec. 50(2) of West Bengal Land Reforms Act, 1955to facilitate edelivery of land records by affixing digital signature. This will help in operationalizing 'anytime, anywhere' service in tune with National E-Governance Plan (NeGP). The State has rolled out OTC-Information services (Over the Counter Information service) to provide copy of RoR, Plot Information and Plot Map from counter within 5-15 minutes through process re-engineering. This has enhanced speed of service delivery to great extent. During 2011-12 on an average about 2.0o lakhs copies of RoR, Plot Information and Plot Map per month were delivered but in 201213, it increased to 4.50 to 4.97 lakhs per month. To reduce the response time of transaction services i.e. mutation, conversion of land etc., BLE (Block Level Entrepreneurs) were engaged in pilot basis at four BLLRO offices. BLES receive and enter the application received from persons into system instantly to ensure service delivery on First in First Out (FIFO) basis. Rs10 is chargedper application as per provision of Information Technology Act, 2000 in addition to

243|Page Land Governance Assessment Framework - West Bengal 
existing application fees and processing fees. Such fee for service delivery is deposited in Project Management Unit (PMU) account.BLES are paid Rs.5/- per application and Rs.5/- remains in PMU account for sustenance of computer infrastructure.

Four Modern Record Rooms were set up in four BL\&LRO Offices and based on such experience MOU was signed with M/S Webel Technology Limited, a State Government undertaking to set up Modern Record Room in another 178 BL\&LRO offices located in Departmental Office Building in the State. It expected the work will be completed by June, 2014. Further under Modern Record Room project all legacy record i.e., Revisional Settlement (RS) record are being digitized to increase its self-life and provide e-delivery to citizens, institutions etc.

Measures have also been taken to update the cadastral maps by High Resolution Remote Sensing Imagery (HRSI) and by ground truthing using Electronic Total Station and Geographical Positioning System (GPS). This will take 2-3 years.

Cost for the survey and preparation of cadastral maps and record of rights is provided by the Government. A very small part of the cost is realized from the citizens as cost of copies of the cadastral maps and record of rights. Recently over the counter services (OTC) has been arranged at Block level offices where citizens are being provided copies of record of rights and cadastral maps at a very nominal cost. Measures have been taken to provide these services on-line. Government of West Bengal has constituted Project management unit to implement the programme of modernization of cadastral maps and record of rights on real time basis and to extend on-line service to citizen under National Land Records Modernization Programme (NLRMP) .But Government of India is yet to decide on the cost effectiveness and sustainability of the programme. Also no decision has been taken so far to determine the fee for sustainability of the programme.

\section{Analysis of present status of cadastre and registry}

1. Real time land parcel cadastral map, record of rights and valuation of land reflects the current status of location, area, ownership, land use and value of land. Since transaction in land changes the actual boundaries, area, ownership, use and value of land parcel, there is a lag between current parcel status and that published in cadastral maps, record of rights and valuation of land. In West Bengal cadastral maps of land parcel were updated(revised)and record of rights prepared in last land reforms survey and settlement operation under West Bengal Land Reforms Act 1955 started in 1974. But cadastral maps and record of rights of 1473 revenue villages are still to be updated even after 39 years of starting of survey-settlement operation. Digitized cadastral maps are in Everest Datum. Cadastral maps can be updated and made dynamic if High Resolution Satellite Imagery (HRSI) or ground survey by Electronic Total Station (ETS) are used or aerial survey is done or combination of above methodologies are adopted. This will require conversion of Everest Datum to WGS 84 Datum. West Bengal Land and Land Reforms Department has taken steps to update existing digitized cadastral maps by using HRSI and ETS. Record of rights also do not reflect the real ground situation as there is lag between recoded ownership data in the record of rights and legal transaction of land taking place. This is due to the fact that (a) it is not mandatory for registering authorities to verify if transferor is the recorded owner of land being transferred as per the record of rights. (b) transferee is not required by law to get his name recorded in the record of rights. There is also a lag between value of land in land valuation register maintained by the registering authorities and value at which land transaction takes place because valuation of land is updated sporadically. Unless ownership status is verified by the registering authorities before registering conveyance of land and it is made mandatory to mutate the name of transferee in record of rights land records will never be

244 I Page Land Governance Assessment Framework - West Bengal 
dynamic. Since two different departments are involved in preparing cadastral maps, record of rights \& registering land transaction through deed of conveyance and valuation of land, there is a gap in the coordination of activities of these two departments. It is to be maintained that in most of North Indian States, better coordination has been achieved by bringing all these activities under one single department. However inter connectivity of Land Reforms Offices and Registration Offices by intranet through SDC will help to achieve better coordination

2. Though Land and Land Reforms Department is mandated under Rules of Business of the State Government to manage the Government land, different departments have Government land at their disposal which is managed by the respective departments. Most of Land held by the departments is not recorded in the record of rights of land, though it is the responsibility of these departments to get the land at their disposal recorded in the record of rights. There is also a gap between the quantum of land at the disposal of the Land \&Land Reforms Department and land recorded in the record of rights, particularly Government land settled with the land poor people under Section 49(1) of West Bengal Land Reforms Act 1955 and land settled through lease with private individual and institutions.

3. Area under city of Calcutta (Kolkata) was never taken up for preparation of records of rights at it was excluded from the purview of the Bengal Tenancy Act 1885, West Bengal Estate Acquisition Act 1953 and West Bengal Land Reforms Act 1955. Though cadastral land parcel map was prepared by Mr. R. B. Smart, a British survey officer during 190314, no record of rights of land parcel was prepared and subsequently updated. Calcutta Municipal Corporation maintains ownership record of land parcel on premises basis which is different from the records of rights prepared for the rest of the state. Other Municipal Authorities also maintains ownership records on premises basis though there is record of rights prepared by the Land \& Land Reforms Department for those municipal areas. Therefore the land records maintained by the Kolkata Municipal Corporation are inconsistent with land records maintained for rest of the state.

4. The record of rights prepared first time under Bengal Tenancy Act 1885, clearly indicated the rent payable by owner of the land and the same was revised in revisional survey under West Bengal Estate Acquisition Act 1953. But important information regarding land revenue payable by the owner is missing from the record of rights prepared under West Bengal Land Reforms Act 1955. The state witnessed a high growth in urbanization of rural areas. High rise buildings with complex land use are mark of urbanization. No consistent practice to prepare cadastral map and record the ownership rights of the high rise buildings with common area rights has been put in place to manage such land.

5. The latest cadastral maps and record of rights are derived from the old cadastral maps, record of rights, land conveyance deeds. In case of any dispute over ownership, area, boundary and land use these legacy data help to resolve the disputes. Though legacy records relating to conveyance of deed for land transaction have been digitized by the registering authorities, legacy data of cadastral maps and record of rights are in the process of digitization and will take 2 to 3 years.

6. Managing an integrated cadastral parcel map data, text data of record of rights, legacy data, conveyance deed, registration data, and valuation of land parcel, updating the same and providing information require variety of technical skill and trained manpower. As of now, digitized cadastral parcel map data and text data of record of rights, land valuation \& land registration information are being managed by officers, in addition to their host of other duties.

7. Transfer of land owned by scheduled tribe to person other than scheduled tribe without permission of competent Revenue Officer is prohibited in West Bengal Land Reforms Act1955. But this restriction is not recorded in the RoRs of ST raiyats. Unless this restriction is formally recorded in the RoRs of ST raiyats, illegal transfer of land owned by this marginalised community cannot be detected and stopped.

245 Page Land Governance Assessment Framework - West Bengal 
8. Government of India is funding the digitization of cadastral parcel maps, record of rights, land valuation data, legacy records under National Land Records Modernization Programme on sharing basis with the States. Once this programme will be over there is no assurance that Central Government will share the cost of updating, maintaining and providing information to the public. Also no decision has been taken either by Central Government or State Government with regard to funding mechanism i.e. either Government funding the project and realising the cost from user or by Public Private Partnership mode and collecting the cost from the user on sharing basis.

\section{Source:}

1. Permanent Settlement (Regulation I of 1973)

2. Bengal PatniTaluk Regulation 1819

3. Rent Act 1859(Act X of1859)

4. The Bengal Tenancy Act 1885

5. Report of Floud Commission

6. West Bengal Non Agricultural Tenancy Act 1949

7. West Bengal Bargadar Act 1950

8. West Bengal Estate Acquisition Act 1953

9. West Bengal Land Reforms Act 1955

10. West Bengal Acquisition of Homestead land for Agricultural Labourers, Artisans and Fisherman Act 1975

11. Chas O BasabaserJanyaBhumidanPrakalpa (Homestead and Kitchen Garden scheme)

12. NijoGrihaNijoBhumiPrakalpa (My Home My Land)

13. Publications of Directorate of Land Records and Surveys

14. Circular No:1459-GE(M)/L-20/10 dated 17.03.2014

15. Calcutta Thika Tenancy Act 1949

16. Calcutta Thika Tenancy(Acquisition and Regulation) Act 1981

17. West Bengal Thika Tenancy(Acquisition and Regulation) Act 2001

\section{Panel 7: Land Valuation and Taxation}

\section{Land valuation}

The levy and collection of stamp duty and registration fees on land/ property transfer are regulated under the Indian Stamp (IS) Act, 1899 and the Indian Registration (IR) Act, 1908 and the Rules framed thereunder as applicable in West Bengal. Instruments to be registered under the Acts are chargeable to stamp duty and registration fees at the rates prescribed by the State Government from time to time. The rate is applied to assess the stamp duty. The West Bengal Stamp (Prevention of under-Valuation Instruments) Rules, 1994 came into effect from 31.01.1994 to control under valuation of properties vis-à-vis government dues. The Registering Officers (RO) were empowered to determine the market value of the properties which are subject matter of the deed of sale, gift, exchange, partition, settlement and certain other classes of instruments.

At present in West Bengal the market value of any property (land, building) is determined through the system of the Computerisation of Registration of Documents (CORD) software started in the year 2000. In the computerized scenario digistised base market value database covering all the plots under the jurisdiction of the registering officer has been created as a database and is interlinked with CORD software. A person desiring to transfer or acquire a property shall have to submit the particulars of the property in the appropriate requisition form. Such particulars are fed in the computer database and the system automatically generates the

246 Page Land Governance Assessment Framework - West Bengal 
market value of the property as per parameters provided in the Requisition Form. The digitised market values are periodically revised for this sensitive issue. For this purpose the "Market Value Monitoring Committee" headed by the District Magistrate has been formed at the district level. This committee recommends any such value change periodically annually or bi-annually as per demand of the situation.

\section{Present status of computerization process}

CORD software developed by NIC, West Bengal State Centre is being used to automate the entire process of registration starting from presentation of deed, stamp duty and fees calculation leading to scanning of Registered Deed and finally delivery of the Deed to the party. The entire process has been streamlined and it takes about half an hour to complete a Deed Registration and its delivery to the party.

As stated earlier Market Value Data Base (MVDB) for all registration offices has been prepared and is used for assessment of market value by CORD. Predefined appreciation and depreciation factors were incorporated in CORD for use with MVDB during such assessment to avoid subjectivity in assessment of market value. The system is now working in all 241 registration offices of the state in a PPP model with three technical support providing private partners. The factors so considered are:

A. Type of property:

- Vacant land

- Land with structure

- Flat/Apartment

B. Appreciation/depreciation factors:

- Proposed use of property and nature as in ROR

- Closeness to road and width of approach road

- Age of structure

- Tenanted or not

- Litigated or not

- Availability of facilities like lift, swimming pool, gymnasium etc.

The newly developed computerized system helped in the following manner:

- Citizens are getting their Deed registered in the same day.

- Quality of Deed Registration has improved considerably

- Cost of such service has reduced considerably

- Very less space requirement for storing of records (digital records)

- Saving cost of maintenance of records,

- Complete elimination of pendency of Deed Registration

- Searching is almost immediate by click of a button

- Substantial increase of collection of Government Dues as at a time all dues are being collected.

- E-payment of Stamp duty (e-stamping) has made the hassles of payment almost nil

Standard user-charge based on the number of pages in the deed is collected from the public and is deposited into a separate account maintained in the name of registering officer. The private partners are paid from this account.

MVDB is revised every year and also as per the need. A committee called District Level Monitoring Committee has been formed in every district for verification, modification (if required) and approval of the revision proposal submitted by the registering officers within that

247| Page Land Governance Assessment Framework - West Bengal 
district. Since the introduction of the system, facilities are being added to make it more citizen centric. In November 2011 online assessment of market value and e-payment of Stamp duty and registration fees have been introduced.

The present system working in the registration officers are of decentralized architecture and hence are working in silos. The State Government is planning to introduce centralized registration system connecting all the registration offices to a central server. This will help in providing registration related services electronically and over the web to the citizen in a better manner.

\section{Property tax}

Section 46(1) of the West Bengal Panchayat Act, 1973 provides that a Gram Panchayat shall impose yearly tax on lands and buildings within the local limits of its jurisdiction at one or two percent of annual value of such lands and buildings depending on such value either within one thousand rupees or more. There are provisions of exemptions also in respect of imposition of tax on the basis of equity or religious, charitable, public purposes etc. Annual value in relation to any land or buildings is calculated at six percent of the market value of such property at the time of assessment.

Section 93 of the West Bengal Municipal Act 1993 provides guidelines about the power to levy Property Tax on lands and buildings within the areas of urban local bodies (ULBs). Property tax is one of the main sources of internal revenue of the ULBs. Provisions have been made to determine such property tax on the basis of a formula. But such tax (annual) shall not exceed $30 \%$ of the annual value of the land or building concerned.

a. Present system of assessment:

Presently in the Urban Local Bodies of this State the following two systems of assessment of lands and buildings are followed:

i. Annual Rental Value (ARV) System: In this system tax is calculated on annual rent that is actually or reasonably be fetched by a property. Here Annual Rent $(\mathrm{AR})=$ Monthly actual or reasonable rent X 12. In this system Annual Value (AV) $=\mathrm{AR}$ minus $\mathrm{x} \%$ (in case of Kolkata Municipal Corporation value of this $\mathrm{x}$ is $10 \%$ ) statutory deduction for maintenance. A percentage of AV is determined as the annual Property Tax. In case of Kolkata Municipal Corporation this tax $=(\mathrm{AV}$ $/ 600+10) \%$ of the AV subject to minimum of $11 \%$ and a maximum of $40 \%$.

ii. $\quad$ Capital Value Method: In this system tax is calculated on Annual Value derived from cost of construction added to cost/ market value of the land. Here AV = (Construction cost + Market value or cost of the land) $\mathrm{X}$ a percent as laid down in the statute minus statutory deduction. Annual Tax = AV X a percentage of AV. In Kolkata Municipal Corporation AV of vacant land is determined at $7 \%$ of the market value of the land.

b. Flaws in the existing system of valuation:

Since enactment of the Calcutta Municipal Act, 1923 these two systems are being followed for assessment of lands and buildings in the municipal areas. With growing rate of urbanization and change in the socio-economic scenario the flaws in these two systems are being surfaced, and due to these flaws the system of assessment of lands and buildings is getting more complex and as a fall out the rate of collection of Property Tax is dwindling and simultaneously the scope of tax management is growing. These flaws are as follows: 


\section{Flaws in Annual Rental Value (ARV) System:}

- Subjectivity: "Reasonable Rent" is a completely subjective term, and creates considerable scope for using discretion at even lower level.

- Discrepancy: This system creates wide spread discrepancy by placing similar properties in dissimilar tax pattern.

- Non transparency: Non transparency of this system leads to mutual mistrust and misunderstanding. Apart from this the system creates ample scope of tax management and entry of middleman in the system.

- Wastage of time of officials: Officials remain busier in arguing with the tax payers, cumbersome and lengthy hearing process and file / document management, than to do the duty related to tax administration.

- Non reflection of actual revenue potential: Subletting, subdivision and collusive rent have been hiding the actual revenue potential. Apart from long term tenancy and Rent Control properties lead to low valuation for low rent.

\section{Flaws in Capital Value (CV) System:}

- Limited availability of sales data and unregistered instruments.

- Under reporting of Transaction Price especially for old buildings.

- Freezing of Tax base.

- Need for qualified staff to assess cost.

- Uncertainty of what assets should be covered.

- Scope for subjectivity and discretion and hence non transparency.

- Inequity between similarly placed properties assessed at different points of time. Subjective element of these systems leads to non-transparency, wastage of time of the civic personnel in cumbersome processes, and above all difference of opinion leading to excessive litigations, and thus wastage of efforts of civic personnel and fund in fighting the court cases.

In this situation to ensure a dynamic process of a transparent tax administration a decision has been taken to switch over the system of valuation of properties in Urban Local Bodies to Unit Area System of assessment.

The general valuation of holdings under WBM Act, 1993 shall be made, unless otherwise directed by the State Government, by the Central Valuation Board, established under the West Bengal Central Valuation Board Act, 1978, (West Ben. Act LVII of 1978) and the preparation of valuation list, amount of property tax determined under section 96 on the basis of such valuation list, and disposal of all applications for review shall abide by the provisions of that Act.

\section{c. West Bengal Valuation Board and Property valuation in ULBs}

The West Bengal Valuation Board was constituted after the enactment of West Bengal Central Valuation Board Act, 1978 to bring about a uniform and rational system of valuation of municipal properties throughout the state. The activities of the Board mainly comprise of undertaking valuation work in specified urban local bodies notified by the state government keeping an eye on overcoming inter-ULB anomalies. Annual valuation of a holding is determined as per provisions of Section 106 of West Bengal Municipal Act, 1993. At the present system valuation for a municipality takes place every five years following a resolution to this effected being adopted by the ULB. The draft valuation list is published for the ULB inviting objections within a specified period. The objections are heard and disposed within six months 
following which the final valuation list is published for the ULB. The state government under section 9(2) of West Bengal Valuation Act, 1978 issues notification indicating the date from which the list will come into effect. Starting from 1988-89 till 2006-07, first time valuation has been done for 117 ULBs, 68 ULBs are covered with second time valuation and third time valuation done for 16 ULBs (Total ULBs in the state 126).

\section{d. Property valuation in Kolkata Municipal Corporation area - Unit Area Assessment (UAA) system}

Keeping in parity with most other cities of India, Kolkata Municipal Corporation has undertaken Unit Area Assessment (UAA) System. The entire city is divided into 293 blocks and these blocks are classified into seven categories (A to $G$ ) on the basis of market value, infrastructure, facilities etc. corresponding to each category, (viz. A, B, C, D, E, F, G) an Annual value / sq. ft. i. e, Base Unit Area Value (BUAV) is assigned, category 'A' having the highest BUAV while ' $G$ ' having the lowest BUAV. It ensures equity at the macro level of the properties lying within the same block or similar category block.

However, in order to remove hardship bustee / slum / thika-tenanted area are categorized as 'G', for the purpose of assessment, irrespective of their geographical location under any block or category. Similarly, all recognized RR colonies including settlements under Government notified EWS (economically weaker sections) and BSUP (Basic Services for Urban Poor) Schemes have been categorized as 'E' irrespective of their geographical situation under any block or category unless it belongs to a block whose category is lower than that of 'E'.

To account for the wide heterogeneity among properties within a block, Multiplicative Factors (MFs) are introduced. MFs would account for variations in terms of size, purpose of use, age of the property, location of the property within the block, nature of occupancy and type of structure, which would be clearly notified and used to increase or decrease Base Unit Area Values of different properties as applicable or to keep it same.

As opposed to the current system, a flat tax rate percentage within min-max limit of $6 \%$ to $20 \%$ would be used and notified in the UAA system which does not depend on the Annual Valuation of the property. Already tax rate for developed bustee is fixed at 8\%. Also, in this system, rate of tax of individual ordinary flat will not depend on cumulative AV of all flats in the premises concerned.

Further, before finally fixing the block division and categories a draft notification was published in official Gazette to get suggestion and objection from the citizens. This facility will similarly be extended to the citizen while fixing category wise Base Unit Area Value(s) of properties. To determine such divisions of blocks with different categories, concerned BUAV, MF values, Tax rate etc. a Municipal Valuation Committee is formed which is constituted by expert from different fields of the society. Similarly an Anomaly Review Committee has been formed to consider citizen's feedback towards such categorization. Such categories and values will be revisited once in five year.

A percentage of annual value will be fixed as the property tax. Assessment of property is done by the assessee himself as opposed to the prevalent system where assessment inspectors are responsible for assessment. It is envisioned that the UAA system would be non-discretionary, transparent, equitable, easy to administer and empower the citizen by providing opportunities for self-assessment.

\section{e. Exemption from property taxes payment}

250|Page Land Governance Assessment Framework - West Bengal 
As per provisions of sections 99 to 105 of West Bengal Municipal Act, 1993, Diplomatic Missions, places of public worship, Government or Government aided educational institutions, holdings used for charitable purposes, welfare homes run by the Government and the buildings with a valuation of Rs. 500/- or less are exempted from payment of property tax. In every five years the periodic assessment of holdings is done. Detailed procedure for such assessment is made in the Act.

Similarly the West Bengal Panchayat Act, 1973 states under section 46(2) states about exemptions from imposition of tax by the Gram Panchayat in the area of its jurisdiction. Lands and buildings used exclusively for public purpose, religious, charitable and educational purposes and when the annual valuation of land or buildings is not more than 250 rupees.

\section{Land Revenue}

Chapter IV of the West Bengal Land \& Land Reforms Act, 1955 contains provisions for determining and payment of revenue to the Government of West Bengal, the landlord of all the lands of the state by the tenants - the raiyats. Under the EA Act, the state acquired the rent receiving interests of the intermediaries against compensation. Detailed provisions were made in the Act regarding assessment and payment of compensation. It was therefore, necessary to obtain first what was the amount that an intermediary was actually collecting as rent from his tenants as on the date of vesting with effect from which his rent receiving interests vested in the state. Keeping this purpose of the Act in view when the land records were revised under the EA Act the rent that was actually being paid by the tenants to their immediate landlords were noted in the records. The Act however, provided for determination of revenue during revisional settlement operation in respect of only the lands for which no rent was paid (niskar land or rent free land) or rent was paid in kind. The basis of such determination - the average yield per acre of the class of land concerned prevailing in the vicinity - was provided in the Act. The Act also provided for determination of rent for different classes of land held by tea-gardens.

When the LR Act with chapter IV containing provisions for determination of revenue came into force on 30 March 1956, no determination was made till 14.04.1981 and revenue was being collected on the basis of the rent that was recorded in land records revised under the EA Act in the fifties. Obviously the rate was very low - rupees 3/4 per acre. If we trace the history of why the rate of rent in Bengal was low compared to that prevailing elsewhere in the country when India became free we get an interesting story which establishes that nothing in this world is an unmixed evil. Since Bengal was a permanently settled area it was the Zamindar's prerogative as a proprietor of land to induct tenant thereon at a rent fixed by him. It was again his prerogative to enhance the rate of rent. The government did not gain thereby because the government could not claim anything more than the revenue at which the estate was settled. The government could at best curb the tendency of indiscriminate enhancement of rent as they did by the Rent Act 1859 and the BT Act of 1885 . But in raiyotary areas, since the government settled the lands directly with the tenants at rent fixed by the government it was open to the government to enhance the rate of rent when the government needed more money and land revenue remained principal source of income of the government. Hence the government freely enhanced the rate of rent. This is how the rate of rent soared in raiyotary area whereas in Bengal the average rate of rent remained low because some Zamindars were more sensible than others and considered tenant's ability to pay, but the revenue officials and tahasildars of raiyotary areas mechanically collected rent at enhanced rate.

From 15.04.1979 the government exempted the raiyats owning land up to 6 acres from paying revenue. Only the raiyats owning more than 6 acres of land were to pay the revenue, and the number of such raiyats after implementation of two ceiling laws is not great in this state. This can be safely said that only a few persons in this state pay land revenue.

251|Page Land Governance Assessment Framework - West Bengal 
Exemptions to small land owners gave rise to a practical problem. The Rent Act of 1859 gave occupancy rights to cultivating tenants and the BT Act of 1885 systematised the rights of such tenants on land. In a dispute between the landlord and the tenant the stock plea of the landlord was that the contestant was not his tenant. Since the tenant was not armed with a patta (a document of creation of tenancy) which the landlord seldom granted in clear violation of legal provisions the tenant was at a serious disadvantage to prove his tenancy. The civil courts in course of time and in acknowledgement of the hapless condition of the tenants to contest the denial by the landlords of the creation of tenancy and applying the provision of the BT Act which made granting of rent receipts and maintenance of counterfoils mandatory titled in favour of the tenants and accepted rent receipts as a proof of tenancy. This is how rent receipts came to be regarded as a valuable document to the tenants.

As a result of exemption the tenants holding lands up to 6 acres were not to pay revenue and so not to get any receipt. They apprehended that exemption of revenue which was a paltry sum in any case was going to rob them of the valuable document which receipt to them is. The government took notice of this apprehension and provided in the Act that the tenant would pay different kinds of cess as before and get receipts and such receipts would be as good as the revenue receipts.

The West Bengal Land Holding Revenue Act, 1979 with comprehensive provisions for determination and payment of revenue came into force with effect from 14.04.1981. This independent Act dealing with revenue matters omitted chapter IV of the LR Act as a logical corollary. But the Act met a road block in the Calcutta High Court and was never implemented.

In 2000, the LR Act was amended and chapter IV was reintroduced by repealing the Land Holding Revenue Act 1979, and the amended provisions were given retrospective effect from 14.04.1981. In 2003 and 2005 chapter IV of the LR Act was again amended. The latest table of the rates at which land revenue is to be paid with effect from 17.12.2005 was provided by the amendment of LR Act in 2005.

Meanwhile, during the long period between the fifties of the last century when records revised under the EA Act recorded the rent the tenants were actually paying to the landlords and the end of 2005 land use pattern had undergone a sea-change. The traditional classification of land as agricultural land and non-agricultural land no longer holds good. There have been a lot many stratifications under both the heads. Land has been put to various forms of commercial and industrial uses, as will be evident from the table containing categories of land and the rates at which revenue is to be paid, provided in the Act. Obviously, the rates vary between Rs. 20/- per acre and Rs. 17,500/- per acre. Main features of the table are the following:

Determination of the rates at which revenue has to be paid is not left with any official of the government. The Act has not only laid down the rates at which revenue has to be paid but also categorized the lands to which such rates apply. What is left is only simple arithmetical calculation. Hence, manipulation at the lower level has thus been minimized, if not fully eliminated.

A clear distinction has been made between the lands within municipal areas and lands in nonmunicipal areas. Although for lands used for the purpose of agriculture in both the areas is the same - Rs. 20/- per acre (to be paid by the raiyats holding more than 6 acres of land), for other categories of land in municipal areas the rates are much higher than the rates of similar categories of land in non-municipal areas.

A new concept of "activities allied to agriculture" meaning fisheries, poultries, piggeries, potteries, floriculture, horticulture, sericulture, dairies, livestock breeding and other land based bio-mass production activities - have been introduced and a slightly higher rate of Rs. 30/- per

252|Page Land Governance Assessment Framework - West Bengal 
acre has been fixed. For land used as homestead and non-agriculture purposes other than commercial and industrial practices double the rate of agricultural land has been fixed.

Another new concept of the principle of the ability to pay has been introduced. For the same category of land if it is held by an individual or a cooperative society the rate is much lower than the rate if such land is held by a company. While for land used as homestead or for nonagricultural purposes an individual will pay at Rs. 40/- per acre, a company will have to pay at Rs 150/- per acre, and for land used for brackish water fisheries the individual or a cooperative society will pay at Rs. 200/- per acre but a company will have to pay at Rs. 400/- per acre, and if land is used for multi-storied building by a cooperative society the rate is Rs. 600/- per acre, while for the same land a company will have to pay at Rs. 800/- per acre.

Land in municipal areas has been categorized under five heads - categories A to E, according to the size of the population, plus a special category such as land in Municipal Corporation has been made. While the rate at which revenue is to be paid for land in category E municipal area is the lowest it has graduated upwards and for land within a Municipal Corporation area the rate is the highest.

It is clear from the provisions as to revenue contained in chapter IV that a modern approach has been adopted in determining the rates of revenue for various categories of land. The approach is fairly comprehensive and the principle of equity according to gains a raiyat as defined in the Act including an individual as well as a company makes for putting the land to different uses has been followed.

The revenue for which provisions have been made in chapter IV discussed above is to be paid by the tenants who own lands and pay revenue to the government as landlord because the government acquired the rent receiving interests of the landlords of such tenants. For the lands owned by the government, the approach is absolutely different. When land is settled for nonagricultural purposes how the rent has to be assessed and at what rate premium or salami is to be charged, when sairati interests such as hats, bazars, fisheries etc., are settled what is the procedure to be followed and what should be the rate of rent for such settlement - have all been extensively dealt with in the West Bengal Land and Land Reforms Manual, 1991, under respective chapters. Below table provides the details of land revenue collection in the state for the last four years: (source - DLRS)

\begin{tabular}{|l|l|}
\hline Year & Amount \\
\hline $2009-10$ & $244.06 \mathrm{cr}$ \\
\hline $2010-11$ & $276.54 \mathrm{cr}$ \\
\hline $2011-12$ & $380.16 \mathrm{cr}$ \\
\hline $2012-13$ & $483.71 \mathrm{cr}$ \\
\hline $2013-14$ (till Dec '13) & $236.11 \mathrm{cr}$ \\
\hline
\end{tabular}

\section{Land valuation for compensation purpose}

For acquisition of land in West Bengal, alongside the application of Land Acquisition Act 1894 (Act-I), Land Requisition \& Acquisition Act of 1948 (Act II) was extensively applied up to the nineties of the last century. Presently, much of the land which was requisitioned under LA Act-II have either been acquired under 9 (a) \& 9 (b) of LA Act (Act-I) or derequisitioned and its possession given back. Regarding the determination of compensation for the acquisition of land under Act-I, there are detailed guidelines in Act I of 1894. Broadly, the valuation of land to be acquired is fixed by determining the market value of the land proposed for acquisition. This is done on the basis of consideration of the value for the transfer of lands of a similar nature in the same locality or any nearby locality. Along with this market value, 30\% is added as solatium, and $12 \%$ is added as interest per annum for a period from the publication of Notice under Section 4

$\mathbf{2 5 3}$ | Page Land Governance Assessment Framework - West Bengal 
to the declaration of onward or possession of land, whichever is earlier. This is how the amount granted as compensation is fixed. There are also provisions for computing the value of structures or buildings, if any, on the lands proposed for acquisition. There are also provisions for granting suitable compensation to the bargadars of such lands.

The land acquisition manual prescribes the procedure for arriving at the market value of land being acquired through the LA Act 1894. The market value of the land is arrived at by taking an average of prices paid for a number of land transfers in the area over a period prior to the date of publication of section 4(1) notification. Usually transactions reflecting abnormally high and abnormally low land prices are ignored for arriving at market value of land. The process naturally does not capture the possible future price of land considering the fact that even with the announcement of any project launching or the purpose of land acquisition (industry or infrastructure) the prices will appreciate in the area.

Coverage of compensation for labourers of the lands proposed for acquisition is not taken into account in Act I. Also, when any piece of land is acquisitioned for setting up industry/township, laying of railway lines, market value of lands lying with raiyats in the vicinity of these lands soar up due to the infrastructural improvements in the surrounding areas. The future prospects are generally not taken into account while evaluating the price of the land fixed for compensation. However, this stands to be a policy decision of the State Authority.

The Government of West Bengal, in supersession of all relevant provision laid down in Land Acquisition Manual, 1991 and previous executive orders, issued a revised procedure and administrative rearrangement order dated 6 June 2006, for various land acquisition related purpose including compensation purpose. The following procedures are to be followed for fixation of appropriate market value of each type-class of land:

1. For each of the specified type-class of the land as separately mentioned for rural and urban land, at least 10 and up to 20 current sale data from the concerned mouza to be collected and placed chronologically in the prescribed format. The sale figures from nearest time up to 12 months back time which can be extended up to 36 months as may be required to get minimum 10 sale data for the relevant class-type of land in the mouza. For the extended period from 12 months to 36 months sale price can be increased by $5 \%$ per annum. In case at least 10 sale data for the relevant mouza is not available from the office of the sub-registrar, sale data from adjacent mouza for same type-class of land needs to be considered.

2. Using the sale data collected for each type-class of land in each mouza in prescribed format, fixation of average market value for the type-class of land is done with a reasoned analysis available. This "value assessment sheet" is prepared, signed and countersigned by the designated officials in the district and used for the purpose of both long-term lease and land acquisition purpose.

3. For such fixation of market value of any type-class of land as stated above, abnormally high or abnormally low value (above or below 200\% of the average value reflected in majority of sales) are carefully discarded.

4. For awarding compensation of each plot of land or for fixing up salami for giving longterm settlement of land, additional valuation is determined on the basis of certain prescribed formulae.

5. In cases of developed urban centres, municipalities and corporations, belting method is applied

6. Fixation of value of land located in rural areas: each mouza is divided into seven typeclass of land
a. Non-irrigated agricultural land
b. Irrigated agricultural land
c. Homestead

254 Page Land Governance Assessment Framework- West Bengal 
d. Danga, patit, fallow and other unused vacant land

e. Land under commercial or industrial use

f. Tanks, ponds and other water bodies

g. Government land including vested land, departmental land and public-utility cum common property land

Each of the above seven type-classes of land in rural areas shall get value addition over and above up to maximum of $10 \%$ on the average market value determined.

7. Fixation of value of land located in municipalities and corporations: the classes of land are categorized as under

a. Land under residential use

b. Land under commercial and industrial use

c. Water bodies

d. Public utility land (public roads, parks, cremation ground, burial ground, land under departmental use)

e. Land not covered under above four types-classes

Each of the above type-class of land in municipalities shall get value addition over and above up to maximum of $10 \%$ on the average market value determined

Following are some parameters which presently form the basis of valuation of land in West Bengal:

1. On the basis of following criteria, rates of revenue to be collected from the raiyats are fixed (Section 22 \& 23, Chapter IV, West Bengal Land Reforms Act, 1955 as amended in 2005).

(i) Use of land. For example, for agriculture purposes, for commercial and industrial activities, homestead, fisheries \& tank fisheries and so on.

(ii) Location of the piece of land, i.e., whether it lies in a rural area, municipal area, or municipal corporation area and so on.

2. Consideration value for the transfer of pieces of land between individuals is calculated on the basis of the consideration values for transfer of land in the vicinity over the past 6 months or a year. (Section 23, the land acquisition Act, 1894 an Clause 33 of Chapter III Executive Instructions by Govt. of West Bengal).

3. For collection of stamp duty \& registration fees from the transferors, lessees, etc., the State Govt. has classified the land into different mouzas\& determined the valuation for similar plots of land in the same belts using the Belting Method \& prepared a rate card. The basis of these classifications is the location of land, present use of the land, nature of land, etc. In cities and big towns where the values of lands largely depend on their shape, size, depth and road frontage, belting system is adopted in determining their values in comparison with another plot of known value. For instance, the land from the road is divided into three belts, the first to a depth of 60,80 or 100 feet, the second belt is one and half time the depth of the first belt to a further depth of 90, 120 or 150 feet and the third consisting of all lands behind. The value of second belt is $2 / 3^{\text {rd }}$ of the first belt and that of the third belt is $1 / 2$ the value of first belt or $3 / 4^{\text {th }}$ of the value of the second belt. With the aid of these relative values of the three belts the land under consideration/ acquisition is valued by comparison with known value of a neighbouring land and the average land value is determined. While adopting belting method of valuation, the appraisal should be done judiciously. 
Land valuation as has been said is not a tailor made process. Each land has to be treated as a special and specific case and valued in most appropriate manner so as to arrive at an appropriate market value. It is an opinion of valuation expert and has to be justifiable as such.

Statement of expenditure vis-à-vis collection of stamp revenue and registration fee

\begin{tabular}{|l|c|c|c|}
\hline Year & Collection (Cr.) & Expenditure (Cr.) & $\begin{array}{c}\text { \% of exp. over } \\
\text { collection }\end{array}$ \\
\hline $2002-03$ & 683.38 & 32.99 & $4.83 \%$ \\
\hline $2003-04$ & 766.90 & 32.82 & $4.28 \%$ \\
\hline $2004-05$ & 964.28 & 34.97 & $3.63 \%$ \\
\hline $2005-06$ & 1087.02 & 48.38 & $4.45 \%$ \\
\hline $2006-07$ & 1168.54 & 32.65 & $2.79 \%$ \\
\hline $2007-08$ & 1352.00 & 38.51 & $2.84 \%$ \\
\hline $2008-09$ & 1501.31 & 37.88 & $2.52 \%$ \\
\hline $2009-10$ & 1916.27 & 60.48 & $3.15 \%$ \\
\hline $2010-11$ & 2418.59 & 64.77 & $2.67 \%$ \\
\hline
\end{tabular}

\section{Panel 8: Dispute Resolution and Conflict Management}

\section{Background:}

For analyzing the system of dispute resolution and conflict management in land matters in West Bengal, it will be relevant to briefly discuss about the evolution of land laws in the State since the British Raj, as the extant land laws have a direct link with the previous ones. In this context, it may be mentioned that the four States of Eastern India ie. West Bengal, Bihar, Odisha (part) and Assam (part) formed the Bengal Presidency during the Rule of the British East India Company and Permanent Settlement Regulation was imposed in 1793 for land management and Revenue Collection in this Presidency by introducing the Zamindary or Intermediary system for collection of revenue. As such the land laws and land management of these four States have a strong similarity because of this legacy. But such Regulation was not applied in the rest of the country. It may be mentioned here that in the Northern States of India, there is Mahal-wari system and in the Southern States it is Raiyat-wari system, which are different from the states in Eastern India.

2. The following are the principal land laws since 1885 , which recognized the rights of tenants or raiyats and record of rights were prepared accordingly.

i) Bengal Tenancy Act, 1885

ii) West Bengal Estates Acquisition Act, 1953

iii) West Bengal Land Reforms Act, 1955.

The Bengal Tenancy Act, 1885 contained provisions for dispute resolution at Revenue courts in certain matters like preparation of record of rights etc but in most other matters like settlement of rent rolls etc the appellate forum were civil courts for dispute resolution. Though the BT Act has since been repealed, the first series of RORs were prepared in the District Settlement operation under the BT Act in the State during 1907 - o8 to 1939-40. These RORs were revised in the Revisional Survey \& Settlement operation under the West Bengal Estates Acquisition Act, 1953 and subsequently under the West Bengal Land Reforms Act, 1955.

256|Page Land Governance Assessment Framework - West Bengal 
It is a well-known fact that cases filed for resolving disputes in judicial courts go through a longdrawn process and as such the legislature in the State incorporated provisions in the subsequent Land Laws, which have kept most of the causes of land disputes beyond the jurisdiction of civil courts. Better dispute resolution mechanisms are available in the provisions in these Laws and connected Rules in West Bengal. On one hand, extensive bar to civil jurisdiction regarding land disputes has been introduced, especially in the West Bengal Land Reforms Act, 1955, as well as in the earlier West Bengal Estates Acquisition Act, 1953, on the other hand there are provisions in most of the chapters of the WBLR act, for dispute resolution in the Revenue Courts which are quasi judicial in nature and much less time consuming so that litigants may have faster relief. This will be evident if we analyze the relevant provisions in the Land Laws and rules in the State.

\section{Analysis of provisions in the Land Laws for dispute resolution:}

\section{A) WBEA Act 1953:}

(i) Sec $57 \mathrm{~B}-$ Bar to civil jurisdiction in respect of certain matters, including preparation or revision of Record of Rights, any alteration of any entry in the ROR etc.

(ii) Appeals in certain matters like determination of compensation etc were to be preferred to a special judge or tribunal appointed for this purpose, and not in civil courts.

These provisions were obviously incorporated for faster conflict resolution than civil courts.

Section 44(2)(a) of the WBEA Act provides for correction of RORs, finally published during 1954 - 1960. The force of the provision is being extended from time to time (presently till 2017) for providing relief to the raiyats in case of dispute in EA RORs in the Revenue court.

Bar to civil jurisdiction is there in almost every chapter of WBLR Act and also bar to engaging advocates point to the wish of the legislature to provide easier, faster and less costly mode of dispute resolution to the litigants.

\section{B) WBLR Act, 1955}

\section{Provisions to bar the jurisdiction of the Civil Courts:}

i. Chapter IIA - Restriction of Alienation of land by Scheduled Tribes - Bar to civil jurisdiction u/s 14I

ii. Chapter IIB - Ceiling Laws - Bar to civil suits regarding determination of land ceiling $\mathrm{u} / \mathrm{s}$ 14X

iii. Chapter III - Bargadars - Bar to civil jurisdiction u/s 21 regarding matters u/s 17, 18, 19B \& 20B. U/s 21(3), Civil or Criminal court will refer the matter regarding determination of Bargadarship to the Authority u/s 18(1).

iv. Chapter VIIA - Preparation or revision of ROR - Bar to civil jurisdiction u/s 51C(1) \& (2).

v. Chapter IX- Bar to civil court u/s $61 \mathrm{reg}$. determination of the Revenue Officer in land matters under provisions of this Act.

Cases related to Title determination (Title Suits) are disposed of by Civil Courts.

Provisions for dispute resolution in Revenue courts during preparation or revision of record of rights (RORs) under the WBLR Act, 1955:

For Preparation of land records in West Bengal the unit of survey and settlement is a mauza or a revenue village. When an order is passed by the Revenue Authorities on behalf of the Government that the record of right of any mauzabe revised or prepared u/s 51 of the WBLR Act, the RORs are prepared or revised by following the process under Schedule A of Rule 22 of the WBLR Rules, 1965:

257|Page Land Governance Assessment Framework - West Bengal 
i) Theodolite Traverse Survey

ii) Cadastral Survey

iii) Preliminary record writing ( Khanapuri)

iv) Local explanation (Bujharat)

v) Attestation

vi) Publication of draft record of rights (RORs)

vii) Disposal of objections

viii) Preparation and publication of final record of rights (RORs)

Provided that any of the steps referred to any of the items (i) to (v) may be omitted or amalgamated with previous permission of the Government.

Let us now discuss in brief about the work done at individual stages as noted above, to examine the scope of dispute resolution from the very beginning of record preparation in the State:

A) We have already stated that the mapping and recording system in West Bengal are different from the States in Northern, Western or Southern India. In those states, maps are prepared for individual plot/ holding / survey numbers showing dimensions of each side of the plot/ holding / survey numbers, where as the unit of cadastral mapping and preparation records in West Bengal is an entire mauza or a revenue village, area of which may vary fro 100 acres to 10,000 acres. No dimension of the plots are shown on the map as the survey is done by engineering survey method, in which maps are prepared in a particular scale, so that the area of individual plots are extracted from the map itself. Theodolite Traverse survey is first conducted to establish control points of high accuracy in and around the mauza and then detailed survey is conducted by cadastral survey methods to survey all plots inside the mauza, using those control points to maintain accuracy to prepare the cadastral map of the mauza. Each plot is then numbered for preparation of record of rights by field verification in presence of the Raiyats.

B) In the stages called Khanapuri and Bujharat, Preliminary records are prepared in presence of the Raiyats, and the contents of the records are explained to them. There is scope for dispute resolution as necessary corrections are made both in maps and records if any objection is raised at this stage.

C) During Attestation stage, a proclamation is issued in the concerned mauza requesting all raiyats to be present during attestation of the records by the Revenue Officer, who incorporate changes in the map and records wherever objections are raised by giving opportunity of representation to all interested parties, thereby allowing the raiyats to have opportunity of resolving disputes during Attestation.

D) After Attestation, The total record of rights of the mauza are placed in Draft Publication at the office of the Revenue Officer and kept open of one month for public inspection and inviting objections if any. The Revenue Officers dispose of the objections by giving opportunity of hearing to all interested parties and incorporated corrections in the maps and records accordingly and resolve any dispute raised before him.

E) After disposal of all objections at the Draft Publication stage, the RORs are then placed for Final Publication and again kept open for public inspection for one month.

There are provisions for preferring objection even after final publication of RORs $\mathrm{u} / \mathrm{s}$ $51 \mathrm{~A}(4)$ and $51 \mathrm{~A}(5)$ to superior Revenue Officers, including the Collector.

F) Orders passed by the district revenue authorities were challenged previously at the High Court of Calcutta. As disposal of the appeal cases in High Court was very slow and a large number of cases piled up, West Bengal Land Reforms \& Tenancy Tribunal

258|Page Land Governance Assessment Framework - West Bengal 
was created in 1997 by enacting the West Bengal Land Reforms \& Tenancy Tribunal Act 1997, which started functioning in 1999 for expediting disposal or disputes under six specified Acts, including the WBEA Act 1953 and WBLR Act, 1955. This was done in pursuance of the amendment of the Constitution of India under Article 323B. This Tribunal has the power of the single Bench of the High Court with article 226 and 227 of the Constitution of India. The Tribunal has so far disposed of more than 30000 Transferred Appeal cases from the High court.

G) There is sanctioned strength of four Benches at the Tribunal, out of which two are functioning now. As per record, 4101 Original Applications (appeals) were filed during 2012 , out of which 2015 cases have been disposed of within 2012. Had the other two Benches been functioning then the pending number of cases would have been minimal. (Source: Report of the WBLR\&T Tribunal to the Government.)

H) The total number of post Final Publication cases pending before the Revenue Authorities is 4,29,601. Though apparently the number appears to be very large, but taking into consideration the total number of Finally Published Mauza being 39,838, the average number of disputes pending per mauza comes to about 11. However, the cases should have been disposed of earlier. (Source: Directorate of Land Records, West Bengal report to the Government for October 2013).

4. During the investigation in the assigned area in the theme of Dispute Resolution and Conflict Management in Land matters, different aspects of land dispute resolution mechanism have been looked into and analyzed, as stated above and suggestions for remedy on weak points have been made as follows:

\section{A. Time taken for Dispute Resolution on land related matters in Courts:}

The percentage of litigations related to land and property matters in respect of overall number of cases in the State is approximately 20\%, taking into consideration of the cases pending in different courts, from the District Courts to the High Court. On a comparative study of Revenue Court cases with Civil Court cases on land related disputes, it has been observed that a litigation is disposed of at an average period ten months in a Revenue Court while in a Civil Court a Title Suit is seldom resolved before two years in the earliest.

A Case Study of a Revenue Court: Mutation Case No. MT/ 3652/13 u/s 50 of the WBLR Act revealed that the case was filed on 04.022013 for mutation of the applicant's name in the Revenue Records, which was disposed of on 10.05. 2013. Thereafter, Revenue Appeal was filed by the concerned party on 01.07.2013 and the appeal was disposed of 31.12.2013. Thus it took about ten months for dispute resolution, including appeal, in the Revenue Court.

This is the general time frame for disposal of record correction /mutation cases in Revenue Courts.

In a Case Study of a Civil Court Case, it was found that Title Suit No 54 of 1981 was filed before the Ld. Munsiff in the month of January 1981 and it was disposed of on 19.08.1983, after 18 hearing dates.

\section{B. Suggestions for early disposal of Land related disputes:}

i) Early disposal of record correction cases, mainly Mutation cases, by the Revenue authorities, is impeded when difference exists between the facts in the Land Records maintained Revenue authorities and that in the records of the Registration Department. As such, a system should be

259|Page Land Governance Assessment Framework - West Bengal 
introduced for interlinking the two departments so that simultaneous updation of Land Records can be done when any transfer is executed (through the Registration Department). This is possible in West Bengal as Land Records maintained by the Revenue Department (i.e. the Land Reforms Deptt.) have all been computerized, and the functioning of the Land Registration Department has also been fully computerized. The bridging between the two systems will keep the records updated and thereby reduce the scope of disputes in this sphere to the minimum.

ii) In other Revenue cases, the litigants are served notices by the office and it becomes quite time consuming for various reasons. In civil courts, the litigants are asked to serve notice to all interested parties and the plaintiff, in his own interest, takes all steps to make it a good service to other parties. Similar system of service should also be introduced in the Revenue courts for reduction of time for servicing of notices. Also no unnecessary adjournments should be granted. There should be specific time frame for disposal of cases (say, within two months in normal cases).

iii) For early disposal land dispute related cases, which are mainly Title Suits, adjournments should be avoided, if sought on unreasonable or filmsy grounds. In some cases it has been observed that more than 50 dates have been given before final disposal. There should specific provision in the laws that a suit be disposed of within a year, if not earlier. For this purpose, necessary amendments in the relevant rules of the Civil Procedure Code are required.

\section{Classification of land related disputes:}

On a study of different types of litigation related to land in the State, especially cases instituted before the Land Reforms Tenancy Tribunal, it appears that the average percentage of cases instituted for different causes in land disputes may be classified as follows:

i. Incorrect measurement of land - 05\%

ii. Erroneous apportionment of share - 33\%

iii. Incorrect Mutation - 25\%

iv. Sale / purchase related issues - 10\%

v. Inheritance issues - $20 \%$

vi. Encroachment on Govt. land 07\%

\section{Suggestions for improvement in dispute resolution:}

Procedure with time schedule for preparation and revision of record of rights has been prescribed in the WBLR Rules. There are several stages during the preparation / revision of land records when the litigants have scope for participation in the proceedings. But fact remains that non-participation or absence of the parties during the relevant stages of preparation of land records is one of the causes of faulty recording in land records. Lack of awareness on the part of the stake-holders is a major reason for such absence. Steps should be taken for awareness development by wide publicity through local print media or electronic media, which would ensure greater public participation. This will help in reducing future litigations.

However, the present provisions of the Law have provided scope for resolving any dispute, if the litigant approaches the Revenue Authorities.

\section{E. Rate of filing cases:}

The West Bengal Land Reforms and Tenancy Tribunal was constituted in 1998 as per provisions of the WBLR\&TT Act, 1997, which was enacted under the guideline of the Article 323 B of the Constitution of India. The rate of filing of cases in the Tribunal is around 4000 per annum. The number of cases filed in the year 2012 was 4101 and the number of cases disposed of was 2015, i.e. approximately $50 \%$ of the cases filed.

260|Page Land Governance Assessment Framework - West Bengal 
The Tribunal has a sanctioned strength of four Benches, out of which two are operational now. The other two are not functioning because of shortage of Tribunal Judges.

(Source: Report of the WBLR\&T Tribunal to the Government.)

\section{F. Suggestions for improvement:}

The other two Benches, each with one Judicial Member and one Administrative Member, are required to be made functional in the earliest, so that achievement in dispute resolution may be almost $100 \%$ at this forum.

\section{G. Cost of litigation:}

The cost of litigation borne by the litigant varies from court to court. In cases before the Revenue Authorities, the cost of both the litigant and the Government is minimal, as the litigant can plead his case in person or through his representative, who may be a lawyer.

However, in Civil Courts, a litigant has to bear a considerable amount of cost towards the fees of lawyers for pleading his case. Poor litigants may take the help of Legal Aid Services, but the prevailing system in the State does come to much of a help for them. The cost of litigation in the Civil Courts, including that of the Tribunal or the High Court may vary from Rs 5000/- to Rs 50,000/-, depending upon the status/seniority of the Ld Advocate.

\section{H. Suggestion for Redressal:}

The function of the Legal Aid Services is to be improved so that the poor litigants can avail the aid in true sense and spirit, enabling them to protect their interest on their lands.

\section{Long Pending cases related to land disputes:}

On study of long pending cases in the Land Reforms Tenancy Tribunal, the grounds for such pendency appear to be:

i. Repeated adjournments sought by the applicant,

ii. Non-availability of the Lawyer because of his otherwise engagements in other courts

iii. Non-submission of proper records or papers by interested parties, including the Government.

iv. Evidence of good service of notices to interested parties (especially when there is a large number involved) etc.

\section{J. Suggestions for remedial measures:}

The above- mentioned grounds mainly relate to court cases and rarely to Revenue courts.

For remedial measure, the following steps may be taken:

i. $\quad$ There should not be any unnecessary adjournment, even on lawyer's ground

ii. The concerned Departments should ensure timely submission of proper records and papers.

iii. The number of dates for disposal of a case should be limited, preferably three dates and those should also be allowed within a short span.

\section{K. Importance of Training in speedy Resolution of Land Disputes:}

Training plays an important part in the speedy and effective system of dispute resolution in the State, both in respect of functionaries in the revenue courts and in the civil courts. State Government should design and take up an intensive, continuous and comprehensive training

261|Page Land Governance Assessment Framework - West Bengal 
and capacity building programme for all Revenue Officers, who are engaged in dispute resolutions at different stages.

Similarly, training on land laws and rules should also be an important component of the training programme of Judicial Officers, who may play a positive role in expediting resolving land disputes. Even there are instances where Civil Courts have passed orders in land matters, where there are specific Bars to Civil Jurisdiction as per extant Land Laws, thereby complicating the disputes.

From the above discussion and analysis it transpires the extant land laws in West Bengal have in-built mechanism of dispute resolution at Revenue Courts which take much lesser time to dispose of cases than Civil courts, which mainly dispose of Title cases (Title Suits), including partition, pre-emption cases etc in land related matters.

\section{Panel 9: Institutional Arrangements \& Policies}

\section{A. Institutional mapping}

Land continues to be of enormous economic, social and symbolic relevance in West Bengal and across the country. Most of the population in the villages depends on land. Therefore, land is very important and dear to the villagers who constitute $70 \%$ of the population of West Bengal. The total land in the state is $86,87,540$ hectares, out of which the net cultivated area is $54,63,678$ hectares. This land is about $63 \%$ of the total area and is held by 430 lakh land holders/ raiyats.

Board of Revenue, the apex administrative body, which was active in colonial state formation during the company period, played a crucial role in revenue management prior to the departmentalisation of state affairs. The establishment of the Calcutta Revenue Council and Patna Revenue Council in 1770 heralded the colonial state formation. Both the councils were planned to be co-ordinated by an apex body called the Board of Revenue in Calcutta. Since then it was reconstituted and reorganized in 1786, 1793, 1822, 1829, 1861, 1889 and 1913 to meet the growing demands of State revenue administration. After Independence, Land and Land Revenue Department was reconstituted to augment agrarian reforms including tribal welfare and revenue collection. However, in 1952, a separate department of the Tribal Welfare was formed. From 1977 the department was renamed as Land and Land Reforms Department.

Till 1996, the Board of Revenue, West Bengal, a branch of the Land and Land Reforms Department with independence in some matters exercised and discharged the following powers and functions, namely :-

(a) The recovery of agricultural and land improvement loans;

(b) The administration of Acts relating to the collection of public demands and sums recoverable as a public demand;

(c) The management of Government estates, attached or encumbered estates, the Murshidabad Estate and the administration of Acts relating to -

i. Land Records,

ii. Survey, Settlement and Colonisation,

iii. Alluvion and Diluvion,

iv. Waste Lands,

v. Government Lands and Estates,

vi. Partition of Estates,

vii. The assessment and collection of Land Revenue,

262|Page Land Governance Assessment Framework- West Bengal 
viii. Miscellaneous revenue subjects such as treasure trove, escheats, money orders, revenue agents;

(d) Supervision and control of all establishments employed in the discharge of the functions referred to in clauses (a) to (c ) above, save in respect of services for which any other appointing authority is prescribed, and the appointment, posting, transfer, promotion, punishment and discharge or dismissal of, and the promotion, punishment and discharge or dismissal of, and the grant of leave to persons so employed, in accordance with the rules and principles laid down by Government in this behalf.

In the year 1996 Board of Revenue was abolished and merged with the Land and Land Reforms Department. At present the L\&LR Department administers agrarian reforms, land management, collection of land revenues and cess.

1. The Land \& Land Reforms Department of Government of West Bengal is the basic department entrusted with all activities relating to land and land reforms of the state. It is one of the biggest departments of the state.

2. Directorate at state level: Under the L\&LR Department lies the Directorate of Land Records \& Surveys. This Directorate is also one of the biggest Directorates of the state. The Director is responsible for preparation and revision of maps, preparation, revision and maintenance of records of rights and implementation of all land reforms activities laid down in the West Bengal Estates Acquisition Act, 1953 and West Bengal Land Reforms Act, 1955 and the Rules framed thereunder as well as the other Acts and Rules the implementation of which are entrusted to the DLR\&S.

3. District level: Each district has a District Land \& Land Reforms Officer who is assisted by one or more Deputy District Land \& Land Reforms Officers and other technical and nontechnical staff. The DLL\&RO enjoys all the powers of the Collector of a district. He works under the direct supervision and control of the DLR\&S and in charge of all land and land reforms activities of the district.

4. Sub-Divisional level: There is a Sub-Divisional Land \& Land Reforms Officer, who works under the supervision and control of the DL\&LRO. The SDL\&LRO directly supervises the works of the Block Land \& Land Reforms Officers within the respective sub-division.

5. Block level: At each block there is a Block Land \& Land Reforms Officer. He is the main functionary in the hierarchy of the land and land reforms administration. His job relates to:

a) Preparation and revision of maps, and preparation, revision and maintenance of records of rights, and custodian of such records

b) Implementation of land reforms measure, such as application of the ceiling provisions, distribution of vested land, protection of bargadars etc., management of land at the disposal of state government falling within his jurisdiction and utilisation of land

c) Quasi-judicial matters - implementation of regulatory provisions of the Acts and Rules, disposing of disputes between the bargadars and land-owners, harvesting disputes etc.

He is assisted by two/ three Revenue Officers to look after the respective branches of work under his overall supervision.

6. Gram Panchayat level: At this level there is a Revenue Inspector whose job is to collect revenues and cesses and other government dues, to do crop survey and agricultural census and do such other jobs relating to preparation and revision of maps and preparation, revision and maintenance of records of rights, land management and land utilisation as may be assigned to him by the higher authorities.

263|Page Land Governance Assessment Framework - West Bengal 
To meet the various requirements of other departments and agencies, acquisition of land under different Acts is also made by the Land \& Land Reforms Department which acts as the appropriate government in the state.

For acquisition of land within the city of Kolkata comprising the first 100 wards of Kolkata Municipal Corporation, the First Land Acquisition Collector, Kolkata acts as the agent of the state government.

For acquisition of land in the districts, the Collectors of the districts act as the agents of the state government. Each Collectorate has been provided with a separate land acquisition wing with a number of Land Acquisition Officers. This wing of the Collectorate carries out the instructions of the state government at different stages of land acquisition.

Therefore, all activities relating to land and land reforms and acquisition of land are carried out in this state under the unifying command of the Land \& Land Reforms Department. And all such activities are to be carried out in accordance with relevant Acts, Rules made thereunder and Land \& Land Reforms Manual and Land acquisition Manual. All these taken together give out the policies of the government.

So, there is hardly any scope of overlapping in land and land reforms administration in the state. The lands held by other departments, like the traditional Irrigation and Waterways department, PWD department and Forest department and the new ones like the Kolkata Metropolitan Development Authority (KMDA), a statutory authority under the Urban Development Department, and West Bengal Industrial Development Corporation, a corporation under Commerce and Industries Department as well as West Bengal Industrial Infrastructure Development Corporation, were given to them for utilisation for specific purposes. KMDA holds lands for construction of township, vital roads in and around the city of Kolkata and WBIDC and WBIIDC are given land for the purpose of making lands available for industrial purposes.

\section{Some of the important Acts administered by the Land \& Land Reforms Department}

\section{State laws}

1) The West Bengal Estates Acquisition Act, 1953

2) The West Bengal Land Reforms Act, 1955

3) The Land Acquisition Act, 1894 (now repealed and replaced by The Right to Fair Compensation and Transparency in Land Acquisition, Rehabilitation and Resettlement Act 2013

4) The West Bengal Land Reforms and Tenancy Tribunal Act, 1997

5) The West Bengal Premises Tenancy Act, 1997

6) The West Bengal Land Development \& Planning Act, 1948

7) The West Bengal Acquisition of Homestead Land for Agricultural Labourers, Artisans and Fishermen Act, 1975

8) The West Bengal Restoration of Alienated Land Act, 1973

9) The Kolkata Land Revenue Act, 2003

10) The Bengal Survey Act, 1875

11) The West Bengal Public Land (Eviction of Unauthorized Occupants) Act, 1962

12) The West Bengal Thika Tenancy (Acquisition and Regulation) Act, 2001

\section{Central laws}

1) Contract Act, 1870

264 I Page Land Governance Assessment Framework- West Bengal 
2) Transfer of Property Act, 1882

3) The Registration Act, 1908

4) Indian Stamp Act, 1899

5) The Limitation Act, 1963

6) The Indian easements Act, 1882

\section{Major Field level functions relating to land and land reforms}

- $\quad$ Settlement of land u/s 49(1) W.B.L.R. Act and issue of pattas (Deed of settlements)

- $\quad$ Recording of bargardars

- $\quad$ To ensure that the restrictions imposed by law on the use of land are not violated by the raiyats

- $\quad$ To ensure that protection to the tribal raiyats given by law is not violated

- $\quad$ To adjudicate disputes / conflicts between land owners and bargadars in relation to share of produce, termination of barga cultivation, eviction etc.

- $\quad$ Assessment of land revenue and collection thereof.

- $\quad$ Maintenance of r-o-r.

\section{B. Rural Framework}

India became independent in 1947. In the debate of the Constituent Assembly on the right to property, it was unanimously resolved that the cultivators of land should be conferred with the rights to hold land directly under the state by abolishing the estates and eliminating the intermediaries. The Constitution of India came into force on 26.01.1950. The articles 31, later $31 \mathrm{~A}, 31 \mathrm{~B}$ and $31 \mathrm{C}$ provided for acquisition of estates and all pre-existing rights of the intermediaries.

In pursuance to these Constitutional provisions different States passed legislations to abolish Zamindary. In this State, the West Bengal Estates Acquisition Act 1953 (EA Act) was passed. It came into force on $12^{\text {th }}$ February 1954.

The EA Act had two objects:

e) To abolish Zamindary - that is all rent receiving interests;

f) To impose a ceiling on land held by individuals.

To carry out purposes of the Act records of rights were revised to obtain the position of land as on 15.4.1955 or 16.4.1956 as applicable - the dates with effect from which all lands and rights therein vested in the state. Those who held land on and from that date became tenants directly under the state.

\section{The West Bengal Land Reforms Act, 1955}

As a follow-up of the EA Act by a comprehensive measure of land reforms so as to remodel the system of land tenure, the West Bengal Land Reforms Act 1955 (LR Act) was passed. It came into force on 30.03.1956. According to the present definition of a raiyat under the Act whoever holds land for any purpose whatsoever is a raiyat and land as defined in the Act means land of every description.

The LR Act deals with the following:

\begin{tabular}{|c|c|}
\hline Chapter & \multicolumn{1}{c|}{ Subject dealt with } \\
\hline II & Rights and obligations of the raiyat, right is heritable and transferable, but \\
\hline \hline 265 | P a g e L a n d G overnance A s sessment Frame work - W e st Bengal
\end{tabular}




\begin{tabular}{|c|l|}
\hline IIA & without any sub-soil right \\
\hline IIB & Restrictions on alienation of land by a Scheduled Tribe \\
\hline III & Rights and obligations of bargadars (share croppers) \\
\hline IV & $\begin{array}{l}\text { Provisions for determining and payment of revenue to the Government of } \\
\text { west Bengal by the raiyats }\end{array}$ \\
\hline V & $\begin{array}{l}\text { Provides for consolidation of plots of land and formation of co-operative } \\
\text { farming societies (post reform measure) }\end{array}$ \\
\hline VI & $\begin{array}{l}\text { Deals with principle of distribution of land at the disposal of the state } \\
\text { government }\end{array}$ \\
\hline VII & Maintenance of records of rights up to date \\
\hline VIIA & Provides for preparation or revision of record of rights \\
\hline VIII & Management of land \\
\hline
\end{tabular}

\section{Implementation of the reforms: an overall assessment}

Thus the two Acts - EA and LR Act form the legal framework for West Bengal land reforms with focus on the following:

- $\quad$ Abolition of Zamindary and all rent-receiving interests [WBEA]

- Imposition of ceiling on land held by individuals [WBEA]

- $\quad$ Bringing all the tenants directly under the State with equal status [WBEA]

- $\quad$ Imposition of new ceiling according to the size of a family [WBLR]

- $\quad$ Distribution of ceiling surplus land (WBLR)

- $\quad$ Abolition of distinction between agricultural land and non-agricultural land [WBLR] and Non-agricultural tenants treated as raiyats [WBLR]

\section{Hiatus between policy and implementation}

Gap between legislation and implementation: Some land reforms measures provided for in the WBLR Act such as consolidation of holding, formation of Co-operative Farming Society and Co-operative Common Service Society have not been implemented by the successive governments.

Gap between programme and implementation: The Directorate of Land Records and Surveys is the main agency through which all the provisions of the WBLR Act are implemented. One of the main programmes is to revise the records of rights to record the updated position of land:

\begin{tabular}{|l|c|c|c|}
\hline \multicolumn{1}{|c|}{ Item } & Programme & Implementation & Short fall \\
\hline $\begin{array}{c}\text { *1. Final publication } \\
\text { of record-of-rights }\end{array}$ & 42042 (villages) & $\begin{array}{c}\text { [ Aug, 2013] } \\
\text { 40537(villages) }\end{array}$ & 1505 \\
\hline $\begin{array}{l}\text { *2. Recording of } \\
\text { pattadars in the } \\
\text { ROR }\end{array}$ & 3136297 & 2455961 & 680336 \\
\hline
\end{tabular}

The gap in case of (1) is not large, but for (2) it is quite significant.

266 Page Land Governance Assessment Framework- West Bengal 
Land records and updation: The provisions under Sec.50 to keep the RoR up-to-date have not been implemented. All the changes that are taking place regularly are not being incorporated in the records. According to the present system the onus is on the successor to take action for recording the changes. Since it is the obligation of the government also to keep the records up-to-date ways have to be found out to make the government take the initiative.

In all the record of rights -taken up from the first decade of 1900 under the BT Act, revised in the fifties under the EA Act and again revised under the LR Act taken up from 1975 possession of land of whatever kind has been recorded faithfully.

Persons possessing government land without being legally inducted on such land have been recorded as "unauthorized occupiers". Persons forcibly occupying the lands of another private person have been recorded as "forcible occupiers". Persons possessing lands on permission from the owners of such lands have been recorded as "permissive possessors". Legally speaking, such possessions differ in character and import. But the fact remains that possession of any kind has scrupulously been recognized in this state. However, recording of possession of government land that is unauthorized possession has not been recorded in recent times to avoid legal complications.

\section{Urban framework}

Premises tenancy - Before the wounds of the World War II could be fully healed up came the partition of India bringing lakhs of displaced persons from the erstwhile East Pakistan. Housing problem took a new shape and assumed a new dimension. The new state government of Independent India thought of a comprehensive measure, not only to control profiteering in rent but also regulate landlord-tenant relationship and provide protection against eviction on landlord's pleasure. Temporary measures taken in 1948 and 1950 paved the way for more comprehensive and precise West Bengal Premises Tenancy Act, 1956. However, this pro-tenant law created its own problems. The landlords did not maintain the buildings and no new investment was made in housing sector. Since this became an all-India phenomenon the Central government took the initiative in changing the bias of the rent control legislation. A model act was drafted and sent to the states to consider. West Bengal decided to change the Act of 1956.

The policy of the state government was to provide protection only to the relatively poorer tenants and restrict the heritable right. Eventually the government succeeded in enacting the West Bengal Premises Tenancy Act, 1997 replacing the 1956 Act. The main features of the Act are: (a) a cut-off rent was fixed. Tenants paying rent above that would not come within the purview of this Act; (b) Some restrictions have been put on the right of inheritance of tenancy; (c) Civil Courts' jurisdiction has been ousted; (d) Provisions have been made for automatic increase of rent.

Thika Tenancy: Right from the early days of the city of Calcutta and its sister town Howrah there existed a precarious tenancy popularly known as thika tenancy meaning a tenancy in which the interests of the tenants are not permanent. In a premises tenancy, the landlord is the owner of both land and the structures made thereon, but in a thika tenancy the landlord remains the owner of the land and the tenant becomes the owner of the structures.

The thika tenants were virtually tenants at will and hence could be evicted any time. An ordinance stopping eviction was promulgated in 1948 and the next year the Calcutta Thika Tenancy Act, 1949 was passed. It extended to the city of Calcutta and the municipal areas of Howrah. The main object of the Act was to restrict the landlord's right to evict the tenants. 1981 saw the emergence of completely a new legislation- The Calcutta Thika and other Tenancies and Lands (Acquisition and Regulation) Act, 1981. Under this Act the lands and interests therein of the landlords vested in the State and the thika tenants became tenants directly under the State. Rights of the thika tenants thus became secure. Eventually the Government replaced the Act of

267|Page Land Governance Assessment Framework - West Bengal 
1981 by West Bengal Tenancy (Acquisition and Regulation) Act, 2001. The Act was amended in 2010 to bring within its fold "certain other tenancies". This Act as its title suggests was extended to all the municipal areas of the State.

The Urban Land (Ceiling and Regulation) Act, 1976: As the title suggests this is not a landlord tenant law. Its objectives are the following-

(1) To prevent concentration of urban property in the hands of a few persons and speculation and profiteering in such property;

(2) To bring about socialisation of urban land to sub serve the common good by ensuring its equitable distribution;

(3) To discourage construction of luxury housing leading to conspicuous consumption of scarce building material;

(4) To secure orderly urbanisation.

To achieve these objectives the Act provides for imposition of ceiling on vacant land, acquisition of excess vacant land by the state governments with powers to dispose of the vacant lands thus acquired to subserve the common good, regulation of the transfer of vacant land within the ceiling limit and also land with building and restriction on the plinth area of the residential buildings to be constructed in future.

For equitable distribution the Act provided for the following:

(1) To allow a person to hold excess vacant land if such person intends to utilise such land for construction of dwelling units for weaker sections of the society;

(2) To empower the state government to allot excess vacant land that has vested in the state for providing residential accommodation to the employees of any industry;

(3) To empower the authority under the Act to have first option to purchase vacant land sought to be transferred by a person holding land within the ceiling limit.

In West Bengal, no action under the above three heads has been taken.

The object of prevention of concentration of lands in fewer hands has also turned out to be a failure. Under the Act the extent of land occupied by a building, land appurtenant thereto meaning the spaces to be compulsorily kept open for the enjoyment of such building and additional extent of 500 square meters of land if such building or any part thereof is used for residential purposes- is not vacant land. No part of such land will vest in the state. Therefore, any rich man intending to purchase all the lands with buildings of the city of Calcutta can do so without breaking the law. The Act therefore has failed to achieve its main objectives

In respect of land to which only the WBLR Act applies (such land consists more than 99\% of the total land of the state) severe restrictions have been imposed on change of use from its present position, and particularly from agri-use to non-agri-use, without thinking of the need of land for infrastructure, industry or urbanization. It was thought that agriculture would provide the best employment opportunities to accommodate those who live off land. Moreover, it would also provide total food security and maintain ecological balance. These were the public purposes as conceived of by the policy makers in the 1980s, and the restrictions on land rights served such purposes. But now it is found that there is need for more infrastructure, industry and urbanization in the state. Agriculture can no longer sustain all the rural people; and employment opportunities have to be created by developing infrastructure etc. One may very well question whether the existing restrictions are serving public purpose or not anymore?

Urban Land (Ceiling and Regulation) Act, 1976 was enacted to bring parity between the holders of agriculture land already subject to ceiling law and the holders of urban land. However, the

268|Page Land Governance Assessment Framework - West Bengal 
public purpose of meeting the increasing demand for housing has been hindered. There is a mismatch between the supply of and the demand for urban housing in the state.

The importance, however, has been paid to ensure planned urban development, of course within the framework of ceiling provisions under the WBLR Act and ULCR Act, as the case may be. The West Bengal Town \& Country (Planning and Development) Act, 1979 and the rules framed thereunder in 2008 and 2010 have made detailed provisions relating to the use of urban land for various purposes. There are regulatory measures meant to prevent haphazard and unplanned urban development. Since government's role in building infrastructure, setting up of industry, constructing housing projects has become limited there is no alternative to bringing in private enterprises to these fields of economic development. The restrictions and regulating measures to ensure planned development is definitely welcome for public good, but the ones that hamper development can never bring any good to the people in the long run.

\section{Land disputes}

The Revenue Officers attached to the Block Land \& Land Reforms Office act as the primary authorities to resolve dispute between the raiyats, between the raiyats and their bargadars. They also implement the ceiling provisions of the Act and other regulatory provisions. They enjoy exclusive jurisdiction to decide such cases at the primary level. Persons aggrieved with their decisions may prefer appeal before the DLLRO. Against the orders of the appellate authority people may approach the West Bengal Land Reforms \&Tenancy Tribunal (WBLRTT), created under the WBLRTT Act, 1997 in pursuance to the provisions of Article 223B of the Constitution of India by excluding the jurisdiction of the High Court as a Court of the first instance. Since the Tribunal does not have to maintain the court formalities that the High Court maintains and since all the benches of the Tribunal are division benches of which one member is technically equipped by virtue of his experience of work in land reforms organisation disposal of cases is much quicker, and the process is much cheaper.

Appeal against the decision of the Tribunal can be filed only before a Division Bench exercising writ jurisdiction under Articles 226 and 227 and so a separate bench has been earmarked to hear such appeals. The result is quicker disposal of appeals.

Before the Tribunal was created, cases remained pending in the High Court for years together. As a result of the creation of the Tribunal barring people from approaching the High Court as a court of the first instance the people have benefited immensely from cheaper process and quicker disposal of cases.

\section{E. Land use change:}

In West Bengal whoever holds land for any purpose whatsoever is called a raiyat. He is the owner of the land and his right is heritable and transferable. Before 1981 he could change the use of his land according to his choice. By an amendment of the West Bengal Land Reforms Act 1955 (hereafter WBLR) made in 1981 severe restrictions have been put on the change of the use of land from its present position. Conversion of land can be made only on permission from the DLLRO who has to consider thousands of things before granting permission.

Conversion of land without permission has been made a cognizable and non-bailable offence punishable with imprisonment up to three years or with fine up to Fifty thousand rupees or with both. Even for a change in the mode of use of the non-agricultural land, such as from residential to commercial or from commercial to industrial or from industrial to residential etc. permission is necessary.

\section{F. Preparation of records of rights and mutation}

269|Page Land Governance Assessment Framework- West Bengal 
In West Bengal Land Reforms Act provision has been made in chapter VIIA (section 50A-51A) for preparation or revision of record of rights called khatian. It is mouza or village based. Each land owner shall have a Khatian having unique khatian number in the Mouza. The document contains the details of the owners like his/her name, address, status of ownership, details of plots (quantity and classification of land, revenue and cess payable). Other interested groups like share-croppers, exchange possessors, and adverse possessors are also recorded against each plot. A Plot is defined by its plot number which is an 5 digit integer and unique in the mouza, by a unique area. Plots are depicted in the cadastral map of the Mouza which are normally prepared ubder 1:3960 scale. Procedure for revising or preparing record of rights has been laid down in rule 22-25 and schedule A of West Bengal Land Reforms Rules 1965.

Provision has also been made in section VII for maintenance and updating of record of rights.

\section{G. Land related programmes}

National Land Record Modernisation programme: The Government of India supported programme has three major components - a) computerisation of land records, b) survey/ resurvey and c) computerisation of registration. Till March 2013, a total of 36.70 million records of rights for 46.54 million land parcels have been digitised and integrated with cadastral maps which has prompted to start Over The Counter (OTC) information service system in July 2012 as a measure of citizen centric service. The process of digitisation and updation in West Bengal was initiated in early 2011 and till December 2012, land records of 40,196 out of 42042 mouzas are digitised and updated. Presently under MPLS-VPN Project of Finance Department, all the service locations i.e. 346 Block Land and Land Reforms (BL\&LRO offices), 63 Sub-divisional Land and Land Reforms (SDL\&LRO )Offices and 18 District Land and Land Reforms (DL\&LROo )offices of Land \& Land Reforms Department is expected to be interconnected by 2014. As on November, 2013, 94 BL\&LRO Offices, 45 SDL\&LRO Offices and 15 DL\&LRO offices are interconnected through MPLS-VPN having 2Mbps connectivity. Land records database of the State will be collocated in State Data Centre (SDC).

Homestead land for landless: In spite of the provisions made in the West Bengal Land Reforms Act 1955 and West Bengal Acquisition of Homestead Land for Agricultural Labourers, Artisans and Fisherman Act 1975, large number of landless people remained outside the benefit provided by the Act. To cover these landless people the State introduced Chas- OBasabaserJanyaBhumidanPrakalpa (Homestead and kitchen garden scheme) in the year 2005o6. Under this scheme land up to 0.16 acres was allotted to the landless people for homestead and kitchen garden purpose. This micro- plot distribution is unique in the sense that Govt. purchased the land form landowners at market rate and distributed free to the landless people. But, this scheme was not seriously implemented by the State Govt. Under the scheme, State granted tenancy right to 5034 families over 579.79 acres of land [Source: Report published by Directorate of Land Records and Surveys, Govt. of West Bengal]. The present Government introduced a new scheme NijoGrihoNijoBhumiprakalpa in Oct 2011 (My Home My Land scheme) with purpose to settle 5.5 Lac landless poor people of the State up to 0.05 acre of land. The land to be settled will be provided from the land at the disposal of State Government and land to be purchased by the State Government. The settlees are to be settled in cluster and will be provided with all essential amenities like drinking water, sanitation, electricity, road and livelihood support by convergence of Govt. schemes. The entire 5.5 lac landless people will be covered under the scheme by 2015-16. As on December 2013, 86,883 families have been allotted land. [Source: Report of Directorate of Land Records and Surveys, Govt. of West Bengal]

\section{H. Women's land rights}

When a woman, be it a Muslim or a Hindu is the established owner of the land from before the time of preparation or revision of record of rights there has been no problem in getting her name recorded. But there has always been a problem in getting the name of a female heir recorded

270|Page Land Governance Assessment Framework - West Bengal 
because the Revenue officials have to depend on the oral evidence of the persons present comprising the male members of the village concerned at the time of recording.

Personal law of the Muslims in Bengal gives the woman the right of inheritance although unequal between the sons and daughters - the ratio being 2:1.

The native Hindus are governed by the Dayabhaga School and those who have come from outside Bengal are governed by the Mitakshara School. No school gave right of inheritance to women except life interest to the widow. The Hindu Women's Right to Property Act came into existence in 1937 when preparation of the record of rights for the first time in Bengal under the Bengal Tenancy Act, 1885 was almost over. Moreover, the Act was found defective and so not enforced in right earnest. Hence the original record of rights under the BT Act did not record the names of female heirs. The Hindu Succession Act giving the right of inheritance to the women and converting life interest into absolute interest came into existence in 1956 when the record of rights under the BT Act were being revised under the EA Act. Before the implications of the revolutionary Hindu Succession Act could be fully understood, the revisional operation was almost over. Moreover, the thrust of revisional operation under EA Act was to obtain the position of land and all pre-existing rights therein as on 15.04.1955 or 14.04.1956, the dates of vesting under EA Act. Naturally recording the names of women according to the new law did not get the importance it deserved.

The latest revision of the records was taken up in 1975 under the LR Act, when the women's legal right to property stood fully established. Hence, attempt was made to record the names of women owners of land. However, the same problem of ascertaining the truth has been faced. The male heirs who normally attend the place where record-writing is done have been found to be reluctant to give out the names of female heirs particularly when they have been married off to a distant place. Brothers are still not reconciled to the sharing of paternal property with the sisters. In a male dominated society where the mind-set of even the persons entrusted with preparation or revision of records is not women-friendly as far as married women's right to paternal property is concerned it has been difficult to elicit information about the existence of female heirs.

Since revisional operation under the LR Act has almost come to an end the effect of the amendment Act of 2005 giving more rights to the Hindu women belonging to a family governed by the Mitaksharaschool has not featured in the records.

In 1993 the government of West Bengal decided to distribute land (the amount of land yet to be distributed was insignificant) in the joint names of husband and wife and issued an order to that effect. In a survey made in 2003 it was found that less than 6\% of the total pattas issued during the 10 years between 1993 and 2003 were issued in the joint names of husband and wife.

This is a concrete evidence of the anti-woman mind-set as far as property right is concerned of the persons entrusted with protecting women's right to property

\section{Land Acquisition}

The Doctrine of Eminent Domain is, primarily, a source of power of the state. It means the power of the Sovereign to take the subjects' property without his consent for public purposes. The concept of public purpose is therefore an essential ingredient in just and appropriate exercise of this power. Payment of compensation though not an essential ingredient is a condition inherent in the doctrine of eminent domain and essential in just exercise of such power. This power under eminent domain is being exercised by almost all the countries of the world and stands firmly established.

271 Page Land Governance Assessment Framework - West Bengal 
The Land Acquisition Act, 1894 (Act I of 1894) applied only to British India. The native states had their own Acts more or less modelled on the 1894 Act.

Section 299 of the Govt. of India Act 1935 provided for compulsory acquisition of land for public purpose. The use of the Act of 1894 therefore continued as before.

Adopting the Doctrine of Eminent Domain the Constitution of India contains articles 31 (omitted in 1978), 31A,31B, 31C and 300A (from 1978) and provides for compulsory acquisition of land. However, the second proviso to Article 31A clearly lays down that for acquisition of land being held in excess of the ceiling limit prescribed in any Act compensation need not be paid at the market value, but for acquisition of land held within the ceiling limit compensation shall not be less than the market value. By dint of these constitutional provisions the Act of 1894, which was adapted along with many other Acts made during the British rule, could withstand many onslaughts against it before the courts even when the right to property was a fundamental right till 1978 and became a Constitutional right thereafter and came out unscathed.

In West Bengal, immediately after Independence two Acts were passed for acquisition of land (a) the West Bengal land (Requisition and Acquisition) Act, 1948, (b) the West Bengal Land Development and Planning Act 1948. Provision for acquisition of land and building were also made in the Calcutta Municipal Act 1951 and Calcutta Municipal Corporation Act 1980.The West Bengal Industrial Infrastructure Development Corporation Act 1974 contained provisions for acquisition of land for the purpose of this state govt. undertaking.Besides, many other Acts including West Bengal Acquisition and Settlement of Homestead Land Act 1969 and the West Bengal Acquisition of Homestead Land for Agriculture Lobourers, Artisans and Fishermen Act 1975 were passed for acquisition of land for various public purposes. By way of a state of West Bengal amendment of the 1894 Act provisions were made for paying compensation to the bargadars (share croppers) in addition to the compensation to be paid to the owners of the land.

Article $31 \mathrm{~A}$ of the Constitution of India lays down that compensation for acquisition of land held within the ceiling limit shall not be less than its market value. The 1894 Act says that compensation shall be assessed on the basis of the market value. It is evident that neither the constitution nor the 1894 Act prevented any Govt. from paying higher compensation or providing any other relief over and above cash compensation. As the facts stand out different states adopted different procedures for assessing market value and paid solatium at different rates. The procedure hitherto followed in this state has been with an eye to keeping the market value as low as possible to serve Govt. interest. None ever cared to bother whether market value thus assessed was just or not. However, to the land- losers compensation was invariably much less than the price at which land changed hands from a willing seller to a willing buyer.

The protest movement at Singur and Nandigram had a seismic effect affecting land acquisition in other parts of the country, West Bengal issue thus became an all-India issue. The Central Govt. and the leaders of different political parties were forced to take notice and relook at the way 1894 Act was being implemented. However, the Central Govt. decided that instead of fullscale amendment of the 1894 Act a new Act should be made.

After a long deliberation for a few years The Right to Fair Compensation and Transparency in Land Acquisition, Rehabilitation and Resettlement Act 2013 has been passed. This Act seeks to ensure -"a human participative , informed and transparent process for land acquisition for industrialization development of essential infrastructural facilities and urbanization with the least disturbance to the owners of the land and other affected families and provide just and fair compensation to the affected families and make adequate provision s for such affected persons for their rehabilitation and resettlement and for ensuring that the cumulative outcome of compulsory acquisition should be that affected persons become partners in development leading to an improvement in their post-acquisition social and economic status and for matters connected therewith or incidental there to ".

272 | Page Land Governance Assessment Framework - West Bengal 
The Government of West Bengal, opposed to the passing of the new Act and has declared that the government is not going to acquire any land from unwilling land owners even for constructing a power station or widening national highways, let alone acquisition of land for industry, which should purchase land from the open market. Hence, this state, for the present, has nothing to do with the new Act.

\section{J. Land policy and consultation}

It can be inferred from the WB Land Reforms Act, 1955, the Rules made thereunder and the WB Land and Land Reforms Manual 1991 dealing with all kinds of land beyond the city of Kolkata comprising the first 100 (one hundred) Wards of Kolkata Municipal Corporation, and the WB Thika Tenancy (Acquisition and Regulation) Act, 2001 and Rules made thereunder dealing with tenancy within the city of Kolkata that this state has comprehensive land policies on all kinds of land and land related matters.

These policies have come into place through a process of evolution. Some of the landmarks of this process may be discussed to know how the policies came into place.

Unlike in other parts of the country lands were permanently settled with proprietary rights in 1793 with the Zamindars who had hitherto been mere collectors of revenue by robbing the peasants of their right of ownership of land in Bengal, Behar and Orissa.

Right from the beginning of the $19^{\text {th }}$ century the peasants started agitating against the oppression of the Zamindars. Peasant wings of all the political parties were organizing movements after movements. With the joining of the left parties in the 1930 s the peasant movements gained much more momentum and became more intensive. The British Government set up Flaud commission to examine whether permanent settlement had outlived its utility. The Commission recommended abolition of zamindary in its report submitted in 1940.

Provisions were made in the Constitution of India for acquisition of estates. In pursuance to the constitutional provisions different states made laws for abolition of Zamindary. In this state, the WB Estates Acquisition Act, 1953 was passed vesting all the rent receiving interests. Thus this legislation took its shape as a result of continuous movements against the Zamindary system keeping in view the interests of the principal stakeholders - the tillers of land - the man behind the plough.

Imposition of ceiling is another landmark. The socialist elements in the Indian National Congress and the left parties from 1930s started pleading for abolition of large holdings and the redistribution of surplus lands. In recognition of such demand it was decided in the Constituent Assembly that ceiling should be imposed on the holding of lands. Provisions were made in Article 39(b) and (c) of the Constitution of India to ensure that the ownership and control of the material resources of the community are so distributed as best to sub-serve the common good and that the operation of the economic system does not result in the concentration of wealth and means of production to the common detriment.

To fulfill the constitutional obligations the WBEA Act, 1953 imposed ceiling of 25 (twenty five) acres on agricultural land and 15 (fifteen) acres on non-agricultural land [maximum 20 (twenty) acres including homestead] on the holding of an individual.

When those who were going to lose land came to know of the ceiling provisions they did all they could do to evade the provision. They resorted to various designs to circumvent the law and displayed rare ingenuity. Since then one of the principal items of work of the land reforms administration of this state has been to detect lands held clandestinely and vest such lands by drawing up proceedings in accordance with law. All such actions were challenged in courts

273 I P a e Land Governance Assessment Framework - West Bengal 
giving rise to a lot of litigations involving thousands of acres of land. It took years to dispose of the cases.

In 1971 came the new ceiling on land on the basis of the size of the family by amendment of the WBLR Act which was again amended in 1981 and 1986 to bring within the net of the ceiling provisions the lands of the non-agricultural tenants and all other kinds of land. The amendments of 1981 and 1986 were challenged, and appeals are still pending before the Supreme Court. The Writ Petitioners armed with the Stay Order till the disposal of the appeals are enjoying surplus lands. But it should be pointed out that due to the constant vigilance of the prospective stakeholders no owner other than the insignificant few enjoying the benefit of injunction has been able to hold on any land in excess of the ceiling area.

For distribution of surplus land due care has been taken to involve the representatives of the landless and land-poor - the stakeholders for whom the ceiling was imposed to take away lands from those who had much more than they needed. Panchayet representatives and land reforms officials hold enquiries jointly to identify the vested land. The Panchayat functionaries then identify and select the beneficiaries. On their recommendation land is finally settled. This is how participation of the stakeholders has been ensured and for this no landowner has been able in this state to prevent an allottee of vested land from taking over possession of such land. No instance of paper allotment.

Over the centuries lands have been cultivated by bargadars (share-croppers) who cultivate others' lands on condition of paying a share of the produce. The Flaud Commission noted in its report that 22.5\% (twenty two point five percent) lands were cultivated by bargadars. 1941 Census corroborated this figure. But the bargadars had no right. BT Act ignored them except describing them with a negative mandate that they are not tenants. The left parties made several movements all over Bengal to air the grievances of bargadars. The most famous one was the Tebhaga Movement. After abolition of Zamindary,LR Act sought to protect their right of cultivation to some extent. But since most of the bargadars were not recorded their eviction could not be stopped. Towards the end of 1970 s the Government resorted to a special drive called "operation barga" to record those bargadars who, for fear of incurring the wrath of the owners of land failed to get their names recorded. A few lakhs of bargadars in addition to six lakhs which stood recorded from before were thus recorded. Thereafter, by the amendments of the LR Act made in 1981 and 1986 bargadars' right to cultivation was made heritable and fully secure. This is how policies with regard to bargadars were framed. Within the city of Calcutta there exists a tenancy known as thika tenancy. The tenant took land from the landlord on rent and constructed structures to be used for manufacturing or commercial or residential purpose. Since such tenants did not enjoy any legal right the landlords used to evict them at will. To stop eviction Calcutta Thika Tenancy Act was passed in 1949. Eviction could not be stopped. In 1981 Calcutta Thika and other tenancies (Acquisition and Regulation) Act was passed. Landlords' rights were acquired and the thika tenants became tenants directly under the state. Rights of thika tenants have thus been made secure. For removing some defects pointed out by the Supreme Court the Act of 1981 has been replaced by the Act of 2001, but acquisition of landlords' interests under the Act of 1981 and the thika tenants becoming tenants directly under the State have been duly protected.

The principles of equity and redistribution of land have been the driving forces behind the legislations embodying the policies of this state discussed above. The policies seek to safeguard the interests of the downtrodden who over the centuries have been at the receiving end. There is not a single instance of twisting policy in favour of the more privileged.

\section{K. Property registration and tax}

274|Page Land Governance Assessment Framework - West Bengal 
The levy and collection of stamp duty and registration fees during the land/ property transfer are regulated under the Indian Stamp (IS) Act, 1899 and the Indian Registration (IR) Act, 1908 and the Rules framed thereunder as applicable in West Bengal. Instruments to be registered under the Acts are chargeable to stamp duty and registration fees at the rates prescribed by the State Government from time to time. Under the IS Act, the stamp duty to be paid depends on the real nature or substance of the transactions recorded in the instruments and not on any title or description or nomenclature given by the parties who execute the instruments. The Registering Officer (RO) is empowered to ascertain the market value of the properties which is the subject matter of the instrument and to compute proper stamp duty chargeable thereon in the prescribed manner as provided in the Act. At present in West Bengal the market value of any property (land, building) is determined through the system of the Computerisation of Registration of Documents (CORD) software started in the year 2000. The West Bengal Stamp (Prevention of Under-Valuation of Instruments) Rules 2001 was introduced with effect from 1.3.2001.

Property tax is one of the main sources of internal revenue of the ULBs. Provisions have been made to determine such property tax on the basis of a formula. But such tax (annual) shall not exceed $30 \%$ of the annual value of the land or building concerned.

Present system of assessment:

Presently in the Urban Local Bodies of this State the following two systems of assessment of lands and buildings are followed:

i. Annual Rental Value (ARV) System: In this system tax is calculated on annual rent that is actually or reasonably be fetched by a property.

ii. $\quad$ Capital Value Method: In this system tax is calculated on Annual Value derived from cost of construction added to cost/ market value of the land.

The West Bengal Valuation Board was constituted after the enactment of West Bengal Central Valuation Board Act, 1978 to bring about a uniform and rational system of valuation of municipal properties throughout the state. The activities of the Board mainly comprise of undertaking valuation work in specified urban local bodies notified by the state government keeping an eye on overcoming inter-ULB anomalies. Annual valuation of a holding is determined as per provisions of Section 106 of West Bengal Municipal Act, 1993. At the present system valuation for a municipality takes place every five years following a resolution to this effected being adopted by the ULB.

\section{Environment and ecology}

Most of the land related major Acts in West Bengal were enacted much before ecology and environment issues came in the development discourse. However, the WBLR Act, though not in an expressed manner but in an environment protection notion captures following provisions:

A raiyatis required to maintain and preserve his land in such a way that - (i) its area is not diminished; or (ii) its character is not changed; or (iii) it is not used for any purpose other than the purpose for which it was settled, without the permission of the collector. Again by virtue of sec $4 \mathrm{~A}(\mathrm{i})$ of the Act the collector of Darjeeling district may issue directions to the raiyats of the three hilly subdivisions of Darjeeling, Kurseong and Kalimpong as to the form of cultivation to be adopted by them. The collector is also empowered to prevent araiyat from cutting more than one tree from his land without the former's permission. These regulatory measures are intended to prevent soil erosion or landslides so that ecological balance may be maintained.

275|Page Land Governance Assessment Framework - West Bengal 
Sec $4 \mathrm{C}(1)$ requires a raiyat to obtain permission from the collector for any change of classification of his land. If the change sought for is to establish an industry or brick field etc. which may result in noxious waste products which may adversely affect environment, the collector may withhold permission of conversion [rule 164(i), W.B. Land and Land Reforms Manual, 2003]

In November 2005 West Bengal government promulgated the landmark environmental notification, the East Kolkata Wetlands (Conservation and Management) Ordinance (enactment in 2006) to safeguard the 12,500 hectares (comprising $46 \%$ water body and $39 \%$ agricultural land) fragile wetland located in the eastern fringes of the city of Kolkata. These wetlands are well known over the world for their multiple uses. The wetlands are man-made and the system of wastewater treatment is the largest in the world. It has saved the city from constructing and maintaining a wastewater treatment plant. The East Kolkata Wetlands Management Authority formed under the provisions of the Act is chaired by the Chief Secretary, has been entrusted with the statutory responsibility for conservation and maintenance of the wetland area by maintaining the existing land use practices. For any change in land use within this area the appropriate authority under WBLR Act has to take permission from the concerned wetland authority. 
Annexure 2: Panel Reports (Aide Memoire)

\title{
Panel 1: Land Rights Recognition
}

\author{
10 February 2014 \\ Landesa, West Bengal \\ Venue: Senator Hotel, Kolkata
}

\section{Introduction}

The Land Governance Assessment Framework (LGAF), developed by the World Bank in partnership with $\mathrm{FAO}^{3}$, UN Habitat, IFAD4, IFPRI5, the African Union, and numerous bilateral partners, is a diagnostic tool to assess the status of land governance at the country level in a participatory process that draws systematically on local expertise and existing evidences from the field of works. It relies more on the practical experiences from the insiders' perspectives rather than building upon on outsiders views. In India, it is being implemented through invitation of Department of Land Resources, Ministry of Rural Development, Govt. of India and State Governments in about 7 states - Andhra Pradesh, Bihar, Jharkhand, Odisha, Gujarat, Karnataka and West Bengal. Globally the exercise is being undertaken in 35 countries of the world.

The LGAF process is guided by a framework of 27 'Land Governance Indicators' (LGI) covering 5 core thematic areas. Each indicator is further broken down into a number of 'dimensions' with pre-coded statements (on a scale from A to D). There are in total of 116 dimensions in the LGAF.

In 2012, the Government of West Bengal (GoWB) requested the World Bank to carry out a comprehensive analysis of the State's land sector to identify issues and policy implications of their land tenure systems. Recommendations and findings from the LGAF assessment would enable policymakers to adopt regulatory and institutional measures necessary to strengthen the land governance system. As per the guideline from the World Bank, the whole work was divided into nine panelsand experts for each panelwere engaged for in-depth study on the dimensions.

Landesa, India is the implementing agency of LGAF at the country level with its Technical Advisory Group at place in New Delhi. The first meeting of the Panel 1 that dealt with the points related to the issue 'Land Rights Recognition' was discussed on February 10, 2014 in Kolkata. The meeting was organised by the State Coordinator -Landesa West Bengal and the Project Team leader -State Director, Mr. Pinaki Halderat conference hall of the Senator Hotel. Eminent personalities, representing different fields of works and a 'panel of experts' participated in the discussion. The panel of experts was comprised of personalities with exponentially rich experiences of working on the Land Governance issues in the state and at national level. The use of Panels to form consensus on the assessment of a set of LGAF dimensions is crucial to implement the work.

The current document deals with the discussions conducted during the first meeting of sharing the findings of the Panel 1 and arrive at a general consensus regarding the analysis and recommendations suggested by the panellists.

3FAO-Food and Agriculture Organisation

4IFAD- International Fund for Agricultural Development

5IFPRI-International Food Policy Research Institute

277| Page Land Governance Assessment Framework - West Bengal 


\section{Panel 1- Recognition of a continuum of Rights: the law recognizes a range of rights held by individuals}

As mentioned earlier, the LGAF is expected to initiate an open, comprehensive discussion on the country's land issues, and to serve as a critical step forward in their efforts to improve land governance. With specialists from different fields coming together for the first time, people look forward to building consensus.

\section{Context}

Being a multidimensional concept, poverty is tough to define and there are quite a few indicators of poverty. Among these, landlessness is a key predictor of poverty. Different aspects of poverty, such as social security, food security, and family nutritional status are directly related to landlessness of a family. In rural areas, and particularly for poor families, ownership of land, even as small as a homestead plot makes a huge difference in their lives and helps them to initiate their journey towards prosperity.

The achievement of the Millennium Development Goals (MDGs) necessitates progress in all major areas related to the well-being of the people, including poverty reduction and improvements in education, health, gender equality. This may require setting priorities in terms of dealing with various dimensions of poverty.

Landesa deals with the core rural poverty issue related to the landlessness. Household access to and control over land and secure rights to it have impacts beyond the level of individuals and families. Research has helped to develop a positive relationship between equitably distributed land and poverty reduction.

Landesa's involvement in LGAF could be considered as a step towards initiating a wider discussion in the context of land governance. This organised discussions and follow up discourses would hopefully help in strengthening its global discussion for pushing the 'Land' issue to be included in post 2015 MDG (Millennium Development Goals). Analysing and assessing the land governance would provide the government with crucial recommendations to revise its policies or build new policies aiming at more efficient and equitable land governance system.

\section{Purpose}

The first panel discussion in West Bengal State of India provided a valuable opportunity for a collective learning on "legal provisions for the recognition, enforcement and mechanisms to provide secure land tenure for the population" in the state. The broad objectives of the meeting were to discuss and arrive at a consensus regarding the following critical issues attached to the first dimension:

a) Gaps in existing evidences

b) Areas for regulatory or institutional change to make the situation better

c) Piloting new approaches and interventions to improve land governance on a broader scale (e.g. by strengthening land rights and improving their enforcement); and

d) Criteria to assess the effectiveness of these measures.

The special feature of this process is that-

278 Page Land Governance Assessment Framework- West Bengal 
It follows a self-assessment process

- Having a comparable format to highlight good practices

Having an increased profile of land governance; improved communication

口 To publicize \& mainstream state-level innovations nationally

It provides a basis for participatory monitoring

\section{Expectations}

The expectations from the discussion for Panel 1: Land Tenure Recognition were

- Panelists would discuss over the analysis of each parameters and arrive at a consensus to finalize the gradations

- Gaps would be identified against each parameter and recommendations will come out to bridge those gaps

- Provide policy suggestions/ recommendations on the related issues on land governance

\section{Participation}

The discussion was attended by the 'panel of experts' on relevant fields and a few very eminent professionals from areas other than direct implementation of land governance.

1. Mr. Anil Kumar Chakroborty, Expert Investigator- LGAF;

2. Mr. Tapan Kumar Shome, Ex- Directorate of Land Records and Survey (DLRS), Government of West Bengal

3. Mr. KrishnapadaShandillya, Ex-Special Secretary, Government of West Bengal

4. Mr. Sukumar Banerjee, Ex- Officer, LR Department, Government of West Bengal

5. Mr. Apurva Mukherjee, Professor, Netaji Institute for Asian Studies, West Bengal

6. Ms. Swati Bhattacharya, Chief- reporter- District, AnandabazarPatrika

7. Ms. ReshmiGanguly, Program Officer, Action Aid Association (Kolkata Region)

8. Mr. Biprodas Bhattacharjee-Professor Vivekananda Institute of Science and Technology, West Bengal

9. Mr. Pinaki Halder, State Director, Landesa, State Coordinator and Project Team LeaderLGAF- West Bengal

Landesa Kolkata team members were also present to aid the uninterrupted flow of the panel discussion. The names of those present were-

- Mr. Supriya Chattopadhyay, Communications Manager, Landesa- West Bengal

- Mr.Sudipta Biswas, District Program Manager, Landesa- West Bengal

- Mr.Anindya Dey, Office Manager, Landesa- West Bengal

- Ms.Udita Chatterjee, Research and Documentation Officer, Landesa- West Bengal

- Mr.Debasis Mondal, Office Assistant, Landesa- West Bengal

\section{Discussion}

Mr. Pinaki Halder, LGAF- West Bengal Project Leader and State Director, Landesa West Bengal welcomed all present and started the day's proceeding with a power point presentation delineating the purpose of the panel discussion, about LGAF, the core thematic areas of LGAF before venturing into the detailed discursive discussion on Panel 1 : Land Tenure recognition.

The panel has two indicators as follows:

Indicator 1: Recognition of a continuum of rights: the law recognizes a range of rights held by individuals (incl. secondary rights of tenants, sharecroppers, women etc.) 
Indicator 2: Respect for and enforcement of rights

Under Indicator 1 there were four dimensions and within Indicator 2 there were seven dimensions. Each dimension has four gradations-ranked by the panel from A to D. The dimensions were explicitly discussed in great detail to get the panelists' inputs to incorporate changes in the gradations and analysis.

\section{The dimensions under indicator 1 were:}

1.1. a. Individuals' rural land tenure rights are legally recognized

1.1. b. Individuals' rural land tenure rights are protected in practice

1.2. Customary tenure rights are legally recognized and protected in practice

1.3. Indigenous rights to land and forest are legally recognized and protected in practice

1.4. Urban land tenure rights are legally recognized and protected in practice

At the outset of the meeting, it was mentioned that Dimension 1 of indicator 1 , has been subdivided into two parts - (a) Individuals' rural land tenure rights are legally recognized and b) Individuals' rural land tenure rights are protected in practice.

\section{The dimensions under indicator 2 were:}

2.1. Accessible opportunities for tenure individualization exist

2.2. Individual land in rural areas is recorded and mapped

2.3. Individual land in urban areas is recorded and mapped

2.4. The number of illegal land sales is low

2.5. The number of illegal lease transactions is low

2.6. Women's property rights are recorded

2.7. Women's property rights to land are equal to those by men both in law and in practice

Points discussed under the land governance indicators:

The panel head, Mr. Anil Kr. Chakroborty mentioned that while conducting the study and analyzing the data for categorizing them under the grades as mentioned in the LGAF format, some level of estimations were used. For example, for the first dimension under indicator 1, it was found that almost all the land tenure rights are legally recognized in case of West Bengal suggesting almost $100 \%$ of cases. In that case, the first grade (that says more than $90 \%$ of cases are legally recognized) was identified though some level of estimation was involved in that selection. In all cases, the analysis included the explanations for selecting.

The statement mentioned under the gradation level for dimension 2- Customary tenure rights are legally recognized and protected in practiceunder indicator 1stirred confusion where it was raised that it might not be a justified idea to mention that customary rights are legally recognized.This followed a range of interactions between the moderator, the panelist, representatives from media and civil society organization where the important inference drawn was that if customary rights are not codified then it will not come under legislation. Some field examples like customary rights of fishermen community in Sunderban Delta came up and it fueled the debate that all customary rights are not legally recognized or protected. Finally, panelists drew inference that until and unless customary rights are not codified then it will not come under legislation.

The last phrase 'protected in practice' in dimension 3 Indigenous rights to land and forest are legally recognized and protected in practice under Indicator 1 was the point of ambiguity as stressed by the member of the civil society organization for she said that the Forest Rights Act

280|Page Land Governance Assessment Framework - West Bengal 
(FRA) 2006has laid down rights for protecting the rights of the forest dwellers but there are gaps in implementation. Citing experiences from the field of vulnerability of tribal people in mine areas of Birbhum district, she further pointed out that such a generalized statement would leave very less / no scope for addressing this gap and / or making policy recommendation. Panel experts mentioned that adequate explanations will be given in the analysis section and suitable recommendation points will be made for addressing this situation.

A pertinent question was raised by the civil society organization representative while discussing Dimension 1Accessing opportunities for tenure individualization under LGI 2. Her point of concern was that there is a contradiction of individualization of tenure when considered in case of individualization of community rights and that of women's rights. To this one of the panelists shared that individualization of individual tenure and individualization of common land are different and that point will be taken care of in the consolidation of the learnings from the LGAF exercise in West Bengal. The ranking of the specific dimension will also reflect this.

Discussion as against the dimension 2 Individual land in rural areas is recorded and mapped under Indicator 2, Mr. T.K Shome, ex-DLRS mentioned that a survey conducted by the Directorate of Land Records and Survey, Government of West Bengal suggests that the work related to this is done with a great perfection in West Bengal. The study shows that the recording and mapping of land is done almost with $99 \%$ perfection, i.e. the no. of plots in the LR map can be tallied with the no. of plots in the RoR (Record of Rights) very easily.

All the dimensions under each of the two indicators were discussed in detail and the final gradation and recommendations corresponding to the gradations are finalised as follows:

Indicator 1: Recognition of a continuum of rights: the law recognizes a range of rights held by individuals (incl. secondary rights of tenants, sharecroppers, women etc.)

\begin{tabular}{|l|l|l|}
\hline \multicolumn{1}{|c|}{ Dimension } & \multicolumn{1}{|c|}{ Grade } & \multicolumn{1}{c|}{ Change in Grade } \\
\hline $\begin{array}{l}\text { 1.1.a: Individuals' rural } \\
\text { land tenure rights are } \\
\text { legally recognized }\end{array}$ & $\begin{array}{l}\text { A: Existing legal framework } \\
\text { recognizes and protects rights held } \\
\text { by more than 90\% of the rural } \\
\text { population }\end{array}$ & No change in Grade \\
\hline
\end{tabular}

\section{Observation:}

- Expert Investigator referred to the analysis report and mentioned that Bengal Tenancy Act, 1885 clearly identified the rural tenures and provided a set of rights and safeguards for the tenures (Sections 23,23A, 52 to 55, 161-163 etc.). The WBLR Act has comprehensively laid down the rights and duties of a tenure holder. He stressed that almost $100 \%$ land rights are legally protected (as a result of Land Reforms measures taken in the State).

- Mr.Shome and other panelists supported that as per existing legal framework in the state, land tenure rights are almost 100\% recognized. Rights of the Riyats are defined in the Acts.

- As per query of Prof. Mukherjee and Ms.Ganguly, EI further explained that rights of tenure includes the rights of bargadars (sharecroppers) which are also clearly defined in Acts.The term 'tenure holder' includes raiyats and bargadars.

- One of the panelists rectified that 'rights of heritability' mentioned in analysis report will be under Sec.4 (1), not Sec.2.

\section{Recommendation:}

Since the tenure rights are $100 \%$ recognized by law, no further recommendation was made.

281|Page Land Governance Assessment Framework- West Bengal 


\begin{tabular}{|l|l|l|}
\hline \multicolumn{1}{|c|}{ Dimension } & \multicolumn{1}{|c|}{ Grade } & \multicolumn{1}{c|}{ Change in Grade } \\
\hline $\begin{array}{l}\text { 1.1.b:Individuals' rural } \\
\text { land tenure rights are } \\
\text { protected in practice }\end{array}$ & $\begin{array}{l}\text { A: Existing legal framework } \\
\text { recognizes and protects rights held } \\
\text { by more than 90\% of the rural } \\
\text { population }\end{array}$ & \\
\hline
\end{tabular}

\section{Observation:}

- EI mentioned that rights granted by the Act are protected in practice. The laws of the land provide remedial measures against interference with lawful exercise of the rights. If somebody comes with valid documents, government takes step to protect his rights. Even policy administration and Panchayats provide necessary protection.

- One panelist added that once a riyat or bargadar gets his rights recorded, he is provided full protection in practice. There is no ambiguity.

- All other panelists agreed the points mentioned by EI and accepted the ranking.

\section{Recommendation:}

To record one's name as a raiyator bargadars so that he can get protection under law.

\begin{tabular}{|c|c|c|c|}
\hline \multicolumn{2}{|r|}{ Dimension } & Grade & Change in Grade \\
\hline & $\begin{array}{lr}\text { Customary } & \text { tenure } \\
\text { rights are } & \text { legally } \\
\text { recognized } & \text { and } \\
\text { protected } & \text { in } \\
\text { practice } & \end{array}$ & $\begin{array}{l}\text { A: There is legal recognition and } \\
\text { effective protection of all } \\
\text { customary rights }\end{array}$ & No change in grade \\
\hline
\end{tabular}

- Referring to the background report, EI shared that there are two customary rights - (a) Any right of way or other easement attached to the land comprising the tenure and (b) Fishing right which is also an easement right. He further added rights of people over natural resources, fishing rights which are very much applicable in Sunderban areas are considered as customary rights. These are legally recognized and protected in practice.

- The Moderator pointed out that the term 'customary right' has not been used in any legislation. He requested Prof. Mukherjee to share his views. Prof. Mukherjee explained that until and unless any right is codified by law, it cannot be considered as customary right. Community rights and to some extent forest rights can be taken into consideration as customary rights in our context. Here the framework is focused on individual rights.

- One panelist suggested that occupancy rights may be considered as customary rights in this context. Mr.Shome added that all customary rights enjoyed by people from time immemorial have been recognized by law when Bengal Tenancy Act came into being. $\mathrm{He}$ further explained that though there is no provision of customary rights in WBLR Act but Easement Act describes what kind of rights can be enjoyed by whom. He further cited some example of customary rights. The land which is used by people as graveyard, playground or grazing ground etc. are considered as customary rights though it is recorded by the name of individuals. It is mentioned in the record also that the land can be used for the common purpose.

- Ms.Ganguly pointed out that the areas which are recognized as non-revenue or delta region in Sunderban where the fishermen communities are working for their livelihood, are not recognized as their customary rights. Then how can we claim that customary rights are $100 \%$ recognized or protected? Mr.Shome explained that there are two types of land - government land individual land. Individual land again may be under the category of institutional or cooperative or group. If the land is being used by the fishermen community customarily (in practice) and it is recorded in the name of individual, they

282|Page Land Governance Assessment Framework - West Bengal 
are entitled to enjoy the customary right. They only need to approach to the government and get it recorded. Once it is recorded, this easement cannot be ignored any way.

- Considering the fact that customary tenure rights are legally recognized and protected in practice, all panelists agreed to accept grade A.

\begin{tabular}{|c|c|c|}
\hline Dimension & Grade & Change in Grade \\
\hline $\begin{array}{l}\text { 1.3. Indigenous rights to } \\
\text { land and forest are } \\
\text { legally recognized } \\
\text { and protected in } \\
\text { practice }\end{array}$ & $\begin{array}{l}\text { A: Recognition and effective } \\
\text { protection of all indigenous rights }\end{array}$ & $\begin{array}{l}\text { Ranking was changed from } \\
\text { A to } \mathbf{B} \text {. }\end{array}$ \\
\hline
\end{tabular}

\section{Observation:}

- The moderator explained the term indigenous rights as a sub-category of customary right which is generally undocumented rights held by "original" or very long-term occupants of that land, often associated with less density of population and shifting cultivation, and/ or the prominence of forestland.

- Prof. Mukherjee wanted to know that does 'protected in practice' mean it is protected by the government only or it is protected from the entire socio-economic fabric. Ms.Ganguly cited the example of Deucha in Birbhum district where government is going to allow mining and tribal community are going to be evicted. They will be rehabilitated in some other place which is uncertain. In that case, can we say that their indigenous right is protected? IE explained that if it is acquisition then indigenous rights cannot be protected. For the purpose of acquision there is provision that permission should be taken from concerned Gram Sabha.

- She again raised a point that tribal people may not have capacity to take decision in the Gram Sabha or their participation in Gram Sabha is also doubtable. Though as per legal framework their rights are protected but there is huge gap between policy and practice. All other panelists accepted that.

- One panelist pointed out that the implementation of FRA 2006 is very sluggish in the state. Recently, it has got some pace. Till December 2013, 31000 individual and 312 community pattas have been issued. Mr.Shome added that since there is no survey data within forest mouza, Forest Department is giving patta by making a notional map and recording their rights. Government should conduct a survey for mapping the habitations within forest areas. It should be brought under record then only their indigenous rights will be protected.

- Ms. Swati Bhattacharaya shared some grey areas in policy which causes dispute between Forest department and forest dwellers regarding their rights over NTFP. But other panelists opined that in those cases their rights are recognized by law but due to attitudinal problem of particular Forest Officials it causes dispute. These cases can be considered as their rights are not protected in practice.

- All panelists came to a conclusion that though the indigenous rights are recognized by law, it is protected partly in practice. Hence they decided to grade the dimension as $B$ instead of $A$.

\section{Recommendation:}

- There is a need to functionalise the mechanism of protecting the customary tenure rights by conducting a thorough survey of forest habitation and include them in the land record.

- All customary rights need to be codified in order to ensure protection under law.

283 P a ge Land Governance Assessment Framework- West Bengal 


\begin{tabular}{|l|l|l|}
\hline Dimension & \multicolumn{1}{|c|}{ Grade } & Change in Grade \\
\hline 1.4. Urban land tenure & A: Existing legal framework & No change in grade \\
rights are legally & recognizes rights held by more than & \\
recognized and & $90 \%$ of the urban population & \\
protected in & & \\
practice & & \\
\hline
\end{tabular}

\section{Observation:}

- The EI stated that the WBLR Act 1955 is applicable in the entire state of West Bengal except the area described in Schedule I of the Calcutta Municipal Corporation Act, 1980 (Ward No.1-100). So the WBLR Act extends to the entire state including the ULBs except old Calcutta. So, it can be claimed that urban land tenure rights are legally recognized. He also mentioned that land record survey was not conducted in old Calcutta area.

- Addressing the queries from other panelists Mr. Banerjee shared that government officials proposed for survey but it was not accepted by political government. EI added that a proposal was submitted to the government for inserting a separate section by amending WBLR Act. Due to lack of political will notification has not been issued till date.

- The panel came to the conclusion that as per amendment in WBLR Act (1980) all urban households holding land are equally recognized as raiyats like that of rural raiyats. In addition to that the rights of tenants are protected by Thika Tenancy Act 2001. Different categories of urban raiyats are recognized by different Acts. Hence, as far as legal framework is concerned, it recognizes and protects the rights of urban tenure holders.

\begin{tabular}{|l|l|l|}
\hline \multicolumn{1}{|c|}{ Indicator 2: Respect for and enforcement of rights } & Change in Grade \\
\hline \multicolumn{1}{|c|}{ Dimension } & \multicolumn{1}{|c|}{ Grade } & No change in grade \\
2.1. Accessible & D: Although there is demand, the & \\
opportunities for tenure & law provides no opportunities for \\
individualization exist & $\begin{array}{l}\text { those holding land under } \\
\text { customary, group, or collective }\end{array}$ & \\
& $\begin{array}{l}\text { tenures to fully or partially } \\
\text { individualize land rights }\end{array}$ & \\
\hline Observation:
\end{tabular}

- One panellist wanted to know the meaning of individualization of tenure, does it mean segregated land tenure? Referring to the explanatory note EI explained that during BT Act tenure was recorded jointly or singly. WBEA followed the same procedure. During revision under WBLR Act all joint tenures have been split. Hence, tenure rights are already individualized.

- Answering the query of another panellist Mr. Shome explained that in case of joint patta also record is being maintained separately.

- One panellist raised the issue of collective rights and community rights. EI shared that as a result of implementation of FRA 2006, 312 community rights have been recorded in the State. Recording community rights in forest fringe areas have made progress recently. But the problem lies in cooperation from Forest Department Officials.

- One panellist pointed out whether individualization is done for collective or group tenure, EI explained that law does not permit individualization of collective or group

284 Page Land Governance Assessment Framework- West Bengal 
tenure.

- Mr. Shome further added that individualisation happens by law (WBLR Act) as there is the provision for 'One Man one Khatian (Record of Rights)'. But, some gaps remain in the implementation of the law.

- Ms. Ganguly wanted to know that in case of joint patta whether the title is provided in separate name or not. Other panellists explained that Patta is given in joint name (names of

- both husband and wife is mentioned). Ideally, name should be recorded separately and in that case two separate records are supposed to be provided. But practically singly record is provided. Mr. Shandillya added that as per Act there should be separate khatian for each raiyat. If it is not done practically then in the single record share of each tenure holder (may be 50\% each) should be mentioned. This issue is largely being ignored (may be because of lack of manpower or lack of legal awareness).

\section{Recommendation:}

The Government may consider the measures for ensuring speedy (recording of) individualisation of tenure.

\begin{tabular}{|l|l|l|}
\hline \multicolumn{1}{|c|}{ Dimension } & \multicolumn{1}{|c|}{ Grade } & \multicolumn{1}{|c|}{ Change in Grade } \\
\hline $\begin{array}{l}\text { 2.2. Individual land in } \\
\text { rural areas is recorded } \\
\text { and mapped }\end{array}$ & $\begin{array}{l}\text { A: More than 90\% of individual } \\
\text { land in rural areas is formally } \\
\text { recorded and mapped. }\end{array}$ & No change in grade \\
\hline
\end{tabular}

\section{Observation:}

- Referring to the previous discussion EI restated that legal framework provides for individualization of land records.

- Mr. Shome referred to a survey study conducted by the Directorate of Land Records and Survey, GoWB where one sample was taken randomly from each district. The objective was to identify the number of plots mentioned in map and number of plots mentioned in RoR. The study reveals that the recording and mapping of land is done almost with $99 \%$ perfection. But it has to be noted that records are not updated.

- EI suggested to make the reference to this study (Dimension 2 of LGI 2 of Panel 6) along with the analysis for this dimension.

\begin{tabular}{|l|l|l|}
\hline \multicolumn{1}{|c|}{ Dimension } & \multicolumn{1}{|c|}{ Grade } & \multicolumn{1}{c|}{ Change in Grade } \\
\hline $\begin{array}{l}\text { 2.3. Individual land in } \\
\text { urban areas is recorded } \\
\text { and mapped }\end{array}$ & $\begin{array}{l}\text { A: More than 90\% of individual } \\
\text { land in urban areas is formally } \\
\text { recorded and mapped }\end{array}$ & No change in grade \\
\hline
\end{tabular}

\section{Observation:}

- Referring to the analysis report EI shared that all individual lands in urban areas except those falling within Calcutta Municipal Corporation (Ward 1 - 100) are mapped and recorded. Section 19 of the Kolkata Land Revenue Act, 2003 provides that maps and records of these hundred wards would be prepared under the provisions of the WBLR Act. The notification has not been done yet.

- All other panellists accepted the gradation proposed by EI.

\section{Recommendation:}

There is a need to conduct a survey of the first hundred wards [1-10o] of Kolkata Municipal Corporation and maps and records are to be prepared under the provision of WBLR Act. 


\begin{tabular}{|c|c|c|}
\hline Dimension & Grade & Change in Grade \\
\hline $\begin{array}{l}\text { 2.4. The number of } \\
\text { illegal land sales is low }\end{array}$ & $\begin{array}{l}\text { B: The number of illegal land } \\
\text { transactions is low and some are } \\
\text { unambiguously identified on a } \\
\text { routine basis }\end{array}$ & No change in grade \\
\hline
\end{tabular}

\section{Observation:}

- Referring to the analysis report EI shared that illegal land sale is taking place in terms of transfer of patta land, transfer of lease holding land (e.g. Salt Lake city), transferring land without registration and alienation of tribal land.

- One panellist shared his experience that bargadars are sometimes seen to be selling land.

- Mr. Shome pointed out that transfer of raiyat land without registration is high in rural areas. It is because they want to avoid the cost of stamp duty which is very high. Other panellists added that oral transfer of land and even exchange of land is taking place rampantly. It is a very important issue associated with this which needs to be addressed by the government.

- One panellist shared a case in Midnapore where a party by investment of huge money asked all pattaholders (around 100 acres of land) to surrender their land to the government. Now, the party occupied the land and requesting the government to settle the land to them. Since the land is now free from incumbrances nand it belongs to government, government can consider the request. Clandestine arrangements are taking place in rural areas in different forms.

- Other panellists shared that tribal land alienation is still a problem in some pockets of the state. Though people are now reluctant to purchase tribal land fearing that no registration is possible, clandestine arrangements in different forms are taking place. One apnelist cited the example that in mines areas like Birbhum few parties are obtaining license for open mining by making partnership with tribes. After getting license they are making huge money through mining keeping the tribes in dark.

- One panellist pointed out that because of restriction of transferring tribal land, tribes are also facing problem. There are certain cases when tribal are willing to sell land because of valid reason but cannot because of the restriction. Mr. Banerjee suggested that some sort of institutional arrangement may be made to resolve those issues. Land Corporation may be set up for allowing the selling of tribal land to other when there is no buyer. But IE pointed out that same arrangement was made for bargadars as per $21 \mathrm{C}$ in WBLR Act. But it has remained silent.

\section{Recommendation:}

- All transaction should be ensured through registration. Reduction in stamp duty or other incentives may be put in place to encourage registration of all transaction.

- Institutional arrangement should be made for setting up Land Corporation for buying the distressed sale to arrest the trend of illegal settlements. Mechanism should also be developed for proper monitoring.

\begin{tabular}{|l|l|l|}
\hline \multicolumn{1}{|c|}{ Dimension } & \multicolumn{1}{c|}{ Grade } & Change in Grade \\
\hline $\begin{array}{l}\text { 2.5. The number of } \\
\text { illegal lease transactions } \\
\text { is low }\end{array}$ & $\begin{array}{l}\text { D: Existing legal restrictions on } \\
\text { land leases are routinely neglected }\end{array}$ & No change in grade \\
\hline Observation: & & \\
\hline
\end{tabular}

286|P a g L Lnd Governance Assessment Framework - West Bengal 
- EI stated that lease transaction in the state was totally prohibited as per WBEA Act. Further amendments have been made creating permission under certain circumstances. Despite restrictions, it is being practiced clandestinely.

- One panellist mentioned about a case where a person took power of attorney and clandestinely transacted land on lease.

- All other panellists agree that though law does not permit lease transaction it is being done clandestinely.

\section{Recommendation:}

An in-depth study may be conducted by an independent organization to assess the extent and nature of lease transaction. The study should reflect on the practical scenario and make recommendation to the government accordingly.

\begin{tabular}{|c|c|c|}
\hline Dimension & Grade & Change in Grade \\
\hline $\begin{array}{l}\text { 2.6. Women's property } \\
\text { rights are recorded }\end{array}$ & $\begin{array}{l}\text { D: Less than } 15 \% \text { of land recorded } \\
\text { to physical persons is recorded in } \\
\text { the name of women either } \\
\text { individually or jointly }\end{array}$ & No change in grade \\
\hline
\end{tabular}

\section{Observation:}

- Referring to the analysis report EI shared that Women's rights are recognized in practice by formal system. Women's property rights are recorded in the R-O-R during each settlement.

- One panellist shared the recent development where issuing patta in the name of women either singly or jointly has been given utmost priority. One panellist suggested that LR Department should be manned by women to bring about changes in attitude.

- Mr. Banerjee suggested that there is a need to take up the work of ensuring the recording of women's' property rights in the state in a mission mode (something like Operation Barga).

\section{Recommendation:}

- Government should take up a clear policy on land rights for women.

- Exemption in stamp duty in case of registration of land in the name of women may be introduced.

\begin{tabular}{|l|l|c|}
\hline \multicolumn{1}{|c|}{ Dimension } & \multicolumn{1}{|c|}{ Grade } & Change in Grade \\
\hline $\begin{array}{l}\text { 2.7. Women's property } \\
\text { rights to land are equal }\end{array}$ & Cquality of women's property & No change in grade \\
to those by men both in & rights to those by men is & \\
law and in practice & $\begin{array}{l}\text { established by law, but there are } \\
\text { considerable limitations to } \\
\text { exercising such rights in practice }\end{array}$ & \\
\hline
\end{tabular}

\section{Observation:}

- EI mentioned that Hindu Succession Act 1955 and other Act provide for equal rights for women. But there is lacuna in practice.

- One panellist added that the Amendment in Hindu Succession Act 2005 is also a very important step towards equality of rights.

- Other panellists opined that there is a need to include the provision of prioritising women (as for prioritisation of women in the LR manual (through amendment).

287|Page Land Governance Assessment Framework - West Bengal 


\section{Recommendation:}

- To make it compulsory for including women's name in the Record of Rights (RoR);

- To reopen the past cases where land title (patta) has been given in single title for including women's name in those titles making it a joint title;

- To amend the law for making joint ownership compulsory;

- To provide financial relief to women by providing revenue concession through $25 \%$ of exemption of rent paid by them (Data source: UN women study in Madhya Pradesh, Bihar, Andhra Pradesh and Kerela, Landesa)

- To aware Women's groups on the legalities of property rights

\section{Panel 2: Rights to Forest and Common Lands \& Rural Land Use Regulations}

17 February 2014

Landesa

Venue: Landesa Kolkata Office

Mr. Pinaki Halder, LGAF- West Bengal Project Leader and State Director, Landesa West Bengal welcomed all present and started the day's proceeding with a power point presentation delineating the purpose of the panel discussion, about LGAF, the core thematic areas of LGAF before venturing into the detailed discursive discussion on Panel 2: Rights to Forest and Common Lands \& Rural Land Use Regulations.

The expectations of this meeting were-

- Panelists would discuss over the analysis of each parameters and arrive at a consensus to finalize the gradations

- Gaps would be identified against each parameter and recommendations will come out to bridge those gaps

- Provide policy suggestions/ recommendations on the related issues on land governance

Following were the participants of the meeting-

1) Dr. A.K Raha, IFS (Retd), Ex-PCCF/WB

2) Mr.Atonu Chatterjee, MD, WBTDCC

3) Dr.Kulandaivel, IFS, DCF (HQ), GoWB

4) Prof. Apurba Kr. Mukhopadhyay, N.I.A.S, Kol

5) Mr.ArindamDutta, ADM \& DL\&LRO, PaschimMedinipur

6) Mr.Ashoke Kr. Nayar, Programme Officer, Action Aid India

7) Mr.SashiBhushanPraharaj, Manager cum Field Officer, LAMP, Bankura

8) Mr.RathinMahapatra, Accountant, LAMP, Belagaria

9) Mr. Pinaki Halder, State Director, Landesa, State Coordinator and Project Team LeaderLGAF- West Bengal

$\mathbf{2 8 8}$ | Page Land Governance Assessment Framework - West Bengal 
Landesa Kolkata team members were also present to aid the uninterrupted flow of the panel discussion. The names of those present were-

- Mr. Supriya Chattopadhyay, Communications Manager, Landesa- West Bengal

- Mr. Sudipta Biswas, District Program Manager, Landesa- West Bengal

- Dr. Shyamal Kumar Jana, Districts Manager, Landesa-West Bengal

- Ms. Udita Chatterjee, Research and Documentation Officer, Landesa- West Bengal

- Dr. Jayanta Munsi, District Program Manager, Landesa-West Bengal

- Mr. Debasis Mondal, Office Assistant, Landesa- West Bengal

The panel has two indicators as follows:

Indicator 1: Rights to forest and common lands

Indicator 2: Effectiveness and equity of rural land use regulations

Under Indicator 3 there areeight dimensions and within Indicator 4 there are six dimensions. Each dimension has four gradations-ranked by the panel from A to D. The dimensions were explicitly discussed in great detail to get the panelists' inputs to incorporate changes in the gradations and analysis.

\section{The dimensions under indicator 1 are:}

i. Forests and common lands are clearly identified in law and responsibility for use isclearly assigned.

ii. Rural group rights are formally recognized and can be enforced.

iii. Users' rights to key natural resources on land (incl. fisheries) are legally recognized and protected in practice.

iv. Multiple rights over common land and natural resources on these lands can legally coexist.

v. Multiple rights over the same plot of land and its resources (e.g. trees) can legally coexist.

vi. Multiple rights over land and mining/ other sub-soil resources located on the same plot can legally coexist

vii. Accessible opportunities exist for mapping and recording of group rights

viii. Boundary demarcation of communal land

\section{The dimensions under indicator 2 are:}

i. $\quad$ Restrictions regarding rural land use are justified and enforced.

ii. Restrictions on rural land transferability effectively serve public policy objectives

iii. Rural land use plans are elaborated/changed via public process and resulting burdens are shared

iv. Rural lands, the use of which is changed, are swiftly transferred to the destined use.

v. Rezoning of rural land use follows a public process that safeguards existing rights

vi. $\quad$ For protected rural land use (forest, pastures, wetlands, national parks etc.) plans correspond to actual use.

All the dimensions under each of the two indicators were discussed in detail and the final gradation and recommendations corresponding to the gradations are finalised as follows:

\begin{tabular}{|c|c|c|}
\hline \multicolumn{3}{|c|}{ Indicator 1:Rights to forest and common lands } \\
\hline Dimensions & Grade & Change in grade \\
\hline $\begin{array}{lrr}\text { 2.1.1. } & \text { Forests } & \text { and } \\
\text { common } & \text { lands } & \text { are }\end{array}$ & $\begin{array}{l}\text { B: Forests and common lands are } \\
\text { clearly identified, responsibility for }\end{array}$ & No change in grade \\
\hline
\end{tabular}

289|Page Land Governance Assessment Framework - West Bengal 
clearly identified in law land use is clearly identified but and responsibility for implementation is ambiguous.

use is clearly assigned.

\section{Observation:}

- At the very outset, Mr. Halder explained the meaning of common land as the land which is used for common purpose by the community like grazing ground, graveyard, playground etc. But as per law, there is no classification of common lands in this State. He further requested the ADM/DL\&LRO to reflect on this issue.

- Mr.Dutta shared that common lands which are used by the community for common purpose are identified in the records. But common lands within forest are not identified.

- Dr.Raha shared that in forest areas in the districts of southern West Bengal (Bankura, West Midnapore and Purulia) are highly fragmented. Most of the common lands identified in forest areas are vested waste lands which are yet to be distributed in few parts vested lands have been distributed to landless families in 1980s. Records are also updated. Currently, we are trying to set up land bank for providing land to the industries especially wastelands which are not in use. For that purpose we are trying to identify vested waste lands. As per records, there are huge chunk of vested waste lands which are not in use. But when we went to the field, we found that there is hardly in vested waste lands which have not been distributed as patta or not being used by the community. Then we felt the need of updating land records.

- Mr.Dutta shared that land bank which the LR Department is maintaining does not contain full data of vested land. At the same time records are not fully updated. The amount of land which has been distributed may not be reflected in the land bank.

- Dr.Raha pointed out that in many places lands are under encroachment. But Mr.Dutta shared that encroachment is more in semi-urban and fringe areas rather than rural areas. Dr. Kulandaivel cited some example of Bankura district where vested lands have been identified effectively and accurately but it has been found that lands are under encroachment by local people for cultivation and other purpose. As far as forest department is concerned, we have clear data of vested lands (esp. in Bankura, Purulia and Midnapore). Mr. Halder wanted to know whether it is done in other districts also especially in North Bengal. Dr. Kulandaivel answered that the situation in North Bengal is different because there is another conflicting issue of Tea Garden areas.Dr. Raha added that Forest Department took initiative to update land records using GPS technology 5 years back by the fund from Government of India. As of now $90 \%$ of the forest lands are clearly demarcated. He also added that forest areas in South Bengal are surveyed and it is in conformity with the Revisional Survey of LR Department. But the forest areas in North Bengal are left out from Cadastral Survey and Revisional Survey. There are huge chunk of blocks which are not part of CS or RS and these are being maintained as forest blocks. But the demarcation of boundaries are very clear (almost 98\%) and there is no ambiguity.

- Dr.Kulandaivel shared that Forest Department conducts 'creation' every year. It identifies forest areas, degraded forest etc. and updates the map (de-created). On the basis of that we propose for re-creation (artificial regeneration of forest). The department knows where is unplanned forest land, where is proper forest land, where is waste lands etc.So, Forest Department is very clear about its boundaries. There is no ambiguity in it.

- Dr.Raha pointed out that there is ambiguity in implementation. There is no ambiguity between forest land and common land. The grey areas are - common land within forest areas and maintaining records of lands for pattas given to families in forest areas (because pattas were given hurriedly without clear updating of records).

- Mr. Chatterjee pointed out that encroachment is the problem of implementation.

290|Page Land Governance Assessment Framework- West Bengal 
Secondly he emphasised that common lands within forest areas are sometimes not demarcated properly. There may or may not be common lands within forest areas which are being used by people. Forest Department has not taken initiative to identify and record those areas as common land. So, steps should be taken to classify those forest lands.

- When Dr.Raharaised the issue of common property resourcesMr. Chatterjee explained that when a particular community are using the usuerfactright of that area is considered as common property. For example, people who are engaged in collection of 'tendu' leaves traditionally in a particular period of time in a year (January to June) are claiming their usufruct right. He further explained that, for example, if a piece of forest land is used by the community as common property like ICDS centre,there is special provision for using that land [under Sec3(2)] for that particular purpose only not exceeding 1 hectare. It is clearly defined under FRA 2006.

- Dr.Raha shared another problem of granting community rights. The land which is being used by the community is legally meant for ST and other traditional forest dwellers as per FRA. But in few cases community comprises other non-forest dwellers who are almost 50\%. If the right is granted to the community, elite class will enjoy the facility and actual forest dwellers will be deprived. So it is becoming difficult to grant the right to actual forest dwellers.

- When one panelist wanted to know about the role of Joint Forest Management Committee Dr.Raha explained that the people who are living within forest areas or around forest areas should constitute Joint Forest Management Committee for protection of the forest and also getting usufruct benefit from the forest. As per the Act, all people within the community are entitled to be member of JFMC. In West Bengal in general, JFMCs are not dominated by tribal population. Where there is more than 50\% representation from tribes JFMCs are enjoying community rights as per Act. Where tribal representation is less than 50\%, they have the rights under government resolution on joint forest management. This is outside the purview of the FRA. JFMC right is not a statutory right; is by executive order/resolution. But the JFMCs constituted under FRA are enjoying statutory rights. If all are brought under the purview of FRA, they can enjoy statutory rights.

- Mr. Chatterjee cited the example of LAMP and suggested an alternative way. LAMP is acting as cooperative of collectors. All members of LAMP are not actually collectors. There are number of members who belong to other community. LAMP is demanding community rights on the basis of the list of collectors only. Likewise if tribal members are taken out separately and community rights are given to them, we can avoid the complexity.

- Panelists concluded that the scenario in West Bengal is different from other States (Chattisgarh, Jharkhand etc.). Because of less tribal population and domination by other population in the State, there is problem of granting community rights in forest areas.

- Mr. Chatterjee and other panelist pointed out that common land within forest areas are not identified but outside the forest areas are clearly identified. So, they suggested rephrasing the statement for ranking it accurately.

- Mr. Halder suggested that if we get data from a district on Common land clearly identified outside the forest areas and assumed common lands identifiable within forest areas, we can show it as an example to substantiate the fact. He requested Mr.Dutta to provide the same for West Midnapore district. Mr.Dutta agreed to provide that.

- Dr.Raha raised the issue of lack of coordination between Forest Department and LR Department. Because of that, there is huge information gap between two departments regarding areas identified as protected forest, areas identified as common lands, areas distributed as forest patta etc.

291|Page Land Governance Assessment Framework - West Bengal 


\section{Recommendation:}

- Forest Department is required to play proactive role in physical verification of common lands and updating records (record of common land, record of forest patta, record of actual waste lands etc.)

- Gap in information between LR Department and Forest Department needs to be bridged.

- Executive order should be issued followed by practical guideline so that L\&LR Department and Forest Department work in tandem.

\begin{tabular}{|l|l|l|}
\hline \multicolumn{1}{|c|}{ Dimensions } & \multicolumn{1}{c|}{ Grade } & \multicolumn{1}{c|}{ Change in grade } \\
\hline $\begin{array}{l}\text { 2.1.2 Rural group rights } \\
\text { are formally recognized } \\
\text { and can be enforced }\end{array}$ & $\begin{array}{l}\text { C: The tenure of most groups in } \\
\text { rural areas is formally recognized } \\
\text { but ways for them to gain legal } \\
\text { representation are not regulated. }\end{array}$ & No change in grade \\
\hline
\end{tabular}

\section{Observation:}

- Referring to the analysis report, Dr.Raha explained that group rights are formally recognized by the JFMC but not by the FRA. Benefits like NTFP being enjoyed by JFMC are recognized by Executive Order, it is not a statutory right as it is not supported legally. Then we can say that tenure of most groups in rural areas is formally recognized.

- Mr. Chatterjee pointed out that the rights of the people over common property resource is not legally recognized either. The benefits they are enjoying that are because of traditional practice (from mouth to mouth) which is not written elsewhere. Now, the effort is on to bring it under formal legal recognition.

- Panelists agreed that if we divide regulation into two parts then we can say that in case of JFMC legal representation is not regulated and in case of common property resources it is regulated.Mr. Chatterjee cited the example of arrangement of allowing sal leaves collection to the traditional collectors which are not backed by legal framework.

- Panelists suggested that we need to define 'Rural Groups rights' under Joint Forest Management and Protection Committee (JFMC) and 'Community Rights' under Forest Rights Act (FRA) in the explanatory note for more clarification.

\section{Recommendation:}

- Provision should be made in FRA to incorporate the system of JFMC giving some waiver or making some alteration.

- Scope of 'community rights' to be widened up to include other forest dwellers along with $S T$.

\begin{tabular}{|l|l|l|}
\hline \multicolumn{1}{|c|}{ Dimensions } & \multicolumn{1}{|c|}{ Grade } & Change in grade \\
\hline $\begin{array}{l}\text { 2.1.3 Users' rights to key } \\
\text { natural resources on }\end{array}$ & $\begin{array}{l}\text { D: Users' rights to key natural } \\
\text { resources are not legally recognized }\end{array}$ & No change in grade \\
$\begin{array}{l}\text { land (incl. fisheries) are } \\
\text { legally recognized and } \\
\text { protected in practice }\end{array}$ & and often not protected in practice & \\
\hline
\end{tabular}

\section{Observation:}


- Dr. Raha shared that in Sundarban, local fishermen used to enjoy customary fishing rights in the Sundarban Rivers within Reserved Forest boundary. However, no such right has been recognised under FRA 2006. Until and unless it is legally recognized, it depends upon the whims of the forest officials whether they will be able to enjoy the customary rights or not and to what extent.

- Dr. Kulandaivel added that government cannot punish any official because of denial of providing benefits to people until and unless it is not legally recognized. Naturally, government officials are indifferent on this issue. It completely depends on their goodwill.

- All other panelists agreed to the fact shared by them and justified the ranking.

\section{Recommendation:}

Synergy is required for provisioning JFMC under FRA. Bringing about certain changes in JFMC may also be required.

\begin{tabular}{|l|l|l|}
\hline \multicolumn{1}{|c|}{ Dimensions } & \multicolumn{1}{c|}{ Grade } & \multicolumn{1}{c|}{ Change in grade } \\
\hline $\begin{array}{l}\text { 2.1.4 Multiple rights over } \\
\text { common land and } \text { Co-existence is possible by law }\end{array}$ & $\begin{array}{l}\text { Grade is changed from C to } \\
\text { natural resources on } \\
\text { these lands can legally } \\
\text { coexist }\end{array}$ & \\
\hline
\end{tabular}

\section{Observation:}

- Dr. Raha explained multiple rights to other panelists showing one example. JFMC constituted under government resolution is enjoying the rights over NTFP like sal leaves, tendu leaves etc. At the same time WBTDCC has been enjoying rights on the same. Whether these two rights are co-existing or creating any conflict of interest.

- Mr. Chatterjee and Mr. Praharaj shared that it has been co-existing since long back. No conflict has been found till date at ground level.

- Dr.Raha further explained the issue citing some example. Using same piece of land as playground and also as grazing ground by a community or collecting NTFP from the same forest by different groups is some field are co-existing in practice. He further added that there is possibility of conflict when a group who is allowed collecting sal leaves only and want to collect sal seed. Multiple rights are not clearly segregated by executive order. So, it may or may not be respectory in practice.

- Mr.Dutta opined the statement would more appropriate if the word 'rarely' is removed.

- The house agreed that statement in B is more appropriate than in C. Rights are legally co-existing and respected in practice but there should be proper mechanisms to resolve disputes if it arises so.

\begin{tabular}{|l|l|l|}
\hline \multicolumn{1}{|c|}{ Dimensions } & \multicolumn{1}{c|}{ Grade } & \multicolumn{1}{c|}{ Change in grade } \\
\hline $\begin{array}{l}\text { 2.1.5 Multiple rights over } \\
\text { the same plot of land } \\
\text { and its resources (e.g. } \\
\text { trees) can easily co-exist }\end{array}$ & $\begin{array}{l}\text { Co-existence is possible by law } \\
\text { but rarely respected in practice }\end{array}$ & $\begin{array}{l}\text { Grade is changed from C to } \\
\text { B. }\end{array}$ \\
\hline Observation: \\
- Considering the discussion held on the previous dimension, panelists suggested \\
changing the grade from C to B.
\end{tabular}

293|Page Land Governance Assessment Framework - West Bengal 
- Dr.Raha gave an example where a particular piece of land is owned by a tribe and forest is being managed by Forest Department. But the person wanted to cut the trees on the ground that the land belongs to him. In this case, co-existance is there in law but it is not respected in practice.

\begin{tabular}{|l|l|l|}
\hline \multicolumn{1}{|c|}{ Dimensions } & \multicolumn{1}{c|}{ Grade } & \multicolumn{1}{c|}{ Change in grade } \\
\hline $\begin{array}{l}\text { 2.1.6 Multiple rights over } \\
\text { land and mining/ other } \\
\text { sub-soil } \begin{array}{l}\text { D: Co-existence is not possible by } \\
\text { located on the same plot } \\
\text { can legally coexist }\end{array}\end{array}$ & $\begin{array}{l}\text { law; mining rights override land } \\
\text { rights }\end{array}$ & \\
\hline
\end{tabular}

\section{Observation:}

- Dr.Raha shared that if any forest land is selected for mining then it is handed over to Mining Agency. Forest Department no longer manages that land. But as per law, if the land was belonging to any tribal, clearance is required from Gram Sabha before transferring the land to Mining Agency.

- All panelists agreed to grade it as D as the statement is very much justified.

\begin{tabular}{|l|l|l|}
\hline \multicolumn{1}{|c|}{ Dimension } & \multicolumn{1}{c|}{ Grade } & \multicolumn{1}{c|}{ Change in grade } \\
\hline $\begin{array}{l}\text { 2.1.7 Accessible } \\
\text { opportunities exist for } \\
\text { mapping and recording } \\
\text { of group rights }\end{array}$ & $\begin{array}{l}\text { B: The law provides opportunities } \\
\text { for those holding group land under } \\
\text { customary, group, or collective } \\
\text { tenures to record and map these } \\
\text { rights if they so desire. Procedures } \\
\text { to do so are affordable and include } \\
\text { basic safeguards against abuse. }\end{array}$ & \\
\hline
\end{tabular}

\section{Observation:}

- One of the panellists suggested that it would be wise to write the word 'imperative' instead of 'desire' in the statement B because maintaining record is mandatory. Panelists agreed that practically it is affordable.

- Dr.Raha shared that when the area of forest is big then there is no problem in granting community rights over NTFP in specific areas to a particular community by demarcation. But when the area of forest is very small and interest groups are large in number, then it becomes a problem to demarcate a particular area for a particular community. Practically, rough estimate is made for demarcation.

- All panelists agreed that recording the right should be made mandatory. Process is also affordable.

- Dr.Kulandaivel shared some field level problem in demarcation. But he insisted that demarcation should be made mandatory to tackle future problem also keeping in mind growing population and decreasing manforest ratio.

\section{Recommendation:}

Recording and mapping of the rights of the groups who are holding land under customary, group, or collective tenures should be made mandatory.

\begin{tabular}{|lr|l|l|}
\hline \multicolumn{2}{|c|}{ Dimensions } & \multicolumn{1}{c|}{ Grade } & Change in grade \\
\hline $\begin{array}{l}\text { 2.1.8 } \\
\text { demarcation }\end{array}$ & Boundary & $\begin{array}{l}\text { D: Less than 10\% of the area under } \\
\text { communal and/or indigenous land }\end{array}$ & No change in grade \\
\hline
\end{tabular}

294|Page Land Governance Assessment Framework - West Bengal 


\begin{tabular}{|c|c|c|}
\hline communal land & $\begin{array}{l}\text { has boundaries demarcated and } \\
\text { surveyed and associated claims } \\
\text { recorded }\end{array}$ & \\
\hline \multicolumn{3}{|l|}{ Observation: } \\
\hline \multicolumn{3}{|c|}{$\begin{array}{l}\text { All panelists agreed that percentage is indicative (not exact figure) and it is definitely less } \\
\text { than } 10 \% \text {. Hence, they all agreed to grade it as D. }\end{array}$} \\
\hline \multicolumn{3}{|c|}{ Indicator 2: Effectiveness and equity of rural land use regulations } \\
\hline Dimensions & Grade & Change in grade \\
\hline $\begin{array}{l}2.2 .1 \text { Restrictions } \\
\text { regarding rural land use } \\
\text { are justified and } \\
\text { enforced }\end{array}$ & $\begin{array}{l}\text { A: Regulations regarding } \\
\text { restrictions on rural land use } \\
\text { effectively serve public purpose and } \\
\text { are enforced }\end{array}$ & $\begin{array}{l}\text { Gradation changed from } A \\
\text { to } B\end{array}$ \\
\hline
\end{tabular}

\section{Observation:}

- Dr.Raha said that there are a number of regulations regarding converting agricultural land into non-agricultural land, ecological and environmental perspective in land use, consideration of water bodies for land use, use of wetland etc. But the enforcement of these regulations is very weak.

- Mr.Dutta suggested that changes are required in law. Law provides for penalising the raiyats only. Often the raiyats do not change while other persons can change who are either taking the land forcibly or by encroachment. Law does not make any provision to penalise encroachers. One panelist opined that it is difficult to trace other persons except raiyats. Another panelist said that the problem is in implementation.

- Mr.Dutta shared another example. A vested land which is encroached and due to use for other purpose ignoring regulations classification changes. Government cannot take any action. Dr.Raha shared that in Malda and Murshidabad districts the land which is classified as orchard land may be used for other construction purposes ignoring regulations.

- One of the panellists for example shared that the implementation of the Inland Fisheries Act, Non-forestry Act etc. are very weak because of lack of implementation machinery and proper infrastructure.

- Mr. Halder said that this has to be strengthened with some data or case study.

- All panelists suggested grading it as B instead of A.

\begin{tabular}{|c|c|c|}
\hline Dimensions & Grade & Change in grade \\
\hline $\begin{array}{l}\text { 2.2.2 Restrictions on } \\
\text { rural land transferability } \\
\text { effectively serve public } \\
\text { policy objectives }\end{array}$ & $\begin{array}{l}\text { A: There are a series of regulations } \\
\text { that for the most part serve public } \\
\text { purpose and that are enforced }\end{array}$ & No change in grade \\
\hline
\end{tabular}

\section{Observation:}

- Dr.Raha shared that transferability of land is restricted by laws in cases of land of Scheduled Tribes, homestead plots/patta etc. There are other several laws which restricts transferability of land. As far as enforcement is concerned, it is weak.

- One of the panellists shared that enforcement level is not satisfactory.But we cannot say that it is not enforced.

- All panelists agreed that regulations are there and it is enforced by and large though

295|Page Land Governance Assessment Framework- West Bengal 


\begin{tabular}{|c|c|c|}
\hline Dimensions & Grade & Change in grade \\
\hline $\begin{array}{l}2.2 .3 \text { Rural land } \begin{array}{l}\text { use } \\
\text { plans }\end{array} \\
\text { elaborated/changed } \\
\text { public process } \\
\text { resulting burdens are } \\
\text { shared }\end{array}$ & $\begin{array}{l}\text { A: Public input is required and } \\
\text { sought in preparing and amending } \\
\text { rural land use plans (incl. rezoning) } \\
\text { and relevant decisions are arrived } \\
\text { at in a transparent and public } \\
\text { process }\end{array}$ & No change in grade \\
\hline
\end{tabular}

\section{Observation:}

- Mr. Halder mentioned that provision has been made in Sec. $4 \mathrm{C}$ of the Land Reforms Act. (Local enquiry, public hearing etc.). He mentioned that Panchayat Act needs to be referred to for the analysis of this dimension.

- All panelists agreed that public input is required and sought through different mechanism. Though there may be some debate on level of transparency but we cannot say that decisions are arrived at in a non-transparent process. Hence, A is the most suitable option for gradation.

\begin{tabular}{|l|l|l|}
\hline \multicolumn{1}{|c|}{ Dimensions } & \multicolumn{1}{c|}{ Grade } & \multicolumn{1}{c|}{ Change in grade } \\
\hline $\begin{array}{l}\text { 2.2.4 Rural lands, the } \\
\text { use of which is changed, } \\
\text { are swiftly transferred to } \\
\text { the destined use }\end{array}$ & $\begin{array}{l}\text { C: Between 30\% and 50\% of the } \\
\text { land that has had a change in land } \\
\text { has changent in the past 3 years } \\
\text { (e.g. forest, pastures, wetlands, } \\
\text { national parks etc.). }\end{array}$ & $\begin{array}{l}\text { Change in grade from C to } \\
\text { A. }\end{array}$ \\
\hline
\end{tabular}

\section{Observation:}

- ADM, Paschim Midnapore mentioned that in maximum cases, permission is made post facto. Whenever prior permission is there, it is changed by one month. Even in case of forest land transfer is done within 3 years.

- When one panelist wanted to know how the change takes place, Mr.Dutta shared that either the change has to be compensated by forest land or by providing any other land for the forestry. Dr.Kulandaivel further clarified that if the forest land is given for the non-forestry purpose, compensation has to be given. Once permission is given for change, it takes no time to transfer.

- One of the panellists shared that it is important to make afforestation compulsory. Another panellist said that if the forest land is given for non-forest purpose clearance has to be given.

- Mr. Halder mentioned that the 'analysis' of this dimension has to be changed and the Forest Conservation Act has tobe referred.

- All panelists agreed to grade it as A because on an average more than $70 \%$ of the land that has had a change in land use assignment in the past 3 years has changed to the destined use.

\begin{tabular}{|l|l|l|}
\hline \multicolumn{1}{|c|}{ Dimensions } & \multicolumn{1}{c|}{ Grade } & \multicolumn{1}{c|}{ Change in grade } \\
\hline $\begin{array}{l}\text { 2.2.5 Rezoning of rural } \\
\text { land use follows a public } \\
\text { process that safeguards } \\
\text { existing rights }\end{array}$ & $\begin{array}{l}\text { B: Processes for rezoning are public } \\
\text { and clear but mechanisms to } \\
\text { safeguard existing rights are not } \\
\text { fully effective }\end{array}$ & $\begin{array}{l}\text { Grade changed from } B \text { to } \\
\text { A. }\end{array}$ \\
\hline Observation:
\end{tabular}

- Dr.Raha referred to Indian Forest Act, 1927 and Wildlife protections Act, 1972 and mentioned that if government declares a private land as sanctuary it must follow a

296 | Page Land Governance Assessment Framework- West Bengal 


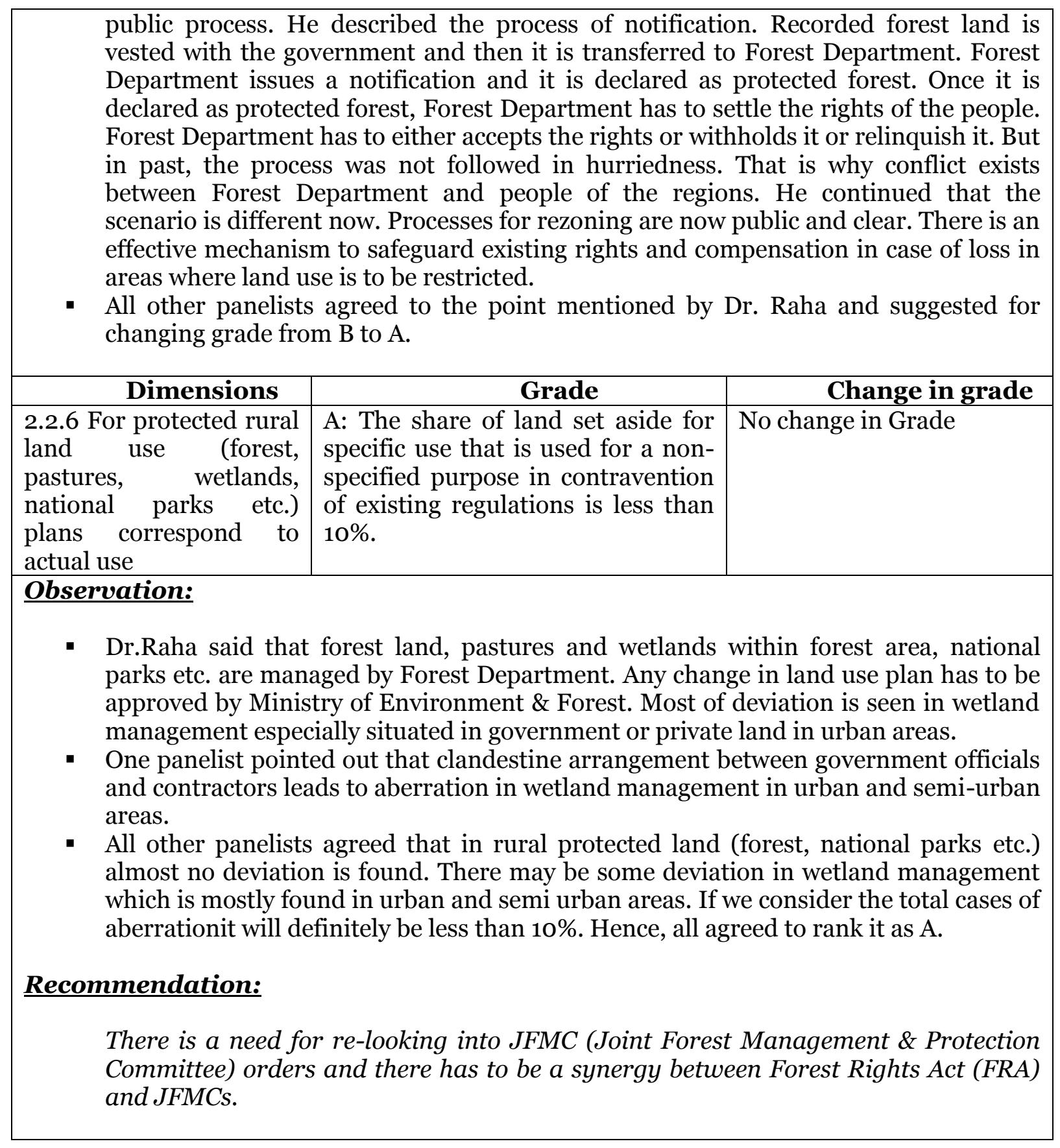

Panel 3: Urban Land Use, Planning, and Development

\author{
10 March 2014 \\ Landesa
}

Venue: Landesa Kolkata Office

The meeting was started with a warm welcome to the panelists by Mr. Pinaki Halder, LGAFWest Bengal Project Leader and State Director, Landesa, West Bengal.After making a brief presentation delineating the purpose of the panel discussion, about LGAF, the core thematic areas of LGAF, Land Governance Indicators and Dimensions etc. he ventured into the detailed discursive discussion on Panel 3: Urban Land Use, Planning, and Development. 
Following were the participants of the meeting-

1) Mr.Anup K. Matilal, Ex-Joint Secretary, Urban Development Dept., Govt. of WB

2) Mr.SaibalThakurata, Chief Town Planner, Urban Development Dept., Govt. of WB

3) Ms.Annapurna Shaw, Professor, IIM - Kolkata

4) Ms.Nirmala Banerjee, Retd Professor, Centre for Studies in Social Science, Kolkata

5) Ms.ReshmiGanguly, Programme Officer, Action Aid

6) Mr. Pinaki Halder, State Director, Landesa, State Coordinator and Project Team LeaderLGAF- West Bengal

Landesa Kolkata team members were also present to aid the uninterrupted flow of the panel discussion. The names of those present were-

- Mr. Supriya Chattopadhyay, Communications Manager, Landesa- West Bengal

- Ms. Udita Chatterjee, Research and Documentation Officer, Landesa- West Bengal

- Mr. Debasis Mondal, Office Assistant, Landesa- West Bengal

The panel has five indicators as follows:

1. Restrictions on rights: land rights are not conditional on adherence to unrealistic standards.

2. Transparency of land use restrictions: changes in land use and management regulations are made in a transparent fashion and provide significant benefits for society in general rather than just for specific groups.

3. Efficiency in the urban land use planning process: land use plans are current, implemented, do not drive people into informality, and cope with urban growth.

4. Speed and predictability of enforcement of restricted land uses: development permits are granted promptly and based on reasonable requirements.

\section{Tenure regularization schemes in urban areas}

There are two dimensions under Indicator 1, three dimensions under Indicator 2, four dimensions under Indicator 3, two dimensions under Indicator 4 and three dimensions under Indicator 5. Each dimension has four gradations-ranked by the panel from A to D. The dimensions were explicitly discussed in great detail to get the panelists' inputs to incorporate changes in the gradations and analysis and to incorporate their suggestions or policy level recommendation.

\section{The dimensions under indicator 1 are:}

i. Restrictions on urban land ownership/transfer effectively serve public policy objectives.

ii. Restrictions on urban land use (disaster risk) effectively serve public policy objectives.

\section{The dimensions under indicator 2 are:}

i. Process of urban expansion/infrastructure development process is transparent and respects existing rights.

ii. Changes in urban land use plans are based on a clear public process and input by all stakeholders.

iii. Changes in assigned urban land use are swiftly followed by actual land use change.

\section{The dimensions under indicator 3 are:}


i. Policy to ensure delivery of low-cost housing and services exists and is progressively implemented.

ii. Land use planning effectively guides urban spatial expansion in the largest city.

iii. Land use planning effectively guides urban development in the four next largest cities.

iv. Planning processes are able to cope with urban growth.

\section{The dimensions under indicator 4 are:}

i. Provisions for residential building permits are appropriate, affordable and complied with.

ii. A building permit for a residential dwelling can be obtained quickly and at a low cost.

The dimensions under indicator 5 are:

i. Formalization of urban residential housing is feasible and affordable.

ii. In cities with informal tenure, a viable strategy exists for tenure security, infrastructure, and housing.

iii. A condominium regime allows effective management and recording of urban property.

All the dimensions under each indicator were discussed in detail and the final gradation and recommendations corresponding to the gradations are finalised as follows:

\begin{tabular}{|l|l|l|}
\hline Indicator 1:Restrictions on rights & \multicolumn{1}{|c|}{ Change in Grade } \\
\hline \multicolumn{1}{|c|}{ Dimensions } & \multicolumn{1}{|c|}{ Grade } & No change is proposed \\
3.1.1. Restrictions on urban & B: There is a series of \\
land ownership/transfer & $\begin{array}{l}\text { regulations that are for the most } \\
\text { effectively serve public serve public purpose but } \\
\text { policy objectives } \\
\text { enforcement is deficient. }\end{array}$ \\
Observation: \\
- Prof. Nirmala Banerjee shared that urban planning has never been in tune with the \\
growing urban population. Planning for the poor has never taken due place in metro \\
city planning. She also commented that there is no coordination between metro city \\
planning and planning in other urban areas. \\
- She also pointed out that we talk about metro city planning and census town \\
planning but are less concerned on how they are organically and functionally \\
connected and there is lack of viable relationship being established. \\
She again commented that the urban legislations/ regulations have never really \\
accounted for the working poor community in cities and towns who are actually \\
contributing to the process of urban development. \\
Prof. Annapurna Shaw opined that all the legislations (e.g. Urban Land Ceiling Act) \\
have been drafted with very good intention but again the implementation of \\
important provisions is tardy. \\
Other panelists in line with Prof. Shaw agreed that the regulations that exist have \\
good intention but enforcement is weak. Hence they agreed to grade it as B. \\
One panelist shared that government has made progress in updating the land records \\
which is available in the website for the public. In addition to that, government has \\
experimentally started to update the registration process (Howrah and Rajarhat) \\
where transfer of land will be recorded and it will be accessible to the public.
\end{tabular}

299 Page Land Governance Assessment Framework- West Bengal 


3.1.2 Restrictions on urban
land use (disaster risk)
effectively serve public
policy objectives

B: There are a series of regulations that are for the most part serve public purpose but Grade $\boldsymbol{D}$ was proposed instead of $B$.

\section{Observation:} that are not enforced.

- One panelist referred that The West Bengal Town and Country (Planning \& Development) Act, 1979 provides for Disaster Risk Reduction (DRR) in land use and development control plan.

- Expert Investigator shared that the government has been talking about the provision for increasing the height of building by increasing FAR like, for example, what has been done in Hyderabad. But still it has not been enforced. Receiving a query from another panelist, he shared that the limit of ceiling height varies from ULB to ULB at present. Prof. Shaw added that height description of buildings have been defined in Easter Metropolitan bypass areas in Kolkata.

- Mr. Halder referred to the background report where Expert Investigator has mentioned about different barriers - legal, political, financial and social to implement these regulations. Example was cited of conflicting provisions between Acts. Prof. Shaw added political reluctance to redevelop land in fear of the burden of disturbing settlements and rehabilitating people.

- One of the panelists commented that there is no provision of transfer of development rights in Kolkata Municipal Corporation Act as it is so in the states of Maharashtra, Tamil Nadu and Andhra Pradesh to redevelop the older part of the city.

- One of the panelists suggested that there should be proper planning before undertaking any development (systematic land use planning) project.

- One panellist pointed that there is huge quantum of fallow land or encroached land within the city. If these areas are identified and recovered properly and utilized for development projects, there will be no need to use fringe areas.

- Panelists agree that there is a need to revisit the regulations because these are not serving any public purpose. Hence they decided to grade it as D instead of B.

\section{Recommendation (if any):}

1. There is a need to review the present situation from time to time to incorporate changes in policies or making new regulations.

2. There should be an exercise to recover city lands from encroachment.

3. WBT\&C (P\&D) Act needs thorough revisions/ updating to overcome conflicts and to address present planning issues. Change of land use and conversion of land are treated separately in two departments under two acts, leading to harassment and confusion.

\begin{tabular}{|c|c|c|}
\hline \multicolumn{3}{|c|}{ Indicator 2: Transparency of land use restrictions } \\
\hline Dimensions & Grade & Change in Grade \\
\hline $\begin{array}{l}\text { 3.2.1Process of urban } \\
\text { expansion/infrastructure } \\
\text { development process is } \\
\text { transparent and respects } \\
\text { existing rights }\end{array}$ & $\begin{array}{l}\text { C: Information on planned } \\
\text { urban expansion and } \\
\text { infrastructure development is } \\
\text { publicly available with sufficient } \\
\text { anticipation but the way in } \\
\text { which land rights by those } \\
\text { affected are dealt with is largely } \\
\text { ad hoc. }\end{array}$ & $\begin{array}{l}\text { Grade } \mathbf{D} \text { is proposed } \\
\text { instead of C. }\end{array}$ \\
\hline
\end{tabular}

\section{Observation:}

- One panelist commented that information on planned urban expansion and infrastructure development is publicly not available. But, EI stated that it is available.

- When Prof. Shaw wanted to know where the information is available, EI informed

300|Page Land Governance Assessment Framework - West Bengal 
that though it is not available in the website any person can formally approach to the department for information and it is made available. Another way of getting information is RTI.

- Prof. Shaw shared her experience of approaching Housing \& Urban Development Corporation (HUDCO) office for some data regarding expansion plan. She concluded that she was not provided any information by the officials showing the lame excuse of confidentiality.

- EI shared that all 126 Urban Local Bodies (ULBs) in West Bengal have already prepared Draft Development Plan (DDP) and these have been approved by the Bodies. There was scope of sharing information with the public and to incorporate public opinions in the plan.

- Chief Town Planner reiterated that once the Draft Development Plan (DDP) is ready it will be uploaded in the website and will be available to the public. Inputs and suggestions will also be invited from the citizens.

- Prof. Shaw stressed that the information on planned urban expansion and infrastructure development is not publicly available till date (which is under process). Hence the group decided to grade it as D instead of C.

\begin{tabular}{|l|l|l|}
\hline \multicolumn{1}{|c|}{ Dimensions } & \multicolumn{1}{|c|}{ Grade } & \multicolumn{1}{c|}{ Change in Grade } \\
\hline $\begin{array}{l}\text { 3.2.2 Changes in urban } \\
\text { land use plans are based on } \\
\text { a clear public process and } \\
\text { input by all stakeholders }\end{array}$ & $\begin{array}{l}\text { C: Public input is sought in } \\
\text { preparing and amending land } \\
\text { use plans but the public } \\
\text { comments are largely ignored in } \\
\text { the finalization of the land use } \\
\text { plans. }\end{array}$ & $\begin{array}{l}\text { Gradation was changed } \\
\text { from C to B. }\end{array}$ \\
\hline \multicolumn{1}{|c|}{ Dimensions } & \multicolumn{1}{|c|}{ Grade } & Change in Grade \\
\hline $\begin{array}{l}\text { 3.2.3 Changes in assigned } \\
\text { urban land use are swiftly } \\
\text { followed by actual land use } \\
\text { change }\end{array}$ & $\begin{array}{l}\text { B: Between 50\% and 70\% of the } \\
\text { land that has had a change in } \\
\text { land use assignment in the past } \\
\text { 3 years has changed to the } \\
\text { destined use. }\end{array}$ & No change in grade \\
\hline
\end{tabular}

\section{Observation:}

- When asked by one panelist about the nature of land, Mr.Thakurta, Chief Town Planner made it clear that two kind of lands are there - existing land and prososed land. Here for the purpose of discussion, proposed land is taken into consideration.

- EI shared that when HUDCO prepares any plan for economically weaker sections, changes in proposed land are followed immediately. And development project is implemented in the very assigned land. In certain cases, due to political whims, change in land use plan is not being followed.

- After a long discussion panelists came to conclusion that when any land is marked for commercial /industrial use or residential use or use of public purpose, the change is followed by the authority. But compromises are made to certain extent.

- When Prof. Banerjee wanted to know if there is any provision for revision, Mr.Thakurta shared that there is provision for revision of land use plan after every 10 years. He stressed that in $100 \%$ cases changed plan is followed in 3 years and in more than $70 \%$ cases it is changed to the destined use (based on experience and evidence).

- Prof. Shaw countered that there are lot cases, which are published in newspapers, where the rules (plans) are violated backed by political parties. Then we cannot say it is followed in $100 \%$ cases. Prof. Banerjee supplemented that people have to resort to legal process in the cases of violation of rule. She added that there is also chance of mismatch between legislative and administrative orders.

- Mr.Thakurta stated that administration cannot take action in cases of violation of rule because of the non-availability of data. He also agreed that there is lack of

301|Page Land Governance Assessment Framework - West Bengal 
appropriate mechanism and sometime political will to follow with the proposed actions identified and incorporated in the DDP.

- Prof. Shaw stated that there are a number of small Municipalities where there is no progress in changing land use plan. Mr.Thakurta agreed that Municipalities do not have any mechanism to change the actual land use after it has been assigned. He also added that Municipalities only sanction the plan for construction of houses or commercial building but the there is no provision for development of Municipal areas. Then EI added that for that purpose DDP has been prepared for all Municipalities. Prof. Banerjee stated there is huge gap between policy making and its implementation. She continued that there is no machinery or administrative control over what happens after taking any policy decision (lack of follow up action / monitoring).

- The panel concluded that there is no readily available data to substantiate how much land that has had a change in land use assignment in the past 3 years has changed to the destined use. Based on the experience it can be said that more than $50 \%$ cases it happen. Hence, the panel agreed to the rank (B) proposed by EI.

\section{Recommendation (if any):}

- Prof. Shaw suggested that the GIS technology could be leveraged to ascertain the change happening over time in actual land use.

- One Panelist suggested that there has to be a separate cell for land use control.

Indicator 3: Efficiency in the urban land use planning process

\begin{tabular}{|l|l|l|}
\hline \multicolumn{1}{|c|}{ Dimensions } & \multicolumn{1}{|c|}{ Grade } & \multicolumn{1}{c|}{ Change in Grade } \\
\hline $\begin{array}{l}\text { 3.3.1 Policy to ensure } \\
\text { delivery of low-cost housing } \\
\text { and services exists and is } \\
\text { progressively implemented }\end{array}$ & $\begin{array}{l}\text { and services exists but for low cost housing } \\
\text { implementation is not always } \\
\text { effective. As a result the } \\
\text { number of thes suggested to } \\
\text { change the grade from B to } \\
\text { inadequate shelter declines but } \\
\text { still remains high. }\end{array}$ & \\
\hline
\end{tabular}

\section{Observation:}

- Prof. Shaw argued that there is no state level mandatory policy of low cost, affordable housing for economically weaker section in urban areas. But, Mr.Thakurta stated that there is a policy both for government housing projects and housing projects being implemented in PPP mode or fully owned private projects. Prof. Shaw cited the example of South City Project in Kolkata where there is no provision for economically weaker section. Mr.Thakurta referred to the gazette notification made by the government in 2012 paving the way for reservation of $25 \%$ of dwelling units in any housing project planned with more than 5000 sq. meter area.

- One panelist commented that in spite of PPP affordable housing is not being adhered or implemented. Even there is no mechanism to monitor whether it is being implemented or not.

- One panelist referred that unlike Andhra Pradesh, Karnataka and Tamil Nadu, West Bengal does not have state level mandatory policy for low cost housing scheme.

- Prof. Banerjee pointed out that there are two departments who are managing the development activities in urban areas, i.e. Urban Development Department and Municipal Affairs. There is lack of coordination between two departments. Even the there are certain circular or notification from any particular department which is in conflict with the rules of other department.

- Mr.Thakurta shared that $74^{\text {th }}$ Amendment Act has not been implemented in any state fully. West Bengal Government followed by Maharastra has formed Metropolitan Planning Committee where attempt has been made to bridge the gap of coordination between two departments. 
- EI stated that as far as legislation is concerned, West Bengal is much progressive that other states. District Planning Committee has been established all districts as per the provision laid down in $73^{\text {rd }}$ and $74^{\text {th }}$ Amendment Act. But he agreed that implementation is tardy.

- Referring to the background report Mr. Halder mentioned that as per USHA Study Report 5,55,000 urban settler have received shelter and around 2,00,000 are in worst condition who need adequate shelter. In last 7 years BSUP and IHSDP has taken care of fair amount of shelters for the poor.

- There was a debate on the issue of number of shelterless people increasing or decreasing considering the fact that 'slum' has been defined from different angle and in general 'notified' slums are only taken into consideration.

- The panel concluded that though as per Government Notification ((Notification No.1448/T\&CP/C-2/3A-2/2011 dated 20th July, 2011) LIG for EWS are being constructed, it is not at par with the huge requirement of masses and above all it is not affordable to them. So, it does not meet the demand of EWS. Hence, the panel suggested to change the grade from $\mathrm{B}$ to $\mathrm{D}$.

\begin{tabular}{|l|l|l|}
\hline \multicolumn{1}{|c|}{ Dimensions } & \multicolumn{1}{|c|}{ Grade } & \multicolumn{1}{|c|}{ Change in Grade } \\
\hline $\begin{array}{l}\text { 3.3.2 Land use planning } \\
\text { effectively guides urban } \\
\text { spatial expansion in the }\end{array}$ & $\begin{array}{l}\text { C: In the largest city, while a } \\
\text { hierarchy of regional/detailed } \\
\text { largest city }\end{array}$ & $\begin{array}{l}\text { All present accepted this } \\
\text { Grade for the dimension. } \\
\text { law, in practice irban spatial } \\
\text { expansion occurs in an ad hoc } \\
\text { manner with infrastructure } \\
\text { provided some time after } \\
\text { urbanization. }\end{array}$ \\
\hline
\end{tabular}

\section{Observation:}

All panelists unanimously agreed to grade it as $\mathrm{C}$.

\begin{tabular}{|c|c|c|}
\hline Dimensions & Grade & Change in Grade \\
\hline $\begin{array}{l}\text { 3.3.3 Land use planning } \\
\text { effectively guides urban } \\
\text { development in the four } \\
\text { next largest cities }\end{array}$ & $\begin{array}{l}\text { C: In the four major cities in the } \\
\text { country, while a hierarchy of } \\
\text { regional/detailed land use plans } \\
\text { is specified by law, in practice } \\
\text { urban development occurs in an } \\
\text { ad hoc manner with } \\
\text { infrastructure provided some } \\
\text { time after urbanization. }\end{array}$ & $\begin{array}{l}\text { All present accepted this } \\
\text { Grade for the dimension. }\end{array}$ \\
\hline
\end{tabular}

\section{Observation:}

All panelists unanimously agreed to grade it as $\mathrm{C}$.

\begin{tabular}{|l|l|l|}
\hline \multicolumn{1}{|c|}{ Dimensions } & \multicolumn{1}{|c|}{ Grade } & \multicolumn{1}{c|}{ Change in Grade } \\
\hline $\begin{array}{l}\text { 3.3.4 Planning processes } \\
\text { are able to cope with urban } \\
\text { growth }\end{array}$ & $\begin{array}{l}\text { B: In the largest city, the urban } \\
\text { planning process/authority is } \\
\text { able to cope to some extent with } \\
\text { the increasing demand for } \\
\text { serviced units/land as evidenced } \\
\text { by the fact that most new } \\
\text { dwellings are formal. }\end{array}$ & $\begin{array}{l}\text { Alls are OK with } \\
\text { suggested that it should be } \\
\text { supported by data. }\end{array}$ \\
\hline $\begin{array}{l}\text { Observation: } \\
\text { Prof. Shaw shared that number of slum dwellers are increasing due to lack of proper } \\
\text { housing or low-cost rent facilities. The question was raised whether planning process } \\
\text { is taking care of the market demand. }\end{array}$ \\
\hline
\end{tabular}

303|Page Land Governance Assessment Framework - West Bengal 
- Mr.Thakurta shared that the rent legislation (Thika Tenancy Act) is pro-tenant, as such there are substantial numbers of unutilised vacant housing but the owners tend to avoid letting it out to tenants. As per a central government study the problem of housing shortage can be managed up to $70 \%$ if the unutilized houses are used for rent.

\begin{tabular}{|l|l|l|}
\hline Indicator 4: Speed and predictability of enforcement of restricted land uses \\
\hline \multicolumn{1}{|c|}{ Dimensions } & \multicolumn{1}{|c|}{ Grade } & \multicolumn{1}{c|}{ Change in Grade } \\
\hline $\begin{array}{l}\text { 3.4.1 Provisions for } \\
\text { residential building permits } \\
\text { are appropriate, affordable } \\
\text { and complied with }\end{array}$ & $\begin{array}{l}\text { A: Requirements to obtain a } \\
\text { justified, afing permit are technically } \\
\text { complied with. }\end{array}$ & $\begin{array}{l}\text { Grade was changed from } \\
\text { A to B. }\end{array}$ \\
\hline
\end{tabular}

\section{Observations:}

- EI stated that building permits are technically justified, affordable and complied with. Prof. Banerjee shared some clandestine arrangements. When an applicant is ready to build houses by the contractor chosen by Municipal Corporation Officials or political leader, they don't need formal permission from the office. Or people can evade formal permission by paying penalty.

- EI reiterated that rules for building construction which have been made by the government are praiseworthy. Mr.Thakurta supported that when any person is applying for permission he has to comply with all provisions. They stressed on 'requirement' to obtain a building permit are technically correct. Prof. Banerjee countered that when any building is being constructed without permission, they are escaping all rules by paying penalty only.

- Considering the above fact the panel decided to change the rank from A to $\mathrm{B}$. The panel agreed to the point - "requirements are partly complied with".

- When Prof. Shaw wanted to know about the fee structure (whether it is affordable or not) EI informed that it is very nominal.

\begin{tabular}{|l|l|l|}
\hline \multicolumn{1}{|c|}{ Dimensions } & \multicolumn{1}{c|}{ Grade } & \multicolumn{1}{c|}{ Change in Grade } \\
\hline $\begin{array}{l}\text { 3.4.2 A building permit for } \\
\text { a residential dwelling can } \\
\text { be obtained quickly and at a } \\
\text { low cost }\end{array}$ & $\begin{array}{l}\text { A: All applications for building } \\
\text { permits receive a decision } \\
\text { within 3 months. }\end{array}$ & $\begin{array}{l}\text { All the Panelists agreed to } \\
\text { grade it as } \text { A. }\end{array}$ \\
\hline
\end{tabular}

\section{Observation:}

- All the ULBs have citizen's Charter which clearly mentions about the modalities to obtain building permit and the maximum period within which (within 90 days) the decision is to be taken.

- The expert investigator shared that a new act - West Bengal Right to Public Service Act, 2013 has come up which is giving better and satisfactory results. Government Officials are bound to provide service to the citizen within stipulated time period.

- Prof. Banerjee shared some bitter experience which are often heard from the public that file has been lost or some other excuse by the government officials and delaying the process. Mr.Thakurta shared that due to enactment of this recent legislation, concerned government officials are penalized in those cases by deducting their salaries or delaying increment etc.

\begin{tabular}{|l|l|l|}
\hline Indicator 5: Tenure regularization schemes in urban areas \\
\hline \multicolumn{1}{|c|}{ Dimensions } & \multicolumn{1}{|c|}{ Grade } & Change in Grade \\
\hline $\begin{array}{l}\text { 3.5.1 Formalization of } \\
\text { urban residential housing is } \\
\text { feasible and affordable }\end{array}$ & $\begin{array}{l}\text { B: The requirements for } \\
\text { formalizing housing in urban } \\
\text { areas are clear, straight-forward, } \\
\text { and affordable but are not }\end{array}$ & No change in gradation. \\
\hline
\end{tabular}

304|Page Land Governance Assessment Framework - West Bengal 


\begin{tabular}{|l|l|l|}
\hline Observation: & $\begin{array}{l}\text { implemented consistently in a } \\
\text { transparent manner. }\end{array}$ \\
\hline Expert Investigator stressed that requirements are very clear. Other panelists shared \\
that in practice formalization process depends on Building Inspector to a great \\
extent. Clandestine practices are there where without following all provisions in the \\
rule houses are formalized. \\
Prof. Banerjee advocated for making stringent rule so that corrupt practices can be \\
removed. Existing loopholes in the Acts creates opportunity for corruption. \\
Mr.Thakurta shared that stringent rule cannot solve all issues rather it can \\
complicate more. So, Inspectors are given some discretionary authority to regularize \\
the housings after checking the compliance of provisions. Prof. Shaw advocated for \\
the provision of penalty in case of malpractices. \\
One panelist said that Grade C is more suitable than Grade B. But finally Grade B was \\
selected for this dimension considering the fact that 'requirements' are clear, straight \\
forward and affordable.
\end{tabular}

\begin{tabular}{|l|l|l|}
\hline \multicolumn{1}{|c|}{ Dimensions } & \multicolumn{1}{|c|}{ Grade } & \multicolumn{1}{c|}{ Change in Grade } \\
\hline $\begin{array}{l}\text { 3.5.2 In cities with informal } \\
\text { tenure, a viable strategy } \\
\text { exists for tenure security, } \\
\text { infrastructure, and housing }\end{array}$ & $\begin{array}{l}\text { Anfovide incentives for new } \\
\text { informal occupations and a } \\
\text { strategy exists to regularize land } \\
\text { rights and provide services to } \\
\text { existing informal occupants. }\end{array}$ & $\begin{array}{l}\text { Panelists suggested to } \\
\text { grade it as D instead of A. }\end{array}$ \\
\hline
\end{tabular}

\section{Observation:}

- EI referred to Thika Tenancy Act, Urban Land Ceiling Act, Acts related to use of government or railway land etc. which provides for informal occupation. But, there is no government policy yet to regularize land rights and provide services to existing informal occupants.

- Other Panelists also opined that there is clear strategy of the government to address the problem. EI shared some recent development like taking initiative for formulation of policy as a prelude to implement Rajiv AwasYojana, a study (USHA) has been conductedto map the informal tenure (by conducting survey particularly in slums) within the KMDA area, a committee has been set up under the chairmanship of Chief Minister and first meeting of the committee has been convened by the State Finance Minister. So we can say that process has already been started.

- Other panelists opined that since these initiatives are in the beginning we cannot say that regulations exist. Hence, finally panelists agreed to grade it as D instead of A.

\begin{tabular}{|l|l|l|}
\hline \multicolumn{1}{|c|}{ Dimensions } & \multicolumn{1}{|c|}{ Grade } & Change in Grade \\
\hline $\begin{array}{l}\text { 3.5.3 A condominium } \\
\text { regime allows effective } \\
\text { management and recording } \\
\text { of urban property }\end{array}$ & $\begin{array}{l}\text { B: Common property under } \\
\text { condominiums is recognized } \\
\text { and the law has clear provisions } \\
\text { for management and publicity of } \\
\text { relevant records but these are } \\
\text { not always followed in practice. }\end{array}$ & \\
\hline
\end{tabular}

\section{Observation:}

- Referring to the background report, Expert Investigator shared that the law has clear provisions for management and publicity of relevant records under the West Bengal Apartment Ownership Act, 1972. Common property has been clearly recognized by the act. Yet the management still remains very poor. Other panelists discussed on the issues of management of common space in apartments, registration of common 
property (under Cooperative Registration Act) etc. and came to a conclusion that the management is not at par.

- Panelists agreed that Registration Department is prompt enough to register land and individual flats. But, problem lies with other departments to come forward resulting in delayed recording. Hence, all present agreed to grade it as B.

\title{
Panel 4: Public Land Management
}

\author{
17April 2014 \\ Landesa \\ Venue: Landesa Kolkata Office
}

1.o The meeting for panel 9 was started again post lunch with a warm welcome to the panelists by Mr. Pinaki Halder, LGAF- West Bengal Project Leader.After having a brief introduction to the theme, he led the discussion towards opinion of the panelists regarding background note followed by detailed discursive discussion on review of the dimensions and their ranking.

2.0 Following were the participants of the meeting-

1) Mr.T. K. Shome, IAS (Retd.), Ex-Director, Directorate of Land Record \&Survey,Govt. of West Bengal

2) Mr.A. K. Chakraborti, IAS (Retd.), Ex-Secretary, Board of Revenue, Govt. of West Bengal

3) Mr.S. Banerjee, IAS (Retd.), Ex-Member - WBLRTT, Govt. of West Bengal

4) Mr.P. K. Pramanik, DDG-National Informatics Centre, West Bengal

5) Mr. Pinaki Halder, State Director, Landesa, State Coordinator and Project Team LeaderLGAF- West Bengal

6) Dr. Jayanta Munsi, District Project Manager, Landesa - West Bengal

Landesa Kolkata team members were also present to aid the uninterrupted flow of the panel discussion and take the minute of the meeting. The names of those present were-

- Mr. Supriya Chattopadhyay, Communications Manager, Landesa- West Bengal

- Mr.SudiptaBiswas, Districts Project Manager, Landesa - West Bengal

- Ms. Udita Chatterjee, Research \& Documentation Officer, Landesa - West Bengal

- Mr. Debasis Mondal, Office Assistant, Landesa- West Bengal

3.0 The Moderatormade a brief presentation of the background information regarding this panel and invited feedback from the panelists. He covered the following points in his presentation - (a) definition of public land (b) nature and typology of public land (c) role of L\&LR Department in management of public land (d) role of other government departments in management of public land (e) settlement issues of different type of land etc.

4.o After detailed discussion on background note, discussion was carried out for reviewing the dimension andjustification of ranking. The panel has three indicators: (1) Identification of public land and clear management (2) Justification and time-efficiency of acquisition process (3) Transparency and fairness of acquisition procedures.

4.1 There are six dimensions under Indicator 1, three dimensions under Indicator 2 and five dimensions under Indicator 3. Each dimension has four gradations-ranked by the panel from A to D. The dimensions were explicitly discussed in great detail to get the panelists' inputs to

306|Page Land Governance Assessment Framework - West Bengal 
incorporate changes in the gradations and analysis and to incorporate their suggestions or policy level recommendation. The major observation from the panel discussion, suggestion for necessary changes or modification in the explanation and policy level recommendations are given below.

\begin{tabular}{|c|c|c|}
\hline \multicolumn{3}{|c|}{ Indicator 1: Identification of public land and clear management } \\
\hline Dimensions & Grade & Change in Grade \\
\hline $\begin{array}{l}\text { 4.1.1. Criteria for public } \\
\text { land ownership are } \\
\text { clearly defined and } \\
\text { assigned to the right } \\
\text { level of government. }\end{array}$ & $\begin{array}{l}\text { A: Public land ownership is justified } \\
\text { by provision of public goods and } \\
\text { effectively and transparently managed } \\
\text { at the appropriate level of } \\
\text { government. }\end{array}$ & No change is proposed \\
\hline
\end{tabular}

\section{Observation:}

- During discussion (background note) on definition of public land the panel suggested to include 'land acquired for public purposes' along with khasmahal land and land vested in the state by operation of the Ceiling Acts.

- The panel concluded that there is no ambiguity in ownership and management of public land. It is clearly defined by law. The roles and responsibilities of concerned departments or public institutions or local bodies in management of lands are clearly defined. Responsibilities have been entrusted to appropriate level following the principle of subsidiarity. Hence, the panel agreed to the grade (A) proposed by Expert Investigator.

\begin{tabular}{|l|l|l|}
\hline \multicolumn{1}{|c|}{ Dimensions } & \multicolumn{1}{c|}{ Grade } & \multicolumn{1}{c|}{ Change in Grade } \\
\hline $\begin{array}{l}\text { 4.1.2 There is a complete } \\
\text { recording of public land. }\end{array}$ & $\begin{array}{l}\text { B: Between 60\% and 90\% of } \\
\text { public land is clearly identified } \\
\text { on the ground and on maps. }\end{array}$ & $\begin{array}{l}\text { The panel suggested to } \\
\text { rank it as 'C' in place of } \\
\text { 'B'. }\end{array}$ \\
\hline
\end{tabular}

\section{Observation:}

- Mr.Chakraborti stated that all public lands are mapped and surveyed in the State. Public lands are also recorded in the name of concerned department or public institution or local bodies. But there is gap that records are not updated.

- Mr.Shome pointed out that notice is also served for making change in records. But it is not done timely and consistently. It results into creating gap in updated information.

- The panel concluded that there is no readily available data which can show actual gap in clearly identifiable public land. Based on the experience of working with the system, it can be said that around $50 \%$ public lands are clearly identifiable. Hence, the panel suggested that grade ' $\mathrm{C}$ ' will be more appropriate than ' $\mathrm{B}$ '.

\begin{tabular}{|l|l|l|}
\hline \multicolumn{1}{|c|}{ Dimensions } & \multicolumn{1}{|c|}{ Grade } & \multicolumn{1}{|c|}{ Change in Grade } \\
\hline $\begin{array}{l}\text { 4.1.3 Information on } \\
\text { public land is publicly } \\
\text { accessible. }\end{array}$ & $\begin{array}{l}\text { C: All the information in the public land } \\
\text { inventory is only available for a limited } \\
\text { set of public property and there is little or } \\
\text { no justification why records are not } \\
\text { accessible. }\end{array}$ & $\begin{array}{l}\text { po change is } \\
\text { proposed. }\end{array}$ \\
\hline
\end{tabular}

\section{Observation:}

- After explanation of the point by the moderator, Mr.Shome stated that all informations on public land are available because of the computerization. Other panelists opined that records may not be updated. 
- The panel came to conclusion that though concerned departments or institutions owning public lands are required to maintain their separate Land Registers but it is not done regularly. Information on such public lands is not available to the public on request and there is no justification offered for such non- availability. Hence the panel agreed to grade (C) proposed by EI.

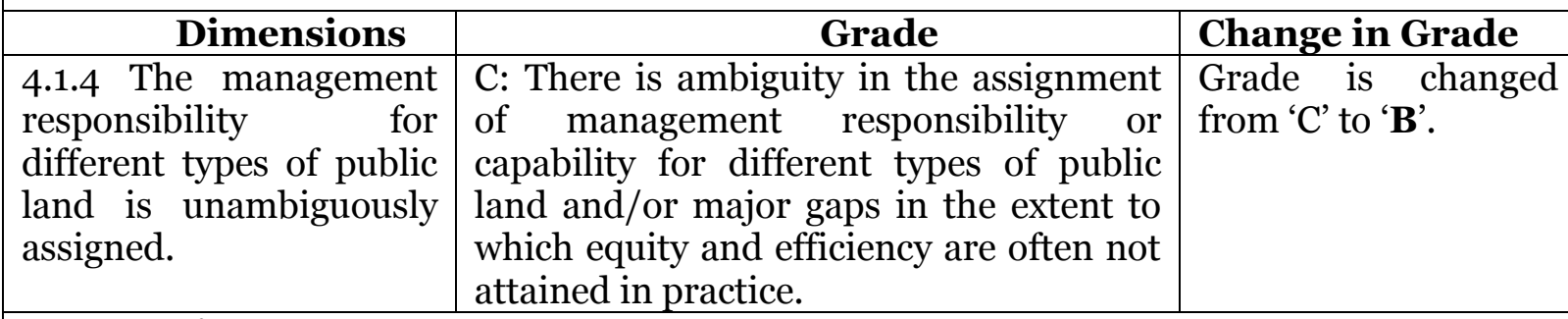

\section{Observation:}

- After explanation by the moderator, the panel opined that there is no ambiguity in assignment of management responsibilities to the concerned departments or public institutions or local bodies. It clearly defined by law.

- One panelist pointed out that responsibility is not assigned on the basis of the efficiency of the institutions. Another panelist added that in spite of being the custodian of land, L\&LR Department does not exercise control over it. Because of absence of any mechanism to oversee the function of concerned department or public institutions or local bodies there remains a gap in practice.

- Taking into account the points raised by the panelists, it was finally decided to grade the dimension as ' $\mathrm{B}$ ' instead of ' $\mathrm{C}$ '.

\begin{tabular}{l|l|l|}
\hline \multicolumn{1}{|c|}{ Dimensions } & \multicolumn{1}{|c|}{ Grade } & \multicolumn{1}{|c|}{ Change in Grade } \\
\hline $\begin{array}{l}\text { 4.1.5 Responsible public } \\
\text { institutions B: There are some constraints in the }\end{array}$ Grade is changed \\
$\begin{array}{l}\text { sufficient resources for } \\
\text { their land management } \\
\text { responsibilities. }\end{array}$ & $\begin{array}{l}\text { financial and/or human resource } \\
\text { capacity but the system makes most } \\
\text { effective use of available resources in } \\
\text { managing public lands adequately. }\end{array}$ & \\
\hline Observations: &
\end{tabular}

All panelists unanimously agreed that available financial /human resources are not sufficient for the responsible institutions to manage the public land handed over to them. It is also true that the system makes optimum utilization of available resources in managing public land. Hence, the panel suggested to change the grade from ' $\mathrm{B}$ ' to ' $\mathrm{C}$ '.

\begin{tabular}{|l|l|l|}
\hline \multicolumn{1}{|c|}{ Dimensions } & \multicolumn{1}{|c|}{ Grade } & \multicolumn{1}{c|}{ Change in Grade } \\
\hline $\begin{array}{l}\text { 4.1.6 All essential } \\
\text { information on public land } \\
\text { allocations to private } \\
\text { interests is publicly } \\
\text { accessible. }\end{array}$ & $\begin{array}{l}\text { Aand allocations (the locality and } \\
\text { area of the land allocation, the } \\
\text { parties involved and the } \\
\text { financial terms of the allocation) } \\
\text { is recorded and publicly } \\
\text { accessible. }\end{array}$ & $\begin{array}{l}\text { Grade is changed from 'A'. } \\
\text { to }\end{array}$ \\
\hline
\end{tabular}

\section{Observation:}

- Referring to the relevant sections of the rules the moderator stated that the settlements are entered in a register. People can access this information upon request only.

- One panelists raised an issue that Development Authorities like 


\begin{tabular}{|c|c|c|}
\hline $\begin{array}{l}\text { SantiniketanSrinik } \\
\text { Authority etc. are } \\
\text { done. } \\
\text { - } \text { One panelist point } \\
\text { made on the basis } \\
\text { accessible. } \\
\text { After a long delibe } \\
\text { public land alloce } \\
\text { transaction details } \\
\text { will be more appro }\end{array}$ & $\begin{array}{l}\text { etan Development Authority, Assansol D } \\
\text { supposed to upload the information in the } \\
\text { ted out that in case of land allocation to } \\
\text { of terms and conditions set with the parties. } \\
\text { eration, the panel came to a conclusion th } \\
\text { ation like area of land, location, parti } \\
\text { etc. are not made readily available by the p } \\
\text { priate than 'A'. }\end{array}$ & $\begin{array}{l}\text { urgapur Development } \\
\text { website. But it is not } \\
\text { rivate industries, it is } \\
\text { It is not made publicly } \\
\text { at key information on } \\
\text { es involved, financial } \\
\text { ublic. Hence, grade 'C' }\end{array}$ \\
\hline Indicator 2: Justificati & on and time-efficiency of acquisition $p$ & rocesses \\
\hline \begin{tabular}{|c|} 
Dimensions \\
\end{tabular} & \begin{tabular}{|l|} 
Grade \\
\end{tabular} & Change in Grade \\
\hline $\begin{array}{l}\text { 4.2.1 There is minimal } \\
\text { transfer of acquired land } \\
\text { to private interests. }{ }^{6}\end{array}$ & $\begin{array}{l}\text { D: More than } 50 \% \text { of land acquired in the } \\
\text { past } 3 \text { years is used for private purposes. }\end{array}$ & $\begin{array}{l}\text { Grade is changed } \\
\text { from ' } D \text { ' to 'A'. }\end{array}$ \\
\hline $\begin{array}{l}\text { Observation: } \\
\text { - After explanation } \\
\text { difficult to differen } \\
\text { the moderator exp } \\
\text { company or any pri } \\
\text { - The panel, based } \\
\text { acquired in the pa } \\
\text { should be ranked a }\end{array}$ & $\begin{array}{l}\text { of the dimension by the moderator, one p } \\
\text { thiate the purpose of land acquisition as 'pu } \\
\text { plained that if the acquired land is hande } \\
\text { ivate party then it will be considered as priv } \\
\text { on their rich experience, concluded that } \\
\text { st } 3 \text { years is used for private purposes. H } \\
\text { ' 'A' instead of 'D'. }\end{array}$ & $\begin{array}{l}\text { anelist stated that it is } \\
\text { blic' or 'private'. Then } \\
\text { d over to any private } \\
\text { ate purpose. } \\
\text { ess than } 10 \% \text { of land } \\
\text { ence, the dimensioned }\end{array}$ \\
\hline Dimensions & $\begin{array}{l}\text { Grade } \\
\end{array}$ & Change in Grade \\
\hline $\begin{array}{l}\text { 4.2.2 Acquired land is } \\
\text { transferred to destined } \\
\text { use in a timely manner. }\end{array}$ & $\begin{array}{l}\text { A: More than } 70 \% \text { of the land that has } \\
\text { been acquired in the past } 3 \text { years has } \\
\text { been transferred to its destined use. }\end{array}$ & $\begin{array}{l}\text { Grade is changed } \\
\text { from 'A' to ' } \mathbf{B} \text { '. }\end{array}$ \\
\hline Observations: & & \\
\hline $\begin{array}{l}\text { There is no readily availa } \\
\text { transferred to destined us } \\
\text { government it can be said } \\
\text { panel suggested that grade }\end{array}$ & $\begin{array}{l}\text { se within } 3 \text { years. Based on the rich exper } \\
\text { that } 50 \% \text { to } 70 \% \text { cases are transferred to de } \\
\text { 'B' will be more appropriate than ' } A \text { '. }\end{array}$ & $\begin{array}{l}\text { ases of acquired land } \\
\text { ience of working with } \\
\text { estined use. Hence, the }\end{array}$ \\
\hline Dimensions & Grade & Change in Grade \\
\hline $\begin{array}{l}4.2 .3 \text { The threat of land } \\
\text { acquisition does not lead } \\
\text { to pre-emptive action by } \\
\text { private parties. }\end{array}$ & A: None at all. & $\begin{array}{l}\text { Grade is changed } \\
\text { from 'A' to 'B'. }\end{array}$ \\
\hline Observations: & & \\
\hline $\begin{array}{l}\text { The panel agreed that gen } \\
\text { through competent court } \\
\text { rank the dimension as 'B'. }\end{array}$ & $\begin{array}{l}\text { nerally the case of taking pre-emptive actio } \\
\text { is not found. Thus the panel suggested that }\end{array}$ & $\begin{array}{l}\mathrm{n} \text { by any private party } \\
\text { it would be perfect to }\end{array}$ \\
\hline
\end{tabular}

\footnotetext{
${ }^{6}$ In some countries in the process of urban expansion privately land held maybe acquired before land use planning is implemented and then sold/returned to previous owners in a different form. This is not to be considered for ranking this dimension. Transfer of acquired land to private interests is excluded.
}

309|Page Land Governance Assessment Framework- West Bengal 


\begin{tabular}{|l|l|l|}
\hline \multicolumn{1}{|c|}{ Dimensions } & \multicolumn{1}{|c|}{ Grade } & Change in Grade \\
\hline $\begin{array}{l}\text { 4.3.1 Compensation is } \\
\text { provided for the } \\
\text { acquisition of all rights } \\
\text { regardless of their } \\
\text { recording status. }\end{array}$ & $\begin{array}{l}\text { social and economic status, is paid to all } \\
\text { those with rights in acquired land } \\
\text { (ownership, use, access rights etc.) } \\
\text { regardless of the recording status. }\end{array}$ & \\
\hline
\end{tabular}

\section{Observations:}

- The moderator referred to existing legal framework under three relevant Acts i.e. Land Acquisition Act 1894, WBEA Act 1953 and WBLR Act 1955 which provide for paying compensation to land owners and sharecroppers under different clause. All other panelists agreed to the point raised by him.

- One panelist pointed out that there is no provision in any Act but by virtue of Executive Order (2006) compensation is also paid to agricultural labourers who worked on the acquired agricultural lands. The panel suggested to add this point in analysis also.

- The panel drew inference that there is no doubt that compensation is provided for the acquisition of all rights regardless of their recording status. However, the level of compensation is not always just and transparent (especially, it does not consider social and economic status of to those whose rights are not recorded). Hence the panel suggested to change the grade from A to B.

\begin{tabular}{|l|l|l|}
\hline \multicolumn{1}{|c|}{ Dimensions } & \multicolumn{1}{c|}{ Grade } & Change in Grade \\
\hline $\begin{array}{l}\text { 4.3.2 Land use change } \\
\text { resulting in selective loss } \\
\text { of rights there is } \\
\text { compensated for. }\end{array}$ & $\begin{array}{l}\text { D: Where people lose rights as a result of } \\
\text { land use change outside the acquisition } \\
\text { process, compensation is not paid. }\end{array}$ & No change in grade \\
\hline
\end{tabular}

\section{Observations:}

All the panelists agreed to the point that there is no provision to compensate for any loss of rights due to change in land use. Whatever provision we have that is compensation for loss of rights as a result of acquisition. Hence, the panel unanimously accepted the grade (D) proposed by the EI.

\begin{tabular}{|c|c|c|}
\hline Dimensions & Grade & Change in Grade \\
\hline $\begin{array}{l}4.3 \cdot 3 \text { Acquired owners } \\
\text { are } \\
\text { promptly. }\end{array}$ & $\begin{array}{l}\text { D: Less than } 50 \% \text { of acquired land } \\
\text { owners receive compensation within one } \\
\text { year. }\end{array}$ & $\begin{array}{l}\text { Grade is changed } \\
\text { from ' } D \text { ' to 'B'. }\end{array}$ \\
\hline
\end{tabular}

\section{Observations:}

- The moderator mentioned that there may be some time lag between acquisition and payment of compensation because of various reasons like confusion regarding ownership, minor dispute over land ownership / share, production of incomplete documents by land owners etc.

- One panelist pointed out that the moment government acquires land on paper, it is considered as vested land. The raiyat (land owner) can use the land until it is occupied by the government.

- Considering the average number of delay cases in practice, the panel arrived at a consensus that between $70 \%$ and $90 \%$ of acquired land owners receive compensation within one year. Hence, it would be most suitable to rank it as ' $\mathrm{B}$ ' in place of ' $\mathrm{D}$ '.

\begin{tabular}{|l|l|ll|l|}
\hline \multicolumn{2}{|c|}{ Dimensions } & \multicolumn{2}{c|}{ Grade } & Change in Grade \\
\hline 4.3.4 & There are & A: & Independent avenues to lodge a & No change in grade \\
\hline
\end{tabular}

310|Page Land Governance Assessment Framework - West Bengal 


\begin{tabular}{|l|l|l|}
\hline $\begin{array}{l}\text { independent } \quad \text { and } \\
\text { accessible avenues for }\end{array}$ & $\begin{array}{l}\text { complaint against acquisition exist and } \\
\text { are easily accessible. }\end{array}$ & \\
appeal against & & \\
acquisition. & & \\
\hline
\end{tabular}

\title{
Observations:
}

- The moderator mentioned that the first instance appellate forums in regard to compensation under the three Acts i.e. LA Act, WBEA Act, WBLR Act are defined. All these appellate forums are independent and easily accessible.

- The panel concluded that whatever be the level of competent authority, it is easily accessible by the public to lodge complaint against acquisition. Hence, the panel agreed that ranking 'A' is justified.

\begin{tabular}{|c|c|c|}
\hline Dimensions & Grade & Change in Grade \\
\hline $\begin{array}{lrr}4.3 .5 & \text { Timely } & \text { decisions } \\
\text { are made } & \text { regarding } \\
\text { complaints } & \text { about } \\
\text { acquisition. } & \\
\end{array}$ & $\begin{array}{l}\text { A: A first instance decision has been } \\
\text { reached for more than 80\% of the } \\
\text { complaints about acquisition lodged } \\
\text { during the last } 3 \text { years. }\end{array}$ & $\begin{array}{l}\text { Grade is changed } \\
\text { from ' } A \text { ' to ' } \mathbf{C} \text { '. }\end{array}$ \\
\hline
\end{tabular}

\section{Observations:}

- The moderator mentioned that in most of the cases the decision is taken by the first instance Court regarding complaints about acquisition.

- One panelistadded that a writ petition can be filed in the High Court against acquisition itself. For other cases like admissibility of compensation and amount thereof could be appealed to the next appellate forum or High Court.

- The panel suggested to add this point in dimension analysis.

- The panel concluded that a high number of cases reach to next appellate court or the High Court due to complexities of cases and it takes time to be resolved. On average 30-50\% cases, first instance decision is taken by 3 years. Hence, the panel arrived at a consensus that grade ' $C$ ' will be most appropriate than grade ' $A$ '.

\section{Panel 5: Transfer of Large Tracts of Land to Private Investors}

\author{
24 April 2014 \\ Landesa \\ Venue: Landesa Kolkata Office
}

1.o The meeting was started with a warm welcome to the panelists by Mr. Pinaki Halder, LGAFWest Bengal Project Leader and State Director, Landesa, West Bengal and introduction among each other.After making a brief presentation delineating the purpose of the panel discussion, about LGAF, the core thematic areas of LGAF, Land Governance Indicators and Dimensions etc.

311 Page Land Governance Assessment Framework - West Bengal 
he ventured into the detailed discursive discussion on Panel 5: Transfer of Large Tracts of Land to Private Investors.

2.0 Following were the participants of the meeting-

1) Dr.P. K. Das, Associate Professor, Department of Economics, Centre for Studies in Social Science, Kolkata

2) Mr.Shyama Prasad Mukherjee, Ex-OSD, West Bengal Industrial Development Corporation

3) Mr.Sukumar Banerjee, IAS (Retd.), Ex-Special Secretary, L\&LR Department, Govt. of West Bengal

4) Mr.Sunil Nair, Chief Marketing Officer, Bengal Aerotropolis Projects Limited

5) Dr.Vivekananda Mukherjee, Associate Professor, Department of Economics, Jadavpur University

6) Mr. Pinaki Halder, State Director, Landesa, State Coordinator and Project Team LeaderLGAF- West Bengal

2.1 Landesa Kolkata team members were also present to aid the uninterrupted flow of the panel discussion. The names of those present were-

- Mr. Supriya Chattopadhyay, Communications Manager, Landesa- West Bengal

- Mr.SudiptaBiswas, Districts Project Manager, Landesa- West Bengal

- Mr. Debasis Mondal, Office Assistant, Landesa- West Bengal

3.0 The Moderator made a brief presentation of the background information regarding this panel and invited feedback from the panelists. He covered the following points in his presentation - (a) background data of type of land in the State according to use (b) availability of land for private investment purpose (c) issues of management of land including public land (d) procedure of transfer of public land to private investors (e) role of WBIDC, WBIIDC, WBSIDC etc. (f) rehabilitation and resettlement issues etc.

4.0 After detailed discussion on background note, discussion was carried out for reviewing the dimension and justification of ranking. The panel has four indicators: (1) Transfer of public land to private use follows a clear, transparent, and competitive process and payments are collected and audited (with the exception of transfers to improve equity such as land distribution and land for social housing) (2) Private Investment Strategy (3) Policy implementation is effective, consistent and transparent and involves localstakeholders and (4) Contracts involving public land are public with agreements monitored and enforced.

4.1 There are five dimensions under Indicator 1, seven dimensions under Indicator 2, four dimensions under Indicator 3 andthree dimensions under Indicator 4. Each dimension has four gradations-ranked by the panel from A to D. The dimensions were explicitly discussed in great detail to get the panelists' inputs to incorporate changes in the gradations and analysis and to incorporate their suggestions or policy level recommendation.

5.0 The major observation from the panel discussion, suggestion for necessary changes or modification in the explanation and policy level recommendations are given below.

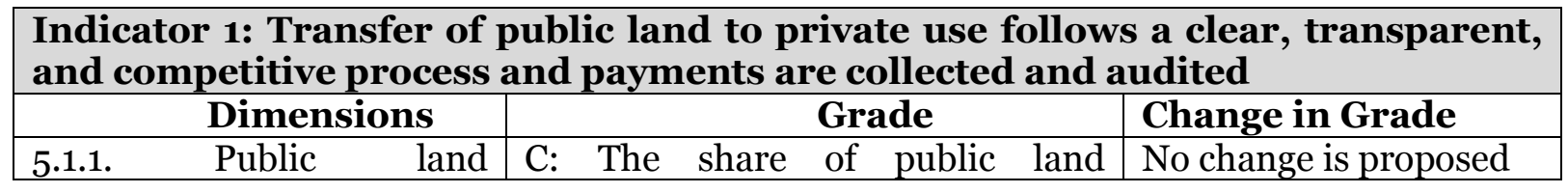

312|Page Land Governance Assessment Framework - West Bengal 


\begin{tabular}{|l|l|}
\hline $\begin{array}{l}\text { transactions are conducted } \\
\text { in an open transparent } \\
\text { manner }\end{array}$ & $\begin{array}{l}\text { disposed of in the past } 3 \text { years } \\
\text { through sale or lease through } \\
\text { public auction or open tender } \\
\text { process is between 50\% and 70\%. }\end{array}$ \\
\hline
\end{tabular}

\section{Observation:}

- Expert Investigator started discussion with brief explanation to the panel on this dimension. He explained the meaning of few terms like 'public holding', 'acquisition' etc. when he was requested so by one panelist. He also delineated the process of transfer of public land to private investors as per government guideline laid out in the WBLR Manual 1991.

- The moderator requested Mr.S.P.Mukherjee to share his experience regarding the process followed by WBIDC, HIDCO or L\&LR Department. Mr.Mukharjee briefly described the process which was also supplemented by Mr. Banerjee. Upon request from one panelistMr. Mukherjee explained the terms and conditions prepared and followed for long term settlement.

- One panelist queried whether the auction is made or not, Mr. Mukherjee responded that as per Government Order (26.12.2012) for industrial development project highest price is not the main criteria and auction is not the only mode of allotment either. Detailed development plan is prepared. Price is fixed by the government following certain criteria like acquisition price, cost of capital, development charges and premium as applicable. He also added that unlike past process, the auction has been started by WBIDC and HIDCO after this Government Order.

- One panelist raised the issue of transparency of bidding process. Mr.Mukharjee shared a case of HIDCO at Rajarhat where bidding process was cancelled because only a single party participated in the process. HIDCO went for re-advertisement.

- When one panelist wanted to know about the pricing method, other panelists responded that it is basically fixed taking into consideration thelocal market value. When asked about the past process of transfer, Mr. Banerjee shared that it was done simply on the basis of application from the interested parties (subject to availability of public land). There was no scope of assessment whether second party is more eligible or not. Price was fixed on the basis of local market value keeping in mind that government is not loser.

- Mr. Banerjee shared a case of Panagarh Industrial Park where WBIDC went for advertisement for allocating land to private investors. The advertisement also highlighted that facilities as per prescribed norms will be provided to the parties by the government. In spite of that out of 2700 acre of land, only 1458 acre was transferred on lease. The anchor investor was a fertilizer company. Finally, after the failure of bidding process, government decided to allocate rest of the land to any interested parties on a fixed rate.

- The panel concluded that after 2012 there has been major change in transfer process (public auction or open tender process). On an average, more than $60 \%$ of public lands disposed through sale or lease have been done through public auction or open tender process. Hence, the panel agreed to grade the dimension as ' $\mathrm{C}$ '.

\begin{tabular}{|l|l|l|}
\hline \multicolumn{1}{|c|}{ Dimensions } & \multicolumn{1}{|c|}{ Grade } & Change in Grade \\
\hline $\begin{array}{l}\text { 5.1.2 Payments for public } \\
\text { leases are collected }\end{array}$ & $\begin{array}{l}\text { A: More than 90\% of the total } \\
\text { agreed payments are collected from } \\
\text { private parties on the lease of } \\
\text { public lands. }\end{array}$ & \\
\hline
\end{tabular}

\section{Observation:}

- EI explained the terms of payment for long term leases i.e. lease agreement for 30 years and lease agreement for 99 years. The issues covered rate, price fixation, 
concession, mode of payment etc. He also presented a data of last three years on quantum of land sanctioned on long-term lease and amount received by government as rent, premium etc.

- Mr. Nair suggested to re-check the data because it shows that less quantum of land has been sanctioned in 2010-11 than 2009-10. Other panelists opined that the figure may reflect current reality because the quantum of land available has been nearing to saturation point.

- Considering the facts and figures presented by the Expert Investigator, the panel agreed that more than $90 \%$ of the total agreed payments are collected from private parties on the lease of public lands. Hence, the panel accepted the grade (A) proposed by the EI.

\begin{tabular}{|l|l|l|}
\hline \multicolumn{1}{|c|}{ Dimensions } & \multicolumn{1}{|c|}{ Grade } & \multicolumn{1}{c|}{ Change in Grade } \\
\hline $\begin{array}{l}5.1 .3 \text { Public land is } \\
\text { transacted at market prices } \\
\text { unless guided by equity } \\
\text { objectives }\end{array}$ & $\begin{array}{l}\text { Aenerally divested at market prices } \\
\text { in a transparent process } \\
\text { irrespective of the investor's status } \\
\text { (e.g. domestic or foreign). }\end{array}$ & No change in grade \\
\hline
\end{tabular}

\section{Observation:}

- The Expert Investigator explained the general practice of price fixation. In determining the premium and other lease terms factors like location of the land to be settled, the purpose of the settlement, suitability of the land for the lease purpose, prevailing price of land in the locality etc. are taken into account. In this process, price never becomes less than market price. Moreover, sometimes it may become higher than market price.

- One panelist shared the case of Andal where price rose up to three to four times higher than market price because of higher demand of land in that location. Another panelist pointed out that there is no circle rate in West Bengal. Even rate varies from Mouza to Mouza.

- One panelist pointed out that during fixation of price much weightage is given to the recent sale prices of land of similar type as obtained from the Registration Office. In this context, another panelistreferred to the Government Order (26.12.2012) which clearly specifies that land allotted for private use should be based on market prices. However, there are provisions for relaxations to accommodate weaker sections of the society or to meet other social objectives.

- The panel came to a conclusion that in the State context, public land is transacted at market price. All transactions irrespective of the status of the investor's status are carried out in a transparent manner. Hence, the panel agreed to the grade (A) proposed by the EI.

\begin{tabular}{|l|l|l|}
\hline \multicolumn{1}{|c|}{ Dimensions } & \multicolumn{1}{|c|}{ Grade } & Change in Grade \\
\hline $\begin{array}{l}\text { 5.1.4 The public captures } \\
\text { benefits arising from } \\
\text { changes in permitted land } \\
\text { use }\end{array}$ & $\begin{array}{l}\text { B: Mechanisms to allow the public } \\
\text { to capture significant share of the } \\
\text { gains from changing land use are } \\
\text { not always used, although generally } \\
\text { applied transparently. }\end{array}$ & $\begin{array}{l}\text { Gradation was changed } \\
\text { from B to C. }\end{array}$ \\
\hline Observation: & \multicolumn{1}{|l}{} \\
\hline
\end{tabular}

- The EI briefed the kind of benefit which can be accrued from the land use by different stakeholders. He stated that it is very difficult to quantify the benefit to be accrued from the land use. In general, only short term tangible benefits are taken into

314|Page Land Governance Assessment Framework - West Bengal 
account. Long term benefits are ignored.

- One panelist cited the example of allocating land to TATA Hospital at New Town area, which accrued huge fiscal benefit because of absence of any comprehensive mechanism to capture all short-term and long-term benefit.

- The panel suggested that an independent benefit assessment mechanism should be adopted to quantify the short-term and long-term benefits that will accrue to the public.

- The panel arrived at a consensus that gradation should be changed from $\mathrm{B}$ to $\mathrm{C}$ in the ground that there is no mechanism in practice to quantify the benefits as a whole, only tangible benefits are captured in the reports.

\begin{tabular}{|l|l|l|}
\hline \multicolumn{1}{|c|}{ Dimensions } & \multicolumn{1}{|c|}{ Grade } & Change in Grade \\
\hline $\begin{array}{l}\text { 5.1.5 Policy to improve } \\
\text { equity in asset access and }\end{array}$ & $\begin{array}{l}\text { B: Policy is in place to improve } \\
\text { access to and productive use of }\end{array}$ & No change in grade \\
$\begin{array}{l}\text { use by the poor exists, is } \\
\text { implemented effectively } \\
\text { and monitored }\end{array}$ & $\begin{array}{l}\text { assets by poor and marginalized } \\
\text { groups, is applied in practice, but is } \\
\text { not effective }\end{array}$ & \\
\hline
\end{tabular}

\section{Observation:}

After brief explanation of the dimension by the moderator followed by analysis made by EI, the panel accepted the fact presented by EI. The panel unanimously agreed to the grade (B) proposed by the EI.

\begin{tabular}{|c|c|c|}
\hline \multicolumn{3}{|c|}{ Indicator 2: Private investment strategy } \\
\hline Dimensions & Grade & Change in Grade \\
\hline $\begin{array}{l}\text { 5.2.1 Land to be made } \\
\text { available to investors is } \\
\text { identified transparently and } \\
\text { publicly, in agreement with } \\
\text { right holders }\end{array}$ & $\begin{array}{l}\text { B: A policy to identify land that can } \\
\text { be made available to investors } \\
\text { exists, based on ad hoc assessment } \\
\text { of land potential but with } \\
\text { community consultation and } \\
\text { agreement, and is applied in more } \\
\text { than 90\% of identified cases. }\end{array}$ & No change in grade \\
\hline
\end{tabular}

\section{Observation:}

- EI stated that L\&LR Manual 1991 and Government Order dated 26.12.2012 clearly lay out the process to be followed for identification of land that can be made available to investors. Hence, it can be said that policy does exist. But, it is based on ad hoc assessment of land potential. Barring the case of Singur, consultation with community is made.

- Mr. Nair cited the example of acquisition of land for Durgapur Aerotroplois and for industrial parks at Panagarh, Raghunathpur, Kharagpur and Naihati where community consultation was made for selection of sites and fixing compensation package.

- Mr. Mukherjee stated that as far as WBIDC is concerned, land is identified transparently and publicly, in agreement with right holders.

- One panelist shared that after preparation of initial development plan (proposed area to be acquired) consultation is made with community. Changes are incorporated in the plan accordingly.

- After the detailed discussion, the panel decided to rank the dimension as 'B'.

\begin{tabular}{|lcr|l|l|}
\hline \multicolumn{3}{|c|}{ Dimensions } & \multicolumn{1}{c|}{ Grade } & Change in Grade \\
\hline $\begin{array}{l}5.2 .2 \\
\text { selected }\end{array}$ & Investments & are & A: Process is in place that properly & No change in grade \\
considers both national and local & on
\end{tabular}

315|Page Land Governance Assessment Framework - West Bengal 


\begin{tabular}{|c|c|c|}
\hline $\begin{array}{l}\text { economic, socio-cultural } \\
\text { and environmental impacts } \\
\text { in an open process }\end{array}$ & $\begin{array}{l}\text { benefits and is adhered to. Benefit } \\
\text { sharing mechanism are in place }\end{array}$ & \\
\hline \multirow{2}{*}{\multicolumn{3}{|c|}{$\begin{array}{l}\text { Observation: } \\
\text { All the panelists unanimously agreed that the process is more or less followed in practice and } \\
\text { ranking ' } A \text { ' is appropriate for the dimension. }\end{array}$}} \\
\hline & & \\
\hline Dimensions & Grade & Change in Grade \\
\hline $\begin{array}{lr}5.2 .3 \quad \text { Public } & \text { institutions } \\
\text { transferring land to } \\
\text { investors are } & \text { clearly } \\
\text { identified and regularly } \\
\text { audited }\end{array}$ & $\begin{array}{l}\text { B: Institutions to make decisions } \\
\text { are clearly identified and have the } \\
\text { necessary capacity (incl. resources } \\
\text { for field verification) and strong } \\
\text { incentives in ensuring socially } \\
\text { beneficial outcomes but processes } \\
\text { may be complex and difficult for } \\
\text { investors. }\end{array}$ & No change in grade \\
\hline
\end{tabular}

\section{Observation:}

- EI stated that there is no doubt that institutions are clearly identified. In the State context, L\&LR Department and public institutions like WBIDC, WBIIDC, WBSIDC etc. can transfer land to investors.

- One panelist raised an issue whether they have the capacity to handle land transfer to private investors. Mr. Mukherjee explained that WBIDC has five men committee comprising technical experts from various fields to scrutinize and assess the actual land requirement, water source, viability (technical and social) aspects of any proposal for setting of an industry. He also added that during preparation of detailed project report, social impact assessment is done.

- One panelist pointed out that there is doubt that institutions are audited regularly. Other panelists responded that there is provision for internal as well as external audit. Institutions have to comply with the audit quires raised by Auditor General.

- The panel concluded that the process is bit complex and time taking. Though there is provision for 'single window' service, but practically it is not investor friendly. Hence, the panel accepted the grade (B) proposed by EI.

\begin{tabular}{|l|l|l|}
\hline \multicolumn{1}{|c|}{ Dimensions } & \multicolumn{1}{|c|}{ Grade } & Change in Grade \\
\hline $\begin{array}{l}5.2 .4 \text { Public bodies } \\
\text { transferring land to }\end{array}$ & $\begin{array}{l}\text { A policy is in place for effective } \\
\text { inter-ministerial and coordination }\end{array}$ & $\begin{array}{l}\text { Grade is changed from } \\
\text { A to B. }\end{array}$ \\
$\begin{array}{l}\text { investors share information } \\
\text { and coordinate to minimize } \\
\text { and resolve overlaps } \\
\text { (including sub-soil). }\end{array}$ & $\begin{array}{l}\text { and land rights are well } \\
\text { coordinated across sectors, and is } \\
\text { applied effectively. }\end{array}$ & \\
\hline
\end{tabular}

\section{Observation:}

- EI explained the process of transferring land and interrelationship between different government departments or public institutions. Referring to the LR Manual 1991 and consecutive Government Order (2012) he highlighted that policy does exist.

- One panelist pointed out the scope of conflict between Central Government and State Government citing the example that surface right transfer is dealt with by the state while sub-soil rights (say coal mine) are considered by central government. He also added that there is no avenue for coordination between central and state governments when large scale acquisition of land is involved.

- The panel came to a conclusion that though there is some sort of inter-departmental 
coordination at the State level but there is no avenue for coordination between central and state government. There is no policy to minimize and resolve overlaps. Hence, the panel suggested to change the grade from 'A' to 'B'.

- The panel also suggested that some formal mechanism like identifying a nodal agency from both state and central government for compliance and reconciliation might be considered.

\begin{tabular}{l|l|l|}
\hline \multicolumn{1}{|c|}{ Dimensions } & \multicolumn{1}{c|}{ Grade } & Change in Grade \\
\hline $\begin{array}{l}\text { 5.2.5 Compliance with } \\
\text { contractual obligations is }\end{array}$ & $\begin{array}{l}\text { C: Monitoring of compliance is } \\
\text { limited or only part of the results }\end{array}$ & No change in grade \\
regularly monitored and \\
remedial action taken if \\
needed.
\end{tabular}

\section{Observations:}

- Referring to the background note EI stated that there is provision laid out in the policy for compliance of contractual obligation and taking action for non-compliance. But in practice, monitoring mechanism is very week. In case of non-compliance, the matter goes to court and it takes long time for settlement.

- The panel unanimously agreed to the point raised by the EI and accepted the grade (C) proposed by him.

\begin{tabular}{|l|l|l|}
\hline \multicolumn{1}{|c|}{ Dimensions } & \multicolumn{1}{|c|}{ Grade } & Change in Grade \\
\hline $\begin{array}{l}\text { 5.2.6 Safeguards effectively } \\
\text { reduce the risk of negative } \\
\text { effects from large scale } \\
\text { land-related investments. }\end{array}$ & $\begin{array}{l}\text { C: Sartly in line with global best } \\
\text { practice }\end{array}$ & No change in grade \\
\hline
\end{tabular}

\section{Observation:}

- EI mentioned about the institutional framework which provides control over environmental impact. He briefed the role of Pollution Control Board and BioDiversity Board. He also explained the norms laid out in the guideline for taking care of environmental aspect.

- One panelist raised the issue of social impact assessment. EI along with other panelists responded that it is done by the public institutions like WBIDC, WBSIDC etc. during feasibility assessment.

- All panelists agreed to the point that though there are provisions for safeguard to effectively reduce the risk of negative effect, but still there is gap in practice. Hence the panel unanimously agreed that ranking $(\mathrm{C})$ is appropriate for the State.

\begin{tabular}{|l|l|l|}
\hline \multicolumn{1}{|c|}{ Dimensions } & \multicolumn{1}{|c|}{ Grade } & Change in Grade \\
\hline $\begin{array}{l}5.2 .7 \text { The scope for } \\
\text { resettlement is clearly }\end{array}$ & $\begin{array}{l}\text { B: Applied resettlement policy is } \\
\text { partly in line with global best }\end{array}$ & \\
circumscribed change in grade \\
procedures exist to deal & practice, and in most cases applied & \\
with it in line with best & & \\
practice. & & \\
\hline
\end{tabular}

\section{Observation:}

- The EI stated that there is R\&R Policy document of WBIDC which prescribes norms for resettlement. It deals with compensation package and also protects the interest of sharecroppers and landless labourers. But in practice, there remains gap leaving the scope for grievances. Appropriate remedial measures are not taken fully.

317 Page Land Governance Assessment Framework - West Bengal 
- The panel accepted the fact without any debate and agreed to rank the dimension as 'B'.

\begin{tabular}{|c|c|c|}
\hline \multicolumn{3}{|c|}{$\begin{array}{l}\text { Indicator 3: Policy implementation is effective, consistent and transparent and } \\
\text { involves local stakeholders }\end{array}$} \\
\hline $\begin{array}{l}\text { Indicator 3: Policy imple } \\
\text { involves local stakeholde } \\
\text { Dimensions }\end{array}$ & Grade & Change in Grade \\
\hline $\begin{array}{l}5 \cdot 3.1 \text { Investors provide } \\
\text { sufficient information to } \\
\text { allow rigorous evaluation of } \\
\text { proposed investments. }\end{array}$ & $\begin{array}{l}\text { A: Investors' business plans } \\
\text { (application materials) require } \\
\text { sufficient evidence of technical } \\
\text { viability, community consultation, } \\
\text { and availability of resources to } \\
\text { effectively identify project risk and } \\
\text { viability and effectively monitor } \\
\text { progress. }\end{array}$ & No change in grade \\
\hline
\end{tabular}

\section{Observation:}

- Regarding the information provided by the investor the EI stated that the investor has to submit detailed project report (DPR) which is reviewed by a Five-man Committee. Community consultation has to take place as per prescribed norm during preparation of DPR.

- Mr. Nair shared a case of joint venture project at Andal with Bengal Aerotropolis where the anchor investor had to comply with all the formalities in respect of justifying technical viability and community consultation. The investor had to undertake a full research work to understand the community behavior and develop formula of compensation for right losers as well as the community in general including the corporate social responsibility (CSR) policy.

- Other panelists opined that it is more or less true in case of other projects. Though in the past this aspect was not taken much care, but post Singur episode it is taken care of seriously. Considering the fact the panel suggested that ranking (A) is justified.

\begin{tabular}{|c|c|c|}
\hline Dimensions & Grade & Change in Grade \\
\hline $\begin{array}{l}\text { 5.3.2 Approval } \\
\text { investment plans follows a } \\
\text { clear process with } \\
\text { reasonable timelines. }\end{array}$ & $\begin{array}{l}\text { A: All investment application } \\
\text { related documents are reviewed } \\
\text { according to a uniform process } \\
\text { and receive a response within } 3 \\
\text { months of date of submission }\end{array}$ & $\begin{array}{l}\text { Grade is changed from A to } \\
\text { B. }\end{array}$ \\
\hline
\end{tabular}

\section{Observation:}

- The EI stated that the process of approval of plans laid out in the policy has already been discussed. He also mentioned that as per guideline it should be completed in one month but practically it may take $2-3$ months.

- Regarding the time taken by the WBIDC, Mr. Mukherjee and others opined that it takes around six months.

- Considering the time taken to process the approval of investment plan, the panel suggested that grade ' $\mathrm{B}$ ' will be more appropriate than ' $\mathrm{A}$ '.

\begin{tabular}{|l|l|l|}
\hline \multicolumn{1}{|c|}{ Dimensions } & \multicolumn{1}{|c|}{ Grade } & \multicolumn{1}{c|}{ Change in Grade } \\
\hline $\begin{array}{l}5.3 .3 \text { Right holders and } \\
\text { investors negotiate freely and }\end{array}$ & land wose holding rights to & Grade is changed from C to \\
directly with full access to & investment have incentives \\
relevant information. & $\begin{array}{l}\text { to properly negotiate but } \\
\text { their rights are unclear or } \\
\text { opportunities to obtain }\end{array}$ & \\
\hline
\end{tabular}

318|Page Land Governance Assessment Framework - West Bengal 


\begin{tabular}{|l|l|l|}
\hline & $\begin{array}{l}\text { relevant information or } \\
\text { assistance do not exist. }\end{array}$ & \\
\hline
\end{tabular}

\section{Observation:}

- Referring to the analysis report the EI stated that there is scope for the investor and the right holders to negotiate on site selection of a project, price of land, rehabilitation of land losers etc. He also mentioned about an Executive Order which goes forward to arrange for the negotiation on site selection also by formation of two committees viz. 'site selection committee' and 'screening committee' which has not been envisaged in Land Acquisition Act 1894.

- Mr. Banerjee and Mr. Mukherjee shared that right holders generally submit petition for further clarification if required.

- The panel opined that it cannot be said that opportunities to obtain relevant information or assistance do not exist. There may be certain limitation to get adequate information and assistance. So, the panel decided to change the grade from 'C' to 'B'.

\begin{tabular}{|l|l|l|}
\hline \multicolumn{1}{|c|}{ Dimensions } & \multicolumn{1}{c|}{ Grade } & Change in Grade \\
\hline $\begin{array}{l}\text { 5.3.4 Contractual provisions } \\
\text { regarding benefit sharing are } \\
\text { publicly disclosed. }\end{array}$ & $\begin{array}{l}\text { B: Modalities for benefit sharing } \\
\text { are routinely included in relevant } \\
\text { contractual arrangements, but } \\
\text { there is limited public disclosure. }\end{array}$ & No change in grade \\
\hline
\end{tabular}

\section{Observation:}

- After explanation of the point by the Expert Investigator, one panelist opined that fiscal incentives are given to the private investors to attract investment but government does not disclose the agreement. Disclosure is very limited in practice in the State.

- One panelist cited the example of Singur where lot of fiscal benefit was given to TATA for establishing NANO Car Factory. The agreement was not disclosed. Even after filing RTI the agreement was not disclosed and the matter went to court. Since, private parties were involved with the government and they are not bound to disclose information due to confidentiality policy of the company, the matter remained undisclosed.

- The panel concluded that grade B is justified in this regards. Also the panel suggested that government should take up policy to make the lease agreement public to bring transparency in the process.

\begin{tabular}{|c|c|c|}
\hline \multicolumn{3}{|c|}{$\begin{array}{l}\text { Indicator 4: Contracts involving public land are public with agreements } \\
\text { monitored and enforced. }\end{array}$} \\
\hline $\begin{array}{c}\text { Dimensions } \\
\end{array}$ & $\begin{array}{c}\text { Grade } \\
\end{array}$ & Change in Grade \\
\hline $\begin{array}{l}\text { 5.4.1 Information on spatial } \\
\text { extent and duration of } \\
\text { approved concessions is } \\
\text { publicly available. }\end{array}$ & $\begin{array}{l}\text { A: Comprehensive } \\
\text { consolidated information on } \\
\text { spatial extent, duration, and } \\
\text { parties involved in } \\
\text { concessions/leases is available } \\
\text { publicly. }\end{array}$ & No change in grade \\
\hline \multicolumn{3}{|c|}{$\begin{array}{l}\text { Observations: } \\
\text { - The EI mentioned about the "West Bengal State Support for Industries Scheme, } \\
2013 \text { " which provides various incentives to the private parties for setting up } \\
\text { industries. } \\
\text { Mr. Nair stated information on 'approved concession' is available in case of WBIDC } \\
\text { and WBIIDC. Mr. Mukherjee stated that it is also available in case of HIDCO. All }\end{array}$} \\
\hline
\end{tabular}

319|Page Land Governance Assessment Framework - West Bengal 


\begin{tabular}{|c|c|c|}
\hline $\begin{array}{l}\text { information regarding } \\
\text { institutions. } \\
\text { - The panel unanimous } \\
\text { justified. }\end{array}$ & $\begin{array}{l}\text { this is available in the website } \\
y \text { accepted the fact and agreed that }\end{array}$ & $\begin{array}{l}\text { the concerned public } \\
\text { (A) proposed by EI is }\end{array}$ \\
\hline Dimensions & Grade & Change in Grade \\
\hline $\begin{array}{l}5.4 .2 \text { Compliance with } \\
\text { safeguards on concessions is } \\
\text { monitored and enforced } \\
\text { effectively and consistently. }\end{array}$ & $\begin{array}{l}\text { C: There is little third-party } \\
\text { monitoring of investors' } \\
\text { compliance with safeguards and } \\
\text { mechanisms to quickly and } \\
\text { effectively ensure adherence are } \\
\text { difficult to access for affected } \\
\text { communities. }\end{array}$ & $\begin{array}{l}\text { Grade is changed from } \mathrm{C} \\
\text { to } \mathbf{B} \text {. }\end{array}$ \\
\hline $\begin{array}{ll}\text { Observations: } \\
\text { - } \\
\text { EI mentioned about tl } \\
\text { as external audit by Co } \\
\text { - Other panelists also } \\
\text { compliance of audit ob } \\
\text { - The panel concluded t } \\
\text { and effectively reach } \\
\text { more appropriate inst }\end{array}$ & $\begin{array}{l}\text { mptrovision of internal audit by the } \\
\text { agreed to the provisions but stat } \\
\text { agreed } \\
\text { servation. } \\
\text { hat third party monitoring is in place } \\
\text { dherence. Hence the panel suggeste } \\
\text { ad of 'C'. }\end{array}$ & $\begin{array}{l}\text { organization itself as well } \\
\text { ed that problem lies in } \\
\text { but there is gap in quickly } \\
d \text { that ranking 'B' will be }\end{array}$ \\
\hline $\begin{array}{l}\text { Dimensions } \\
\end{array}$ & $\begin{array}{l}\text { Grade } \\
\end{array}$ & Change in Grade \\
\hline $\begin{array}{l}\text { 5.4.3 Avenues to deal with } \\
\text { non-compliance exist and } \\
\text { obtain timely and fair } \\
\text { decisions. }\end{array}$ & $\begin{array}{l}\text { D: There is little third-party } \\
\text { monitoring of investors' } \\
\text { compliance with contractual } \\
\text { provisions and mechanisms to } \\
\text { quickly and effectively reach } \\
\text { arbitration are virtually non- } \\
\text { existent. }\end{array}$ & $\begin{array}{l}\text { Grade is changed from } \\
\text { D to } \mathbf{B} \text {. }\end{array}$ \\
\hline $\begin{array}{l}\text { Observations: } \\
\text { - } \\
\text { As per above discussio } \\
\text { party monitoring and } \\
\text { gaps in quickly and eff } \\
\text { One panelist pointed } \\
\text { place or not. Other pa } \\
\text { generally it does not } \\
\text { reached quickly and e } \\
\text { panel suggested to ran }\end{array}$ & $\begin{array}{l}n \text { the panel accepted the fact that the } \\
\text { also compliance of audit observation } \\
\text { ectively reach adherence. } \\
\text { out whether in case of non-complia } \\
\text { helists opined that there is mechanis } \\
\text { go up to that level. In case it goes } \\
\text { ffectively. The arbitration process al } \\
\text { k the dimension as 'B' instead of 'D'. }\end{array}$ & $\begin{array}{l}\text { re are provisions for third } \\
\text { But the there are certain } \\
\text { nce any arbitration takes } \\
\text { m for arbitration also. But } \\
\text { upto that level, it is not } \\
\text { so takes time. Hence, the }\end{array}$ \\
\hline
\end{tabular}

\section{6.o Recommendations:}

- The panel suggested that an independent benefit assessment mechanism should be adopted to quantify the short-term and long-term benefits that will accrue to the public because of permitted changes in land use.

- There is no avenue for coordination between central and state governments when large scale acquisition of land is involved leaving scope for disputes being arisen which may take a long process for reconciliation. For example, the surface right transfer is dealt with by the state while sub-soil rights (say coal mine) are considered by central government.

320|Page Land Governance Assessment Framework - West Bengal 
Some formal mechanism like identifying a nodal agency from both state and central government for compliance and reconciliation might be considered.

\title{
Panel 6: Public Provision of Land Information - Registry and Cadastre
}

\author{
17 April 2014 \\ Landesa \\ Venue: Landesa Kolkata Office
}

1.o Mr. Pinaki Halder, LGAF- West Bengal Project Leader and State Director, Landesa, West Bengal welcomed the panellists and the meeting started with a round of introduction. He then explained the purpose of the Workshop, and provided an overview of the LGAF. His presentation focused on the following: (i) global land issues; (ii) overview of land governance; (iii) purpose of the LGAF (iv) structure, process and methodology of LGAF; and (iv) Expectations from the panellists in this workshop. He also explained the outline of the workshop and role of the panellists. After making this brief presentation, he led the discussion towards opinion of the panellists regarding background note followed by detailed discussion on review of the dimensions and their ranking.

2.0 Following were the participants of the meeting-

1) Mr.T. K. Shome, IAS (Retd.), Ex-Director, Directorate of Land Record \&Survey,Govt. of West Bengal

2) Mr.A. K. Chakraborti, IAS (Retd.), Ex-Secretary, Board of Revenue, Govt. of West Bengal

3) Mr.S. Banerjee, IAS (Retd.), Ex-Member - WBLRTT, Govt. of West Bengal

4) Mr.P. K. Pramanik, DDG-National Informatics Centre, West Bengal

5) Mr. Pinaki Halder, State Director, Landesa, State Coordinator and Project Team LeaderLGAF- West Bengal

6) Dr. Jayanta Munsi, District Project Manager, Landesa - West Bengal

Landesa Kolkata team members were also present to aid the uninterrupted flow of the panel discussion and take the minute of the meeting. The names of those present were-

- Mr. Supriya Chattopadhyay, Communications Manager, Landesa- West Bengal

- Mr.SudiptaBiswas, Districts Project Manager, Landesa - West Bengal

- Ms. Udita Chatterjee, Research \& Documentation Officer, Landesa - West Bengal

- Mr. Debasis Mondal, Office Assistant, Landesa- West Bengal

3.0 The Expert Investigator, Mr. Shome briefly elaborated the background information regarding this panel and invited feedback from the panelists. He shared the gradual evolution of different survey and settlement operations, relevance of these surveys, accuracy of the information generated, kind of services available to the public and recent development in this regards. Regarding the availability and accessibility of land related information, Expert Investigator shared the steps taken by the government for computerization. Mr.Pramanikshared some detailed information and demonstrated the service available through internet

321 Page Land Governance Assessment Framework - West Bengal 
(www.banglarbhumi .com) before the panel. They reviewed the type and nature of information available through website, its usability, cost effectiveness and accessibility to the public. The panel commented that this will curb the corrupt practice related to land management at different levels by offering atransparent system. Mr.Pramanik along with other panelists praised the action taken by this government and mentioned it to be a good model before the other States.

3.1 All panelists opined that the information given in the background note is exhaustive, to the point, pertinent and justified and addressed the issues of provision of public information in the context of West Bengal quite effectively.

4.0 After detailed discussion on background note, discussion was carried out for reviewing the dimensions andjustification of ranking. The panel has five indicators: (1) Mechanisms for recognition of rights (2) Completeness of the land registry (3) Reliability: registry information is updated and sufficient to make meaningful inferences on ownership (4) Cost-effectiveness \& sustainability: land administration services are provided in cost-effective ways that are sustainable in the long term (5) Fees determined transparently to cover cost of service provision.

4.1 There are four dimensions under Indicator 1, seven dimensions under Indicator 2, two dimensions under Indicator 3, two dimensions under Indicator 4 and three dimensions under Indicator 5. Each dimension has four gradations-ranked by the panel from A to D. The dimensions were explicitly discussed in great detail to get the panelists' inputs to incorporate changes in the gradations and analysis and to incorporate their suggestions or policy level recommendation. The major observation from the panel discussion, suggestion for necessary changes or modification in the explanation and policy level recommendations are given below.

\begin{tabular}{|c|c|c|}
\hline \multicolumn{3}{|c|}{ Indicator 1:Mechanisms for recognition of rights } \\
\hline Dimensions & Grade & Change in Grade \\
\hline $\begin{array}{l}\text { 6.1.1 Land possession by } \\
\text { the poor can be } \\
\text { formalized in line with } \\
\text { local norms in an } \\
\text { efficient and transparent } \\
\text { process. }\end{array}$ & $\begin{array}{l}\text { B: There is a clear, practical process } \\
\text { for the formal recognition of } \\
\text { possession but this process is not } \\
\text { implemented effectively, consistently } \\
\text { or transparently. }\end{array}$ & No change is proposed \\
\hline \multicolumn{3}{|c|}{$\begin{array}{l}\text { Observation: } \\
\text { The Expert investigator referred to the Sec.49 of WBLR Act, West Bengal Acquisition } \\
\text { of Homestead land for Agricultural Labourers, Artisans and Fisherman Act 1975, } \\
\text { Government schemes like Chas-O-Basabaser-Janyo-Bhumidan-Prakalpa and Nijo- } \\
\text { Griho-Nijo-BhumiPrakalpa which provide for formal recognition of possession by the } \\
\text { land-poor. The process of selection of beneficiaries for the same is transparent. He } \\
\text { also added that there may be certain gaps in implementation like sporadic partisan } \\
\text { approach for beneficiary identification etc.In addition to this, he highlighted another } \\
\text { gap of not issuing Record of Rights from earlier days (at present the practice of } \\
\text { distribution of RoR along with land title is ensured). A total number of 31,41,232 } \\
\text { families have been given patta till October } 2013 \text { whereas RoR have been given to } \\
\text { 24,57,347 families creating a gap of around } 7 \text { lakh. } \\
\text { Mr.Chakraborti opined that there were some irregularities in selection of } \\
\text { beneficiaries. But, selection process was by and large fair (at least 95\% correct). } \\
\text { Considering the fact that in spite of clearly defined policies for formal recognition of } \\
\text { possession there are certain gaps in terms of transparency and consistency. Hence, } \\
\text { the panel suggested to keep the ranking as B. }\end{array}$} \\
\hline & & \\
\hline
\end{tabular}

322 Page Land Governance Assessment Framework- West Bengal 
6.1.2 Non-documentary evidence is effectively used to help establish rights.
D: Non-documentary forms of evidence are almost never used to obtain recognition of claims to property.

\section{Observation:}

No change is proposed

|

- Expert Investigator elaborated the scope of establishing rights and stressed that it is always done on the basis of some documents. Even in case of the rights of the sharecroppers it is recorded on the basis of the field enquiry, hearing from land owners and local Panchayats.

- One panellist pointed out that there is an established system of recording of possession in the State. In the State context, recognition without document is not encouraged. Hence, the panel agreed to grade the dimension as D.

\begin{tabular}{|l|l|l|}
\hline \multicolumn{1}{|c|}{ Dimensions } & \multicolumn{1}{|c|}{ Grade } & Change in Grade \\
\hline $\begin{array}{l}\text { 6.1.3 Long-term } \\
\text { unchallenged possession } \\
\text { is formally recognized. }\end{array}$ & $\begin{array}{l}\text { Becognize long-term, unchallenged } \\
\text { ressession but applies only to one } \\
\text { specific type of land (e.g. either public } \\
\text { land or private land). }\end{array}$ & $\begin{array}{l}\text { Change is proposed } \\
\text { from B to C. }\end{array}$ \\
\hline
\end{tabular}

\section{Observation:}

- Expert Investigator explained the legal framework under which the unchallenged possessions are recognized. He also explained the conditions which enables the possessions to be formally recognized.

- One panellist raised the issue of adverse possession and wanted to know about its feasibility to be recognized. Mr.Chakraborti responded that adverse possession is not possible in case of public land. It is possible in case of private land only which is also very minimal in practice.

- The panel agreed to the point that unchallenged possessions are recognized legally which is subject to the decision of the court. The panel then concluded that legislation is there to formally recognize the unchallenged possession but legal hurdles to implement it, scope becomes very limited. Hence, the panel suggested that ranking $\mathrm{C}$ will be more appropriate than $\mathrm{B}$.

\begin{tabular}{|l|l|l|}
\hline \multicolumn{1}{|c|}{ Dimensions } & \multicolumn{1}{|c|}{ Grade } & Change in Grade \\
\hline $\begin{array}{l}\text { r.1.4 First-time } \\
\text { recording of rights on }\end{array}$ & $\begin{array}{l}\text { A: On-demand recording of rights } \\
\text { includes proper safeguards to prevent }\end{array}$ & No change in grade \\
demand includes proper & abuse and costs do not exceed o.5\% of & \\
safeguards and access is & the property value. & \\
not restricted by high & & \\
fees. & & \\
\hline
\end{tabular}

\section{Observation:}

- EI briefed the legal provisions and the procedure of first time recording of rights. He also presented the data on fees for mutation which is very minimal (do not exceed $0.5 \%$ of the property value).

- All other panelists accepted the detailed analysis on this issue provided by the EI and unanimously agreed to the grade proposed by the EI.

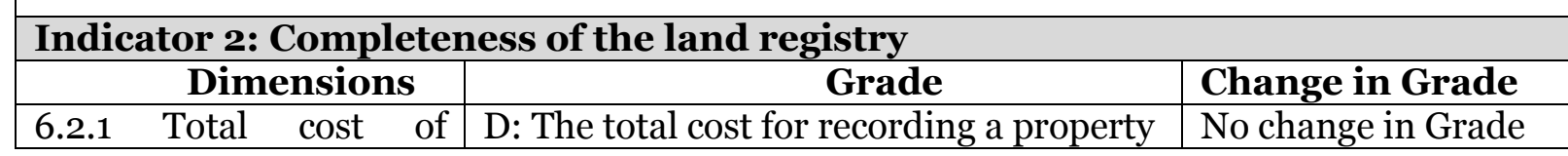

323 I P a e Land Governance Assessment Framework - West Bengal 


\begin{tabular}{|c|c|c|}
\hline $\begin{array}{l}\text { recording a property } \\
\text { transfer is low. }\end{array}$ & \multicolumn{2}{|c|}{$\begin{array}{l}\text { transfer is equal to or greater than } 5 \% \text { of } \\
\text { the property value. }\end{array}$} \\
\hline \multicolumn{3}{|l|}{ Observation: } \\
\hline \multicolumn{3}{|c|}{$\begin{array}{l}\text { After explanation by the Moderator followed by additional data shared by Expert } \\
\text { investigator, all other panelists agreed that the rate is high in the State. Considering the } \\
\text { present rate (which is } 5 \% \text { of property value in rural areas and } 6 \% \text { of property value in urban } \\
\text { areas) for recording of property transfer the panel decided that the ranking (D) is } \\
\text { appropriate. }\end{array}$} \\
\hline $\begin{array}{c}\text { Dimensions } \\
\end{array}$ & Grade & Change in Grade \\
\hline $\begin{array}{l}\text { 6.2.2 Information held in } \\
\text { records is linked to maps } \\
\text { that reflect current reality. }\end{array}$ & $\begin{array}{l}\text { A: More than } 90 \% \text { of records for } \\
\text { privately held land recorded in } \\
\text { the registry are readily } \\
\text { identifiable in maps (spatial } \\
\text { records). }\end{array}$ & No change in grade \\
\hline
\end{tabular}

\section{Observation:}

- After briefing by the moderator, Mr. Banerjee agreed that on the basis of long association with land governance it can be said that in $98 \%$ cases record of land is linked to map.

- Mr.Pramanik shared his experience that the system of digitized map enables easy identification of ownerless land. It helps the department to update the records accordingly.

- When one panellist queried whether the plot is identifiable in the map or not, Mr.Pramanik responded that it is $\mathbf{1 0 0 \%}$ identifiable. But, change in use of plot (demarcation within the plot because of increase in number of shareholders) which is not recorded, cannot be linked with map. All other panellists agreed that it is definitely linked and identifiable but may not be updated because of unchanging nature of records.

- When one panellist wanted to know the implication of "current reality" the moderator explained the same along with its bearing with ownership and record. Mr.Pramanik added that record may not reflect current reality because mutations are not always done promptly.

- Considering the fact that in more than 90\% cases records are identifiable and it is linked to map, the panel suggested to rank it as A.

\begin{tabular}{|l|l|l|}
\hline \multicolumn{1}{|c|}{ Dimensions } & \multicolumn{1}{|c|}{ Grade } & Change in Grade \\
\hline $\begin{array}{l}\text { 6.2.3 All relevant private } \\
\text { encumbrances } \begin{array}{l}\text { C: Relevant private encumbrances are } \\
\text { recorded. }\end{array}\end{array}$ & $\begin{array}{l}\text { recorded but this is not done in a } \\
\text { consistent and reliable manner. }\end{array}$ & \\
\hline
\end{tabular}

\section{Observation:}

- EI explained the type of private encumbrances as easement rights, possession of land with consent, adverse possession,forcible possession and rights of the share croppers (under WBEA Act). However, he added, private encumbrances are recorded in the RoR inconsistently and it does not reflect ground reality.

- One panellist stated that rights of the sharecroppers are not considered as private encumbrance under the provision of WBLR Act. He also added that 'mortgage in bank' is still not recorded as private encumbrances on the body of r-o-r.

- Suggestion came up from the panel that government should consider recording private encumbrances like bank and private institutions.

- EI shared recent development that the initiative taken by the State Government for

324|Page Land Governance Assessment Framework - West Bengal 
Pramanik also accepted the fact of progress.

- Taking into account the situation in the State that recording of private encumbrances

in the RoR still does not reflect the ground reality, the panel suggested to rank it as 'C'.

\begin{tabular}{|c|c|c|}
\hline Dimensions & Grade & Change in Grade \\
\hline $\begin{array}{l}6.2 .4 \text { All relevant public } \\
\text { restrictions or charges } \\
\text { are recorded. }\end{array}$ & $\begin{array}{l}\text { C: Relevant public restrictions or charges } \\
\text { are recorded but this is not done in a } \\
\text { consistent and reliable manner. }\end{array}$ & No change in grade \\
\hline
\end{tabular}

\section{Observations:}

- EI explained the term public restriction and mentioned the scope of public restriction as restriction on transfer of land beyond ceiling limit without approval of revenue officer, long-term settlement of land, short-term settlement, settlement through patta of government land etc.

- Mr. Chakraborti opined that 'creation of tenancy' should also be included in restrictions. But EI and other panelists suggested that it is not necessary to mention here because it is not recorded.

- The panel accepted that there are certain gaps in recording public restrictions or charges like land revenue, lease etc. So, it can be concluded that recording is not done consistently. Hence the panel accepted the ranking (C) proposed by the EI.

\begin{tabular}{|l|l|l|}
\hline \multicolumn{1}{|c|}{ Dimensions } & \multicolumn{1}{|c|}{ Grade } & Change in Grade \\
\hline $\begin{array}{l}\text { 6.2.5 There is a timely } \\
\text { response to requests for } \\
\begin{array}{l}\text { accessing Copies or extracts of documents } \\
\text { records. }\end{array}\end{array}$ & $\begin{array}{l}\text { A: recording rights in property can generally } \\
\text { be obtained within 1 day of request. }\end{array}$ & \\
\hline
\end{tabular}

\section{Observations:}

EI mentioned that because of the introduction of Over the Counter (OTC) service public can access all RoR and map related information within 15 minutes. He also added that since all maps and RoRs are digitized except 1-100 wards of Kolkata Municipal Corporation, people can easily access it through internet. Mr. Pramanik and other panellists agreed to the fact and accepted the grade (A) proposed by EI.

\begin{tabular}{|c|c|c|}
\hline Dimensions & Grade & Change in Grade \\
\hline $\begin{array}{l}6.2 .6 \text { The registry is } \\
\text { searchable. }\end{array}$ & $\begin{array}{l}\text { A: The records in the registry can be } \\
\text { searched by both right holder name and } \\
\text { parcel. }\end{array}$ & No change in grade \\
\hline
\end{tabular}

\section{Observations:}

Considering the fact that land records and cadastral maps are available on website, it is easily searchable. As the panel also agreed that people can get the service from the OTC easily, it is appropriate to grade the dimension as ' $\mathrm{A}$ '.

\begin{tabular}{|l|l|l|}
\hline \multicolumn{1}{|c|}{ Dimensions } & \multicolumn{1}{|c|}{ Grade } & Change in Grade \\
\hline $\begin{array}{l}\text { 6.2.7 Land information } \\
\text { records are easily } \\
\text { accessed. }\end{array}$ & $\begin{array}{l}\text { A: Copies or extracts of documents } \\
\text { recording rights in property can be } \\
\text { obtained by anyone who pays the } \\
\text { necessary formal fee, if any. }\end{array}$ & No change in grade \\
\hline
\end{tabular}

\section{Observations:}

Considering the fact of digitization of all records and maps and making it accessible from the 
website or available with nominal fees as mentioned by the EI, the panel unanimously agreed to rank the dimension as 'A'.

\begin{tabular}{|c|c|c|}
\hline \multicolumn{3}{|c|}{$\begin{array}{l}\text { Indicator 3:Reliability: Registry information is updated and sufficient to make } \\
\text { meaningful inferences on ownership }\end{array}$} \\
\hline Dimensions & Grade & Change in Grade \\
\hline $\begin{array}{l}\text { 6.3.1 Information in } \\
\text { public registries is } \\
\text { synchronized to ensure } \\
\text { integrity of rights and } \\
\text { reduce transaction cost. }\end{array}$ & $\begin{array}{l}\text { C: Links are in place for some types of } \\
\text { land information and checks are } \\
\text { insufficient to eliminate a significant } \\
\text { number of potentially fraudulent } \\
\text { transactions. }\end{array}$ & No change in grade \\
\hline
\end{tabular}

\section{Observations:}

- EI mentioned that in case of land acquisition land information are synchronized promptly by the help of Bhu-Adhigrahan and Bhu-Chitra software. He also mentioned that State Government has taken steps to synchronize digital records of land transaction, RoRs\& cadastral parcel and legacy records through intranet at State Data Centre. Regarding this, he also identified gaps like bank loans and court orders are not recorded in RoRs and during land transaction RoRs are not verified properly.

- Based on their long experience, other panelists agreed with the EI. Considering the above fact, they opined that the process of synchronization at present cannot ensure elimination of all fraudulent practices. Hence, the panel agreed to grade the dimension as 'C'.

\begin{tabular}{|l|l|l|l|}
\hline \multicolumn{1}{|c|}{ Dimensions } & \multicolumn{1}{|c|}{ Grade } & Change in Grade \\
\hline $\begin{array}{l}\text { 6.3.2 Registry } \\
\text { information is up-to- } \\
\text { date and reflects ground } \\
\text { reality. }\end{array}$ & $\begin{array}{l}\text { Between 70\% and 90\% of the } \\
\text { registry/cadastre is up-to-date and } \\
\text { reflects ground reality. }\end{array}$ & No change in grade \\
\hline
\end{tabular}

\section{Observations:}

- After the explanation by the EI, the panel came to a conclusion that the state has a mechanism to update registry information but it cannot be said that it reflects ground reality well. The panel identified one gap that the State has not made a good progress in updating mutation of records.

- There is no readily available data to assess the percentage of updated ownership information in registry or cadastre. The panel suggested ranking it as 'B' primarily on the basis of vast and cumulative field experience.

\section{Indicator 4: Cost-effectiveness and sustainability

Dimensions $\quad$ Grade

Change in Grade

6.4.1 The registry is $\mathrm{D}$ : The total fees collected by the registry No change in grade financially sustainable are less than $50 \%$ of the total registry through fee collection to operating costs.

\section{Observations:}

EI shared some data on the amount of fees payable to get information (RoR, map etc.) along with amount spent for the salary of the staff and cost for infrastructure. It is quite evident that the total fees collected by the registry are less than $50 \%$ of the total registry operating costs. Hence, all the panelists unanimously agreed to grade it as D.

$$
\begin{array}{|l|l|l}
\text { Dimensions } & \text { Grade } & \text { Change in Grade }
\end{array}
$$

326|Page Land Governance Assessment Framework- West Bengal 
6.4.2 Investment in land admin. is sufficient to cope with demand for high quality services.
C: Human and physical capital No change in grade investment is sufficient to maintain medium service standards but does not allow to proactively adapt to new developments.

\section{Observations:}

After explanation by the EI, the panel concluded that the numbers of staff deployed at the field level are not sufficient to provide quality service. At the same time more investment is required by the government to enhance the quality of service. Given the huge workload at delivery point due to non-fulfilment of vacant positions has been denying effective service in a timely manner. But it cannot be said that there is no investment in capital in the system. It is not as per requirement. Hence, the panel decided to grade the dimension as $\mathrm{C}$.

\begin{tabular}{|c|c|c|}
\hline Dimensions & Grade & Change in Grade \\
\hline $\begin{array}{l}\text { 6.5.1 Fees have a clear } \\
\text { rationale, their schedule } \\
\text { is public, and all } \\
\text { payments are accounted } \\
\text { for. }\end{array}$ & $\begin{array}{l}\text { B: A clear rationale and schedule of fees } \\
\text { for different services is not publicly } \\
\text { accessible, but receipts are issued for all } \\
\text { transactions. }\end{array}$ & No change in grade \\
\hline
\end{tabular}

\section{Observations:}

- Referring to the government policy for providing service to the people at a token rate, the EI said that there is no rationale for fixation of fees. All other panelists accepted the point.

- EI also added that fees schedule is available at respective land record offices and registration offices. Other panelists agreed that fee structure is not made public. There is lack of transparency and uniformity in maintaining fee structure.

- When one panellist wanted to know whether receipt is issued for transaction or not, EI responded that it is done sincerely. All other panelists also supported the fact that there is transparency in issuing receipts after payment of fees.

- Mr. Pramanik provided additional information that a mechanism has been developed through internet that after completion of registration process, mutation case will automatically be initiated. Though it requires further proceeding. He provided the source of information as 'wbregistration.gov.in'.

- The panel agreed to the grade (B) proposed by EI.

\begin{tabular}{|l|l|l|}
\hline \multicolumn{1}{|c|}{ Dimensions } & \multicolumn{1}{c|}{ Grade } & Change in Grade \\
\hline $\begin{array}{l}\text { 6.5.2 Informal payments } \\
\text { are discouraged. }\end{array}$ & $\begin{array}{l}\text { B: Mechanisms to detect and deal with } \\
\text { illegal staff behaviour exist in all registry } \\
\text { offices but cases are not systematically or } \\
\text { promptly dealt with. }\end{array}$ & No change in grade \\
\hline
\end{tabular}

\section{Observations:}

- EI presented a data which clearly shows that inspite of number of illegal transactions complaints were lodged against 75 employees in three years. Only 10 employees were punished.

- Other panelists agreed that in spite of having Service Conduct Rules its enforcement is very poor. There is lack of proper monitoring mechanism. Government system is not prompt in taking action against guilty employees.

- The panel accepted the grade (B) proposed by EI.

327|Page Land Governance Assessment Framework - West Bengal 


\begin{tabular}{|l|l|l|}
\hline \multicolumn{1}{|c|}{ Dimensions } & \multicolumn{1}{|c|}{ Grade } & Change in Grade \\
\hline $\begin{array}{l}\text { 6.5.3 Service standards } \\
\text { are published and } \\
\text { regularly monitored. }\end{array}$ & $\begin{array}{l}\text { C: Service standards have been } \\
\text { established, but have not been published } \\
\text { and there is little attempt to monitor } \\
\text { performance against the standards. }\end{array}$ & No change in grade \\
\hline
\end{tabular}

\section{Observations:}

EI shared that West Bengal Rights to Public Service Act 2013 has been enacted. But State Government has established service standard and published the same for a few services, not for all services. All other panelists agreed to fact presented by EI. They opined that ranking (C) is justified.

\section{Panel 7: Land Valuation and Taxation}

Date-28 $8^{\text {th }}$ April 2014

Venue: Landesa Kolkata Office

1.o The meeting was started with a warm welcome to the panelists by Mr. Pinaki Halder, LGAFWest Bengal Project Leader and State Director, Landesa West Bengal. After making a brief presentation delineating the purpose of the panel discussion, about LGAF, the core thematic areas of LGAF, Land Governance Indicators and Dimensions etc. he ventured into the detailed discursive discussion onPanel 7: Land Valuation and Taxation.

2.o Following were the participants of the meeting-

1) Mr. P. K. Pramanik, DDG- NIC- West Bengal

2) Mr.Sabyasachi Roy, Ex. Inspector General- Revenue, GoWB

3) Dr. Vivekananda Mukherjee, Associate Professor, Department of Economics, Jadavpur University

4) Mr. Anup K. Matilal, Retd. Officer, L\&LR and Urban Development Departments, GoWB

5) Mr. Pinaki Halder, State Director, Landesa, State Coordinator and Project Team LeaderLGAF- West Bengal

2.1 Landesa Kolkata team members were also present to aid the uninterrupted flow of the panel discussion. The names of those present were-

- Mr. Supriya Chattopadhyay, Communications Manager, Landesa- Kolkata

- Mr. Sudipta Biswas, District Program Manager, Landesa-Kolkata

- Mr. Jayanta Munsi, District Program Manager, Landesa-Kolkata

- Ms. Udita Chatterjee, Research and Documentation Officer, Landesa- Kolkata

- Mr. Debasis Mondal, Office Assistant, Landesa- Kolkata

3.0 The Moderator made a brief presentation of the background information regarding this panel and invited feedback from the panelists. He covered the following points in his presentation - (a) legal framework for land valuation system (b) basic criteria for land valuation and role of CORD software (c) role of West Bengal Valuation Board (d) exemption issues for special categories (e) land revenue related issues. During his briefing panelists raised certain issues regarding the scope of improvement of the function of CORD software like its efficiency, updation of market value, linking up valuation with CORD software etc. 
4.0 After detailed discussion on background note, discussion was carried out for reviewing the dimension and justification of ranking. The panel has two indicators: (1) Transparency of valuations: valuations are based on clear principles, applied uniformity, updated regularly and publicly accessible; (2) Collection efficiency: land and property taxes are collected and the yield from doing so exceeds collection cost. There are two dimensions under Indicator 1 and four dimensions under Indicator 2 as follows.

4.1 The dimensions under indicator 1 are-

(i) There is a clear process of property valuation

(ii) Valuation rolls are publicly accessible

4.2 The dimensions under indicator 2 are-

(i) Exemptions from property taxes payment are justified and transparent

(ii) All property holders to pay property tax are listed on the tax roll

(iii) Assessed property taxes are collected

(iv) Receipts from property tax exceed the cost of collection

5.0 Each dimension has four gradations-ranked by the panel from A to D. The dimensions were explicitly discussed in great detail to get the panelists' inputs to incorporate changes in the gradations and analysis and to incorporate their suggestions or policy level recommendation.The major observation from the panel discussion, suggestion for necessary changes or modification in the explanation and policy level recommendations are given below.

\begin{tabular}{|c|c|c|}
\hline \multicolumn{3}{|c|}{$\begin{array}{l}\text { Indicator 1: Transparency of valuations: valuations are based on clear } \\
\text { principles, applied uniformly, updated regularly, and publicly accessible. }\end{array}$} \\
\hline Dimensions & Grade & Change in Grade \\
\hline $\begin{array}{l}\text { 7.1.1. There is a clear } \\
\text { process of property } \\
\text { valuation. }\end{array}$ & $\begin{array}{l}\text { A: The assessment of land/property } \\
\text { values for tax or compensation } \\
\text { purposes reflects market prices with } \\
\text { minimal differences between recorded } \\
\text { values and market prices across } \\
\text { different uses and types of users and } \\
\text { valuation rolls are regularly updated. }\end{array}$ & No change is proposed \\
\hline
\end{tabular}

Observation:

- For every Municipal Corporation areas, there is a Valuation Board, who reviews property tax system in every five years. Accordingly they prescribed new tax rate for the property holders in those areas.

- Existing tax rate reviews in every five years gap as the Municipalities don't have enough infrastructural facilities to review the same on yearly basis.

- In case of any particular area within any Municipality different tax rate/tax structure is not possible on actual basis. So they mutually agreed with the property holders before fixation of their tax rate.

- In case of property registration, it is difficult to give actual definition of "market value'. It is found practically that in case of fast growing peri-urban areas (in some cases in particular village areas also) always two different rates prevails. One is Government Rate and the other is Local Rate. A gap (under-valuation) always found in those two rates (local rate often higher than the Govt. rate). In those particular cases, the Government always lose revenue.

- Sometimes, over-valuation in particular cases are also observed. Generally it depends upon the actual classification of any particular land in the land records e.g. a

329|Page Land Governance Assessment Framework - West Bengal 


\begin{tabular}{|c|c|c|}
\hline \multicolumn{3}{|c|}{$\begin{array}{l}\text { particular land is "Shali" in reality but termed as multi-crop in the existing land } \\
\text { records of L\&LR dept. Moreover that particular land is quite potential in case of } \\
\text { commercial purpose. In that case over-valuation might happen. } \\
\text { Gap between Govt. value and local value in in selected areas is also observed. But in } \\
\text { most of the cases, both rates are more or less same. } \\
\text { One question was raised by a panelist- whether variations are at par with the Market } \\
\text { value, if not what is the average variation? The answer to this question was given by } \\
\text { other panellists - variations are happening; it is comparable between the government } \\
\text { price and market price. There is possibility of under-valuation and over-valuation. In } \\
\text { land use maps due to classification of land the value of land is less even if the land has } \\
\text { got potential for fetching high price. }\end{array}$} \\
\hline Dimensions & Grade & Change in Grade \\
\hline $\begin{array}{l}\text { 7.1.2 Valuation rolls are } \\
\text { publicly accessible. }\end{array}$ & $\begin{array}{l}\text { A: There is a policy that } \\
\text { valuation rolls be publicly } \\
\text { accessible and this policy is } \\
\text { effective for all properties that } \\
\text { are considered for taxation. }\end{array}$ & No change is proposed \\
\hline
\end{tabular}

\section{Observation:}

- The moderator mentioned that the roll is prepared by the West Bengal Valuation Board is published for the ULB inviting objections within a specified period.

- Mr.Pramanik added that plot-wise Govt. valuation of property in West Bengal is available in the dept. website i.e. www.wbregistration.gov.inAll information are available in that site and it is accessible to everyone.

\begin{tabular}{|l|l|l|}
\hline \multicolumn{4}{|c|}{ Indicator 2: Collection efficiency: land and property taxes are collected } \\
and the yield from doing so exceeds collection cost
\end{tabular}

As per Govt. order all religious institutions, charitable institutions etc. are exempted from paying any property tax to the Govt. There is provision for exemption for economically weaker and socially vulnerable section. They only need to produce valid document for exemption. But it is also mentioned that "Discretionary" power is conferred on the Chairpersons (Municipalities, Corporation etc.) for exemption of property tax payment in particular cases. But there is no clear-cut guideline about the categories or rate for discretion. Sometimes the concerned authorities get influenced by the political motives. So option " $\mathrm{B}$ " is found to be suitable.

\begin{tabular}{|l|l|l|}
\hline \multicolumn{1}{|c|}{ Dimensions } & \multicolumn{1}{|c|}{ Grade } & Change in Grade \\
\hline $\begin{array}{l}7.2 .2 \text { All property } \\
\text { holders liable to pay } \\
\text { property tax are listed on } \\
\text { the tax roll. }\end{array}$ & $\begin{array}{l}\text { A: More than 80\% of property holders } \\
\text { liable for land/property tax are listed on }\end{array}$ & No change in grade \\
\hline Observation: & & \\
\hline
\end{tabular}

330|Page Land Governance Assessment Framework - West Bengal 
- More than 80\% property holders in town areas are liable to pay property tax are listed on the tax roll. In case of peri-urban areas, the Govt. is giving more emphasis towards preparation of new tax rates to generate funds. $13^{\text {th }}$ Finance Commission recommended giving more emphasis to generate internal revenue. Accordingly the Govt. is giving priority to prepare new tax structure for new peri-urban areas. The concerned urban authorities prepare their new tax rate in consultation with the other Municipalities or urban bodies. Generally they consult with the neighbouring municipalities or urban bodies.

- One panelist cited an example regarding consulting neighbouring ULBs. The Newtown Kolkata Development Authority (NKDA) formed by an administrative order from the West Bengal Assembly three months back. Immediately it had started to prepare its new tax rate by taking ideas from the existing tax rate of neighbour Salt lake Municipality. In this process, it will start to collect tax shortly.

- The panel suggested to consultPanchayat\& Rural Development Department for getting data regarding the collection of tax for land and building properties by the Panchayats in rural areas.

\begin{tabular}{|l|l|l|}
\hline \multicolumn{1}{|c|}{ Dimensions } & \multicolumn{1}{c|}{ Grade } & Change in Grade \\
\hline $\begin{array}{l}\text { 7.2.3 Assessed property } \\
\text { taxes are collected. }\end{array}$ & $\begin{array}{l}\text { B: Between 70\% and 80\% of assessed } \\
\text { land/ property taxes are collected. }\end{array}$ & No change in grade \\
\hline
\end{tabular}

\section{Observations:}

Currently all Municipal bodies serve notice to every property holders to pay tax as well as every municipality deputes one staff responsible for particular area for tax collection. As a result, collection of property tax is regular.

\begin{tabular}{|l|l|l|}
\hline \multicolumn{1}{|c|}{ Dimensions } & \multicolumn{1}{c|}{ Grade } & \multicolumn{1}{c|}{ Change in Grade } \\
\hline $\begin{array}{l}\text { 7.2.4 Receipts from } \\
\text { property tax exceed the cost } \\
\text { of collection. }\end{array}$ & $\begin{array}{l}\text { A: The amount of property taxes } \\
\text { collected exceeds the cost of } \\
\text { staff in charge of collection by a } \\
\text { factor of more than 5. }\end{array}$ & No change in grade \\
\hline
\end{tabular}

\section{Observation:}

- Regular Tax collection depends upon two factors i.e. Efficiency of serving notice and Timely visit to the property holders for tax collection. If both of those factors go well, then collection definitely could be regular.

- There is no full proof mechanism to collect tax from the defaulters. Government lacks proper infrastructure to pay attention in this direction.

- Data available from State Finance Commission and JnNURM suggest that collection of tax varies from Municipality to Municipality, Gram Panchayat to Gram Panchayat. In every case, tax collection is higher than cost of collection. On an average, collection is more than five times higher than cost of collection.

\section{6.o Recommendations:}

- There is a need for coordination among the different layers of the government in use of Market Value Data Base (MVDB) in CORD not only for the purpose of collection of stamp-duty revenue/registration fee as currently done, but also for calculation of base of property/land tax and land revenue. This will allow for less discretion in determination of tax base, which is essential for a transparent and efficient tax regime.

331|Page Land Governance Assessment Framework - West Bengal 
- The discretion used in determination of property tax base and rate as in the present system should be reduced. The credible mechanisms should be designed towards collection of property taxes from defaulters.

\title{
Panel 8: Dispute Resolution \& Conflict Management
}

\author{
12 April 2014 \\ Landesa \\ Venue: Landesa Kolkata Office
}

1.o The meeting was started with a warm welcome to the panelists by Mr. Pinaki Halder, LGAFWest Bengal Project Leader and State Director, Landesa, West Bengal and introduction among each other. He then explained the purpose of the Workshop, and provided an overview of the LGAF. His presentation focused on the following: (i) global land issues; (ii) overview of land governance; (iii) purpose of the LGAF (iv) structure, process and methodology of LGAF; and (iv) Expectations from the panellists in this workshop. He also explained the outline of the workshop and role of the panellists. After making this brief presentation, he led the discussion towards opinion of the panellists regarding background note followed by detailed discursive discussion on Panel 8: Dispute Resolution \& Conflict Management.

2.0 Following were the participants of the meeting-

1) Mr. C. R. Das, Ex-Hon'ble Administrative Member, West Bengal Land Reform \& Tenancy Tribunal,Govt. of West Bengal

2) Mr.Sukumar Banerjee, Ex-Administrative Member, West Bengal Land Reform \& Tenancy Tribunal, Govt. of West Bengal

3) Mr.KallolChaudhuri, Senior Advocate, Kolkata High Court and WBLRTT

4) Mr.Hasanul Islam, Independent Consultant, Kolkata

5) Mr. Pinaki Halder, State Director, Landesa, State Coordinator and Project Team LeaderLGAF- West Bengal

Landesa Kolkata team members were also present to aid the uninterrupted flow of the panel discussion. The names of those present were-

- Mr. Supriya Chattopadhyay, Communications Manager, Landesa- West Bengal

- Mr.SudiptaBiswas, Districts Project Manager, Landesa - West Bengal

- Mr. Debasis Mondal, Office Assistant, Landesa- West Bengal

3.0 The Expert Investigator briefly elaborated the background information regarding this panel and invited feedback from the panelists. One panelist asked to define 'conflict'. Expert Investigator explained the meaning, scope and nature of conflict resolution to the panelists. Panelists were also briefed about the level and pattern of conflict and also different forum for conflict resolution. He explained the role of West Bengal Land Reform and Tenancy Tribunal, its function and relation with other institutions.

3.1 In this context one panelist raised the question on relevance of Sec.6(3) of West Bengal Estate Acquisition Act 1953. Expert Investigator and other panelists held a detailed discussion on the issue. Provision of conflict resolution in different Acts especially WBEA Act and WBLR Act were discussed in details.

3.2 All panelists opined that the information given in the background note is accurate, pertinent and justified and addressed the issues of conflict resolution in the context of West Bengal quite effectively.

332|Page Land Governance Assessment Framework - West Bengal 
4.0 After detailed discussion on background note, discussion was carried out on justification of dimension wise ranking and its explanation. The panel has two indicators: (1) Assignment of responsibility and (2) the share of land affected by pending conflict is low and decreasing. There are four dimensions under Indicator 1 and three dimensions under Indicator 2. Each dimension has four gradations-ranked by the panel from A to D. The dimensions were explicitly discussed in great detail to get the panelists' inputs to incorporate changes in the gradations and analysis and to incorporate their suggestions or policy level recommendation. The major observation from the panel discussion, suggestion for necessary changes or modification in the explanation and policy level recommendations are given below.

\begin{tabular}{|c|c|c|}
\hline \multicolumn{3}{|c|}{ Indicator 1: Assignment of Responsibility } \\
\hline Dimensions & Grade & Change in Grade \\
\hline $\begin{array}{l}\text { 8.1.1. There is clear } \\
\text { assignment } \\
\text { responsibility for conflict } \\
\text { resolution. }\end{array}$ & $\begin{array}{l}\text { A: There are no parallel avenues for } \\
\text { conflict resolution or, if parallel } \\
\text { avenues exist, responsibilities are } \\
\text { clearly assigned and widely known } \\
\text { and explicit rules for shifting from one } \\
\text { to the other are in place to minimize } \\
\text { the scope for forum shopping. }\end{array}$ & No change is proposed \\
\hline
\end{tabular}

\section{Observation:}

- The Expert investigator explained the nature of dispute and when it may arise. He continued that there are specific provisions in the respective Acts like WBEA and WBLR Act to address those issues. The State has clear guidelines for resolving conflicts or objections.

- Referring to the specific provisions in the relevant Act and process of dispute resolution through government machinery other panelists fully agreed that there is clear assignment of responsibility of conflict resolution in the land laws of West Bengal. Hence all agreed to rank the dimension as A.

- Panelists suggested that mechanism should be developed in such a way that maximum number of cases can be settled at the lower level. It can reduce the pressure at higher level resulting speedy dispute resolution. For the purpose, government may take appropriate measure to build the capacity of the field level officials and / or recruit sufficient number of staff at the field level.

\begin{tabular}{|l|l|l|}
\hline Dimensions & Grade & Change in Grade \\
\hline $\begin{array}{l}\text { 8.1.2 Conflict resolution } \\
\text { mechanisms are accessible } \\
\text { to the public. }\end{array}$ & $\begin{array}{l}\text { first instance of conflict } \\
\text { resolution are accessible at the } \\
\text { local level in the majority of } \\
\text { communities. }\end{array}$ & \\
\hline
\end{tabular}

\section{Observation:}

- Referring to the analysis report the Expert Investigator said that there is scope of participation of people (i.e. the Raiyats, and other stakeholders) in the process of conflict resolution whether it is at the lower level or at the higher level. He cited the example of change or alteration in records of rights which is made public during draft publication and also during final publication.

- One panelist said that the State has the mechanism which people can easily access. If any seek intervention of the government mechanism for conflict resolution, he or she can approach the government at local level. The case may be resolved at that very level. If it is not possible to resolve the case at that level, it can go to the higher level.

- Considering the fact that government institution at local level is easily accessible to

333|Page Land Governance Assessment Framework - West Bengal 
the public for conflict resolution, all panelists agreed to rank the dimension as A.

- A suggestion came up from the panel that government may take appropriate measure for wide publicity of the availability of service. Organizing awareness camp at grass root level or carrying out campaign through media may yield results.

\begin{tabular}{|c|c|c|}
\hline Dimensions & Grade & Change in Grade \\
\hline $\begin{array}{lr}8.1 .3 \text { Mutually } & \text { accepted } \\
\text { agreements } & \text { reached } \\
\text { through } & \text { informal } \\
\text { dispute } & \text { resolution } \\
\text { svstems are encouraged. }\end{array}$ & $\begin{array}{l}\text { D: There is no effective informal or local } \\
\text { dispute resolution system in place that } \\
\text { can resolve a significant number of land } \\
\text { related disputes effectively. }\end{array}$ & No change in grade. \\
\hline
\end{tabular}

\section{Observation:}

- After explanation of the statement, one panelist said that there is no provision of informal dispute resolution in this State because it is not recognized by the formal judicial or administrational dispute resolution system in the State.

- One panelist pointed out that in the past there was practice of village level conflict resolution related to land. But gradually this system has disappeared because of many reasons like lack of faith on village head, intrusion of political biasness, vested interest of different stakeholders, lack of updated knowledge of headmen regarding land laws etc.

- One panelist said that there is no provision of Nyay (justice) Panchayat in the State. And also the political atmosphere is not suitable for informal conflict resolution in the State.

- All other panelists agreed to the point that in the context of West Bengal, informal dispute resolution mechanism will not be an effective alternative solution. Hence, all panelists opined that ranking the dimension as D is justified.

\begin{tabular}{|c|c|c|}
\hline Dimensions & Grade & Change in Grade \\
\hline 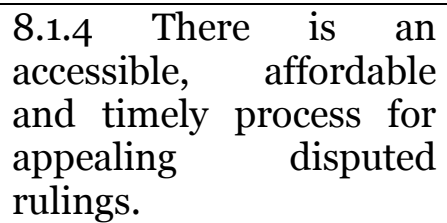 & $\begin{array}{l}\text { C: A process exists to appeal rulings on } \\
\text { land cases at high cost and the process } \\
\text { takes a long time/ the costs are low but } \\
\text { the process takes a long time. }\end{array}$ & No change in grade \\
\hline
\end{tabular}

\section{Observation:}

- Referring to the background note the Expert investigator made a comparative analysis of number of cases resolved and average time taken between Civil Court and Revenue Court. He concluded that Land Reform \& Tenancy Tribunal (LRTT) is very fast in resolving disputes compared to Civil Court and it takes around 10 month to resolve any cases whereas civil court takes around 2 years.

- Other panelists shared their experience too and agreed to the fact mentioned by the Expert investigator.

- One panelist pointed out that because of increase of population and huge pressure on man and land ratio, numbers of pending cases are increasing in both cases.

- Other panelists reflected on the data of the Supreme Court shared by the Expert Investigator and agreed that the fact is true regarding average time taken by the courts. But all agreed that institutions for conflict resolution are easily accessible to the public.

- All panelists came to a consensus that expenditure incurred by the people for resolving dispute varies because of nature of case and time taken in the court. Average cost of resolving dispute is higher in civil court than that of LRTT.

- One panelist suggested vesting power to additional department / institution to settle

334 I Page Land Governance Assessment Framework - West Bengal 


\begin{tabular}{|l|l|l|}
\hline \multicolumn{3}{|c|}{ the cases of change of ownership, change of name in the records etc. to resolve the } \\
cases timely and reduce the cost thereof. \\
Another suggestion came up from the panel that government may take initiative to \\
make the LRTT fully functional with four benches. \\
- All panelists agreed to rank the dimension as C unanimously. \\
\hline $\begin{array}{l}\text { Indicator 2: The share of land affected by pending conflicts is low and } \\
\text { decreasing. }\end{array}$ & Change in Grade \\
\hline $\begin{array}{l}\text { 8.2.1 Limensions } \\
\text { constitute and disputes } \\
\text { proportion of cases in } \\
\text { the formal legal system. }\end{array}$ & $\begin{array}{l}\text { B: Land disputes in the formal court } \\
\text { system are between 10\% and 30\% of the } \\
\text { total court cases. }\end{array}$ & \\
\hline Obsange in Grade \\
\hline
\end{tabular}

\section{Observation:}

After explanation by the Moderator followed by additional information shared by Expert investigator, all other panelists agreed to the percentage figure of court cases related to land dispute. They mentioned that their experience also reflects the same figure. Hence all panelists agreed to rank the dimension as B.

\begin{tabular}{|l|l|l|}
\hline \multicolumn{1}{|c|}{ Dimensions } & \multicolumn{1}{c|}{ Grade } & \multicolumn{1}{c}{ Change in Grade } \\
\hline $\begin{array}{l}\text { 8.2.2 Conflicts in the formal } \\
\text { system are resolved in a } \\
\text { timely manner. }\end{array}$ & $\begin{array}{l}\text { A: A decision in a land-related } \\
\text { conflict is reached in the first } \\
\text { instance court within 6 months } \\
\text { for more than 90\% of cases. }\end{array}$ & $\begin{array}{l}\text { The panel decided to rank } \\
\text { the dimension as B instead } \\
\text { of A. }\end{array}$ \\
\hline
\end{tabular}

\section{Observation:}

- The Expert Investigator stated that resolution of dispute through district land administration system takes lesser time. But formal legal takes more time because of lengthy judicial process coupled with adjournment of cases due to absence of Judge or lawyer or parties etc.

- All panelists suggested that the average time taken should be 10 to 12 months (based on their long experience with the process) instead of 6 months as mentioned by the Expert investigator.

- Panelists suggested that certain specific number of designated officials should be placed at the district or lower level who will exclusively deal with land dispute cases. This initiative can save the time of conflict resolution.

- Suggestion also came up from the panel that an appropriate monitoring mechanism should be developed to track the pending cases in the LRTT and facilitated speedy action.

\begin{tabular}{|l|l|l|}
\hline \multicolumn{1}{|c|}{ Dimensions } & \multicolumn{1}{|c|}{ Grade } & Change in Grade \\
\hline $\begin{array}{l}\text { 8.2.3 There are few long- } \\
\text { standing (> 5 years) land } \\
\text { conflicts. }\end{array}$ & $\begin{array}{l}\text { B: The share of long-standing land } \\
\text { conflicts is between 5\% and 10\% of the } \\
\text { total pending land dispute court cases. }\end{array}$ & No change in grade \\
\hline
\end{tabular}

\section{Observation:}

- Referring to the analysis report, the Expert Investigator explained the reasons for long pendency of cases. Other panelists supported the fact of frequent adjournment of hearing due to non-availability of lawyers or judge or parties or due to failure of submission of documents etc.

- One panelist pointed out that the decision of the government of West Bengal to establish LRTT in the year 1998 has brought about a radical change in the scenario. 
Sometimes, huge numbers of cases are transferred to LRTT in a bulk to reduce the load of civil court and make the process faster. But still, there may be certain long pending cases because of nature of complication of the cases, involvement of huge number of interested parties etc.

- All panelists agreed to the figure proposed by the Expert investigator that there are between $5 \%$ and $10 \%$ of the total pending land dispute court cases which are long long-standing. Hence the panelists agreed to rank the dimension as B.

\title{
5.0 Recommendations from the panel:
}

- Mechanism should be developed in such a way that maximum number of cases can be settled at the lower level. For the purpose, government may take appropriate action to deploy sufficient number of officials at the field level who have judicial acumen. These officials should exclusively deal with dispute resolution. Government should also take action to enhance the capacity of the existing field level officials. This step will help the government to resolve the disputes in a timely manner reducing the cost of settling cases and also reduce the burden of settling piled up cases at LRTT or Civil Courts.

- Government may take appropriate measure for wide publicity of the availability of service of dispute resolution at community level. Awareness camp at grass root level may be organized by the government. Carrying out campaign through media may also yield good results.

- Power may be vested to additional department / institution to settle the cases of petty disputes like change of ownership, change of name in the records (mutation) etc. to resolve the cases timely at the lower level and reduce the cost thereof.

- Another suggestion came up from the panel that government may take initiative to make the LRTT fully functional with six or at least four benches.

- Suggestion also came up from the panel that an appropriate monitoring mechanism should be developed to track the pending cases in the LRTT and bring it to the notice of the government and take appropriate action.

\section{Panel 9: Institutional Arrangement and Policies}

\author{
8 March 2014 \\ Landesa \\ Venue: Landesa Kolkata Office
}

1.o The meeting was started with a warm welcome to the panelists by Mr. Pinaki Halder, LGAFWest Bengal Project Leader and State Director, Landesa West Bengal in the presence of Mr. Gregory Rake, outgoing Country Director of Landesa. Taking the advantage of the presence of Mr. Gregory Rake, Mr. Pinaki Halder requested him to make a small presentation on the work of Landesa on land issue and its experience of working with government in India. Mr. Rake made a small presentation before the panelists on "Securing Land Rights for the Poor in India Challenges \& Way forwards" which was followed bysharing of experiences from the panelists. After closing that chapter, Mr. Halder ventured into the detailed discursive discussion on Panel 9: Institutional Arrangement and Policies.

2.0 Following were the participants of the meeting-

1) Mr. K.L. Mukhopadhyay, Member (Retd), WB Land and Land Reform Tribunal

2) Mr. T.K. Shome, Former DLRS, Govt. of WB

3) Mr. Anup K. Matilal, Former Officer in L\&LR Dept., Govt. of WB

336 | Page Land Governance Assessment Framework - West Bengal 
4) Mr. A.K. Chakraborti, Ex-Special Secretary, Board of Revenue, Govt. of WB

5) Mr. C.R. Das, Member (Retd), WB Land and Land Reform Tribunal

6) Mr. Gregory Rake, India Country Director (outgoing), Landesa

7) Mr. Pinaki Halder, State Director, Landesa, State Coordinator and Project Team LeaderLGAF- West Bengal

Landesa Kolkata team members were also present to aid the uninterrupted flow of the panel discussion. The names of those present were-

- Mr. Supriya Chattopadhyay, Communications Manager, Landesa- West Bengal

- Dr. Shyamal Kumar Jana, Districts Manager, Landesa-West Bengal

- Ms. Udita Chatterjee, Research and Documentation Officer, Landesa- West Bengal

- Mr. Debasis Mondal, Office Assistant, Landesa- West Bengal

3.o Addendum: Second and Third round of panel discussions were held on $12^{\text {th }}$ April 2014 and $17^{\text {th }}$ April 2014 respectively at Landesa Kolkata office. Before going into details about the dimension analysis and its ranking on both days, the participants were briefed about the background of the theme, its objective and indicators and dimensions covering the panel. Inputs were sought from the panelists regarding analysis of the dimensions and justification of ranking. Suggestions came up from both panels have also been incorporated and certain change in ranking have also been made accordingly.

3.1 The participants in the second panel discussion were as follows:

1) Mr. C. R. Das, Ex-Administrative Member, West Bengal Land Reform \& Tenancy Tribunal, Govt. of West Bengal

2) Mr. Sukumar Banerjee, Ex-Administrative Member, West Bengal Land Reform \& Tenancy Tribunal, Govt. of West Bengal

3) Mr. Kallol Chaudhuri, Senior Advocate, Kolkata High Court and WBLRTT

4) Mr. Hasanul Islam, Independent Consultant, Kolkata

5) Mr. Pinaki Halder, State Director, Landesa, State Coordinator and Project Team LeaderLGAF- West Bengal

3.2 The participants in the third panel discussion were as follows:

1) Mr. T. K. Shome, IAS (Retd.), Ex-Secretary and Director, Directorate of Land Record \& Survey, Govt. of West Bengal

2) Mr.A. K. Chakraborti, IAS (Retd.), Ex-Secretary, Board of Revenue, Govt. of West Bengal

3) Mr. S. Banerjee, IAS (Retd.), Ex-Special Secretary, L\&LR Department and ex-Member WBLRTT, Govt. of West Bengal

4) Mr. P. K. Pramanik, DDG-National Informatics Centre, West Bengal

5) Mr. Pinaki Halder, State Director, Landesa, State Coordinator and Project Team LeaderLGAF- West Bengal

4.0 The panel has two indicators as follows:

1. Clarity of mandates and practice: institutional mandates concerning the regulation and management of the land sector are clearly defined, duplication of responsibilities is avoided and information is shared as needed.

2. Equity and non-discrimination in the decision-making process: policies are formulated through a decision-making process that draws on inputs from all concerned. The legal framework is non-discriminatory and institutions to enforce property rights are equally accessible to all.

337|Page Land Governance Assessment Framework - West Bengal 
4.1 Under Indicator 1 there are six dimensions and within Indicator 2 there are seven dimensions. Each dimension has four gradations-ranked by the panel from A to D. The dimensions were explicitly discussed in great detail to get the panelists' inputs to incorporate changes in the gradations and analysis.

\subsection{The dimensions under indicator 1 are:}

i. Land policy formulation, implementation and arbitration are separated to avoid conflict of interest.

ii. Responsibilities of the ministries and agencies dealing with land do not overlap (horizontal overlap).

iii. Administrative (vertical) overlap is avoided.

iv. Land right and use information is shared by public bodies; key parts are regularly reported on and publicly accessible.

v. Overlaps of rights (based on tenure typology) are minimal and do not cause friction or dispute.

vi. Ambiguity in institutional mandates (based on institutional map) does not cause problems.

\subsection{The dimensions under indicator 2 are:}

i. Land policies and regulations are developed in a participatory manner involving all relevant stakeholders.

ii. Land policies address equity and poverty reduction goals; progress towards these is publicly monitored.

iii. Land policies address ecological and environmental goals; progress towards these is publicly monitored.

iv. The implementation of land policy is costed, matched with benefits and adequately resourced.

v. There is regular and public reporting indicating progress in policy implementation.

vi. Land policies help to improve land use by low-income groups and those who experienced injustice.

vii. Land policies proactively and effectively reduce future disaster risk.

5.0 All the dimensions under each of the two indicators were discussed in detail and the final gradation and recommendations corresponding to the gradations are finalised as follows:

\begin{tabular}{|c|c|c|}
\hline \multicolumn{3}{|c|}{ Indicator 1:Clarity of mandates and practice } \\
\hline Dimensions & Grade & Change in Grade \\
\hline $\begin{array}{l}\text { 9.1.1. Land policy } \\
\text { formulation, } \\
\text { implementation and } \\
\text { arbitration are } \\
\text { separated to avoid } \\
\text { conflict of interest. }\end{array}$ & $\begin{array}{l}\text { A: In situations that can entail } \\
\text { conflicts of interest or are sensitive to } \\
\text { abuse (e.g. transfers of land rights) } \\
\text { there is a clear separation in the roles } \\
\text { of policy formulation, implementation } \\
\text { and arbitration. }\end{array}$ & No change in grade \\
\hline
\end{tabular}

\section{Observation:}

- Expert Investigator stated that there is no ambiguity in law or policy. Land administration system is very clear cut under the control of Land \& Land Reform Department. Land policy is formulated in the department itself at the highest level involving Minister in Charge, Principal Secretary to the Department, and other higher level officials and inputs are taken from field level officials. Mr. K.L.Mukhopadhyay stated that all policy decisions are taken politically (by political 
government/ruling party) which may or may not be in consultation with other parties. All policy decisions come through Legislative Assembly by passing legislation. He also added that since MLAs are people's representatives and their opinion are taken into consideration, it can be said that all stakeholders are consulted in the policy making process.

- Referring to the background note Expert Investigator mentioned about Land Acquisition Act, the W.B. L.R. Act, the WBEA Act, the Homestead Act, the Kolkata Land Revenue Act and the Forests Acts including the Forests Rights Act are taken in to consideration for implementation. For arbitration Forest Act, WBEA Act, Homestead Act and WBLR Act are taken into consideration. The dispensations provided in the WBEA Act, WBLR Act and the Homestead Act for arbitration are quite independent and separated from implementing agencies. Only in case of Forest Act, Land Acquisition Act and WBLR Act there are certain overlapping between implementation and arbitration.

- Mr. K.L. Mukhopadhyay did not agree with the term 'conflict of interest'. He stressed that in spite of having separate mechanism conflict of interest does exist. It is the duty of the legislator or policy makers to take steps to defuse the tension. Mr. Shome differed from his opinion and stated that conflict of interest exists between landlord and tenants, between individuals and between state and individuals. EI intervened that two types of conflict are there - inter departmental conflict (e.g. Conflict between Forest Department and Land Reform Department) and conflict between state and individuals. Arbitration is related in the context of transfer of land rights.

- All panelists finally agreed that as far as the state of West Bengal is concerned, LR Department has absolute single command over land. There is clear cut separation of policy formulation, implementation and arbitration. There is no scope of conflict of interest because of overlapping.

\begin{tabular}{|l|l|l|}
\hline \multicolumn{1}{|c|}{ Dimensions } & \multicolumn{1}{|c|}{ Grade } & \multicolumn{1}{c|}{ Change in Grade } \\
\hline $\begin{array}{l}\text { 9.1.2 Responsibilities } \\
\text { of the ministries and }\end{array}$ & $\begin{array}{l}\text { A: The mandated responsibilities } \\
\text { exercised by the authorities dealing }\end{array}$ & No change in grade \\
$\begin{array}{l}\text { agencies dealing with } \\
\text { land do not overlap } \\
\text { (horizontal overlap). }\end{array}$ & $\begin{array}{l}\text { with land governance are non- } \\
\text { overlapping with those of other land } \\
\text { sector agencies. }\end{array}$ & \\
\hline
\end{tabular}

\section{Observation:}

- Referring to the background note EI stated that at the government level the domain of activities i.e. functions, duties and responsibilities etc., of different departments are clearly defined following the 'Rules of Business' leaving no or little scope for any overlap which may result in functional conflict. He also mentioned that overlapping exists to some extent between the function of LR Department and Forest Department due to Forest Rights Act. For example, 'patta' (land title) is given to the forest dwellers by the LR Department but control over forest land lies with Forest Department. Hence, there is possibility of conflict. Since the Chief Minister herself is in charge of the LR Department and she has been playing proactive role in resolving dispute with forest department, the situation has changed. So, functionally there is no inter-departmental conflict.

- Mr. Mukhopadhyay stated that being empowered by the verdict of Supreme Court of India and as per FRA, forest people have been demanding their record of rights (RoR) over the land where they have been cultivating for so many years. And the issues are being resolved. So, theoretically there is no functional overlapping but practically there may be a few.

- Mr. T.K. Shome shared about some recent development. He mentioned that government issued a clear guideline in 2012 on Management of Land where roles of

339|Page Land Governance Assessment Framework - West Bengal 
different departments / institutes have been clearly defined. Question was raised by one panelist whether there is any scope of crossing jurisdiction. Mr. Mukhopadhyay answered that Overlapping may only occur in case of the subject stipulated in the concurrent list of the Constitution of India.

- One panelist asked whenever any land is handed over to other department like Urban Development, Irrigation etc. are they given the right to manage that land fully or not. Mr. Mukhopadhyay answered that the role of that department in managing that piece of land is clearly 'defined'.

- All panelists finally agreed to grade it as A because in case of transfer of rights of land to other department / institute also the role of that department / institute is clearly defined leaving no scope of functional overlapping.

- Data Source: Rules of Business 2012

\begin{tabular}{|l|l|l|}
\hline \multicolumn{1}{|c|}{ Dimensions } & \multicolumn{1}{|c|}{ Grade } & \multicolumn{1}{|c|}{ Change in Grade } \\
\hline $\begin{array}{l}\text { 9.1.3 Administrative } \\
\text { (vertical) overlap is } \\
\text { avoided. }\end{array}$ & $\begin{array}{l}\text { A: Assignment of land-related } \\
\text { responsibilities between the different } \\
\text { levels of administration and } \\
\text { government is clear and non- } \\
\text { overlapping. }\end{array}$ & \\
\hline
\end{tabular}

\section{Observation:}

- Mr. Mukhopadhyay stated that there is absolutely no scope of vertical overlapping. There is only single command. Government order for administration is issued by the DLRS only, which is executed through collectorates at district level. (Collectorates only execute the order of the state government. They act as mere agent, there is no separate authority.)

- All other panelists agreed that role of the government functionaries are defined at each level. Hence, there is no scope of vertical overlapping.

\begin{tabular}{|l|l|l|}
\hline \multicolumn{1}{|c|}{ Dimensions } & \multicolumn{1}{|c|}{ Grade } & Change in Grade \\
\hline 9.1.4 Land right and & B: Information related to rights in & No change in grade \\
use information is & land is available to interested & \\
shared by public & institutions and although this & \\
bodies; key parts are & information is available at reasonable \\
regularly reported on & cost, it is not readily accessible as the \\
and publicly & $\begin{array}{l}\text { information is not maintained in a } \\
\text { accessible. }\end{array}$ & \\
\hline Oniform way. & & \\
\hline
\end{tabular}

\section{Observation:}

- One panelist shared that by paying requisite fees certified copies are available from the government. The other way of getting information is filing RTI by paying Rs.10/only. Regarding this point Mr. Shome shared that digitized information (maps, records etc.) has been made available now in the website.

- Referring to the background note where it has been mentioned that "The different government departments or public bodies like municipalities, panchayats etc. do maintain inventories of land owned and managed by them" one panelist shared his experience of not seeing any such information in certain districts (e.g. Cooch Bihar). Another panelist shared that it is not true for all districts. It varies from district to district and even institute to institute. There are a number of examples where Municipalities or Panchayats are also maintaining records of the land managed by them.

- One panelist pointed out that information maintained by parastatal bodies may

340|Page Land Governance Assessment Framework - West Bengal 
sometimes vary with the information maintained by LR department. Mr. Mukhopadhyay shared his experience by citing the example of Kolkata Dhapa land as the land was acquired for using as dumping ground only. The Supreme Court held as many cases that unused acquired land can be used by the government for other public purposes only. In spite of that Kolkata Municipal Corporation (KMC) is selling the unused land to private companies as an exhorbitantly high price obtained through auction.

- Mr. Mukhopadhyay again pointed out that copy of record given by LR Dept. may sometimes vary from the record given by Municipalities. Mutation granted by the LR Department is the authentic one because entries in the RoRs carry statutory precaution of correctness which Municipal record does not.

- EI pointed out that apart from Municipalities and Panchayats some other departments like PWD, Irrigation etc. are also maintaining information of land managed by them. But it should be kept in mind that 'records' of land maintained by LR Department only are public documents.

- Since digitized information (maps, records etc.) are uploaded in the website and it is accessible by the public, all panelists agree to the fact that information is available. But considering the situation that there are certain gaps in maintaining uniformity in information managed by different institutions, panelists decided to grade it as B.

\begin{tabular}{|c|c|c|}
\hline Dimensions & Grade & Change in Grade \\
\hline $\begin{array}{lcr}9.1 .5 & \text { Overlaps } & \text { of } \\
\text { rights (based } & \text { on } \\
\text { tenure typology) } & \text { are } \\
\text { minimal and do not } \\
\text { cause friction } & \text { or } \\
\text { dispute. } & \end{array}$ & $\begin{array}{l}\text { A: The issues identified in the tenure } \\
\text { Legal framework and procedures for } \\
\text { land-related matters (incl. renewable } \\
\text { and subsoil resources) are fully } \\
\text { consistent and a unified mechanism } \\
\text { for complaint and grievance redress is } \\
\text { available in case of overlap. }\end{array}$ & $\begin{array}{l}\text { The panel finally ranked it } \\
\text { as ' } B \text { ' in place of 'A'. }\end{array}$ \\
\hline
\end{tabular}

\section{Observation:}

- Mr. Mukhopadhyay said that since land is used throughout the year for multiple cropping there is lean period when land can be used for grazing for cattle of the community.

- All panelists agreed that the case of friction is not the result of overlapping rights in the State.

- Mr. Halder queried about any case of friction in terms of use of land for mining subsoil resources. Mr. Mukhopadhyay and Mr. Shome answered that sub-soil right has never been granted to the raiyats who enjoy the right to use the surface land only.

- IE opined that community rights, easement rights and customary rights are legally defined; there is no ambiguity. And there is no scope of friction or dispute due to overlapping of rights.

- Mr. Mukhopadhyay added that whatever conflicts are there in practice in our State are absolutely political in nature (intentionally created by political parties to win the favour of a section of people) but there is no conflict in legal framework.

- Panel came to the conclusion that there is no conflict between community rights, easement rights and customary rights. There may be some overlapping of rights in practice like using cultivable land for grazing purposes during lean season or using leased open cast mining area for pastoral purpose. Conflicts arising out of such friction are insignificant in number. Most of the cases are settled at local level (though there is no uniform procedure for grievance handling or conflict resolution). Hence, the panel decided to rank the dimension as $\mathbf{B}$ instead of A.

\begin{tabular}{|l|l|l|} 
Dimensions & Grade & Change in Grade \\
\hline
\end{tabular}

341|Page Land Governance Assessment Framework - West Bengal 


\begin{tabular}{|l|l|l|}
\hline $\begin{array}{l}\text { 9.1.6 Ambiguity in } \\
\text { institutional W: With minor exceptions, the }\end{array}$ & $\begin{array}{l}\text { Grade is changed from B to } \\
\text { processes applied by public } \\
\text { mandates (based on } \\
\text { institutional map) } \\
\text { does not cause } \\
\text { institutions dealing with land are fully }\end{array}$ & integrated and consistent. \\
problems. & & \\
\hline
\end{tabular}

Observation:

- One panelist wanted to know the meaning of 'institutional map'. Mr. Halder and Mr. Shome explained that the land which has been transferred to other departments and department or agencies who are dealing with lands (managing by themselves).

- Mr. Mukhopadhyay explained that when any land is given to other department it becomes the asset of that department; management of that land becomes the responsibility of that department which is defined. He added that if any land which was given by the LR Department for a particular purpose to other department and if such land was not used for that purpose, the land should be relinquished to LR Department. There is no scope of ambiguity.

- During third round of panel discussion (17-04-2014) the panel concluded that though different public institutions owning land resource maintain register related to land owned and managed by them those are pathetically outdated. There is lack of coordination between LR Department and other concerned public institutions like Panchayat, Municipalities etc. Hence, the panel finally suggested ranking it as ' $D$ ' in place of 'B'.

\begin{tabular}{|c|c|c|}
\hline \multicolumn{3}{|c|}{ Indicator 2:Equity and non-discrimination in the decision-making process } \\
\hline Dimension & Grade & Change in Grade \\
\hline $\begin{array}{l}\text { 9.2.1 Land policies } \\
\text { and regulations are } \\
\text { developed in a } \\
\text { participatory manner } \\
\text { involving all relevant } \\
\text { stakeholders. }\end{array}$ & $\begin{array}{l}\text { A: A comprehensive land policy exists } \\
\text { or can be inferred by the existing } \\
\text { legislation, and those affected by } \\
\text { decisions were consulted beforehand } \\
\text { and their feedback on the resulting } \\
\text { policy is incorporated. }\end{array}$ & $\begin{array}{l}\text { Grade is changed from A to } \\
\text { B. }\end{array}$ \\
\hline
\end{tabular}

\section{Observation:}

- The Expert Investigator referred to the awareness camp held during 1970 s and 1980 s among bargadars, landowners, PRI members etc. (stakeholders) and inputs received from field level officials for policy formulation (e.g. Operation Barga, amendment of Sec. 21B of WBLR Act regarding presumption to be Bargadars etc.). He also cited example of recent consultation held between government and representatives from industries regarding amendment of Sec. 4A, 4B, 14Z etc.

- Mr. Mukhopadhyay pointed out that the conflict of interest between landlord and tenants, owners of the land and bargadars has always been there. But in representative democracy the interest of different stakeholders are put forward during policy formulation. Though policies are formulated in a participatory manner (by representatives from stakeholders) through legislation, it is politically influenced by ruling party because they enjoy majority in the assembly. He also added that no policy could serve the interest of both parties equally. Referring to the legislation (Premises Tenancy Act) in 1956 he claimed that provisions (rent control) were protenants. In other state of the country also legislations were pro-tenants. The Supreme Court also supported such laws. The result was disastreous. The land lords did not maintain the buildings and created huge dead stock. Investment in housing sector dried up. Government of India took alarm and set up as many as three expert committees to go into this problem and suggests solutions. It again involved a

342 | Page Land Governance Assessment Framework - West Bengal 
consultation process engaging all stakeholders (house owners, tenants, business associations, civil societies etc.) to have a balanced view. Since land is a state subject, Government of India prepared a model Act and sent to the states for making their own laws following the model. After consultation with all stakeholders the Premises Tenancy Act of 1997 was enacted.

- Mr. Shome tried to conclude that there may be conflict of interest among different stakeholders, but the process of consultation does exist. In most of the cases participation of stakeholders are through their elected representatives (through MLAs in the Legislative Assembly). Mr. Mukhopadhyay added that it not only involves representatives, views of stakeholders are also taken into consideration directly. He cited the example of Bengal Tenancy Act. Before passing the legislation a draft bill was prepared in 1880 and it was circulated seeking the views of all concerned. All other panelists agreed.

- One panelist referred to the role of website where opinion is invited from all section of society during drafting any policy. He referred to the Land Acquisition Bill of 2013 which was uploaded in the website and suggestions were invited from all stakeholders.

- All panelists came to the conclusion that although land policies do not exist as such on each and every matter such process can be inferred from legislations. In addition to that all agreed that there is doubt on whether the suggestion of all stakeholders are incorporated in the legislation (because there will always be some sort of conflict of interests). One panelist suggested reframing the statements for correct gradation. Finally, panelist could not arrive at a consensus. (Majority accepted C while 1-2 panelists stuck to A.).

- During second round of panel discussion (12-04-2014) panelists agreed that though there is no such policy document in the State but there is solid legal framework which lays the ground for land policy. But there are certain gaps. For example, existing legal framework provides the guideline for use of excess land but illusive about payment of compensation regarding land acquisition.

- Panelists concluded that though the process of legislation is more or less participatory in nature but the level of participation is not satisfactory. There remains doubt whether their feedbacks are incorporated or not. In the past, there was very little scope of participation of affected people. Though the practice of putting the policy in the website is in place but no one can guarantee the involvement of the affected stakeholders through this way. Hence, the panel decided to grade the dimension as B instead of A.

\section{Recommendation:}

- EI and Mr. Mukhopadhyay stated that WBLR Act and Thika Tenancy Act between them cover the tenancy related issues of the entire state in a comprehensive menner.

\begin{tabular}{|l|l|l|}
\hline \multicolumn{1}{|c|}{ Dimensions } & \multicolumn{1}{|c|}{ Grade } & \multicolumn{1}{c|}{ Change in Grade } \\
\hline $\begin{array}{l}\text { 9.2.2 Land policies } \\
\text { address equity and }\end{array}$ & $\begin{array}{l}\text { C: Land policies incorporate some } \\
\text { equity and poverty objectives but }\end{array}$ & No change in Grade \\
$\begin{array}{l}\text { poverty reduction goals; } \\
\text { progress towards these is } \\
\text { publicly monitored. }\end{array}$ & these are not regularly and & \\
meaningfully monitored. & \\
\hline
\end{tabular}

\section{Observation:}

- One panelist wanted to know the implication of the term equity. Mr. Halder explained him that the policy should be made in such a way that serves the interest of the most marginalized and vulnerable section of the society. He also gave thrust on

343 | Page Land Governance Assessment Framework - West Bengal 
gender equity.

- EI mentioned that recording of bargadars through 'Operation Barga' was a step taken by the state government to serve the interest of the sharecroppers who are considered as most marginalized section in agrarian society. While discussing on the background note Mr. Mukhopadhyay objected to giving credit to 'Operation Barga' only as a measure to record the name of the sharecroppers. He stated that as per data, there were 0.6 million recorded bargadars already existing before the special drive called 'Operation Barga' was launched. Hence, EI agreed to change the language as "recording of bargadar including Operation Barga".

- While EI mentioned that land policies incorporated some equity and poverty objectives, other panelists opined that no policy decision was taken in favour of women in the past. Some policy measures have been taken in recent past.

- All panelists came to a conclusion that though there are some policies to address the issues of equity and poverty there is still a gap especially in addressing gender equity. There is also lacuna from the government's end to monitor the implementation of policies. For example, in spite of the government notification (1994) to incorporate the name of women in land distribution there was hardly any monitoring mechanism to ensure it.

\begin{tabular}{|c|c|c|}
\hline Dimensions & Grade & Change in Grade \\
\hline $\begin{array}{l}\text { 9.2.3 Land policies } \\
\text { address ecological and } \\
\text { environmental goals; } \\
\text { progress towards these is } \\
\text { publicly monitored. }\end{array}$ & $\begin{array}{l}\text { C: Land policies incorporate some } \\
\text { ecology and environmental } \\
\text { sustainability objectives but these } \\
\text { are not regularly and meaningfully } \\
\text { monitored. }\end{array}$ & No change in grade \\
\hline
\end{tabular}

\section{Observation:}

- EI shared that in Bengal Tenancy Act there was a provision that Zaminders should construct, repair and maintain embankment on the side of river to prevent flood and soil erosion. He enquired other panelists whether it can be considered as ecological measure. Other panelists opined that the purpose of that was to protect land of tenants from natural calamities. The spirit was to cast an obligation on the Zaminders. Hence it did not serve the ecological or environmental goal. Mr. Halder explained that ecological and environmental goal refers to the changes happening in land use whether that is adversely affecting the relationship between human welfare and environment and policies have shown intention to take care to prevent this.

- Mr. Mukhopadhyay referred to Sec.4C in WBLR Act which provides for not changing the character of land used for any purpose and also conservation of wetland, planting of sapling after cutting trees, compensatory water body etc.

- One panelist referred to the government circular of 2005-06 from Environment Department that prohibits some actions and make provision of penal measure in case of violation regarding wetland management in Kolkata Municipal Corporation (KMC) area.

- During second round of panel discussion (12-04-2014), all panelists came to a conclusion that during formulation of policies ecological and environmental issues were not taken much care of. Though existing legal framework leaves enough scope for improvement considering the present scenario, but there are certain provisions of law to meet ecological and environmental needs by default. WBLR Act provides for addressing certain land issues like management of water bodies, taking care of land used for quarry, sand mining etc. Panelists also unanimously agreed that there is no meaningful monitoring system of the government. Hence, the panel decided to rank it as $\mathrm{C}$.

\begin{tabular}{|l|l|l|} 
Dimensions & Grade & Change in Grade \\
\hline
\end{tabular}

344 I Page Land Governance Assessment Framework - West Bengal 


\begin{tabular}{|l|l|l|}
\hline $\begin{array}{l}\text { 9.2.4 The } \\
\text { implementation of land }\end{array}$ & $\begin{array}{l}\text { D: The implementation of land } \\
\text { policy is not costed and there is } \\
\text { policy is costed, matched } \\
\text { inadequate budget, resources and } \\
\text { with benefits and } \\
\text { capacity to implement the land } \\
\text { policy. }\end{array}$ & .
\end{tabular}

\section{Observation:}

- Mr. Mukhopadhyay pointed that LR department is one of the biggest budget recipients from the government. Mr. Shome opined that though it is true but still budgetary provision is not adequate and it is not costed fully. Mr. Shome added that Cost benefit analysis has never taken place; ad hoc allotment of budget is made as per requirements (e.g. budget allotted for computerization).

- All panelists agreed that item wise cost benefit analysis has never been done. Government has not taken it seriously to prepare detailed budget for specific plans. One panelist shared that most of the fund from central government has been used for infrastructural development of the department only. Recently government has utilized budget for computerization.

- When Mr. Mukhopadhyay enquired from other panelists whether due to inadequate budget LR Department cannot procure resources to implement policy Mr. Shome addressed that it is true. There are huge numbers of posts in the department lying vacant due to inadequate budget.

- The house could not arrive at a consensus. One or two panelists preferred to grade it as ' $\mathrm{C}$ ' (because they don't agree that budget is not prepared at all) while rest of the panelists preferred to grade it as D (because budget, resources and capacity are inadequate and cost benefit analysis is not done).

- During second round of panel discussion Mr. Banerjee and others agreed to the points raised in the first round of discussion. They suggested (based on their long experience of working with the Government at very senior level) to grade it as 'D' considering the fact that there is inadequate budget, resources and capacity to implement the land policy and implementation of land policy is not costed effectively and efficiently.

\begin{tabular}{|c|c|c|}
\hline Dimensions & Grade & Change in Grade \\
\hline $\begin{array}{l}\text { 9.2.5 There is regular } \\
\text { and public reporting } \\
\text { indicating progress } \\
\text { in policy } \\
\text { implementation. }\end{array}$ & $\begin{array}{l}\text { A: Formal land institutions report on } \\
\text { land policy implementation in a } \\
\text { regular, meaningful, and } \\
\text { comprehensive way with reports being } \\
\text { publicly accessible. }\end{array}$ & $\begin{array}{l}\text { Grade is changed from A to } \\
\text { C. }\end{array}$ \\
\hline
\end{tabular}

\section{Observation:}

- Mr. Mukhopadhyay pointed out that Minister-in -Charge of the department in her budget speech every year refers to all aspects of implementation of the policy in a year. How policies are being implemented stated in the budget session.

- One panelist mentioned that monthly statement published from DLRS describes in detail how much land has vested, how much vested land has been distributed etc. DLRO holds meeting every month and consolidates data of the district and progress is reviewed. This progress report is sent to the DLRS.

- Another panelist asked to make it clear whether the report is being made available publicly or not. Mr. Shome clarified that it is uploaded in the website and people can easily access those.

- Third round of panel discussion (17-04-2014) came up with suggestion that department follows a formal reporting system. There is a clearly defined bottom-up progress reporting system which is maintained regularly (on a monthly basis). But,

345 I Page Land Governance Assessment Framework - West Bengal 
this report is not made public on a regular basis. It is also difficult to get the information from the department by the public. Even though the budget speech contains the details of progress and performance of the department these are not publicly accessible, neither the monthly progress report generated by the office of DLRS. So, the panel suggested that ranking $\mathrm{C}$ is more appropriate than $\mathrm{A}$.

\begin{tabular}{|l|l|l|}
\hline \multicolumn{1}{|c|}{ Dimensions } & \multicolumn{1}{|c|}{ Grade } & Change in Grade \\
\hline $\begin{array}{l}\text { 9.2.6 Land policies } \\
\text { help to improve land }\end{array}$ & $\begin{array}{l}\text { A: Policy is in place to improve } \\
\text { access to and productive use of }\end{array}$ & No change in grade \\
use by low-income & assets by poor and marginalized & \\
groups and those who & groups, and is applied in practice & \\
experienced injustice. & and is effective. & \\
\hline
\end{tabular}

\section{Observation:}

- Mr. Mukhopadhyay explained the spirit of land reform. If the land is concentrated in the hand of few they will enjoy the whole benefit depriving majority of population who are directly or indirectly dependant on land. The ceiling limit has enabled the government to take away surplus land for distribution among the landless or land poor people. Hence, it caters to the need of low-income groups. Additionally, if government provides inputs like seeds, fertilizers in subsidized rate to the farmers, it will enhance production and more people of low-income group will be benefitted. The very purpose of land reform in the state was to create a condition of near equal opportunity for all.

- Other panelists shared that land reform policy in West Bengal has enabled access to (e.g. irrigation, inputs, institutional credits etc.) and productive use of assetsby the poor through redistributive justice. There are a number of schemes / policies like Kissan Credit Card, facilities to BPL families, MGNREGA etc. which are directed towards the benefit of low-income group and contributing to productive use of assets. One panelist added that more 50\% of the budget resources in MGNREGA are being used for the conservation of irrigation facilities in this state. There are different schemes from agriculture department in the state for providing inputs at subsidized rate to the marginal farmers (holding land less than one acre).

- One panelist pointed out that the state has only one gap in policy in serving the interest of women.Other panelists also agreed to rank it as A but accepted that policy should address the gender equiety adequately.

\section{Recommendation:}

Gender issues should be incorporated in the policy. And mechanism should be developed to monitor the implementation of the policy.

\begin{tabular}{|l|l|l|}
\hline \multicolumn{1}{|c|}{ Dimensions } & \multicolumn{1}{c|}{ Grade } & \multicolumn{1}{c|}{ Change in Grade } \\
\hline $\begin{array}{l}\text { 9.2.7 Land policies } \\
\text { proactively and } \\
\text { effectively reduce future } \\
\text { disaster risk. }\end{array}$ & $\begin{array}{l}\text { C: Policy is in place to prevent } \\
\text { settlement in high risks areas but } \\
\text { which is not enforced. }\end{array}$ & $\begin{array}{l}\text { Suggested to change it } \\
\text { from C to D. }\end{array}$ \\
\hline Observation:
\end{tabular}

- One panelist referred to the risk associated with indicrimante changes in the use of land.He cited an example that KMC has clear policy on wetland management. It does not permit infrastructure development in wetland, it rather provides for protection and restoration of wetlands. But there is shortcoming in implementation of this policy.

346|Page Land Governance Assessment Framework - West Bengal 
- The EI referred to explanatory note and raised the issue of settlements in areas with perceptible risks such as along open drains, under high tension wires, along river banks and in the flood prone plains, near sites where hazardous materials are disposed off and so on, especially in the cities. He wanted to know from other panelists whether there is any comprehensive policy to prevent this. Mr. Halder shared a recent development. There is an initiative to develop a land use plan for the entire state. Seven districts have already land use maps. They have also identified the land which can be used for the purpose of urbanization. Chief Minister declared that we are developing a comprehensive Land Use Policy but still it is not in place. Once it is in place, it will allow us to make proper plan on which land to be used and which to be left creating scope for preventing settlement in hazardous areas.

- Mr. Mukhopadhyay referred to the Town and Country Planning rules made in 200810 detailing land use plan for KMDA area. The minimum required area of land for the development of township has been fixed under the rule. The rule also prohibits construction of residential building in high risk zones.

- Mr. Halder shared another recent development. He referred that Prof. Shantanu Jha of Kalyani University took initiative to involve National Remote Sensing Agency (NRSA) to take satellite images of Kalyani Municipality. He has prepared a detailed urban land use plan for the first time in West Bengal. He is trying to disseminate information through different forums to show the most vulnerable areas (satellite images) which were marshy lands or wasteland a few hundred years before. He is appealing to the government to protect those areas by rehabilitating those families who have been living there.

- All panelists agreed that there is policy but there is no political will to implement it effectively. Clandestine arrangement with political leaders and irregular practices in government departments are the stumbling blocks in enforcing those policies.

- During second round of panel discussion (12-04-2014), Mr. Islam shared a recent development that land use plan has been prepared by the government in 2007 for urban areas. But he along with others agreed that the State does not have any comprehensive Land Use Policy.

- Mr. Banerjee pointed out that though there is provision for restriction of land use pattern in three hilly Sub-divisions of Darjeeling district as per WBLR Act (Sec.4A), but it is silent about other high risk zone. For example, in spite of being located in high risk zone (coal mine area), Asansol, Raniganj etc. cities are developing day by day. He also added that whatever has so far been done has been by executive order. There is no legislative or policy framework to regulate the land use in order to prevent future disaster risk. Hence, the panel agreed to rank it as ' $D$ ' instead of ' $C$ '. 


\section{List of Expert Investigators}

\begin{tabular}{|c|c|c|c|}
\hline $\begin{array}{c}\text { Proposed } \\
\text { Panel/LGAF } \\
\text { thematic area }\end{array}$ & $\begin{array}{l}\text { Name and } \\
\text { position }\end{array}$ & $\begin{array}{c}\text { General } \\
\text { Qualifications, } \\
\text { expertise \& years of } \\
\text { experience }\end{array}$ & $\begin{array}{l}\text { Specific justification for } \\
\text { choice \& other remarks }\end{array}$ \\
\hline $\begin{array}{l}\text { Recognition and } \\
\text { respect for existing } \\
\text { rights }\end{array}$ & $\begin{array}{ll}\text { Anil } & \text { K. } \\
\text { Chakraborti, } & \\
\text { IAS (Retd) } & \end{array}$ & $\begin{array}{l}\text { M.Sc in Physics from } \\
\text { Calcutta University, } \\
\text { expertise in rural land } \\
\text { tenure, drafting land } \\
\text { legislations and } \\
\text { implementing land } \\
\text { reforms policies }\end{array}$ & $\begin{array}{l}\text { Last position held - } \\
\text { Secretary, Board of } \\
\text { Revenue, one of the most } \\
\text { knowledgeable persons in } \\
\text { the state in different } \\
\text { aspects of land tenure and } \\
\text { land reforms }\end{array}$ \\
\hline $\begin{array}{l}\text { Land Use Planning, } \\
\text { Management and } \\
\text { Taxation }\end{array}$ & $\begin{array}{l}\text { Anup Kr. } \\
\text { Motilal, WBCS } \\
\text { (Exe) Retd. }\end{array}$ & $\begin{array}{l}\text { M.A. in Modern } \\
\text { History, overall } 33 \\
\text { years of experience in } \\
\text { rural development, } \\
\text { land reforms, urban } \\
\text { land use }\end{array}$ & $\begin{array}{l}10 \text { years' experience in } \\
\text { land administration and } \\
\text { management, served as } \\
\text { Project Manager in Kokata } \\
\text { Urban Services for Poor } \\
\text { project (DFID supported) } \\
\text { with focus on urban land } \\
\text { use, planning and taxation }\end{array}$ \\
\hline $\begin{array}{l}\text { Forestry/ } \\
\text { Commons land }\end{array}$ & $\begin{array}{lr}\text { Dr. } & \text { Atanu } \\
\text { Kumar } & \text { Raha, } \\
\text { IFS (Retd) }\end{array}$ & $\begin{array}{l}\text { Ph. D in } \\
\text { Environmental } \\
\text { Science, M. Sc. in } \\
\text { Physics, r Post } \\
\text { graduate in Forestry, } \\
\text { 35 years of forest } \\
\text { management } \\
\text { experience }\end{array}$ & $\begin{array}{l}\text { Last position - Principal } \\
\text { Chief Conservator of } \\
\text { Forests, West Bengal, } \\
\text { introduced Joint Forest } \\
\text { Management through } \\
\text { people's participation }\end{array}$ \\
\hline $\begin{array}{l}\text { Transfer of Public } \\
\text { Land to Private } \\
\text { Use }\end{array}$ & $\begin{array}{l}\text { Dr. Pranab Kr. } \\
\text { Das }\end{array}$ & $\begin{array}{l}\text { Ph. D in Economics } \\
\text { from Jadavpur } \\
\text { University, 20 years' } \\
\text { research and teaching } \\
\text { experience in } \\
\text { macroeconomics }\end{array}$ & $\begin{array}{l}\text { Currently Associate } \\
\text { Professor of Economics, } \\
\text { Centre for Studies in Social } \\
\text { Science, }\end{array}$ \\
\hline $\begin{array}{l}\text { Management of } \\
\text { Public Land and } \\
\text { Public Provision of } \\
\text { Land Information }\end{array}$ & $\begin{array}{l}\text { T. K. Shome, } \\
\text { IAS (Retd) }\end{array}$ & $\begin{array}{l}\text { B.Sc. (Hons), MA, } 36 \\
\text { years of experience in } \\
\text { rural development, } \\
\text { land administration, } \\
\text { computerization of } \\
\text { records, }\end{array}$ & $\begin{array}{l}\text { Present - Director of Land } \\
\text { Records \& Surveys \& Ex- } \\
\text { officio Secretary to L\&LR } \\
\text { Department. Lead role in } \\
\text { implementation on of } \\
\text { computerization of land } \\
\text { records, integration of land } \\
\text { reforms set up with } \\
\text { registration offices }\end{array}$ \\
\hline $\begin{array}{l}\text { Dispute } \\
\text { and Resolution } \\
\text { Management }\end{array}$ & $\begin{array}{l}\text { Chittaranjan } \\
\text { Das, IAS (Retd) }\end{array}$ & $\begin{array}{l}\text { B. Sc. with honours in } \\
\text { Statistics, } 25 \text { years of } \\
\text { experience in land }\end{array}$ & $\begin{array}{l}\text { Last position }- \text { Member of } \\
\text { West Bengal Land } \\
\text { Reforms Tenancy Tribunal }\end{array}$ \\
\hline
\end{tabular}

348 | Page Land Governance Assessment Framework - West Bengal 


\begin{tabular}{|c|c|c|c|}
\hline & & $\begin{array}{l}\text { survey, } \\
\text { modernisation, } \\
\text { management, and } \\
\text { land related training } \\
\text { of officers }\end{array}$ & $\begin{array}{l}\text { (2010-2011) } \\
\text { Land dispute resolving in } \\
\text { the capacity of District } \\
\text { Magistrate }\end{array}$ \\
\hline $\begin{array}{l}\text { Policies and } \\
\text { Institutional } \\
\text { Arrangements }\end{array}$ & $\begin{array}{l}\text { Kanai Lal } \\
\text { Mukhopadhyay, } \\
\text { WBCS (Retd.) }\end{array}$ & $\begin{array}{l}\text { B.A. (Hons.) in } \\
\text { Economics, 30 years } \\
\text { of experience in land } \\
\text { reforms and } \\
\text { settlement, land } \\
\text { administration and } \\
\text { dispute resolution at } \\
\text { higher level }\end{array}$ & $\begin{array}{l}\text { Last position - Member of } \\
\text { the West Bengal Land and } \\
\text { Land Reforms Tenancy } \\
\text { Tribunal (1998-2003), } \\
\text { before that Secretary, } \\
\text { Board of revenue, Govt. of } \\
\text { West Bengal }\end{array}$ \\
\hline State Coordinator & $\begin{array}{l}\text { Pinaki Halder, } \\
\text { Ex -WBCS (Exe) }\end{array}$ & $\begin{array}{l}\text { M.A in Sociology, B. } \\
\text { Sc. in Chemistry, } 25 \\
\text { years of experience in } \\
\text { rural development, } \\
\text { land reforms } \\
\text { implementation }\end{array}$ & $\begin{array}{lr}\text { State } & \text { Director, Landesa/ } \\
\text { Rural } & \text { Development } \\
\text { Institute } & \end{array}$ \\
\hline
\end{tabular}

\section{Composition of Panels}

\begin{tabular}{|c|c|c|c|}
\hline Panel & Experts name & Position & $\begin{array}{l}\text { Organization/ institution of } \\
\text { residence }\end{array}$ \\
\hline \multirow{9}{*}{ 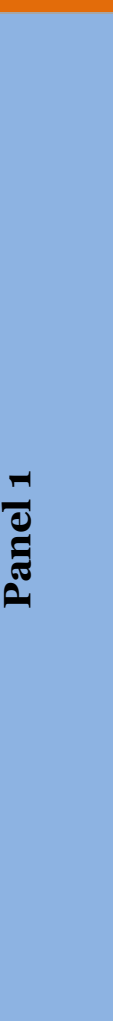 } & $\begin{array}{l}\text { Mr. Anil Kumar } \\
\text { Chakroborty, IAS } \\
\text { (Retd.) }\end{array}$ & Ex-Secretary & $\begin{array}{l}\text { Board of Revenue, Govt. of West } \\
\text { Bengal }\end{array}$ \\
\hline & $\begin{array}{l}\text { Mr. K. P. Sandilya, } \\
\text { IAS (Retd.) }\end{array}$ & $\begin{array}{l}\text { Ex. Special Secretary, } \\
\text { GoWB }\end{array}$ & L\&LR Department \\
\hline & $\begin{array}{l}\text { Mr. Tapan Kumar } \\
\text { Shome, IAS (Retd.) }\end{array}$ & Ex- Director & $\begin{array}{l}\text { Directorate of Land Records and } \\
\text { Survey (DLRS), Government of } \\
\text { West Bengal }\end{array}$ \\
\hline & $\begin{array}{l}\text { Prof. Apurba } \\
\text { Mukhopadhyay }\end{array}$ & Prof of Political Science & Netaji Institute of Asian Studies \\
\hline & $\begin{array}{lr}\text { Mr. } & \text { Sukumar } \\
\text { Banerjee, } & \text { IAS } \\
\text { (Retd.) } & \end{array}$ & Ex- Member & $\begin{array}{l}\text { WBLRTT, Government of West } \\
\text { Bengal }\end{array}$ \\
\hline & $\begin{array}{l}\text { Dr. Biprodas } \\
\text { Bhattacharjee- }\end{array}$ & Professor & $\begin{array}{l}\text { Vivekananda Institute of Science } \\
\text { and Technology, West Bengal }\end{array}$ \\
\hline & Swati Bhattacharjee & Chief Editor (Rural) & Ananda Bazar Patrika \\
\hline & Ms. Reshmi Ganguly & Program Officer & $\begin{array}{l}\text { Action Aid Association (Kolkata } \\
\text { Region) }\end{array}$ \\
\hline & Mr. Pinaki Halder & State Director & Landesa, West Bengal \\
\hline \multirow{2}{*}{ ฮูల } & $\begin{array}{l}\text { Dr. Atanu Kumar } \\
\text { Raha, IFS (Retd.) }\end{array}$ & $\begin{array}{l}\text { Ex-Principal Chief } \\
\text { Conservator of Forests }\end{array}$ & Govt. of West Bengal \\
\hline & Dr.Kulandaivel, IFS & IFS & DCF (HQ), Govt. of West Bengal \\
\hline
\end{tabular}

349|Page Land Governance Assessment Framework - West Bengal 


\begin{tabular}{|c|c|c|c|}
\hline & $\begin{array}{lr}\text { Mr. } & \text { Atonu } \\
\text { Chatterjee, } & \text { WBCS } \\
\text { (Exe.) } & \end{array}$ & Managing Director & $\begin{array}{l}\text { W.B. Tribal Development Credit } \\
\text { Cooperative, Nodal officer for } \\
\text { FRA }\end{array}$ \\
\hline & $\begin{array}{l}\text { Mr. Arindam Dutta, } \\
\text { WBCS (Exe.) }\end{array}$ & Addl. District Magistrate & $\begin{array}{l}\text { District Land \& Land Reforms } \\
\text { Officer, West Medinipur }\end{array}$ \\
\hline & $\begin{array}{l}\text { Prof. Apurba } \\
\text { Mukhopadhyay }\end{array}$ & $\begin{array}{lrr}\text { Professor } & \text { of } & \text { Political } \\
\text { Science } & \text { and } & \text { Political } \\
\text { Studies } & & \end{array}$ & Netaji Institute for Asian Studies \\
\hline & $\begin{array}{l}\text { Mr. Ashoke Kr. } \\
\text { Nayar }\end{array}$ & Programme Officer & Action Aid India \\
\hline & $\begin{array}{l}\text { Mr. Sashi Bhushan } \\
\text { Praharaj }\end{array}$ & Manager cum Field Officer & LAMP, Bankura \\
\hline & $\begin{array}{l}\text { Mr. } \\
\text { Mahapatra }\end{array}$ & Accountant & LAMP, Belagaria \\
\hline & Mr. Pinaki Halder & State Director & Landesa, West Bengal \\
\hline & Mr. Anup K. Matilal, & Ex-Joint Secretary & $\begin{array}{l}\text { Urban Development Dept., Govt. } \\
\text { of WB }\end{array}$ \\
\hline & $\begin{array}{l}\text { Prof. Annapurna } \\
\text { Shaw }\end{array}$ & Prof. Public Policy & $\begin{array}{l}\text { Indian Institute of Management, } \\
\text { Calcutta }\end{array}$ \\
\hline$\stackrel{m}{d}$ & $\begin{array}{l}\text { Prof. } \\
\text { Banerjee }\end{array}$ & Ex. Prof. of Economics & $\begin{array}{l}\text { Centre for Studies in Social } \\
\text { Sciences, Kolkata }\end{array}$ \\
\hline ลี & Mr. Saibal Thakurta & Chief Urban Planner & KMDA \\
\hline & $\begin{array}{l}\text { Ms. } \quad \text { Rashmi } \\
\text { Ganguly }\end{array}$ & Program Officer & $\begin{array}{l}\text { Action Aid Association (Kolkata } \\
\text { Region) }\end{array}$ \\
\hline & Mr. Pinaki Halder & State Director & Landesa, West Bengal \\
\hline & $\begin{array}{l}\text { Mr. Tapan Kumar } \\
\text { Shome, IAS (Retd.) }\end{array}$ & Ex- Director & $\begin{array}{l}\text { Directorate of Land Records and } \\
\text { Survey (DLRS), Government of } \\
\text { West Bengal }\end{array}$ \\
\hline & $\begin{array}{l}\text { Mr. Anil Kumar } \\
\text { Chakroborty, IAS } \\
\text { (Retd.) }\end{array}$ & Ex-Secretary & $\begin{array}{l}\text { Board of Revenue, Govt. of West } \\
\text { Bengal }\end{array}$ \\
\hline 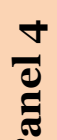 & $\begin{array}{lr}\text { Mr. } & \text { Sukumar } \\
\text { Banerjee, } & \text { IAS } \\
\text { (Retd.) } & \end{array}$ & Ex-Member & $\begin{array}{l}\text { WBLRTT, Government of West } \\
\text { Bengal }\end{array}$ \\
\hline A & Mr. P. K. Pramanik & Deputy Director General & $\begin{array}{l}\text { National Informatics Centre, West } \\
\text { Bengal }\end{array}$ \\
\hline & Mr. Pinaki Halder & State Director & Landesa, West Bengal \\
\hline & Dr. Jayanta Munsi & District Project Manager & Landesa - West Bengal \\
\hline & Dr. Pranab Kr. Das & Associate Professor & $\begin{array}{l}\text { Centre for Studies in Social } \\
\text { Science, }\end{array}$ \\
\hline$\frac{2}{8}$ & $\begin{array}{l}\text { Mr. Shyama Prasad } \\
\text { Mukherjee }\end{array}$ & Ex-OSD & $\begin{array}{l}\text { West Bengal Industrial } \\
\text { Development Corporation }\end{array}$ \\
\hline ฝี & Sukumar Banerjee & $\begin{array}{l}\text { Ex. Advisor, Land } \\
\text { Acquisition }\end{array}$ & WBIDC \\
\hline & Mr. Sunil Nair & Chief Marketing Officer & $\begin{array}{l}\text { Bengal Aerotropolis } \\
\text { Limited }\end{array}$ \\
\hline
\end{tabular}

350|Page Land Governance Assessment Framework - West Bengal 


\begin{tabular}{|c|c|c|c|}
\hline & $\begin{array}{l}\text { Dr. Vivekananda } \\
\text { Mukherjee }\end{array}$ & Associate Professor & $\begin{array}{l}\text { Department of } \text { Economics, } \\
\text { Jadavpur University }\end{array}$ \\
\hline \multirow{7}{*}{ ع } & Mr. Pinaki Halder & State Director & Landesa, West Bengal \\
\hline & $\begin{array}{l}\text { Mr. Tapan Kumar } \\
\text { Shome, IAS (Retd.) }\end{array}$ & Ex- Director & $\begin{array}{l}\text { Directorate of Land Records and } \\
\text { Survey (DLRS), Government of } \\
\text { West Bengal }\end{array}$ \\
\hline & $\begin{array}{l}\text { Mr. Anil Kumar } \\
\text { Chakroborty, IAS } \\
\text { (Retd) }\end{array}$ & Ex-Secretary & $\begin{array}{l}\text { Board of Revenue, Govt. of West } \\
\text { Bengal }\end{array}$ \\
\hline & $\begin{array}{lr}\text { Mr. } & \text { Sukumar } \\
\text { Banerjee, } & \text { IAS } \\
\text { (Retd.) } & \end{array}$ & $\begin{array}{l}\text { Ex. Advisor, Land } \\
\text { Acquisition }\end{array}$ & WBIDC \\
\hline & Mr. P. K. Pramanik, & Deputy Director General & $\begin{array}{l}\text { National Informatics Centre, West } \\
\text { Bengal }\end{array}$ \\
\hline & Mr. Pinaki Halder & State Director & Landesa, West Bengal \\
\hline & Dr. Jayanta Munsi & District Project Manager & Landesa - West Bengal \\
\hline \multirow{6}{*}{ ¿ี } & Mr. P. K. Pramanik, & Deputy Director General & $\begin{array}{l}\text { National Informatics Centre, West } \\
\text { Bengal }\end{array}$ \\
\hline & Mr. Sabyasachi Roy, & Ex. Inspector General & Board of Revenue, GoWB \\
\hline & $\begin{array}{l}\text { Dr. Vivekananda } \\
\text { Mukherjee }\end{array}$ & Associate Professor & $\begin{array}{l}\text { Department of } \\
\text { Jadavpur University }\end{array}$ \\
\hline & Mr. Anup K. Matilal & Ex-Joint Secretary & $\begin{array}{l}\text { Urban Development Dept., Govt. } \\
\text { of WB }\end{array}$ \\
\hline & Mr. Pinaki Halder & State Director & Landesa, West Bengal \\
\hline & Dr. Jayanta Munsi & District Project Manager & Landesa - West Bengal \\
\hline \multirow{5}{*}{ 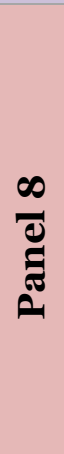 } & $\begin{array}{l}\text { Mr. Chittaranjan } \\
\text { Das, IAS (Retd) }\end{array}$ & Ex-Member & WBLRTT, Govt. of West Bengal \\
\hline & $\begin{array}{lr}\text { Mr. } & \text { Sukumar } \\
\text { Banerjee, } & \text { IAS } \\
\text { (Retd.) } & \end{array}$ & Ex- Member & $\begin{array}{l}\text { WBLRTT, Government of West } \\
\text { Bengal }\end{array}$ \\
\hline & $\begin{array}{ll}\text { Mr. } & \text { Kallol } \\
\text { Chowdhury } & \end{array}$ & Senior Advocate & Kolkata High Court and WBLRTT \\
\hline & Mr. Hasanul Islam & Social Development Expert & Independent Consultant, Kolkata \\
\hline & Mr. Pinaki Halder & State Director & Landesa, West Bengal \\
\hline \multirow{5}{*}{ 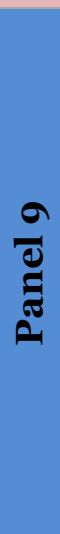 } & $\begin{array}{l}\text { Mr. Kanai Lal } \\
\text { Mukhopadhyay, } \\
\text { WBCS (Retd.) }\end{array}$ & Ex-Member & $\begin{array}{l}\text { WBLRTT, Govt. of West Bengal } \\
\text { and Ex-Secretary, Board of } \\
\text { revenue, Govt. of West Bengal }\end{array}$ \\
\hline & $\begin{array}{l}\text { Mr. Tapan Kumar } \\
\text { Shome, IAS (Retd.) }\end{array}$ & Ex- Director & $\begin{array}{l}\text { Directorate of Land Records and } \\
\text { Survey (DLRS), Government of } \\
\text { West Bengal }\end{array}$ \\
\hline & Mr. Anup K. Matilal & Ex-Joint Secretary & $\begin{array}{l}\text { Urban Development Dept., Govt. } \\
\text { of WB }\end{array}$ \\
\hline & $\begin{array}{l}\text { Mr. Anil Kumar } \\
\text { Chakroborty, IAS } \\
\text { (Retd.) }\end{array}$ & Ex-Secretary & $\begin{array}{l}\text { Board of Revenue, Govt. of West } \\
\text { Bengal }\end{array}$ \\
\hline & Mr. Chittaranjan & Ex-Member & WBLRTT, Govt. of West Bengal \\
\hline
\end{tabular}

351|Page Land Governance Assessment Framework - West Bengal 


\begin{tabular}{|l|l|l|}
\hline Das, IAS (Retd) & \multicolumn{1}{|c|}{$\begin{array}{l}\text { Mregory Rake } \\
\text { India Country Director } \\
\text { (outgoing) }\end{array}$} & Landesa, India \\
\hline $\begin{array}{l}\text { Mr. Sukumar } \\
\text { Banerjee, IAS } \\
\text { (Retd.) }\end{array}$ & Ex-Member & $\begin{array}{l}\text { WBLRTT, Government of West } \\
\text { Bengal }\end{array}$ \\
\hline $\begin{array}{l}\text { Mr. Kallol } \\
\text { Chowdhury }\end{array}$ & Senior Advocate & Kolkata High Court and WBLRTT \\
\hline $\begin{array}{l}\text { Mr. Hasanul Islam } \\
\text { Mr. Pinaki Halder }\end{array}$ & Social Development Expert & Independent Consultant, Kolkata \\
\hline
\end{tabular}

\section{Annexure 4: Government Orders}

Attached in pdf format

352 Page Land Governance Assessment Framework - West Bengal 